\author{
MUSEU DE ARQUEOLOGIA E ETNOLOGIA \\ UNIVERSIDADE DE SÃO PAULO
}

PROGRAMA DE PÓS-GRADUAÇÃO EM ARQUEOLOGIA

MARCONY LOPES ALVES

\title{
Objetos distribuídos do Baixo Amazonas: um estudo da cerâmica Konduri
}

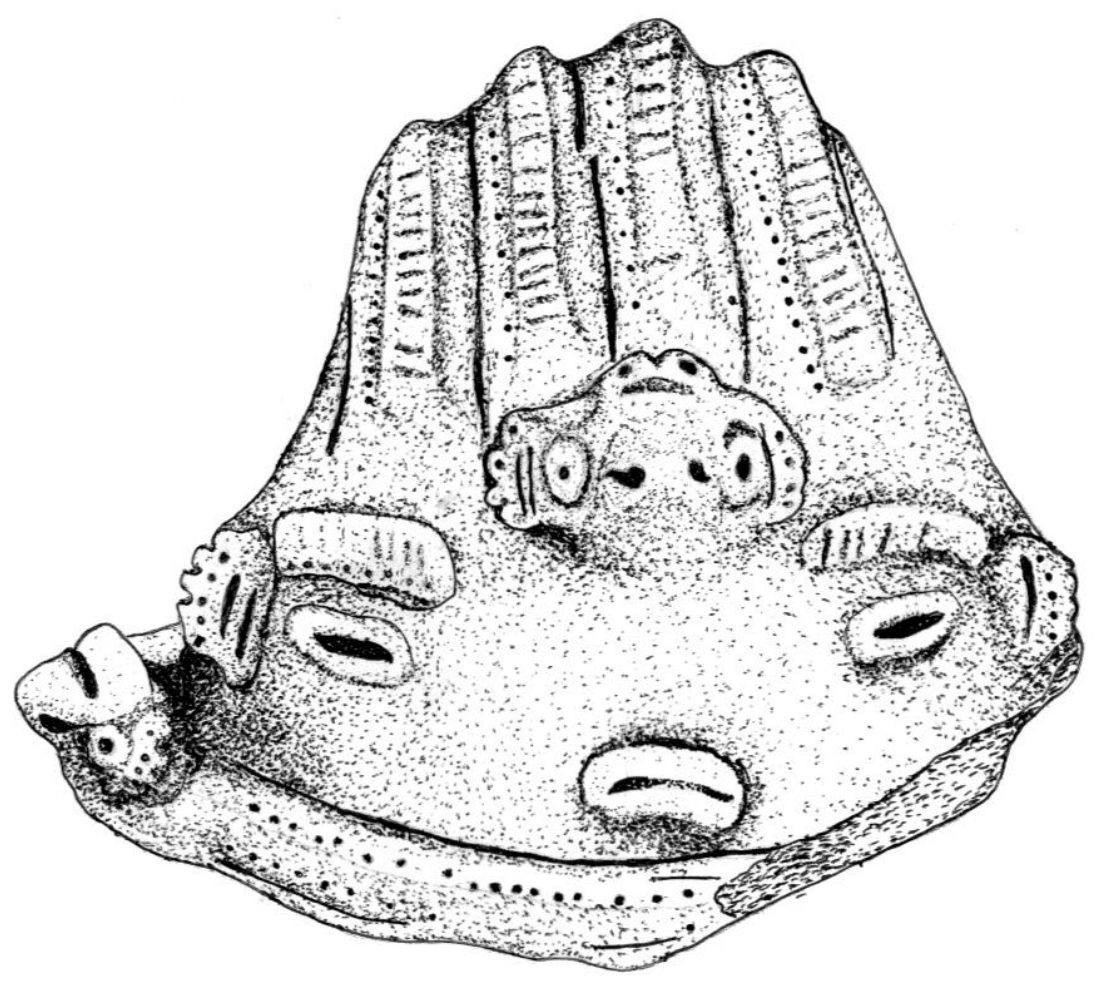

São Paulo 


\title{
Objetos distribuídos do Baixo Amazonas: um estudo da cerâmica Konduri
}

\author{
Versão corrigida \\ (A versão original está disponível na biblioteca do MAE-USP)
}

Dissertação apresentada no Museu de Arqueologia e Etnologia da Universidade de São Paulo para obtenção do título de: Mestre em Arqueologia.

Área de Concentração: Arqueologia

Orientadora: Profa. Dr. ${ }^{a}$ Fabíola Andréa Silva

Linha de pesquisa: Arqueologia e Sociedade

São Paulo

2019 
Autorizo a reprodução e divulgação integral ou parcial deste trabalho, por qualquer meio convencional ou eletrônico, para fins de estudo e pesquisa, desde que citada a fonte.

Ficha catalográfica elaborada pelo Serviço de Biblioteca e Documentação, MAE/USP, com os dados fornecidos pelo(a) autor(a)

objetos distribuídos do Baixo Amazonas: um estudo da cerâmica Konduri / Marcony Lopes Alves;

orientadora Fabíola Andréa Silva. -- São Paulo, 2019. $417 \mathrm{p}$.

Dissertação (Mestrado - Programa de Pós-Graduação em Arqueologia) -- Museu de Arqueologia e Etnologia, Universidade de São Paulo, 2019.

1. Arqueologia Amazônica. 2. Tecnologia cerâmica. 3. Estilo Konduri. 4. Coleções de museu. 5. Biografia de artefatos. I. Silva, Fabíola Andréa, orient. II. Título. 
Para minha mãe, Glória

Minhas irmãs, Sirley, Marta e Cidinha

Meu irmão, Marcelo 


\section{Agradecimentos}

Este trabalho é o resultado de três anos de pesquisa e dedicação. Contou com a participação, colaboração, apoio e incentivo de familiares, amigos, colegas e professores. De norte a sul do país, pulando de um estado para o outro, eu tentei reunir objetos que foram distribuídos entre colecionadores, pesquisadores e instituições. Nesse processo, eu também me tornei uma pessoa distribuída em redes de conhecimento e afetos que permitiram o meu amadurecimento como pessoa e pesquisador. Espero que as páginas seguintes possam refletir ao menos parcialmente este aprendizado. Um filho de agricultores que volta antropólogo (e agora arqueólogo) produz conhecimento científico!

Em primeiro lugar agradeço ao Conselho Nacional de Pesquisas (CNPq) pela bolsa concedida ao longo de dois anos. Essa bolsa permitiu que eu me mantivesse durante os cursos em São Paulo e também financiou parte significativa das viagens e as despesas nos outros estados do país.

Fabíola Silva, minha orientadora, acreditou no potencial deste trabalho desde a primeira vez que enviei o projeto. Com frases como "tu precisas de mais erudição", aprendi e continuo aprendendo muito.

André Prous é o meu grande mestre. Esta dissertação é boa medida inspirada em seus ensinamentos e sua capacidade de instigar a ver além. Não tenho como agradecer sua constante generosidade. Já nos conhecemos há mais de uma década e jamais teria trilhado dos caminhos da arqueologia sem sua recepção e preocupação. Sua constante preocupação comigo é um alento em momentos difíceis. Deixo aqui registrado que o senhor leu e me enviou por correio a dissertação comentada.

Camila Jácome sempre me apoiou em minhas "viagens" e, com bom humor, me ensinou muito sobre generosidade acadêmica. Mais do que ninguém sempre acreditou que era possível fazer um estudo sobre a cerâmica Konduri. Seus comentários durante a banca ajudaram substancialmente a reformular algumas ideias, a organização dos temas e os incontáveis erros ortográficos.

Klaus Hilbert me abriu as portas do Laboratório de Arqueologia na PUC-RS e permitiu que eu vasculhasse os preciosos manuscritos de seu pai e Protásio Frikel. Também o 
agradeço por aceitar participar de minha banca e por sua leitura e crítica desta longa dissertação.

Cristina Barreto tem sido desde o começo de minha graduação uma grande fonte de inspiração. Sua recepção no Museu Goeldi e nossas muitas conversas foram fundamentais para a construção de vários argumentos apresentados. Depois da defesa conversamos sobre esta dissertação e seus comentários me fizeram refletir sobre várias das escolhas analíticas que acabei tomando.

André Strauss, hoje professor do MAE-USP, me ensinou e me inspirou muito a realizar este trabalho. Todos seus comentários são sempre certeiros e sempre me mostraram o melhor caminho, mesmo quando eu não o segui.

Vera Guapindaia foi extremamente generosa compartilhando relatórios de pesquisa, fazendo sugestões e incentivando este trabalho. Nossas conversas e e-mails trocados forma fundamentais para que jamais desistisse.

A presença de Francisco Noelli ao longo da realização deste trabalho foi muito enriquecedora. Todo o seu incentivo, provocações e sugestões de leitura me fez acreditar que é possível fazer muito mais.

Agradeço a todos os professores do MAE que contribuíram para minha formação nas aulas ou em conversas de corredor. Em especial, menciono Eduardo Neves por ter oferecido uma leitura essencial do meu memorial de qualificação e por sempre acreditar em minha pesquisa. Sou grato a Maria Isabel Fleming que também foi membro da minha banca de qualificação. Agradeço também a querida professora Ximena Villagrán por todas nossas conversas, por sua sinceridade e empatia. Não posso deixar de mencionar Veronica Wesolowski por todo o importante trabalho na Comissão de Pós-Graduação - fundamental para mim ao longo do curso e das demandas.

O Laboratório de Estudos Interdisciplinares sobre Tecnologia e Território (LINTTMAE/USP) é como uma família na qual seus membros sempre se apoiam. Silvia Cunha Lima comentou e discutiu minha ficha de análise oferecendo novas perspectivas de análise. O pequeno, mas importante "grupo Karib" composto pelos amigos e colegas Meliam Gaspar e Igor Rodrigues foi essencial para reflexões teóricas e metodológicas ao longo dessa trajetória. 
Meliam Gaspar compartilhou comigo várias de suas inquietações e enfrentamos o desafio de ler e aplicar as ideias de Olivier Gosselain e Valentine Roux a contextos amazônicos. Além disso, Meliam leu quase todos os capítulos ainda em fase de preparação. Se isso já não bastasse, ela também imprimiu e depositou a dissertação para mim. Não há palavras para te agradecer, Meliam! Igor Rodrigues foi meu professor em laboratório e na sala de aula, e me apoiou em vários momentos difíceis desta e de outras aventuras. Nossas conversas e suas sugestões foram fundamentais para o desenvolvimento deste trabalho e a minha formação como arqueólogo. Pesquisando no sertão baiano, distante do rio-mar, Juliana Freitas foi uma amiga e colega incrível. Não tenho como agradecer todo seu apoio contínuo e amizade verdadeira.

Agradeço das instituições de guarda onde estudei coleções. Sou grato, no MAE-USP, a Cristina Demartini por todas as conversas sobre as coleções, as dicas sobre como abordar o material e muitos outros conselhos. O conhecimento e apoio de Demartini enriqueceram muito este trabalho. Também agradeço a Francisca Figols, Carla Gilbertoni, Regivaldo e Daria. Vários dos bolsistas dos bolsistas me ajudaram muito reunindo informações, anotado outras, me ajudando a tirar e levar as peças da Reserva Técnica. Cito apenas algumas pessoas: Maju, Vitor, e Mateus. Alexandre e a Bia, por quase um mês, tiraram fotos do acervo para esta pesquisa a pedido de Cristina Demartini.

No Museu Nacional da UFRJ, agradeço a professora Rita Scheel-Ybert por permitir que eu estudasse o material e todo o apoio oferecido à pesquisa. Angela Rabello, Mariana Ferreira e Leonardo Weissman forma fundamentais para o trabalho me auxiliando em tudo. Agradeço também a Lourdes do Centro de Documentação de Línguas Indígenas por permitir consultar as cartas de Nimuendajú. Mal sabia eu que não teria outra oportunidade como aquele acervo! Guardo o Museu Nacional no meu coração. O Museu Nacional vive!

No Museu Paraense Emílio Goeldi, fui muitíssimo bem recebido, em 2018, por Helena Lima, com quem tive o privilégio de discutir várias os materiais na bancada e hipóteses da arqueologia amazônica. Agradeço por todos os ensinamentos e também por ter compartilhado relatórios, fotografias e ideias. Leonardo e Camila me ajudaram muito e sempre ficavam um pouco depois do horário quando eu queria cumprir metas de análise. Além deles, vários dos bolsistas se tornaram amigos durante os meses de trabalho. Agradeço especialmente a Laurênia Nery por ter me ajudado com as análises e, depois, na consulta de documentação no 
Arquivo Agradeço a Edithe Pereira por sua gentileza e as fotografias de coleções cedidas. Sou grato a toda equipe do Arquivo Guilherme de La Penha por sempre me permitir um rápido e fácil acesso a documentação. Agradeço especialmente ao Mazildo e ao Pablo que não se cansava de pegar aquela caixa a mais que eu queria. Bem ao lado do Arquivo, encontrei o incrível professor Nelson Sanjad, que me fez ficar ainda mais encantado com a História das Ciências. Sempre sai de nossas conversas querendo aprender mais! Agradeço também a Cássia Rosa por nossas conversas e por ter compartilhado sua monografia que muito me ajudou no desenvolvimento do capítulo 2.

No Museu de História Natural, eu agradeço a Mariana Cabral pela liberdade para pesquisar mesmo já não sendo da casa. Também sou grato à maravilhosa oportunidade de queimar cerâmica com Lílian Panachuk. Os comentários e sugestões de Lílian sobre a cerâmica Konduri, com toda a sua experiência de campo e laboratório, foram de extrema importância para esta pesquisa. Além disso, agradeço pela cedida para o capítulo 4.

No Museu de Ciências e Tecnologia da PUC-RS, além do professor Klaus Hilbert, sou grato a Filipi Pompeu e Ana Paula Bezerra, que tornaram muito agradável e mais fácil o trabalho.Filipi ainda digitalizou alguns livros para a realização desta pesquisa.

O Dr ${ }^{\circ}$ Alessandro Pezzati do Penn Museum enviou-me toda a documentação referente a coleção John Mayer e correspondências relacionadas a Helen Palmatary. Sem sua disponibilidade e agilidade dificilmente conseguiria atar os nós que unem as histórias das coleções arqueológicas do Baixo Amazonas. Alex, I'm very grateful to you.

Rodrigo Oliveira, junto com André Strauss, se mobilizou para realizar tomografias na tentativa de estudar o processo de produção dos vasos de gargalo, cujos resultados ainda não conseguimos finalizar. A professora Bruna Cigaran gentilmente compartilhou comigo fotografia da cerâmica com padrões incisos "espinha de peixe" do município de Itaituba. Agradeço a Natalia Lozada por compartilhar uma foto muito importante de um apêndice “cabeça de urubu" encontrada no sítio Aguerito. Stéphen Rostain enviou me alguns textos para a discussão sobre a coleção Cullère e sobre a Tradição Arauquinóide. Ana Carolina Cunha se disponibilizou para tirar fotos da coleção de Protásio Frikel em Lagoa Seca/PB e as enviar para a realização desta pesquisa. Deusdedit Carneiro Leite Filho, diretor do Centro de Pesquisa de História Natural e Arqueologia do Maranhão, cedeu gentilmente fotografias das peças Konduri disponíveis no acervo da instituição. Agradeço ao professor Alfredo Palau por 
ter enviado fotografia das peças que coletou no lago Moura. Agradeço a Aricy Curvello por responder com prontidão as minhas questões sobre a coleção que reuniu. Sidney Canto me explicou várias questões sobre a atuação da Igreja na Prelazia de Santarém e me cedeu informações importantes para a construção do capítulo 2.

Deixo um agradecimento mais que especial a quem ajudou a escrever e formatar esta dissertação. Gustavo Jardel ouviu todos os meus lamúrios e fez com que eu me mantesse firme na escrita ao longo de horas de conversas por telefone. Kelly catou todas as referências perdidas ao longo dos capítulos. Jaqueline Belletti leu e comentou toda dissertação apontando erros ortográficos e me enchendo de esperança ao compartilhar suas questões. Sarah virou uma noite me acalmando, formatando e corrigindo erros de referência poucas horas antes do prazo final de entrega. Henrique confeccionou e refez várias vezes os mapas apresentados. Jéssica Cardoso recortou várias imagens usadas no capítulo 4. Marta, minha irmã, também se dedicou bastante a tarefa de recortar a imagens. Mateus Mota revisou o resumo em inglês e ajudou na formatação da versão final.

O MAE-USP me recebeu muito bem. Todos os funcionários foram muitos gentis, a começar pela Regina, Karen e Claudia. Agradeço a toda à equipe da biblioteca do MAE-USP. Ao Hélio, em particular, porque com sua generosidade inigualável e conhecimento, eu pude, mesmo fora de São Paulo, continuar tendo acesso a textos difíceis de encontrar. Os colegas do MAE me ajudaram muito ao longo de todo o percurso. Os amigos da iconografia amazônica, Emerson Nobre e Erêndira Oliveira, moram no meu coração e agradeço por todo apoio, conversas e incentivos. A turma da "quinta série" também ofereceu um apoio inestimável: Daniella Ortega, Kelly Brandão (também uma amazonista), Isabela Müller, Fabrício Bernardes, Renato Saad, Renata Estevam, Jordana Barbosa. Também não posso esquecer-me de Eliane Chim, que desde nosso campo na Lapa do Santo tem sido uma grande amiga. Certamente, estou esquecendo várias pessoas e desde já me desculpo! Obrigado!

Agradeço as e os colegas, professores/as e amigos/as amazonitas que me ajudaram a trilhar este caminho e comigo compartilharam informações, livros e anseios: Laura Furquim, Maurício Silva, Caroline Caromano, Márcio Amaral, Leandro Cascon, Thiago Kater, Rafael Lopes, Márjorie Lima, Guilherme Mongeló, Bruno Barreto, Vinícius Oliveira, Joana Troufflard, João Aires da Fonseca, Kika Landi, Daniel Cruz, Jennifer Watling e Carlos 
Augusto Zimpel. Deixo um agradecimento especial a Filipo Bassi e a Clarice Biancchezzi pelo apoio em trilhar uma nova pesquisa.

Amigas e amigos também me ajudaram de todas as formas. Em Belo Horizonte, eu agradeço ao Afonso e a Nadya por permitirem que eu compartilhasse de sua casa e do dia a dia. Guardo boas lembranças do apartamento e da convivência entre eu, Carol e vocês. Elber Glória compartilha comigo as angústias e as esperanças de mineiros interessados em Amazônia. Nossas conversas e inquietações aparecem em várias das páginas seguintes. $\mathrm{O}$ apoio dos meus amigos, Gustavo, Sarah, Ric, Amanda e Tiago foi fundamental para sobreviver à vida acadêmica, as demandas, os medos. Nossa amizade é uma das colunas de sustentação para minha esperança! Em Belém, reencontrei Tallyta Suenny, que me ajuda sempre que pode desde os tempos da graduação. Sou grato a Larisse e Cristiano por acolher um desconhecido por duas semanas em sua casa em Belém. No Rio de Janeiro, Helena Assunção permitiu que eu me ajudasse em sua linda casa durante a estadia e também me explicou várias coisas importantes. Elena Welper, especialista na vida e obra de Nimuendajú, contribuiu com sugestões importantes sobre a pesquisa documental. Também agradeço a Maria Luísa Lucas por ter me apresentado a Elena. Agradeço a minha querida colega de MAE, de casa e amiga, Letícia Corrêa, por me proporcionar um ambiente maravilhoso para morar em São Paulo. Sua amizade foi essencial para sobreviver nesta grande metrópole. Juliana (de novo) e Josi nos receberam (eu e Carol) em sua casa em 2018 em São Paulo e nos divertimos muito naquela casa tão "arqueológica".

Agradeço família de minha companheira por me receber tão bem e entender os desafios de escrever centenas de páginas. Agradeço especialmente a Márcia, minha sogra, pelo apoio fundamental nos últimos meses de escrita.

Esta dissertação é resultado do trabalho e dedicação da minha família que me apoiou afetiva e financeiramente. Sem o carinho da minha mãe eu jamais poderia sonhar em escrever tantas páginas e me aventurar por tantos lugares. Sem Sirley e seu apoio incondicional eu não teriam coragem para tentar ir mais longe. Sem as falas diretas e os pés no chão da Marta eu nunca aceitaria os desafios da vida. Sem Marcelo, o retorno não seria tão bom. Sem a Cidinha não daria para seguir adiante. Amo vocês, apesar de sempre estar meio longe. Obrigado por acreditar em mim incondicionalmente! 
Por fim, a minha companheira, Caroline, que, ao longo dos últimos três anos viu sua vida girando para diferentes cidades e crises de ansiedade. Sem você e seu amor eu não conseguiria. Obrigado por me apoiar, me ajudar fotografando peças e compartilhando todas as angústias e prazeres que esta pesquisa gerou. Eu te amo. 
“(...) le terme culture désigne une question, et non une réponse.” [(...) o termo cultura designa uma questão e não uma resposta. ”]

(Tim Ingold in DESCOLA; INGOLD, 2013, p. 46)

"Es ist halt so: Je naeher man zuschaut, um so mehr Probleme und Fragezeichen tauchen auf."

[É assim: quanto mais você olha, mais problemas e pontos de interrogação aparecem.].

Carta de Protásio Frikel a Peter Hilbert. Oriximiná 25/1/1953. 


\section{Resumo}

O estilo cerâmico (ou fase) Konduri é conhecido por uma decoração repleta de incisões, entalhes e ponteados e alta concentção de cauixi na pasta. Essa cerâmica é encontrada nos níveis superficiais de sítios arqueológicos com terra preta ao longo dos rios Nhamundá e Trombetas, afluentes da margem esquerda do rio Amazonas. Na outra margem do grande rio, sua dispersão alcança os municípios de Juruti/PA e Parintins/AM. As datações radiocarbônicas disponíveis apontam que sua produção ocorreu por volta de 1250 e 1650 AD. Esse estilo foi definido formalmente como uma unidade arqueológica por Peter Paul Hilbert em 1955. Apesar do crescimento substancial das pesquisas no Baixo Amazonas, poucas revisões foram feitas em relação a sua caracterização inicial. Esta dissertação busca rediscutir alguns elementos da caracterização do estilo a partir da análise de diferentes coleções reunidas em cinco museus brasileiros desde o século XIX até meados do século XX. A noção de "objeto distribuído" serve como fio condutor entre episódios recentes de seu colecionamento, ao mesmo tempo em que permite discutir as escolhas técnicas e os processos de transmissão de conhecimento vinculados a produção cerâmica no passado pré-colonial. São discutidas as redes intelectuais e de colecionadores que permitiram sua chegada aos museus e também às limitações e possibilidades dessas coleções para o estudo do passado pré-colonial. Tendo isso em vista e partir das análises cerâmicas, são delineadas algumas características de performance mobilizadas na produção da cerâmica Konduri. Os resultados obtidos nas pesquisas recentes servem como base comparativa, para contrabalancear os vários vieses das amostras. Por oposição, o estudo dos materiais permitiu identificar conjuntos cerâmicos minoritários caracterizados por atributos tecnológicos distintos associados à cerâmica Konduri. A partir disso são desenvolvidas hipóteses acerca da existência de redes de troca e fluxo de pessoas e informações no Baixo Amazonas durante o período pré-colonial tardio.

Palavras-chave: Arqueologia amazônica; estilo Konduri; Tecnologia cerâmica; Biografia de Artefatos. 


\begin{abstract}
Konduri pottery style (or phase) is mostly known for its modelled, incised, punctuated and notched decoration and high amounts of sponge spicule in the fabric. This pottery is found on upper levels of archaeological sites with dark earth (terra preta), along the Nhamundá and Trombetas rivers, which are tributaries of the left margin of the Amazon. On the other bank its dispersion reaches the municipalities of Juruti/PA and Parintins/AM. Radiocarbon dating puts its production between the years 1250 and 1650 AD. This style was formally defined as an archaeological unit by Peter Paul Hilbert in 1955. Despite the recent research growth in the region, very few revisions were made to the initial definition of the style. This master thesis seeks to re-discuss its characterization starting from collections housed in five Brazilian museums and gathered during the $19^{\text {th }}$ and $20^{\text {th }}$ centuries. The notion of "distributed object" serves as a guiding thread in the articulation between the recent episodes in the artefact biographies, the technical choices in the production process, and the transmission of knowledge in the pre-colonial past. The intellectual and collector networks and the limitations and possibilities of these materials for the study of the pre-colonial past are discussed. Considering the limits and bias of these collections, it is possible to construct hypothesis about technical choices in Konduri style at a regional scale. For this task, the results of recent fieldwork researches are used as a comparative resource. Besides Konduri material, sets of less frequent styles are identified as non-local, suggesting the existence of exchange networks and fluxes of people and information on the late Pre-Colonial Lower Amazon.
\end{abstract}

Key-Words: Amazonian Archaeology; Konduri style; Pottery technology; Museum Collections; Artifact Biography. 


\section{Lista de figuras}

Figura 1. Modelo de objeto distribuído baseado na carreira de um artista ocidental individual. Esse modelo pode ser expandido e incluir vários outros artistas dentro de um contexto amplo. Adaptado de Gell, 1998. 38

Figura 2. Vaso de cariátides coletado por Curt Nimuendajú. Essa é uma das vasilhas mais características do estilo Tapajó ou Santarém, definido pelo etnólogo alemão. Extraído de Nimuendajú, 2004. 55

Figura 3. Fragmentos indicadas por Nimuendajú como pertencentes ao estilo Kondurí: a. figura 30- D; b. figura 30-F; c. figura 30-B; d. figura 31-B. Peças provenientes de Santarém (a,c,d) e Lago Grande (b). Adaptado de Palmatary, 1939. 57

Figura 4. Fragmento com elementos "barrocos" característico do que Barata (1950) chamou de "cerâmica de Oriximiná". Extraído de Barata, 1950.

Figura 5. Esquema resumindo a classificação da cerâmica coletada por Peter Hilbert. Figuras adaptadas de Hilbert, 1955a

Figura 6. Elementos identificados como característicos da "cerâmica temperada com areia". Adaptado de Hilbert, 1955a

Figura 7. Apliques e fragmentos de borda agrupados no estilo Globular. Adaptado de Hilbert, 1955a.

Figura 8. Elementos destacados na descrição de Hilbert (1955a) em relação às características dos pés trípodes. Adaptado de Hilbert, 1955a.

Figura 9. Cronologia de formação das coleções de cerâmica no baixo curso dos rios Trombetas e Nhamundá. $\mathrm{MD}=$ Musée Dobrée; $\mathrm{PM}=$ 'Penn Museum; NMAI = National Museum of American Indian; VM = Världskulturmuseet; MI = Museu do Índio (Lagoa Seca, PB); MEP = Museu do Estado de Pernambuco; MHN = Museu de História Natural e Jardim Botânico da UFMG; MAE = Museu de Arqueologia e Etnologia da USP; MPEG = Museu Paraense Emílio Goeldi; MN = Museu Nacional da UFRJ 
Figura 10. Apliques e fragmentos de borda coletados por Barbosa Rodrigues nas adjacências do Lago Parú. Essas são provavelmente as primeiras figuras de cerâmica arqueológica do Baixo Amazonas que foram publicadas. Adaptado de Barbosa Rodrigues, 1876.

Figura 11. Organograma mostrando algumas das relações estabelecidas entre pesquisadores, colecionadores e diretores de museu as décadas de 1920 e 1950

Figura 12. Fotografia de Curt Nimuendajú com texto no verso "Minha canoa no lago Curumucury”. Esse lago atualmente se situa no município de Juruti e os sítios arqueológicos da área apresentam cerâmica Konduri. Foto: Curt Nimuendajú. Coleção Etnográfica Carlos Estevão de Oliveira/Museu Virtual. Disponível em: $<$ http://www3.ufpe.br/carlosestevao/> Acesso em 14 de dezembro de 2018.

Figura 13. Fotografia enviada pelo bispo Amando ao Museu Universitário da Filadélfia mostrando o padre Mayer no local onde teriam sido encontrados dois vasos efígie. Arquivo Penn Museum/ Pasta John Mayer.

Figura 14. Vista de Getúlio Vargas ao Museu Paraense Emílio Goeldi em 1940. Ao seu lado a direita está o diretor, Carlos Estevão, e a sua esquerda o interventor José Gama Malcher. Fonte: Coleção Etnográfica Carlos Estevão/Museu Virtual. Disponível em: < https://www3.ufpe.br/carlosestevao/museu-virtual-fotoetno.php> Acesso em 21 de novembro de 2018. 96

Figura 15. Página da revista Vida doméstica com fotografias da coleção reunida por Anibal Freire. A partir da consulta ao acervo da Reserva Técnica de Mário Simões e ao relatório de pesquisa de Cristiana Barreto (2014) foi possível identificar as peças maiores. Fotos: Barreto (2014 - estatuetas a esquerda) e Marcony Alves, 2018 (vasos). Essas peças foram erroneamente associadas as coletas de Curt Nimuendajú durante a reorganização das coleções na década de 1960.

Figura 16. Casal Rose e Robert Brown em 1944 ao lado da jornalista, à esquerda. Ao fundo, em uma estante, é possível ver um vaso de cariátides, um vaso efígie e uma estatueta cerâmica. As duas primeiras peças foram incluídas em diferentes estudos arqueológicos da cerâmica Santarém e catálogos de peças arqueológicas. Fonte: Diário Carioca, 19/11/1944, p.3. 99 
Figura 17. Helen Palmatary com dois vasos efígie que na época pertenciam à coleção de Carlos Liebold. Atualmente ambas pertencem a Coleção Tapajônica do MAE-USP. Fonte: Palmatary, 1960.

Figura 18. Ubirajara Bentes em seu escritório ao lado de um vaso efígie que pertenceu a coleção Liebold e atualmente faz parte da Coleção Tapajônica do MAE-USP. Disponível em: < http://ignacioneto.blogspot.com/2012/04/em-santarem-para-ao-lado-do-hotel-nova.html>. Acesso em 21 de dezembro 2018 104

Figura 19. Fluxo de peças arqueológicas (venda e doação) do sítio a grandes museus. As setas indicam a direção da circulação dos objetos, a partir dos casos estudados na documentação dos museus e nas reservas técnicas 108

Figura 20. Apliques com modificações recentes (incisões e pintura): a. pé de vasilha trípode com incisões e furo formando cara (coleção Ubirajara Bentes/ Coleção Tapajônica MAEUSP); b. aplique pintado com tinta óleo verde e esmalte de unha rosa (coleção Aricy Curvello MHN-UFMG); c. aplique pintado com esmalte de unha roxo (coleção Aricy Curvello MHNUFMG);

Figura 21. Gargalo com pintura de esmalte de unha roxo da coleção doméstica da senhora Laudelina (Comunidade de Ajará, Lago Sapucuá) na cidade de Oriximiná. Foto: Marcony Alves, 2014.

Figura 22. Quadrantes sugeridos por Pearce como articuladores da classificação de objetos no pensamento ocidental moderno

Figura 23. Vasilha identificada como "vaso globular Konduri" em um catálogo e no site da instituição ～(http://www.museunacional.ufrj.br/dir/exposicoes/arqueologia/arqueologiabrasileira/arqbra001.html). Extraído de O Museu Nacional (1986).

Figura 24. Superfície repleta de fragmentos cerâmicos em um dos sítios arqueológicos visitados por Peter Hilbert em 1952. Arquivo pessoal Klaus Hilbert/ MCT-PUCRS..... 126

Figura 25. Sondagem realizada durante o campo de 1952 por Peter Hilbert. Fotografia sem identificação de sítio arqueológico. Fonte: Acervo Pessoal de Klaus Hilbert/ MCT-PUCRS. 
Figura 26. Fragmentos Konduri com etiqueta da Comissão Geológica Imperia/MN.

Figura 27. Dois fragmentos da coleção Barbosa de Faria com indicação de proveniência diferente no livro tombo que remontam. Durante o transporte ou curadoria as peças se misturaram e foram associdas a sítios distintos.

Figura 28. Fragmentos das coleções 881 e Peter Hilbert (1952) no acervo do MPEG: a fragmento com indicação de proveniência em letra cursiva; b - fragmento com texto atribuído por Hilbert a Nimuendajú; c - fragmento com proveniência indicada por Hilbert. 133

Figura 29. Materiais com marcações com uma única inicial, provavelmente realizadas por Protásio Frikel: a-b coleção Charles Townsend (MPEG) ; c-d coleção Protásio Frikel (Museu do Índio, Lagoa Seca, PB).

Figura 30. Fragmentos da coleção 006 (MP) e Luís Paixão (APA): a - fragmento da coleção do MP que pertenceu à coleção Paixão; b - fragmento sem número de registro coletado por Harald Schultz em 1950 no sítio Santa Rita (Parintins); c- fragmento da coleção Paixão (APA) identificado em foto de 1935.

Figura 31 Fragmentos da coleção Tapajônica (MAE-USP): a - marcações do colecionador e da instituição; b - diferentes marcações da instituição. 138

Figura 32. Vista do sítio Araticum (PA-OR-77) cortado pela estrada. Este é o mesmo sítio identificado por Aricy Cuvello na década de 1970. Fonte: Brandt, 1996.

Figura 33. Comparação entre vasilha Pocó (sítio Terra Preta) e apêndices "globulares". Coleções 881, (a-b), Peter Hilbert (b-d), Barbosa de Faria/Comissão Rondon (f). Proveniência: a-b (Trombetas enseada), b-d (Oriximiná), Lago Paru. 151

Figura 34. Conjuntos cerâmicos reunidos a partir de suas características formais na região entre Juruti e rio Trombetas. Notar que os estilos "não locais" estão associados ao estilo Konduri neste esquema. A cerâmica Pocó e "Santa Rita" são as mais antigas e a histórica tardia, a mais recente. 155

Figura 35. Gráfico de estimativa de porcentagem de antiplástico na pasta cerâmica. Adaptado de Orton e Hughes (2013). 
Figura 36 Antiplásticos do sítio Posto Aurora II, (Coleção Aricy Curvelo). A foto F é de uma peça coletada por Peter Hilbert no lago de Faro.

Figura 37. Métodos de construção das vasilhas: uso de ranhuras de ligação (a-d), produção de assadores sobre trançado (e-f), furos para unir borda de paredes (g-h).

Figura 38. Apliques ocos e com furo de ventilação. a - pé oco; b- pé oco com furo retilíneo; cpé oco com furo cônico; d- pé maciço com furo com o dedo; e - pé maciço com furo; f - pé com ocagem pouco profunda; g- pé com ocagem profunda. h- pé oco com ocagem rasa e furo; i- apêndice oco com furo; j - apêndice aplicado em borda oco. Proveniência/procedência:aTerra Preta (Col. Peter Hilbert); b- Ponta da Mafada (Col. Peter Hilbert); c- Sucurijú (Col. Barbosa de Faria); d - Babaçu (Col. Peter Hilbert e Harald Schultz); e- Posto Aurora II (Col. Aricy Curvello); f - sem proveniência (Col. Tapajônica); g- Araticum (Col. Aricy Curvello); h- Lago Batata (Col. Aricy Curvello); i- Posto Aurora II; j- sem proveniência (Col. Tapajônica).

Figura 39. Fragmento bastante erodido com vestígio de alisamento fino abaixo de um ângulo. Procedência: Coleção Tapajônica/ MAE-USP.

Figura 40. Fragmento de borda encontrado ainda articulado a outros fragmentos no sítio Greig II. Sua superfície mostra-se bastante erodida. Adaptado de Castro, 2018. 197

Figura 41. Tipos de configuração do núcleo. A face externa nessa figura é convexa (superior) e a interna é côncava (inferior).

Figura 42. Vasilhas inteiras ou semi-inteira. Proveniênci/ procedência: a-b Oriximiná (Col. Frederico Barata); c- Cajual (Col. Peter e Klaus Hilbert); d - Trombetas enseada (Col. T-881); e - Lago Sapucuá (doador desconhecido).

Figura 43. Vasilhas possivelmente relacionadas ao estilo Konduri. Proveniência/procedência: Superior (Superior/ Col. Paul Le Cointe); Inferior(Lago Grande de Curuaí/ Doação Harald Sioli). 204

Figura 44. Classificiação de morfologias a partir das reconstituições. 205

Figura 45. Pratos concêntricos ou vasilhas de dupla borda do estilo Santarém. Não são conhecidos exemplares com "segunda borda" na cerâmica Konduri. 
Figura 46. Diferença entre apêndices em pleno relevo (a-d) e apêndices achatados (e-h). As peças a e e são apêndices não figurativos. Proveniência/procedência: a - Posto Aurora II (Col. Aricy Curvello); b - Alema (Col. Aricy Curvello); Terra Santa (Col. Peter Hilbert); d Aimim (Col. Aricy Curvello); e - Faro (Col. Aricy Curvello); f- Cocal (Col. Peter Hilbert); g - Posto Aurora II (Col. Aricy Curvello) h - Ponta da Mafada (Col. Peter Hilbert).

Figura 47. Pés ou suportes com diferentes proveniências e tamanhos.

Figura 48. Detalhe da produção de cuias pintadas em Monte Alegre (José Joaquim Freire, 1785). Disponível em http://objdigital.bn.br/acervo_digital/div_manuscritos/mss1255454/mss1255454.htm. Acesso em 21 de junho de 2019. 220

Figura 49. Projeções de vasilhas Konduri com pés trípodes, uma vasilha com abertura restrita e mais profunda e dois assadores. Proveniência: a- Santo Antônio (Coleção Peter Hilbert); bPosto Aurora II; c- Babaçu.

Figura 50. Pés com marcas de corte na porção superior. Proveniência/procedência:a- Fortaleza (Col. Peter Hilbert e Harald Schultz); b- Sacuri (Col. Barbosa de Faria); c- Lago Batata (Col. Aricy Curvello); d- Ponta da Mafada (Col. Peter Hilbert).

Figura 51. Alças. Proveniência/procedência: a- Pocó (Col. Peter e Klaus Hilbert); b- sem procedência (Col. Tapajônica); c - Cocal (Col. Barbosa de Faria); d - Posto Aurora II (Col. Aricy Curvello e- sem proveniência (Col. Frederico Barata); f- sem proveniência (Col. Tapajônica); g- sem proveniência (Col. Peter Hilbert e Harald Schultz); ); h - Faro (Col. Charles Townsend Jr.); i- rio Trombetas (Col. Luís Paixão/MP); j - Porto Trombetas (Col. Aricy Curvello); k - Faro (Col. Peter Hilbert).

Figura 52. Rodelas de tortual de fuso. Proveniência/procedência: a- Santa Maria (Col. Barbosa de Faria); b - Terra Santa (Col. MD 112).

Figura 53. Fragmentos com canaletas (a-b) e furos pós-queima (c-d). Proveniência/procedência: Juruti Velho? (Col. Peter Hilbert e Harald Schultz); b - Mabaia (Col. Peter Hilbert); c - Babaçu (Col. Peter Hilbert e Harald Schultz); d - Serrinha (Col. Peter Hilbert). 227 
Figura 54. Brunidura (a-c) e possível resina (d). Proveniência/procedência: a - sem proveniência (Col. Tapajônica/ Foto: Alexandre Reocaro); b - Lago Batata (Col. Aricy Curvello/Foto: Caroline Teixeira); c - Posto Aurora II (Col. Aricy Curvello/Foto: Caroline Teixeira); d - Posto Aurora II (Col. Aricy Curvello).

Figura 55. Apêndice achatado com presença de pintura na face interna e externa, além de detalhes da incisão e entralhe aplicados na pasta úmida. Proveniência/procedência: Posto Aurora I (Col. Aricy Curvello).

Figura 56. Fragmentos com vestígios de pintura vermelha (a-f), vermelha e amarela (g-h) e amarela (i, j). Proveniência/procedência: a- Posto Aurora II (Col. Aricy Curvello/ Foto: Caroline Teixeira); Babaçu (Col. Peter Hilbert e Harald Schultz); c - Posto Aurora II (Col. Aricy Curvello); d - Oriximiná (Col. Peter Hilbert); g e- Terra Santa (Col. Peter Hilbert/PUCRS); f - sem referência (Col. Tapajônica); g- sem referência (Col. Charles Townsend Jr.); h- Oriximiná (Col. Peter Hilbert); i- Posto Aurora II (Col. Aricy Curvello); j sem proveniência (Col. Tapajônica).

Figura 57. Pintura preta sobre engobo vermelho (a-b) e pintura preta aplicada diretamente sobre o suporte (c-d). Proveniência/procedência: a - Lago Batata (Col. Aricy Curvello); b- rio Trombetas (Col. Barbosa de Faria); c- Porto Trombetas (Col. Aricy Curvello); d - Greig II (Projeto Arqueológico Porto Trombetas).

Figura 58. A aplicação das técncias decorativas plásticas na cerâmica Konduri: possíveis instrumentos e gestos. Desenhos autorais e d extraído de Shepard, 1956. 237

Figura 59. Combinação de técnicas decorativas plásticas na cerâmica Konduri. Proveniência/procedência: a- Faro (Col. Peter Hilbert); b- sem proveniência (Col. Frederico Barata); c- Jacupá (Col. Barbosa de Faria); d- Posto Aurora II (Col. Aricy Curvello)..........238

Figura 60. Elementos decorativos usados na composição dos olhos em apêndices e motivos gráficos

Figura 61. Padrões incisos Proveniência/procedência: a- sem proveniência (Col. Frederico Barata); b- sem referência (Col. Comissão Rondon); c- Santo Antônio (Col. Peter Hilbert); d Oriximiná (Col. Peter Hilbert); e - Serrinha (Col. Peter Hilbert); f- Sacuri (Col. Barbosa de Faria); g - Babaçu (Col. Peter Hilbert e Harald Schultz); h - Serrinha(Col. Peter Hilbert); i Sacuri (Col. Barbosa de Faria); j - Fortaleza (Col. Peter Hilbert e Harald Schultz); k - Babaçu 
(Col. Peter Hilbert e Harald Schultz); 1 - Fortaleza (Col. Peter Hilbert e Harald Schultz); m Mabaia (Col. Peter Hilbert); n - Oriximiná (Col. Peter Hilbert); o - Serrinha (Col. Peter Hilbert); p - Posto Aurora II (Col. Aricy Curvello); q - Fortaleza (Col. Peter Hilbert e Harald Schultz); r - Babaçu (Col. Peter Hilbert e Harald Schultz); s - Cocal (Col. Peter Hilbert)... 241

Figura 62. Apêndices aviformes e sua diversidade morfológica. Proveniência/procedência: a sem proveniência (Col. Tapajônica); b- Terra Santa (Col. Peter Hilbert); c - sem proveniência (Col. Charles Townsend Jr.); d - Santa Maria (Col. Barbosa de Faria); e - Fortaleza (Col. Peter Hilbert e Harald Schultz); f - sem proveniência (Col. Peter Hilbert); g - sem proveniência (Col. Comissão Rondon); h - sem proveniência (Col. Peter Hilbert); i - sem proveniência (Col. Tapajônica); j- Terra Preta 1/2/ Juruti (MD-19); k - sem proveniência (Col. Peter Hilbert)

Figura 63. Disposição nos apêndices em vasilhas: refletidos em eixos de simetria (a-b) ,apêndice compondo a partir do corpo da vasilha um zoomorfo (c) e suportes sugerindo possíveis pés de seres zoomorfos (d-e), como ocorre em vasilhas tetrápodes Wauja (f/ extraído de Ribeiro, 1988). 246

Figura 64. Apêndices do grupo "A" composto por figuras zooantropomorfas aplicadas ao lábio. Proveniência: Superior, Posto Aurora II (Col. Aricy Curvello); a - Posto Aurora II (Col. Aricy Curvello); b- Santa Maria (Col. Barbosa de Faria); c - Aibi (Col. Peter Hilbert); d Terra Santa (Col. Aricy Curvello); e- Oriximiná (Col. Peter Hilbert); f- Boca dos Anjos (Col. Barbosa de Faria).

Figura 65. Homem Wai Wai com um grande tubo de cabelo com plumas na extremidade. Esse elemento pode ser análogo ao encontrado em apêndices do Grupo A. Disponível em: https://samlinger.natmus.dk/ES/asset/222327 Acesso em 25 de junho de 2019. 250

Figura 66. Grupos de apêndices B, C, D, E, F, e G. Proveniência/procedência: a - Ponta da Mafada (Col. Peter Hilbert).b, h, 1 - sem proveniência (Col. Tapajônica); c, d - Babaçu (Col. Peter Hilbert e Harald Schultz); d, f - Santo Antônio (Col. Peter Hilbert); e- Cocal (Col. Peter Hilbert); g- Abuí (Col. Barbosa de Faria); i - sem proveniência (Col. Charles Townsend Jr.); j, n - Oriximiná (Col. Peter Hilbert); m - sem proveniência (Col. Frederico Barata); n Alema (Col. Aricy Curvello); o - Cocal (Col. Barbosa de Faria); p - Posto Aurora II (Col. Aricy Curvello). 
Figura 67. Motivo cara antropomorfa delimitada por retângulo (a, c, d), com nariz (b), com elemento sobre o rosto (botão) semelhante a nariz (d-e), sobreposta por ave (s) ou zoomorfo indeterminado (f-i). Proveniência/procedência: a, f- Terra Santa (Col. Charles Townsend Jr.); b, d - Sacuri (Col. Barbosa de Faria); c- Posto Aurora II (Col. Aricy Curvello); g- sem proveniência (Col. Tapajônica); h - Terra Preta/Juruti (Col. Protásio Frikel/PUCRS); i - Serra do Matió (Col. Peter Hilbert)

Figura 68. Aro emplumado com pingente de pele de ave atada ao aro produzido pelos Tiriyó do rio Erepecuru. Esse elemento pode ter sido figurado tanto nos apêndices do Grupo A quanto no motivo cara antropomorfa. Fonte: O MUSEU GOELDI (1986). 256

Figura 69. O "dualismo" na iconografia Konduri. Pés com motivo cara antropomorfa em posição invertida a orientação da vasilha (a-c); apêndice do Grupo A com cara sugerida em posição da borda para cima e emborcada (d); apêndice com cara sugerida na lateral e também vista da face interna (e). Proveniência/procedência: a- sem proveniência (Col. Rose e Robert Brown/ extraído de Barata, 1950); b- sem proveniência (Col. Walter Marinho/ foto Igor Rodrigues); c - sem proveniência (Col. Charles Townsend Jr.); d- Pocó (Col. Peter e Klaus Hilbert); e - Óbidos (Col. Comissão Rondon). 258

Figura 70. Variedades de caraipé (ou caripé) utilizados atualmente por ceramistas no município de Juruti. Notar primeiro monte a esquerda com elementos maiores e mais grossos e o outra, à direita, com elementos mais finos. Ceramistas na comunidade pesquisada denominam o primeiro como "caripé-vidro" e o outro apenas como "caripé". Extraído de Panachuk, 2011.

Figura 71. Vasilhas cerâmicas do Alto Xingu com cauixi em alta concentração na pasta: a produção Kuikuro com feixe de cauixi; b - produção Wauja com espículas relativamente alinhadas. Coleção particular (doação de Iandé Arte Indigena). 264

Figura 72. Borda com aplique grosso e maciço aplicado ao lábio. Coleção Idelza/ Lago Sapucuá 268

Figura 73. Peças associadas por diferentes autores a uma relação entre os produtores das cerâmicas Konduri e Santarém: a) prato de dupla borda da coleção Frederico Barata mencionado por Hilbert (1955a); b) prato de dupla borda mencionado por Palmatary (1960); c) aplique "cabeça de urubu" encontrado por Nimuendajú no Lago Sapucuá; d) aplique cabeça 
de urubu da coleção Barbosa de Faria mencionado por Palmatary (1960). Extraído respectivamente de Hilbert (1955a), Palmatary (1960), Nordenskiold (1930) e Palmatary (1960).

Figura 74. Fragmento de prato concêntrico classificado como parte do "Modo Konduri Incisões Retilíneas" e considerado um marcador de "influências" Santarém sobre a cerâmica Konduri em Gomes (2002). Coleção Tapajônica/MAE-USP. 273

Figura 75. Partes estruturais dos vasos de gargalo. coleção Valentim Bouças, Museu Nacional/Universidade Federal do Rio de Janeiro, Rio de Janeiro. Extraído de Alves, 2018.

Figura 76. Diversidade morfológica, de apêndices e motivos incisos em vasos de gargalo Santarém. Coleção Frederico Barata (MPEG). Motivos incisos de diferentes coleções (Adaptado de Alves, 2016) 284

Figura 77. Partes dos vasos de gargalo. Proveniência: sem informação (a, e, r), lago Sapucuá (b,j), Sucurijú (c), Sacuri (d, f, g), Cocal (h, u), Conuri (k), Santa Maria (k-m, s), Porto Trombetas (o), Aimim (p-q), coleções Tapajônica (a,e, r), Peter Hilbert (b,h,i), Aricy Curvello (o-q), Rosilane/Conuri (j, n) e Barbosa de Faria/Comissão Rondon (c, d, f, k-m, s-u) 287

Figura 78. Vasos de gargalo com as mesmas características dos fragmentos identificados nas coleções com cerâmica Konduri: a- peça coletada por indígenas no rio Mapuera (aldeia Tamiúru)/Foto Rogério Tobias. B- vaso de gargalo coletado no rio Acaupu/Coleção Curt Nimuendajú (MPEG); c- vaso sem proveniência da coleção Protásio Frikel (Museu do Índio, Lago Seca/PB). Foto: Ana Carolina Cunha. 288

Figura 79. Pasta de vasos de gargalo com alta concentração de caco moído e predominância de núcleos escuros. Fragmentos das coleções Peter Hilbert (a-b), Aricy Curvello (c-e) e Projeto Norte Amazônico (f).

Figura 80. Perfil de diferentes fragmentos que compõem vasos de gargalo: gargalos (a-c), bojo lobado (d-e), anelar (f), apêndices em forma de cabeça de ave (g) e batraquiformes com variações de modos de construção (h-j). Coleções Peter Hilbert (a, d), Barbosa de Faria/Comissão Rondon (b,-c, e-f, h-j) e Aricy Curvello (g). 293 
Figura 81. Fragmentos de vasos de gargalo coletados por Nimeudajú no Lago Grande de Curuaí. Esses fragmentos exibem características muito similares à dos encontrados na área de dispersão da cerâmica Konduri.

Figura 82. Estatuetas antropomorfas com base semilunar do estilo Santarém. Extraído de Funarte (1981), à esquerda, e Barros et al. (2015), à direita.

Figura 83. Fragmentos de estatuetas encontradas em contextos Konduri. Coleção Idelza/Conuri (a, h), Oriximiná (b), Terra Preta 1/2 (c), Sacuri (d, m), Santa Maria (e, i), Cuminá (f) lago Juruti Velho (g), Fortaleza (j), Babaçu (k), lago Sapucuá (n). Coleção Peter Hilbert (b), Peter Hilbert e Harald Schultz (g, j, k) Barbosa de Faria/Comissão Rondon (d-f, i, m-n), material doado/MPEG (c) e Idealza/Conuri (a, h). 296

Figura 84. Fragmentos de estatueta provenientes do sítio João Braz Material doado (MPEG).

Figura 85. Estatueta e fragmentos de estatueta distintos. Proveniência: Terra Santa (a), Boca dos Anjos (b), Oriximiná (c-d). Coleções Barbosa de Faria/Comissão Rondon (b), Peter Hilbert (b-c) e material doado/MPEG (a).

Figura 86. Outros fragmentos com características do estilo Santarém. Proveniência: Fortaleza (a, h), Sacuri (b, d, e, i), Ilha Paru (f) Oriximiná (g). Coleções Peter Hilbert (a, c, h) e Barbosa de Faria/Comissão Rondon (b, d-g, i).

Figura 87. Cerâmicas do grupo "pasta laranja" associado ao estilo Santarém. Proveniência: Santa Maria (a-c), Castanhal (d), Sacuri (f), Cocal (m), Babaçu (n), Oriximiná (h), rio Trombetas (e), Conuri (g), sem referência (i, k), Faro (j), Sucurijú (1). Coleções Barbosa de Faria Comissão Rondon (a-c, e-f, k), Peter Hilbert (j, m), Peter Hilbert e Harald Schultz (i, n), superfície da comunidade de Castanhal (d), coleção Reuni/Conuri. 302

Figura 88. Apêndices em forma de "morcego" (a) e caras antropomorfas na coleção Nimuendajú. (b-d). Proveniência: Santarém (a,b, d) e Carariacá/Lago Grande (c). 303

Figura 89. Fragmentos do estilo Paurá. Coleção Nimuendajú (a-d) extraído de www.varldskulturmuseerna.se; coleção 006 (MAE/USP)/ Fotos: DAPE/MAE. 304 
Figura 90. Fragmentos de cerâmica do estilo Paurá nas coleções de cerâmica Konduri. Proveniência: Mabaia (a), Serrinha (b), Varre Vento (c), sem proveniência (d), Sacuru (e), Preguiça (f), Boa Vista (g). Coleções Peter Hilbert (a-c), Barbosa de Faria/Comissão Rondon (d-f) e material de superfície (SOUZA, sd) 305

Figura 91. Fragmentos de cerâmica Espinha de Peixe: Erepecuru (a-b), Cocal (b-c, k, m), Oriximiná (e), Lago Batata (f-i), Sucurijú (j, 1), Sacuri (n). Coleções Barbosa de Faria/Comissão Rondon (j, 1, m, n), Peter Hilbert (a-e, k) e Aricy Curvello (f-i). 308

Figura 92. Elementos antiplásticos e concentração na cerâmica Espinha de Peixe: Erepecuru (a, d), Cocal (b, e) e Lago Batata (c, f). Coleções Peter Hilbert (a,b, d, e ) e Aricy Curvello (c, f). A indicação "fd" marca feldspato e "qz", quartzo 309

Figura 93. Reconstituições e perfis de borda de vasilhas Espinha de Peixe. 312

Figura 94. Elementos vinculados ao estilo Konduri por meio de ancestralidade comum e/ou difusão . Assadores: a- Santarém (Nimuendajú, 2004); b- Saracá (Machado, 1991); c-Paredão (Hilbert, 1968/ Moraes, 2013); d - Sawré Muybu (Rocha, 2017). Alças sobre orifício: e Paredão (Moraes, 2006); f/g - Paredão (Hilbert, 1968); h- Saracá (Stampanoni, 2016); i Saracá (Machado, 1991); j’- Axinim (Bars Hering et al., 2014); k - Manacapuru (Hilbert, 1968). Pés modelados: 1- Saracá (Machado, 1991); m - Santarém (Nimuendajú, 2004); n Santarém (Coleção Tapajônica/MAE-USP/Desenho Marcony Alves); o - Axinim (Simões; Lopes, 1987). 320

Figura 95. Borda do estilo Santarém encontrada por Nimuendajú no baixo curso do rio Iriri, afluente do Xingu. Fotografia disponível em www.varldskulturmuseerna.se. Desenho adaptado de Nimuendajú, 2004, p. 227. 324

Figura 96. Indígena Palikur transportando uma grande vasilha para armazenamento de bebida fermentada em uma canoa. Vasilhas durante o período pré-colonial podem ter sido transportadas da mesma maneira; as menores, como os vasos de gargalo de mais fácil transporte. Extraído Vidal, 2015. 328

Figura 97. Rede de circulação de bens industrializados no começo do século XX nas Guianas. Adaptado de Barbosa, 2005 331 


\section{Lista de tabelas}

Tabela 1. Semelhanças entre as cerâmicas Santarém e Konduri. Extraído de Hilbert (1955a:73).

Tabela 2. Diferença entre as cerâmicas Santarém e Konduri. Sintetizado de Hilbert (1955a:73)

Tabela 3. Quantidade de fragmentos cerâmicos por sítio arqueológico na quantificação realizada por Guimarães (1985) e na realizada em 2017. O asterisco $\left(^{*}\right)$ indica que foram incluídas as 3 peças que se perderam na reserva técnica de arqueologia do MHN

Tabela 4. Sítios com localização com confiabilidade média representados nas coleções...... 148

Tabela 5. Sítios com localização com confiabilidade baixa representados nas coleções....... 149

Tabela 6. Sítios com localização com confiabilidade alta representados nas coleções

Tabela 7. Quantidade total de peças analisadas por estilos cerâmicos em cinco instituições.153

Tabela 8. Quantidade de peças analisadas em relação ao total de cada coleção e sua organização nas instituições. 160

Tabela 9. Materiais com informação de proveniência destacados ao longo do capítulo....... 162

Tabela 10. Fragmentos de vasos de gargalo em coleções estudadas. 292

Tabela 11. Proveniência de fragmentos do estilo Paurá em coleções da região dos rios Trombetas e Nhamundá. 306

Tabela 12. Quantidade de fragmentos do estilo Espinha de Peixe por proveniência. 311

Tabela 13. Complexos cerâmicos do Baixo e Médio Amazonas com elementos morfológicos compartilhados com o estilo Konduri. Fontes: Gomes, 2016; Gomes, 2008; Rocha, 2017; Moraes, 2013; Moraes, 2006, Stampanoni, 2016 


\section{Lista de gráficos}

Gráfico 1. Quantidade por tipos de fragmentos coleções ocasionais. O asterisco (*) indica que foram incluídas as peças consideradas Konduri, selecionadas em meio ao conjunto com outros estilos

Gráfico 2. Quantidade por tipo de fragmento em coleções diagnósticas. O asterisco (*) indica que foi considerada apenas parte da coleção $(82,2 \%)$.

Gráfico 3. Quantidade de sítios com diferentes quantidades de peças nas coleções diagnósticas. 150

Gráfico 4 Datações calibradas obtidas para o sítio Boa Vista entre 500 a.C e 1500 AD a partir de informações publicadas em Guapindaia (2008). Fonte: OxCal v4.2.4 (Ramsey; Lee, 2013), r:5 SHCal13 atmospheric curve (Hogg et al., 2013)

Gráfico 5 Datações obtidas para o sítio Cipoal do Araticum entre 500 a.C e 1500 AD publicadas em Guapindaia e Fonseca (2013) . Fonte: OxCal v4.2.4 (Ramsey; Lee, 2013), r:5 SHCal13 atmospheric curve (Hogg et al., 2013)

Gráfico 6 Datações radiocarbônicas publicadas e inéditas posteriores ao ano 1000 AD em sítios com cerâmica Konduri. Fonte: Hilbert; Hilbert, 1980; Guapindaia, 2008; Guapindaia; Chumbre, 2012; Guapindaia; Fonseca, 2013; Panachuk, 2016a; Hilbert, sd. Fonte: OxCal v4.2.4 (Ramsey; Lee, 2013), r:5 SHCal13 atmospheric curve (Hogg et al., 2013)....

Gráfico 7. Frequência de combinações de antiplástico nas peças Konduri analisadas neste estudo 181

Gráfico 8. Porcentagem de combinações de antiplástico por proveniência. Abreviações: $\mathrm{cx}=$ cauixi; $\mathrm{mn}=$ mineral; $\mathrm{cm}=$ caco moído/chamote; $\mathrm{bt}=$ bolota de argila $; \mathrm{cp}=$ caraipé $; \mathrm{cv}=$ carvão; ind = indeterminado

Gráfico 9. Frequência de classe de concentração de cauixi nas peças Konduri analisadas. 186

Gráfico 10. Frequência de classe de concentração de antiplásticos minerais isolados ou associados a cauixi. 
Gráfico 11. Frequência de intervalos de comprimento máximo de elementos antiplásticos a partir de todas as peças Konduri analisadas neste trabalho.

Gráfico 12. Porcentagem e frequência de uso do método de ocagem e/ou furo de ventilação em pés modelados.por proveniência

Gráfico 13. Porcentagem de classe tratamento de superfície na face externa por proveniência

Gráfico 10. Porcentagem de classes de coloração por proveniência.

Gráfico 15. Porcentagem configuração de núcleo por proveniência.

Gráfico 16. Quantidade por espessura nas coleções analisadas

Gráfico 17. Frequência de classes morfológicas por proveniência.

Gráfico 23. Frequência de intervalos de diâmetros nas classes morfológicas 4, 5,6 e 7.....208

Gráfico 19. Frequência de classes de inclinação de borda por sítio.

Gráfico 19. Frequência de classes de lábios por sítio.

Gráfico 20. Frquência de classes de base por sítio.

Gráfico 22. Frequência de pés modelados considerando todas as peças analisadas com informação de proveniência.

Gráfico 23. Altura e comprimento máximo (junção com a base) de pés modelados quatro amostras.

Gráfico 24. Frequência de combinações de técnicas de decoração plástica identificadas nas peças Konduri analisadas.

Gráfico 25. Frequência de áreas de aplicação de técnicas de decoração plástica nas amostras de cerâmica Konduri analisadas. FE = Face Externa; FI = Face Interna. 236

Gráfico 26. Frequência de antiplástico em fragmentos de vasos de gargalo. Coleções Aricy Curvello, Barbosa de Faria/Comissão Rondon, Peter Hilbert (1952), Peter Hilbert e Harald Schultz (1953), 881, 1564 e material doado (MPEG). 
Gráfico 27. Comparação entre diâmetros dos vasos de gargalos inteiros provenientes do sítio Aldeia e adjacências e os gargalos associados a mesma morfologia encontrados em coleções provenientes do rio Trombetas.

Gráfico 28. Antiplástico em fragmentos de estatuetas antorpomorfas nas coleções Barbosa de Faria/Comissão Rondon, Peter Hilbert e Aricy Curvello. 297

Gráfico 29. Frequência por tipo de antiplástico em cerâmica Espinha de Peixe nas coleções Aricy Curvello, Barbosa de Faria/Comissão Rondon e Peter Hilbert. 307

Gráfico 30. Frequência de classes de espessura em cerâmica Espinha de Peixe. Coleções Aricy Curvello, Barbosa de Faria/Comissão Rondon e Peter Hilbert. 310 


\section{Lista de mapas}

Mapa 1. Mapa feito por Nimuendajú sintetizando a distribuição dos estilos Tapajó e variantes no rio Arapiuns e Monte Alegre (vermelho) e Kondurí (azul) no Baixo Amazonas. É indicada com círculo vermelho a Serra de Parintins, como limite da ocorrência de fragmentos do estilo Tapajó associado ao Kondurí e outros estilos próximo ao rio Xingu. Em azul o autor indica áreas com outros estilos, além de marcar as áreas ocorrência de urnas funerárias (graburnen). Extraído de Hilbert, 1986

Mapa 2. Detalhe do mapa publicado por Oliveira (1939) em que ele apresenta várias localizações de sítios arqueológicos na região do Baixo Amazonas. Os únicos sítios identificados na bacia do rio Trombetas são lago do Jacaré e Oriximiná (Uruximiná). Adaptado de Oliveira, 1939

Mapa 3. Localização aproximada de sítios no Google Earth a partir de anotações e croquis de campo produzidas por Peter Hilbert em sua expedição a Juruti e Parintins em 1953. Não há informações sobre o sítio Babaçu, apenas uma correlação entre uma região conhecida e sítios mapeados por Scientia (2003).

Mapa 4. Localização de sítios com amostras nas coleções analisadas. Autor: Henrique Koslowski.

Mapa 5. Localização de sítios arqueológicos com cerâmica Konduri. Dados reunidos a partir da bibliografia e levantamento por meio do programa Google Earth realizado por Klaus Hilbert (sd) para o rio Nhamundá.

Mapa 6. Dispersão aproximada da cerâmica Konduri e uma possível dispersão ainda especulativa sobre áreas desconhecidas.

Mapa 7. Dispersão de materiais cerâmicos provavelmente obtidos por trocas na área de dispersão do estilo Konduri.

Mapa 7. Localização esquemática de complexos cerâmicos do Baixo e Médio Amazonas (Santarém-Manaus) com elementos morfológicos compartilhados com o estilo Konduri. Elaboração: Hnrique Koslowski e Marcony Alves. 
Mapa 9. Mapa de dispersão de muiraquitãs e outros amuletos de pedra verde no norte da América do Sul e Antilhas. Esse mapa não cobre achados mais recentes, como na bacia do rio Xingu. Extraído de Boomert, 1987

Mapa 9. Modelo postulado de sistemas regionais de intercâmbio Arawak no norte da América do Sul por volta do ano 1000 AD. Notar a área de dispersão da cerâmica Konduri marcada parcialmente como parte desses sistemas seguindo o curso do rio Amazoans, mas excluindo a terra firme. Adaptado de Eriksen, 2011 


\section{Sumário}

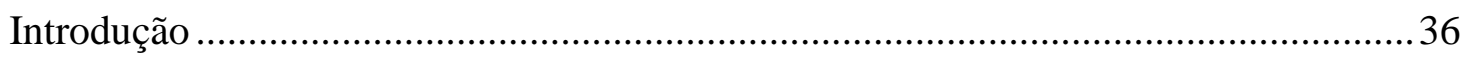

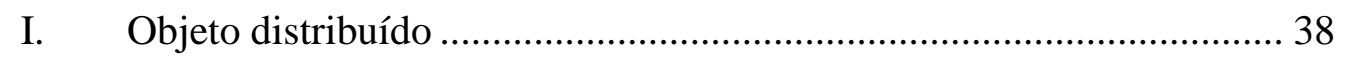

II. A construção de um problema .......................................................... 40

III. Estudo de coleções ................................................................. 42

IV. Estilo técnico e processos históricos.............................................. 45

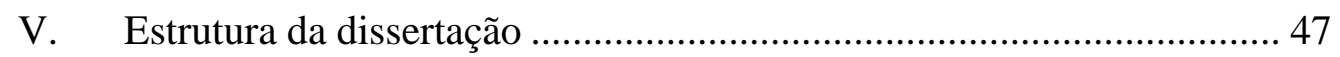

1 Capítulo 1 - A construção do estilo Konduri........................................................ 49

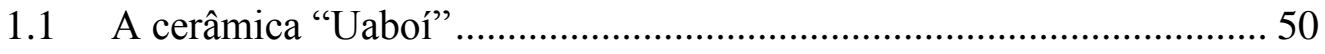

1.2 A primeira construção do estilo Konduri........................................ 53

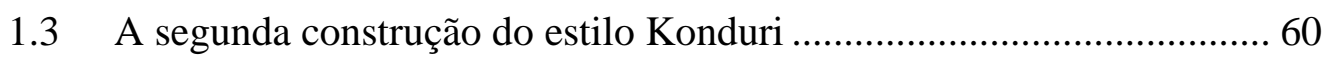

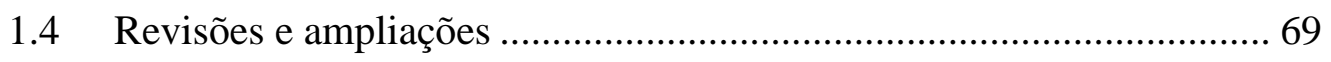

1.5 Estratigrafia, cronologia e outros materiais ................................. 71

1.6 Estilo, complexo, fase ou cultura? .............................................. 73

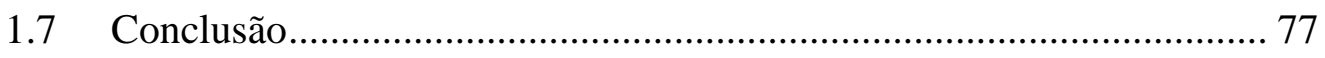

2 Capítulo 2 - A formação das coleções e o seu legado ............................................ 80

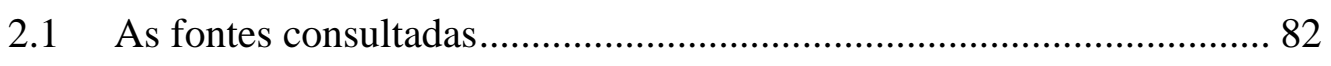

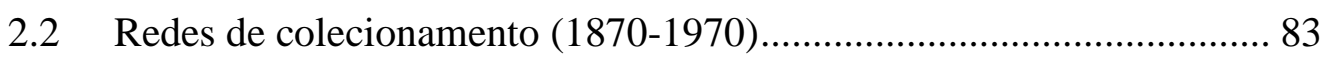

2.2.1 Expedições de mapeamento e os "ídolos de pedra" ..................................86

2.2.2 Nimuendajú e a "descoberta" da cerâmica de Santarém ...........................8 88

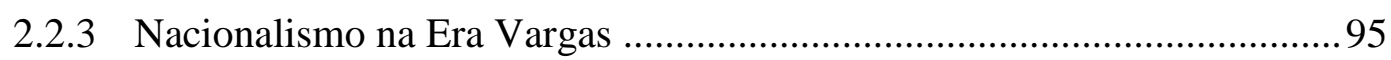

2.2.4 Entre colecionadores, etnólogos e arqueólogos .................................... 98

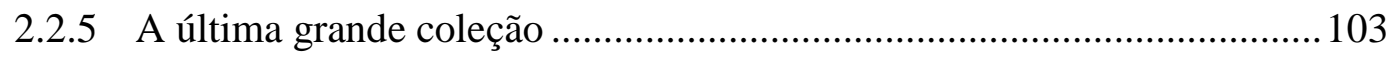

2.3 Artefatos em diáspora ................................................................ 106

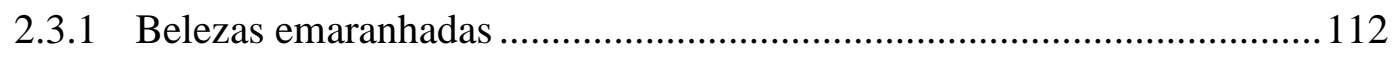


2.3.2 Integridade e fragmentação

2.4 Conclusão: misturas materiais e analíticas

120

3 Capítulo 3 - Problemas metodológicos no estudo de coleções de museu

3.1 Coleta e transporte

3.2 Curadoria e documentação

3.2.1 Museu Nacional

3.2.2 Museu Paraense Emílio Goeldi

3.2.3 Museu de Arqueologia e Etnologia

3.2.4 Museu de História Natural e Jardim Botânico da UFMG

3.3 Composição das coleções 140

3.4 Localização de sítios 143

3.5 Dimensão da população 150

3.6 Problemas de classificação 152

3.7 Método de análise cerâmica 156

3.8 Modelando as amostras 161

3.9 Conclusão 164

4 Capítulo 4 - A cerâmica Konduri em perspectiva regional 166

4.1 Dispersão geográfica e cronologia do estilo 167

4.2 Cadeia operatória e variabilidade técnica 177

4.2.1 Inclusões

4.2.2 Técnicas e métodos de produção

4.2.3 Tratamento e conservação de superfície

4.2.4 Cor da face externa

4.2.5 Configuração de núcleos

4.2.6 Espessura de paredes 201

4.2.7 Morfologia 202 


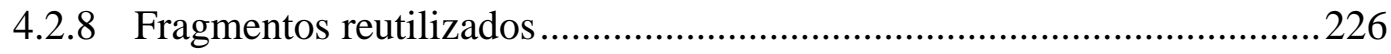

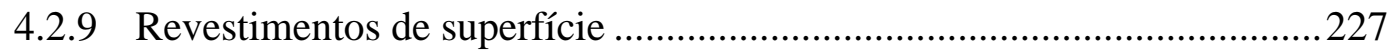

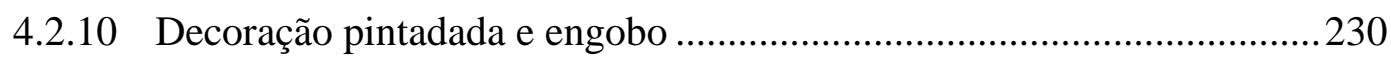

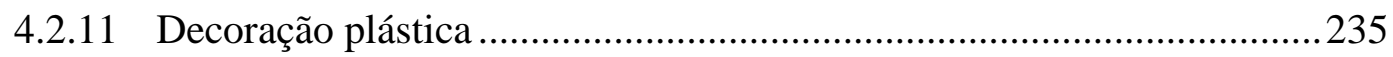

4.3 Iconografia e técnicas visuais ..................................................... 242

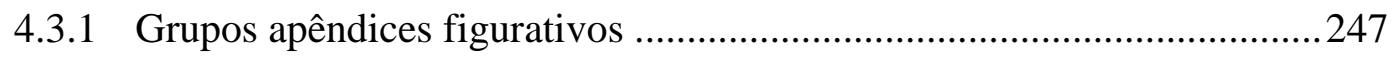

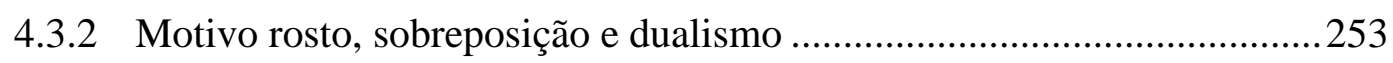

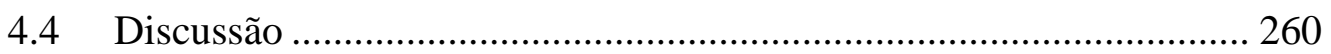

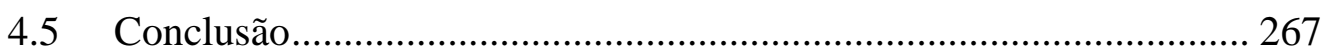

5 Capítulo 5 - Cerâmicas e esferas de interação no Baixo Amazonas ..................... 270

5.1 O problema da “influência Santarém” .............................................. 271

5.2 Diferenciando processos históricos ............................................ 274

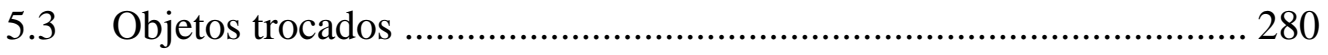

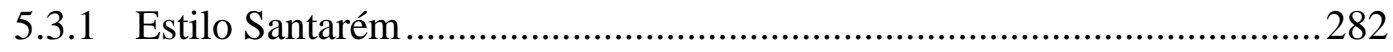

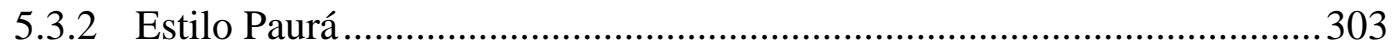

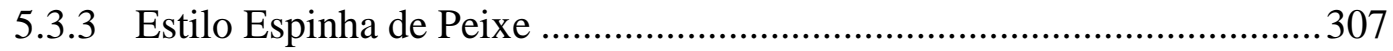

5.4 Semelhanças morfológicas: empréstimos ou ancestralidade? ............ 313

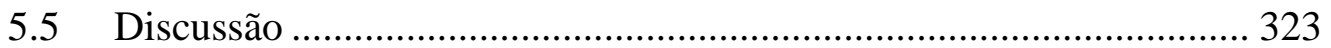

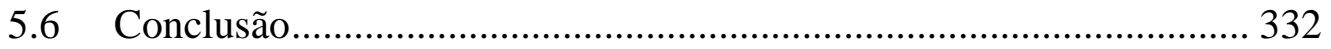

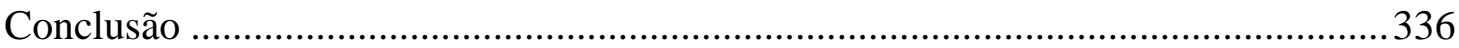

I. Museus e história da arqueologia no Brasil ....................................... 337

II. Redes de interação e mobilidade pré-coloniais.................................. 340

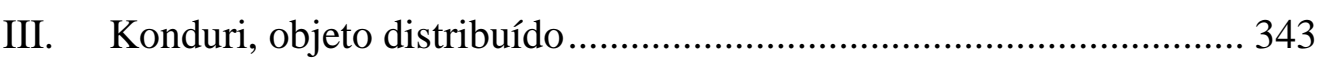

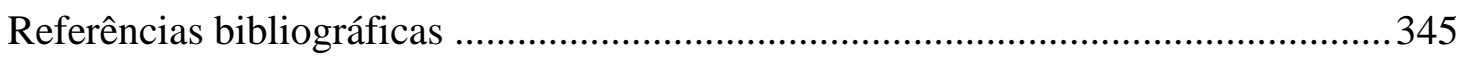

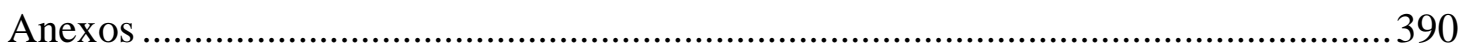

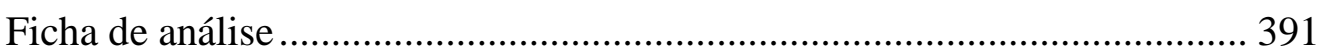


Levantamento de coordenadas geográficas de sítios Konduri ..................... 395

Mapa com sítio sarqueológicos com cerâmica Konduri ............................. 407

Projeções de morfologia de vasilhas do estilo Konduri ............................... 409 


\section{Introdução}

“Acabamos todos misturando os tempos.”

(LATOUR 1994, p. 74)

Esta dissertação é uma tentativa de reconectar ideias e coleções de museu formadas em 140 anos de pesquisa arqueológicos no Baixo Amazonas com o objetivo revisitar a construção do complexo cerâmico Konduri, explicitamente definido por Peter Hilbert (1955a).Indo na contramão da necessidade contínua de novas escavações e interpretações at the trowel's edge (VOSS, 2012), este é um esforço analítico a partir de materiais em reservas técnicas e arquivos. Uma visada para uma Amazônia de barro e papel dispersa pelo Brasil e entre continentes, cuja história, para retomar a epígrafe, "mistura tempos". Desse modo, mesmo que tangencialmente, este trabalho combina a perspectiva arqueológica com referenciais da História das Ciências e Museologia. A escolha por realizar este levantamento resulta da percepção de que devido a um lapso temporal e metodológico das pesquisas, certas concepções se perpetuaram sem terem sido avaliadas criticamente e outras, que também deveriam ser consideradas, foram sendo deixadas de lado. Há problemas de teoria e método neste legado, que precisam ser rediscutidos para que possamos avançar na compreensão do passado pré-colonial do Baixo Amazonas.

Foram feitas análises cerâmicas em cinco instituições brasileiras com grandes acervos, formados desde o século XIX, buscando compreender tanto suas histórias recentes quanto ter uma visão geral da tecnologia cerâmica pré-colonial Estas instituições. Estas instituições são: Museu de Arqueologia e Etnologia da Universidade de São Paulo (MAE-USP), Museu Paraense Emílio Goeldi (MPEG), Museu Nacional de Universidade Federal do Rio de Janeiro (MN), Museu de História Natural e Jardim Botânico da Universidade Federal de Minas Gerais (MHN) e Museu de Ciências e Tecnologia da Pontifícia Universidade Católica do Rio Grande do Sul (MCT). Foram também levantadas coleções em outras instituições no Brasil, Estados Unidos e Europa 
com peças provenientes do Baixo Amazonas. Longe de exaurir seu potencial, o estudo aqui desenvolvido busca mostrar as possibilidades que esses materiais oferecem.

A prática arqueológica, como se sabe, carrega consigo uma destruição de partes dos contextos estudados, que sobrevivem apenas por meio dos registros produzidos. Os artefatos, a não ser em casos especiais, não costumam ser destruídos, permanecendo em instituições, que os salvaguardam. Nesse sentido, os museus são o repositório principal para a retomada de pesquisas anteriores e daquilo que foi permanentemente modificado. As reorientações da arqueologia no século XX fizeram com que se desenvolvesse uma necessidade contínua de novas escavações, sendo as reanálises uma prática menos frequente. $\mathrm{O}$ esquecimento dos acervos deve, no mínimo, ser considerado uma contradição. Precisamos aplicar a própria premissa da arqueologia de que o passado é importante para construir o futuro dentro de nossas próprias interpretações do passado, integrando os materiais que já mobilizamos em outras pesquisas. Os museus e os arquivos permitem testar nossos métodos e os limites de nossas interpretações. Os “arquivos escritos em barro", como uma vez se referiu Emílio Goeldi (1898) em relação às coleções arqueológicas, são fundamentais para uma ciência com muitos altos e baixos na Amazônia e diversos desafios teórico-metodológicos.

As chamas que, no dia 2 de setembro de 2018 destruíram grande parte do Museu Nacional da Universidade Federal do Rio de Janeiro, anularam muitas possibilidades de repensar as interpretações "clássicas”, consumindo em poucas horas um legado único, construído por várias gerações de pesquisadores. Poucos meses antes, parte das análises para esta dissertação foi realizada naquele museu, fornecendo elementos imprescindíveis para a construção dessa dissertação. Esta pesquisa teve um ponto de inflexão nesta instituição, quando na graduação, em 2015, o estudo de parte do acervo permitiu a formulação de novas hipóteses para um antigo problema (ALVES, 2016, 2018). Parte da “Amazônia de barro e papel”, devorada pelo fogo, persiste nas páginas que seguem. Honrar as gerações que lá trabalharam e trabalham é manter as coleções e o conhecimento em constante movimento, criticando, revisando e valorizando o que já foi construído. Isso não é sinônimo de uma apologia do racismo ou colonialismo perpetrado pelas instituições ocidentais. Ao contrário é uma forma de reconhecer o caráter libertador do conhecimento científico e sua capacidade de expor os erros do passado, de criticar o seu legado e permitir a construção de outro futuro. Sem os 
modelos feitos de corpo inteiro de rostos e corpos indígenas vivos, crânios estourados por tiros ou objetos de cultos afro-brasileiros tomados a força pela polícia, perdemos um pouco da memória daquilo que muitos querem apenas esquecer e outros repetir.

\section{Objeto distribuído}

O título da dissertação faz referência à noção um tanto vaga de "objeto distribuído", desenvolvida por Alfred Gell, em Art and Agency. Não se trata de um conceito a ser discutidos à exaustão, nem um modismo a ser apresentado como panaceia das questões arqueológicas da Amazônia pré-colonial. Seu uso é bem menos pretensioso. Essa expressão foi escolhida porque consegue condensar as diferentes camadas das biografias dos objetos e dos conceitos usados para descrevê-las. A noção de "objeto distribuído" é ampla e plástica o suficiente para capturar as nuances que compõe o estudo das coleções com cerâmica Konduri.

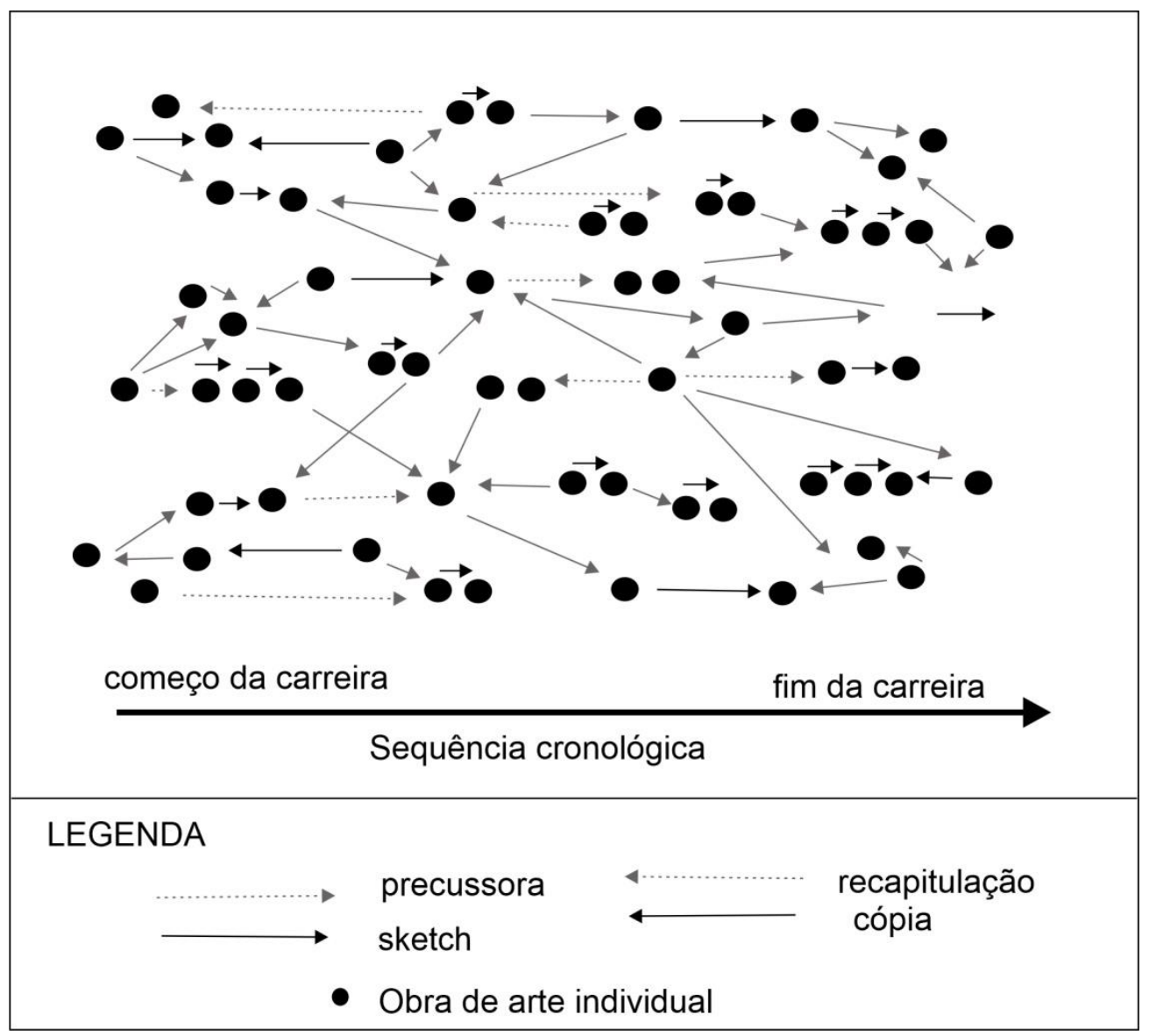

Figura 1. Modelo de objeto distribuído baseado na carreira de um artista ocidental individual. Esse modelo pode ser expandido e incluir vários outros artistas dentro de um contexto amplo. Adaptado de Gell, 1998. 
A expressão "objeto distribuído" é sinônima de "estilo", ou seja, um modo característico de fazer algo. O corpus da arte das Ilhas Marquesas discutido por Gell, por exemplo, pode ser pensado como um "objeto macroscópico" ou "unidade" da mesma maneira que pode ser pensada como uma unidade estilística. O mesmo argumento é retomado em relação às obras completas de artistas ocidentais em que as obras se comunicam como trabalhos precursores e retentores, formando linhagens e períodos - estilos individuais e suas fases ou momentos (Figura 1). Como um objeto visto em várias escalas, a unidade é apenas tênue, nela existindo vínculos mais fortes que outros e modificações ao longo do tempo.

Por outro lado, os artefatos associados como objeto distribuído são índices da própria distribuição da pessoa (humana) e sua intencionalidade mesclada a potencialidades não humanas. Essa perspectiva é das teorias etnográficas melanésias (STRATHERN, 2006 [1988]) que mostram como as pessoas são conceptualizadas enquanto "divíduos", formados por relações, e não seres indivisíveis, à maneira ocidental. "A pessoa singular pode ser imaginada como um microcosmo social." (STRATHERN, 2006, p.41). Os artefatos, da mesma maneira, para Gell, são microcosmos de relações com outros artefatos e com os humanos - aqueles que os fizeram, que os encomendaram, que os encontraram, etc. Mauss (2003 [1923]) muito antes já tinha notado como as coisas não são inertes nos contextos dadivosos da Polinésia e, que, em certo sentido, o "espírito das coisas" se liga àquelas que as possuem. Esse é o caso dos braceletes e colares trocados no kula trobiandês tão conhecido depois da etnografia de Malinowski. A pessoa singular existe (re)partida entre as relações que estabelece. Como explica Gell (op. cit., 222):

(...) a person and a person's mind are not confined to particular spatio-temporal coordinates, but consist of a spread of biographical events and memories, and a dispersed category of material objects, traces and livings, which can be attributed to a person and which, in aggregate, testify to agency and patienthood during a biographical career which may indeed prolong itself long after biological death.

As coleções estudadas são, no sentido mais denotativo, “objetos distribuídos"; reúnem objetos provenientes de uma região com mais de $30 \mathrm{mil} \mathrm{km}^{2}$ e que foram reunidas por pessoas diversas (desde crianças ribeirinhas até colecionadores profissionais trabalhando para museus), por vezes comerciadas, e chegaram a 
instituições de vários estados do Brasil e da Europa e dos Estados Unidos. Em consonância com Gell, Susan Pearce (1995) afirma que todas as coleções também podem funcionar como "biografias materiais". Ao mesmo tempo, os conjuntos artefatuais formam "eixos de coerência" que permitem identificar imediatamente uma conexão com o estilo empregado em sua produção no período pré-colonial. Em outra camada ainda o título desta dissertação faz referência às possíveis relações de troca e interação no período pré-colonial tardio evidenciadas pelos estudos das coleções e que serão expandidos no último capítulo.

\section{A construção de um problema}

O germe desta pesquisa começou a se desenvolver, em 2012, em uma organização da reserva técnica do Museu de História Natural e Jardim Botânico da Universidade Federal de Minas Gerais, no antigo prédio do Biotério, onde era mantida uma coleção de cerâmica do rio Trombetas coletada pelo advogado e poeta Aricy Curvello. Lá, pela primeira vez, encontramos as belas cerâmicas amazônicas. A proposta inicial surgiu no âmbito do Projeto Norte Amazônico, coordenado pelos professores André Prous e Ruben Caixeta, cuja principal objetivo era conectar a história indígena recente e o passado pré-colonial da região rio Mapuera, um afluente do rio Trombetas (JÁCOME, 2011, 2017). Realizando uma iniciação científica com o material lítico e cerâmico de uma região adjacente a dispersão do estilo Konduri, vislumbramos a possibilidade um estudo iconográfico da cerâmica, muito inspirado em estudos de iconografia Tupi e Marajoara, algo que acabou não sendo realizado. Em 2015, com um auxílio financeiro do Colegiado de Graduação em Antropologia de UFMG, passamos duas semanas no Museu Nacional revendo o material coletado por João Barbosa de Faria e brevemente descrito por Helen Palmatary (1960). No Museu Nacional, confirmamos uma suspeita de que os vasos de gargalo, um dos tipos de vasilha mais emblemáticos da cerâmica Santarém, também eram encontrados associados à cerâmica Konduri. Alguns elementos iconográficos puderam ser estudados, mas a maior parte da discussão desenvolvida em uma monografia de conclusão de curso (ALVES, 2016) e depois em um artigo (ALVES, 2018) foi a da existência de trocas de objetos cerâmicos no Baixo Amazonas.

O número de pesquisas na região de dispersão da cerâmica Konduri ainda é pequeno frente ao tamanho e a potencialidade dos sítios na região em que Orellana teria 
encontrado as guerreiras "Amazonas". O cenário das pesquisas arqueológicas na Amazônia é bastante oportuno para ampliar os estudos sobre o estilo Konduri. O número de pesquisas e a intensidade dos debates sobre a ocupação pré-colonial amazônica têm crescido exponencialmente nas últimas duas décadas. As pesquisas arqueológicas se reinventam em um processo de revisão das proposições e do legado de Betty Meggers e um novo interesse por temas clássicos do histórico-culturalismo (NEVES, 1999-2000, 2008, 2010, 2011; LIMA, 2008, 2010, 2015; MORAES, 2013; BARRETO; LIMA; BETTENCOURT, 2016). A predominância dos estudos de cerâmica já não é absoluta e estudos de vestígios orgânicos e líticos têm se tornado cada vez mais comum. O determinismo ecológico e o ímpeto classificatório ganharam outros traços com as pesquisas da Ecologia Histórica. O debate sobre "complexidade social" parece ter deixado de lado a marcada oposição entre "tribo" e "cacicado" e caminhado para discussões menos classificatórias sobre os processos de adensamento populacional (NEVES e MORAES, 2012; NEVES, 2015). O “modelo cardíaco" de Lathrap (1970) vem sendo avaliado a partir dados empíricos e novas hipóteses têm emergido sobre a expansão das principais famílias linguísticas da Amazônia (CORRÊA, 2014; HECKENBERGER, 2005, 2011; HORNBORG, 2005).

O Baixo Amazonas é uma região particularmente importante nos debates empreendidos nas últimas décadas, tanto em relação às ocupações pré-coloniais tardias quanto em relação as mais recuadas temporalmente (NEVES et al., 2014; ROOSEVELT et al., 1991; ROOSEVELT et al., 1996). No início do debate sobre a existência de complexificação social na Amazônia, na década de 1990, Anna Roosevelt retomou os relatos etno-históricos da região e a elaboração da cerâmica Santarém/Tapajó para sustentar seus argumentos, além de iniciar escavações na área (ROOSEVELT, 1993, 1999; QUINN, 2004). Denise Gomes (2008, 2011, 2016a) rediscutiu a complexificação social na área de Santarém e a partir do estudo de coleções de museu e pesquisas sistemáticas mostrou a existência de "comunidades autônomas" contemporâneas a ocupação Tapajó e possíveis relações cosmológicas e como os modos de agremiação e fissão de coletivos. Uma série de dados sobre sítios, publicações na margem direita do baixo Tapajós têm sido gerada, com as pesquisas de Schaan (2012, 2015, 2016), Stenborg (2016) e associados que têm discutido as ideias de "complexidade" e a relação de centro e periferia tanto no sítio Porto, na atual cidade de Santarém, quanto em sítios do município de Belterra. 
O conhecimento sobre os mais de 30 mil quilômetros do Baixo Amazonas é, no entanto, desigual. Apesar de as pesquisas terem se iniciado há mais de um século e se adensado nos últimos quinze anos, sabe-se muito mais sobre os sítios arqueológicos na margem direita do baixo curso do rio Tapajós do que qualquer outra área. Restam ainda grandes espaços pesquisados apenas por Curt Nimuendajú, na década de 1920, como a área do rio Arapiuns e do Lago Grande de Curuaí. Outras ainda são praticamente desconhecidas, com no curso do rio Cuminá, pesquisado em trabalhos pioneiros de Protásio Frikel. As ocupações associadas ao estilo Konduri tem sido integrada lentamente nos debates contemporâneos da arqueologia amazônica. A cerâmica Konduri nunca é esquecida nas sínteses sobre a arqueologia amazônica (MEGGERS e EVANS, 1961; LATHRAP, 1970; NEVES, 2008), mas é quase sempre uma figura sem rosto, à sombra da ocupação Tapajó. Peter Hilbert (1955a) definiu o estilo Konduri e o diferenciou do estilo Santarém a partir de um levantamento e coleta de superfície na região dos rios Trombetas e Nhamundá. O quadro construído por Hilbert foi pouco alterado apesar de o autor indicar que sua análise era ainda provisória. Retomar as proposições de Hilbert é fundamental. Por que não começar com as coleções que ele estudou e coletou?

\section{Estudo de coleções}

As coleções de museu foram à base do conhecimento arqueológico do final do século XIX e início do XX. Grandes conjuntos de peças inteiras e elaboradas, reunidas por arqueólogos e colecionadores, chegaram aos museus e foram objeto das primeiras pesquisas arqueológicas. A necessidade de explicar o contexto e sua espacialidade levou ao desenvolvimento de métodos e técnicas para criar amostras melhor controladas. As coleções, ao longo do século passado, tornaram-se cada vez menos atrativas devido à ausência de informações de contexto. A dificuldade de precisar qual a representatividade da coleção em relação ao conjunto total é o principal problema apontado em relação a esses materiais. Como destaca Angela Huster (2013, p.77), existe uma relação de "amor e ódio" com as coleções: ao mesmo tempo em que faltam as referências de contexto, as coleções geralmente apresentam grande quantidade de objetos raros e íntegros.

Huster (op. cit., p. 78) menciona três modos em que se costuma estudar objetos de coleções de museu em arqueologia: (1) aplicação de novos métodos de análise; (2) 
estudos descritivos de peças únicas ou raras; (3) estudo de um conjunto de artefatos como uma unidade coesa. As duas primeiras formas de análise são bem aceitas e geram menos problemas sobre a representatividade da amostra. O conjunto de artefatos tratados como uma unidade, no entanto, pode gerar distorções dependendo da documentação existente sobre a coleta e se existe uma maneira de identificar os vieses da amostra. Uma das maneiras de realizar um estudo mais controlado das coleções é considerando apenas uma classe de artefatos e comparando suas variáveis. A seleção de peças realizada pelo colecionador/coletor pode ser avaliada e suas potencialidades explicitadas. As coleções não podem ser abandonadas nas reservas técnicas, salienta Huster, sem que se discuta como poderiam contribuir para os estudos arqueológicos.

$\mathrm{Na}$ arqueologia brasileira tem havido um crescente interesse por estudos de coleções museológicas. Estão sendo feitas tentativas de analisar com novos métodos físico-químicos antigas coleções (FREITAS et al., 2009); análises descritivas de conjuntos de peças raras (FONSECA, 2010; PORRO, 2010; ALVES; PROUS, 2016); e também estudos de conjuntos coesos de artefatos (PROUS, 2010; PROUS; LIMA, 2012; BARRETO, 2009; NEVES, 2008; BARBOSA, 2011; CORRÊA, 2014, OLIVEIRA, 2016; NOBRE, 2017, etc.). Nos estudos de arqueologia amazônica essa tendência tem se direcionado a iconografia, valendo-se especialmente dos elementos figurativos e correlações com cosmologias indígenas contemporâneas. Esses trabalhos mostram a potencialidade das coleções e a necessidade de abordar os materiais para além dos modelos classificatórios tradicionais. Pouco se tem refletido, no entanto, sobre os vieses das coleções de museu, sendo uma exceção o artigo de Scatamacchia et al. (1996) e outros artigos publicados, até 2006, na seção de "Estudos de Curadoria" da Revista do Museu de Arqueologia e Etnologia.

Existem coleções com quantidades variadas de peças Konduri em diferentes instituições no Brasil e em algumas do exterior - particularmente no Museu da Cultura Mundial em Gotemburgo, Suécia. Muitas das peças Konduri, pertencentes a essas coleções, nunca foram estudadas e outras foram estudadas há décadas atrás, a partir de metodologias pouco sistemáticas. É notório, por exemplo, a existência de duas coleções reunidas por Peter Paul Hilbert no Museu Paraense Emílio Goeldi - uma reunida com colaboração de Harold Schultz em 1953 cujos resultados nunca foram publicados. Outras coleções, reunidas por ribeirinhos e eruditos locais chegaram a museus e 
colocam uma maior complexidade, uma vez que quase não se dispõe de informações contextuais e as peças de áreas muito distintas foram colocadas juntas.

As coleções museológicas, fonte inesgotável de peças "típicas”, não podem ser desconsideradas por sua "descontextualização". A falta e a limitação, normalmente associada a esses materiais, podem ser revertidas em uma perspectiva regional e as informações do processo de colecionamento permitem inferir, em muitos casos, áreas distintas e/ou os sítios em que foram realizadas as coletas. Comparações exploratórias podem ser delineadas, bem como o desenvolvimento de novas hipóteses. Os resultados da pesquisa permitem estabelecer caracterizações tecnológicas e proposições sobre variações locais.

As coleções de museu são "híbridos" de objetos feitos no passado pré-colonial e a seleção e disposição modernas. Não é possível separar a materialidade dessas de seus agenciamentos recentes e sua hibridez (LATOUR, 1994). As pesquisas que ignoram completamente esse fato acabam por reduzir as informações sobre os materiais estudados; toda a cadeia de formação das coleções é importante para avaliar as possibilidades interpretativas sobre o passado pré-colonial. A seleção e a história acumulada por esses conjuntos de objetos influenciam fortemente o conhecimento científico. Em uma região como o Baixo Amazonas, em que muito do conhecimento arqueológico foi gerado a partir do estudo de coleções, uma posição reflexiva sobre o papel da seleção de artefatos por diferentes atores sociais é fundamental. Não é a proposta explicar as "coleções em si", mas ao longo da pesquisa tornou-se patente a necessidade de compreender e reconhecer como o colecionismo é parte constitutiva do conhecimento gerado e que é preciso avaliar seus efeitos na amostra disponível para estudo e nas proposições feitas por outros/as pesquisadores/as.

Uma perspectiva biográfica das coleções permite compreender a formação de algumas das questões levantadas em torno do estilo Konduri, informando tanto do passado mais recuado quanto o mais recente (KOPYTOFF, 1986; PEARCE, 1995; GOSDEN, MARSHALL, 1999; HAMILAKIS, 1999; HOLTORF, 2002). É preciso reavaliar o conhecimento gerado em relação às pesquisas recentes, sem descartar por princípio as proposições desenvolvidas a partir dos estudos de coleções nem assumi-las completamente. Nesse sentido, esta dissertação é um retorno ao estudo de coleções de 
cerâmica Konduri, que tenta integrar informações de coleções reunidas por diferentes pessoas, com diferentes interesses e em locais distintos. O estudo comparado de coleções permite contrapor os modos de seleção e a "imagem" que eles produzem. Quais são seus vieses? O quanto é possível apreender do conjunto Konduri a partir dessas coleções? As análises de materiais coletados sistematicamente realizadas nos últimos anos (GUAPINDAIA, 2008; CHUMBRE, 2014; PANACHUK, 2016a) permite contrapor preliminarmente as coletas intensivas e não seletivas às extensivas e seletivas. Por sua vez, o estudo de peças mais elaboradas, raramente encontradas por arqueólogos/as em contexto, permite uma complementação do amplo conjunto de dados dos materiais coletados em escavações sistemáticas.

\section{Estilo técnico e processos históricos}

O material cerâmico tem sido por décadas o principal elemento para a constituição dos quadros histórico-culturais da Amazônia pré-colonial. O modelo analítico predominante para o estudo de cerâmica foi o difundido por Meggers e Evans (1957) a partir de seu estudo das ocupações da ilha de Marajó e estado do Amapá. O "método Ford", como ficou conhecido na América Latina, consiste na construção de cronologias de sítios a partir da seriação de atributos. $\mathrm{O}$ antiplástico foi o principal atributo na arqueologia amazônica seguindo as indicações de Meggers e Evans (1960, 1970.), o que se perpetuou por décadas por meio do Programa Nacional de Pesquisas Arqueológicas (PRONAPA) e o Programa Nacional de Pesquisas Arqueológicas da Bacia Amazônica (PRONAPABA). A classificação a partir de seriação de materiais coletados em pequenas sondagens foi uma premissa defendida pelos autores, que consideravam que "the cultures are simple, the sites are small, and the maximum of data can be secured with minimum digging”. (EVANS; MEGGERS, 1960, p. 10).

Pesquisas partindo de outras premissas diferentes das postuladas por Meggers e Evans, começaram a se multiplicar a duas décadas na arqueologia amazônica brasileira. Esse estudo tem enfatizado a importância de se considerar a variabilidade dos conjuntos artefatuais e os processos de produção dos artefatos (SILVA, 2000, 2016; DIAS; SILVA, 2001; MACHADO, 2005-2006; MORAES, 2013; GASPAR, 2014; BELETTI, 2015; JÁCOME, 2017, etc.). Esses estudos menos tipológicos tem combinado referências francesas e estadunidenses de estudo de tecnologia e características de performance (LEMONNIER, 1992; SCHIFFER;SKIBO, 1987, 1997). O 
redirecionamento das análises de cerâmica, baseados na crítica teórica a dicotomia estilo/função, tem servido para reavaliar o significado da variabilidade artefatual. A cerâmica tem deixado de ser resumida apenas a um marcador histórico-cultural e passada a ser vista com um ator em diferentes esferas da vida social.

A análise da cerâmica Konduri, desenvolvida nas páginas que se seguem, como outras realizadas na arqueologia amazônica, foi orientada pela noção de estilo técnico ou tecnológico (LEMONNIER, 1986, 1992, 1993; HEGMON, 1998; CHILTON, 1998, 1999). O conceito de "estilo" é fundamental para a arqueologia e existe grande diversidade de posições sobre sua abrangência e capacidade explicativa (CONKEY, 1990; DIETLERT; HERBICH, 1998; SACKETT, 1990). Inclusive, ao longo da dissertação será discutido seu uso no sentido de unidade histórico-cultural. Em síntese, a diferença de uma perspectiva de estilo tecnológico situa-se no pressuposto de que "estilo" não se resume a apenas uma parte limitada da forma acabada dos artefatos ou seu aspecto visual (REEDY; REEDY, 1994). Existem escolhas culturais envolvidas em toda a produção dos artefatos e, do ponto de vista do pesquisador/a, existem várias escolhas possíveis, mas que foram efetivadas apenas a partir de um conjunto específico de alternativas e interesses. A cadeia operatória de uma vasilha cerâmica, por exemplo, combina procedimentos como a coleta de argila, processamento e adição de temperos, manufatura, secagem e queima, que podem ser feitos de modos variados. O estilo está presente em todas as escolhas feitas e combinadas, sendo essas relacionadas com as experiências do artesão/ã e conhecimentos transmitidos entre gerações (VAN der LEEUW, 1993; GOSSELAIN, 1998， 2000，2016; CHILTON, 1998, 1999; PFAFFENBERGER, 1992).

Se as escolhas tecnológicas diferem, deve haver motivos para que algumas das alternativas possíveis tenham sido escolhidas e outras não. Umas das apostas analíticas associadas à abordagem de estilo tecnológico (ou técnico) é que essa escolha se encontra na relação entre humanos e as potencialidades das matérias (INGOLD, 2000). Schiffer e Skibo $(1997,2001,2008)$ denominam de "características de performance" as capacidades comportamentais das matérias durante ou após a manufatura de um artefato. As escolhas tecnológicas não são apenas "estilo", no sentido de escolhas humanas idiossincráticas, nem "função", como parte dos aspectos utilitários e adaptativos. Os artesãos/ãs conhecem ou descobrem as propriedades das matérias e as 
manipulam para produzir determinados efeitos. Assim, a escolha de uma determinada argila ou tempero pode estar relacionada ao interesse por uma determinada resistência a choque térmico ou uma cor, por exemplo. Como a produção de um artefato acontece em cadeia, diferentes escolhas feitas ao longo do processo se entrecruzam. Em termos analíticos, é preciso tentar evidenciar os diferentes "pesos" dessas escolhas, direcionadas a uma performance. O colecionismo, e não apenas as escolhas do passado pré-colonial, também pode ser pensado a partir da performance visual de certos artefatos.

Muitos estudos etnoarqueológicos dos processos ligados à produção, uso e distribuição cerâmica (GOSSELAIN, 1992, 2000, 2016; SILVA, 2000, 2008, 2016) e a relação desse tipo de material com outros aspectos da vida social (LATHRAP, 1983; LATHRAP, DeBOER, 1979; DEGOY, 2008) oferecem possibilidades interpretativas para discutir os "pesos" das escolhas relacionadas à produção de cerâmica Konduri.

Gosselain $(1998,2000,2017)$ oferece uma importante contribuição teórica aos estudos de tecnologia ao mostrar como um estilo ou tradição técnica é resultado de uma série de fatores, formando a imagem de um agregado complexo e dinâmico, cuja história pode ser compreendida a partir de relações no espaço e no tempo. Essa perspectiva é complementar - e não oposta como sugere Gosselain, 1998 - ao estudo das mudanças técnicas em relação às transformações dos modos de vida desenvolvida pela arqueologia comportamental (SCHIFFER; SKIBO, 1987).

\section{Estrutura da dissertação}

A dissertação está dividida em cinco capítulos. O primeiro capítulo apresenta uma revisão conceitual da constituição do "estilo Konduri" como unidade arqueológica, formando um breve estado da arte e apontando as principais questões levantadas pelas pesquisas desde o século XIX. O capítulo 2, por sua vez, apresenta e discute alguns elementos da biografia das coleções estudadas que, em geral, não são coleções de cerâmica Konduri, mas coleções com cerâmica Konduri. A formação e a expansão da cadeia de colecionamento de artefatos cerâmicos praticado por ribeirinhos, eruditos e museus é discutida neste capítulo. Uma complexa trama existe em torno das coleções em que se combinam as representações científicas e políticas. O capítulo 3 discute os vieses e os desafios de analisar coleções de museu visando produzir interpretações ou 
hipóteses válidas para a arqueologia pré-colonial amazônica. Toda a cadeia de obtenção e conservação das coleções é pensada em relação às misturas, perdas e ganhos de informação a partir das práticas de colecionamento assistemáticas. O capítulo 4 apresenta preliminarmente os resultados de análise da cerâmica Konduri, discutindo os atributos usados para caracterizar essa cerâmica, desde as primeiras pesquisas. Isso permite construir uma síntese sobre a cerâmica Konduri e formular hipóteses sobre sua variabilidade formal e espacial e variação temporal. O capítulo 5 retoma o tema da existência de trocas no Baixo Amazonas a partir de conceitos formulados pela arqueologia ao longo do século passado, como esfera de interação, convergência, difusão, troca e persistência. São apresentados os resultados de conjuntos cerâmicos minoritários identificados junto à cerâmica Konduri que podem ter sido obtidos por trocas e discutimos alguns elementos regionais vinculados a processos de fluxo de informação e a circulação de objetos. A discussão retoma brevemente as pesquisas etnohistóricas e etnográficas sobre o norte da América do Sul e as hipóteses sobre a formação de redes de troca entre o período pré-colonial tardio e o início da colonização europeia. A conclusão reata os nós da dissertação e apresenta algumas perspectivas para as pesquisas futuras em contextos Konduri. 


\title{
1 Capítulo 1 - A construção do estilo Konduri
}

\author{
“(...) it is incidental to ask whether cultures exist. They exist \\ through the fact of their being invented, and through the effectiveness \\ of this invention"
}

WAGNER, 1981, p. 17

A classificação é uma ferramenta utilizada por qualquer ciência para descrever e interpretar os fenômenos que estuda. Unidades arqueológicas, como estilos, séries, fases e tradições, são classes que permitem identificar, organizar e comparar vestígios materiais em diferentes escalas de variabilidade/variação formal e proximidade espaçotemporal (WILLEY, PHILIPS, 1958; DUNNELL, 2002, 1986; LYMAN et al., 1997). Muitas dessas unidades foram criadas ainda na primeira metade do século XX, como resultado de um interesse teórico por cronologias regionais com base nos conjuntos artefatuais (TRIGGER, 2008). Apesar de algumas dessas unidades parecerem quase realidades empíricas, elas são produtos de escolhas analíticas, de premissas e os objetivos do pesquisador/a (ADAMS, ADAMS, 1991). Dessa maneira, tais ferramentas podem e devem ser debatidas, revistas ou mesmo abandonadas.

Apesar das críticas e dos problemas do conceito de "cultura arqueológica" e suas variantes, é urgente a sua discussão na arqueologia. Não aconteceu, de fato, uma substituição completa do conhecimento e interpretações gerados pela arqueologia histórico-cultural (ver ROBERTS, LINDEN, 2011). Mesmo com a influência global da arqueologia processual e pós-processual, essas abordagens continuaram restritas, além de em muitos casos, conservarem as classificações anteriores. A arqueologia précolonial da Amazônia, em particular, mantém muito da herança do século passado, sendo ainda centrais as categorias de fase e tradição (NEVES, 2010, 2011; LIMA, 2015). Todavia, as principais discussões conceituais sobre seu uso e construção datam de várias décadas atrás (WILLEY, PHILIPS, 1953, 1958; ROUSE, 1955; DUNNELL, 2002). 
Este capítulo discute a construção da unidade arqueológica "estilo Konduri”. O termo Konduri é usado nesta e em outras pesquisas para qualificar (1) um conjunto particular de cerâmica arqueológica encontrada no Baixo Amazonas, ao mesmo tempo em que (2) uma ocupação indígena temporal e espacialmente definida que, presumivelmente, seria caracterizada por um padrão de assentamento e outros conjuntos artefatuais característicos. A primeira acepção se refere ao conceito de "complexo cerâmico" e o segundo ao de "fase" ou "cultura arqueológica" (MEGGERS, EVANS, 1970). A relação metonímica entre o primeiro e o segundo conceito é um tema a ser explicitado. O objetivo do capítulo é por em evidência os critérios mobilizados para as classificações criadas para a região dos rios Trombetas e Nhamundá, considerando suas implicações para a arqueologia regional contemporânea. A história particular da arqueologia do Baixo Amazonas, anterior às proposições de Meggers e Evans (1957, 1970), oferece elementos interessantes, que vão de encontro a algumas das críticas desenvolvidas na arqueologia brasileira, profundamente vinculadas ao Programa Nacional de Pesquisas Arqueológicas (PRONAPA) e seus seguidores (MACHADO, 1991; DIAS, 1994, 1995, 2007; DIAS; HOELTZ, 2015; NOELLI, 1999; BARRETO, 1999-2000; OLIVEIRA, 2002; FUNARI, 1994, CABRAL, 2011). A história da arqueologia da região apresenta algumas particularidades, como a convergência da noção de "estilo" desenvolvida por Curt Nimuendajú, influenciado pelo Kulturkreise, e as construídas nas décadas seguintes pelo culturalismo estadunidense.

\subsection{A cerâmica "Uaboí"}

O Baixo Amazonas foi uma das primeiras áreas estudadas arqueologicamente no Brasil, ainda no século XIX. Entre os materiais coletados, os muiraquitãs e as estatuetas líticas ganharam maior notoriedade nos estudos americanistas. Esses artefatos líticos foram logo incluídos em debates amplos sobre migração e difusão no continente americano (BARBOSA RODRIGUES, 1899; FONSECA JÚNIOR, 2010; PORRO, 2010). A cerâmica arqueológica do Baixo Amazonas, ao contrário, quase não despertou interesse entre os pesquisadores pioneiros da época, com exceção de Barbosa Rodrigues (1875b, 1876). O primeiro rótulo para as cerâmicas encontradas na região dos rios Trombetas e Nhamundá não foi baseado em uma classificação de artefatos, mas em associações com informações etno-históricas e história oral. 
O naturalista João Barbosa Rodrigues buscou identificar, durante seu mapeamento geográfico dos rios Trombetas e Nhamundá, os vestígios arqueológicos correlatos às narrativas das crônicas coloniais e de informantes indígenas, como a das “Amazonas". As descrições dos sítios arqueológicos e de artefatos líticos e cerâmicos foram as primeiras a ser publicadas sobre o Baixo Amazonas (BARBOSA RODRIGUES, 1875b). Outros naturalistas que passaram pela região do rio Trombetas apenas mencionaram a existência de cerâmica indígena arqueológica (PENNA, 1877; DERBY, 1898).

Barbosa Rodrigues não construiu uma classificação dos materiais encontrados, apenas a relação com etnônimos. Essa tentativa gerou a primeira identidade material da cerâmica encontrada entre os rios Trombetas e Nhamundá (ver FERREIRA, NOELLI, 2009). A correlação feita era direta e não era considerada a diferença cronológica entre as ocupações indígenas na região, nem se detém sobre as características dos objetos. $\mathrm{Na}$ ilha Paru, no rio Amazonas, entre as cidades de Óbidos e Santarém, Barbosa Rodrigues encontrou um sítio arqueológico de terra preta com cerâmica arqueológica, onde supôs ter vivido a "tribo" identificada pelos cronistas coloniais como das "Amazonas" (1875b, p. 89-91). No baixo curso do rio Trombetas, na Serra de Conuri, menciona ter encontrada cerâmica que teria sido produzida pelos "antigos Cunurys e Uabóys", conhecidos nas crônicas do século XVII e XVIII (BARBOSA RODRIGUES, 1875a, p. 9). No baixo rio Nhamundá, ele identificou um sítio com cerâmica arqueológica que associou aos "Uabóys" a partir da interpretação do indígena Antonio Henrique, que o acompanhava na missão do mapeamento do rio Nhamundá: “Julgo que pertencia á dos Uabóys, porque não só o velho Antonio, como outros filhos de Uabóys, a quem mostrei depois, disseram, que outr'ora seus pais usavam louça com o feitio da de que trato." (BARBOSA RODRIGUES, 1875b, p. 38).

A estratégia de combinar narrativas indígenas a pesquisa arqueológica, apesar de não ter sido comum na arqueologia no Brasil imperial, era frequente no Sudoeste dos Estados Unidos (FOWLES, MILLS, 2017). O termo “Anasazi”, por exemplo, utilizado para denominar uma cultura arqueológica daquela região, foi obtido com indígenas Apache, que trabalharam em pesquisas de campo no final do século XIX (COLWELLCHANTHAPHONH, 2009). Infelizmente, não há muita informação sobre o indígena Antonio Henrique e quais os significados da identificação da cerâmica com o passado 
dos Uaboí. As informações acerca desse etnônimos são ainda muito escassas. A primeira menção conhecida de uma variante, "BaBuhi", data de 1725, mas não há nenhuma indicação além do próprio termo (PORRO, 2010). Protásio Frikel, na década de 1950, relata que questionou indígenas do rio Nhamundá sobre o etnônimo "Wabuí". Ela afirma que '[r]iram e responderam: 'Somos nós, daqui, do Nhamundá. Os Chawiyána, Hichkaruyána, Kuiyána... todos eles são Wabuí'.” (FRIKEL, 1958, p. 128). Os critérios de identificação acionado pelo indígena Antonio pode não ser equivalente a perspectiva arqueológica e essa complexidade conceitual não foi considerada por Barbosa, á época. No caso dos Asurini do Xingu, por exemplo, a cerâmica identificada como não-Asurini é relacionada a ação de Anumaí, um demiurgo dos tempos míticos (SILVA, 2002, 2015; GARCIA, 2017).

A primeira denominação, dada por um pesquisador, para as cerâmicas arqueológicas não delimitava um conjunto material específico. $\mathrm{O}$ estudo de Barbosa Rodrigues teve pouca repercussão nos estudos posteriores, com exceção de um único trabalho. João Barbosa de Faria, etnólogo da Comissão de Inspeção de Fronteiras, em 1928, realizou uma expedição etnográfica e coletou cerâmica arqueológica em Óbidos, Oriximiná e ao longo do rio Trombetas. A partir desse material publicou um estudo na década de 1940, o primeiro a tratar especificamente da cerâmica encontrada na bacia do rio Trombetas (FARIA, 1946). A discussão desse trabalho se focou principalmente em uma associação especulativa das figurações cerâmicas e interpretações sobre a cosmologia Muisca (ou Chibicha) da Colômbia. Apesar de o autor não explicitar o motivo dessa escolha, é provável que ele seguisse a indicação feita por Konrad Preuss, de que as esculturas líticas de San Agustín apresentariam semelhanças estilísticas com os "ídolos de pedra” encontrados no baixo Trombetas (FONSECA JÚNIOR, 2010). Uma das conclusões do autor, por exemplo, era que "[e]m virtude de suas afinidades religiosas com os povos Chibcha [identificadas a partir das esculturas cerâmicas], os Uaboí devem ser considerados um ramo dessa raça” (op. cit., p. 24). O autor interpretava a elaboração da "arte cerâmica" como resultado da uma influência andina, seguindo o legado do conceito de "degeneração" dos povos indígenas (FERREIRA, NOELLI, 2007).

Poucas descrições foram feitas do material e do contexto de coleta na região do rio Trombetas. Seguindo Barbosa Rodrigues, Faria considera o material encontrado 
como "cerâmica da tribo Uabó'". O autor ainda afirma que "Uaboí" era uma denominação genérica de tribo "constituída por cinco hordas ou clãs denominados Uaboí, Conuri, Querena, Paracoimã e Paracuatá" (op. cit., p.6). Essa é uma leitura equivocada do trecho em que Barbosa Rodrigues menciona "tribos" ou "nações" - e não clãs - que teriam sido reunidas em um aldeamento na foz do rio Nhamundá (BARBOSA RODRIGUES, 1875b. p. 22). Não há nenhuma discussão, nem embasamento documental, para a associação mantida por Faria.

\subsection{A primeira construção do estilo Konduri}

Entre 1923 e 1927, o etnólogo Curt Nimuendajú foi contratado pelo Museu Etnográfico de Gotemburgo para formar coleções de artefatos arqueológicos da bacia amazônica. A partir dessas expedições Nimuendajú formou várias coleções na cidade de Santarém e suas imediações. Em 1924, passou por sítios arqueológicos de terra preta no baixo curso do rio Trombetas, no município de Juruti e Parintins. A partir de coletas assistemáticas, selecionando peças decoradas, ele realizou a primeira classificação de cerâmicas arqueológicas. Essa classificação, no entanto, permaneceu quase desconhecida até o ano de 2004, quando seus relatórios e algumas cartas ao Museu foram finalmente publicados (NIMUENDAJÚ, 2004). Algumas das informações contidas nos relatórios eram conhecidas por meio de cartas que o etnólogo enviava a uma série de pesquisadores (LINNÉ, 1928; NORDENSKIÖLD, 1930; PALMATARY, 1939, 1960). Nimuendajú nunca sistematizou sua classificação, mas a partir de seus escritos é possível compreender alguns de seus critérios e premissas. Nimuendajú teve apenas um trabalho póstumo publicado em português sobre essas expedições arqueológicas e este apenas mencionava as informações arqueológicas e se focava nas fontes escritas sobre os Tapajó (NIMUENDAJÚ, 1949). Um breve relato de suas pesquisas arqueológicas foi publicado em alemão, mas permaneceu pouco conhecido entre os pesquisadores amazonistas até recentemente (NIMUENDAJÚ, 2001 [1929]).

Nimuendajú não se dedicou aos estudos arqueológicos da mesma maneira que a etnologia. Em sua perspectiva de "antropologia de salvamento", parecia mais urgente estudar os modos de vida e conhecimentos indígenas contemporâneos, que eram vistos como na iminência da extinção, do que estudar artefatos arqueológicos (GRUPIONI, 1998). Seus estudos etnográficos e arqueológicos são descritivos e pouco se dedicam a discussões conceituais. $\mathrm{O}$ autor estava em diálogo direto com a etnologia germânica e se 
valeu de seus conceitos (WELPER, 2002), que à época eram compartilhados pela arqueologia também (REBAY-SALISBURY, 2011). Assim, Nimuendajú se refere aos conjuntos arqueológicos a partir das categorias "estilo" (Stil), "cerâmica" (Keramik) e mais raramente "cultura" (Kultur) como sinônimas, buscando delimitar suas áreas de dispersão. É possível relacionar esse uso a outros amplamente disseminados na antropologia culturalista dos Estados Unidos e de língua alemã. Franz Boas (1955 [1929]), por exemplo, afirma que "[w]ithout stability of form of objects, manufacture or common use, there is no style" (p.11) e que, antes do contato com os europeus, "(...) each locality, and also each cultural period had developed to fixed types that were rigidly adhered to" (p. 144). A noção de "cultura" dessa maneira se sobrepõe a do próprio "estilo", uma vez que ambas exprimem particularidade. Kroeber (1957, p. 3), seguindo a mesma linha de raciocínio, afirma que estilo é um modo de fazer característico e distintivo, indicado pela "consistência de formas" e "padrões em relação". Essas afirmações apesar de não poderem ser associadas diretamente ao trabalho de Nimuendajú - ele não as cita e uma delas é posterior a sua morte -, mostram uma visão geral do que se entendia como "estilo" no momento. A construção do conceito de cultura arqueológica desenvolveu-se a partir dessas mesmas premissas (TRIGGER, 2008), em que se equaciona conjuntos materiais e povos. A julgar por suas descrições, um "estilo" seria, para Nimuendajú, composto por elementos decorativos e algumas vezes morfológicos dos materiais coletados - isto é, cerâmica - com dispersão geograficamente delimitada. Esses elementos poderiam indicar um coletivo humano distinto, com um etnônimos particular, identificável nas crônicas coloniais. 


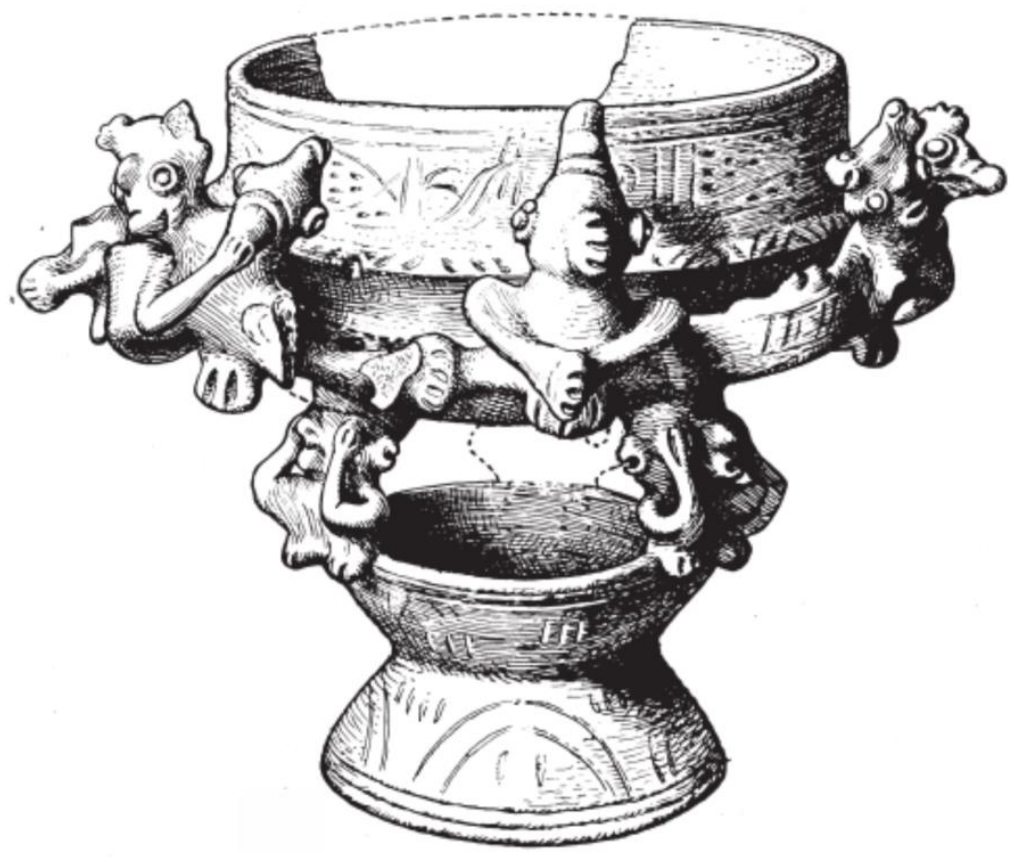

Figura 2. Vaso de cariátides coletado por Curt Nimuendajú. Essa é uma das vasilhas mais características do estilo Tapajó ou Santarém, definido pelo etnólogo alemão. Extraído de Nimuendajú, 2004.

A partir de suas pesquisas no médio e Baixo Amazonas, ele identificou sete estilos cerâmicos, dos quais cinco foram relacionados a etnônimos (Tapajó, Kondurí, Arapiyú, Sapupé, Aruakí) e dois a referências geográficas (Montenegro, Paurá). Esses ainda apresentavam coerência de formas e diferença em relação aos outros. Explica em carta a Gastão Cruls que “(...) achados archeologicos devem ser attribuidos á ultima tribu conhecida no logar"1, mas apenas se for possível fazer uma correlação estratigráfica entre a ocupação indígena e colonial. Antes ele afirma que "[s]i eu attribui a ceramica de Santarém á tribu dos Tapajó [Figura 2] e a de Silves aos Aruakí foi porque imediatamente acima dellas se encontra a camada de cultura moderna. ${ }^{2}$ " Dessa maneira, a classificação dos “estilos" tinha duas dimensões distintas: a comparação de elementos visuais da cerâmica e, na maioria dos casos, a associação com informações etno-históricas que permitiriam conectar os objetos e uma "tribo" produtora. Essa concepção das unidades arqueológicas é bastante semelhante à desenvolvida na arqueologia europeia e dos Estados Unidos no período, apesar de uma preocupação menor de Nimuendajú em relação a diferenças cronológicas e a construção

\footnotetext{
${ }^{1}$ Carta de Curt Nimuendajú a Gastão Cruls, 26/11/1941, Arquivo Curt Nimuendajú/ CELÍN/MN.

${ }^{2}$ Idem.
} 
de cronologias (ver LYMAN et al., 1997). É interessante notar que ele diferenciou a cerâmica Santarém da "Montenegro", que depois foi identificada como pertencendo a uma ocupaçãomais antiga, denominada Pocó (ver HILBERT, HILBERT, 1980; NEVES et al., 2014).

A denominação "Konduri” foi dada a partir da correlação entre a área de Óbidos e Oriximiná e um grupo indígena conhecido nas crônicas do século XVII e XVIII como "Condoriles", "Condorises" e "Condoris" (BETENDORF, 1910; PINTO, 2006; HERIARTE, 1874). A grafia do etnônimo foi padronizada a partir da sistemática criada pelo próprio etnólogo e depois adotada pela Associação Brasileira de Antropologia (A GRAFIA DOS NOMES TRIBAIS BRASILEIROS, 1955). No caso do estilo Kondurí é possível notar que o etnólogo variava os termos para denominar o conjunto arqueológico. Por vezes falava de "estilo", "cerâmica", "decoração" ou "região dos antigos Kondurí" para se referir às características da cerâmica e também a sua área de dispersão. A associação com o etnônimo também não era direta. Ao mesmo tempo em que identifica a similaridade material destaca que não havia informações etno-históricas sobre qual povo produziu a cerâmica em uma das áreas com esse estilo - o Lago Salé (NIMUENDAJÚ, 2004, p. 139). Ele fez uma ponderação semelhante em relação ao uso do termo "cerâmica Tapajó" (PALMATARY, 1960, p. 18).

Há duas caracterizações sintéticas conhecidas do estilo Kondurí produzidas por Nimuendajú. Em um relatório ao Museu Etnográfico de Gotemburgo ele destaca que há nesse estilo cerâmico:

(...) proper tripod pottery [identificados] from the numerous slender, tapering, rarely cylindrical feet of the vessels. The plastic decoration is characterised by lines consisting of impressed dots on affixed ribs, grooves, and flat warts with punched circles or an impressed point in their centres. Furthermore, decoration consisting of a grotesque pile of ribs, protuberances and warts occurs, so that the original motif is often unrecognisable. [...] Painting in red varnish or black lines on yellow grounds also occurs. Other features are reminiscent of those of the Tapajó pottery. (op. cit., p. 135 - referências a figuras suprimidas).

Em uma carta ainda inédita a Helen Palmatary, Nimuendajú apresenta uma outra caracterização para cerâmica Kondurí ( ver Figura 3): 
Linhas de pontos impressos com um instrumento muito fino, acompanhando paralelamente os contornos (Tap. Pot. [PALMATARY, 1939] Fig. 30. D, F.); fileiras ou grupos de pequenas saliencias papilares com ponto central que não representam olhos (Fig. 31 B.); nas caras humanas bocca projetada para a frente como de quem assobia (Fig. 30. B.).[...] Outro elemento muito comum dela são umas peças cônicas, maciças, do comprimento de um dedo que eu considero pés de vaso (tripodes). São extremamente frequente na região dos Kondurí. ${ }^{3}$

Ambas as caracterizações destacam a presença de vasilhas trípodes e elementos decorativos, como a presença de filetes aplicados e ponteados. Na caracterização enviada a Palmatary ainda são destacados elementos iconográficos como a "boca que assobia”. Nenhuma das duas caracterizações é sistemática, mas evidenciam claramente os principais elementos do que Nimuendajú identificou como cerâmica Kondurí, que são mais ou menos os mesmos, apesar da diferença de mais de um decênio entre um manuscrito e outro.
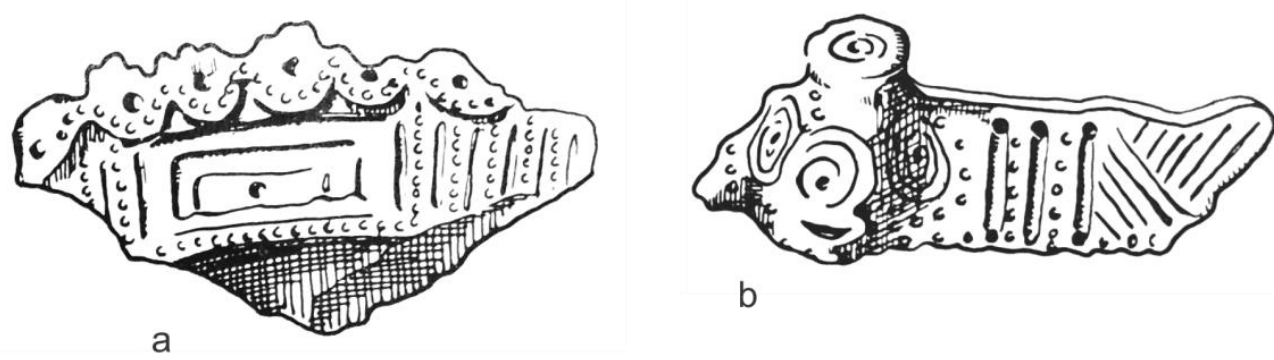

b
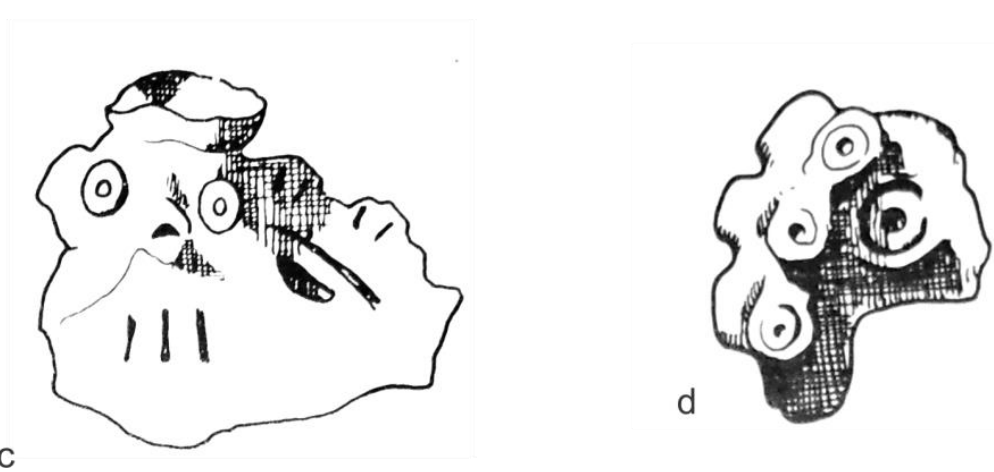

Figura 3. Fragmentos indicadas por Nimuendajú como pertencentes ao estilo Kondurí: a. figura 30- D; b. figura 30-F; c. figura 30-B; d. figura 31-B. Peças provenientes de Santarém (a,c,d) e Lago Grande (b). Adaptado de Palmatary, 1939.

\footnotetext{
${ }^{3}$ Carta de Curt Nimuendajú a Helen Palmatary, 27/10/1939, Arquivo Curt Nimuendajú/ CELÍN/MN.
} 
Em correspondência com Helen Palmatary, Nimuendajú explicita o caráter arbitrário de sua classificação - como de qualquer outra - e destaca que reuniu estilos distintos em um mapa depois publicado pela autora (Mapa 1). Tanto a cerâmica encontrada no rio Arapiuns quanto em Monte Alegre foram associadas ao estilo Santarém como variantes, mesmo o pesquisador considerando - as "divergentes". Por outro lado, ele pensava em termos de áreas de influência amplas. Em um relatório de 1923, antes de começar a utilizar o termo Kondurí, Nimuendajú (2004, p.125) chegou a sugerir que existiria uma "zona Nhamundá" que seria uma "cultura local" dispersa entre Santarém, Lago Grande e rio Trombetas, caracterizada pela presença de muiraquitãs, ídolos de pedra, ausência de urnas funerárias e um estilo cerâmico elaborado característico. Em um mapa enviado a Palmatary, o autor delimita um "círculo cultural" do estilo Tapajó, que além das variantes divergentes (Monte Alegre e Arapiuns), abrangia a maior parte da área de dispersão do estilo Konduri (até a Serra de Parintins) e alcançava quase a foz do rio Xingu (Boca do Coati). Apliques em forma de cabeças de urubu-rei, do "legítimo estilo dos Tapajós" (HARTMANN, 2000, p. 88; NIMUENDAJÚ, 2004, p 156), seriam peças presentes em sítios com cerâmica Konduri obtidos por troca. Além disso, Nimuendajú acreditava que havia peças com um "mixto de ambos os estilos (Kondurí e Tapajó)". 


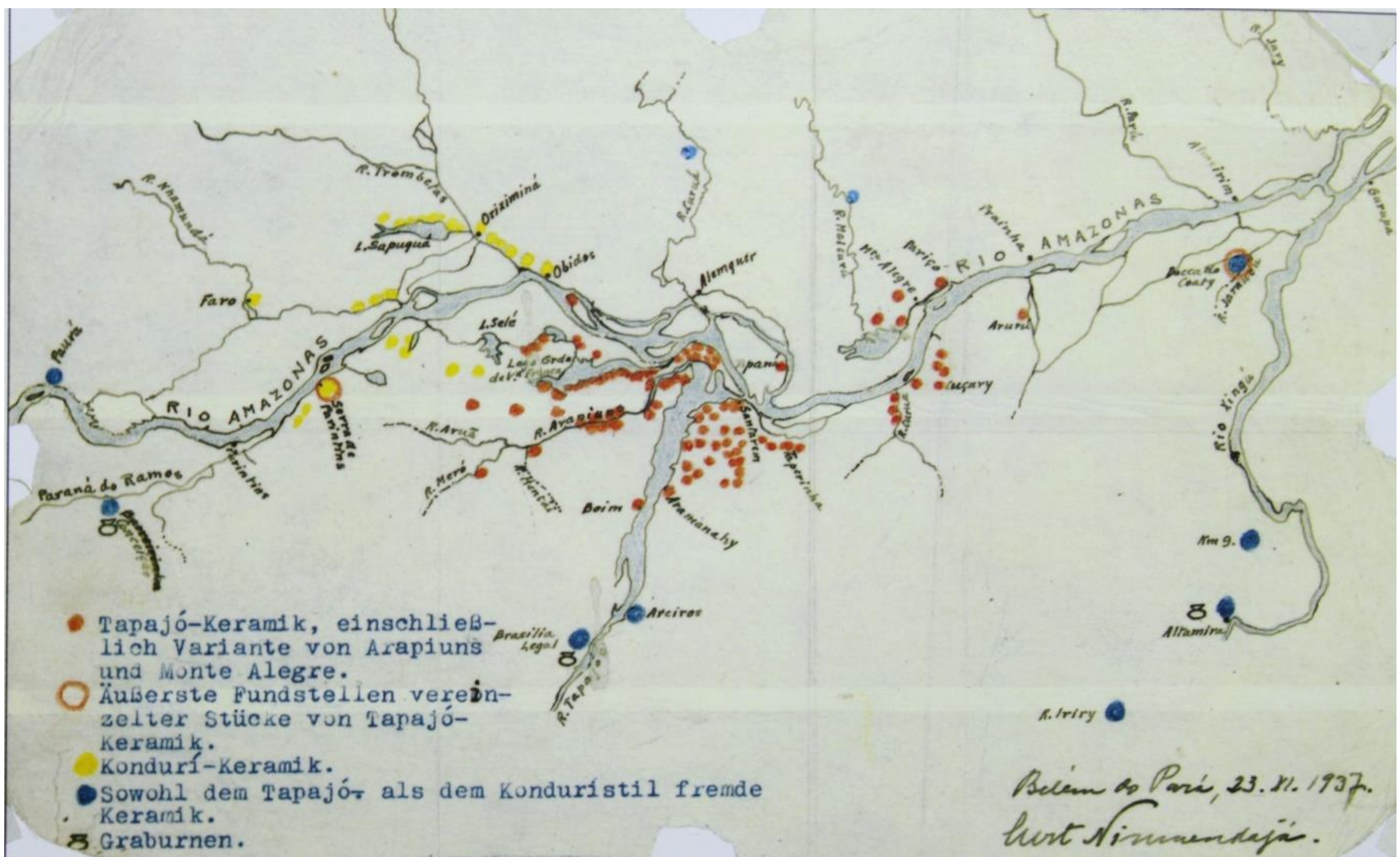

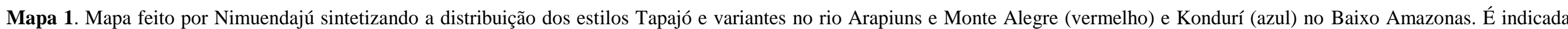

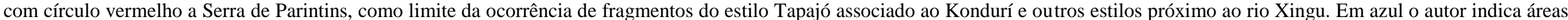
com outros estilos, além de marcar as áreas ocorrência de urnas funerárias (graburnen). Extraído de Hilbert, 1986 


\subsection{A segunda construção do estilo Konduri}

A cerâmica da região do rio Trombetas e Nhamundá figurou pouco nas publicações de autores correspondentes de Nimuendajú, que se voltaram para a cerâmica Santarém (LINNÉ, 1928; NORDENSKIOLD, 1930; PALMATARY, 1939). A denominação “estilo Konduri” quase não chegou a ser mencionada - apenas uma vez por Palmatary (1939) e outra pelo próprio Nimuendajú (2001). Por décadas pairou certa incerteza sobre as informações coletadas e as hipóteses levantadas pelo etnólogo alemão. O estado nebuloso do conhecimento sobre a cerâmica encontrada na região dos rios Trombetas e Nhamundá perdurou ainda mais devido ao caráter especulativo do texto de Barbosa de Faria (1946) e a "cerâmica da tribo Uaboí". A falta de conhecimento sobre a "cerâmica de Oriximiná", como destacou Frederico Barata (1950), levou Peter Hilbert a realizar uma prospecção arqueológica na região dos rios Trombetas e Nhamundá entre novembro e dezembro de 1952 (Figura 4).

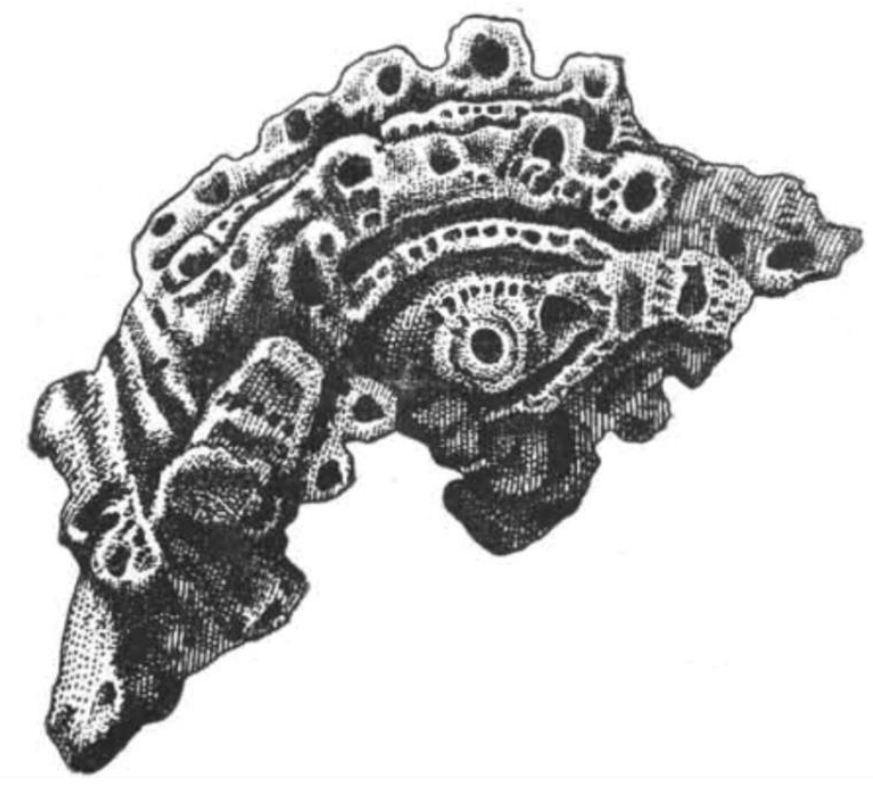

Figura 4. Fragmento com elementos "barrocos" característico do que Barata (1950) chamou de “cerâmica de Oriximiná”. Extraído de Barata, 1950. 
Hilbert realizou um levantamento de sítios arqueológicos no baixo curso do rio Trombetas e do rio Nhamundá, visitando 26 sítios e catalogando outros 30 reconhecidos pelo frei alemão Protásio Frikel e outros 10 mencionados por moradores locais. Nos sítios visitados fez coletas de superfície e, em dois sítios, sondagens de $1,0 \mathrm{~m}^{2}$. Frederico Barata cedeu sua coleção de cerâmica do rio Trombetas para o estudo. Frikel teve uma grande importância na constituição da monografia sobre a cerâmica na região de Oriximiná, uma vez que durante uma década tinha visitado sítios arqueológicos e coletado material ao longo do curso dos rios Trombetas e Nhamundá, além do município de Juruti. Apesar de não ter publicado os resultados de suas incursões, enviou cartas e manuscritos a Hilbert.

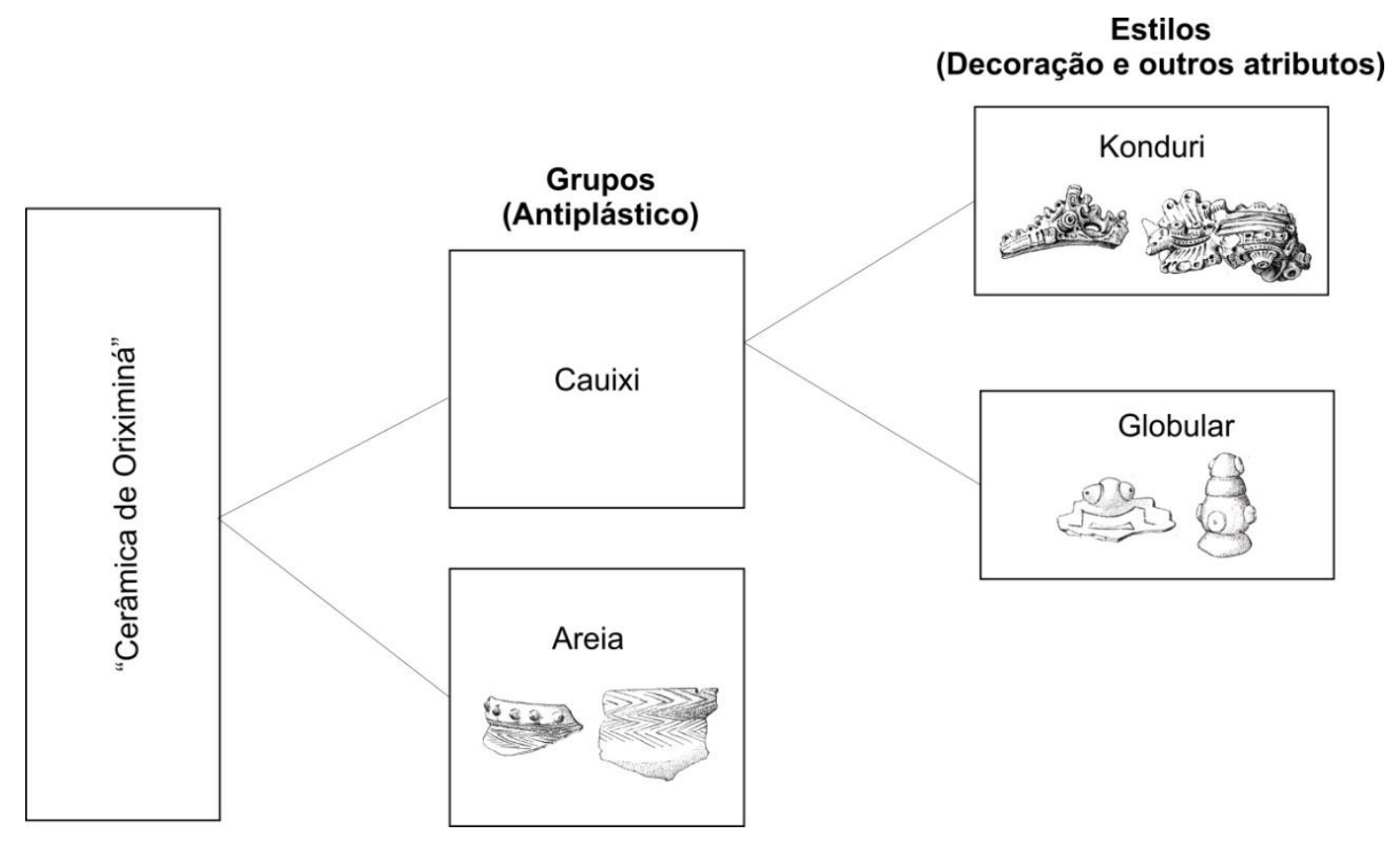

Figura 5. Esquema resumindo a classificação da cerâmica coletada por Peter Hilbert. Figuras adaptadas de Hilbert, 1955a.

A cerâmica arqueológica encontrada nas bacias dos rios Trombetas e Nhamundá foi vista, até a década de 1950, como um conjunto homogêneo, representado por seu aspecto "barroco" compartilhado com a cerâmica Tapajó ou Santarém (CRULS, 1930; BARATA, 1950). Mesmo Nimuendajú não tinha apontado outros conjuntos para a região, além do denominado "Konduri”. O estudo realizado por Peter Hilbert (1955a) 
mostrou, no entanto, que era possível separar em grupos distintos os materiais encontrados nos sítios pré-coloniais da região. Os critérios de classificação usados eram sistemáticos: antiplástico, decoração e morfologia das vasilhas. A "cerâmica de Oriximiná" foi classificada em dois grupos de antiplástico: a cerâmica "temperada com areia" e a "temperada com cauixi", sendo este subdividido em dois "estilos" (Figura 5).

O conceito de estilo empregado por Hilbert não foi definido, mas a julgar pela bibliografia citada, foi tomado de Gordon Willey (1949), de onde também advém o conceito de "tradição". Na síntese sobre a cerâmica da América do Sul do Handbook of South American Indians, Willey faz uso do termo "estilo" para qualificar qualquer conjunto cerâmico distintivo, com caráter histórico e geográfico. Em suas palavras:

The style abstraction, as defined, is a certain specified descriptive range in material, constructional, formal, and ornamental features. These specified features tend to be associated or clustered, to the exclusion of other features of similar functions, in the production of a ceramic specimen. The reality of style classification is that a number of specimens are grouped together on the basis of similarity to each other. It has been usual to demonstrate for each style certain time and space correlates so that the style is not simply a descriptive label but has a definite value placed upon it as a historical and geographical marker in culture studies. (WILLEY, 1949, p. 163).

Hilbert seguiu essa definição, tratando os "estilos" como unidades delimitadas espacial e temporalmente, da mesma maneira que Nimuendajú o fizera. Diferente do último, no entanto, a noção de estilo englobava antiplástico, morfologia e outros atributos da cerâmica, além da decoração. O conceito de estilo empregado por Hilbert é precursor do conceito de fase desenvolvido por Phillips e Willey (1953). Não se trata, portanto, de um "agrupamento alternativo" baseado em "critérios artísticos" distintos dos desenvolvidos por Meggers e Evans (1957), como sugeriu Hilbert (2009, p. 147-148). O sistema de classificação baseado em fases e horizontes-estilo (depois tradições) na arqueologia amazônica foi amplamente adotado apenas a partir dos primeiros trabalhos publicados Meggers e Evans (1957, 1960 e 1961), que são posteriores a monografia sobre a cerâmica de Oriximiná. Antes disso havia outras sínteses, usado outros conceitos para a construção de um quadro histórico-cultural da Amazônia, sendo um deles "estilo". 

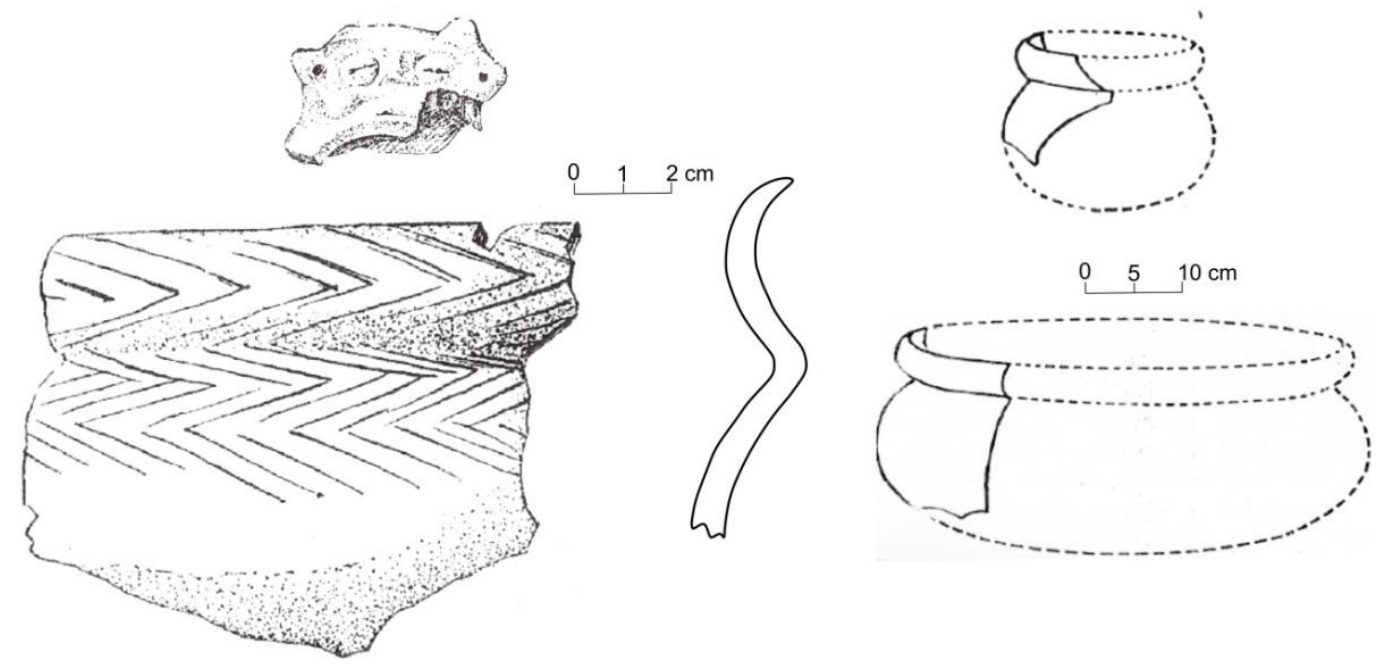

Figura 6. Elementos identificados como característicos da "cerâmica temperada com areia". Adaptado de Hilbert, 1955a.

O grupo de "cerâmica temperada com areia" representava apenas uma pequena parcela ("5\%") do material coletado e não foi tratado como um "estilo". Hilbert, no entanto, não explica se esta escolha estaria relacionada apenas a baixa quantidade de material disponível para estudo (Figura 6). As peças desse grupo foram caracterizadas por exibirem antiplástico com "porcentagem bastante moderada", pasta de cor marrom, tipo de vasilha com estrangulamento e "incisões finas, feitas sem esmero, do tipo "espinha de peixe"", adornos zoomorfos, botões aplicados e ausência de pintura (op. cit., p. 32 e 71). Em termos de dispersão espacial essa cerâmica estaria limitada a região do rio Trombetas. Nimuendajú (2004, p. 138) tratou fragmentos idênticos a essa "cerâmica temperada com areia" como característico de seu "estilo Kondurí".

As peças temperadas com cauixi - cerca de $95 \%$ segundo o autor - foram divididas em dois "estilos" (A e B) cujas denominações foram "Konduri" e "globular". O estilo B ou globular foi caracterizado em relação ao estilo Konduri por uma concentração menor de cauixi na pasta e uma decoração em que "prevalece uma tendência mais calma e concisa" (op. cit., p.63) com apliques construídos a partir da sobreposição de esferas e incisões mais largas (retilíneas ou curvilíneas) (Figura 7). Não foi possível reconstituir nenhuma forma, dada a fragmentação do material coletado. Hilbert ainda destacou a queima de oxidação completa, superfícies quase lisas da cerâmica e a ausência de ranhuras na aplicação de modelagens. 


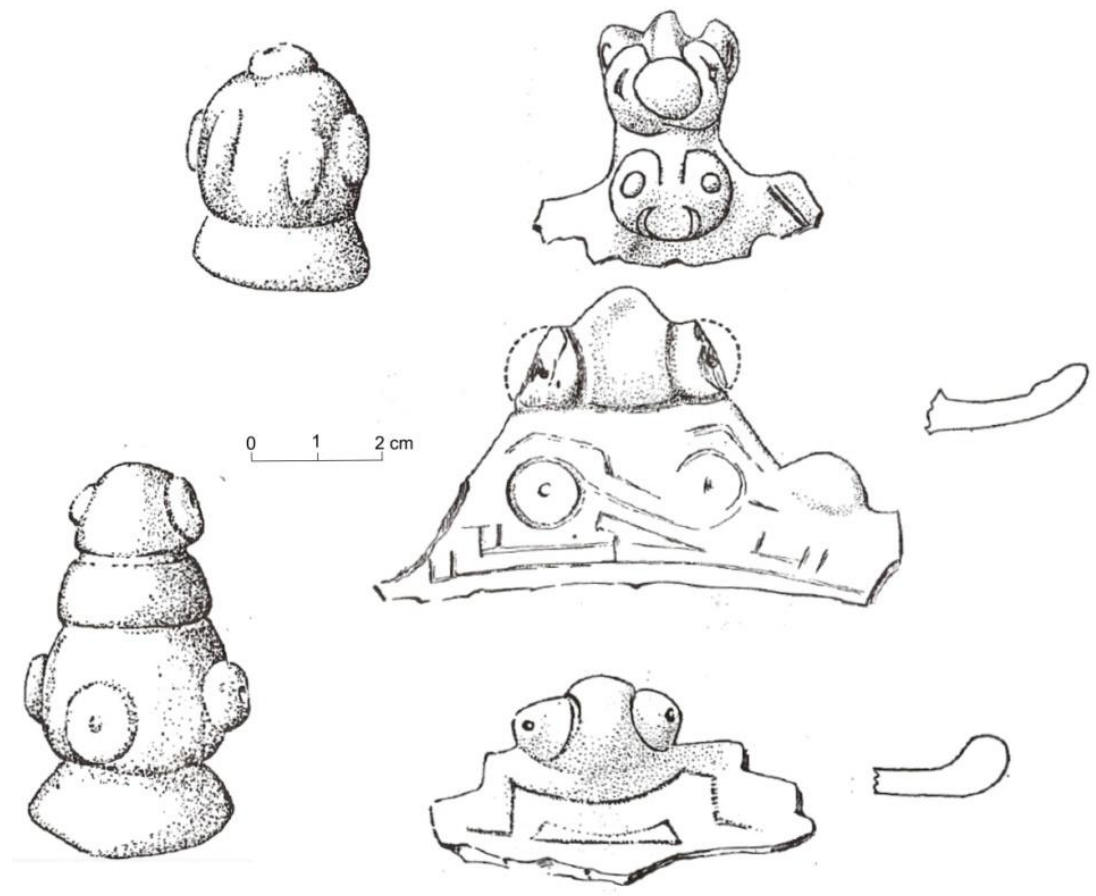

Figura 7. Apliques e fragmentos de borda agrupados no estilo Globular. Adaptado de Hilbert, 1955a.

O "estilo A" representava o maior número de peças coletadas e foi o qual mais espaço foi dedicado na monografia (Figura 8). Provavelmente o intuito inicial de Hilbert era descrever a "cerâmica de Oriximiná" mencionada por Barata (1950), que se refere apenas ao estilo Konduri. Os outros dois conjuntos foram identificados a partir do estudo do material e nunca haviam sido considerados desta maneira. Hilbert (op. cit., p.11) menciona que manteve a denominação "Konduri" dada por Nimuendajú, seguindo indicações presentes nas fichas de peças do Museu Goeldi, que mencionavam "cerâmica Konduri, rio Trombetas até Jamundá". Nimuendajú foi chefe da Seção de Etnologia do Museu Paraense Emílio Goeldi em 1921 e teve uma pequena atuação na década de 1940 na instituição (BARRETO, 1992), o que explica a existência dessas anotações. Em uma carta datada de janeiro de 1953, Frikel informa a Hilbert que Nimuendajú falava da "cultura Konorí" (Konorí-kultur) ${ }^{4}$ na região do rio Trombetas. Nos manuscritos do início da década de 1940, enviados a Hilbert aparecem algumas indicações de "cultura do Juruty", "estilo Juruty" e "estilo Conduri", indicando que ele tinha referências conceituais parecidas com as de Nimuendajú, se não as obteve com este etnólogo. Essas informações não foram citadas por Peter Hilbert, mas certamente influenciaram sua

\footnotetext{
${ }^{4}$ Carta de Protásio Frikel a Peter Hilbert. Oriximiná 25/1/1953. Arquivo Pessoal Klaus Hilbert, PUCRS. ${ }^{5}$ FRIKEL, Protásio. Notas zu Juruty Stil. Sd, 2f. Arquivo Pessoal Klaus Hilbert, PUCRS.
} 
construção do estilo Konduri. Nenhuma das informações mencionadas nos manuscritos de Nimuendajú estava disponível para o autor, o que levou a uma segunda construção do estilo Konduri - agora sem acento agudo na sílaba tônica, mas ainda grafado com "K".

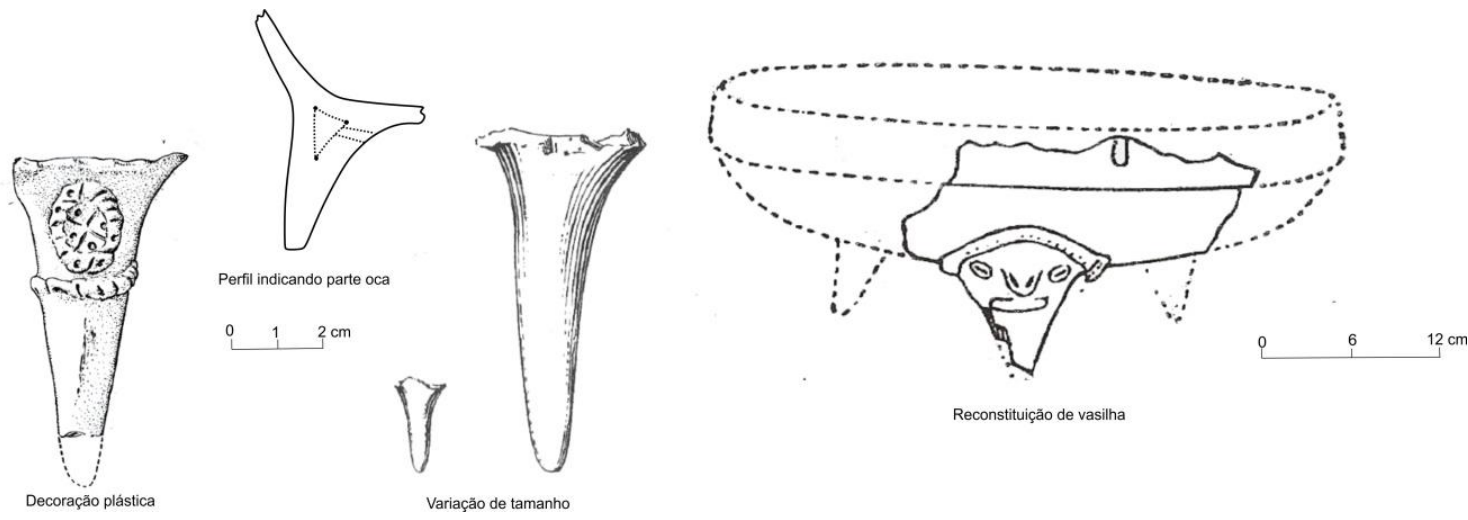

Figura 8. Elementos destacados na descrição de Hilbert (1955a) em relação às características dos pés trípodes. Adaptado de Hilbert, 1955a.

O cauixi abundante da pasta da cerâmica Konduri foi um dos principais atributos enfatizados na cerâmica Konduri. O autor destaca: "Na cerâmica de Santarém, mesmo ampliada 20 vêzes, é difícil vislumbrar um espículo, enquanto que na do TrombetasJamundá os espinhos [espículas] são visíveis por vêzes com uma tal densidade que se tem a impressão de olhar um pedaço de cauixy puro." (op. cit., p. 35 - ênfase adicionada). A cerâmica ainda apresenta um aspecto áspero, facilmente riscável com a unha e a queima geralmente apresentava uma porção reduzida ("camada cinza no interior"). As cores das pastas variam entre "amarelo-sujo", "vermelho-tijolo", "marrom-carminado" e "cinzenta-claro". "A maneira de tratamento da superfície, em virtude dos efeitos geralmente fortes da erosão, é difícil de terminar.” (p. 33), mas foram encontrados vestígios de polimento e de pintura vermelha e amarela na amostra.

A decoração plástica, que chamou a atenção de autores antes de Hilbert, foi cuidadosamente descrita, com uso do vocabulário das artes visuais e hipóteses sobre os 
instrumentos utilizados na sua confecção. O elemento mais emblemático da decoração Konduri é a

(...) aplicação pomposa de entalhes, incisões e pontos ou orifícios, bem como a tendência de dissolver os contornos com esse procedimento. É uma técnica que dá aos adornos um aspecto peculiar de esponja e nos casos mais bem sucedidos, um certo tom 'rococó', mas elegante. (op. cit., p. 57)

Hilbert apenas menciona a predominância de apliques zoomorfos aplicados à borda e voltado para o interior das vasilhas. Em termos de sua técnica de construção, o autor adiciona os diferentes tipos de olhos modelados e/ou ponteados. Também discute a produção dos apliques chamados de "botões" - pequenas modelagens troncocônicas com ou sem ponteado e incisões. Somam-se a isso, os métodos de incisão e ponteados. O autor estabelece, assim, os elementos mínimos e variações da decoração plástica Konduri. Sobre a iconografia, destaca padrão figurativo composto por uma cara antropomorfa sobreposta por um zoomorfo que relaciona com as figuras de "alter ego" das estatuetas líticas da região do rio Trombetas.

\begin{tabular}{|r|l|}
\hline \multicolumn{2}{|c|}{ SEMELHANÇAS } \\
\hline $\mathbf{1}$. & Sítios de terra preta, em planaltos, margens de lagos e rios de terra firme \\
\hline $\mathbf{2 .}$ & Predomínio de adornos antropomorfos e zoomorfos \\
\hline $\mathbf{3 .}$ & Cauixi empregado como antiplástico \\
\hline $\mathbf{4 .}$ & Vasilhas com borda dupla \\
\hline $\mathbf{5 .}$ & Bases anelares \\
\hline $\mathbf{6 .}$ & Vasilhas trípodes (?) \\
\hline $\mathbf{7}$. & Motivo "cabeça dupla" \\
\hline $\mathbf{8 .}$ & Tipo de olhos \\
\hline $\mathbf{9 .}$ & Estatuetas cerâmicas \\
\hline $\mathbf{1 0}$ & Ausência de urnas funerárias \\
\hline $\mathbf{1 1}$ & Parte da cerâmica fabricada sobre esteiras \\
\hline
\end{tabular}

Tabela 1. Semelhanças entre as cerâmicas Santarém e Konduri. Extraído de Hilbert (1955a:73). 
Em termos da morfologia das vasilhas, Hilbert destacou dentro do conjunto Konduri, bordas com algo que o lembravam a um "triângulo" (bordas reforçadas externamente) e bases planas e anelares. Enfatizou também duas morfologias de vasilhas abertas: uma mais rasa, chamada de "prato" e outra muito rasa, chamada de "grelha" (griddle em inglês e conhecidas como "assador" em português). Esses tipos compartilhavam a presença de um friso inciso na borda. As numerosas modelagens cônicas encontradas nas terras pretas foram interpretadas por Hilbert como indicadores da existência de vasilhas trípodes (HILBERT, 1955b), da mesma maneira que Nimuendajú o fizera. Ocorrências mais pontuais também foram mencionadas no texto, como a existência de "alça estendida sobre a abertura" da borda, fusos, estatuetas cerâmicas e fragmentos com padrões incisos raros ("apenas 1\% do material coletado").

\begin{tabular}{|c|c|c|}
\hline \multicolumn{2}{|c|}{ DIFERENÇAS } \\
\hline Característica & Santarém & Konduri \\
\hline Concentração de cauixi & Comedida & Abundante \\
\hline Dureza & Entre 3 e 4 Mohs & Entre 2 e 3 Mohs \\
\hline Decoração plástica de paredes & Incisões retilíneas e curvas & Incisões retilíneas \\
\hline Decoração de apliques e alças & Parcimônia no uso de incisões & $\begin{array}{l}\text { Combinação de incisões, } \\
\text { entalhes e ponteado }\end{array}$ \\
\hline Pintura & & Vermelha e friável \\
\hline Fixação de apliques & Com ranhuras & Ausente \\
\hline Borda oca & Frequente & Ausente \\
\hline Vaso de cariátides & Frequente & Frequente \\
\hline Vasilha trípode & Rara & Presente \\
\hline Alça em ponte & Ausente & Presente \\
\hline Cachimbo angulares & Paros e tintas fixas & \\
\hline
\end{tabular}

Tabela 2. Diferença entre as cerâmicas Santarém e Konduri. Sintetizado de Hilbert (1955a:73). 
No final da monografia, Hilbert destacou, no entanto, que apesar de existir uma "unidade estilística" há diferenças na "qualidade do material empregado e também do cozimento"; "qualidade artística" e "particularidades estilísticas locais" (op. cit., p. 72). Nenhuma dessas diferenças foi discutida. A cerâmica foi descrita de maneira homogeneizante, sem diferenciar as variações (ou variabilidade) dos sítios visitados. O autor sugere que o motivo dessa estratégia descritiva foi a baixa quantidade de peças coletadas, que não permitiriam criar "subdivisões" dentro do conjunto

Como Nimuendajú, Hilbert via a unidade "estilo" como delimitável espacial e temporalmente. A partir de sua prospecção, ele delimitou uma área que ia desde o baixo Cuminá, passando pelo Lago Sapucuá, chegando até o baixo curso do rio Nhamundá. $\mathrm{Na}$ outra margem, ele indicou a dispersão, a partir de outro trabalho de campo, entre os lagos Juruti Velho e Juruti Mirim, sem indicar, no entanto um limite. Hilbert menciona apenas que no rio Madeira haveria já evidências de outro estilo cerâmico. O lago Salé, próximo ao Lago Grande, seria uma “zona de contato” entre o estilo Konduri e Tapajó.

Desde o século XIX, Barbosa Rodrigues (1875b) e Hartt (1885) já apontavam semelhanças entre a cerâmica encontrada no baixo curso do rio Trombetas e no baixo Tapajós.

Comparando a louça [do rio Nhamundá], com a dos Tapajós, que encontrei na serra do Diamantino e Piquiatuba, no distrito de Santarém, achei alguma analogia entre os desenhos e alguns até iguaes, o que veio a convencer-me de que tinham com efeito os índios Tapajós relações com os deste lugar. (BARBOSA RODRIGUES, 1875b, p. 93).

Nimuendajú e outros (CRULS, 1930, 1942; BARATA, 1950) viam uma grande semelhança entre essas cerâmicas. Em alguns casos, a cerâmica do rio Trombetas parecia ser apenas uma "extensão" da própria cerâmica Santarém (PALMATARY, 1939). Delimitar a dispersão do estilo Konduri, significava, não apenas caracterizá-lo, mas diferenciá-lo do estilo Santarém, que na época já era amplamente conhecido. A identificação de uma "zona de contato" entre as "províncias estilísticas" tornava ainda mais premente essa diferenciação. 
Peter Hilbert não apresentou uma análise da cerâmica Santarém, mas deve ter tido contato com o material que compunha a coleção de Frederico Barata. Ele construiu uma lista de traços comparando os estilos que, com exceção das características dos sítios arqueológicos, era totalmente construída a partir da cerâmica. O quadro comparativo composto entre os estilos Konduri e Santarém apresenta 11 semelhanças (Tabela 1) e 11 diferenças, no qual figuram atributos de técnicas de manufatura e morfologia, bem como tipos de vasilhas (vaso de cariátides) e artefatos (cachimbos angulares) (Tabela 2). Para Hilbert as semelhanças existentes indicariam uma relação histórica de deriva dentro da "tradição plástica do Orenoco", mencionada por Willey (1949), e depois denominada Tradição Inciso e Ponteado (MEGGERS; EVANS, 1961; BROCHADO et al., 1968). Além dessa relação de longa duração, haveria uma “ocorrência de peças permutadas ou de comércio entre as duas províncias estilísticas [Tapajó e Konduri], (...) um fenômeno frequente.” (op. cit., p. 72). Essa afirmação vai no mesmo sentido que a de Nimuendajú em relação a peças do "legítimo estilo Tapajó" associado a cerâmica Konduri. Hilbert, inclusive, menciona uma estatueta do estilo Santarém encontrado na cidade de Oriximiná que seria uma "peça de troca".

\subsection{Revisões e ampliações}

A classificação construída por Peter Hilbert tornou-se a principal referência sobre estilo Konduri, que até então não havia sido definido em publicações. Os dois estilos e o grupo de "cerâmica temperada com areia" não foram completamente revisados ou rediscutidos até o momento. Peter e Klaus Hilbert (1980) voltaram à área dos rios Trombetas e Nhamundá, mas pouco trataram do quadro desenvolvido décadas antes pelo autor sênior. Apenas descreveram sumariamente o estilo Konduri. Criaram, no entanto, uma nova unidade arqueológica denominada fase Pocó. A cerâmica Pocó foi definida a partir do uso de cauixi, caraipé e sua combinação associada a várias técnicas decorativas pictóricas (engobo vermelho, branco, vermelho sobre branco etc.) e plásticas (incisões largas em U, escovado, acanalado, raspado-zonado, etc.). Foram apresentadas 6 datações para dois "sítios-tipo", sendo apenas uma associada a ocupação Konduri, apontando uma diferença cronológica significativa.

Denise Gomes (2002), a partir do estudo de uma coleção de museu, manteve a categoria "estilo", mas propôs subdivisões a partir de atributos decorativos (modos) da cerâmica da região do rio Trombetas. Em sua seriação ou "sequência hipotética", 
Gomes relaciona o estilo globular às tradições Saladóide e Barrancóide, seguindo Brochado e Lathrap (1982). Lathrap (1970) já havia inserido peças "globulares" como exemplos do material Barrancoide amazônico. Gomes (2002) propôs três modos decorativos para o estilo Konduri (Fileira de Ponteado, Ponteado em Profusão e Incisões Retilíneas), mas estes não foram retomados em estudos posteriores na região do rio Trombetas. É possível que um deles, inclusive, apresente-se apenas em peças do estilo Santarém, misturadas com as do estilo Konduri nos processos de formação das coleções e que acabaram sendo vistas como uma forma de "influência" sobre o estilo Konduri, seguindo sugestões de Palmatary (1960) e Guapindaia (1993) (ver Capítulo 2).

Vera Guapindaia (2008; GUAPINDAIA, LOPES, 2011), em termos da classificação da cerâmica, alterou pouco o quadro proposto por Hilbert (1955a) e Hilbert e Hilbert (1980), mantendo inclusive a categoria "estilo". A autora sugere que a “cerâmica temperada com areia" poderia fazer parte do estilo Konduri (op. cit., p. 119). O "estilo globular" não é mencionado fora da revisão e a caracterização dos materiais encontrados nos sítios arqueológicos é baseada na distinção entre a ocupação mais antiga (Pocó) e a mais recente (Konduri).

Camila Jácome (2017), apesar de não ter feito uma rediscussão total das categorias construídas por Hilbert (1955a), sugeriu modificações mais amplas no quadro. Para ela, parte do que foi considerado globular poderia ser considerado Pocó, como já sugerido de maneira implícita por Gomes (2002). Jácome, no entanto, ainda mantém a unidade "estilo globular". A cerâmica temperada com areia é para Jácome um “conjunto (...) próprio e distinto da cerâmica Konduri” (op. cit., p. 98), sendo denominado"Espinha de Peixe (op. cit. . Tendo em vista o melhor estado de conservação das superfícies dos fragmentos Espinha de Peixe, sugere que estes podem ser mais recentes. A autora considera a estratigrafia dos sítios pesquisados no rio Mapuera muito perturbadas, impossibilitando fazer uma correlação estratigráfica.

De maneira geral, mesmo com essas revisões o quadro construído por Hilbert se perpetuou e se mantém quase inalterado. Ainda permanece a questão sobre o que representa o "estilo globular" ou a "cerâmica temperada com areia". O estilo Konduri parece ser uma unidade mais consolidada. 


\subsection{Estratigrafia, cronologia e outros materiais}

O crescimento da arqueologia de contrato permitiu a identificação de centenas de sítios arqueológicos e a escavação de algumas dezenas, especialmente nas proximidades de Porto Trombetas e no município de Juruti. Junto com esses resultados, pesquisas acadêmicas (LIMA et al., 2013; JÁCOME, 2017) ampliaram muito a dispersão do estilo Konduri e mapearam a diversidade de sítios. Uma ampla gama de informações foi acumulada em relação à localização de sítios arqueológicos, estratigrafia, cronologia, processo de formação do registro arqueológico, tecnologia lítica, grafismos rupestres, caracterização petrográfica e geoquímica da cerâmica (GUAPINDAIA, 2008; FONSECA JÚNIOR, 2013, 2018; GUAPINDAIA, FONSECA JÚNIOR, 2013; RODET et al., 2010; RODET et al, 2016; DUARTE-TALIM, 2012, 2015; KERN, KÄMPFN, 1989; PEREIRA, 2003; PEREIRA et al., 2008; COSTA et al., 2004a; COSTA et al., 2004b; SCHMIDT et al., 2014, entre outros). Essas informações, no entanto, não foram completamente associadas às diferentes ocupações nos principais sítios escavados. Ainda se compreende pouco a ligação das feições identificadas e a cerâmica Konduri.

Soma-se a esse quadro, certa indefinição estratigráfica. Apesar de ter sido indicada uma camada arenosa entre as ocupações Pocó e Konduri no rio Nhamundá (LIMA, 2008, p. 316), esta não é a realidade na maioria dos sítios. No sítio arqueológico Boa Vista, escavado pelo Projeto Arqueológico Porto Trombetas, não foi identificada uma clara separação entre as camadas com cerâmica Pocó e Konduri (GUAPINDAIA, 2008; GUAPINDAIA e LOPES, 2011). Uma situação ainda mais complexa ocorre no sítio Cipoal do Araticum: a cerâmica Pocó aparece em todos os níveis, variando apenas a proporção (CHUMBRE, 2014, p. 166 e 169; NEVES et al., 2014, p. 141). Panachuk (2016a, p.287) sugere que esse pode ser um padrão em sítios multicomponenciais profundos em sítios com ocupações Pocó e Konduri. Em dois sítios no município de Juruti e em um no município de Nhamundá, todos multicomponenciais e com terra preta profunda, não há nenhuma separação ou hiato entre as ocupações mais antigas e mais recentes, variando apenas a proporção das cerâmicas. As autoras têm sugerido ocupações contínuas para os sítios multicomponenciais, mas é possível que a presença de materiais Pocó resulte de perturbações devido às várias reocupações. Existem sítios arqueológicos com camadas menos densas de terra preta apenas com material Konduri. Além disso, nas camadas 
mais superficiais há apenas (ou majoritariamente) fragmentos Konduri (ver imagens em CHUMBRE, 2014).

A delimitação de uma cronologia de ocupação dos sítios multicomponenciais tem sido um problema devido à indefinição estratigráfica. O sítio Boa Vista apresenta datações que recuam até o século XI, que foram associadas a ocupação Konduri. A cronologia, como a estratigrafia, do sítio Cipoal do Araticum é a mais complexa. Guapindaia e Fonseca (2013) sugeriram uma ocupação contínua entre 2000 a.C. e 1000 AD. Essa continuidade foi proposta porque existe uma datação de 880 a 990 AD e se assumiu que os níveis artificiais teriam uma equivalência em termos de cronologia. Correlacionando as datas com a cronologia de outros sítios, é possível agrupá-las em torno das fases Pocó e Konduri. As datações para a ocupação Konduri, no entanto, teriam que ser recuadas para o século IX. Os sítios unicomponenciais Konduri apresentam datas muito recentes, que giram em torno do século XIV e XV AD. Não conhecidos sítios Pocó unicomponenciais.

Na região de Porto Trombetas foi possível identificar uma diferença nas áreas ocupadas e utilizadas pelos produtores de cerâmica Pocó e Konduri. Guapindaia (2008) mostrou que há uma concentração de sítios arqueológicos com terra preta nas margens de rios e lagos, sendo estes sempre multicomponenciais, com cerâmica Pocó e Konduri em Porto Trombetas. No interflúvio (terras baixas e topo de platô), no entanto, há apenas ocupações Konduri, com manchas de solo escurecido e menor profundidade. A única exceção é o grande sítio Cipoal do Araticum de grandes dimensões e multicomponencial (GUAPINDAIA, FONSECA, 2013). A pesquisadora interpreta os sítios de interflúvio, com menor densidade de material e solo mais claro, como resultado de ocupações temporárias para caça e coleta, enquanto as mais densas seriam resultado de ocupações sedentárias. No caso de um dos sítios em topo de platô, a autora sugere uma utilização para rituais por causa da densidade de material decorado, ausência de terra preta e a presença de várias plantas medicinais nas imediações (GUAPINDAIA; LOPES, 2011).

No sítio Aviso I, apenas com material Konduri, foi identificado o uso de percussão direta dura no lascamento do silexito, além da presença de contas líticas em argilito e uma rodela de fuso (GUAPINDAIA, 2008; GUAPINDAIA, LOPES, 2011). 
Jaqueline Rodet e colaboradores (2010, 2014) apontaram diferenças na tecnologia lítica entre as ocupações Pocó e Konduri no sítio Boa Vista. O material da ocupação Konduri, majoritariamente em silexito, apresenta estigmas de debitagem por percussão direta dura e sobre bigorna, enquanto o da ocupação Pocó apresenta uma indústria marcada pelo lascamento de quartzito e, menos frequentemente silexito, a partir da técnica de percussão sobre bigorna. Além disso, as lâminas polidas de machado parecem apresentar uma morfologia característica denominada por Becker e Mello (1963) como tipo "Sacuri". No sítio Cipoal do Araticum, talvez devido a perturbações na estratigrafia, não foi possível diferenciar o material lítico mais recente do mais antigo (DUARTE-TALIM, 2012, 2015).

A descontinuidade entre as pesquisas realizadas na região dos rios Trombetas, Nhamundá e os municípios de Juruti e Parintins, além da falta de publicações de muitos resultados, impede a construção de um quadro mais amplo da ocupação nas áreas de ocorrência da cerâmica Konduri. O quadro construído por Hilbert (1955a) não foi completamente revisto e não se sabe até que ponto alguma de suas unidades tem validade ou se sobrepõe. A situação do "estilo globular", por exemplo, parece indicar uma resistência em abandonar uma unidade já criada. Esse "estilo" não aparece em nenhum contexto estratigráfico delimitado e a maioria de suas peças mais características podem ser classificadas como Pocó, como apontou Jácome (2017).

\subsection{Estilo, complexo, fase ou cultura?}

A construção da unidade arqueológica estilo Konduri foi um processo com o desenvolvimento paralelo das observações de Nimuendajú e as mais sistemáticas de Peter Hilbert (1955a). A aplicação da noção de "peça de troca" e a comparação por semelhança e diferenças de traços (Santarém-Konduri) evidenciam claramente o tema da constituição dos contatos culturais em arqueologia da primeira metade do século XX (ver LATHRAP, 1956; SHEPARD, 1956). A análise da cerâmica apresenta grande atualidade em sua combinação de diferentes atributos tecnológicos e a comparação entre "escolhas" distintas que aproximam seus conjuntos artefatuais da noção mais recente de estilo tecnológico (HEGMON, 1998). No entanto, o material obtido no levantamento foi tratado de uma maneira homogênea, desconsiderando variações/variabilidade. A amostra reunida por Hilbert era pequena e seu objetivo era apenas caracterizar uma 
cerâmica parecida com a de Santarém. Apesar de a classificação ter sido construída como "provisória", acabou por perdurar por mais de sessenta anos.

O termo "estilo" empregado para caracterizar os grupos Konduri e globular não foi definido e por vezes, gera certos conflitos com o sistema de classificação baseado nos conceitos de fase e tradição predominante na arqueologia brasileira. Mário Simões ora fala em "estilo", ora em "fase" ou também "complexo" Konduri. Machado (1991, p. 21), por exemplo, cita dez fases incluídas na tradição Inciso e Ponteado e distingue o "estilo" Konduri e a "cultura" Santarém. No Baixo Amazonas o uso de "estilo" ao invés de "fase" é corrente até o presente (e.g. GUAPINDAIA, 2008; GUAPINDAIA e LOPES, 2011; PANACHUK, 2011). O próprio Peter Hilbert falou em "fase" Konduri (HILBERT, 1959, 1968) e depois retomou a denominação "complexo" e "estilo" (HILBERT, HILBERT, 1980). Esse é um conflito mais aparente do que real, a julgar que ambos os conceitos foram desenvolvidos pelo mesmo arqueólogo, com uma pequena faixa de tempo. Apesar de quase não ser utilizado na arqueologia amazônica atualmente, o conceito de estilo foi fundamental para as primeiras classificações. Na primeira sistematização das ocupações ceramistas das terras baixas da América do Sul, George Howard (1947, p. 14), valeu-se do conceito de estilo para agrupar "aggregates of pottery traces which distinguish a collection as unit”. Cruxent e Rouse (1963, p. 20), por exemplo, definem estilo como "combinación recorrente de rasgos cerámicos, ya sea de material, de forma o decoración" (ver também CRUXENT, ROUSE, 1958/59). O estilo Konduri, tal qual caracterizado por Hilbert, considera antiplástico, morfologia das vasilhas e decoração, tendo uma dispersão espacial específica, seguindo a proposta de Willey (1949). Nimuendajú pensava em “estilo" apenas em relação aos aspectos visuais dos artefatos.

O uso do conceito de "estilo" não se relaciona a uma diferença teórica ou metodológica, sendo apenas resultado de um momento específico da história da disciplina no Brasil. A monografia A monografia A cerâmica arqueológica da região de Oriximiná é anterior aos trabalhos de Meggers e Evans (1957) e Evans e Meggers (1960), que utilizaram o conceito de "fase" para designar culturas arqueológicas. Uma cultura arqueológica, como definida por Childe (1929: v-vi), é a reunião de "certain types of remains - pots, implements, ornaments, burial rites, house forms - constantly recurring together". Essas culturas foram pensadas pelo autor como "the material 
expression of what today we would call a people" (op. cit.). Seguindo Philips e Willey (1953), Meggers e Evans (1957) expressavam sua dúvida sobre essa perspectiva, segundo a qual uma unidade arqueológica representaria uma "tribo"etnográfica.

Há uma ambiguidade na definição do conceito de "estilo" implicitamente usado por Peter Hilbert (1955a), que é um dos problemas relacionados à maioria das unidades análogas construídas ao redor do globo no século passado. Ao mesmo tempo em que o conceito parece se referir a apenas um conjunto material, existe um pressuposto de que representa toda uma cultura arqueológica. O estilo Konduri, apesar de ter sido caracterizado por 21 atributos cerâmicos, apresenta também um traço referente à dispersão e caracterização dos sítios arqueológicos. Isso indica que mais do que uma unidade de classificação material ou tecnológica, a construção do estilo sugere uma cultura arqueológica ou fase. Por isso, Hilbert pôde intercambiar o uso de "estilo" e "fase" em trabalhos posteriores a sua monografia sobre os rios Trombetas e Nhamundá. A noção de estilo definida por Willey (1949) não equacionava cerâmica e um "todo cultural”, mas outras definições desenvolvidas no mesmo período mantém, inclusive, uma associação entre estilo cerâmico e uma população específica. Howard (1947, p. 14) defendia que "[i]deally each style (...) should represent a homogeneous population". Cruxent e Rouse (1963, p. 20), da mesma maneira, afirmaram que "[1]a cultura compartida por um grupo de comunidades es conocida como 'complejo', 'fase', 'estilo', o 'industria'." Em uma entrevista, décadas depois, o autor manteve a mesma posição (SIEGEL, 1996). Essa sinonímia, no entanto, não é, ao menos conceitualmente, compartilhada por Meggers e Evans (1970, p. 87) que afirmam que

(...) deve ser notado que o complexo cerâmico é uma entre várias categorias de artefatos. Junto com um complexo lítico, complexos de outros objetos materiais, arquitetura, elementos socio-políticos e religiosos, e outras espécies de traços, formam um complexo cultural, cultura pré-histórica ou 'fase' arqueológica.

Em trabalhos mais tardios, Meggers revisou sua definição mantendo a ideia de que as fases representariam "unidades sociais endógamas". Permanece uma ambiguidade no uso do conceito de "fase" ora como referente a um conjunto cerâmico e ora, como definido acima, como um "complexo cultural”. Na definição de tradição, por exemplo, Meggers (1990, p. 191), o conceito de fase parece se referir apenas à 
cerâmica: "Fases que compartilham um mesmo conjunto de técnicas diagnósticas de decoração pertencem a mesma tradição”. (ênfase adicionada). Philips e Willey (1953) defendiam que as "tradições" deveriam abranger todo o tipo de vestígio arqueológico em conjunto, um "todo cultural". Em Method and Theory in American Archaeology, no entanto, revisaram este conceito, restringindo-o a uma única tecnologia ou "sistemas de formas relacionadas" com persistência temporal (WILLEY, PHILIPS, 1958, p. 37).

A utilização dos conceitos de fase e tradição na arqueologia amazônica tende a enfatizar apenas os complexos cerâmicos, como em Neves e Moraes (2012), mas ainda persiste sua equalização a um complexo mais amplo. Isso se mostrou possível em alguns contextos da Amazônia Central que, a partir de pesquisas intensas, mostrou uma correlação entre complexo cerâmico e outros elementos do registro arqueológico (NEVES, 2010, 2011). Neves et al. (2014, p. 138), ao definirem a Tradição PocóAçutuba, delimitam "conjuntos cerâmicos padronizados" combinando ao o início da formação de terras pretas na calha do Amazonas e baixo curso de seus afluentes. Dessa maneira, essa tradição não é somente cerâmica, mas combina um elemento de modificação de paisagem. A tradição Borda Incisa rediscutida por Lima e Neves (2011) inclui também elementos mais amplos, sendo tratada como uma "tradição tecnológica", que inclui e compara cadeias operatórias. As tradições arqueológicas não são pensadas apenas como representantes da dispersão de uma tecnologia, mas também como parte de toda uma "matriz cultural" associadas a famílias linguísticas (Tupi, Arawak, Karib) e um ethos característico desenvolvido ao longo de séculos ou milênios (LATHRAP, 1970; NEVES, 2010; ERIKSEN, 2011). Em suma, parece persistir a ambiguidade dos conceitos de fase e tradição, na medida em que, podem se referir ao complexo cerâmico ou a um "todo cultural"..

Em relação a todos esses termos, é possível dizer que o estilo Konduri é um complexo cerâmico definido tanto por Hilbert (1955a) quanto por trabalhos mais recentes, especialmente do ponto de vista de sua decoração. Essa é uma unidade que mantém um caráter distintivo e a coerência não encontrada em outras unidades construídas durante as pesquisas do PRONAPA/PRONAPABA. A cerâmica da fase Borba, por exemplo, foi considerada indistinta da cerâmica da fase Guarita por Moraes (2013, 2016) ou no caso da cerâmica da cultura Baden da Europa Central (FURHOLT, 2007), em que a denominação agrupava diferentes estilos. Como uma cultura 
arqueológica ou fase no sentido empregado por Meggers, a unidade Konduri é pouco desenvolvida. Além da sua associação com terras pretas e ocorrência em diferentes "compartimentos ambientais", não há muitas informações que possam ser comparadas ou que permitam pensar nas especificidades da ocupação. Isso ainda precisa ser discutido. No estágio atual do conheciemento, não é possível dizer até que ponto existe uma sobreposição entre diferentes características dos complexos tecnológicos e dos sítios arqueológicos ou se há divergência entre uma categoria e outras.

\subsection{Conclusão}

O refinamento teórico e a ampliação do escopo da arqueologia não suplantaram a necessidade da construção de unidades arqueológicas, que sirvam para delimitar continuidades e descontinuidades materiais, em grande parte do mundo (ROBERTS, LIDEN, 2011). Todavia, já não é mais possível fazer o equacionamento de potes, culturas e povos. A padronização da cultura material e sua dispersão geográfica ainda conformam uma questão a ser resolvida a partir de contextos particulares (NEVES, 2011). A desilusão com o conceito de cultura arqueológica e sua falta de correlação direta com uma "realidade social" (HODDER, 1982; SHENNAN, 1989; JONES, 1997) choca-se com a própria discussão sobre conceitos sociológicos e antropológicos, como "cultura" e "sociedade" (WOLF, 1982; INGOLD, 1994; LATOUR, 2005). Vários autores tem criticado a forma que essas noções tomaram nos discurso das ciências sociais por terem sido reificadas. Esses termos, por mais que pareçam indicar "realidades em si", são também formas de classificação. As culturas arqueológicas são “muletas" da mesma maneira que as culturas e áreas etnográficas (WAGNER, 1981). O problema, no caso das fases e tradições, foi sua proliferação sem efetividade, quase a procura de "tribos" (MACEACHERN, 1998) ou ainda a satisfação de interesses particulares (NOELLI, 1999). As unidades classificatórias da arqueologia são ferramentas analíticas construídas para delimitar um determinado conjunto artefatual. Sua escala varia de acordo com os próprios problemas de pesquisa e sua capacidade heurística.

No caso desta dissertação, optamos por manter o termo apresentado "estilo" apresentado por Nimuendajú e Hilbert apesar da predominância de "fase". A justificativa para isso é de que ambos os termos expressam um conjunto material delimitado no tempo e no espaço, mas apenas "estilo" deixa explícito interesse por um 
modo de fazer característico (HEGMON, 1992; SILVA; DIAS, 2001). Além disso, a noção de estilo deixa claro que não se trata de uma "cultura arqueológica" tal como defendido por Meggers e Evans $(1957,1970)$ composto de vários complexos materiais, mas de um único, a cerâmica. Em parte da literatura, especialmente etnoarqueológica, o tratamos como estilo é denominado "tradição técnica", o que evitamos para não gerar uma confusão com os conceitos desenvolvidos por Philips e Willey (1953). A palavra "fase" ainda gera um problema adicional ao fazer uma referência quase direta a "tradição", uma unidade de classificação cuja a aplicabilidade impõe desafios em alguns contextos amazônicos. A ideia de uma cultura arqueológica Konduri, com padrão de assentamento e complexos materiais padronizados ainda não foi plenamente debatida. Ainda é necessário ampliar as pesquisas e comparações para verificar em que medida a padronização da cerâmica corresponde ou não a outras evidências arqueológicas, à maneira que foi feita na Amazônia Central (NEVES, 2011).

. O estilo Konduri é a unidade mais consolidada das que foram propostas por Hilbert (1955a). Não há motivos para descartá-lo ou dividi-lo. Apesar disso, suas características diagnósticas não foram rediscutidas, sendo apenas reproduzidas. A maioria dos atributos, a julgar pelas descrições presentes na bibliografia, mantém-se, mas outros poderiam ser excluídos, como no caso dos cachimbos angulares que datam de outro período, ou ampliados, como o tipo de pintura. Em todo caso, há uma grande variabilidade da cerâmica que não pode ser resumida a apenas um conjunto de traços genéricos. A decoração continuidade sendo o principal elemento para a identificação desse conjunto. Toda a variabilidade tecnológica imbuída na produção desse estilo ainda precisa ser explicada em sua multidimensionalidade (REEDY;REEDY, 1994; SCHIFFER; SKIBO, 1997).

O termo Konduri, (sem o acento agudo como permaneceu na literatura arqueológica) merece algum cuidado para que não se pressuponha que a cerâmica arqueológica seja a manifestação material de uma "nação" indígena específica - "os Konduri”. Muitos etnônimos são conhecidos para a região do rio Trombetas no século XVII e alguns outros para o rio Nhamundá. Heriarte deixa clara a diversidade de etnônimos (1874, p.38) “(...) está o rio das Trombetas, mui povoado de Indios de diferentes naçôes; como sam Conduris, Babuis, Aroases, Tabaos, Curiatos e outros muitos." A denominação Conduri - e suas variantes - foi a que os cronistas mais 
mencionaram (ALVES, 2016), o que reforça a importância dessa coletividade no início da colonização naquela região, mas não permite uma associação direta com um grupo étnico. O próprio Nimuendajú (2004) falava com cautela sobre os povos produtores do estilo cerâmico. A relação entre a ocupação histórica Conduri e os sítios arqueológicos deverá ser tratada a partir de fontes escritas primárias - ainda pouco pesquisadas - e escavações em contextos das primeiras missões religiosas do século XVII na região. 


\title{
2 Capítulo 2 - A formação das coleções e o seu legado
}

\author{
"Yet however much we suppress and quarantine the aesthetic \\ dimension within us, we do wrong to deny its existence. We are, after \\ all, only human. So with self-reflection riding high on the current \\ agenda, why not instead confess our tastes, ask how they are \\ constructed, and explore how they may be in turn constructing our \\ archaeology?"
}

BROODBANK, (1992, p. 542)

As pesquisas arqueológicas na região do Baixo Amazonas carregam a herança das práticas de colecionamento realizadas tanto por particulares quanto por pesquisadores entre o final do século XIX e início do século XX. O complexo Konduri foi construído nesse processo e suas consequências ainda podem ser notadas nas pesquisas mais recentes: os termos, as classificações, os objetos emblemáticos e mesmo algumas questões ainda são aqueles que figuraram nos primeiros estudos sobre a região. A seleção criteriosa realizada por coletores/colecionadores é reificada nos museus, exposições e catálogos. A avaliação estética dos objetos, prezada pelos colecionadores, é também um elemento frequente na relação estabelecida entre arqueólogos/as e seus objetos de estudo (GOMES, 2002) e também entre curadores/as e as peças selecionadas para exposição (SCATAMACCHIA, 2000).

Apesar do número crescente de novas pesquisas, as principais referências ainda são os estudos de coleções particulares ou de coletas assistemáticas (p. ex. HILBERT, 1955a; PALMATARY, 1960; GUAPINDAIA, 1993; GOMES, 2002). Por outro lado, as coleções também continuam sendo reunidas por moradores locais, curiosos e também colecionadores, que compram peças ilegalmente. Essas práticas de colecionamento começam a interessar a arqueologia amazônica como um tema em si (BEZERRA, 2011, 2018; TROUFFLARD, 2012), mas ainda não foram realizados estudos integrando as coleções de museu, mais antigas, e as pequenas coleções particulares ainda em construção. A continuidade dessas práticas tem e terá consequências para o estudo do 
passado pré-colonial. Isso fica claro nas pesquisas de campo de Guapindaia (2008; RODET et al., 2016), no sítio arqueológico Boa Vista, onde as peças cerâmicas mais elaboradas e a maioria das lâminas de machado estudadas faziam parte de coleções de moradores locais doadas a equipe de pesquisadores.

Ignorar as biografias complexas das coleções, como é comum nos estudos arqueológicos, acaba por embaralhar ainda mais as informações, produzindo uma nova “descontextualização". As coleções de museu são "híbridos” temporais, combinando a produção e uso pré-colonial e seus agenciamentos modernos (LATOUR, 1994; HAMILAKIS, 2011). Em áreas, como o Baixo Amazonas, em que muito do conhecimento arqueológico ainda está vinculado ao estudo de coleções de museus, é preciso explorar e avaliar os processos de formação de coleções, bem como seus efeitos materiais e intelectuais/científicos (GILL, CHIPINDALE, 1993; LEIGHTON; SØRENSEN, 2004; BRODIE; LUKE, 2005). Uma arqueologia dos arquivos e reservas técnicas é necessária para pensar as mobilizações modernas dos artefatos pré-coloniais e as proposições correntes dentro do próprio "núcleo duro" da disciplina (HICKS, 2013). Em outras palavras, trata-se de realizar uma arqueologia do "passado contemporâneo" da própria ciência arqueológica (GONZÁLEZ-RUIBAL, 2018).

Este capítulo analisa, a partir de uma perspectiva da biografia dos objetos ou itinerários artefatuais, o processo de formação das coleções de cerâmica no Baixo Amazonas como parte de redes de colecionamento que combinam atores e desejos heterogêneos (KOPYTOFF, 1986; PEARCE, 1995; GOSDEN, MARSHALL, 1999; HAMILAKIS, 1999; JOYCE, GILLESPIE, 2012). Seu objetivo é mapear o fluxo dos objetos e alguns de seus efeitos na construção do conhecimento arqueológico da região. Nesse sentido, é preciso alargar a área de interesse e voltar parte da discussão para o baixo Tapajós, especialmente a cidade de Santarém. A justificativa para tal escolha é a associação entre a cerâmica Konduri e Santarém feita nas coleções de museu e também nos estudos arqueológicos. De maneira geralmente implícita, a cerâmica Konduri, objeto central desta dissertação, aparece como um elemento coadjuvante em um meio a uma narrativa centrada na cerâmica, arte e "civilização de Santarém”. Essa imagem é, em parte, resultado das escolhas, valores e desejos de coletores e colecionadores que conformaram identidades as cerâmicas arqueológicas e deixaram um legado implícito para a arqueologia (DIETLER, 2005; NOELLI; FERREIRA, 2007). Nesse sentido, as 
representações produzidas em torno dos estilo Konduri e Santarém reverberam a afirmação de Holtorf (2002, p. 64) de que "[t]he material identities ascribed to things are not their essential properties but the result of relationships of people and things: their very materiality is potentially multiple and has a history". Não é possível desvincular as coleções de suas histórias modernas ou, nos termos de Latour (1994, 1999), “purifica-las". Como "artefatos herdados", esses materiais catalisam e recombinam os resultados de práticas indígenas pré-coloniais e a de atores modernos diversos.

\subsection{As fontes consultadas}

Para a elaboração deste capítulo, foram utilizadas fontes diversas. As principais foram os arquivos do Museu Paraense Emílio Goeldi (Arquivo Guilherme La Penha), Museu Nacional (Setor de Memória e Centro de Referência de Línguas Indígenas), Museu Paulista, Museu de Arqueologia e Etnologia/USP, Museu de História Natural e Jardim Botânico da UFMG e Museu de Ciências e Tecnologia da PUC/RS (Arquivo Pessoal Klaus Hilbert). A partir de comunicação eletrônica, o serviço de documentação do Penn Museum (Filadélfia/EUA) compartilhou uma profusão de cartas e documentos institucionais dos decênios de 1930 e 1940 . A maior parte dos documentos consultada é composta de cartas, relatórios de campo ou anuais de setor ou ainda notas avulsas. A consulta às próprias peças nas reservas técnicas ofereceram informações preciosas que permitiram sua conexão com as biografias artefatuais. As referências bibliográficas da arqueologia regional acabam também carregam consigo parte da própria história das coleções.

Foram identificadas poucas fotografias relacionadas aos materiais junto ao acervo documental, provavelmente devido ao menor investimento na consulta de fundos e pastas com esse tipo de registro. Isso foi parcialmente contornado com a consulta a Hemeroteca Digital da Biblioteca Nacional (http://bndigital.bn.gov.br/hemerotecadigital/) com palavras-chave como "arqueologia", "cerâmica Santarém” e nomes de envolvidos com o tema, no período entre 1920 e 1980. O Museu Virtual da Coleção Etnográfica Carlos Estevão da Universidade Federal de Pernambuco (https://www3.ufpe.br/carlosestevao/projeto.php) apresenta uma vasta documentação fotográfica em que puderam ser identificadas fotografias enviadas por Nimuendajú em trabalhos de campo arqueológicos. Foram encontrados dois blogs com fotografias 
históricas de Santarém e informações sobre diferentes aspectos da vida na cidade ao longo do século passado (http://sidcanto.blogspot.com / http://ignacioneto.blogspot.com). Não foi possível consultar arquivos importantes, como os da prefeitura e da igreja católica em Santarém, Oriximiná, Óbidos e Lago Seca. Da mesma maneira ficaram de fora acervos documentais pessoais, como o de Frederico Barata e Ubirajara Bentes, além de periódicos locais, dificilmente encontrados na Internet.

Uma breve incursão, em 2014, a cinco comunidades do Lago Sapucuá (Conuri, Castanhal, Ajará, São Pedro, Macedônia, Maceno), realizada no âmbito do Projeto Norte Amazônico, ofereceu elementos etnográficos para pensar modos de coleta e curadoria em coleções de pequena escala formadas por ribeirinhos. Apesar de limitada, essa experiência ressoa com informações produzidas em vários trabalhos com maior densidade etnográfica na Amazônia.

\subsection{Redes de colecionamento $(1870-1970)$}

A constituição de coleções de cerâmica arqueológica do Baixo Amazonas resulta direta ou indiretamente dos valores imbuídos na formação dos museus de História Natural e Antropologia. Naturalistas e, depois, etnólogos e arqueólogos, foram incentivados a recolher materiais para diferentes instituições. De todas as partes do mundo chegavam coleções por meio de doação e venda de particulares ou ainda expedições financiadas pelas instituições. Herdeiros das coleções particulares dos gabinetes de curiosidade e imbuídos do interesse enciclopédico iluminista, esses museus “colecionavam para conhecer" desde a sua criação, nos século XVIII e XIX, até meados do século XX (FARIA, 1989; LOPES, 1997). Indiretamente, o interesse por certos objetos gerou demanda e o desejo de particulares por colecionar peças extraordinárias e “objetos de arte" (SCHAAN, 2007).

Os museus patrocinavam a reunião de grandes coleções com o intuito de “enriquecer” suas coleções: aumentar os objetos possuídos e o prestígio das instituições. Certos museus eram vistos como especializados e mais ricos que outros em certos conjuntos de objetos e reinava a disputa pela criação de coleções cada vez maiores (PENNY, 2002). Castro Faria (op. cit., p. 30) afirma que “[é] com a retórica da riqueza que se escreve o discurso da atividade colecionista e se apologiza a função dos 
museus.". Os artefatos arqueológicos e etnográficos eram um dos elementos materiais reunidos nesses museus, especialmente a partir da segunda metade do século XIX (STOCKING, 1985). Esse é o chamado "Período dos Museus" ou "Era dos Museus" da Antropologia, que alcança toda a primeira metade do século XX, em alguns lugares.

Formaram-se pelo menos quatro museus de História Natural no Brasil vinculados ao desenvolvimento mundial das ciências naturais: Museu Nacional, Museu Paraense, Museu Botânico do Amazonas e Museu Paulista (SCHWARCZ, 1993; LOPES, 1997; FERREIRA, 2011). Esses museus foram constituídos em períodos um pouco diferentes, mas fazem parte de um interesse das elites locais ou nacionais de “civilizar" ou "instruir" o país ou estados/províncias a partir da influência de produções na Europa e Estados Unidos (SANJAD, 2011). As primeiras pesquisas arqueológicas e antropológicas foram realizadas nesses museus junto com estudos de botânica e zoologia. Mais antigo, o Museu Nacional foi fundado em 1818 a partir de coleções de D. João VI foi“"enriquecido” pelo interesse de D. Pedro II por arqueologia e etnografia. Os museus Paraense e Paulista emergiram de interesses locais relacionados à prosperidade econômica advinda da produção de borracha na Amazônia e café no estado de São Paulo - respectivamente nos anos de 1866 e 1893. O Museu Botânico foi criado em 1882, com o apoio da Princesa Isabel, a partir dos trabalhos da Comissão do Amazonas, voltada para o conhecimento científico e mapeamento das fronteiras amazônicas.

Os museus de História Natural tiveram um papel na construção de uma identidade nacional baseada nos elementos materiais coletados dentro do próprio território, como parte de uma política de colonialismo interno, em oposição ao colonialismo "externo" na África e Ásia praticado pelos estados europeus (SCHWARCZ, 1993; FERREIRA, 2007). Apesar dessa diferença, o modelo dessas instituições era cosmopolita e se inspirava na ampliação das teorias científicas debatidas na Europa e Estados Unidos - inclusive, as de cunho racial. Os acervos dessas instituições receberam, mesmo que em pequenas quantidades, peças provenientes de outras partes do mundo a partir de compras e permutas com museus e colecionadores estrangeiros. Assim, no Museu Nacional, por exemplo, havia peças arqueológicas greco-romanas, egípcias e andinas, além de materiais etnográficos da Costa Noroeste 
dos Estados Unidos, Melanésia e Ártico. O material cerâmico da Amazônia recebeu um lugar de destaque e, às vezes de disputa, entre as peças coletadas no interior do país.

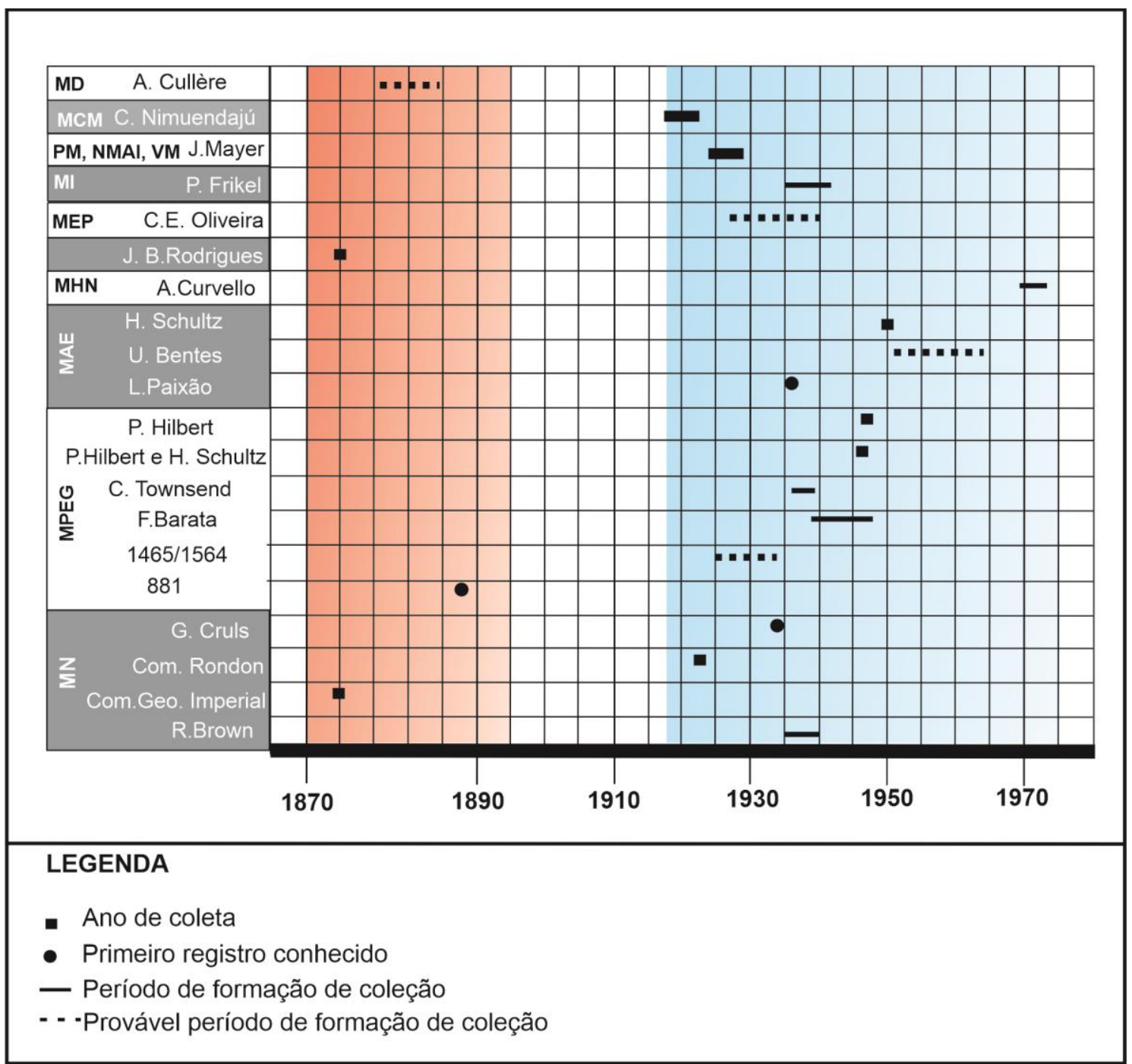

Figura 9. Cronologia de formação das coleções de cerâmica no baixo curso dos rios Trombetas e Nhamundá. MD = Musée Dobrée; PM = `Penn Museum; NMAI = National Museum of American Indian; $\mathrm{VM}=$ Världskulturmuseet; MI = Museu do Índio (Lagoa Seca, PB); MEP = Museu do Estado de Pernambuco; MHN = Museu de História Natural e Jardim Botânico da UFMG; MAE = Museu de Arqueologia e Etnologia da USP; MPEG = Museu Paraense Emílio Goeldi; MN = Museu Nacional da UFRJ.

A compra de peças arqueológicas pelos museus promoveu sua conversão em mercadorias (SCHAAN, 2007; NAJJAR; BEZERRA, 2009), ao mesmo tempo em que a organização de exposições e catálogos de materiais arqueológicos catalisou desejos e 
demandas entre públicos frequentadores e leitores, incentivando a constituição de coleções particulares. No caso da Amazônia brasileira, esse trajeto de idas e vindas do colecionamento praticado pelos museus recaiu especialmente sobre a cerâmica arqueológica que, como afirmou Penna (1877), representaria “os principais monumentos dos povos indígenas" do Brasil.

Em relação às coleções que chegaram aos grandes museus do Brasil, Estados Unidos e Europa, é possível diferenciar para a região do Baixo Amazonas dois períodos de formação de coleções, entre as décadas de 1870 e 1970. O primeiro poder ser situado entre 1870 e 1900, com as expedições de mapeamento, e algumas coleções particulares, seguindo o processo de expansão de museus de História Natural (Figura 9). O segundo momento se inicia na década de 1920, com as coletas do etnólogo Curt Nimuendajú e se estende até a década de 1970. A partir das publicações sobre a cerâmica encontrada na região de Santarém, primeiro na Europa, e depois no Brasil, certo interesse se desenvolveu por peças arqueológicas dessa região. Depois da década de 1960, o número de informações sobre coleções reunidas é menor, o que deve estar relacionado ao desenvolvimento de legislação específica sobre o patrimônio arqueológico e também a profissionalização da arqueologia (PROUS, 1992).

\subsubsection{Expedições de mapeamento e os "ídolos de pedra"}

Durante o século XIX, as pesquisas de naturalistas na Amazônia evidenciaram cerâmicas arqueológicas em cinco áreas na Amazônia brasileira: Ilha de Marajó, interior do Amapá, baixo rio Trombetas, baixo rio Tapajós e a "necrópole Miracanguera" na Amazônia Central. As coleções de cerâmica reunidas no século XIX colocaram o Baixo Amazonas no mapa da arqueologia, mas criaram pouco interesse se comparadas às cerâmicas da Ilha de Marajó e Amapá. Esses materiais foram recolhidos em sítios ou recebidos como doações por expedicionários que mapeavam a geografia amazônica.

A primeira coleção de cerâmica arqueológica do Baixo Amazonas de que se têm relatos foi reunida por Romulus J. Rhome, um migrante dos estados confederados dos Estados Unidos (PALMATARY, 1960). Rhome foi sócio do Barão de Santarém e administrou a Fazenda Taperinha, que recebeu vários naturalistas que realizavam pesquisa na Amazônia brasileira. Em 1875, a Comissão Geológica Imperial, chefiada por Charles Frederich Hartt, visitou a fazenda e recebeu como doação a coleção de 
cerâmica Santarém reunida por Rhome. Essas peças foram depositadas no Museu Nacional e algumas foram descritas por Netto (1885). Durante os trabalhos da Comissão na região do rio Trombetas foram identificadas terras pretas com material cerâmico (DERBY, 1898). Os membros da Comissão coletaram fragmentos cerâmicos em sítios também enviados ao Museu Nacional . Entre 1871 e 1874, João Barbosa Rodrigues realizou expedições de mapeamento a serviço do Império nos rios Tapajós, Trombetas e Nhamundá, onde coletou artefatos líticos e cerâmicos. Entre as peças líticas estava um muiraquitã, encontrado na Ilha Costa do Parú, que foi dado de presente a princesa Isabel. Não se sabe o paradeiro da coleção de fragmentos cerâmicos reunidos no mesmo sítio, mas as estampas publicadas são as primeiras com modelagens características das cerâmicas depois denominadas como Pocó e Konduri (Figura 10).
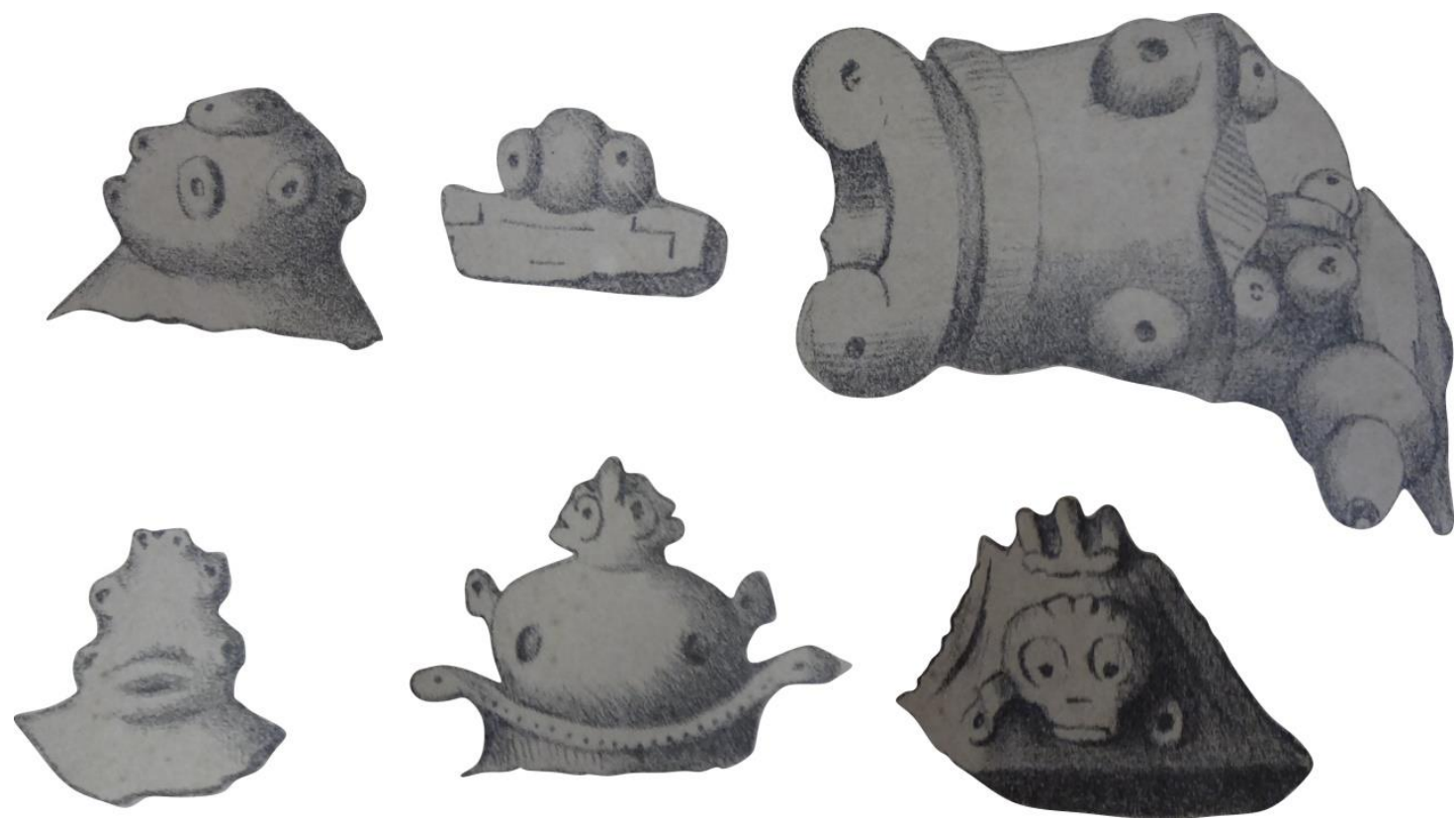

Figura 10. Apliques e fragmentos de borda coletados por Barbosa Rodrigues nas adjacências do Lago Parú. Essas são provavelmente as primeiras figuras de cerâmica arqueológica do Baixo Amazonas que foram publicadas. Adaptado de Barbosa Rodrigues, 1876.

Barbosa Rodrigues (1875) também foi o primeiro a descrever um dos chamados "ídolos de pedra" em um artigo publicado no Jornal do Commercio. Essa peça era uma escultura lítica que pertencera ao padre Antonio Sanches de Brito, em Óbidos, que havia ganhado de um homem que o encontrara na Costa do Paru. O padre passou a usá-lo 
como "ornato de mesa". Depois de sua morte, a escultura se tornou um brinquedo para crianças apelidado de "diabo" e, depois, foi perdida e recuperada no quintal da antiga casa do vigário. Esse e outros objetos da mesma categoria suscitaram junto com os muiraquitãs um amplo debate no final do século XIX e início do XX sobre sua produção por "civilizações avançadas" (FONSECA, 2010). A partir dessas peças surgiu uma primeira onda de interesse colecionista por materiais arqueológicos do Baixo Amazonas, mas que estava voltado especialmente a esculturas em rocha. Por volta da década de 1870 ou 1880, o padre francês Augusto João Maria Cullerre (Auguste-JeanMarie Cullère) atuou no município de Óbidos e reuniu uma coleção com peças arqueológicas e etnográficas - incluindo vários fragmentos do que veio ser chamado de estilo Konduri. Essa coleção foi posteriormente enviada para o Museu Dobrée, em Nantes (ROSTAIN, 2019). As duas peças da coleção Cullère foram serviram de base para as formulações iniciais sobre os "ídolos" de pedra no Congresso Internacional de Americanistas por Pitre de Lisle du Dréneuc (1894), conservador do francês. A partir das informações sobre a coleção Cullère, provenientes do lago Sapucuá, Manoel Francisco Machado, senador do Amazonas entre 1890 e 1900, realizou expedições em busca dos curiosos "ídolos". Contudo, a cerâmica não parece ter interessado a esse colecionador:

(...) em companhia do meu amigo Sr. Vicente A. de Figueiredo, emprehendi em Junho do corrente anno uma excursão ao Sapucoá, onde, entre objetctos de cerâmica, já foi encontrado desses fetiches um que foi enviado ao ilustre Sr. Dreneuc (...). Fiz excavações, e, a não ser cacos de louça, nada encontramos. (MACHADO, 1891, p. 284).

As estatuetas líticas e os muiraquitãs fomentaram muito mais interesse dentro e que os "cacos de louça" fora da arqueologia emergente do final do século XIX (FONSECA, 2010; PORRO, 2010). Até o final da década de 1920 pouco se falava da cerâmica do Baixo Amazonas (ver menções em BARBOSA RODRIGUES, 1876; NETTO, 1885; GOELDI, 2009 [1906]).

\subsubsection{Nimuendajú e a "descoberta" da cerâmica de Santarém}

O interesse pela cerâmica do Baixo Amazonas mudou radicalmente com o início das expedições de Curt Nimuendajú ao Baixo Amazonas. As coletas realizadas por ele, a serviço do Museu Etnográfico de Gotemburgo, entre 1923 e 1927, colocaram em 
evidência "achadouros" e materiais de extrema "beleza". A prática de colecionar cerâmica arqueológica já era comum entre crianças, além das coletas de naturalistas, mas foram os trabalhos desse etnólogo que promoveram a formação de uma rede de colecionamento, propagadora do interesse por certos materiais. Essa rede combinou diferentes atores no Brasil, Estados Unidos e Europa: etnólogos, arqueólogos, diretores de museus, padres, militares, médicos, advogados. Todos esses atores promoveram a "diáspora" dessas cerâmicas pelo mundo - materialmente e via imagens. A partir das relações estabelecidas por Nimuendajú e a própria notícia de seus trabalhos, foram sendo criadas novas coleções e também estudos arqueológicos de parte das peças acumuladas (Figura 12).

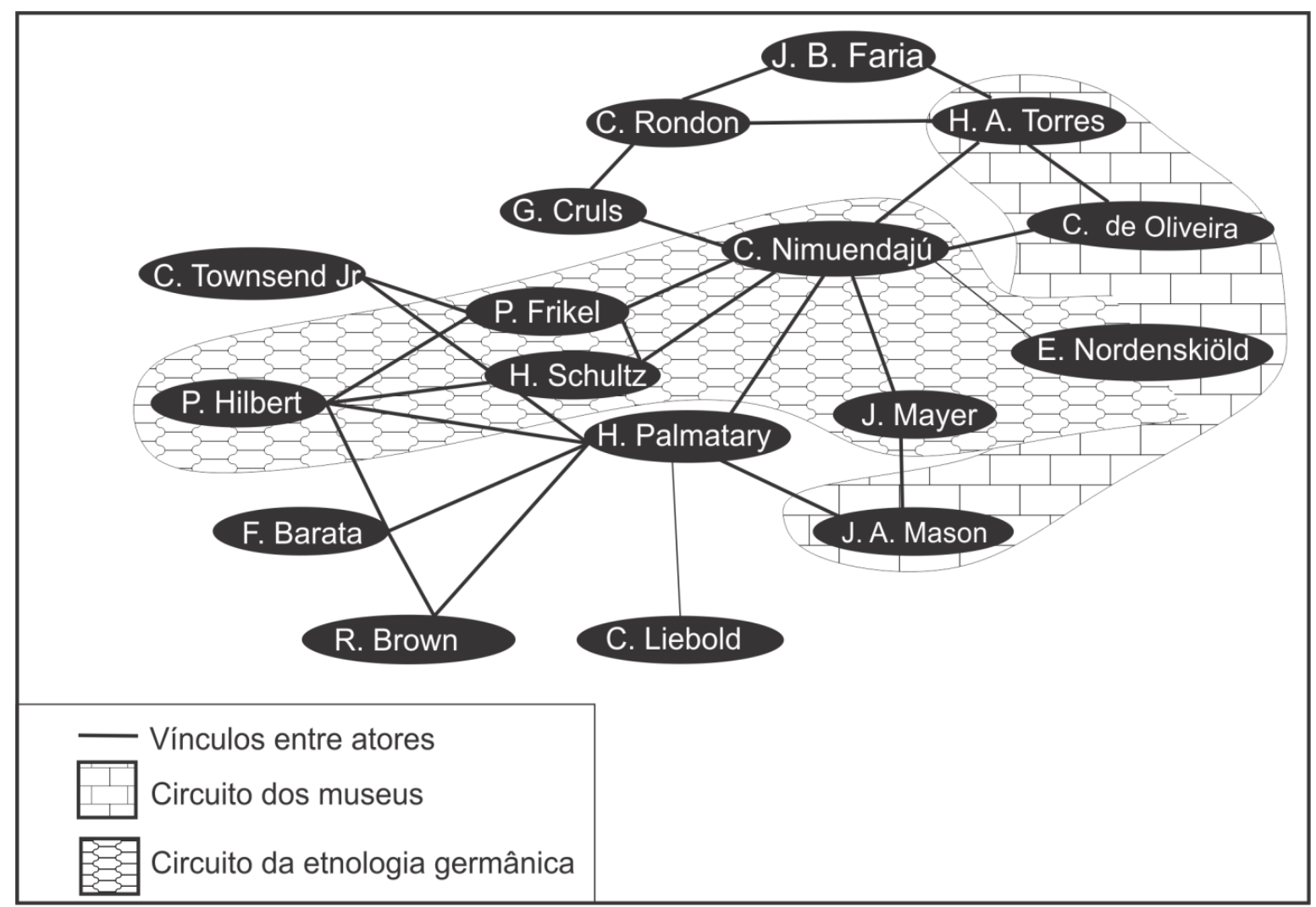

Figura 11. Organograma mostrando algumas das relações estabelecidas entre pesquisadores, colecionadores e diretores de museu as décadas de 1920 e 1950.

Laços estreitos entre germânicos compuseram a rede de práticas de colecionamento, o que certamente se relaciona ao grande interesse sobre os povos 
nativos da América disseminado na sociedade alemã, o chamado "indianthusiasm" e a "paixão museográfica" de sua tradição antropológica e cultural (GRUPIONI, 1998; FRANÇOSO, 2005; WELPER, 2013; PENNY, 2002). Arqueologia e antropologia não se dissociavam em muitas das pesquisas dessa tradição. A pesquisa sobre os povos indígenas da América do Sul foi profundamente marcada pela tradição de língua alemã, tanto pelo interesse especial por esse subcontinente, quanto pela influência de Franz Boas nos Estados Unidos (TAYLOR, 1984). A imigração alemã em massa para diferentes partes do Brasil e países vizinhos potencializou esse interesse e participação tanto em relação aos pesquisadores profissionais quantos colecionadores ou entusiastas.

Como parte dos interesses e relações de uma antropologia germânica, estabeleceu-se a relação entre o diretor do Museu Etnográfico de Gotemburgo Erland Nordenskiöld e imigrante alemão naturalizado brasileiro Curt Nimuendajú, para reunir exemplares arqueológicos da Amazônia brasileira. Em campo, Nimuendajú visitou e coletou peças em uma área muito extensa seguindo o curso do rio Amazonas, desde o médio Tapajós até o rio Urubu, além de seu trabalho no Amapá, Ilha de Caviana e rio Tocantins. Diferentes coleções foram formadas ao longo dos anos, sendo algumas direcionadas a áreas específicas.

A cidade de Santarém foi um dos principais pontos de coleta de Nimuendajú, além de ser ponto de partida para incursões em localidades próximas. Influíram nessa escolha tanto processos relacionados à formação do registro arqueológico, quanto a geopolítica regional. Desde o início da colonização, vários viajantes e naturalistas passaram por Santarém. Era uma cidade relativamente grande e com meios de transporte frequentes, além das facilidades oferecidas pelo Convento de São José, onde Nimuendajú se hospedava (HARTMANN, 2000). Ao mesmo tempo, uma porção significativa do perímetro urbano apresenta terra preta e material arqueológico, constituindo um dos maiores sítios arqueológicos da bacia amazônica - 110 hectares segundo Gomes (2016a). A cidade de Santarém era um lugar ideal para realizar coletas na Amazônia: sem tantas dificuldades de acesso e com facilidade para obter peças arqueológicas andando nas ruas ainda sem pavimentação.

O próprio Nimuendajú (2004 [1923]) comenta com certo espanto que pouco ou nada tenham falado em relação à cerâmica da região antes dele. Gastão Cruls (1942, p. 
193) sugere que o motivo disso é que os naturalistas do século XIX não tiveram a "felicidade de examinar peças grandes e [sic] quasi perfeitas, conservando o luxo de sua ornamentação esculpida". De fato, as coleções de cerâmica do Baixo Amazonas eram compostas quase totalmente por fragmentos - com exceção da estatueta da coleção Rhome. O crescimento da própria cidade, talvez, tenha propiciado a exumação dos fragmentos durante a construção de casas, ruas e aterros. Logo em seus primeiros dias na região, Nimuendajú relata ter encontrado uma quantidade enorme de peças: "Chegado em Santarém, levei três dias a catar fragmentos de uma cerâmica antiga, muito interessante, nas sarjetas das ruas desta cidade. Parece incrível, mas em 24 horas eu já tinha juntado um bom princípio para uma coleção arqueológica!” (20/04/1923 in HARTMANN, 2000, p.35).

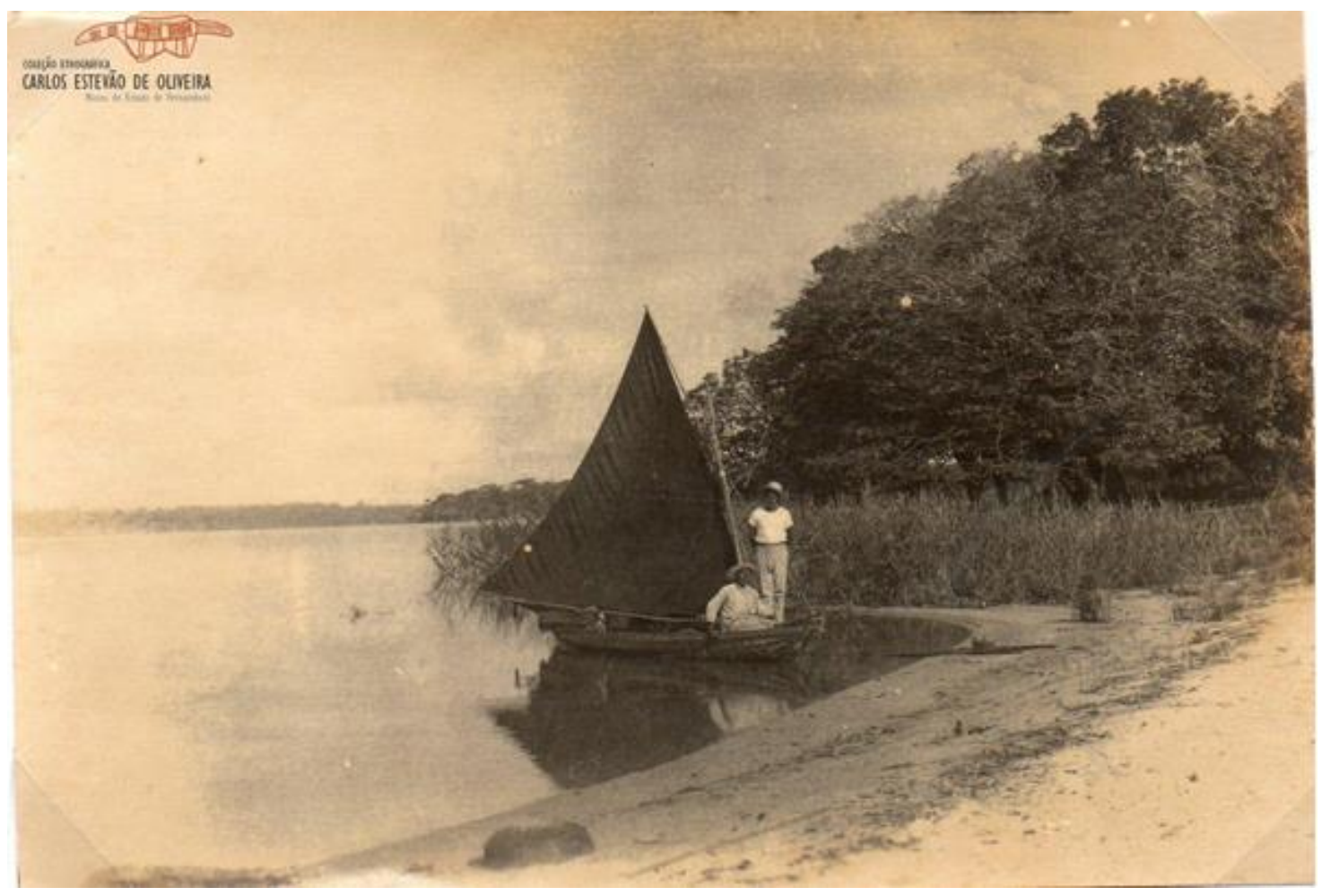

Figura 12. Fotografia de Curt Nimuendajú com texto no verso "Minha canoa no lago Curumucury". Esse lago atualmente se situa no município de Juruti e os sítios arqueológicos da área apresentam cerâmica Konduri. Foto: Curt Nimuendajú. Coleção Etnográfica Carlos Estevão de Oliveira/Museu Virtual. Disponível em:< http://www3.ufpe.br/carlosestevao/> Acesso em 14 de dezembro de 2018. 
A partir das coleções reunidas pelo etnólogo, a cerâmica do Baixo Amazonas deixou o quase anonimato para "elevar" a região uma das de maior interesse de toda a bacia amazônica, junto com a ilha de Marajó e algumas áreas do Amapá. A importância da cidade de Santarém foi muito enfatizada por Erland Nordenskiöld, o diretor do Museu Etnográfico de Gotemburgo: "De tous les lieux d'Amazonie d'oú a été exhumée de la céramique, c'est peut-être Santarem le plus remarquable." (NORDENSKIÖLD, 1930). Mesmo que essa afirmação tenha que ser considerada como parte da estratégia de valorizar o próprio acervo recém-adquirido, é fato que a cultura arqueológica Santarém foi se tornando, se não a maior, a "seconde des grandes civilisations amazonienne [depois da Marajoara]" (MÉTRAUX, 1959, p. 113). Nenhuma síntese sobre a arqueologia amazônica ou as artes pré-colombianas das terras baixas da América do Sul poderia deixar de mencionar a cerâmica Santarém. Os trabalhos de campo se estenderam para áreas mais distantes de Santarém, como os municípios de Parintins, Juruti, Faro e Óbidos (Figura 12). A partir de um trabalho de campo nessas áreas em 1924, Nimuendajú diferenciou a cerâmica Santarém (ou Tapajó) da que ele denominou "Kondurí". A quantidade de peças dessa área foi consideravelmente menor e nenhuma peça inteira foi coletada. Nas coletas seguintes, essas áreas não foram visitadas.

Uma das versões disseminadas sobre a "descoberta" da cerâmica de Santarém por Nimuendajú indica que foram as chuvas torrenciais que a evidenciaram aos olhos do etnólogo (LINNÉ, 1928; CRULS, 1930; NORDENSKIÖLD, 1930; PALMATARY, 1939; OLIVEIRA, 1939). Em carta a Palmatary, Nimuendajú explica que, na verdade, “[q]uem chamou a minha atenção para a existencia dessa ceramica foi um dos frades Franciscanos allemães, residente em Santarem, lá pelo anno de 1922, contando-me que as crianças lá brincavam com figuras de barro que encontravam na terra"6. (cf. BARATA, 1950; MÉTRAUX, 1959). Na época, a Prelazia de Santarém recebia vários missionários vindos da Província da Saxônia (SILVA, 2012). Alguns se dedicaram a etnologia e arqueologia, seguindo a tradição humanista amplamente pelos museus etnográficos alemães e a escola do Kulturkreise, liderada pelo sacerdote católico Max Schmidt (PENNY, 2002; REBAY-SALISBURY, 2011). A relação direta com os povos indígenas através de missões, como a do Curuá, no alto Tapajós, forneciam o material para esses estudos (WELPER, 2002).

\footnotetext{
${ }^{6}$ Carta de Curt Nimuendajú a Helen Palmatary 01/10/1939, Arquivo Curt Nimuendajú/ CELÍN/MN
} 


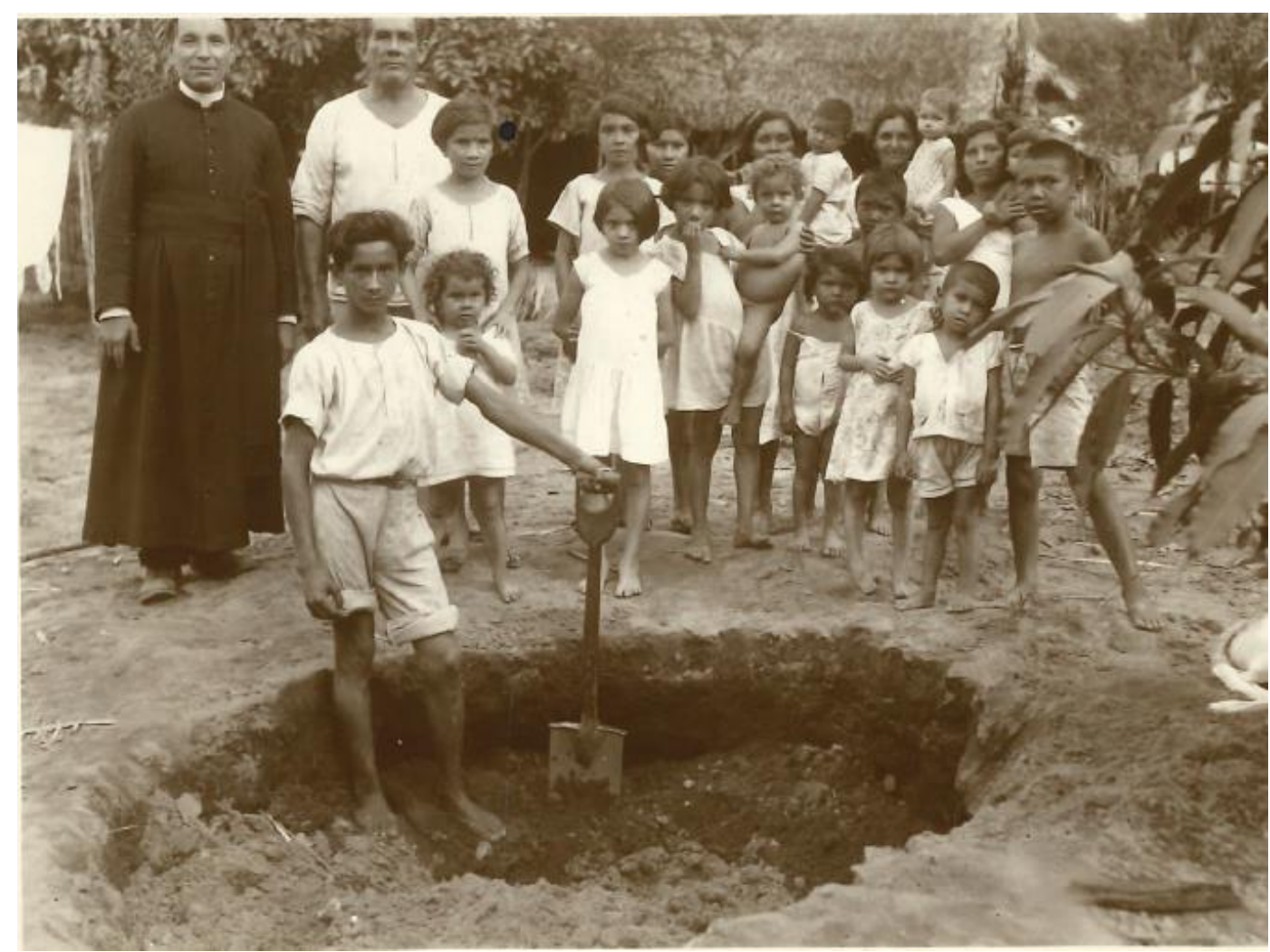

Figura 13. Fotografia enviada pelo bispo Amando ao Museu Universitário da Filadélfia mostrando o padre Mayer no local onde teriam sido encontrados dois vasos efígie. Arquivo Penn Museum/ Pasta John Mayer.

A relação de Nimuendajú com os frades franciscanos que o levou a cidade de Santarém também atraiu religiosos para a pratica de colecionamento. O padre teutoamericano ${ }^{7}$ João Mayer se interessou pela cerâmica Santarém quando se encontrou com o etnólogo entre 1926 e 1927 (MENCHÉN 1979). As crianças que já se interessavam pelos fragmentos, o ajudavam na coleta (Figura 13). Em 1929, Mayer doou uma coleção para o Museu Etnográfico de Leipzig e vendeu uma para o Museu do Índio Americano ${ }^{8}$ de Nova York e outra para o Museu Universitário da Universidade da Filadélfia (Filadélfia), nos Estados Unidos. Esse museu comprou duas outras coleções de Mayer, uma em 1930 e outra em 1933. Nimuendajú comenta que quando passou em Santarém, em 1929, Mayer "já tinha encaixotado tudo e só vivia no antegozo das centenas e mais centenas de dólares que na América do Norte lhe haviam de por esta ou aquela peça." (HARTMANN, 2000, p. 187). Depois da morte, em 1934, o bispo Amando Bahlmann,

\footnotetext{
${ }^{7}$ Carta de G.E. Seltzer (Cônsul Americano em Santarém) ao Diretor do University Museum , 28/10/1935,
} Arquivo Penn Museum, Pasta John Mayer. 
de quem Mayer era secretário, enviou parte de uma coleção que permaneceu em Santarém ao Museu Universitário. O dinheiro obtido da venda seria revertido para o orfanato e "instituições da missão" . A partir dessa coleção foi realizado o primeiro estudo voltado apenas para a cerâmica Santarém, a dissertação de mestrado de Helen Palmatary (1936), que com modificações, foi publicada em 1939, na Suécia.

A atuação de Nimuendajú pode ter gerado interesses menos explícitos. Em 1928, o Serviço de Inspeção de Fronteiras, conhecido também como "Comissão Rondon", atuou no litígio sobre os limites entre Brasil, Guiana Inglesa (atual Guiana) e Guiana Holandesa (atual Suriname). O etnógrafo da Comissão, João Barbosa de Faria, foi enviado para uma missão complementar ao mapeamento do rio Cuminá até a Serra de Tumucumaque (FARIA, 1946; CRULS, 1930; RONDON, 1953). Sua tarefa seria obter informações etnográficas dos povos indígenas que viviam em afluentes do médio curso do rio Trombetas - rios Mapuera e Cachorro. Na ida, ele recebeu uma estatueta lítica, "uma reliquia, da qual o Museu Nacional não deveria ficar desfalcado" ${ }^{10}$. Em seu retorno ele parou em diferentes sítios arqueológicos indicados pelos quilombolas que viviam na região ${ }^{11}$. Em nenhum documento é explicitado o motivo da mudança da separação abrupta de Barbosa de Faria do resto do grupo que compunha a comissão (cf. CRULS, 1930). Talvez houvesse um interesse em gerar novas coleções para o Museu Nacional, como era prática corrente de Rondon (GRUPIONI, 1998). Esse interesse pode justamente em oposição a "evasão" de peças para a Europa. Rondon foi um grande divulgador "da tese de que o Estado deveria regular as relações de missões estrangeiras com populações indígenas, coibindo o comércio de artefatos indígenas, visto como clandestino e prejudicial aos interesses do país." (GRUPIONI, 1998, p.51). Barbosa de Faria não menciona os trabalhos de Nimuendajú, mas relaciona a baixa quantidade de peças encontradas no Lago Sapucuá e Óbidos a exploração de “depósitos archeologicos", que forneceram "farta mésses de material" reunida por "agentes de museus extrangeiros, que frequentemente visitam a costa do Amazonas"12. Era muito

${ }^{9}$ Carta de Amando Bahlmann a Horace E. F. Jaynes, 09/07/1935, Arquivo Penn Museum, Pasta John Mayer.

${ }^{10}$ Idem.

${ }^{11}$ FARIA, João Barbosa de. Relatório dos trabalhos ethnographicos. Ministério da Guerra, Inspeção de Fronteiras. Endereçado a Cândido Mariano Rondon. 22f (incomoleto). Carimbo do Museu Nacional/ Secção de Anthropologia e Ethnographia datado de 21/06/1929, Fundo Heloísa Alberto Torres/SEMEAR/MN.

${ }^{12}$ FARIA, João Barbosa de. Relatório dos trabalhos ethnographicos. Ministério da Guerra, Inspeção de Fronteiras. Endereçado a Cândido Mariano Rondon. 22f (incomoleto). Carimbo do Museu Nacional/ 
recente a passagem de Nimuendajú em alguns dos mesmos sítios visitados por Barbosa de Faria, como Cocal e Uajará, no lago Sapucuá.

\subsubsection{Nacionalismo na Era Vargas}

A coleção reunida por Barbosa de Faria pode ser vista como parte de um sentimento nacionalista de que os estrangeiros conheciam e tinham coleções amazônicas melhores que dos próprios brasileiros (cf. GRUPIONI, 1998). Esse sentimento se disseminou na década de 1930 e 1940, com o governo de Getúlio Vargas. Carlos Estevão de Oliveira, diretor do Museu Goeldi durante todo o governo Vargas e amigo de Curt Nimuendajú, foi um representante desse nacionalismo voltado para as coleções científicas Sua atuação foi central na criação de leis no estado do Pará, controlando a exportação de animais, plantas e artefatos indígenas (FIGUEIREDO, 2001) (Figura 14). Poucos anos depois essa se tornou uma política adotada em todo o país por meio do Conselho de Fiscalização das Expedições Científicas e Artísticas, do qual ele foi membro durante os anos iniciais. A amizade com Nimuendajú permitiu Carlos Estevão acompanhasse de perto a formação das coleções arqueológicas e etnográficas, gerando um interesse por esses objetos. A partir dessa relação algumas peças passaram a formar a coleção particular do diretor do Museu Goeldi e outras passam a compor o acervo da instituição (HARTMANN, 2000). Nimuendajú não enviou cerâmica Santarém para Carlos Estevão porque seus trabalhos no Baixo Amazonas foram abandonados três anos antes de se tornar diretor. Muito do que conseguiu, especialmente para o próprio Museu, foi reunido a partir de uma rede institucional com os prefeitos das cidades do interior.

A cerâmica Santarém foi um alvo no nacionalismo nas coleções devido à notoriedade que começava a ganhar em publicações na Europa e Estados Unidos. O próprio presidente da república conheceu a coleção de cerâmica Santarém reunida no Museu Goeldi, em uma visita a Belém, em $1940^{13}$. A partir do contato com a prefeitura da cidade tinham sido obtidas duas remessas de cerâmica alguns anos antes. A primeira foi enviada em 1934 e contava apenas com "três caixas"14. A segunda remessa foi realizada em 1939 e resulta da compra de cerâmica de cinco colecionadores locais. Em

\footnotetext{
Secção de Anthropologia e Ethnographia datado de 21/06/1929, Fundo Heloísa Alberto Torres/SEMEAR/MN.

13 A NOITE. O presidente em Belém do Pará. 07/10/1940, p. 2.

${ }^{14}$ Carta de Luiz Filipe de Senna Gentil (prefeito de Santarém) a Carlos Estevão de Oliveira, 19/11/1934, Fundo Carlos Estevão de Oliveira, Correspondências, Arquivo Guilherme La Penha/MPEG.
} 
1938, Estevão também negociou diretamente com um morador da cidade de Santarém, Paulo Rodrigues dos Santos, para quem faz um "appello para seu patriotismo" 15 para a venda da peça ao Museu. Outras peças provenientes do Baixo Amazonas foram obtidas na Colônia Inglez de Souza, município de Monte Alegre, ou resultado de doações esporádicas, como uma peça coletada pelo limnólogo Harald Sioli, que no início da década de 1940 trabalhou no Museu. Além da formação de um acervo para o Museu Goeldi, Carlos Estevão explica a Serrano, em carta datada de 1938, que pretendia escrever um texto apresentando a cerâmica de Santarém e a necessidade de estudá-la e preservá-la ${ }^{16}$. Um ano depois foi publicado o texto na Revista do recém-criado Serviço do Patrimônio Histórico e Artístico Nacional (OLIVERIA, 1939).

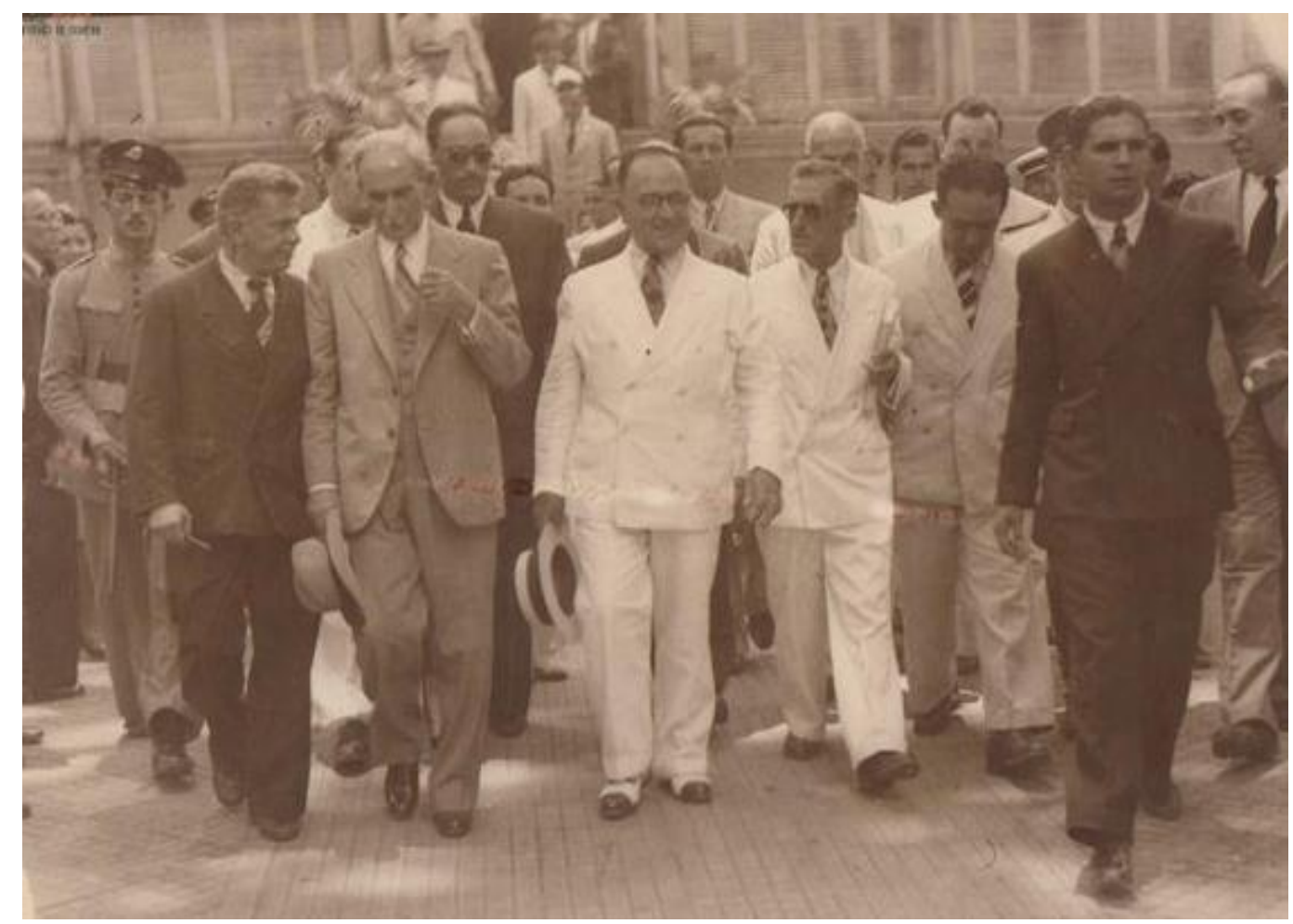

Figura 14. Vista de Getúlio Vargas ao Museu Paraense Emílio Goeldi em 1940. Fonte: Coleção Etnográfica Carlos Estevão/Museu Virtual. Disponível em: < https://www3.ufpe.br/carlosestevao/museu-virtual-fotoetno.php> Acesso em 21 de novembro de 2018.

\footnotetext{
${ }^{15}$ Carta de Carlos Estevão de Oliveira a Antonio Serrano, xx/xx/1938, Fundo Carlos Estevão de Oliveira, Correspondências, Arquivo Guilherme La Penha/MPEG.

${ }^{16}$ Carta de Carlos Estevão de Oliveira a Antonio Serrano, xx/xx/1938, Fundo Carlos Estevão de Oliveira, Correspondências, Arquivo Guilherme La Penha/MPEG.
} 


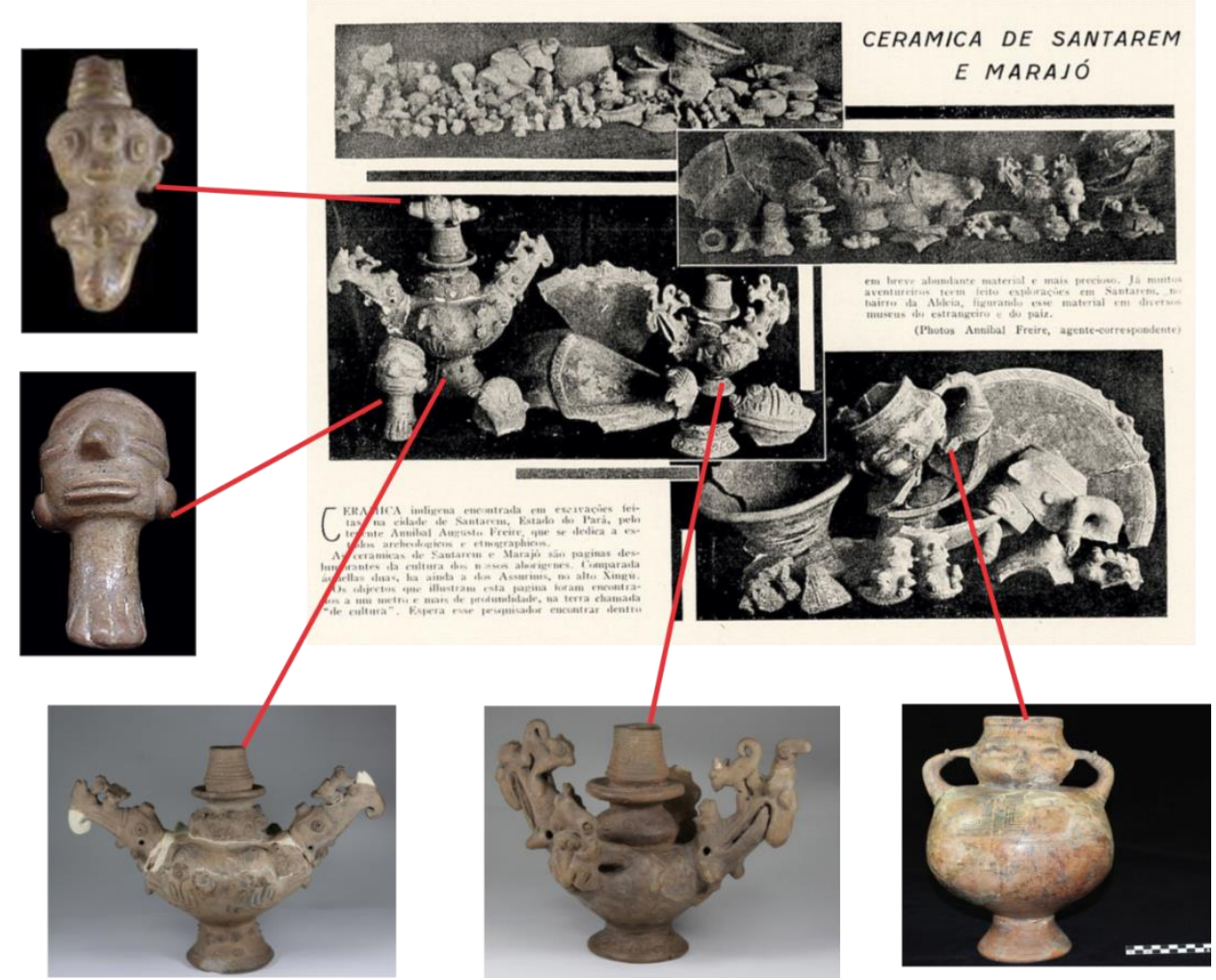

Figura 15. Página da revista Vida doméstica com fotografias da coleção reunida por Anibal Freire. A partir da consulta ao acervo da Reserva Técnica de Mário Simões e ao relatório de pesquisa de Cristiana Barreto (2014) foi possível identificar as peças maiores. Fotos: Barreto (2014 - estatuetas a esquerda) e Marcony Alves, 2018 (vasos). Essas peças foram erroneamente associadas as coletas de Curt Nimuendajú durante a reorganização das coleções na década de 1960.

A apreensão policial foi o primeiro meio de redirecionar materiais de interesse para o Museu Goeldi. Em 1929, Anibal Freire, fotógrafo em Santarém, publicou na revista Vida Doméstica, de circulação nacional, duas fotografias e uma nota sobre sua coleção de cerâmica coletada na cidade de Santarém $^{17}$ (Figura 15). Esse texto deve ter chamado à atenção de Carlos Estevão. No mesmo ano, talvez a pedido dele, Nimuendajú passou em Santarém, entregou cartas a Anibal e viu sua coleção (HARTAMANN, 2000, p. 187). Não se sabe qual o conteúdo das cartas que Nimuendajú entregou ao tenente, mas no arquivo do MPEG, há um ato de apreensão da coleção do tenente Anibal Freire. Esse documento data de um mês e quatro dias após a carta de Nimuendajú. No ato consta também que a atuação resultou de uma ordem do interventor do Pará, Magalhães Barata, certamente influenciado por Carlos Estevão. Em 1936, o diretor do Museu Goeldi informa que a coleção de Anibal Freire foi recebida na

${ }^{17}$ CERÂMICA de Santarém e Marajó. Vida doméstica: Revista do Lar e da Mulher. Rio de Janeiro, n. 172, v.3, jul. de 1932. 
instituição e que outra coleção tinha sido apreendida, desta vez pertencente ao Padre João (John Mayer) ${ }^{18}$. Esta apreensão pode resultar de uma parte da coleção reunida por Mayer e que o bispo Bahlmann tentava vender no exterior.

Outras coleções foram reunidas no boom das coleções de peças arqueológicas do Baixo Amazonas. Algumas delas foram reunidas em iniciativas pontuais, mas análogas a de Carlos Estevão, visando tanto criar um acervo quanto algum conhecimento local. Uma delas foi formada pelo médico e erudito Gastão Cruls em 1938, quando passou por Santarém e Manaus ${ }^{19}$. Na época ele obteve peças tanto para sua própria coleção quanto para o Museu Nacional com moradores da cidade. Outra coleção foi ofertada ao conselheiro financeiro do presidente Vargas, Valentim Bouças, pelo prefeito de Santarém e doada ao Museu Nacional em 1941. Essa pertencera a um trabalhador da Usina Elétrica, segundo Cruls, que chegou a manusear as peças ainda em Santarém. Várias outras coleções foram reunidas em uma onda crescente de interesse na década de 1930 pela “cerâmica de Santarém”. Entre estas é possível citar a reunida pelo Engenheiro Carneiro Mendonça, estudada por Serrano (1938); a comprada pelo bancário e colecionador de minerais e artefatos indígenas Luís Paixão Silva de Araújo Costa (AZEVEDO, 2018); além da reunida por Tristão de Carvalho no rio Nhamundá e repassada a Pompeu Sobrinho, atualmente no Museu do Estado do Ceará. No Museu Britânico há fragmentos cerâmicos de Santarém compradas de Cadman, em 1929, de peça senhorita $U_{r e}^{20}$ e outras doadas pela helenista Alice Grace Carthew ${ }^{21}$ em 1936.

\subsubsection{Entre colecionadores, etnólogos e arqueólogos}

O colecionamento de cerâmica do Baixo Amazonas prosseguiu mais de duas décadas depois do fim dos trabalhos de campo de Nimuendajú, tomando grandes dimensões em coleções particulares, com grande notoriedade no país. Uma delas foi reunida pelo casal estadunidense Rose e Robert Brown que morou em Santarém entre 1941 e 1944. Eles reuniram cerca de 10 mil peças, uma parte coletada por eles mesmos

\footnotetext{
${ }^{18}$ Ofício no 51,17 de fevereiro de 1936. Do Diretor Carlos Estevão de Oliveira ao governador do estado do Pará. Fundo Carlos Estevão de Oliveira, Correspondências, Arquivo Guilherme La Penha/MPEG.

${ }^{19}$ Carta de Gastão Cruls a Curt Nimuendajú, 19/11/1941, Arquivo Curt Nimuendajú/ CELÍN/MN.

20 BRITISH MUSEUM. Collection online. Disponível em: <https://www.britishmuseum.org/research/search_the_collection_database/term_details.aspx?bioId=4110 2> Acesso em 16 de novembro de 2018.

21 BRITISH Collection online. Disponível em: <https://www.britishmuseum.org/research/collection_online/collection_object_details.aspx?objectId=653 572\&partId=1\&people=27671\&peoA=27671-3-9\&page=1> Acesso em 16 de novembro de 2018.
} 
nas ruas e outra comprada de uma mulher indígena que vivia na cidade (PALMATARY, 1960) (Figura 16). A reunião das peças durou "perto de um ano"22, sendo que em 1944, a coleta foi mais intensa porque "demoraram-se mezes no trabalho na Aldeia" (1953, p. 4). No mesmo ano, realizaram uma exposição dos seus achados e no ano seguinte venderam a coleção para a Fundação Brasil Central, que anos depois (em 1954) a doou ao Museu Nacional.

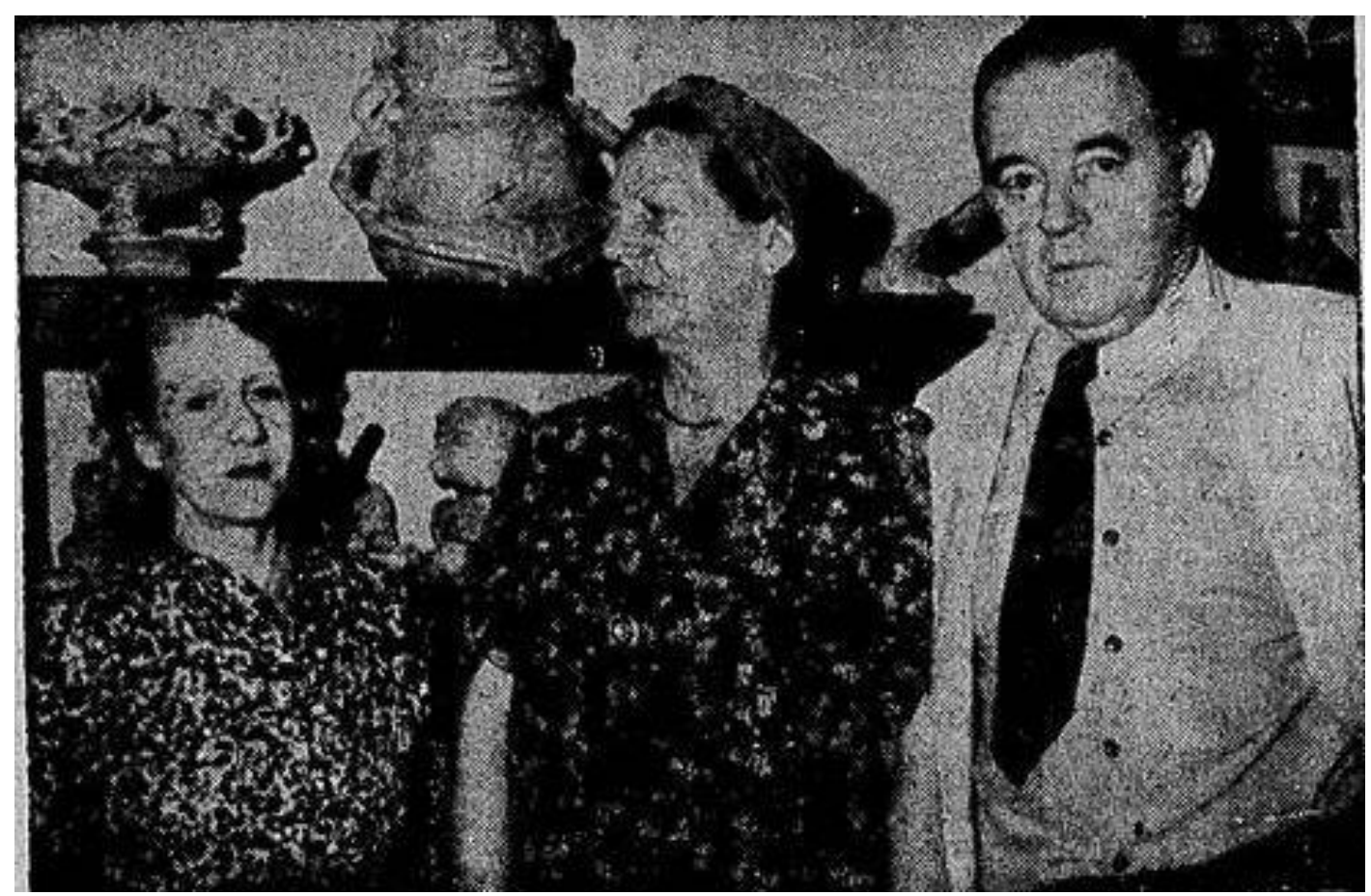

Figura 16. Casal Rose e Robert Brown em 1944 ao lado da jornalista, à esquerda. Ao fundo, em uma estante, é possível ver um vaso de cariátides, um vaso efígie e uma estatueta cerâmica. As duas primeiras peças foram incluídas em diferentes estudos arqueológicos da cerâmica Santarém e catálogos de peças arqueológicas. Fonte: Diário Carioca, 19/11/1944, p.3.

A outra grande coleção reunida por um particular foi a pertencente ao jornalista Frederico Barata, entre as décadas de 1940 e 1950. Ele tanto cavava quintais das casas no bairro Aldeia quanto comprava peças de outras pessoas (op. cit., ibid.). Sua coleção ganhou notoriedade porque ele publicou artigos de jornal e ensaios científicos sobre a cerâmica Santarém, que ainda são referências fundamentais para a arqueologia (GOMES, 2010). Barata teve grande atuação na expansão do grupo de comunicação

\footnotetext{
${ }^{22}$ PRECIOSA herança dos índios da Amazonia. Diário Carioca, Rio de Janeiro, 19 de nov. de 1944, p. 3.
} 
Diários Associados no país, tendo chefiado sua superintendência no Norte do país. Frequentou os círculos intelectuais do Rio de Janeiro e possuía grande erudição em história da arte, antropologia e conhecimento das línguas inglesa e francesa, o que o permitiu dialogar com os arqueólogos que recém chegavam na Amazônia, Betty Meggers, Clifford Evans e também Peter Hilbert (GUAPINDAIA, 1993; ROSA, 2008).

Barata foi presidente, no início dos anos de 1950, do Instituto de Antropologia e Etnologia do Pará (IAEP), uma organização voltada para a promoção do conhecimento antropológico da região, que reunia comerciantes e intelectuais em Belém. Algumas de suas principais publicações foram feitas pelo Instituto, que funcionou em uma sala do Museu Goeldi (ROSA, 2008). À época, o Museu passava por um momento de decadência, com grande falta de recursos e o Boletim do MPEG já não lançava um novo número desde 1933. O IEAP patrocinou algumas pesquisas, incluindo aí o trabalho de campo de Peter Hilbert na região dos rios Trombetas e Nhamundá, em 1952. Hilbert era um alemão que chegou em 1949 para trabalhar com as coleções de "arte" africana do MPEG e que acabou se interessando por arqueologia, a partir de sua participação em uma das etapas de campo realizado em Marajó por Meggers e Evans (HILBERT, 2009). Barata, já em 1950, dizia que seria importante estudar melhor uma cerâmica tão ou mais barroca que a "de Santarém", encontrada no município de Oriximiná. Hilbert deve ter sido estimulado por ele a realizar um estudo na região, com o patrocínio do Instituto. $\mathrm{O}$ material proveniente de Oriximiná, inclusive algumas das raras vasilhas inteiras, foi cedido para o estudo de Hilbert e recebeu ilustrações do artista Manoel Pastana.

A partir da pesquisa sobre a "cerâmica de Oriximiná", Peter Hilbert estabeleceu contato com o frei alemão Protásio Frikel (HILBERT, 2009). Frikel começou a coletar cerâmica arqueológica já no final da década de 1930. Diferente de João Mayer, seu interesse não se voltava a venda, mas ao estudo das peças que afloravam na terra. Desde sua chegada à região de Santarém se coletou material de áreas do Baixo Amazonas: o sambaqui Jauari, em Alenquer, as terras pretas em Santarém, Aveiros, Juruti, Oriximiná e Faro (MARTINS, 2013). Nimuendajú trocou algumas cartas, em seus dois últimos anos de vida, com Frikel sobre os povos indígenas da região do rio Trombetas e o material arqueológico do sítio Jauari ${ }^{23}$. Não há nenhuma informação sobre contatos anteriores. Em todo caso, em meados da década de 1940, Frikel já enumerava 41 sítios

\footnotetext{
${ }^{23}$ Carta de Protásio Frikel a Curt Nimuendajú, 08/04/1945, Arquivo Curt Nimuendajú/ CELÍN/MN.
} 
arqueológicos visitados. O frade fala que "De todos os lugares possuo algum (às vezes muitos) restos de artefatos, sejam líticos sejam ceramica." ${ }^{24}$ Em relação a cerâmica encontrada nos rios Trombetas, Nhamundá e no município de Juruti, Frikel enviou uma série de anotações sobre os sítios arqueológicos que visitou e algumas tentativas de síntese e desenhos de peças. Hilbert (1955a) se valeu de algumas dessas informações em seu ensaio. Ele reuniu várias coleções de peças arqueológicas ao longo da vida e cedeu duas delas para o estudo de Peter Hilbert $(1959,1982)$. A origem germânica permitiu, como na época de Nimuendajú, que uma relação se estabelecesse em torno dos materiais arqueológicos.

O Museu Paulista, na época em condições financeiras muito melhores que o Museu Goeldi, realizou uma série de expedições etnográficas e arqueológicas na bacia amazônica no decênio de 1950. O objetivo desses trabalhos era aumentar o acervo da instituição, que pouco dispunha de materiais etnográficos e arqueológicos, devido à ênfase inicial em zoologia e botânica (FRANÇOSO, 2005) - uma diferença marcante com o Museu Paraense e o Museu Nacional. Esses trabalhos foram realizados pelo etnólogo Harald Schultz, filho de imigrantes alemães, que foi assistente da Seção de Etnologia no MP desde 1947. Entre 1950 e 1956, Schultz passou pela Ilha de Marajó, Santarém, Juruti, Parintins, Itacoatiara, Manaus e Manacapuru. Como no caso de outros etnólogos germânicos, o seu interesse por arqueologia é pouco conhecido e documentado. Não são claros os motivos que levaram Schultz a reunir coleções arqueológicas ou como essa atribuição foi criada no Museu Paulista. Um fato coincidente, que pode estar ligada a seu interesse, é a doação e compra de coleções realizadas. Em 1948, o Museu adquiriu parte da coleção arqueológica de Luís Paixão, com materiais de Marajó e rio Trombetas, e uma única peça proveniente de Santarém (BALDUS, 1949). Em 1951, a coletora e etnóloga Wanda Hanke doou para a instituição uma coleção de fragmentos cerâmicos provenientes do município de Manacapuru (BALDUS, 1952).

As expedições do Museu Paulista parecem ter seguido o caminho das coleções adquiridas. Em uma viagem de Belém a Rio Branco, em 1950, Schultz "colheu"

\footnotetext{
${ }^{24}$ Carta transcrita de frei Protásio Frikel a frei Fidelis Ott, em papel timbrado do Museu Nacional, com seguinte título: Cópia/Político/ Comunicação sobre pesquisas arqueológicas realizadas na região amazônica", sd, Fundo Heloísa Alberto Torres/SEMEAR/MN.
} 
informações de "achadouros" arqueológicos ao longo do rio Amazonas e Purus (BALDUS, 1951). Em 1953, Schultz foi a Santarém comprou uma coleção que contava 666 peças, entre as quais havia uma grande estatueta inteira. Nessas etapas de campo, com ajuda de Peter Hilbert, Schultz fez “(...) visita de cêrca de quarenta sítios arqueológicos nos rios Erepecurú, Trombetas, Paraná-Parintins e redondezas, bem como nos lago Juruti-Velho e Juruti-Mirim e outros. Durante trinta dias percorreu, em canoa com motor de popa, mais de mil quilómetros do Baixo Amazonas e seus afluentes" (BALDUS, 1954, p.281). O material coletado em Juruti e Parintins não foi enviado ao Museu Paulista, permanecendo para estudo no MPEG. Hilbert pretendida complementar seu estudo sobre a cerâmica Konduri, que era baseado em materiais da bacia do rio Trombetas e Nhamundá, na margem oposta do rio Amazonas. Os resultados deste campo nunca foram publicados.

Peter Hilbert e o antropólogo Eduardo Galvão realizaram um campo, em 1957, nos municípios de Santarém, Boim, Brasília Legal, Belterra e Monte Alegre. Dois anos antes o MPEG foi federalizado e passou a fazer parte do Instituto de Pesquisas Amazônicas, o que gerou mais recursos para a pesquisa arqueológica. Foram realizados treze cortes estratigráficos e várias coletas de superfície, incluindo a área urbana de Santarém. "Os objetivos dessa primeira viagem [segundo Galvão] foram estabelecer através de cortes estratigráficos uma possível seriação e cronologia relativa da cerâmica arqueológica tradicionalmente identificada como tipo 'Santarém'; estabelecer a área de difusão, desse tipo de cerâmica, no planalto e ao longo do rio Tapajoz" ${ }^{, 25}$. Os resultados dessa pesquisa também nunca foram publicados e o único documento conhecido é o relatório de campo com uma página.

A formação intensa das coleções particulares continuou na década de 1950 para além do que é possível localizar nos museus. Peter Hilbert (1955a, p. 20) relata o caso de uma vasilha inteira que ele soube que passou de mão em mão de Oriximiná a Faro até chegar na cidade de Parintins e ter seu paradeiro perdido. Helen Palmatary fez o maior levantamento de coleções de cerâmica do Baixo Amazonas, em 1953, e encontrou outros colecionadores além da de Barata e do casal Brown. Alguns desses colecionadores viviam na cidade de Santarém e cidades vizinhas. Ela visitou Charles

${ }^{25}$ GALVÃO, Eduardo. Relatório Anual da Divisão de Antropologia (Janeiro a Dezembro de 20157). MPEG/INPA, 1958. Arquivo Guilherme La Penha/ MPEG. 2f. 
Townsend Jr, em Belterra, o filho de um famoso entomologista que trabalhou nas plantações de seringueira em Fordlândia, que continuou o trabalho do pai para a Ford Motors Company (EVENHUIS, 2015 et al.). Não se sabe exatamente quando começou a reunir sua coleção, mas é provável que tenha sido, entre as décadas de 1930 e 1940, quando trabalhava na região (ROSA, 2004). Outras peças certamente foram adquiridas depois, como as que eram da coleção de Protásio Frikel, provenientes de Faro e Oriximiná (HILBERT, 1955a). Na cidade de Santarém, Palmatary (1960) encontrou o casal de migrantes alemães Carlos e Ilse Liebold, que matinha uma coleção maior de peças encontradas nas ruas da cidade (Figura 17). O geólogo alemão Fritz Ackermann reuniu uma coleção de cerâmica em Oriximiná, que foi fotografada por Meggers e Evans (1957), cujo paradeiro atual é desconhecido.

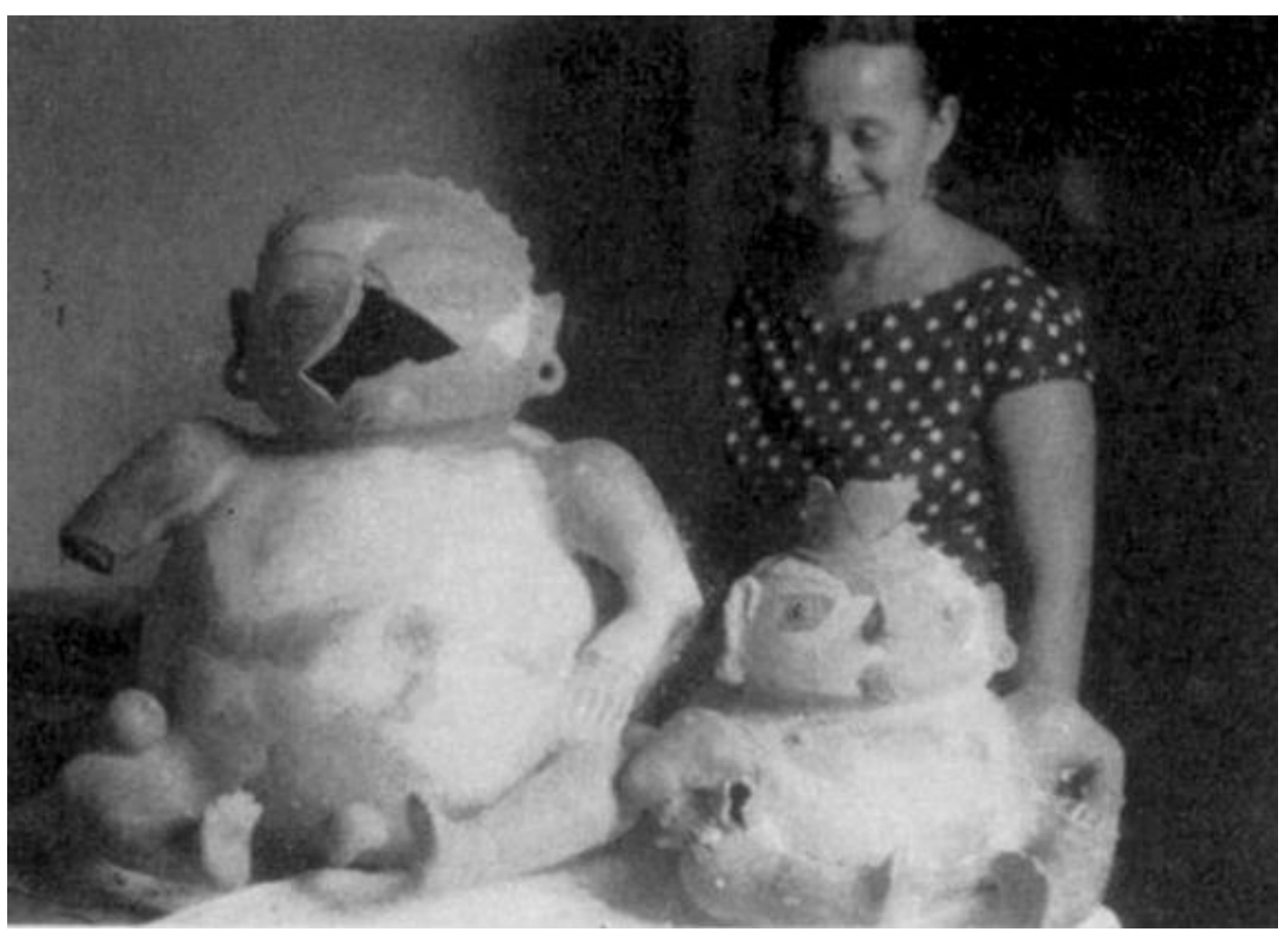

Figura 17. Helen Palmatary com dois vasos efígie que na época pertenciam à coleção de Carlos Liebold. Atualmente ambas pertencem a Coleção Tapajônica do MAE-USP. Fonte: Palmatary, 1960.

\subsubsection{A última grande coleção}

A partir da década de 1960, as informações sobre novas coleções particulares e de pesquisas sistemáticas no Baixo Amazonas diminuíram consideravelmente. Os 
estudos arqueológicos quase não foram levados a diante devido à priorização de áreas menos conhecidas com o PRONAPA e PRONAPABA. Coleções particulares surgiram, certamente, mas não receberam a divulgação das reunidas por Barata ou o casal Brown. A lei $\mathrm{n}^{\mathrm{o}} 3.924$, aprovada em 1961, proibiu o comércio de peças arqueológicas e sua “destruição ou mutilação", tornando ilegais as práticas de colecionamento. As coleções reunidas pelo casal Brown, Frederico Barata, Charles Townsend Jr. passaram a compor o acervo do Museu Nacional e do Museu Goeldi.

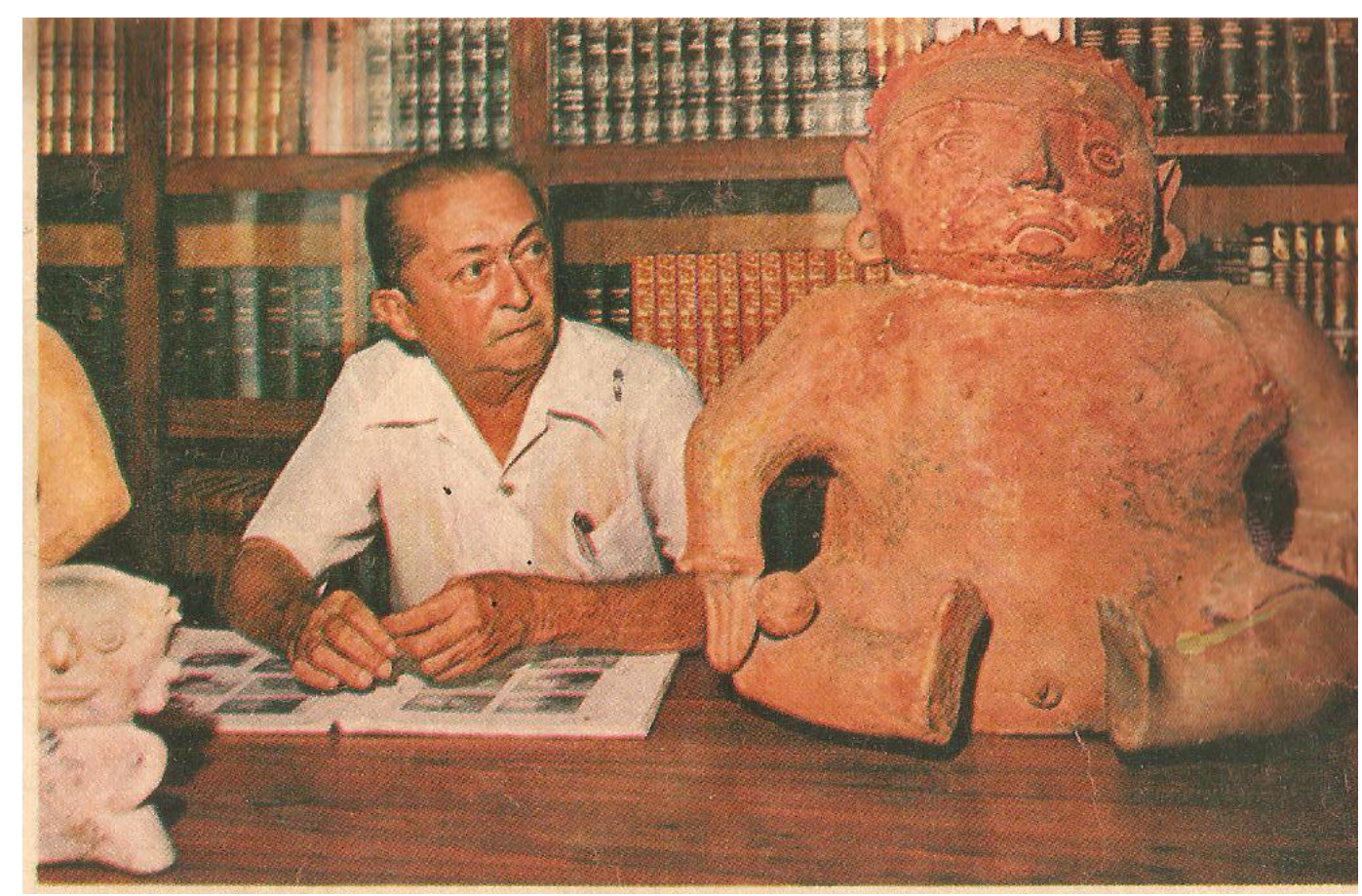

Figura 18. Ubirajara Bentes em seu escritório ao lado de um vaso efígie que pertenceu a coleção Liebold e atualmente faz parte da Coleção Tapajônica do MAE-USP. Disponível em: < http://ignacioneto.blogspot.com/2012/04/em-santarem-para-ao-lado-do-hotel-nova.html>. Acesso em 21 de dezembro 2018.

A coleção reunida por Carlos e Ilse Liebold, com várias vasilhas inteiras, no entanto, não foi vendida ou doada a nenhuma instituição. Em 1960, Harald e Vilma Schultz iniciaram uma negociação para comprar a coleção de Ilse Liebold, depois da morte de seu marido, para o Museu Paulista, mas a negociação não foi efetivada. Em carta a Frederico Barata, Vilma Schultz comenta que conseguir adquiri-la para algum 
museu é "a última possibilidade de juntar uma coleção daquelas" 26 . No mesmo ano, Paulo Duarte tentou patrimonializar a coleção Liebold, via Departamento de Patrimônio Histórico e Artístico Nacional, mas também não obteve um resultado positivo. Várias tentativas de contatar Ilse foram feitas, no entanto ela nunca foi encontrada e o processo foi arquivado.

O paradeiro da coleção Liebold só pode ser mapeado uma década depois. Ignácio Ubirajara Bentes, um advogado que viveu em Santarém, e reuniu uma das maiores coleções de que se tem notícia, havia comprado pelo menos "30 ou 40" peças 27 . Mesmo depois da proibição de comércio de peças arqueológicas, Bentes continuou a reunir e manter sua coleção, cuja existência era de conhecimento público. Na região, ele era conhecido como o "comprador de caretas" 28 por causa de sua incessante busca por peças arqueológicas. Em uma matéria de jornal, é destacado que homens, mulheres e, principalmente, crianças juntavam fragmentos para ele depois das chuvas. Em entrevista disse que já chegara a vender "trezentos ou quinhentos bois" ${ }^{29}$ para comprar cerâmica provavelmente à compra da coleção Liebold (Figura 18). A coleção Bentes ganhou notoriedade porque ele montou uma espécie de "museu" particular em Santarém que foi visitado por várias personalidades, como o rei Leopoldo da Bélgica e o vice-presidente Augusto Rademaker, na década de 1960. As tentativas de compra de sua coleção ganharam também destaque, devido aos elevados valores ofertados por colecionadores e pela Universidade da Pensilvânia e Colúmbia nos Estados Unidos ${ }^{30}$. Em uma matéria do jornal Estado de São Paulo, é mencionada ainda uma proposta feita por um colecionador estadunidense no valor de um milhão de dólares. O grande temor, entre os arqueólogos como Valentim Calderón, era que parte da coleção viesse a sair do país. ${ }^{31}$

26 Carta de Vilma Schultz a Frederico Barata, sd (provavelmente 1960), Documentação Museu Paulista/Correspondências Secção de Etnologia/Herbert Baldus, pasta 1950-1952.

27 BEZERRA DE MENEZES, Ulpiano. Coleção Ubirajara Bentes (antiguidades tapajônicas): Relatório de viagem subvencionada pela FAPESP, de 25 a 31 de dezembro de 1970, para elaboração do projeto "Preservação e aproveitamento científico do patrimônio arqueológico - levantamento a ser realizado em Santarém, Pará”. Serviço de Documentação MAE-USP, Coleção Tapajônica.

${ }^{28}$ CERÂMICA Tapajó, um patrimônio pré-histórico. Estado de São Paulo, 14 de agosto de 1977, p. 27.

29 TAPAJÓS, a civilização pré-histórica do Brasil. Jornal do Comércio, Manaus, 19 de abril de 1971, Caderno 2, p. 3.

${ }^{30}$ BEZERRA DE MENEZES, Ulpiano. Coleção Ubirajara Bentes (antiguidades tapajônicas): Relatório de viagem subvencionada pela FAPESP, de 25 a 31 de dezembro de 1970, para elaboração do projeto "Preservação e aproveitamento científico do patrimônio arqueológico - levantamento a ser realizado em Santarém, Pará”. Serviço de Documentação MAE-USP, Coleção Tapajônica.

${ }^{31}$ Idem. 
A coleção reunida por Bentes foi vendida em 1971 ao Museu de Arqueologia e Etnologia da USP, sendo esta uma história controversa. A obtenção foi negociada pelo diretor do Museu a época, Ulpiano Bezerra de Menezes, em 1970, que pretendia iniciar pesquisas arqueológicas na região de Santarém. Apesar de já ter se tornado ilegal a venda de material arqueológico, a compra foi realizada. ${ }^{32}$. A venda foi efetivada, sendo que a maior parte da coleção veio para o MAE-USP e uma pequena parte continuou em Santarém, tendo, depois, passado a compor a coleção do Centro Cultural João Fona. Uma controvérsia se criou em torno da compra dessa coleção. Segundo Cristina Demartini e Cristiana Barreto (comunicação pessoal, 2017), Bezerra de Menezes relatou que Bentes teria separado uma porção da coleção para ficar em Santarém, contrariado o acordo da venda total da coleção. Bentes afirmou em uma matéria publicado em $O$ Estado de São Paulo, que foi "ludibriado" "pelos homens da USP, através de [seus] artifícios" que pagaram apenas 170 mil cruzeiros ao invés de 300 mil, como teria sido acordado. A matéria tem um tom lacônico, marcado com desilusão de Bentes, que teria perdido as esperanças ao ver sua coleção "esfacelada", em um museu distante de Santarém.

\subsection{Artefatos em diáspora}

As práticas de colecionamento no Baixo Amazonas foram propagadas a partir das coletas de Nimuendajú e se estenderam ao longo do século XX. Qual seria o motivo para essa difusão temporalmente persistente e com poucos correlatos na arqueologia brasileira? Há vários motivos, alguns já elucidados em relação à prática dos museus antropológicos e a tradição de etnologia germânica. É possível combinar a perspectiva mais diacrônica do desenvolvimento das coleções com outra mais sincrônica, seguindo o "rastro" dos artefatos que compõe as coleções e o conceito motor dessa circulação - a "beleza".

Em mais de um século de formação de coleções vários circuitos foram formados até as peças chegarem a coleção de Frederico Barata ou Ubirajara Bentes, os fragmentos que compõe as coleções passaram de mão em mão. Mesmo no caso das coleções reunidas em levantamentos científicos, como o de Barbosa de Faria, Hilbert e Schultz, vários objetos foram recebidos de doação ou mesmo comprados - no caso do último. As coleções, ou partes delas, tiveram diferentes itinerários, ora combinados ora ${ }^{32}$ Idem. 
dispersos. As pesquisas de campo de Nimuendajú não foram apenas cruciais para o desenvolvimento da arqueologia da região, como normalmente se enfatiza. Foram centrais também para o desenvolvimento de um desejo de possuir exemplares dos objetos arqueológicos. Decorre daí um processo que, talvez, tenha sido catalisado pelas políticas nacionalistas da época. O lema "colecionar para conhecer" resume muito das grandes coleções formadas no período. Mesmo não vinculados aos museus formalmente, Gastão Cruls e Frederico Barata produziram estudos influentes sobre a cerâmica do Baixo Amazonas. Em um momento em que a arqueologia era de pouca expressividade no país (PROUS, 1992), os colecionadores particulares foram responsáveis pela formação de um legado de objetos selecionados e hipóteses construidas a partir deles.

Atores muito distintos se encontraram (e se encontram) por meio de um circuito das peças arqueológicas, que conecta pessoas que moram sobre os sítios e moradores de grandes centros, detentores de um determinado capital cultural e econômico. O fluxo de peças está baseado nessa desigualdade econômica entre moradores e colecionadores ou representantes de museus (NAJJNAR; BEZERRA, 2009). Essa diferença econômica também tende a ser geográfica, iniciando uma "diáspora" de fragmentos cerâmicos. Participaram e, em alguns casos participam, dessa rede de circulação de objetos arqueológicos do Baixo Amazonas: (1) moradores da região que reuniram coleções de pequena escala; (2) colecionadores locais, que não apenas juntavam peças quanto às compravam, chegando a formar grandes coleções (3) forasteiros que apenas coletaram ou compraram alguns objetos (souvenires); (4) coletores/pesquisadores de museus, como Nimuendajú, Hilbert; (5) grandes colecionadores, geralmente moradores de outras áreas ou estrangeiros, que compram peças inteiras e podem dispor de altas quantias para obtê-las. A participação dessas pessoas apesar de ser presumível, dificilmente pode ser identificada na documentação. Uma das poucas referências, por exemplo, a uma peça obtida por um indígena é o caso de uma estatueta lítica que teria pertencido a um xamã indígena do rio Trombetas (provavelmente Kaxuyana) que o repassou a Protásio Frikel que, por sua vez, o doou a Charles Townsend Jr. (op. cit.) (Figura 19). 


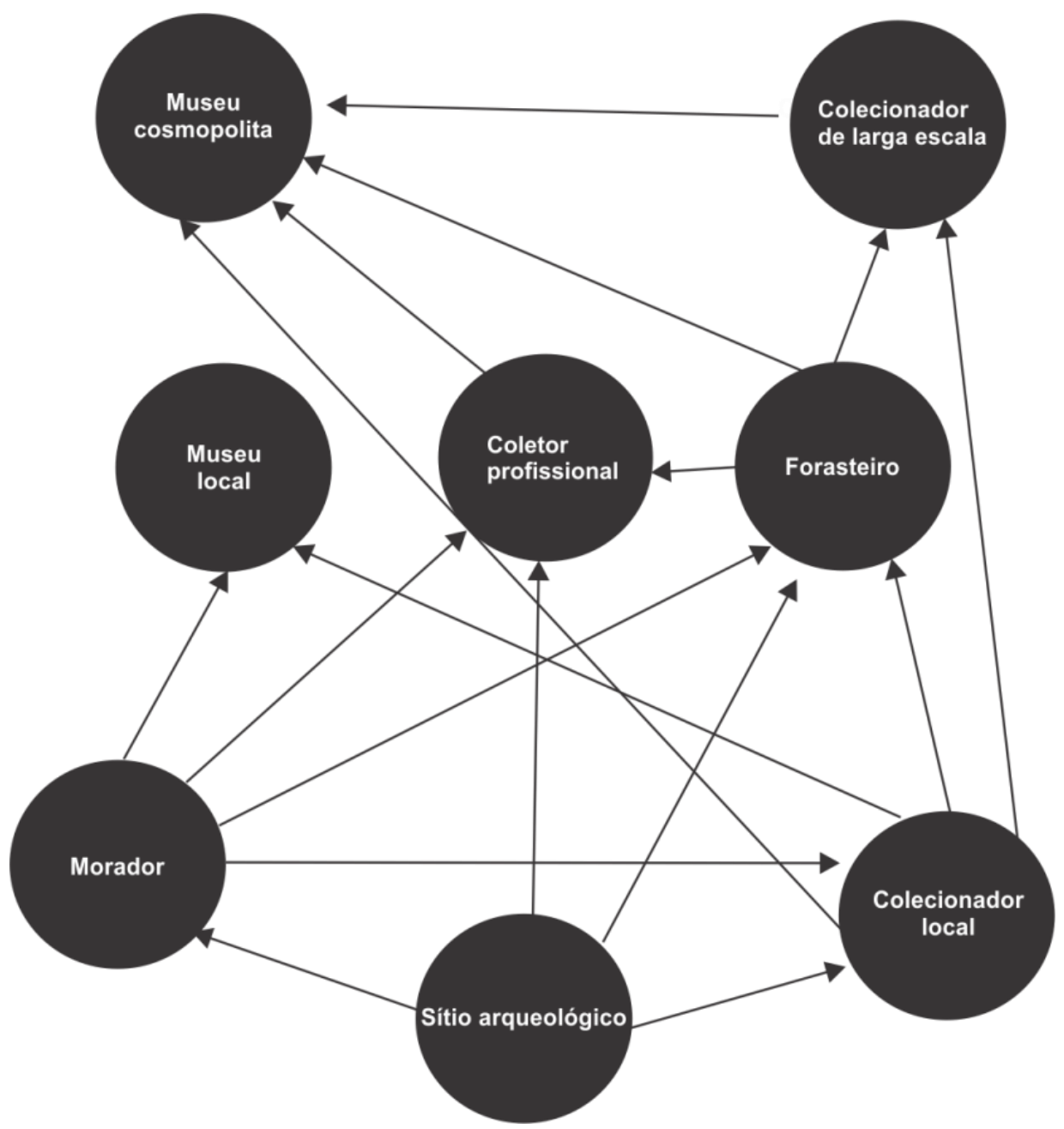

Figura 19. Fluxo de peças arqueológicas (venda e doação) do sítio a grandes museus. As setas indicam a direção da circulação dos objetos, a partir dos casos estudados na documentação dos museus e nas reservas técnicas

Os moradores da região, quilombolas, indígenas e ribeirinhos, foram um elemento central para o circuito das coleções. São essas pessoas que possuem conhecimento sobre a localização dos sítios arqueológicos e entraram (e entram) primeiro em contato com as peças, guardando-as quando parecem interessantes. A prática de colecionar "caretas" continua sendo comum em comunidades tradicionais da Amazônia, de maneira semelhante à praticada por crianças e alguns adultos da década de 1920, tal como relatou Nimuendajú (2004). As coleções reunidas por moradores locais são de pequena escala; geralmente, não chegam a reunir muitas vasilhas inteiras ou milhares de fragmentos de diferentes regiões, como as de Barata ou do casal Brown (TROUFFLARD, 2012; GUAPINDAIA, 2008; JÁCOME, 2017). O trabalho da terra, a 
construção de casas ou mesmo a ação das chuvas, em comunidades ribeirinhas, permite encontrar essas peças, que abundam nas terras pretas.
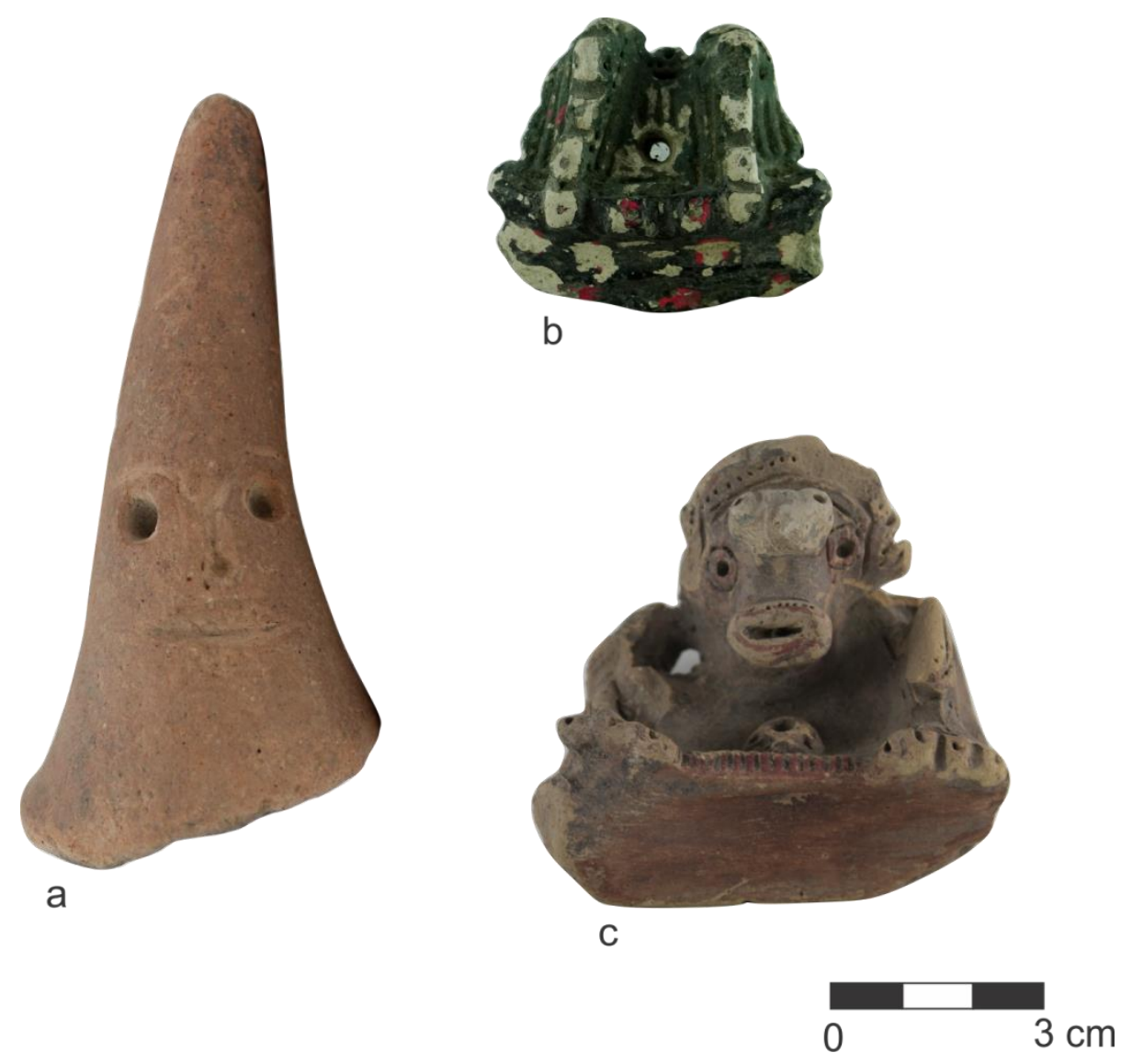

Figura 20. Apliques com modificações recentes (incisões e pintura): a. pé de vasilha trípode com incisões e furo formando cara (coleção Ubirajara Bentes/ Coleção Tapajônica MAE-USP); b. aplique pintado com tinta óleo verde e esmalte de unha rosa (coleção Aricy Curvello MHN-UFMG); c. aplique pintado com esmalte de unha roxo (coleção Aricy Curvello MHN-UFMG).

A venda de peças arqueológicas se tornou cada vez mais comum, à medida que a cerâmica da região ganhou notoriedade. A valoração de materiais arqueológicos pelos museus acabou convertendo-os em mercadorias (SCHAAN, 2007). Como destaca Stocking $(1985$, p. 5) "The very materiality of the objects of material culture entangled them in Western economic processes of the acquisition and exchange of wealth". Essa relação econômica produziu uma verdadeira "caça ao tesouro", em que os sítios 
arqueológicos se tornam jazidas de artefatos. Barata (1950), por exemplo, reconta uma história de Nimuendajú, em que um morador português de Santarém, remexeu a sua escavação em busca de preciosidades. Gastão Cruls (1942, p. 194) comenta que na região de Santarém "depois que [as caretas] começaram a ser procuradas por etnógrafos e curiosos, faz-se mesmo hoje certo comércio na localidade e raro é o caboclo que não possui alguma de reserva entre seus terens, para oferece-los por qualquer cousa, ao primeiro viajante que por elas se interesse". As coleções de "caretas" não são reunidas para a venda, mas podem ser convertidas em mercadoria devido à diferença do valor atribuído às peças e a diferença econômica entre quem as encontra e quem as compra.

O comércio de peças arqueológicas que teve início do século passado ainda se manifesta no presente, mesmo com a proibição legal e maior fiscalização. Em uma reportagem publicada pelo jornal Folha de São Paulo, em 2005, foi denunciada a facilidade para se comprar artefatos líticos ou fragmentos cerâmicos em lojas de artesanato de Santarém ${ }^{33}$. Dois anos antes, o Instituto do Patrimônio Histórico e Artístico Nacional (IPHAN) enviou uma arqueóloga à região, Maria Lucia Pardi, que constatou a venda de material tanto em Santarém quanto no município de Oriximiná ${ }^{34}$. Um conjunto de materiais foi recebido por Pardi de ribeirinhos do Lago Sapucuá e passou a integrar um acervo da Casa de Cultura municipal. Uma grande coleção de fragmentos cerâmicos e material lítico foi doada a Secretaria de Cultura, em 2005, que pertenciam a um comerciante local, que comprava peças arqueológicas (JÁCOME, 2017; FONSECA, 2010). Em Parintins (AM), o fluxo de cruzeiros transatlânticos catalisou a venda de fragmentos de cerâmica por algumas pessoas da comunidade Valéria a turistas (LIMA et al., 2013).

Os museus tanto os cosmopolitas, como Museu Nacional ou Museu Goeldi, ou museus locais, como o Museu Integrado de Óbidos, são instituições que se encontram no fim da cadeia de circulação das peças. No início da cadeia se encontram, geralmente, os moradores de áreas próximas aos sítios. O fluxo de objetos pode acontecer entre categorias de atores distintas ou dentro da mesma categoria. Por exemplo, 10 apliques da coleção comprada em Santarém por Schultz foram permutados

33 ANGELO, Cláudio. Pará vende relíquias a turistas e coleções. Folha de São Paulo, 17 de outubro de 2005. Disponível em: < https://www1.folha.uol.com.br/folha/ciencia/ult306u13868.shtml>. Acesso em 16 de novembro de 2018.

${ }^{34}$ PARDI, Maria Lúcia. Relatório sobre atividades arqueológicas- Belém e Oriximiná - 14 a 19/12/ 2003. Arquivo do Instituto do Patrimônio Histórico e Artístico Nacional, Pará, Belém. 
com o Museu Nacional de Etnologia e Pré-história Luigi Pigorini da Itália, assim como fragmentos foram comprados por Gastão Cruls do colecionador Chrysantho Jobim. São raríssimos os exemplos de peças do Baixo Amazonas que chegaram ao mercado de belas artes, como um vaso de cariátides e um vaso de gargalo da coleção Barbier-Muller leiloados pela Sotheby's ${ }^{35}$. O mercado ilegal de peças arqueológicas do Baixo Amazonas nunca adquiriu o status da cerâmica Marajoara ou das peças andinas e mesoamericanas, de grande interesse aos colecionadores de "artes pré-colombianas". Por outro lado, não se sabe qual é a extensão do tráfico de material arqueológico na região, nem é possível ter acesso a informações de muitas coleções particulares.

Provavelmente, existem milhares de peças provenientes do Baixo Amazonas e dispersas em todo o país e no exterior. Em suas notas de campo de 1953, menciona que em um sítio arqueológico do Lago Juruti Velho "seis sacos" de fragmentos cerâmicos haviam sido coletados. Durante a passagem pelas comunidades do Lago Sapucuá, várias vezes foi mencionado que as "caretas" eram dadas a pessoas do Rio de Janeiro. A existência de coleções pequenas e pouco conhecidas em museus também é uma evidência de tal circulação em pequena escala desconhecida. No Museu do Estado do Maranhão, por exemplo, há seis peças Konduri sobre as quais não se tem nenhuma informação. $\mathrm{O}$ artista pernambucano Abelardo Rodrigues reuniu pelo menos 49 peças de cerâmica de Santarém em meio a centenas de peças de arte sacra e popular ${ }^{36}$. Cândido Portinari também possui alguns exemplares no Rio de Janeiro, segundo Palmatary (1960). Outro artista, o mineiro Petrônio Bax, esteve em Santarém em 1972 e adquiriu alguns apliques cerâmicos e também fotografias da coleção arqueológica e etnográfica de Ubirajara Bentes. Esse material atualmente é salvaguardado pelo Museu de História Natural da UFMG. Na mesma instituição, encontra-se uma coleção de artefatos cerâmicos e líticos reunidos por Aricy Curvello, entre 1975 e 1979, na área de Porto Trombetas, onde trabalhou para a Mineradora Rio Norte (GUIMARÃES, 1985). Débora Magalhães, uma antropóloga, esteve na região de Terra Santa e coletou uma dezena de fragmentos que foram doados ao MPEG, em 1980. Tanto no caso dos turistas como no dos pesquisadores são reunidas apenas pequenas quantidades de peças, não passando de algumas dezenas.

35 SOTHEBY'S. Auction Results: Collection Barbier-Mueller Art Précolombien. Disponível em: <http://www.sothebys.com/en/auctions/ecatalogue/2013/collection-barbier-mueller-pf1340/lot.302.html> Acesso em 17 de novembro de 2018.

${ }^{36}$ MACIEL vê obra de Abelardo Rodrigues. Diário de Pernambuco, Recife, 12 de janeiro de 1980, p. B-8 


\subsubsection{Belezas emaranhadas}

As coleções reunidas entre o século XIX e primeira metade do XX no Baixo Amazonas foram constituídas pelo critério difuso de "beleza". Os sentidos que essa concepção estética podem assumir dependem do agenciamento desses materiais por diferentes habitus, contexto e instituições. A percepção de membros das comunidades tradicionais é marcadamente diferente da compartilhada pelos colecionadores de "arte". São modos de avaliação que podem selecionar os mesmos objetos, sobrepondo os desejos de cada ator, mas ainda divergindo sobre seu valor, ontologia e história.

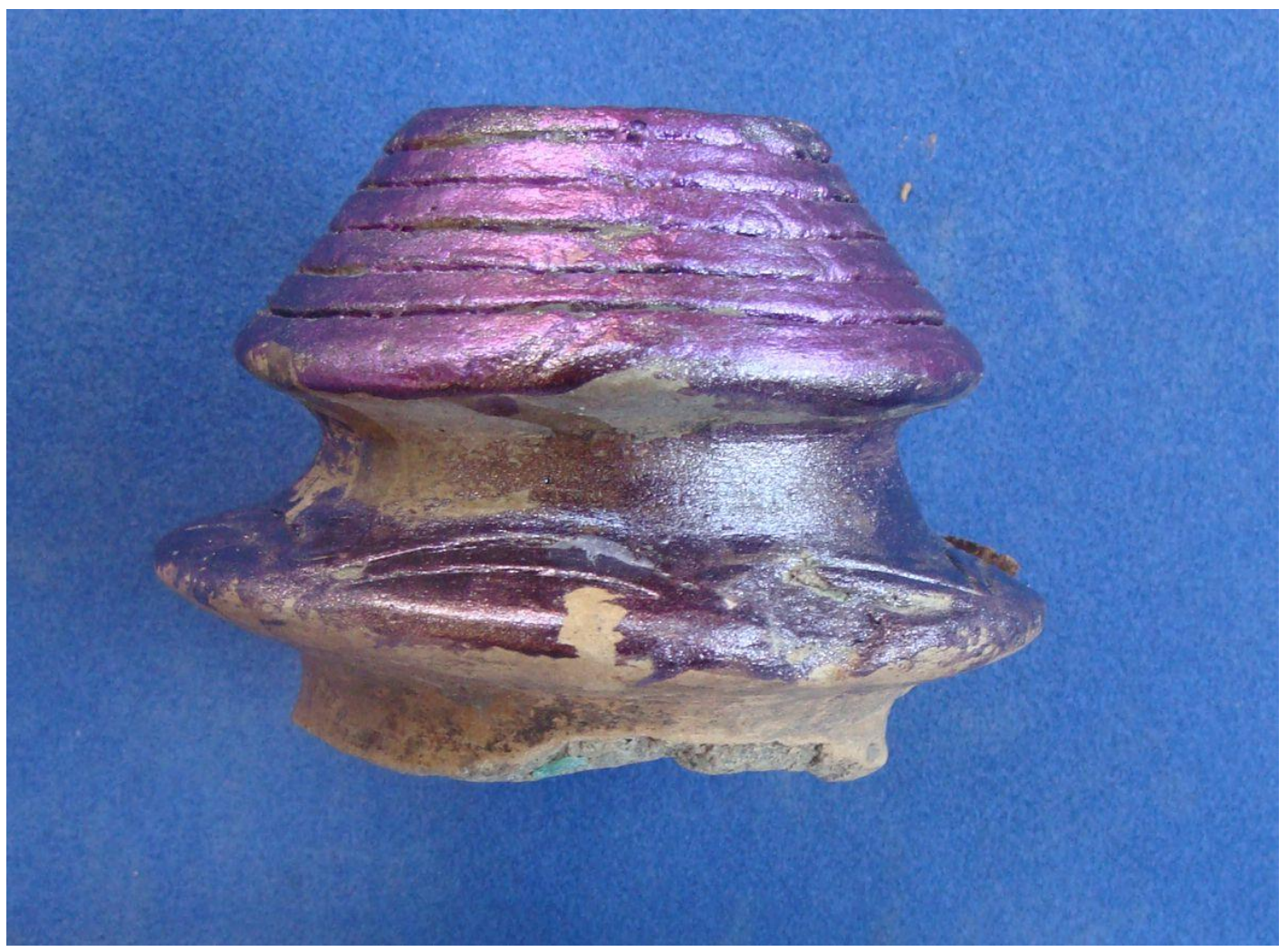

Figura 21. Gargalo com pintura de esmalte de unha roxo da coleção doméstica da senhora Laudelina (Comunidade de Ajará, Lago Sapucuá) na cidade de Oriximiná. Foto: Marcony Alves, 2014.

A maioria das coleções de pequena escala - com exceção das reunidas por professores locais - é produzida fora de um habitus letrado, compartilhado por “curiosos", colecionadores, artistas, etnólogos, arqueólogos e, muitas vezes, turistas. As associações dos materiais feitas por ribeirinhos, quilombolas e indígenas são muito 
variadas e combinam formas onto-epistemológicas não modernas. Em alguns casos, por exemplo, não é reconhecida sua produção humana, mas sim, uma criação "divina", "mítica" ou "natural" (LIMA et al., 2013; ver também SILVA, 2015). A potência agentiva xamânica dos materiais também podem ter efeitos sobre a condição de quem se relaciona com eles (JÁCOME, 2017). Em toda a Amazônia, fora dos âmbitos letrados, as narrativas em torno da cerâmica e outros objetos partem de concepções variadas do que, em termos arqueológicos, é caracterizado como artefato datado de um período específico (BEZERRA, 2011, 2013; CABRAL,2014; ROCHA et al., 2014).

A categoria "careta" (além de suas variações, "carinha" e "caretinha") é fundamental para as comunidades ribeirinhas para descrever as modelagens zoomorfas e é extremamente disseminada na Amazônia brasileira. A possibilidade de reconhecer um rosto humano ou de um animal nas modelagens tornam elas especialmente atraentes. Os principais elementos para a seleção dos objetos para a composição de coleções de pequena escala são critérios visuais como morfologia padronizada, brilho, pintura, elementos plásticos e figurativos. Essas características do design dos artefatos são agrupadas dentro da categoria de "bonito" (SILVA, 2015). A partir desse critério são reunidos objetos distintos, que em termos arqueológicos, seriam atribuídos a diferentes períodos, como fragmentos pré-coloniais e um fragmento de garrafa de grés. Da mesma maneira, objetos naturais, como um seixo de rio, podem ser mantidos em uma coleção porque se assemelham a uma forma humana ou animal. $\mathrm{O}$ interesse pelos elementos visuais das peças leva muitos ribeirinhos coletores de peças a modificá-las, adicionando camadas de “embelezamento", como pinturas, incisões, amarrações, etc (Figura 20).

Na Aldeia Santidade, em que vivem indígenas Wai Wai e outras coletividades Karib, um indígena pintou um aplique em forma de cabeça de ave com as cores que aludem ao animal a qual a figuração é relacionada (JÁCOME, 2011, p. 471). Essa peça teve um cordão inserido em seu orifício formando um colar. Prática semelhante foi vista em peças coletadas por dona Laudelina, no Lago Sapucuá, que pintou algumas peças de sua coleção com esmalte de unha roxo (Figura 21). Os materiais arqueológicos também são mobilizados no cotidiano, como lâminas de machado usadas como peso de porta (TROUFFLARD, 2012). O conhecimento sobre as práticas de colecionamento de pequena escala na Amazônia ainda são limitados. Novos estudos são necessários para 
pensar na articulação do colecionismo praticado em cidades e parte de elementos centrais do ethos moderno.

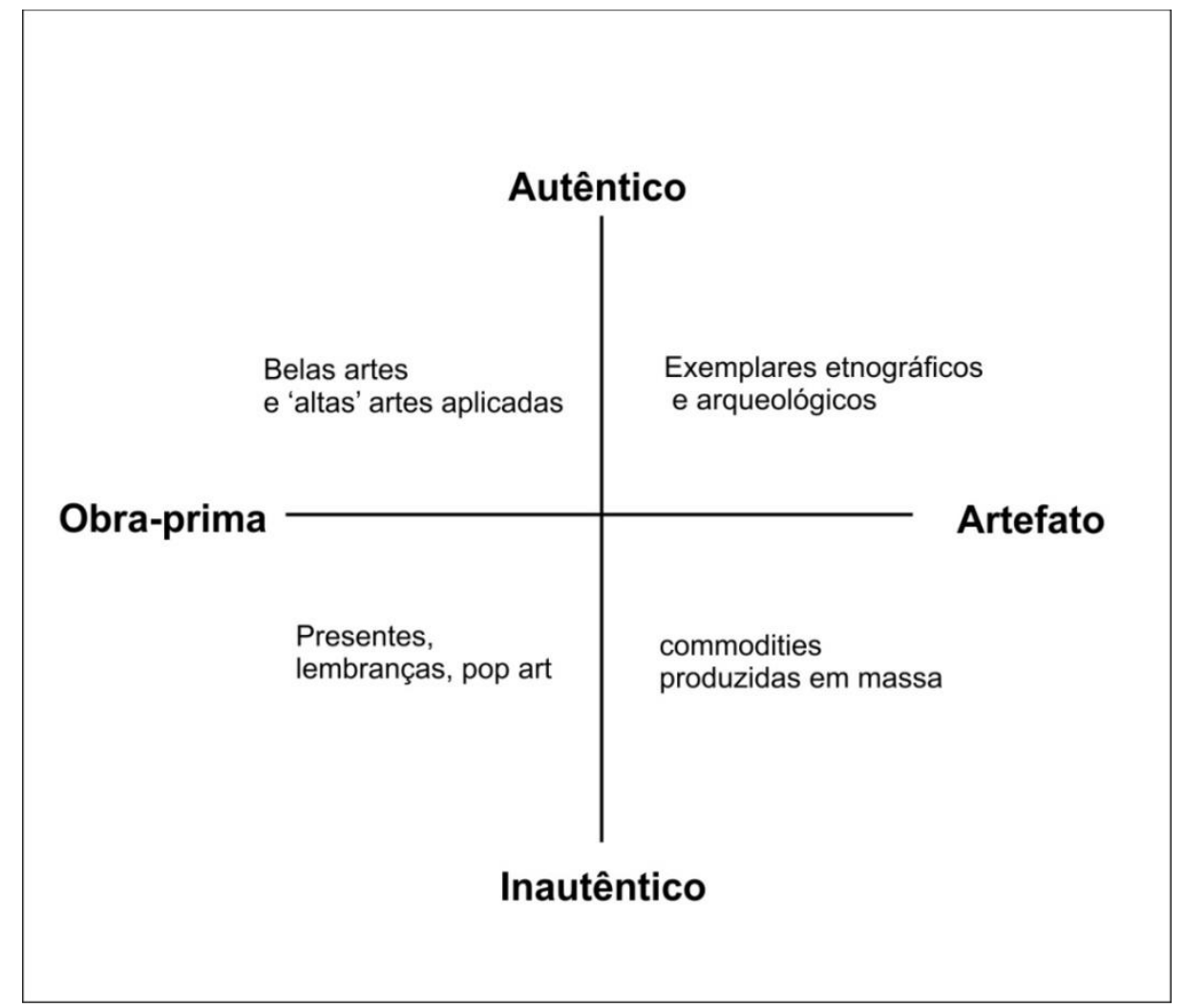

Figura 22. Quadrantes sugeridos por Pearce como articuladores da classificação de objetos no pensamento ocidental moderno

A constituição de coleções de larga escala se vincula ao modo de colecionar denominado de "fetichista" por Pearce (1993). Uma das principais características desse modo de colecionamento considerado "sério" é a reunião de objetos com um valor artístico, científico e/ou econômico, reconhecido por instituições e especialistas. No caso das coleções de cerâmica arqueológica, a mesma ênfase em peças decoradas, encontradas nas coleções de pequena escala, tem papel decisivo nas grandes coleções. Esse interesse é parte de um habitus das classes médias e altas urbanas, interessada em artes e antiguidades, que se desenvolveu a partir do interesse por objetos grecoromanos. Frederico Barata exemplifica essa situação muito bem: fazia parte dos mais altos círculos artísticos e intelectuais do país, em meados do século passado, ter um 
retrato pintado por Portinari e escrever um livro sobre o artista Eliseu Visconti (ROSA, 2008). A partir desse conhecimento e relações estabelecidas é possível "reconhecer" o valor das "caretas" para as ciências e artes.

A composição das coleções tanto particulares como de museus compartilha da lógica ocidental que opõe arte/artefato e autêntico/inautêntico (CLIFFORD, 1988; PEARCE, 1995). Separam-se os objetos do cotidiano (artefatos espúrios), dos objetos etnográficos e arqueológicos (objetos autênticos para o conhecimento), das réplicas e souvenires (obras-primas espúrias) e de objetos de grande importância (obras-primas verdadeiras)(Figura 22). Subjaz a esse modo de classificação, especialmente em arte, um princípio de avaliação estética de todas as produções materiais humanas. Entre as "verdadeiras" obras de arte são incluídas pinturas e esculturas do Ocidente moderno, mas também peças da Antiguidade clássica, consideradas centrais para o cânone da história da arte, desde o século XVIII (ver JECKINS, 1992). Os objetos produzidos fora desses contextos também são avaliados a partir do esteticismo universalista euroamericano, dependendo do contexto em que são apresentados (PRICE, 1986; GELL, 1992). Tanto objetos arqueológicos quanto etnográficos podem ser convertidos em "arte primitiva" a partir de mercados especializados ou museus (STOCKING, 1985). Essa vinculação, no entanto, não é direta e está sujeita a flexibilização da estética clássica (WILLIAMS, 1985). O interesse por muitos dos artefatos de povos não ocidentais se relaciona às tensões e aos padrões estéticos no final do século XIX e início do XX. O "primitivismo" que contagiou vanguardas europeias teve efeitos sobre o modernismo brasileiro e a avaliação dos artefatos arqueológicos. Manoel Pastana, que desenhou peças Santarém e Konduri para publicações de Barata e Hilbert, foi um expoente de uma vertente artística paraense interessada em objetos arqueológicos (ver LINHARES, 2011; MARTINS, 2017). Artistas como Cânido Portinari, Petrônio Bax e Abelardo Rodrigues, colecionaram alguns exemplares de cerâmica Santarém e/ou Marajoara.

Nas coleções particulares e de museu, as vasilhas de cerâmica Santarém foram deslocadas da sua condição de artefatos arqueológicos ao status de obra de arte. A divisão entre o "mero artefato" e a "obra- prima", no caso de artefatos não ocidentais, é fundamentada na avaliação estética dos objetos, convertida em linha evolutiva do "simples" ao "complexo". Os esquemas de valoração do "Outro" no tempo e no espaço seguem um princípio de valorização do que mais parece com "Nós", hierarquizados e 
“complexos" (PEARCE, 1995). Essas formulações evolucionistas tem um longo processo dentro da história da arte, com o desenvolvimento do ideal de beleza grega no século XVIII por Johann Wickelmann (JENKINS, 1992; DIETLER, 2005). No mesmo sentido, Hartt (1885, p. 96) defendeu que "[p]ode-se classificar as tribos e as nações [ameríndias] pelo estado de progresso em que se acha a sua arte ornamental”. Em linhas gerais, as produções materiais de "grandes civilizações" estão mais próximas da "arte", como a dos impérios andinos e mesoamericanos. A elevação e interesse pela "arte" marajoara se sustenta a partir da mesma forma de atribuir valor, desde as primeiras coletas e descrições realizadas por Frederich Hartt (LINHARES, 2011, 2015). Como explicita Métraux (1959), o que chamou a atenção para o Marajó foi o "haut niveau de civilization" indicado pelas urnas funerárias. O mesmo ocorreu com a cerâmica de Santarém, que foi mais enfatizada em relação a encontrada em Monte Alegre e no rio Trombetas. A "beleza" das peças de Santarém, sua "superioridade", permitiu que essa cerâmica ganhasse um espaço dentro da "arte pré-colombiana" em museus e coleções particulares, como a Barbier-Muller.

A arte oleira da "segunda grande civilização amazônica" tornou-se, assim objeto de desejo e fascinação para as coleções particulares e de museus. É provável que depois da cerâmica Marajoara, a Santarém tenha sido a segunda mais colecionada, mesmo com o sucesso das urnas Maracá e Cunani (Aristé), décadas antes. A frequente comparação entre os dois estilos cerâmicos a partir de um vocabulário que emula a história da arte resulta desse processo de avaliação estética e colecionamento. Gastão Cruls (1942, p. 194), por exemplo, afirmou que “A cerâmica tapajônica está para a marajoara como o estilo barroco está para o clássico”. Frederico Barata, por sua vez, não apenas estabeleceu uma comparação, como tentou inverter a "superioridade" artística marajoara em relação a Santarém: "Não hesito em afirmar que, como manifestação de arte, é a cerâmica de Santarém muito mais importante do que a de Marajó."37 A associação direta da "arte indígena" apenas com a cerâmica Marajoara seria o resultado, segundo Barata, da profusão de estudos arqueológicos sobre o tema e as apropriações artísticas dos padrões pintados na cerâmica, tanto no Brasil quanto na Europa. A justificativa para a maior importância da "cerâmica de Santarém" seria a maior "evolução" técnica que as modelagens representariam em relação às pinturas. A

\footnotetext{
${ }^{37}$ BARATA, Frederico. Os animalistas de Santarém. O Jornal. Rio de Janeiro, 27 de setembro de 1942,
} Segunda Seção, p. 1-2. 
tendência a equacionar "progresso da arte ornamental" do qual falava Hartt (1885) permeia todo o discurso de Barata. Essa perspectiva ainda está viva nas relações estabelecidas com objetos não modernos, mesmo por praticantes da arqueologia. Ribeiro (2016), por exemplo, mostra os problemas gerados pela descrição de um estilo cerâmico como "simples", que sustentam a visão de um "baixo desenvolvimento cultural" no extremo Sul do Brasil. A equivalência da elaboração de algumas técnicas com "complexidade social" é o outro extremo da mesma equação evolucionista. Como o legado do conceito de "degeneração" ainda presente na arqueologia amazônica (NOELLI, FERREIRA, 2007), o peso das noções de "arte", "civilização" e "progresso" ainda reverberam nos estudos arqueológicos.

A concepção de arte e sua separação de meros artefatos cotidianos, desde o Renascimento, fazem parte de modo aristocrático de ordenar o mundo e constituir um certo habitus. O modo de reconhecer arte é parte das hierarquias que separam os conhecedores daqueles que não são (PRICE, 1986). As produções materiais da antiguidade greco-romana foram o primeiro conjunto a ser deslocado para esse espectro interpretativo, a partir do Renascimento (DIETLER, 2005). O englobamento de outras “artes", no entanto, foi contínuo, a partir da própria expansão colonial do ocidente. A herança do classicismo e da identidade euro-americana foi atualizada nas cerâmicas amazônicas, como a Marajoara e Santarém. A tendência de equacionar as "belas" cerâmicas a "civilizações" faz parte de uma matriz de pensamento interessada num passado "nobre" da Nação, tal qual Ferreira (2002, 2007) argumenta ter sido fundamental para o pensamento das elites do período imperial. Como bem o autor (2002, p.67): "O índio [dentro da arqueologia nobiliárquica] seria um grego agora nu". A estratégia discursiva no século XIX, analisadas pelo historiador foi a de aproximar o passado pré-colonial do atual território brasileiro às "civilizações" mediterrâneas ou a origens bíblicas. Na primeira metade do século XX, essas associações foram desqualificadas, mas a premissa de equacionar "beleza" a maior nível de desenvolvimento social permaneceu. Sua mobilização na forma de coleções para Museu Nacional e Museu Goeldi durante a Era Vargas foi mais uma tentativa de associar a nação brasileira a uma grande arte ancestral. A analogia estabelecida entre as cariátides gregas e um tipo de vaso de Santarém faz parte do interesse em converter essas peças em "arte". Barata não conseguiu inverter o legado do "Marajoara-mania", mas, como 
mostram publicações, catálogos e exposições, por meio da cerâmica Santarém a “civilização tapajônica" se estabeleceu entre as artes amazônicas.

A metáfora construída por Candance Slater (2002) de "édens emaranhados" (entangled edens) para sintetizar o complexo jogo de imagens e relações como a Amazônia pode ser útil para pensar as coleções e os diferentes atores envolvidos em sua formação e circulação. Slater mostra como coexistem paralelamente as grandes narrativas, como a do El Dourado e suas versões contemporâneas de busca por riqueza, e as narrativas locais de ribeirinhos, quilombolas e indígenas que vivem diariamente em contato com a terra amazônica. De maneira similar, as coleções de cerâmica arqueológica do Baixo Amazonas (e talvez de toda a Amazônia) poderiam ser descritas como "belezas emaranhadas". Virtualmente todas as coleções reunidas fora do contexto de escavações arqueológicas sistemáticas apresentam um mesmo critério difuso norteado pela "beleza". As modelagens pré-coloniais agem na produção de relações estéticas, que ora se associam ao "Belo" aristocrático e civilizatório, ora se convertem em "bonito" que serve de brinquedo e decoração da casa. Os materiais circulam em cadeias, unindo conceitos distintos de beleza, ontologias e classes sociais distintos.

\subsubsection{Integridade e fragmentação}

A integridade das vasilhas arqueológicas é um elemento fundamental para sua mobilização como "arte". A elaboração técnica de motivos pintados e tratamentos plásticos - vista como "ornamentação" - não é suficiente para que materiais passem de artefatos a obras de arte. Esse é um elemento claro no caso dos colecionadores que restauram grandes porções ou mesmo recriam partes inteiras dos objetos para ter uma perspectiva de completude. Pearce (1995, p. 292) enfatiza essa perspectiva em relação a materiais da Antiguidade clássica, que geralmente são aproximados das belas artes: "A classic marble, be it never so battered, has its place without question [como obra de arte]; so has many a relatively humble bowl or plate, providing enough of it survives to a give reasonable idea of its appearance" (ênfase adicionada). Como já mencionado, um dos motivos de Santarém ter gerado tanto interesse no século XX, segundo Cruls (1942), foi que Nimuendajú conseguiu encontrar vasilhas decoradas inteiras, o que não aconteceu com as coletas realizadas por naturalistas no do século XIX. A integridade também foi um elemento essencial para a conversão das cerâmicas Marajoara, Maracá e Aristé em "obras de arte". A integridade das vasilhas geralmente está relacionada a 
contextos funerários na Amazônia. Em Santarém, no entanto, a conservação de vasilhas se deve ao enterramento intencional de vasilhas inteiras ou fragmentadas sem associação com sepultamentos (ver SCHAAN, 2015).

Diferentemente do material encontrado em Santarém e arredores, vasilhas Konduri inteiras ou remontáveis são raríssimas, mesmo com a realização de pesquisas sistemáticas desde a década de 1970. A cerâmica Konduri foi aproximada da categoria "arte" por meio de uma avaliação estética com a Santarém. Cruls (1930) afirma que os tratamentos plásticos da cerâmica do Trombetas são "barrocos" como o da cerâmica de Santarém. Barata (1950) sugere que a cerâmica de Oriximiná refletiria "um estágio da mesma cultura" da arte oleira Tapajó. No entanto, a falta do "luxo" de vasos completos deixou-a a sombra da Santarém, tanto em textos acadêmicos quanto em exposições e catálogos de museu. As diferenças entre as cerâmicas Konduri e Tapajó, percebidas por Nimuendajú (2004) desde 1924, não causaram interesse. Linné (1928) apenas menciona a cerâmica Santarém. Nordenskiöld (1930) menciona a existência de uma cerâmica parecida com a de Santarém entre os rios Trombetas e Nhamundá. Nenhum tópico para discuti-la foi escrito e apenas 4 ilustrações de peças da região dos rios Trombetas e Nhamundá foram incluídas na obra, o que contrasta com o texto e as quase cinquenta ilustrações da cerâmica Santarém. A denominação Konduri não é mencionada nenhuma vez. Nimuendajú, em um curto relatório apenas menciona "tipo divergente [do Santarém], representando talvez os Konduri da época do Descobrimento" (NIMUENDAJÚ, 2001 [1929], p. 192). Palmatary (1939) menciona essa denominação apenas uma única vez, sem tratar de seus atributos. As sínteses sobre a arqueologia amazônica nas décadas seguintes ignoraram a cerâmica encontrada entre os rios Trombetas e Oriximiná ou a mencionaram apenas como "semelhante a Santarém" (CRULS, 1942; HOWARD, 1947; MEGGERS, 1948; WILLEY, 1949; MÉTRAUX, 1959). Por esse motivo, Barata iniciou seu primeiro volume de A arte oleira dos Tapajó chamando a atenção para a quase desconhecida "cerâmica de Oriximiná".

Os catálogos de museus, interessados em divulgar as "belezas" de acervos nacionais, mantiveram o legado construído pelas coleções de peças inteiras e o desconhecimento da cerâmica Konduri. Várias peças foram expostas e muitas foram fotografas para compor catálogos e livros de arte. A cerâmica Konduri permaneceu uma figura sem rosto, mencionada em relação a sua semelhança com Santarém, minoritária 
ou nula em termos de fotografias ou peças expostas. Entre fotografias do acervo do Museu Goeldi publicadas pela Funarte (1981) ou da "arte" pré-colonial em acervos de museus brasileiros (DOW, 1984) não há nenhuma vasilha Konduri e na série organizada pelo Banco Safra (O MUSEU, 1986) há apenas uma. A mesma assimetria foi mantida nas exposições de museus e coleções, que enfatizaram as cerâmicas Marajoara, Santarém, Maracá e Aristé. Nas fotos das exposições do Museu Nacional e Museu Goeldi da década de 1980 vê-se essas peças na exposição de cerâmica amazônica. Na listagem de peças em exposição do Museu Goeldi de 1956, por exemplo, aparecem 54 peças Santarém na sala de arqueologia e apenas 8 fragmentos Konduri, em exposição no corredor $^{38}$. Com exceção do material Santarém, essas já eram as cerâmicas enfatizadas desde o século XIX (MELO, 2017).

\subsection{Conclusão: misturas materiais e analíticas}

O interesse pelas cerâmicas do Baixo Amazonas teve consequências materiais e intelectuais, de maneira semelhante à identificada por Gill e Chippindale (1993) para as estatuetas Cicládicas e por Brodie e Luke (2006) em relação à cerâmica Policrômica Maya. O tratamento do material Konduri como arte e "extensão" daquele encontrado em Santarém também é parte desse processo. Nas coleções, houve uma justaposição material cerâmica proveniente das bacias dos rios Trombetas e Tapajós a partir da seleção estética de coletores/colecionadores. Essa associação material, anterior à discursiva, legou a equívocos e confusões. Como diferenciar peças parecidas quando já estão misturadas? A questão de como diferenciar Konduri de Santarém, tão importante no texto de Hilbert (1955a), não se relaciona apenas aos contextos arqueológicos, mas ao próprio processo de formação de coleções particulares, seus critérios de reunião e o estudo dessas coleções.

Nimuendajú comenta, em carta a endereçada a Palmatary, que "alguns dos elementos tratados pela Snr. como Tapajó [em "Tapajo Pottery”] são característicos do estilo Konduri”39. Palmatary (1939) inclusive situou erroneamente a dispersão do estilo Santarém até a Serra de Parintins, sendo que, o etnólogo queria indicar a presença de

38 GALVÃO, Eduardo. Relatório Anual da Divisão de Antropologia (Janeiro a Dezembro de 1956). MPEG/INPA, 1957. Arquivo Guilherme La Penha/ MPEG. 15f.

${ }^{39}$ Carta de Curt Nimuendajú a Helen Palmatary 01/10/1939, Arquivo Curt Nimuendajú/ CELÍN/MN. 
um elemento Santarém associado à cerâmica Konduri. Ele sugere que Palmatary não foi capaz de reconhecer a diferença porque não the foi mostrado o material da "região" Konduri no Museu Etnográfico de Gotemburgo. Como pano de fundo, vê-se a existência de um interesse menor por meros fragmentos. Gastão Cruls (1942, Prancha 6), provavelmente seguindo a análise de Palmatary (1939), tratou indistintamente o baixo Tapajós e o rio Trombetas, repetindo o erro em relação a dispersão do estilo Santarém. Palmatary (1960), seguindo as indicações de Nimuendajú, reforçou a ideia da existência de "influências" e "combinação" entre os estilos Konduri e Santarém.

Heloisa Alberto Torres e Frederico Barata também difundiram a expressão "civilização Tapajós-Trombetas" como um indicador de algo próximo ao que poderia ser chamado de área cultural. Barata (1952) defende que a "civilização TapajósTrombetas" se caracterizaria pelo compartilhamento de estatuetas líticas elaboradas e os muiraquitãs entre a bacia dos dois rios. $\mathrm{O}$ grande interesse por esses materiais acabou fazendo com que acabassem sendo muito associados à cerâmica Santarém (ex. PROUS, 1992), apesar de, no caso dos "ídolos”, quase todas as peças terem sido encontradas fora da área de ocorrência daquele estilo. Em exposições e catálogos essa questão permaneceu em aberto, seguindo os textos acadêmicos, com as noções de "civilização Tapajós-Trombetas" e "influência". Uma peça no Museu Nacional foi identificada na coletânea organizada pelo Banco Safra (O Museu Nacional, 1986) como "Konduri”, apesar de apresentar a policromia característica de algumas vasilhas do estilo Santarém. As informações de proveniência do exemplar haviam se perdido, mas é possível identificá-la em uma das fotografias publicadas por Barata (1953), que o considera "representativo da cultura dos tapajós" (BARATA, 1952, p. 68). No site da instituição essa peça ainda continua sendo classificada como "Cultura Konduri” (Figura 23). Na sala de arqueologia amazônica no mesmo museu havia até 2015 peças tipicamente Konduri (coleção Barbosa de Faria) associadas a outras do estilo Santarém (coleção Valentim Bouças, Rose e Robert Brown). A análise de coleções de museu com materiais provenientes de áreas muito díspares e praticamente sem nenhuma informações de procedência levaram a cristalização da noção de "influência" e de alguns equívocos (GUAPINDAIA, 1993; GOMES, 2002). Schaan (2016), a partir de pesquisas sistemáticas, mantém a mesma categoria. 


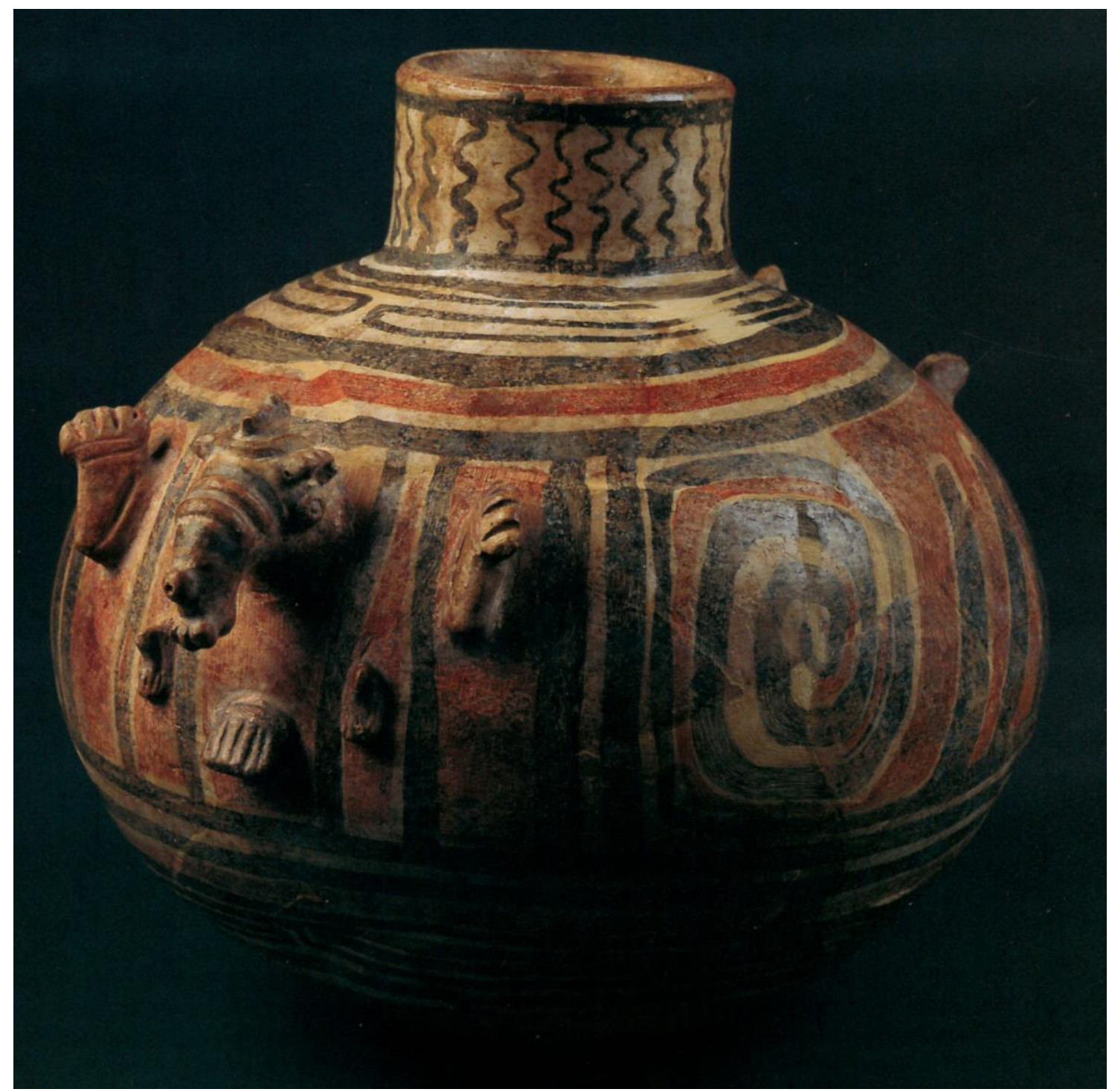

Figura 23. Vasilha identificada como "vaso globular Konduri” em um catálogo e no site da instituição (http://www.museunacional.ufrj.br/dir/exposicoes/arqueologia/arqueologia-brasileira/arqbra001.html). Extraído de O Museu Nacional (1986).

O emaranhamento de "belezas" é também evidente no caso dos cachimbos angulares do período colonial e imperial. Apresentando uma decoração em relevo, chamou a atenção dos colecionadores e foram reunidos junto com as "caretas". Barata (1944) mostrou que havia uma decoração fitomorfa nessas peças que é característica da ornamentação do Barraco, o que demonstraria que essas peças seriam artefatos criados depois do início da colonização europeia. Mesmo assim, uma associação permaneceu nos estudos desse tipo de artefato entre a cerâmica pré-colonial e os materiais mais recentes. No quadro em que Hilbert comparou as cerâmicas Konduri e Santarém, ele 
identifica os cachimbos angulares como "neobrasileiros", mas ainda os incluiu em sua comparação entre as cerâmicas Konduri e Santarém. De maneira, semelhante Palmatary (1960) incluiu o estudo desses artefatos ao seu estudo centrado na cerâmica Santarém. Certa confusão sobre o período de produção dos cachimbos, na ausência de escavações estratigráficas, manteve-se décadas depois (PROUS, 1992). A resolução apareceu apenas a partir da publicação do resultado de análise de cerâmica do período colonial, indicando uma diferença de dois séculos entre a produção da cerâmica Santarém e os cachimbos (SYMANSKI, GOMES, 2012; MUNIZ, GOMES, 2017).

As misturas materiais e suas consequências analíticas são um problema, bem como sua perpetuação em análises arqueológicas. Para contornar ciclos viciosos é, portanto, necessário tratar o processo de formação das coleções de uma maneira análoga ao escrutínio dos processos tafonômicos no registro arqueológico e à crítica das fontes escritas. 


\section{Capítulo 3 - Problemas metodológicos no estudo de coleções de museu}

"Collecting is a process of displacement, of changing cultural contexts and uses, and of the loss and gain of information."

PAREZO 1987, p.

As coleções reunidas por colecionadores particulares ou resultantes de pesquisas antigas são geralmente consideradas insuficientes para o estudo do passado pré-colonial. Para muitos, as chamadas "coleções históricas" são apenas vestígios da própria atividade da arqueologia, sem potencial para pesquisas atuais ou futuras. Como mostrado no capítulo anterior, os vários conjuntos de artefatos reunidos por diferentes atores são, de fato, parte da história institucional e da ciência arqueológica. O objetivo deste capítulo é discutir até que ponto essas coleções de museu podem ser mais que isso. É possível obter resultados confiáveis a partir desses materiais? Qual seria a validade desses resultados? E ainda: qual é a escala adequada para associá-los?

A proposta deste capítulo é apresentar uma avaliação comparada dos problemas, vieses e potencialidades de 18 coleções, reunidas entre 1870 e 1976 e depositadas em cinco instituições diferentes para pensar o estilo tecnológico Konduri. As informações de proveniência de parte das coleções permitem identificar de sítios arqueológicos, localidades ou áreas específicas. Assim, ao invés de considerar as coleções apenas como não representativas ou insuficientes devido a sua falta de informações estratigráficas ou de dispersão espacial, optamos considerá-las potencialmente informativas para estudo de tecnologia em escala regional. O problema da representatividade só poderá ser abordado tangencialmente, uma vez que as coleções estudadas não foram coletadas de maneira que seja possível considerar as proporções como representativas, tal como analisado por outros autores (KINTIGH, 1981; GOETZE; MILLS, 1991). 
Para esta pesquisa foram selecionadas as coleções do Museu Paraense Emílio Goeldi (MPEG), Museu Nacional da Universidade Federal do Rio de Janeiro (MN), Museu de Arqueologia e Etnologia da Universidade de São Paulo (MAE-USP) e Museu de História Natural e Jardim Botânico da UFMG (MHN) porque estas já passaram por processos de curadoria e são de mais fácil acesso, além de dispor, em alguns casos de documentação sobre o contexto de coleta. Como parte da documentação de campo produzida por Peter Hilbert, encontrava-se no Museu de Ciências e Tecnologia da Pontifícia Universidade Católica do Rio Grande do Sul (MCT), o arquivo pessoal de Klaus Hilbert foi consultado junto com alguns exemplares que compuseram parte de acervos no MPEG. Duas dessas coleções tem fundamental importância para o estudo da cerâmica Konduri, uma vez que serviram como base para as primeiras publicações sobre o tema e sua definição ainda em uso (BARBOSA FARIA, 1946; HILBERT, 1955a). Com exceção de alguns poucos exemplares, não foram incluídas nesse estudo as coleções obtidas em escavações sistemáticas realizadas a partir de 1975, dado os limites temporais da pesquisa. Além das coleções estudadas, foram identificadas peças Konduri em diferentes instituições no Brasil e em outros países ${ }^{40}$.

Em relação aos protocolos de coleta atuais, há vários problemas nas coleções de museu analisadas: coleta seletiva, falta de documentação, perda de informações e de material ao longo dos anos. Por esse motivo, as coleções não costumam ser abordadas como amostras coesas, e sim, a partir da descrição de peças raras ou do uso de técnicas arqueométricas também em conjuntos limitados (HUSTER, 2013). Um dos principais desafios para estudar coleções de museu como uma unidade coesa é estabelecer sua representatividade enquanto amostra de estudo. Para contornar os vieses, o principal método utilizado é a comparação com uma amostra obtida em escavações sistemáticas recentes (KINTIGH, 1981; GOETZE; MILLS, 1991; HUSTER, 2013). A expectativa dessas comparações, geralmente, é demonstrar a representatividade (positiva) da coleção antiga. A maioria das coleções de museu não apresenta variabilidade e integridade equiparável a de coletas aleatórias e sistemáticas. Mesmo quando não é possível estabelecer uma representatividade quantitativa, alguns autores defendem que se pode "recontextualizar" os objetos a partir dos resultados de outras pesquisas

${ }^{40}$ Penn Museum (Estados Unidos), Museu da Cultura Mundial (Suécia), Musée Dobrée (França), coleções no interior (Casa de Cultura de Oriximiná, Museu Integrado de Óbidos, Centro Cultural João Fona de Santarém) e na capital do Pará (Museu do Estado do Pará), na região Nordeste do país (Museu do Estado do Maranhão, Museu do Estado do Ceará, Museu do Índio da Ordem dos Frades Menores). 
recentes. Falci et al. (2017) consideram que para realizar uma "recontextualização" arqueológica é necessário que a coleção seja qualitativamente variada - mesmo que não estatisticamente representativa - e com proveniência espaço-temporal delimitada a partir de sua documentação.

\subsection{Coleta e transporte}

Parezo (1987) argumenta que a formação das coleções de museu é análoga aos processos do próprio registro arqueológico. É preciso considerar fatores relacionados à coleta, transporte e acondicionamento na instituição da mesma maneira que a ação das intempéries, fauna e flora no registro. Dessa maneira, para avaliar a potencialidade das coleções serão tratadas as informações relacionadas à coleta, acondicionamento e registro para então se discutir a composição da coleção e a seletividade das amostras.

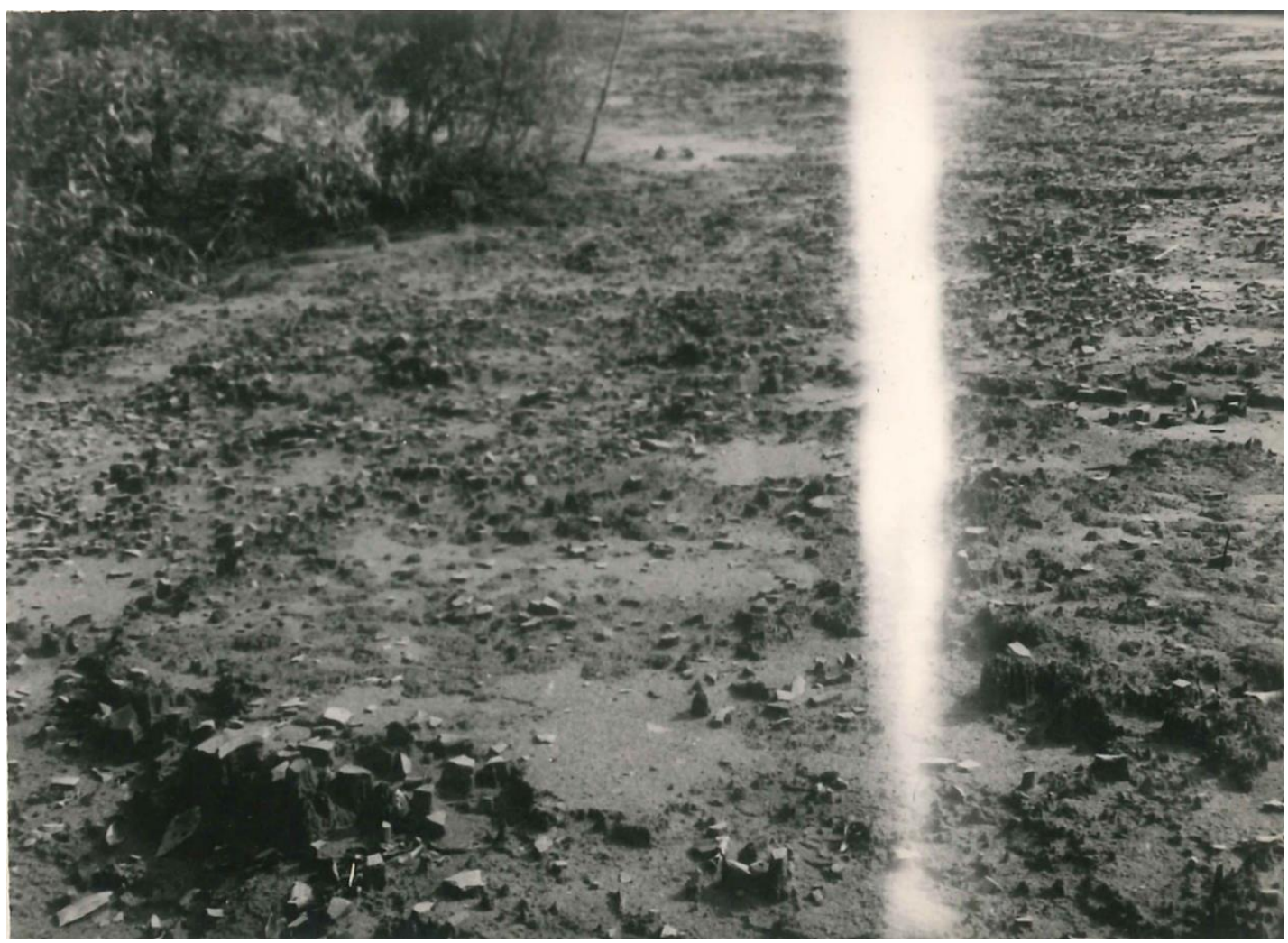

Figura 24. Superfície repleta de fragmentos cerâmicos em um dos sítios arqueológicos visitados por Peter Hilbert em 1952. Arquivo pessoal Klaus Hilbert/ MCT-PUCRS. 
A biografia dos objetos vistos nos museus é complexa: um mesmo objeto pode ter pertencido a duas ou três pessoas, ou talvez até mais, antes de chegar a um museu e ser integrado a coleções e processos curatoriais (PALMATARY, 1960). A baixa quantidade de registros das transações não permite mapear como muitas das peças foram obtidas ou a área de coleta. As partes iniciais da cadeia de circulação de objetos, quando envolvem moradores da região, são quase sempre desconhecidas. Frederico Barata, por exemplo, não fez nenhuma diferenciação entre as peças compradas ou obtidas pessoalmente em uma localidade.

A maioria dos objetos provavelmente foi obtida por meio da inspeção da superfície (Figura 24), mas deve haver uma parcela em todas as coleções obtidas durante a perfuração de buracos - com ou sem a intenção de achar peças (Figura 25). Em todo caso, são coletas aleatórias, das quais não se dispõe de nenhuma informação sobre a distribuição no contexto arqueológico. De modo geral, como em outras coleções assistemáticas, o material era coletado a partir de critérios visuais. Peças consideradas mais "bonitas", mais elaboradas ou que se destacavam pela integridade, tiveram preferência em todas as coleções.

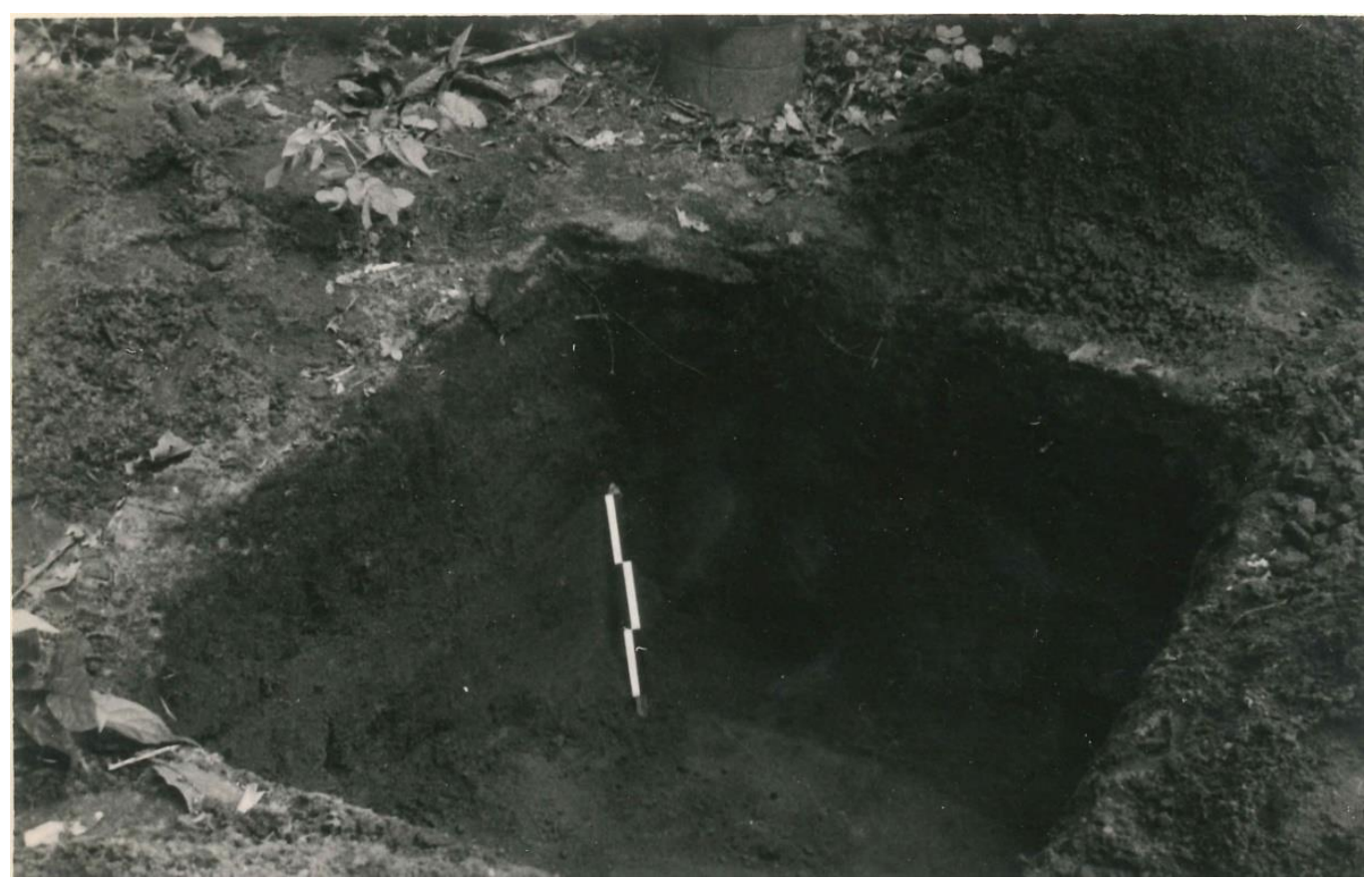

Figura 25. Sondagem realizada durante o campo de 1952 por Peter Hilbert. Fotografia sem identificação de sítio arqueológico. Fonte: Acervo Pessoal de Klaus Hilbert/ MCT-PUCRS. 
A coleção reunida por Peter Hilbert em 1952 (MPEG), João Barbosa de Faria (MN) e Aricy Curvello (MHN) possuem algumas informações devido à existência de publicações e manuscritos sobre as etapas de campo. A maioria das peças foi obtida da mesma maneira que se supõe para as outras. João Barbosa de Faria fala que no sítio Arrozal "desentranhar da terra algumas peças" certos pontos em que fiz escavações, estas [terras pretas] não atingiram um retro [metro] de profundidade" (BARBOSA FARIA, 1946, p. 14). Em geral, parece ter, todavia, realizado coletas de superfície, ora sozinho, ora com ajuda de quilombolas que moravam próximo às terras pretas. Em Oriximiná, ele também afirma ter recebido algumas peças de doação de Helvécio Guerreiro, que fazia buracos, na parte alta da cidade. Peter Hilbert (1955a, p. 29) informa que "[a] mór parte do material aqui exposto [coletado em 1952] foi coletado na superfície do terreno e, em pequena quantidade, nos cortes de estratificação. Algumas peças foram adquiridas dos habitantes das terraspretas, 42 .

Uma consequência a se considerar em relação a peças obtidas em coletas de superfície é seu estado de conservação. Na região dos rios Trombetas e Nhamundá, formam-se praias que resultam da erosão dos barrancos das margens de lagos e rios. Nessas praias são encontradas e foram coletas peças arqueológicas para diferentes coleções. No lago Sapucuá, Barbosa de Faria relata que a ação das águas estava erodindo os sítios e que "grande número de peças colhidas nesta região foram achadas em ponto do lago que o estio acabava de desnudar" ${ }^{43}$. Hilbert (op. cit., p. 19) comenta os fragmentos são arrastados para as praias, principalmente no lago Sapucuá. "A diferença de altura entre a linha da enchente", explica o autor, "e a vasante [sic] é em média de 6 metros, podendo provocar, conforme a topologia da margem, distâncias de 100 a 300 metros separando a terra-preta da linha de vasante [sic], ou seja, das jazidas secundárias de cacos". Como resultado "[o]s fragmentos que se coletam nessas praias apresentam o aspecto de fortemente rolados e lavados, ásperos e com cor característica amarelo clara ou cinza escura”. Em passagem pelo lago Sapucuá, em 2014, ainda no período das cheias, foi possível observar a ação erosiva da água sobre o sítio

\footnotetext{
${ }^{41}$ FARIA, João Barbosa de. Relatório dos trabalhos ethnographicos. Ministério da Guerra, Inspeção de Fronteiras. Endereçado a Cândido Mariano Rondon. 22f (incomoleto). Carimbo do Museu Nacional/ Secção de Anthropologia e Ethnographia datado de 21/06/1929, Fundo Heloísa Alberto Torres/SEMEAR/MN.

42 Idem.

${ }^{43}$ Idem.
} 
arqueológico. Os moradores da comunidade de Conuri e Ajará (ou Uajará) relataram que, com frequência, encontravam e coletavam as peças no período de estiagem, da mesma maneira que relatam Barbosa de Faria e Peter Hilbert.

Outro fator de transformação do contexto arqueológico é a constante reocupação das terras pretas como área de moradia e plantio até o presente. A movimentação do solo evidenciou e fragmentou as peças arqueológicas, especialmente nos níveis mais superficiais. Em várias peças arqueológicas foi possível observar marcas de instrumentos metálicos - provavelmente enxadas - usadas nas lavouras. A implantação de obras para a extração de bauxita teve efeitos ainda maiores sobre alguns sítios arqueológicos, sendo que alguns foram completamente destruídos (GUIMARÃES, 1985).

Não há informações sobre o transporte das peças. Hilbert (1968) afirma explica que os sacos podem se rasgar com a umidade, misturando seu conteúdo e perdendo as informações estratigráficas. $\mathrm{O}$ mesmo pode ser pensado em relação às coletas mais antigas, algumas realizadas por este mesmo pesquisador.

\subsection{Curadoria e documentação}

A grande dificuldade do estudo de coleções de museu como um conjunto é receber uma caixa de peças arqueológicas e não saber em que medida seu conteúdo corresponde ao inicial (KINTIGH, 1981). As coleções quando chegam aos museus passam por diferentes processos que, potencialmente, modificam em maior ou menor medida, sua composição (PAREZO, 1987). Partir do princípio que elas se mantêm nas mesmas condições em que chegaram é um equívoco que pode gerar problemas interpretativos graves. Por mais organizado e por melhores sejam a estrutura e fonte de financiamento de uma instituição, sempre há alguma modificação ou perda. $O$ transporte ou processos de curadoria podem gerar perdas de fichas, sacos podem ser misturados, embalagens podem rasgar, as peças podem se fragmentar, etiquetas e marcações podem se apagar ou ainda algumas peças podem desaparecer. Ao longo do tempo, coleções arbitrárias podem ser criadas a partir das "sobras" de outras ou um reunião de tudo aquilo que não se dispõe de informação (DE BLASIS, MORALES, 1997). A transcrição das informações de um suporte ao outro com perda de informação também pode ter grandes consequências (GRUPIONI, 1998). 
No caso das coleções do Baixo Amazonas, os principais meios encontrados para avaliar a integridade das coleções foram às inscrições nas peças $\left(\mathrm{n}^{\circ}\right.$ de tombo, marcação de proveniência, etiqueta de instituição), a documentação gerada pelo coletor e/ou colecionador e a documentação produzida pelas instituições. Os livros tombo, especialmente quando foram feitos registros no momento de entrada, oferecem uma fonte preciosa de informação de proveniência e procedência. A falta de quantificação no momento da entrada das peças nos museus foi um problema, que inviabiliza a melhor compreensão das perdas que aconteceram ao longo do tempo. Cada instituição adotou procedimentos de registro e curadoria distintos, o que impactou as informações disponíveis e os modos de avaliá-las.

\subsubsection{Museu Nacional}

O livro tombo do $\mathrm{MN}$ foi criado ainda no século XIX e os fragmentos receberam um número individual. As peças foram marcadas apenas com o número de registro sendo a informação relacionada ao livro tombo e, depois, ao banco de dados interno denominado Archaios.

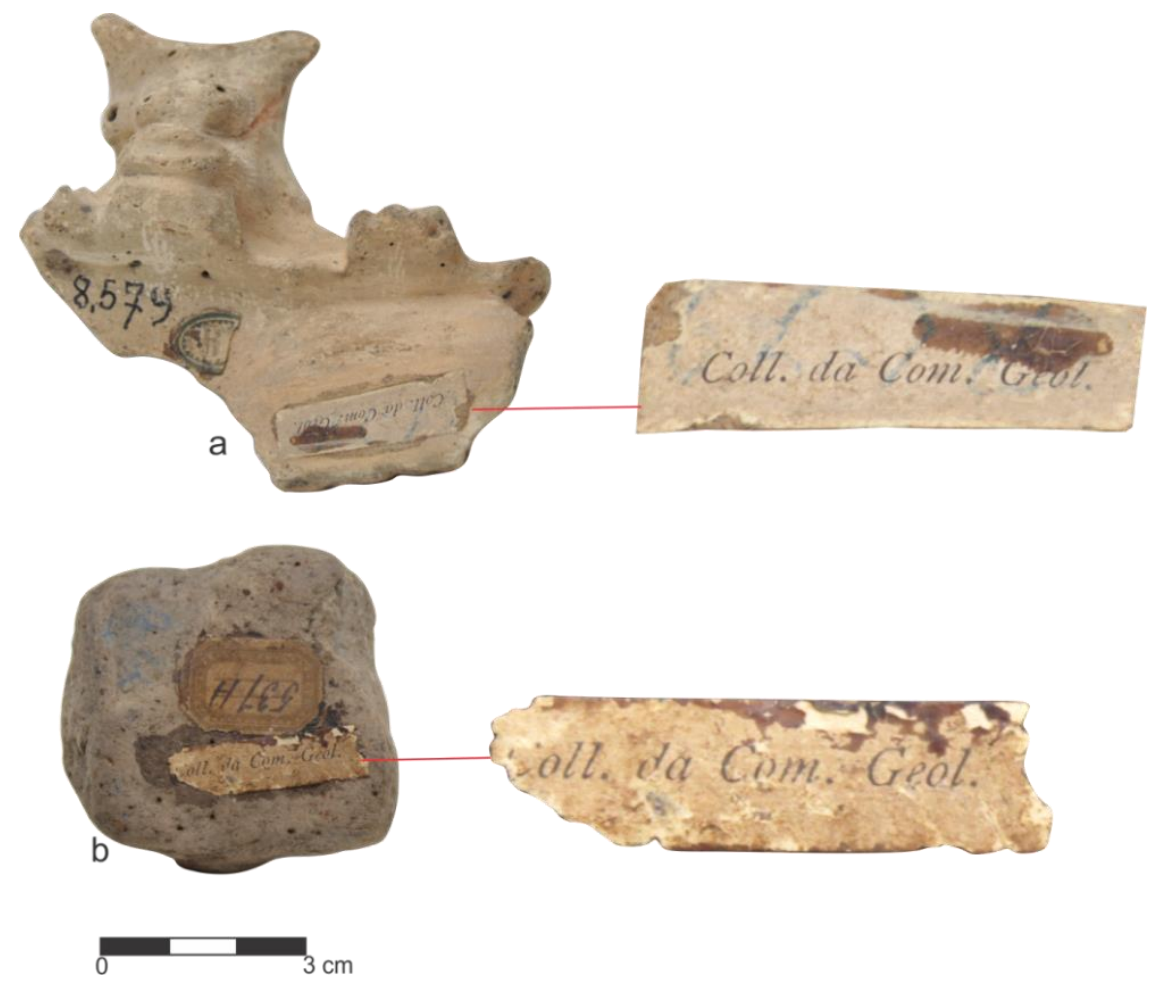

Figura 26. Fragmentos Konduri com etiqueta da Comissão Geológica Imperia/MN. 
Entre as 4 coleções com cerâmica Konduri na instituição, apenas a denominada Amazônia resulta da falta de informação sobre as peças que, provavelmente, faziam parte das outras três. A coleção Comissão Geológica Imperial teve a maior parte da sua informação perdida porque as indicações no livro tombo são incoerentes (Figura 26). Um pequeno fragmento cerâmico é identificado como "urna Marajoara", por exemplo. Apenas duas peças Konduri apresentavam a antiga etiqueta da coleção, mas outras 10 estavam entre os números de tombo das peças da coleção, entre 8.000 e 10.000, sendo considerados parte da coleção Amazônia.
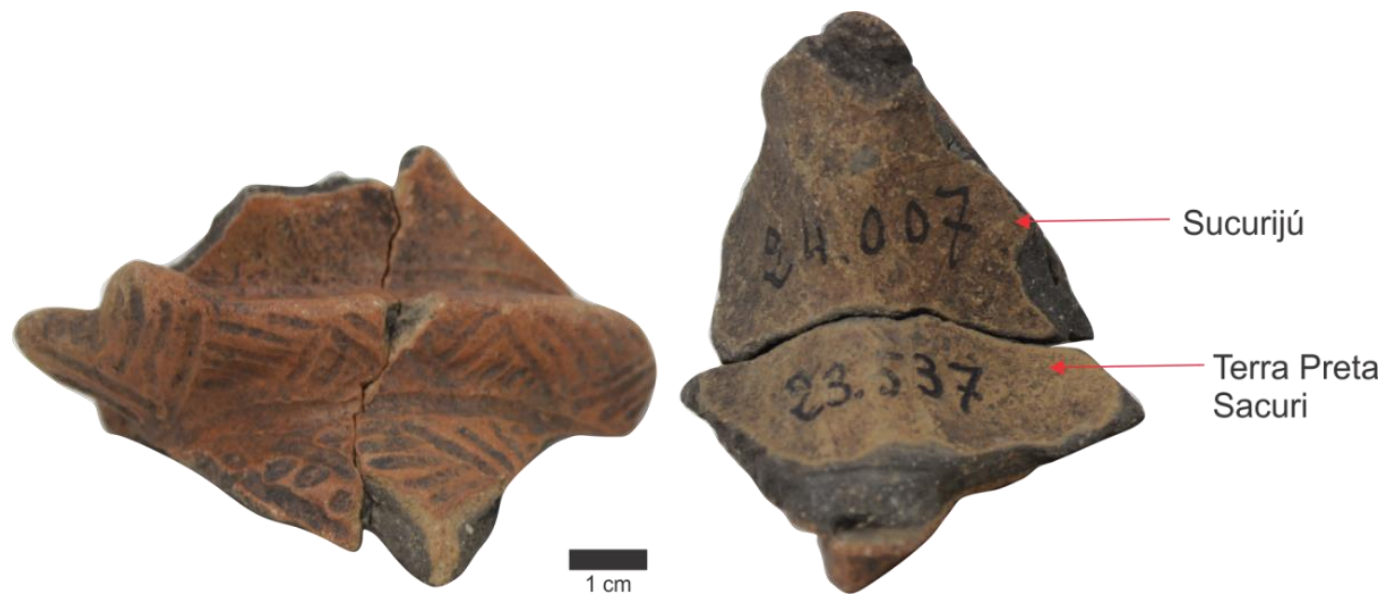

Figura 27. Dois fragmentos da coleção Barbosa de Faria com indicação de proveniência diferente no livro tombo que remontam. Durante o transporte ou curadoria as peças se misturaram e foram associdas a sítios distintos.

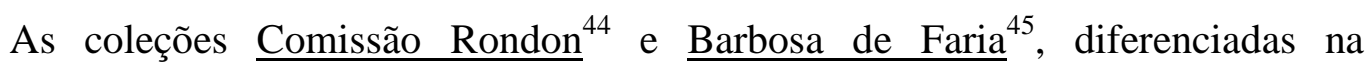
instituição, foram reunidas na mesma expedição, mas doadas em dois ou três momentos distintos $^{46}$. Segundo a documentação disponível, as proveniências foram fornecidas por João Barbosa de Faria, que enviou as peças em sacos distintos, com informação de proveniência por sítio/localidade. A quantidade de peças que apresenta informação de proveniência por sítio no livro tombo é superior na coleção Barbosa de Faria (814/

44 Relação de peças archaeologicas colhidas em 1929, pela inspeção, com indicação de numero e procedência, João Barbosa de Faria, 03/02/1931, 1 f. Caixa 8, envelope 30, SEMEAR/MN.

45 Ofício n²65, Museu Nacional de Edgar Roquette Pinto a Heloísa Alberto Torres, 27/04/1929, 1 f. Fundo Heloísa Alberto Torres. Caixa 8, envelope 37, SEMEAR/MN. 
95,5\%) que a Comissão Rondon (96 / 13,6\%). Dois fragmentos com proveniências distintas da coleção Barbosa de Faria remontaram durante as análises, indicando que alguma mistura ocorreu durante o transporte ou curadoria. As publicações apresentam fotografias publicadas com proveniências discordantes daquelas encontradas no livro tombo (FARIA, 1946; RONDON, 1953). O motivo para isso, talvez, seja organização e publicação póstuma dos manuscritos e fotografias de Barbosa de Faria, que faleceu em 1941 (RODRIGUES, 2004). Apesar de todos esses problemas, de modo geral, as informações sobre proveniência são coerentes e a estratégia de numerar individualmente cada fragmento permitiu manter um maior controle quantitativo.

Entre as peças de diferentes proveniências foram identificadas peças provenientes do rio Nhamundá na coleção_Gastão Cruls. Essas peças foram obtidas de um terceiro (Crisanto Jobim). As informações de proveniência informadas por Cruls foram registradas no tombo são apenas "Fazenda Santa Olímpia, Faro/Ilha das Cotias".

\subsubsection{Museu Paraense Emílio Goeldi}

O livro tombo do MPEG foi criado a partir da reorganização das coleções na década de $1960^{47}$. A maioria das coleções analisadas chegou à instituição antes dessa organização e podem ter se misturado, bem como perdido informações ao longo do tempo. Há quantificação de apenas uma coleção (Frederico Barata) no momento de entrada das peças e os fragmentos não receberem um número de registro (tombo) individualizado - apenas para conjunto. As informações disponíveis no livro tombo são, portanto, secundárias, sendo menos confiáveis que as identificadas no arquivo da instituição, publicações ou marcadas nas próprias peças. As fichas que acompanham os sacos plásticos e marcações com o número de tombo seguem o livro, sendo também resultados de processos curatoriais mais recentes. As marcações de proveniência das peças para as coleções T- 881, Peter Hilbert, Peter Hilbert e Harald Schultz (1953) e Charles Townsend Jr. são elementos mais seguros de identificação, que em um dos casos pode ser checado com a publicação (HILBERT, 1955a).

Entre as 7 coleções que possuem exemplares de cerâmica Konduri, duas apresentam problemas mais graves porque foram criadas em processos curatoriais. A

47 Relatório anual da Divisão de Antropologia do Museu Paraense Emílio Goeldi, 1964. Arquivo Guilherme La Penha/MPEG. 
coleção Nimuendajú foi arbitrariamente formada na década de 1960 a partir peças do estilo Santarém reunidas por Carlos Estevão de Oliveira ou fragmentos do estilo Konduri das coleções Peter Hilbert (1952) e de um doador desconhecido do século XIX (T-881). Não se sabe como a coleção T-881 chegou ao MPEG, mas foi mencionada por Emílio Goeldi (1898, p. 410) e Nimuendajú (2004 [1923], p. 125). As peças dessa coleção receberam marcações de proveniência em escrita cursiva e inclinada (típica do século XIX) e de forma. Parte do que foi escrito em letra de forma deve pode ser atribuído a Nimuendajú segundo Hilbert (1955a). Peças com marcações em letra cursiva e de forma foram identificadas na coleção Peter Hilbert e "Nimuendajú" permitindo identificar que também pertencem a coleção T-881 (Figura 28).

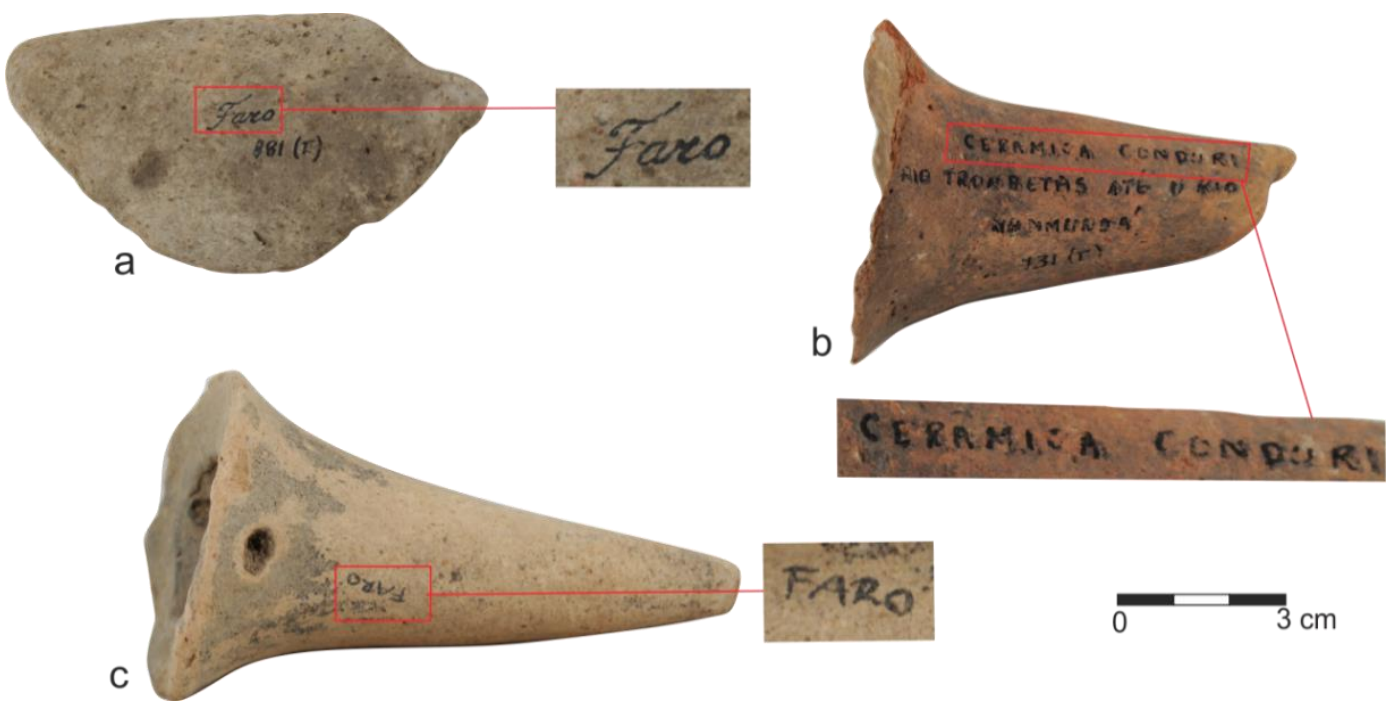

Figura 28. Fragmentos das coleções 881 e Peter Hilbert (1952) no acervo do MPEG: a - fragmento com indicação de proveniência em letra cursiva; b - fragmento com texto atribuído por Hilbert a Nimuendajú; c - fragmento com proveniência indicada por Hilbert.

As coleções Peter Hilbert e Peter Hilbert e Harald Schultz possuem peças de diferentes sítios arqueológicos com proveniências indicadas na documentação e marcadas nas peças. Houve mistura entre as peças de diferentes proveniências, mas foi possível recuperar a procedência original a partir das marcações feitas por Hilbert para 93,1 \% (763) da primeira coleção e 61,8 \% da segunda. Somam-se a essas peças com 
identificação, 20 presentes na coleção "Nimuendajú" pertencentes à reunida em 1952 e uma encontrada na última, mas pertencente à de 1953.

Parte da coleção Peter Hilbert não apresentava marcação (84/ 9,9 \%) ou esta tinha se apagado. Outras três peças exibiam quebra "fresca" permitindo remontagem e a identificação da proveniência. Além disso, formas identificados fragmentos de cerâmica Saracá com inscrição de outra coleção, que foi misturada em processos curatoriais. Uma parcela mais significativa da coleção reunida em 1953 não recebeu marcação do pesquisador. Dois fragmentos remontaram desta coleção, apesar de sua proveniência ser distinta segundo o livro de tombo. As peças de apenas um sítio receberam numeração sequencial e a ausência de vários números sugere que exemplares se perderam. No MCT, há 3 fragmentos com a marcação característica da feita Hilbert (1952), o que reforça que a existência de perdas e deslocamentos.

Hilbert (1955a) menciona 65 sítios arqueológicos, sendo que visitou 26 e obteve informações com Protásio Frikel de 28 e com moradores locais de 11 sítios. Comparando as inscrições nas peças e os sítios mencionados, é possível notar que algumas peças foram marcadas com indicações que não são mencionadas como sítios, como "Mario" e as casas "Balduino", este último entre Serrinha e Terra Preta, no baixo Cuminá. São mencionados também fragmentos cerâmicos doados provenientes do sítio Boa Vista que não foram identificados na coleção. Ao mesmo tempo, sua coleção apresenta peças de sítios conhecidos apenas a partir de informações de ribeirinhos ou de Protásio Frikel e que, portanto foram obtidos por doação (Trindade, Mabaia, Itauaquera, Aibi).

Entre o material da coleção Peter Hilbert é possível que haja uma inscrição indicando diferença entre a profundidade em que as peças foram encontradas em uma sondagem. Nos sacos majoritariamente com fragmentos provenientes do sítio Cocal, há peças marcadas com o nome completo do sítio ("Cocal”) que geralmente são maiores e mais elaboradas em termos de decoração, enquanto que fragmentos menores com pouca ou nenhuma decoração apresentam apenas números. Algumas das peças mais elaboradas também apresentavam inscrições como "Coc 2".

A coleção Charles Townsend Jr. apresenta 3.050 peças entre material cerâmico e lítico (ROSA, 2004). Na instituição há 61 fragmentos identificados como Konduri. 
Parte dessas peças $(29 / 47,5 \%)$ apresenta a marcação com uma letra (C, K, U, T), que é anterior do número de tombo que foram feitas por Protásio Frikel. No Museu do Índio de Lagoa Seca (PB), onde a maior parte da coleção reunida por Frikel se encontra peças com as mesmas marcações (Figura 29).

A coleção Frederico Barata, no momento de entrada, possuía "Fragmentos da região Jamundá-Trombetas [quantidade]: 31 (em 1 caixa)"48, além de duas vasilhas Konduri inteiras. Encontram-se separados como fragmentos Konduri 64 exemplares na reserva técnica. Nenhuma dessas peças apresenta marcação de proveniência e a indicação genérica "Oriximiná" foi apresentada nas publicações de Hilbert (1955a) e Palmatary (1960). Como resultados de processos de compra desconhecidos, sua proveniência é desconhecida, apesar da indicação no livro tombo "rio Nhamundá".

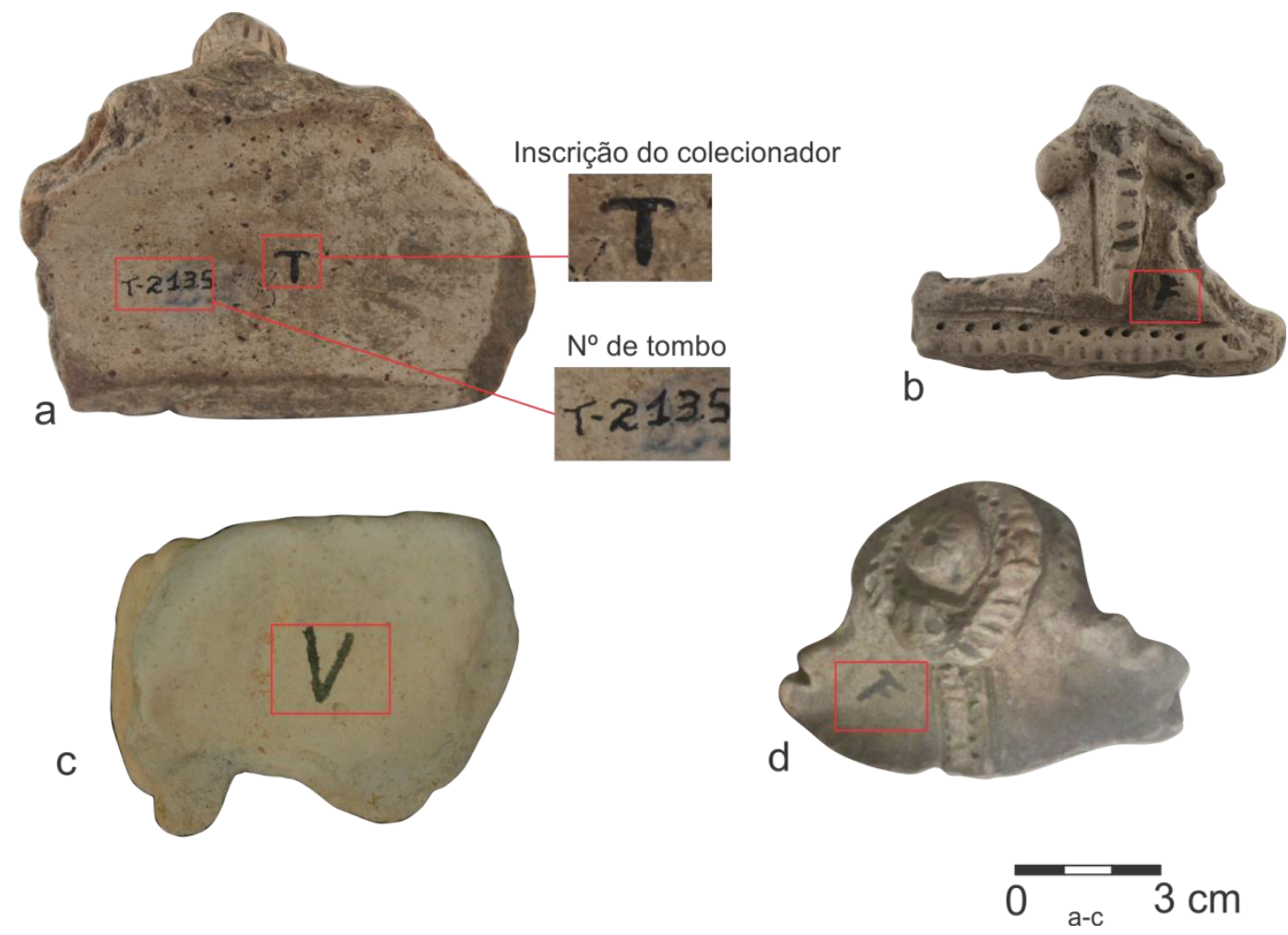

Figura 29. Materiais com marcações com uma única inicial, provavelmente realizadas por Protásio Frikel: a-b coleção Charles Townsend (MPEG) ; c-d coleção Protásio Frikel (Museu do Índio, Lagoa Seca, PB).

${ }^{48}$ Escritura de contrato de compra e venda de uma coleção de peças arqueológicas da Amazônia, que si firmam como outorgante vendedor o Dr. Frederico Barata e como outorgado comprador o Conselho Nacional de Pesquisa, com a interveniência do Instituto Nacional de Pesquisas da Amazônia e o Museu Paraense "Emílio Goeldi". Belém, 27 de janeiro de 1959. Tabelião Armando de Queiroz Santos, Cartório de $3^{\circ}$ Ofício de Notas, Belém, Pará. Fundo Frederico Barata, Arquivo Guilherme La Penha. 
O caso da coleção Eduardo Galvão, que também não tem marcação de proveniência, é um pouco distinta porque não há informações documentais sobre sua procedência. Não foi identificado nenhum registro de uma coleta realizada pelo antropólogo Eduardo Galvão. Há dois conjuntos nessa coleção, um proveniente de Oriximiná e, segundo o livro tombo, coletado em 1965, e outro, proveniente do lago Jacaré e coletado em 1967. Observando o mapa de sítios arqueológicos do Baixo Amazonas, publicado por Carlos Estevão de Oliveira (1939), nota-se apenas dois sítios arqueológicos na bacia do rio Trombetas - os mesmos que compõe a coleção "Eduardo Galvão" (Mapa 2). Sabendo da complexidade do processo de registro dos materiais e da invenção da coleção "Nimuendajú", o material de Oriximiná e lago do Jacaré podem ter sido coletados na década de 1930.

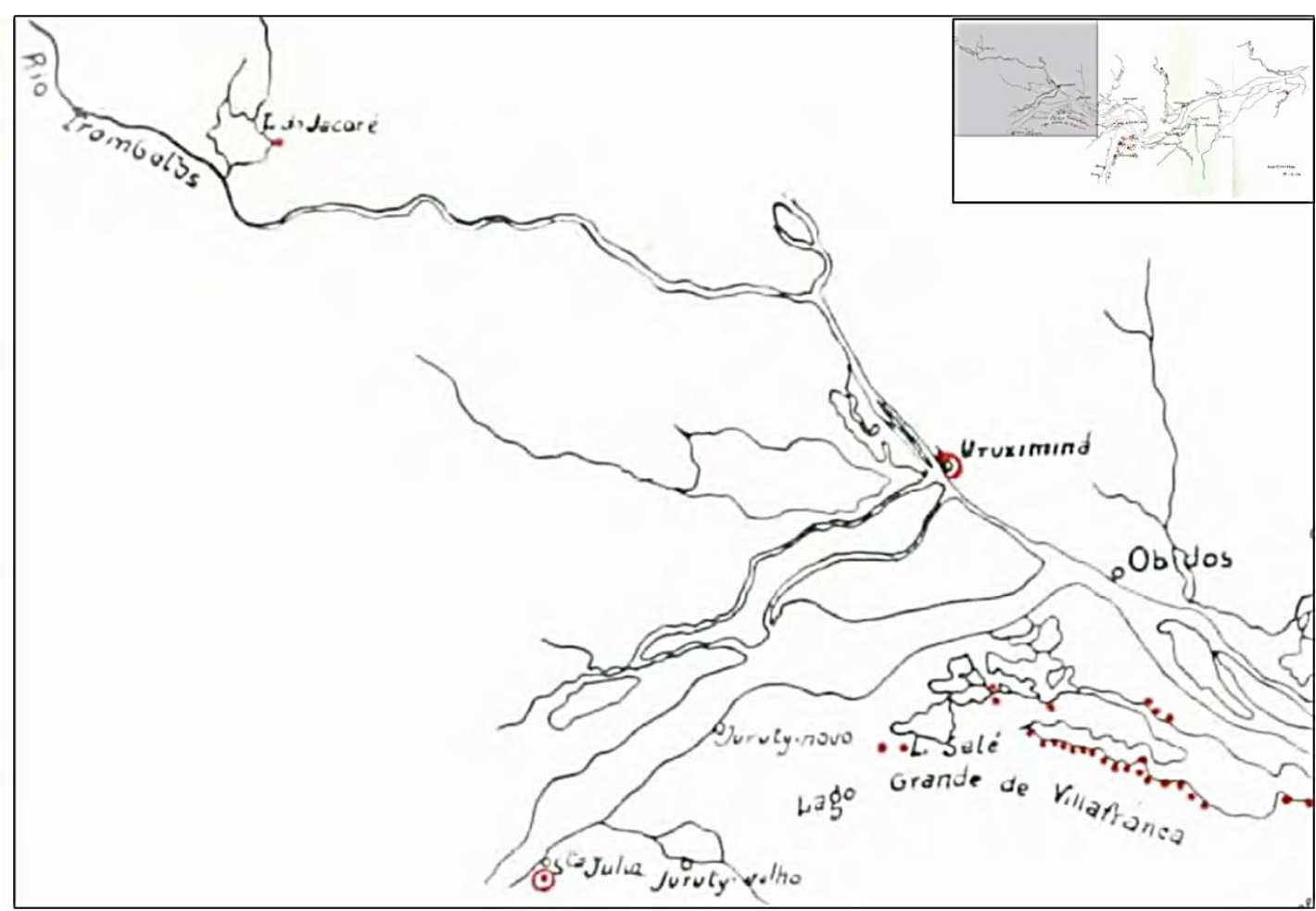

Mapa 2. Detalhe do mapa publicado por Oliveira (1939) em que ele apresenta várias localizações de sítios arqueológicos na região do Baixo Amazonas. Os únicos sítios identificados na bacia do rio Trombetas são lago do Jacaré e Oriximiná (Uruximiná). Adaptado de Oliveira, 1939.

\subsubsection{Museu de Arqueologia e Etnologia da USP}

$\mathrm{O}$ atual MAE reuniu antigas coleções arqueológicas de diferentes instituições: Museu Paulista, Instituto de Pré-História, antigo Museu de Arqueologia e Etnologia e 
Acervo Plínio Ayrosa do Departamento de Antropologia da Faculdade de Filosofia, Letras e Ciências Humanas (FLEMING; FLORENZANO, 2010). Apenas o Instituto de Pré-História não matinha coleções cerâmicas provenientes do Baixo Amazonas. Cada uma das instituições registrava as peças de maneira distinta e, no caso do Museu Paulista, essa sistemática variou ao longo do tempo. Nas peças, em alguns casos, é possível ver a numeração feita pelos colecionadores antes da coleção chegar às instituições.
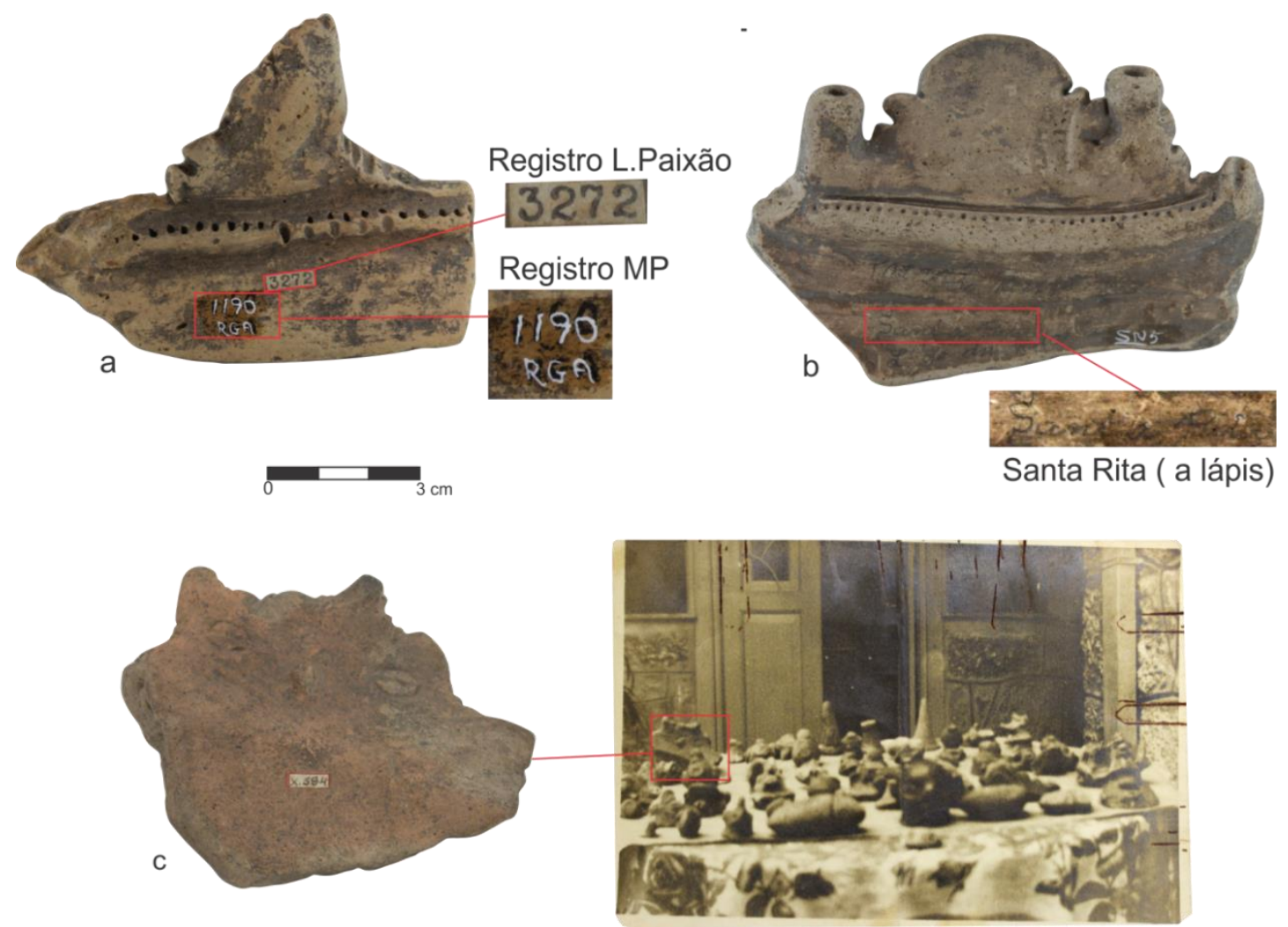

Figura 30. Fragmentos da coleção 006 (MP) e Luís Paixão (APA): a - fragmento da coleção do MP que pertenceu à coleção Paixão; b - fragmento sem número de registro coletado por Harald Schultz em 1950 no sítio Santa Rita (Parintins); c- fragmento da coleção Paixão (APA) identificado em foto de 1935.

A coleção Luís Paixão passou a fazer parte do Acervo Plínio Ayrosa em 1954 e apresenta como única informação de proveniência a anotação no caderno de registro do colecionador: "encontrada nas escavações das terras pretas das margens do Rio Trombetas". A coleção foi obtida por compra. No mesmo registro do colecionador foi possível identificar a entrada de 179 fragmentos cerâmicos. Foram identificadas 73 
peças em uma reserva técnica que fizeram parte do conjunto da coleção do rio Trombetas com a etiqueta do Acervo Plínio Ayrosa. Outras 7 foram identificadas no acervo que passava por reorganização vindo de outra reserva da instituição (Figura 30).

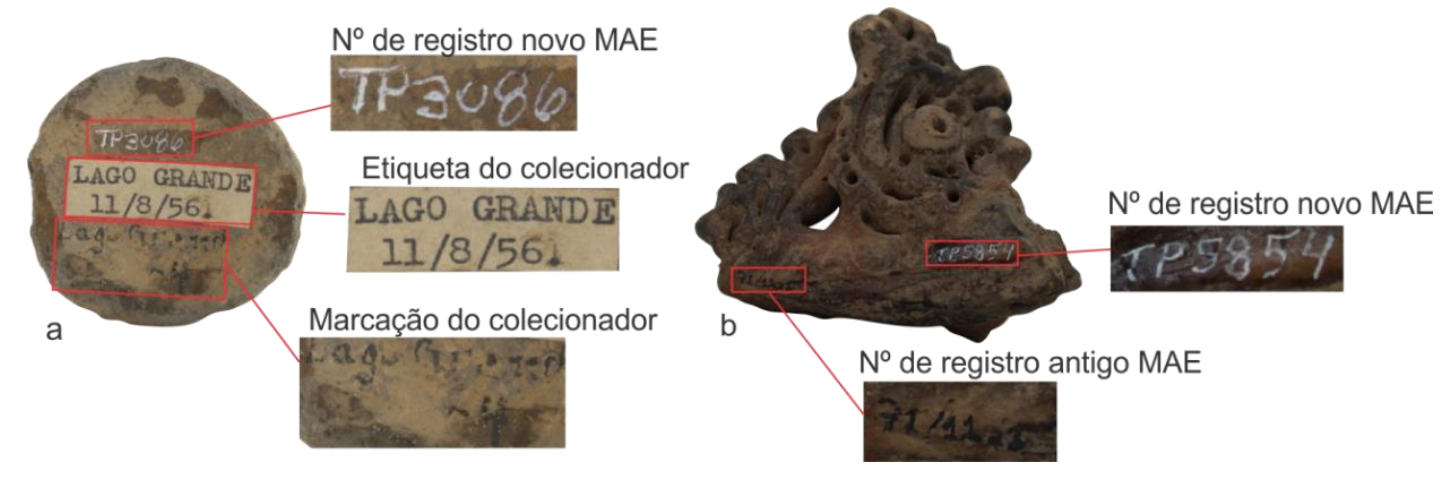

Figura 31 Fragmentos da coleção Tapajônica (MAE-USP): a - marcação do colecionador e da instituição; $b$ - diferentes marcações da instituição.

A coleção $\underline{006}$ fez parte do acervo do Museu Paulista. Esta é composta por fragmentos cerâmicos coletados por Harald Schultz e comprados de outros colecionadores, sendo estas registradas no livro tombo (Registro Geral Arqueologia), com proveniência de município ou localidade. Entre as peças Konduri, há material coletado em 1950 em uma viagem entre Belém e Rio Branco (BALDUS, 1951) e vendidos por Luís Paixão em 1948 (BALDUS, 1949). Apesar de haver informação registrada de 68 fragmentos no livro tombo, foram identificadas no acervo apenas $11,7 \%$ ( 8 peças). Outras 20 não apresentavam marcação ou esta estava apagada.

A coleção Tapajônica foi criada a partir das coleções José da Costa Pereira e Ubirajara Bentes. Durante a sua curadoria foram contabilizadas 8.516 peças cerâmicas (GOMES; BRAGA, 1998, p.325). Não há nenhuma informação de proveniência para essa coleção. A partir do recibo de compra da parte de José da Costa Pereira, sabe-se que havia apenas um fragmento Konduri, que recebeu numeração distinta no antigo Museu de Arqueologia e Etnologia da USP (Figura 31). Durante dois meses foi realizada uma inspeção visual em toda a coleção Tapajônica e foram identificados 251 fragmentos com atributos Konduri diagnósticos. Algumas, como destacado por Gomes 
(2002) apresentavam a inscrição feita pelo colecionador “Óbidos” (8 peças). Outras possuíam proveniência "Lago Grande" (3 peças).

\subsubsection{Museu de História Natural e Jardim Botânico da UFMG}

O MHN conserva uma coleção reunida entre 1975 e 1979 no distrito de Porto Trombetas. Essa coleção foi recebida por intermédio do professor Carlos Magno Guimarães, cuja namorada do irmão era amiga do coletor Aricy Curvello, que trabalhou para a Mineração Rio Norte (Carlos Guimarães, com. pess., 2017). Informações contextuais e a descrição do material foram publicadas por Guimarães (1985).

\begin{tabular}{|c|c|c|c|c|}
\hline Sítio & 1985 & 2017 & Diferença & Diferença (\%) \\
\hline Aimim & 8 & 8 & 0 & 0 \\
\hline Alema & 5 & 6 & -1 & +20 \\
\hline Araticum & 5 & 4 & +1 & -20 \\
\hline Posto Aurora I & 10 & 1 & 0 & 0 \\
\hline Posto Aurora II & 156 & 1 & -34 & $-21,8$ \\
\hline Faro & 11 & 1 & 0 & 0 \\
\hline Lago Batata & 212 & 2 & +26 & $+12,2$ \\
\hline Porto Trombetas & 23 & 1 & -4 & $-17,3$ \\
\hline Terra Santa & 12 & 1 & -1 & $-8,3$ \\
\hline Sem referência & 0 & 7 & +7 & +100 \\
\hline TOTAL & 442 & 4 & 6 & $-1,3$ \\
\hline
\end{tabular}

Tabela 3. Quantidade de fragmentos cerâmicos por sítio arqueológico na quantificação realizada por Guimarães (1985) e na realizada em 2017. O asterisco (*) indica que foram incluídas as 3 peças que se perderam na reserva técnica de arqueologia do MHN

A coleção Aricy Curvello possui 442 fragmentos cerâmicos. O material cerâmico coletado em sete sítios arqueológicos distintos, em áreas de atuação da mineradora ou em suas proximidades. Essa coleta estava voltada a uma maior 
variabilidade do material em superfície. Foi coletada inclusive uma amostra de terra preta em um dos sítios. Também foram comprados apliques cerâmicos de uma pessoa que trabalhava nas obras de Porto Trombetas, provenientes de dois lugares distintos nas proximidades do rio Nhamundá (Faro, Alema) ${ }^{49}$. As peças receberam marcação com proveniência e números de registro em 2005. Apenas alguns exemplares foram numerados durante o estudo anterior da coleção. Guimarães (1985, p. 267) apresenta uma tabela com a quantidade de peças analisadas. Essa tabela permite comparar a quantificação realizada por ele e a realizada durante o estudo da coleção em 2017 (Tabela 3). Em termos gerais, há 6 peças a menos nos conjuntos, mas houve variação na quantidade em dois terços dos sítios. Essa variação é mais significativa nos conjuntos com maior quantidade de peças. É possível que durante a atividade de curadoria, realizada em 2005, alguns fragmentos tenham sido misturados com os de outros sítios, o que explicaria o aumento do número de peças para alguns sítios e redução para outros. A perda de referência de 7 exemplares também contribuiu para a essa diferença.

\subsection{Composição das coleções}

Todas as coleções consideradas apresentam limitações em relação ao método de coleta, falta de informações contextuais e problemas curatoriais. Não é possível fazer uma discussão estatística dos vieses amostrais, portanto é preciso considerar de maneira mais qualitativa a seletividade das coletas, a precisão da localização dos sítios arqueológicos e a quantidade de amostra por sítio (DRENNAN, 2009).

As coleções reunidas com o intuito de representar características da cerâmica regional exibem maior variabilidade dos fragmentos e informação de proveniência mais seguras e precisas. De modo geral, essas coleções poderiam ser qualificadas como "diagnósticas", uma vez que o interesse do coletor era realizar um estudo dos traços culturais mais emblemáticos. Esse é o caso das coleções Barbosa Faria/Comissão Rondon, Peter Hilbert, Peter Hilbert e Harald Schultz e Aricy Curvello. A melhor documentação da proveniência das peças permite relacionar os materiais em escalas locais e regionais de proveniência (sítio arqueológico, localidade, área). A parte do material da coleção "Eduardo Galvão" coletada no lago do Jacaré também grande variabilidade e é proveniente, em princípio, de um único sítio. Essa coleção poderia inclusive resultar de uma coleta de superfície sistemática, dada à alta proporção de

\footnotetext{
${ }^{49}$ Aricy Curvello a Marcony Lopes Alves. Correspondência eletrônica, 26 de junho de 2015.
} 
fragmentos de parede em detrimento das outras categorias. No entanto, as informações de procedência e proveniência são muito limitadas e não muito confiáveis.

As outras coleções, ao menos em termos do material Konduri, poderiam ser qualificadas como "ocasionais", devido à baixa quantidade e variabilidade dos fragmentos, além de informações de proveniência escassas (Gráfico 1). Em alguns casos, foram misturadas a objetos de proveniências e/ou procedências distintas durante a formação da coleção ou devido a processos museais (Tapajônica, Comissão Geológica Imperial, 006, Luís Paixão), gerando uma perda ainda maior de informação.

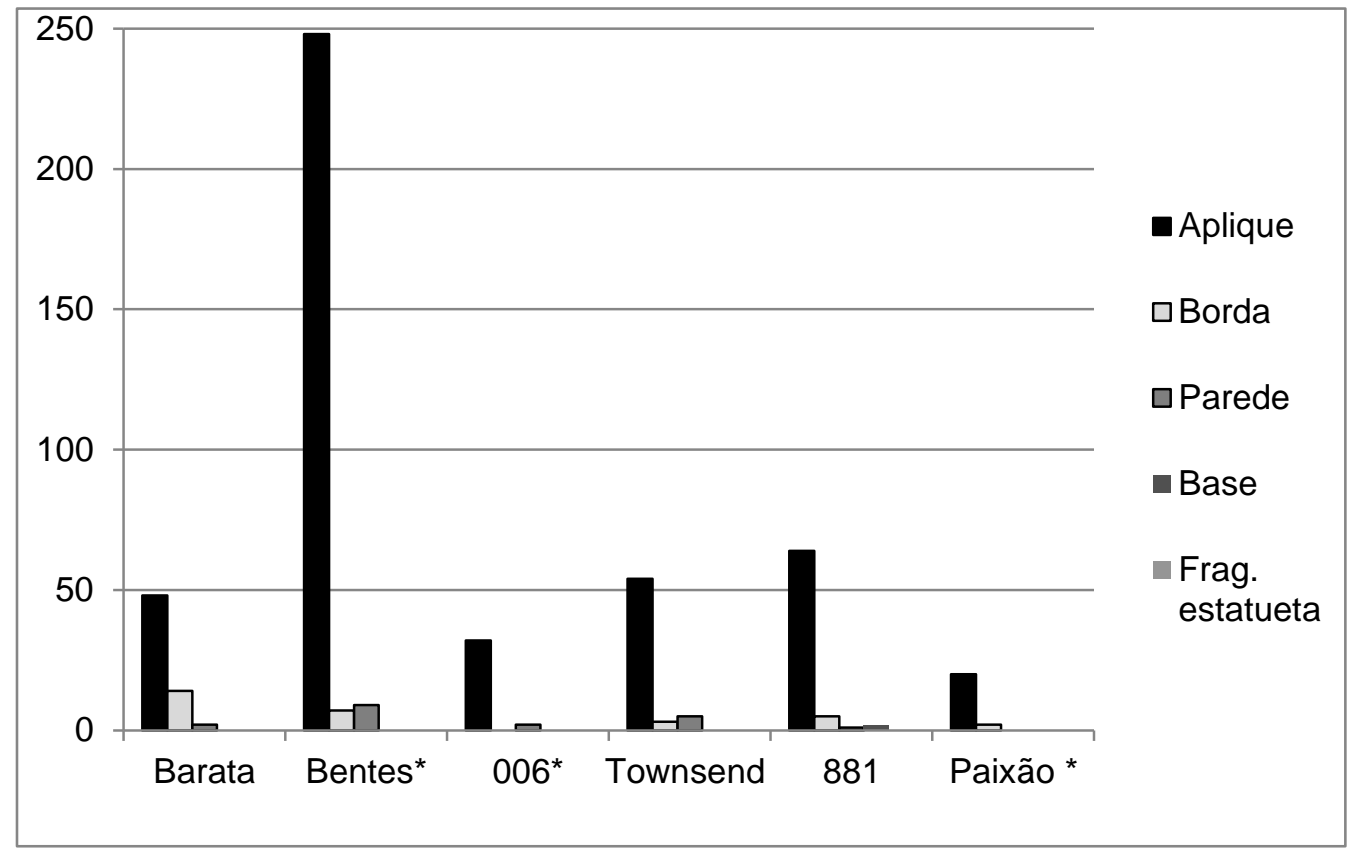

Gráfico 1. Quantidade por tipos de fragmentos coleções ocasionais. O asterisco (*) indica que foram incluídas as peças consideradas Konduri, selecionadas em meio ao conjunto com outros estilos.

Entre as coleções diagnósticas, a Barbosa de Faria/Comissão Rondon é a que apresenta uma maior proporção de apliques, indicando uma coleta mais seletiva em relação às categorias de fragmento disponíveis (Gráfico 2). É notável, por exemplo, o interesse do coletor por uma categoria particular de apliques, os "sapos besouro" e “cabeças de urubu", dada a alta proporção (145/9,3\%) desses artefatos em relação às outras coleções com uma porcentagem muito mais baixa ou nula (ver ALVES, 2018). 
Barbosa de Faria (1946, p. 39) confirma essa predileção ao afirmar que “(...) entre fragmentos de tantas esculturas, se destacam, pela fartura, os dois tipos de figuras representando, um, a cabeça de uma ave de rapina e outra uma rã". Comparando com outras coleções fica evidente uma coleta intensa desses tipos de aplique. Na coleção Aricy Curvello, foram identificados 8 exemplares desses apliques (1,8\% do total), enquanto que nas coleções "Eduardo Galvão", Peter Hilbert (1952) e 881, o percentual é ainda mais baixo - respectivamente . Em outras coleções, nenhum desses apliques foi identificado. No sítio Oriximiná 3, entre os 23.437 fragmentos cerâmicos coletados, apenas um aplique "sapo besouro" foi encontrado - ou seja $0,004 \%$ do total. A preferência por artefatos específicos, em uma proporção menor, também é notável nas coleções reunidas por Peter Hilbert e deste com Harald Schultz. Essas coleções foram reunidas com o intuito de identificar os elementos mais emblemáticos dentre o material cerâmico. Assim, ambas as coleções apresentam uma ênfase em bordas com incisões de assadores ou "grelhas", que foram um tópico de especial interesse no estudo da cerâmica Konduri (HILBERT, 1955a). Os fragmentos das chamadas "alça ponte" também foram preferidos na coleção reunida por Hilbert e Schultz (1953), seguindo também o destaque dado em sua monografia.

As condições dos sítios arqueológicos e as suas áreas visitadas também modificam a amostra; existe um "viés de contexto" (GOETZ; MILLS, 1991). Assim, o mesmo sítio Cocal foi visitado por Nimuendajú, Barbosa de Faria e Peter Hilbert. Em passagem rápida, vendo fragmentos sobre a superfície e coleções domésticas, foram compostos feixes distintos, a partir de um relance da história do sítio arqueológico. Hilbert ainda realizou uma sondagem em Cocal, o que resultou em uma amostra muito maior e mais variada do que as coletadas anteriormente. A proporção de apliques em todas as coleções é alta em relação a materiais obtidos apenas em escavações. Há também diferença entre o material do estilo mais antigo (Pocó) que aparece apenas na coleção Barbosa de Faria. 


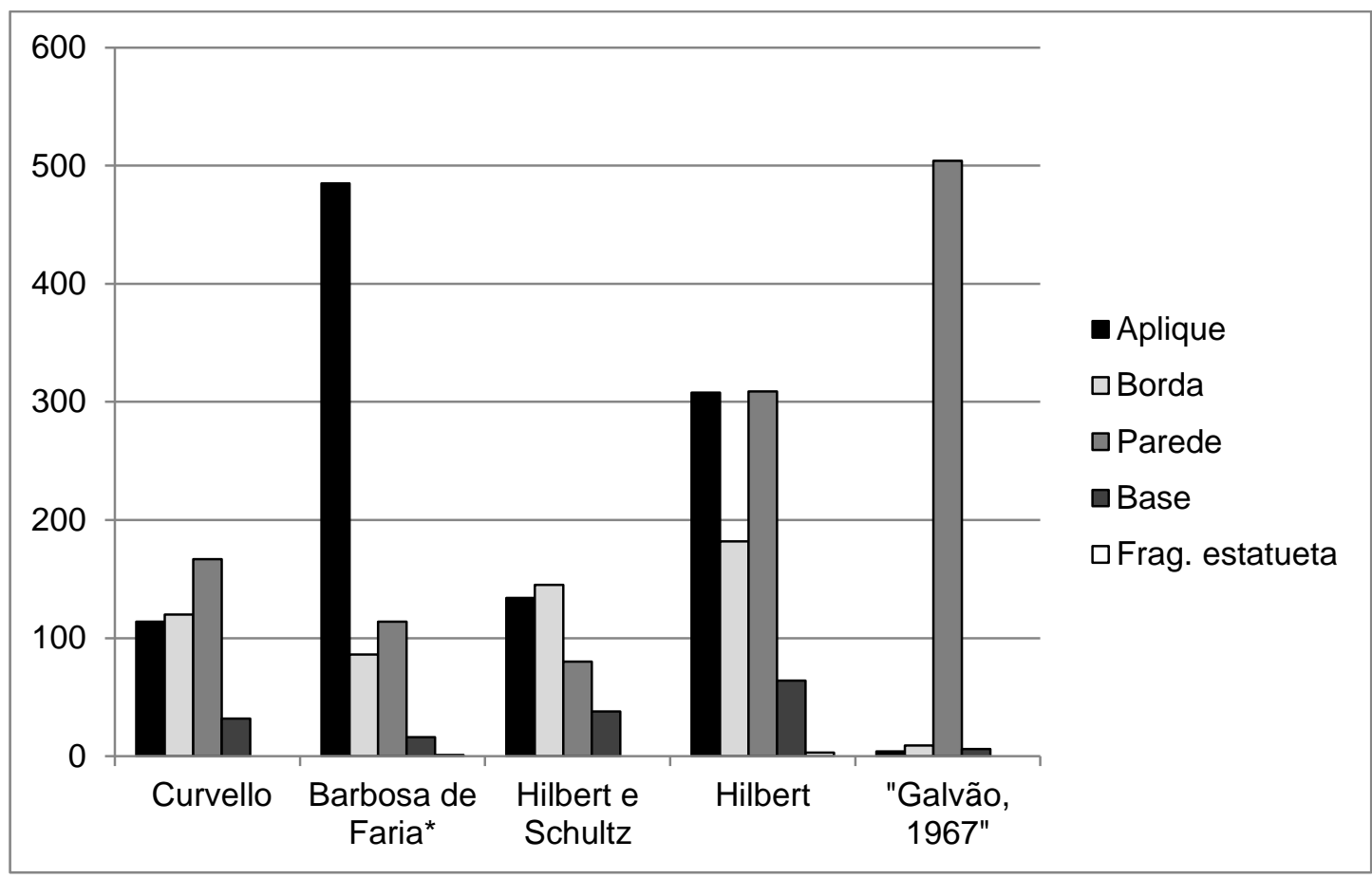

Gráfico 2. Quantidade por tipo de fragmento em coleções diagnósticas. O asterisco (*) indica que foi considerada apenas parte da coleção $(82,2 \%)$.

\subsection{Localização de sítios}

As informações sobre proveniência e sua precisão variam consideravelmente, mesmo nas coleções diagnósticas. Há conjuntos de peças cuja proveniência é uma área, como "lago Sapucuá", "Nhamundá”, "Trombetas", "Cuminá”, "Erepecurú”, etc. A maioria das peças em coleções diagnósticas, no entanto possui referência por sítio arqueológico. Esse é um dado importante se interessa abordar o material em uma perspectiva regional e não apenas a partir de seus formais.

Localizar geograficamente esses sítios, com alguma confiabilidade, não é uma tarefa simples dada à ambiguidade de muitas referências geográficas mencionadas pelos pesquisadores. Os mapas produzidos nas expedições de Barbosa de Faria (1946) e Hilbert permitem identificar localidades com alguma confiabilidade no Google Earth. No caso da coleta realizada por Hilbert e Schultz existem apenas croquis da localização dos sítios na caderneta de campo e algumas referências geográficas. A falta de marcação e as informações genéricas em parte dessa coleção levam a se questionar também se alguns conjuntos se referem a um sítio ou uma área mais ampla (lago Juruti Velho, Juruti Mirim, Oriente de Parintins). Os sítios identificados por Aricy Curvello são de 
mais difícil identificação, uma vez que o coletor não produziu mapas e muitas das referências geográficas são vagas. Se o mapa publicado por Oliveira (1939) for, de fato, relacionado à coleção "Eduardo Galvão" é possível identificar aproximadamente a localização dos sítios.

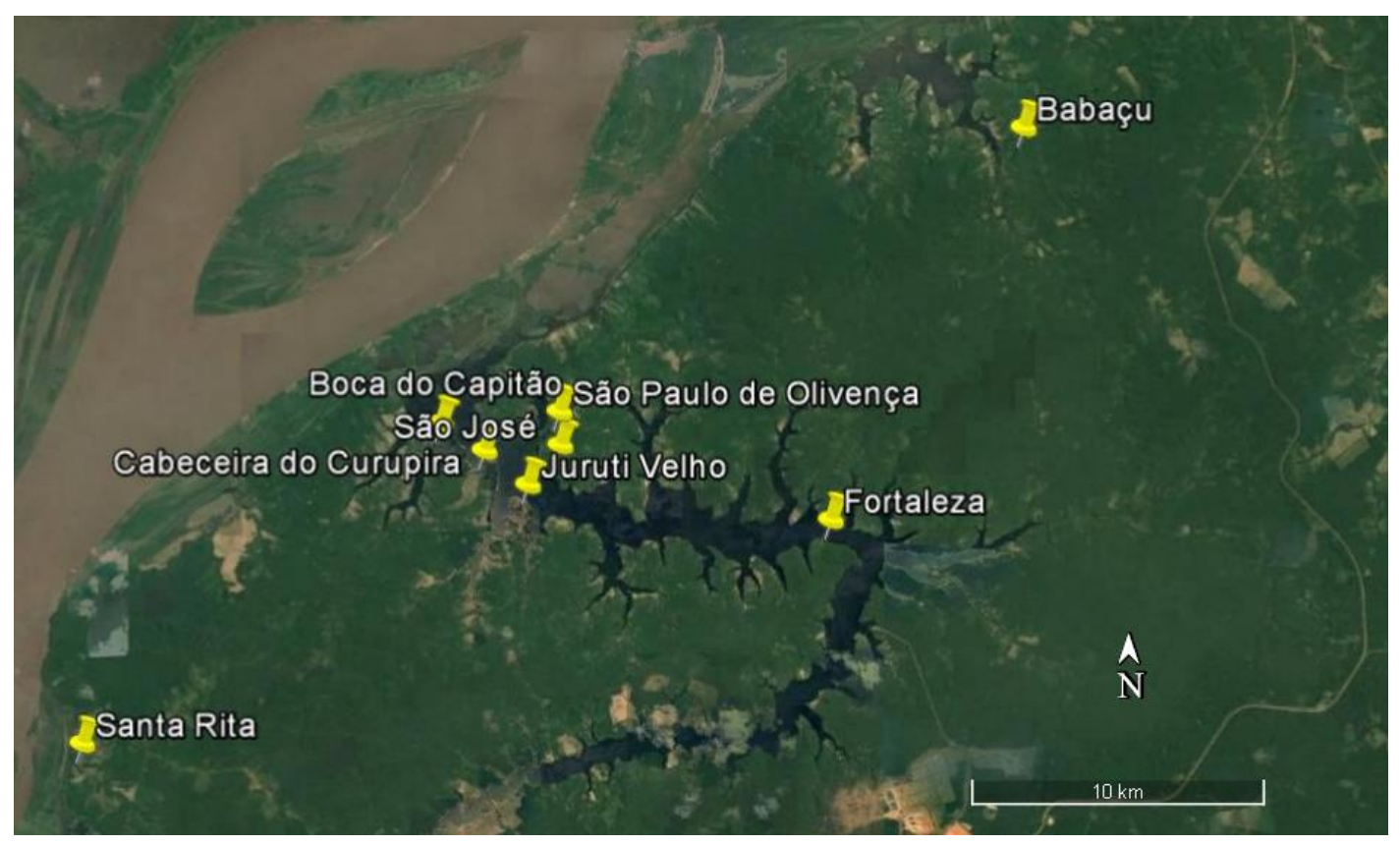

Mapa 3. Localização aproximada de sítios no Google Earth a partir de anotações e croquis de campo produzidas por Peter Hilbert em sua expedição a Juruti e Parintins em 1953. Não há informações sobre o sítio Babaçu, apenas uma correlação entre uma região conhecida e sítios mapeados por Scientia (2003).

Excluindo as proveniências genéricas ou muito duvidosas, há 46 sítios arqueológicos representados nas quatro principais coleções diagnósticas. Entre estes, a maioria (26) apresenta uma alta confiabilidade de sua localização devido às informações geográficas e arqueológicas disponíveis. Outros sítios possuem indicações geradas pelos coletores muito mais difíceis de correlacionar com maior precisão, mas é possível situar os sítios em lugares que podem distar desde metros até quilômetros de sua real localização.

Um dos facilitadores para a localização aproximada é o uso das denominações das comunidades ribeirinhas como referência nas expedições de Barbosa de Faria e Hilbert. O nome dessas comunidades se manteve desde o final do século XIX 
(BARBOSA RODRIGUES, 1875a). As folhas topográficas da região permitem dessa maneira identificar comunidades/sítios arqueológicos. As coordenadas das comunidades da margem direita do rio Trombetas e lago Sapucuá reunidas pelo Instituto Chico Mendes (ICMBio) em Porto Trombetas, em geral, sobrepõe-se a sítios arqueológicos. Esse é o caso, por exemplo, do quilombo Abuí nas margens do lago homônimo, visitado por Barbosa de Faria, que continua mantendo o mesmo nome até o presente. Pesquisas recentes também revisitaram sítios em que foram feitas coletas de superfície ou escavações.

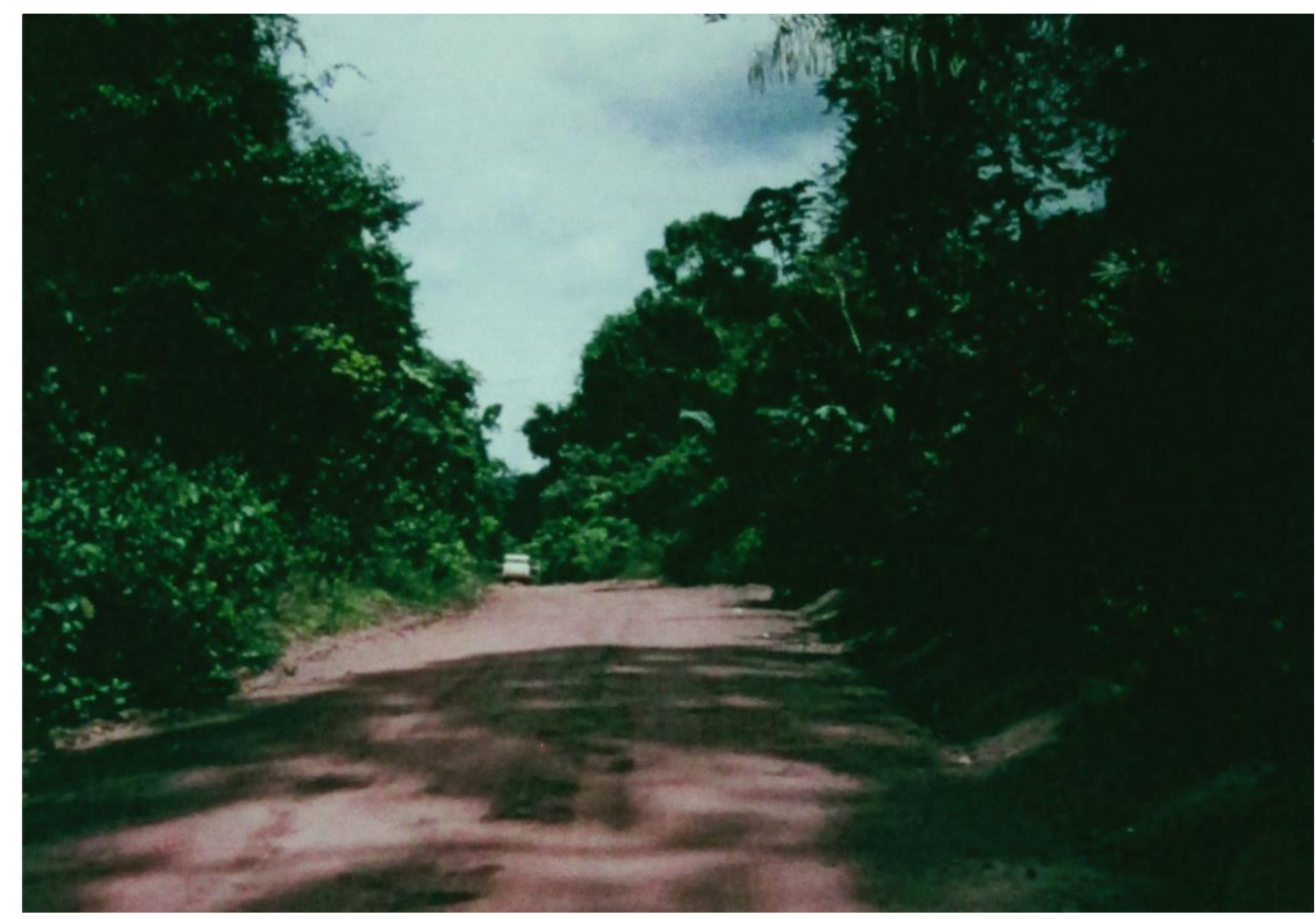

Figura 32. Vista do sítio Araticum (PA-OR-77) cortado pela estrada. Este é o mesmo sítio identificado por Aricy Curvello na década de 1970. Fonte: Brandt, 1996.

A ideia de sítio arqueológico como área delimitada no espaço também é difícil de ser aplicada no caso em que existem denominações diferentes sobre as quais não se sabe se são meras variações na escrita ou se referem a locais distintos. Esse o caso de quatro proveniências diferenciadas no livro tombo do MN: Terra Preta, Sacuri; Terra Preta Jacupá; Igarapé Sacuri; Jacupá, Sacuri. Existem duas comunidades em frente à cidade de Oriximiná denominadas Sacuri e Jacupá, que podem ser equivalentes aos 
locais de coleta. Da mesma maneira, todo o lago, na época da expedição realizada por Barbosa de Faria, era denominado "Jacupá". Além disso, o coletor considera "Jacupá" um sítio localizado em ilha e, de fato, há uma no lago. Tanto pode ser o caso de terem sido realizadas coletas em 4 sítios, quanto em apenas um. Essa é uma das poucas áreas da margem direita do baixo curso do rio Trombetas que ainda não foi prospectada sistematicamente. Com mais pesquisas, essas denominações poderão ser mais bem contextualizadas.

Em áreas que foram prospectadas com maior intensidade nas últimas décadas, é possível correlacionar às antigas informações a coordenadas precisas. Esse é o caso de 13 sítios com coordenadas obtidas em pesquisas posteriores no lago Sapucuá (Uajará, Cocal, Boca dos Anjos, Ascensão, Ponta da Mafada, Ponta dos Souza, Pimenta, Santo Antônio, Terra Preta), Porto Trombetas (Araticum), Juruti (Fortaleza, Babaçu) e Óbidos (Sucurijú) (BRANDT, 1996; FONSECA, 2018; SCIENTIA, 2003; MARIANO, 2017) (Figura 32). Considerando a descrição de Barbosa de Faria, é muito provável que o sítio "Laranjal" seja o mesmo identificado como "PA-OR-73: Colônia" por uma equipe do MPEG (ARAÚJO COSTA et al., 1986). O mesmo acontece com o sítio identificado como "Posto Aurora I" por Aricy Curvello que, considerando as pesquisas recentes deve se tratar de Greig I, estudado pela equipe do MPEG (GUAPINDAIA, 2008; GUAPINDAIA; LOPES, 2012). Não foi possível, entretanto, correlacionar o sítio Posto Aurora II, situado apenas $1,0 \mathrm{~km}$ de Posto Aurora I segundo Guimarães (1985) aos outros sítios identificados na área. No caso do sítio denominado "Lago Batata" não é possível fazer uma correlação muito confiável dada a grande quantidade de sítios na orla do lago. O comentário sobre a grande dimensão desse sítio leva por exclusão considerá-lo como possivelmente equivalente a outros dois como PA-OR-86 e PA-OR92. Klaus Hilbert conseguiu localizar 9 sítio no rio Nhamundá no Google Earth a partir do mapa publicado por Peter Hilbert e o conhecimento adquirido em etapas de campo realizadas na região em 1975 e 1992, o que dá maior confiabilidade as localizações aproximadas para essa área. 


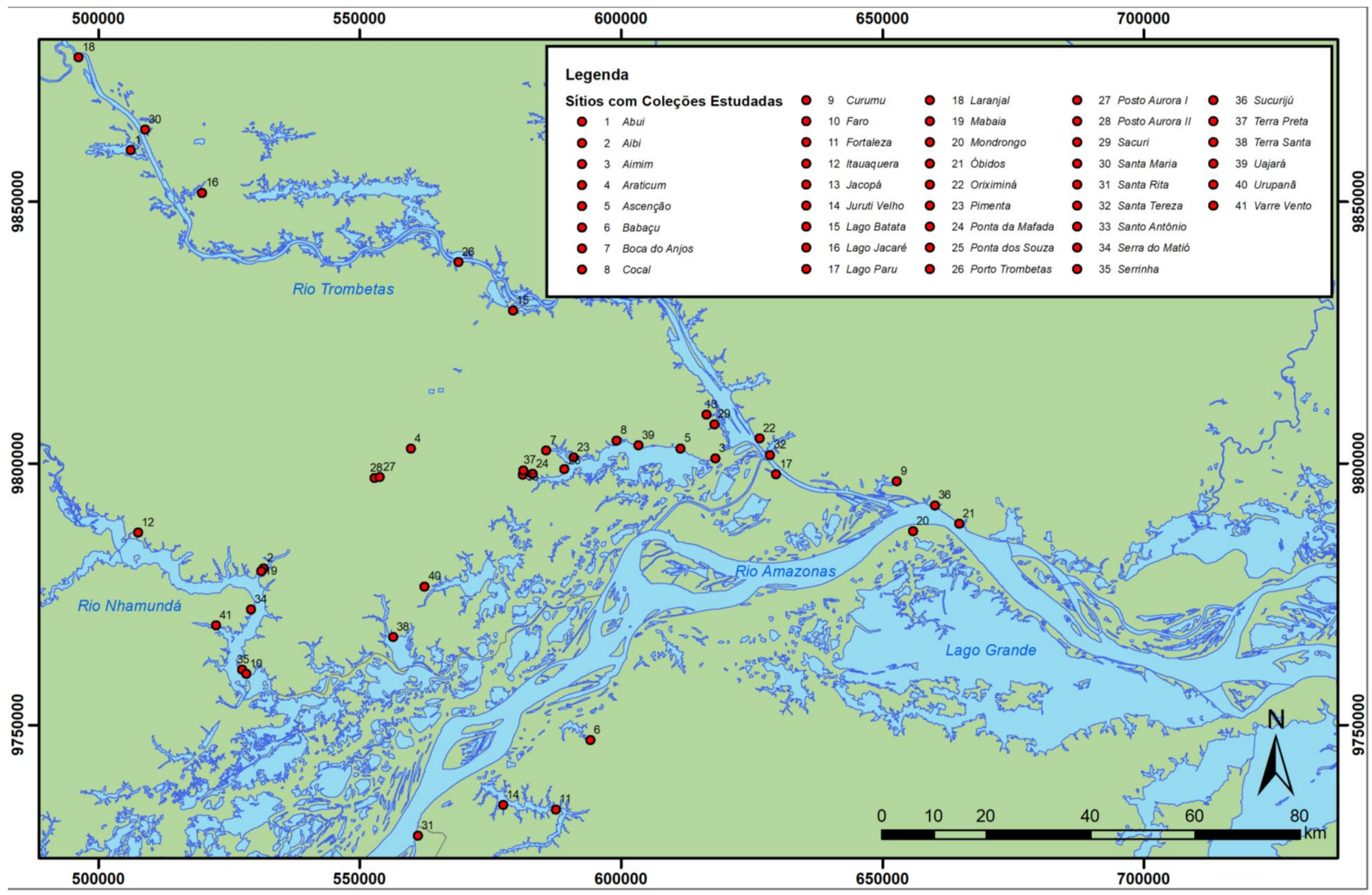

Mapa 4. Localização de sítios com amostras nas coleções analisadas. Autor: Henrique Koslowski. 
A partir do levantamento de informações em fontes bibliográficas, arquivísticas e cartográficas construímos uma escala de avaliação de confiabilidade das informações sobre a localização de cada sítio. Foram identificados como sítios com baixa confiabilidade aqueles cuja informação permite situar de maneira muito aproximada a área de coleta. Esse é o caso do sítio Arapapá, na Ilha Paru, localizado em uma área que ainda não foi alvo de prospecções sistemáticas, mas que é muito restrita geograficamente. Sítios com localização aproximada qualificada como média dispõe de uma melhor descrição da área de coleta e, ás vezes, prováveis sítios identificados prospecções na área. O caráter vago de muitas descrições ou alguma contradição interna ainda deixa dúvidas em relação à localização dos sítios dessa categoria. Por fim, há os sítios que foram revisitados em pesquisas mais recentes e dos quais se dispõe de um ponto de GPS ou localização no Google Earth disponibilizada por Klaus Hilbert. Com a reunião de pontos de GPS ou coletados a partir do Google Earth foi construído um mapa para visualizar a dispersão regional e a escala da pesquisa (Mapa 4)

\begin{tabular}{|c|l|l|}
\hline \multicolumn{1}{|c|}{ Sítio } & Confiabilidade & Denominação atual \\
\hline Curumú & Média & Não identificada \\
\hline Igarapé Mondrongo & Média & Não identificada \\
\hline Posto Aurora I & Média & Greig I \\
\hline Lago Batata & Média & Indeterminada \\
\hline Abuí & Média & Não identifificada \\
\hline Santa Maria & Média & A mesma \\
\hline Itauaquera & Média & A mesma \\
\hline Serra do Matió & Média & A mesma \\
\hline Serrinha & Média & A mesma \\
\hline Varre Vento & Média & Serra do Babaçu \\
\hline Babaçu & &
\end{tabular}

Tabela 4. Sítios com localização com confiabilidade média representados nas coleções. 


\begin{tabular}{|c|l|l|}
\hline \multicolumn{1}{|c|}{ Sítio } & Confiabilidade & Denominação atual \\
\hline Lago Paru & Baixa & Não identificada \\
\hline Sacuri & Baixa & Não identificada \\
\hline Posto Aurora II & Baixa & Não identificada \\
\hline Lago Jacaré & Baixa & Não identificada \\
\hline Urupanã & Baixa & A mesma \\
\hline Aibi & Baixa & A mesma \\
\hline
\end{tabular}

Tabela 5. Sítios com localização com confiabilidade baixa representados nas coleções.

\begin{tabular}{|c|c|c|}
\hline Sítio & Confiabilidad & Denominação atual \\
\hline Óbidos & Alta & A mesma \\
\hline Sucurijú & Alta & São Gonçalo \\
\hline Jacupá & Alta & Não identificada \\
\hline Oriximiná & Alta & A mesma \\
\hline Santa Tereza & Alta & A mesma \\
\hline Ascensão & Alta & A mesma \\
\hline Boca dos Anjos & Alta & A mesma \\
\hline Cocal & Alta & A mesma \\
\hline Pimenta & Alta & A mesma \\
\hline Ponta da Mafada & Alta & A mesma \\
\hline Ponta dos Souza & Alta & A mesma \\
\hline Santo Antônio & Alta & A mesma \\
\hline Terra Preta & Alta & A mesma \\
\hline Uajará & Alta & A mesma \\
\hline Araticum & Alta & A mesma \\
\hline Porto Trombetas & Alta & Não identificada \\
\hline
\end{tabular}




\begin{tabular}{|lll|}
\hline Sítio & Confiabilidad & Denominação atual \\
\hline Laranjal & Alta & Colônia \\
\hline Terra Santa & Alta & A mesma \\
\hline Faro & Alta & A mesma \\
\hline Mabaia & Alta & A mesma \\
\hline Fortaleza & Alta & Fortaleza II \\
\hline Santa Rita & Alta & A mesma \\
\hline
\end{tabular}

Tabela 6. Sítios com localização com confiabilidade alta representados nas coleções.

\subsection{Dimensão da população}

A quantidade de fragmentos no caso de peças provenientes de sítios arqueológicos distintos é importante para um estudo em escala regional. Nas quatro coleções diagnósticas com informações mais seguras, há apenas 8 sítios com mais de 100 fragmentos (Gráfico 3). Muitas das amostras não chegam a somar 25 fragmentos, sendo a maioria composta por menos de 10 . Outras amostras possuem 26 e 100 peças, o que possibilita elementos mínimos para se tenha uma noção de aspectos da variabilidade da cerâmica.

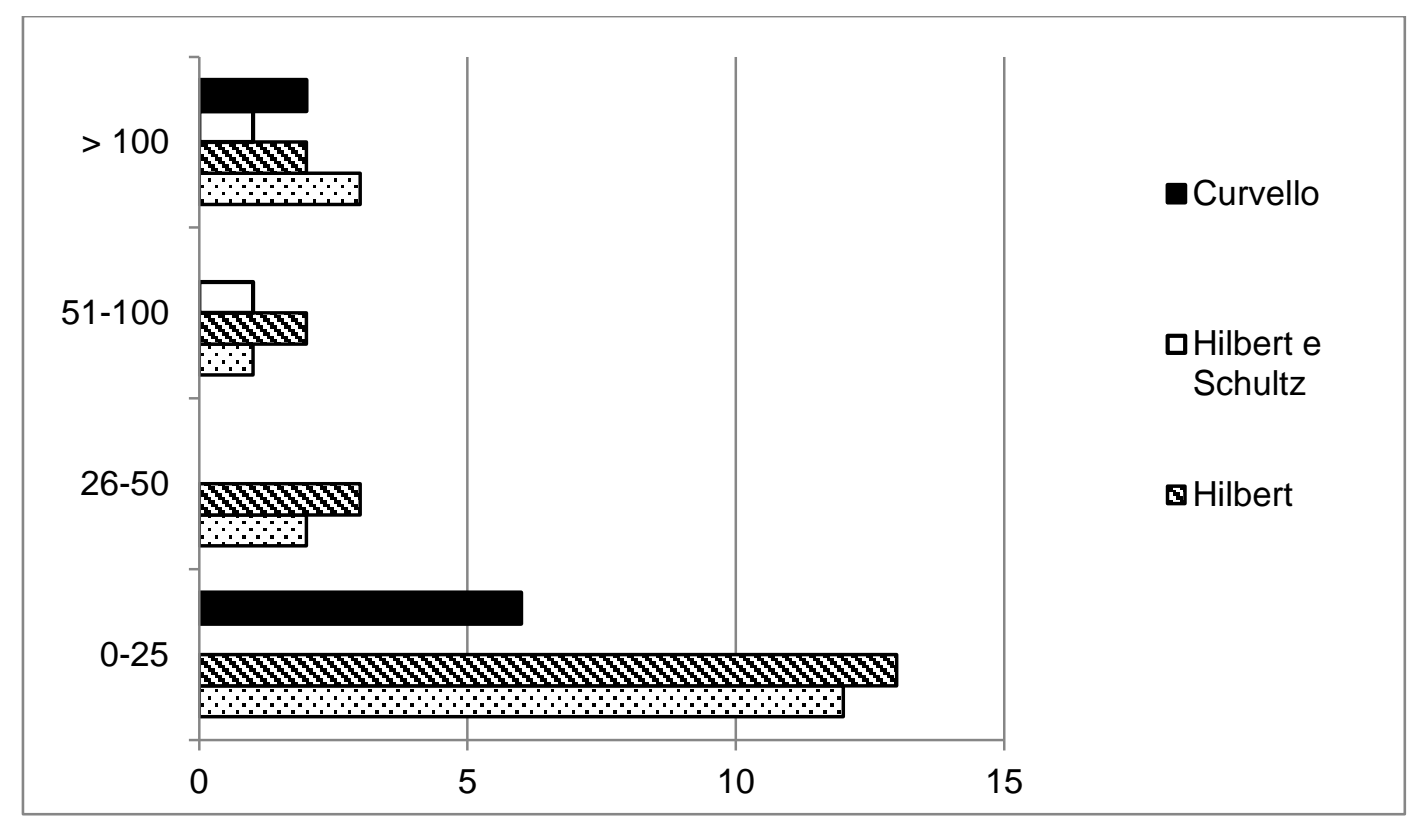

Gráfico 3. Quantidade de sítios com diferentes quantidades de peças nas coleções diagnósticas. 

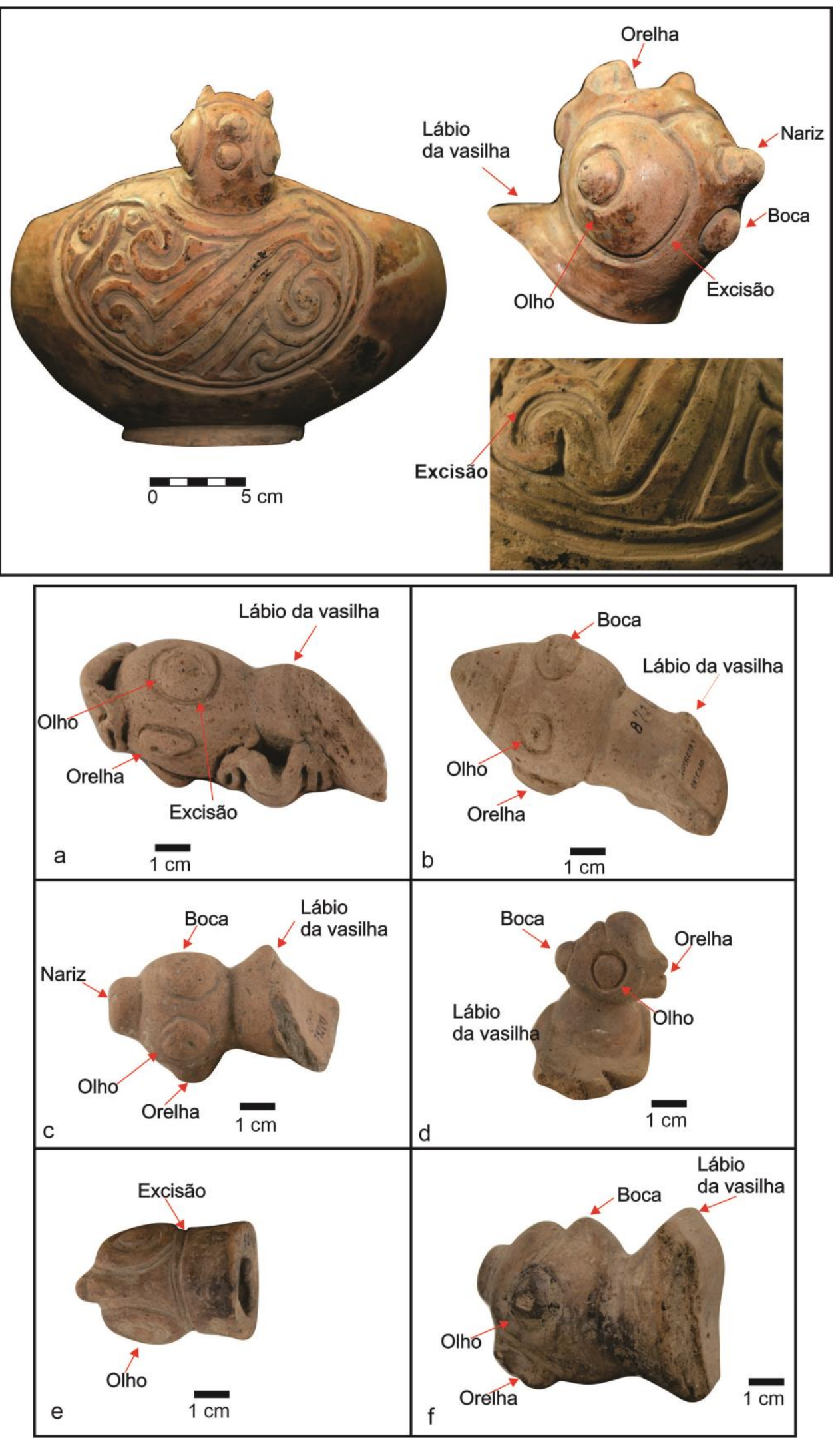

Figura 33. Comparação entre vasilha Pocó (sítio Terra Preta) e apêndices "globulares". Coleções 881, (a-b), Peter Hilbert (b-d), Barbosa de Faria/Comissão Rondon (f). Proveniência: a-b (Trombetas enseada), b-d (Oriximiná), Lago Paru. 


\subsection{Problemas de classificação}

As coleções de museu são palimpsestos de materiais de diferentes proveniências e períodos. Separar os objetos de diferentes estilos a partir de suas características visuais, especialmente a decoração, ou antiplástico é uma atividade que carrega uma incontornável subjetividade. A classificação em diferentes estilos é orientada a partir da bibliografia e da experiência prévia, mas sempre há fragmentos que são muito pequenos ou cujas características não parecem ser suficientemente "diagnósticas", como modelagens distintas das mais frequentes. Sempre são possíveis idiossincrasias técnicas que não podem ser apreciadas fora de conjuntos obtidos sistematicamente. Os principais critérios para diferenciação atributos visuais, especialmente a decoração. Quando não há decoração, sempre é mais difícil identificar, mas alguns atributos como tratamento de superfície (polimento ou alisamento), morfologia e antiplástico podem ser também diferenciadores. As dificuldades em torno da classificação em estilos cerâmicos são extremas no caso das coleções de museu, mas esse é um problema enfrentado também na análise de materiais obtidos em escavações sistemáticas em sítios multicomponenciais (MACHADO, 2005, 2005-2006; MORAES, 2006).

Além dos problemas relacionados à própria formação das coleções, as unidades "estilo globular" e "cerâmica temperada com areia" precisaram ser revistas durante o estudo. Nenhuma pesquisa realizada em Oriximiná ou Juruti identificou uma camada de ocupação "globular". Como já havia sido notado por Lathrap (1970, p.120), os apliques e as incisões curvas desse estilo são tipicamente Barrancóide. O mesmo propôs Gomes (2002) em sua seriação hipotética. A amostra do estilo "globular" coleta por Hilbert era muito pequena e nenhuma era proveniente de sondagens. Como apenas foram publicados os resultados preliminares dos trabalhos realizados na década de 1970, não foi possível realizar uma comparação entre os materiais coletados em 1952 (HILBERT; HILBERT, 1980) (Figura 33). Uma rápida consulta a duas vasilhas inteiras Pocó coletadas no sítio Terra Preta, escavado durante a realização do Projeto Arqueológico Porto Trombetas (MPEG), evidenciou características comuns como o polimento da superfície, incisões e excisões largas, engobo vermelho e branco, apêndices zoomorfos arredondados ("globulares"). O mesmo é notável a partir do trabalho realizado por Chumbre (2014) em que a cerâmica dos níveis mais antigos apresenta superfícies polidas e o uso intenso de excisão. Isso nos leva a crer que o estilo "globular" deve ser considerado como representante do que foi considerado Pocó. As coletas seletivas 
provavelmente influenciaram na reunião preferencial de apliques "globulares" e poucas bordas com apliques, mascarando a variabilidade Pocó.

Scientia (2008) identificou apliques característicos "globulares" entre a superfície e $50 \mathrm{~cm}$ de profundidade no sítio Terra Preta 1. Ao mesmo tempo, outros fragmentos de borda característicos aparecem desde os níveis mais profundos e também poderiam ser tratados como "globulares", seguindo Hilbert (1955a). A perturbação da estratigrafia pode ser um fator atuante para a associação desses materiais. Tanto em Terra Preta 1 quanto em Cipoal do Araticum, o material identificado como Pocó aparece desde a superfície até os níveis mais profundos. Talvez, a partir da escavação de sítios com a estratigrafia menos perturbada, seja possível retomar a unidade "globular". Uma possibilidade ainda não totalmente formalizada, mas sugerida por Panachuk (2016a), é de que exista um conjunto material mais antigo semelhante ao da tradição Saladóide e um mais recente, Barrancóide.

\begin{tabular}{|l|l|r|}
\hline Complexos cerâmicos & Quantidade & Porcentagem \\
\hline Konduri & 2334 & $72,28 \%$ \\
\hline Produção não local & 463 & $14,53 \%$ \\
\hline Pocó & 251 & $7,88 \%$ \\
\hline Histórico & 16 & $0,50 \%$ \\
\hline Santa Rita, Parintins & 13 & $0,41 \%$ \\
\hline Indeterminado & 125 & $3,89 \%$ \\
\hline TOTAL & 3202 & $100 \%$ \\
\hline
\end{tabular}

Tabela 7. Quantidade total de peças analisadas por estilos cerâmicos em cinco instituições.

O grupo "cerâmica temperada com areia” foi construído devido a características muito distintas dos estilos Konduri ou"globular" (HILBERT, 1955a). A principal diferença foi a presença de um antiplástico mineral, mas também morfologia e padrão inciso particulares. Com as escavações sistemáticas, ficou claro que essa cerâmica 
aparece associada a cerâmica Konduri (GUAPINDAIA, 2008). A singularidade da "cerâmica temperada com areia" é marcante, o que justifica sua delimitação como um estilo específico. Jácome (2017) aventou a possibilidade de que essa associação representaria uma perturbação entre camadas mais recentes e mais antigas. Por outro lado, nenhum sítio apenas com cerâmica "Espinha de Peixe" foi encontrado até o momento Considerando os dados disponíveis, pode ser mais parcimonioso tratar a cerâmica Espinha de Peixe como contemporânea a Konduri e possivelmente resultado de trocas de objetos - ou seja, de produção não local. Essa proposta é reforçada pela presença de outros conjuntos minoritários associados ao estilo Konduri, com atributos característicos de outros estilos encontrados em áreas adjacentes, o que permite considerá-los como de produção não local com maior confiabilidade (Tabela 7). No Capítulo 5 as características desses conjuntos serão discutidas e a hipótese em relação às trocas será refinada.

No sítio Santa Rita, no município de Parintins, há outro estilo cerâmico ainda não descrito, caracterizado pelo uso de cauixi como antiplástico, vasilhas restritivas com flange labial, filetes entalhados acompanhados de pequenos apêndices, ponteado no lábio, incisões em "ponto de osso", linhas pretas pintadas sobre engobo branco (Figura 34). Lima (2007) identificou esse mesmo material cerâmico nos níveis inferiores do sítio Santa Rita, indicando uma história de ocupação distinta dos sítios a leste (Juruti, rios Nhamundá e Trombetas). A partir das coleções domésticas, Lima e Silva (2004, p.33) já haviam identificado a presença de material cerâmico que poderia estar associado à fase Paredão da Tradição Borda Incisa Fragmentos semelhantes são encontrados nas coleções reunidas pelos moradores da comunidade. Essa cerâmica pode ser do mesmo estilo identificado no sítio Parintins 7 por Panachuk (2014) e vinculada à Tradição Borda Incisa. Uma urna funerária em forma de prato foi encontrada por moradores em 2018 na comunidade de Santa Rita ${ }^{50}$ indicando mais uma diferença marcante com o vasilhame Konduri. Outras pesquisas com mais informações contextuais poderão rever esta proposta esquemática baseada unicamente em características formais dos artefatos e as informações disponíveis na bibliografia.

50 Bianchezzi, Clarice; MACHADO, Michel; SOUZA, Daiane; BATALHA, Jéssica. NOTA A IMPRENSA. Disponível em: https://www.parintins24hs.com.br/restos-mortais-em-urna-funerariaencontrada-na-valeria-tem-aproximadamente-de-mil-anos/. Acesso 10 de agosto de 2018. 


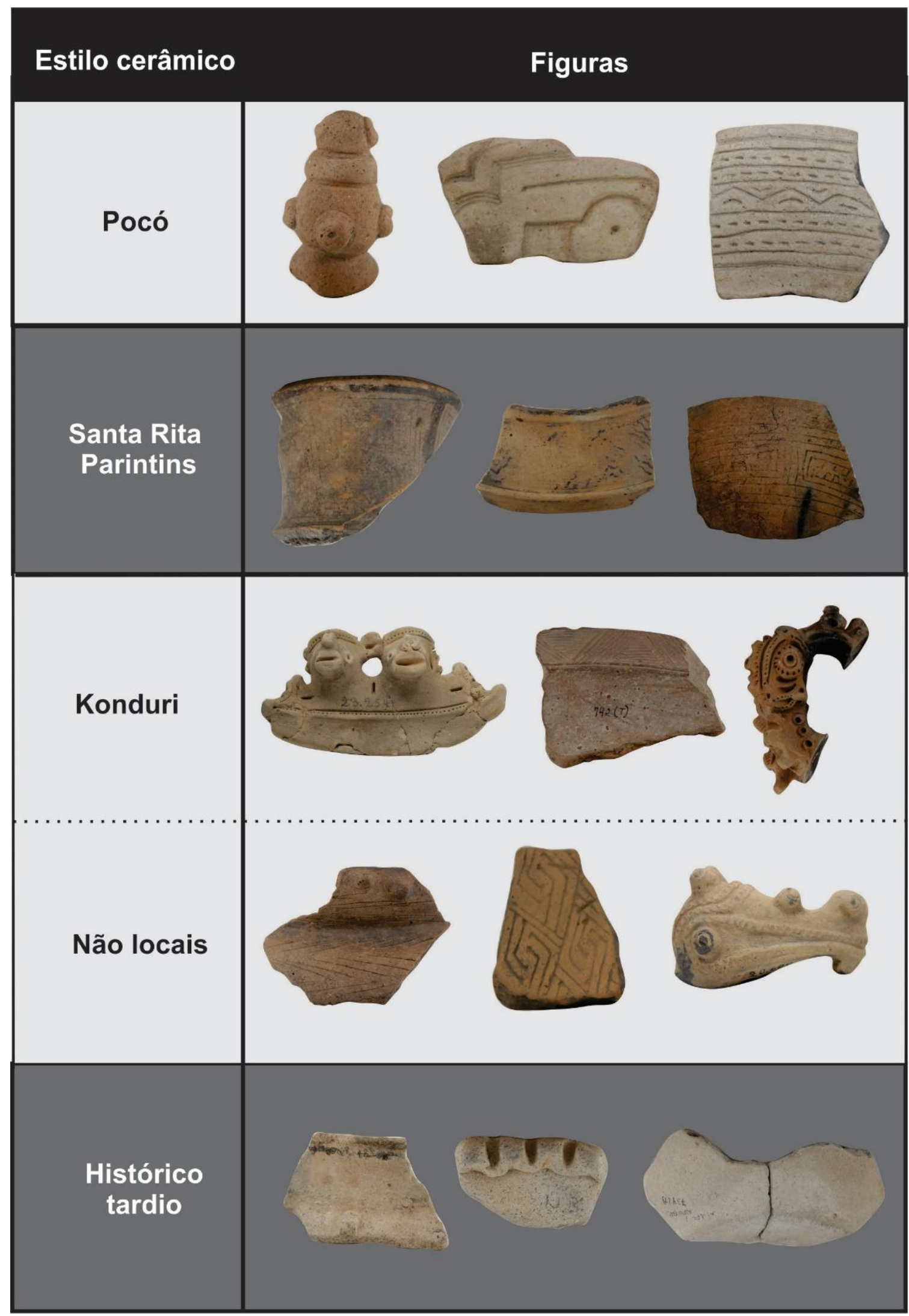

Figura 34. Conjuntos cerâmicos reunidos a partir de suas características formais na região entre Juruti e rio Trombetas. Notar que os estilos "não locais" estão associados ao estilo Konduri neste esquema. A cerâmica Pocó e "Santa Rita” são as mais antigas e a histórica tardia, a mais recente. 


\subsection{Método de análise cerâmica}

Considerando as limitações em relação às informações contextuais, é possível analisar o material cerâmico de coleções de museu a partir dos mesmos métodos de análise macroscópica. Desse modo, descrevemos cada peça em um banco de dados voltado a compreensão de aspectos macroscópicos da cadeia operatória. A ficha descritiva foi construída a partir da proposta pelo Projeto Norte Amazônico na Universidade Federal de Minas Gerais (JÁCOME, 2017), tendo sido adaptada a partir da consulta de manuais de análise cerâmica (SHEPARD, 1956; RYE, 1981; RICE, 1987; ORTON; HUGHES, 2013), fichas de análise de outros trabalhos (RODRIGUES, 2011; MACHADO, 2005; GASPAR, 2014; BELETTI, 2016) e também atributos de interesse destacados por Hilbert (1955a). Os atributos descritos sistematicamente foram: parte da vasilha representada, antiplástico, cor, indicativos de queima, morfologia (lábio, borda, base, contorno, abertura da boca), alisamento, tratamento de superfície, decoração, variações morfológicas de apliques, modificações antrópicas recentes e conservação das superfícies. Em relação aos indicativos de queima, o único atributo observado foi a configuração do núcleo. A queima de cerâmica em atmosfera oxidante tende a gerar um núcleo mais claro enquanto uma atmosfera redutora, um mais escuro. A presença de matéria orgânica também influencia na coloração do núcleo (RYE, 1981, p. 116). Por esse motivo, evitamos o uso das expressões "oxidante" ou "redutor" para denominar a configuração do núcleo. Denominando-os apenas a partir de uma sequência numérica seguindo a proposta de Gaspar (2014).

A análise de pasta consistiu na observação das características dos elementos antiplásticos ou inclusões: sua natureza, concentração e comprimento. Isso foi feito tanto com o uso da lupa binocular quanto de microscópios digitais portáteis (Dino Lite AM3113T e Cooling Tech 500x). A observação na lupa permite uma melhor compreensão do relevo dos elementos presentes na pasta e sua textura. Os microscópios, por sua vez, permitem realizar fotografias com diferentes aumentos e medir os grãos de antiplásticos (ver DRUC; CHAVEZ 2014). Nas análises realizadas no MN foi utilizado apenas o Cooling Tech 500x, uma vez que o outro microscópio - com melhor resolução - não estava disponível e não havia lupa binocular na reserva técnica da instituição. A porcentagem aproximada de inclusões foi estimada a partir do gráfico reproduzido em Orton e Hughes (2013) (Figura 35). O comprimento máximo das inclusões foi estimado diretamente a partir das fotografias retiradas com microscópios 
digitais. As espículas de cauixi não foram medidas dada a sua variação micrométrica. Devido a sua importância para compreender o complexo Konduri, sua porcentagem foi medida em separado de outras inclusões.
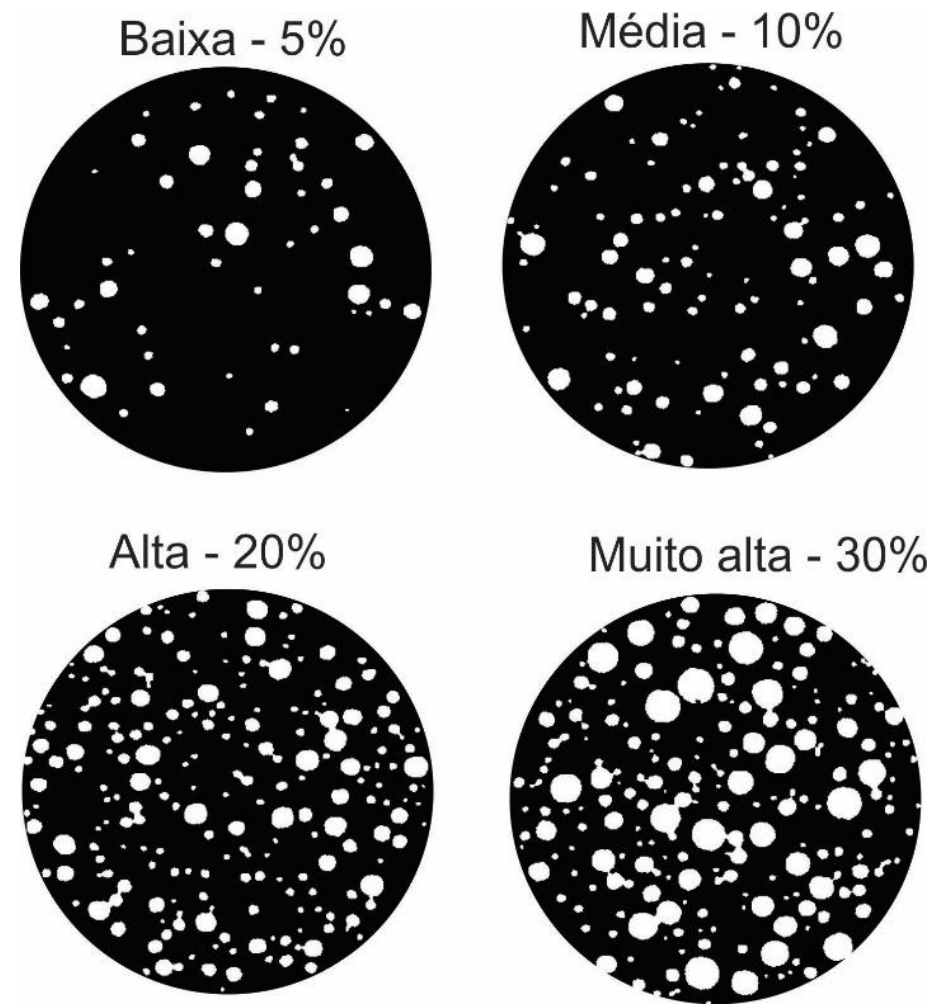

Figura 35. Gráfico de estimativa de porcentagem de antiplástico na pasta cerâmica. Adaptado de Orton e Hughes (2013).

Mantivemos a separação entre tratamento de superfície e decoração, seguindo Shepard (1956). O primeiro processo engloba apenas a regularização da superfície (alisamento fino ou grosso e polimento). O outro, por sua vez, engloba uma ampla gama de técnicas plásticas e pictóricas formando motivos e padrões gráficos e revestimentos de superfícies (engobo, brunidura, resina). Foram descritas na tabela apenas a combinação de técnicas e sua localização, sendo descritas à parte as características de motivos e padrões gráficos. A manutenção da separação não busca reificar a diferença entre "utilitário" e "simbólico", como o uso corrente do termo "decoração" pode sugerir, mas apenas organizar as informações. A expressão "modificação de superfície" 
utilizada por Orton e Hughes (2013) para agrupar apenas as alterações plásticas (incisões, ponteados), poderia ser usada para englobar os mesmos atributos tratados como decoração.

O limite de tempo e recursos para analisar coleções em diferentes instituições levou a adoção de reduções de atributos analisados em relação às fichas adotadas em outras pesquisas. A face externa foi tomada como principal foco descritivo de cor e alisamento. Isso se justifica porque, em geral, esses atributos não tendem a diferir entre as faces. Quando uma diferença significativa foi notada, esta foi indicada como observação. Ao final das análises, ficou claro que esta não foi a melhor solução, uma vez que podem não ter sido anotadas todas as ocorrências distintas de tratamento de superfície entre as faces. Em termos da coloração isso pareceu menos problemático, mas o mesmo pode ter ocorrido.

Devido aos próprios problemas de conservação de materiais em superfície e nas instituições de guarda poucos vestígios de uso se conservaram (fuligem, depósito carbônico, abrasão, etc). Por esse motivo, esse atributo foi anotado apenas como observação. Marcas de reutilização dos fragmentos, como a presença de sulcos, também foram anotadas dessa maneira. Nesse caso, houve menos problemas porque as ocorrências eram, de fato, muito menos frequentes e fáceis de controlar.

O diâmetro das vasilhas foi estimado com o uso de um ábaco com as bordas estabilizadas. Para estimar diâmetro de bordas com apêndices no lábio partiu-se do princípio que era possível estimar o diâmetro da porção mais próxima do lábio com o uso de um copiador de contornos paralelo ao lábio, uma solução desenvolvida por Igor Rodrigues durante os trabalhos do Projeto Norte Amazônico. Optar por desenhar as bordas dessa maneira. Sabemos, entretanto, que tal escolha pode levar a equívocos quanto à angulação da borda. Trabalhos futuros com exemplares maiores poderão confirmar ou não as tentativas de projeção. Hilbert (1968) projetou a morfologia de duas vasilhas que análises posteriores mostraram ser equivocadas, talvez devido aos problemas com a conservação e dimensão dos fragmentos (ver MORAES, 2013). Outra convenção foi o uso de bases planas para todas as reconstituições, uma vez que estas eram predominantes no conjunto estudado. $\mathrm{O}$ uso de bases arredondadas, ao contrário, 
cria a falsa impressão de que esse era um atributo comum, apesar de haver poucos indicativos para este tipo de base (PANACHUK, 2016b; SCIENTIA, 2013).

A grande quantidade e diversidade de apliques modelados nas coleções de museu criou a necessidade de observar alguns atributos específicos. O primeiro foi à diferenciação entre (1) apêndices (ou "adornos"), (2) alças e (3) pés modelados ou suportes. O termo "aplique" é utilizado de maneira genérica para qualquer modelagem proeminente aderida a superfície de um pote, a exceção de pequenos filetes e botões. Os apêndices, por sua vez, são elementos morfológicos figurativos ou não, cuja funcionalidade não pode ser diretamente relacionada à preensão ou à suspensão. Seguindo algumas questões colocadas por Hilbert (1955a) sobre métodos de queima e construção das vasilhas consideramos a presença de ranhuras, furos, solidez e forma do apêndice. As ranhuras são um indicador do método de "costura" enquanto a presença de furos e modelagens ocas são relacionadas a queima das vasilhas.

Em relação à morfologia dos apêndices foram opostos os com uma forma mais arredondada, em relevo pleno, e aqueles achatados ou em placa. No caso dos apêndices figurativos, também foram considerados os tipos de olhos. Há uma grande diversidade no modo de formar olhos nas modelagens e este tem sido um atributo tradicionalmente considerado na arqueologia do baixo Amazonas e Orinoco. Os olhos podem ser compostos de apenas de um ponto feito com instrumento maciço (tipo A) ou oco (tipo B) $)^{51}$, um disco ou elipse modelado ou uma incisão, podendo esses elementos serem combinados. Inicialmente, tentamos medir todos os apêndices, mas isso foi abandonado durante os trabalhos devido ao tempo necessário e a impossibilidade de comparar dimensões. Apenas os pés modelados tiveram altura máxima e diâmetros máximos e mínimos considerados. Também foi considerada a variação da ponta (extremidade inferior) dos pés modelados.

\footnotetext{
${ }^{51}$ A diferença entre ponto A e B foi proposta por Guapindaia (1993).
} 


\begin{tabular}{|c|c|c|c|c|}
\hline Museu & Coleção & Amostra & Total & Analisado \\
\hline \multirow{3}{*}{$\begin{array}{l}\text { MAE- } \\
\text { USP }\end{array}$} & Tapajônica & Selecionada & 8516 & 301 \\
\hline & 006 & Selecionada & SD & 34 \\
\hline & Luís Paixão & Selecionada & $179 *$ & 14 \\
\hline \multirow{3}{*}{ MCT } & Protásio Frikel & Instituição & 1 & 1 \\
\hline & Peter Hilbert & Instituição & SD & 5 \\
\hline & Peter e Klaus Hilbert & Instituição & SD & 6 \\
\hline MHN & Aricy Curvello & Não selecionada & 436 & 436 \\
\hline \multirow[b]{4}{*}{$\mathbf{M N}$} & Amazônia & Selecionada & SD & 11 \\
\hline & Comissão Geológica & Selecionada & $\mathrm{SD}$ & 5 \\
\hline & Gastão Cruls & Selecionada & 36 & 2 \\
\hline & $\begin{array}{l}\text { Comissão Rondon/ } \\
\text { Barbosa de Faria }\end{array}$ & $\begin{array}{l}\text { Não selecionada/ } \\
\text { Selecionada }\end{array}$ & 1210 & 803 \\
\hline \multirow{9}{*}{ MPEG } & Peter Hilbert & Não selecionada & 876 & 876 \\
\hline & Peter Hilbert e & Não selecionada & 406 & 406 \\
\hline & $\begin{array}{l}\text { Charles Townsend } \\
\text { Jr. }\end{array}$ & Instituição a & 3050 & 62 \\
\hline & Frederico Barata & Instituição & 66 & 66 \\
\hline & $\mathrm{T}-881$ & Não selecionada & 72 & 72 \\
\hline & $\begin{array}{l}\text { T-1564 ("Galvão, } \\
1965 ")\end{array}$ & Não selecionada & 38 & 38 \\
\hline & $\mathrm{T}-1465 / 1466$ & Selecionada & 511 & 24 \\
\hline & MD 13 e 42 & Não selecionada & 31 & 31 \\
\hline & Outros & Instituição & 5 & 5 \\
\hline
\end{tabular}

Tabela 8. Quantidade de peças analisadas em relação ao total de cada coleção e sua organização nas instituições. 
Durante a pesquisa notamos a importância da documentação fotográfica das peças com vários detalhes iconográficos. Por este motivo, com exceção dos fragmentos de parede lisos, todas as peças foram fotografadas individualmente - às vezes, em vários ângulos. Posteriormente, este material poderá servir para a montagem de um catálogo da cerâmica Konduri ou da região dos rios Trombetas e Nhamundá e municípios de Óbidos, Juruti e Parintins.

No total foram analisados 3197 fragmentos cerâmicos e 7 vasilhas inteiras/semiinteiras em 5 instituições ${ }^{52}$ (Tabela 7) (Tabela 8).Essa quantidade, entretanto, não representa a soma de todas as coleções de museu com cerâmica Konduri nessas instituições. O objetivo inicial era analisar a totalidade de fragmentos das coleções visando construir uma interpretação mais holística possível das amostras disponíveis e sua variabilidade. Isso foi realizado no $\mathrm{MNH}$, que serviu de "plano piloto" da pesquisa, uma vez que a coleção contava com pouco mais de 400 fragmentos e horários flexíveis de trabalho no laboratório. Nas outras instituições, não foi possível dado os limites de tempo, recursos e as próprias singularidades dos conjuntos. Algumas coleções somam milhares de fragmentos provenientes de áreas muito além do âmbito deste trabalho, além de pouca ou nenhuma informação contextual. Assim, foram adotadas estratégias de amostragem e seleção que privilegiassem peças com maior controle sobre sua proveniência e/ou exibisse atributos formais de interesse (bordas, paredes decoradas, apliques). No caso de coleções com melhor documentação e conservação, tentamos analisar toda a amostra de um sítio ou área, não excluindo peças de outros estilos, datados de períodos diferentes.

\subsection{Modelando as amostras}

. O interesse inicial de recontextualização das coleções era descrever e discutir as amostras individualmente por proveniência e ampliando a escala a partir disso. Todavia, dada dimensão das amostras essa estratégia se mostrou pouco proveitosa. Optamos, dessa maneira, por buscar uma visão geral de todo o material classificado como Konduri, balanceando os resultados com amostras de coleções diagnósticas com mais de 50 fragmentos e informações contextuais mais seguras. Os resultados

\footnotetext{
${ }^{52}$ Além dessas peças foram analisadas estatuetas e vasilhas inteiras do estilo Santarém (43 peças) tendo em vista a comparação com o esitlo Konduri.
} 
apresentados precisam ser vistos como qualitativos mesmo que apresentados numericamente, dado os vieses das coletas assistemáticas.

Foram analisadas 2334 peças Konduri provenientes de áreas muito diversas ao longo dos cursos dos rios Trombetas, Nhamundá e municípios de Óbidos, Juruti e Parintins. Em relação a 582 peças não há nenhuma referência de local de coleta ou apenas denominações genéricas, como "Trombetas", "Nhamundá", "Óbidos" ou “Oriximiná”. Dessa maneira foram selecionadas as amostras de 7 sítios com mais de 50 peças cada e com informações de proveniência mais seguras para poder construir uma perspectiva regional da tecnologia cerâmica. Foram consideradas amostras das coleções Peter Hilbert, Peter Hilbert e Harald Schultz, T-1564 (“Eduardo Galvão") e Aricy Curvello. No caso dos sítios Oriximiná e Cocal foram reunidos os dados disponíveis de materiais de diferentes coleções. As outras amostras são apenas de uma coleção. No total as peças com essas informações de proveniência somam 37, 19\% de toda cerâmica Konduri analisada ().

\begin{tabular}{|l|l|c|l|}
\hline \multicolumn{1}{|c|}{ Coleção } & Ś́tio & 147 & $6,29 \%$ \\
\hline Peter Hilbert e Harald Schultz & Babaçu & 91 & $3,89 \%$ \\
\hline Peter Hilbert e Harald Schultz & Fortaleza & 71 & $3,04 \%$ \\
\hline Peter Hilbert & Serrinha & 217 & $9,29 \%$ \\
\hline Peter Hilbert; Barbosa de Faria & Cocal & 64 & $2,74 \%$ \\
\hline Peter Hilbert; T-1564 & Oriximiná & 158 & $6,76 \%$ \\
\hline Aricy Curvello & Lago Batata & 121 & $5,18 \%$ \\
\hline Aricy Curvello & Posto Aurora II & 869 & $37,19 \%$ \\
\hline TOTAL & & & \\
\hline
\end{tabular}

Tabela 9. Materiais com informação de proveniência destacados ao longo do capítulo.

Além da descrição sistemática, adotamos a estratégia de consultar e fotografar materiais em pequenas coleções e descrever algum atributo de interesse (como 
antiplástico) ou realizar desenhos de perfil e estimativas de diâmetro de orifício. No MPEG foram consultadas as coleções Deborah Magalhães e uma série de pequenos conjuntos denominados "materiais doados" (90, 96, 97, 112, 113). Além dessas peças foram consultadas caixas de material do sítio Greig II (Projeto Arqueológico Porto Trombetas). No MHN 19 fragmentos Konduri entre os materiais coletados dos sítios Takará Velho, Mapuium e Tawanî, no baixo e médio curso do rio Mapuera foram também descritos (ver JÁCOME, 2017). Em 2014, junto com André Prous, fotografamos, medimos e desenhamos o perfil de uma série de fragmentos (404 no total) pertencentes a coleções domésticas na cidade de Oriximiná e em comunidades do lago Sapucuá (Ajará, Castanhal, Conuri, Icatu, Macedônia, São Pedro e São Francisco). Apesar dessas informações não serem sistemáticas, são complementares as obtidas durante o estudo das coleções.

Uma série de fotografias de grandes coleções que não foram estudadas pôde ser consultada a partir da colaboração de outros pesquisadores. Essas imagens serviram para construir uma perspectiva mais abrangente sobre a cerâmica Konduri, apesar de não ter sido realizada nenhuma quantificação ou descrição a partir desta documentação. Fotografias de coleções na Casa de Cultura de Oriximiná/PA, Escola Municipal Santa Maria Goretti (Oriximiná), Centro Cultural João Fona, que fizeram parte do levantamento realizado pelo Projeto Norte Amazônico, foram cedidas por Camila Jácome. Helena Lima nos enviou uma série de fotografias de coleções domésticas reunidas na comunidade de Santa Rita (Parintins/AM), registradas durante a realização do Projeto Baixo Amazonas. André Prous fotografou a pequena coleção Pompeu Sobrinho no Museu do Estado do Ceará e também compartilhou as imagens. Deusdedit Carneiro enviou-nos imagens de 4 peças conservadas no Museu do Estado do Maranhão. Ana Carolina Cunha também contribuiu com fotos de conjunto e individuais tiradas da coleção Protásio Frikel no Museu do Índio (Lagoa Seca, PB). Edithe Pereira enviou registros de peças coletadas por uma moradora em Terra Santa. Além disso, foram consultadas as fotografias do acervo Museu da Cultura Mundial de Gotemburgo disponíveis em uma base de dados online

Em relação às informações acessadas a partir de pesquisas sistemáticas, consideramos especialmente as informações disponíveis em relação aos sítios Aviso I, Bela Cruz I, Bela Cruz II, Boa Vista, Cipoal do Araticum e Greig II na região de Porto 
Trombetas (GUAPINDAIA, 2008; CHUMBRE, 2014; CASTRO, 2018); Oriximiná 3, próximo a foz do rio Trombetas (SCIENTIA, 2013); Tawanî, localizado na foz do rio Mapuera, afluente do médio curso do rio Trombetas (JÁCOME, 2017); e também os sítios Terra Preta 1 e Terra Preta 2, localizados no município de Juruti (SCIENTIA, 2008, 2016; PANACHUK, 2011, 2016a). As áreas escavadas, dimensão das amostras coletadas, metodologias de análise cerâmica são distintas fazendo com que a comparação nem sempre seja possível. Além disso, no caso de sítios multicomponenciais, não foram apresentados os resultados por unidade arqueológica de classificação (Konduri, Pocó, etc.). Dessa maneira, as frequências dos atributos, em muitos casos, aparecem combinadas. Nossa escolha foi por abordar as informações de maneira qualitativa, apenas como um contraponto ao que foi notado a partir das coleções de museu.

\subsection{Conclusão}

As coleções de museu não são um caso absoluto de amostras enviesadas em arqueologia. Muito dos dados arqueológicos foi e continua sendo estatisticamente enviesada, em maior ou menor grau (DRENNAN, 2009). Isso não invalida as pesquisas arqueológicas, mas exige um cuidado com os vieses e suas consequências interpretativas. A escala de estudo e abordagem da pesquisa definem o potencial e as limitações das coleções e amostras. As questões desenvolvidas por cada pesquisa poderão ou não ser respondidas dada qualidade das informações contextuais e sua integridade. Se a escala de análise inclui a estratigrafia dos sítios e diferenças cronológicas, poucas serão as coleções de museu com esse potencial. Kintigh (1981) demonstrou que uma coleção reunida por Leslie Spier, em 1916, ainda mantinha sua representatividade e integridade, permitindo a compreensão de vários contextos. Outras coleções de museu se encontram no gradiente entre boas informações contextuais e sua perda completa. Mesmo no caso de coleções com vieses assistemáticos, é possível produzir proposições válidas ainda que a quantificação tenha que ser entendida como parcial ou totalmente qualitativa.

Os vieses criados pela coleta seletiva de fragmentos, a falta de documentação e a mistura de materiais de diferentes proveniências são desafios para a construção de interpretações confiáveis sobre a produção da cerâmica Konduri. Certos resultados precisam ser considerados com cautela e sempre que possível contraposto às 
informações publicadas sobre escavações sistemáticas. A existência de informação relativamente seguras de proveniência para vários sítios, alguns com centenas de fragmentos, permite produzir um levantamento (ou prospecção) preliminar da variabilidade formal em escala regional. Essas informações poderão ser avaliadas e incluídas no estudo dos materiais dessas áreas específicas em estudos futuros. A combinação desses conjuntos materiais e informações permite $\mathrm{o}$ avanço do conhecimento como "coleção de referência", ao mesmo tempo em que permite ter uma dimensão quantitativa de materiais que são à base da principal referência sobre a cerâmica Konduri. 


\section{Capítulo 4 - A cerâmica Konduri em perspectiva regional}

“(...) le terme culture désigne une question, et non une réponse.”

(Tim Ingold in DESCOLA; INGOLD, 2013, p. 46)

In the archaeological idiom of artifacts, tradition acts as a time-binding glue that holds together culture history, arguably archaeology's major contribution to world knowledge. Without tradition, prehistory crumbles into a jumble of curios (DeBOER;

SUNDSTROM, 2012, p. 1)

As unidades arqueológicas na arqueologia amazônica foram construídas principalmente a partir das técnicas decorativas e dos tipos de antiplástico (MACHADO, 1991). O caso Konduri, apesar de sua história de construção particular, não é diferente. Sua característica diagnóstica é a decoração que combina incisão, ponteado, entalhes e modelagem, qualificada como "grotesca", "sobrecarregada", "barroca”, "tom de rococó" (NIMUENDAJÚ, 2004; BARATA, 1950; HILBERT, 1955; PROUS, 1992). A isso são somados atributos morfológicos como a presença de pés cônicos e apêndices modelados, vasilhas muito rasas e abertas e também padrões gráficos característicos (ALVES, 2018). A ênfase em atributos decorativos não é um problema em si quando é possível identificar eixos de coerência relacionados a conhecimentos adquiridos e transmitidos dentro de uma cadeia operatória. É isso que mostra Gosselain $(2016,2017)$ a partir do caso etnográfico da tradição policrômica do Niger. Essa tradição tecnológica (ou estilo) é marcada pelo uso particular de técnicas decorativas e algumas morfologias em uma região de mais 50 mil km com significativa variabilidade entre as etapas de cadeia operatória em cada área. A construção de uma unidade analítica, como a tradição policrômica do Niger, permite formular hipóteses para explicar os processos históricos que resultaram em sua formação (GOSSELAIN, 2018). De maneira análoga, um estilo técnico Konduri deve ser visto por princípio como um continuum de variações, formando um agregado de processos técnicos e históricos direcionados por redes de transmissão de conhecimento. 
O contínuo e o descontínuo são produto das premissas e das escalas analíticas (KNAPPETT, 2011).

Este capítulo é uma tentativa preliminar de sintetizar os dados obtidos durante a análise das coleções e também algumas informações disponíveis na bibliografia, inspirada em Gosselain (2016, 2017) e Schiffer e Skibo (1987). Seu objetivo é pensar a cerâmica Konduri como um modo de fazer oleiro característico no espaço e no tempo. Em A cerâmica arqueológica da região de Oriximiná, Peter Hilbert (1955a) apresentou uma "descrição qualitativa" das amostras. Apesar de sua estratégia ter sido positiva para criar uma imagem coerente, a análise sistemática mostra que, existem elementos menos frequentes que também precisam ser considerados. Queremos aqui retomar a sugestão do autor de que existiram diferenças "na qualidade do material empregado e também no cuidado do cozimento", na "qualidade artística" e também "particularidadesestilísticas locais" (HILBERT, 1955, p. 72). Muito do que foi dito por Hilbert (1955a) será aqui revisto e, em muitos casos, reafirmado e expandido. Este capítulo pode ser lido em continuidade às formulações iniciais, atualizando o estado da arte sobre a cerâmica Konduri. Como naquela monografia, foi necessário adotar uma escala regional para abarcar amostras com populações reduzidas, com informações contextuais variadas e vieses de coleta que enfatizam apliques e fragmentos decorados.

\subsection{Dispersão geográfica e cronologia do estilo}

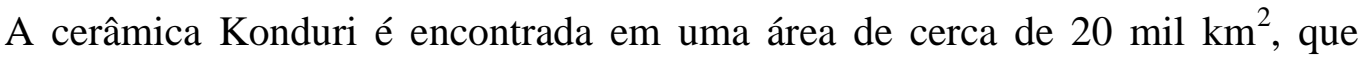
engloba na margem esquerda do rio Amazonas, parte do curso dos rios Nhamundá e Trombetas e chegando até as imediações do município de Óbidos (PA); e na margem direita, desde o lago Salé, em Juruti (PA) até a porção ocidental do município de Parintins (AM). Foi possível chegar a essa dispersão territorial a partir do levantamento de coordenadas geográficas em publicações (FONSECA, 2018; SCIENTIA, 2003, 2014, 2016; LIMA, 2005; PANACHUK, 2016a; MARIANO, 2017), relatórios de pesquisa e um banco de dados cedido pelo professor Klaus Hilbert, formando a partir de suas pesquisas no baixo Amazonas com coordenadas coletadas no Google Earth. Este último banco de dados foi utilizado por Groote-Bidlingmaier (2016, p. 148) para construir um modelo territorial da ocupação Konduri. Esse modelo, entretanto, prevê uma área muito menor do que a levantada na margem direita do rio Amazonas. A autora considerou apenas o sítio Santa Rita na margem direita, sendo que foram identificados 
dezenas de sítios em levantamentos realizados pela Scientia Consultoria (2003). O território calculado na margem norte parece bastante coerente, apesar de sabermos pouco ainda sobre sua ocorrência extremo-oriental. Nosso levantamento considerou um número maior de fontes de informação para esta área permitindo formar um cenário mais amplo. Foram excluídos sítios cuja associação ao estilo Konduri ainda não está clara em várias áreas, como em Juruti, com sítios de "ocupação indígena" sem definição de estilo/fase (SCIENTIA, 2003) ou nos rios Mapuera, Cachorro e Médio Trombetas (ARAÚJO COSTA et al., 1986; JÁCOME, 2017). A área próxima a Cachoeira Porteira (médio Trombetas), a montante de Porto Trombetas, e os sítios mais a oriente da dispersão Konduri deixam dúvidas sobre sua relação com a cerâmica Konduri. Mais pesquisas são necessárias para compreender o contexto local.

O mapeamento atual parece representar o "núcleo" ou "centro" da dispersão. As margens principalmente em áreas de terra firme são praticamente desconhecidas. Esse é o caso do baixo/médio curso do rio Erepecuru. Hilbert (1955a) informa que Protásio Frikel identificou sítios com cerâmica Konduri na área, mas as pesquisas ainda não foram retomadas. Da mesma maneira, o médio/alto curso do rio Nhamundá ainda não foi prospectado em nenhuma pesquisa arqueológica. Apesar da identificação de material Konduri a oeste de Parintins ainda sabe-se pouco sobre os sítios e qual a frequência de material caracteristicamente relacionável ao estilo. O mesmo acontece na outra extremidade nos municípios de Óbidos, Curuá e Alenquer onde foram identificados alguns fragmentos Konduri, mas estes parecem ser achados isolados em meio a outros estilos cerâmicos (HILBERT, 1959). O sítio São Gonçalo na comunidade de Sucurijú, próximo à cidade de Óbidos, foi classificado como relacionado à cerâmica Santarém, a partir de uma prospecção recente (MARIANO, 2017), mas o material com essa referência na coleção reunida por Barbosa de Faria mostra exemplares característicos da cerâmica Konduri e de cerâmica não-local associados. Na extremidade setentrional, Araújo-Costa et al. (1986) identificaram vários sítios cuja cerâmica quase não apresenta a decoração ou os antiplásticos característicos no rio Trombetas, acima de Cachoeira Porteira, e no rio Cachorro. Leonor Valentino (com. pess., 2018) encontrou nessa área um vaso torácico característico da cerâmica Koriabo, por exemplo. Os trabalhos do Projeto Norte Amazônico mostraram que, no caso do médio alto curso do rio Mapuera, o maior afastamento do rio Trombetas representa também o aparecimento de outro estilo, que pode ser vinculado à fase Tarumã (JÁCOME, 2017). No caso da margem 
direita da foz do rio Nhamundá, sabemos que a dispersão não deve ser muito maior devido à presença de sítios com a cerâmica Paurá no lago homônimo e em Remanso (NIMUENDAJÚ, 2004). As margens do Paraná de Ramos são, como no caso de Óbidos, ainda uma incógnita porque são encontrados exemplares da cerâmica Konduri, mas também elementos semelhantes ao estilo Paurá.

À medida que o conhecimento arqueológico for sendo ampliado em relação aos limites da dispersão do estilo Konduri, será possível discutir em maior profundidade o seu significado. As informações disponíveis sugerem áreas contíguas entre estilos cerâmicos distintos. No ocidente do Lago Grande de Curuaí, por exemplo, Nimuendajú (2004) encontrou cerâmicas Konduri associada a outras do estilo Santarém. No baixo/médio curso do rio Mapuera, com exceção do sítio Tawanî, a cerâmica Konduri é encontrada em baixa frequência associada uma cerâmica com antiplástico predominantemente mineral (JÁCOME, 2017). O mesmo pode ocorrer na margem do rio Amazonas no município de Óbidos (MARIANO, 2017). Esse material Konduri minoritário pode ser resultado de trocas de objetos e/ou circulação de pessoas na região - um tema que será retomado no próximo capítulo. Diferenças abruptas entre estilos ou a existência de vazios ou buffer zones, por sua vez, podem indicar relações de evitação ou conflito (DeBOER,1981). Considerando as evidências disponíveis, é mais provável um cenário de interações com uma contiguidade de áreas ocupadas por produtores de estilos distintos. 


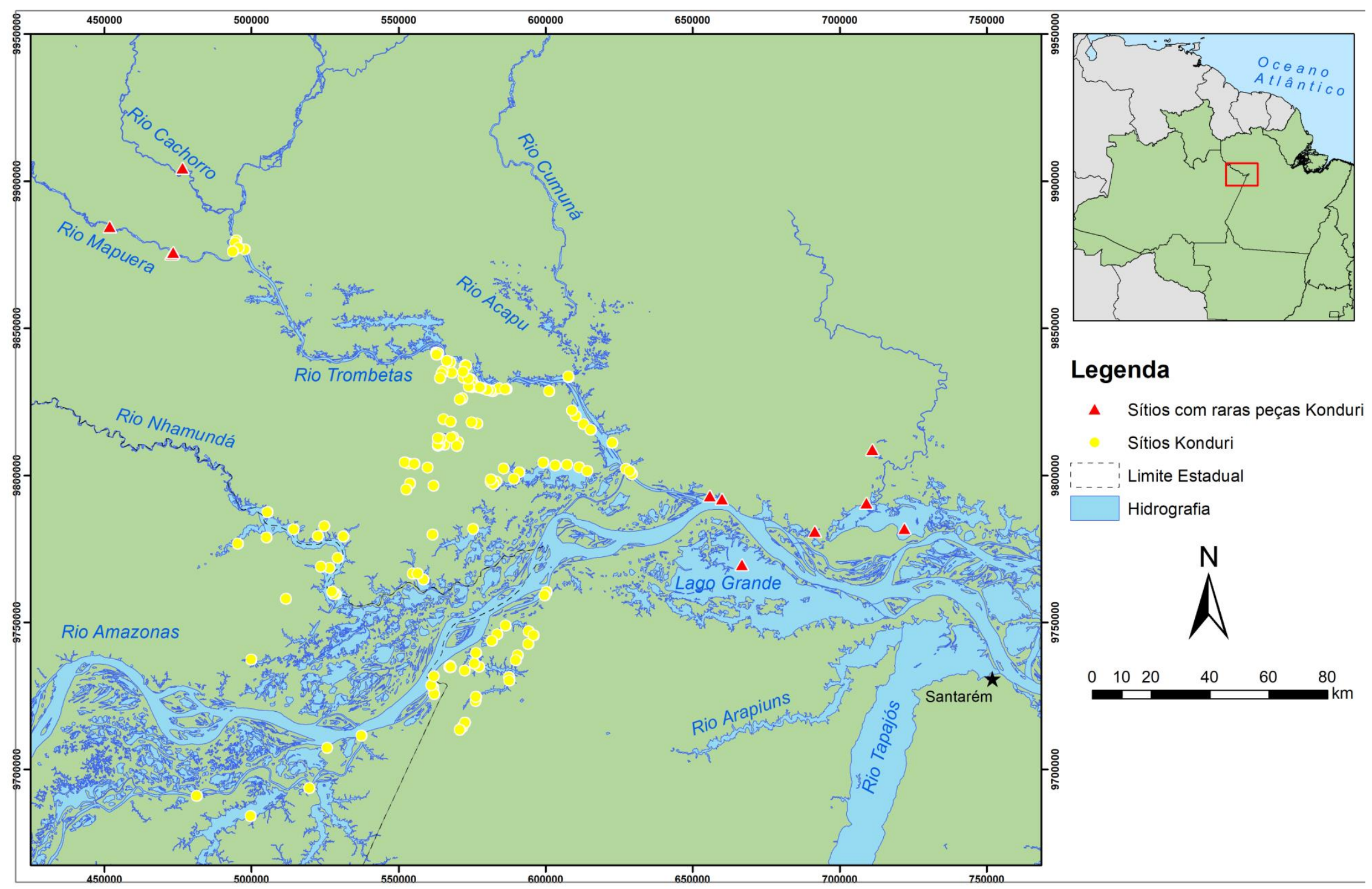

Mapa 5. Localização de sítios arqueológicos com cerâmica Konduri. Dados reunidos a partir da bibliografia e levantamento por meio do programa Google Earth realizado por Klaus Hilbert (sd) para o rio Nhamundá. 


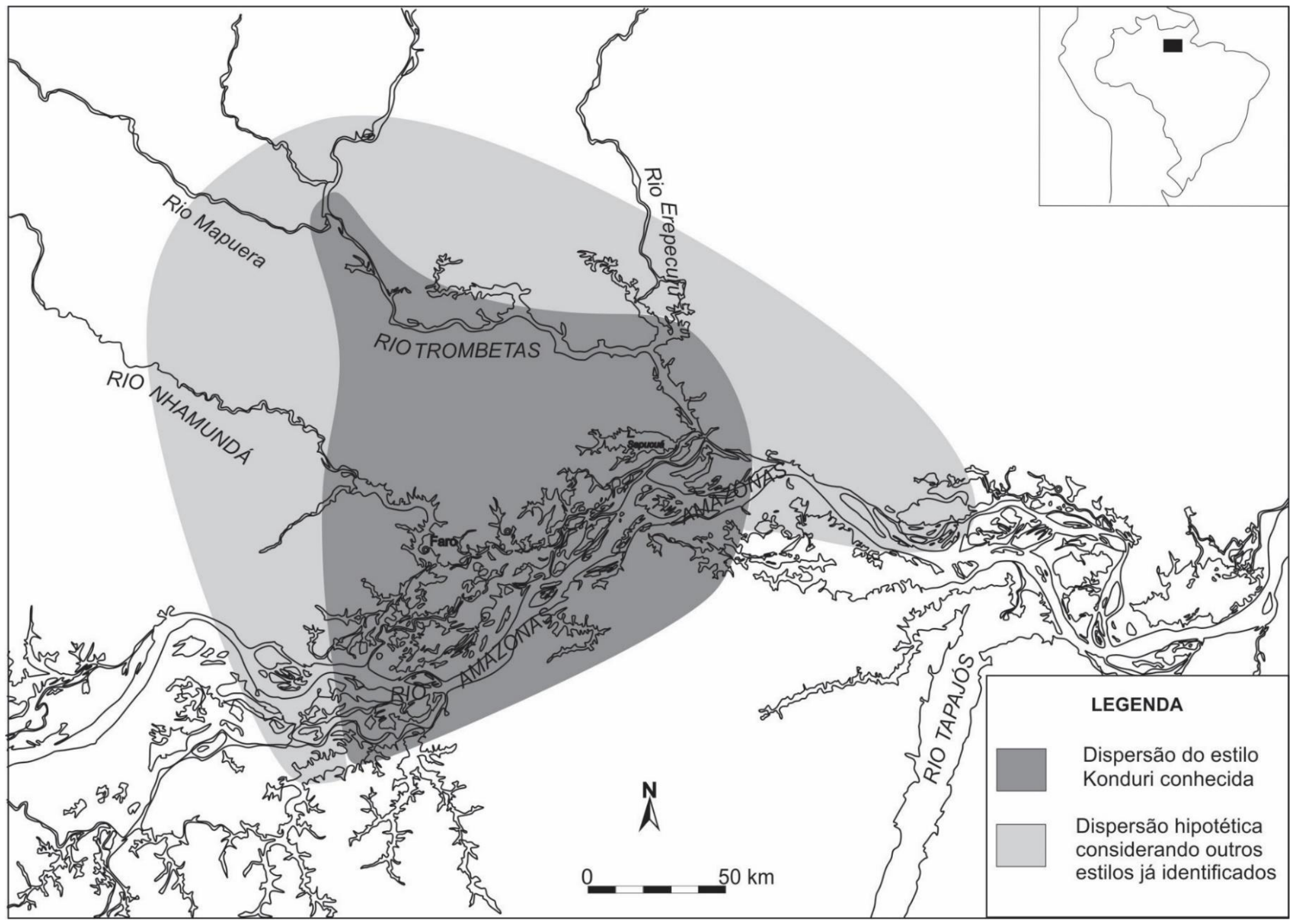

Mapa 6. Dispersão aproximada da cerâmica Konduri e uma possível dispersão ainda especulativa sobre áreas desconhecidas. 


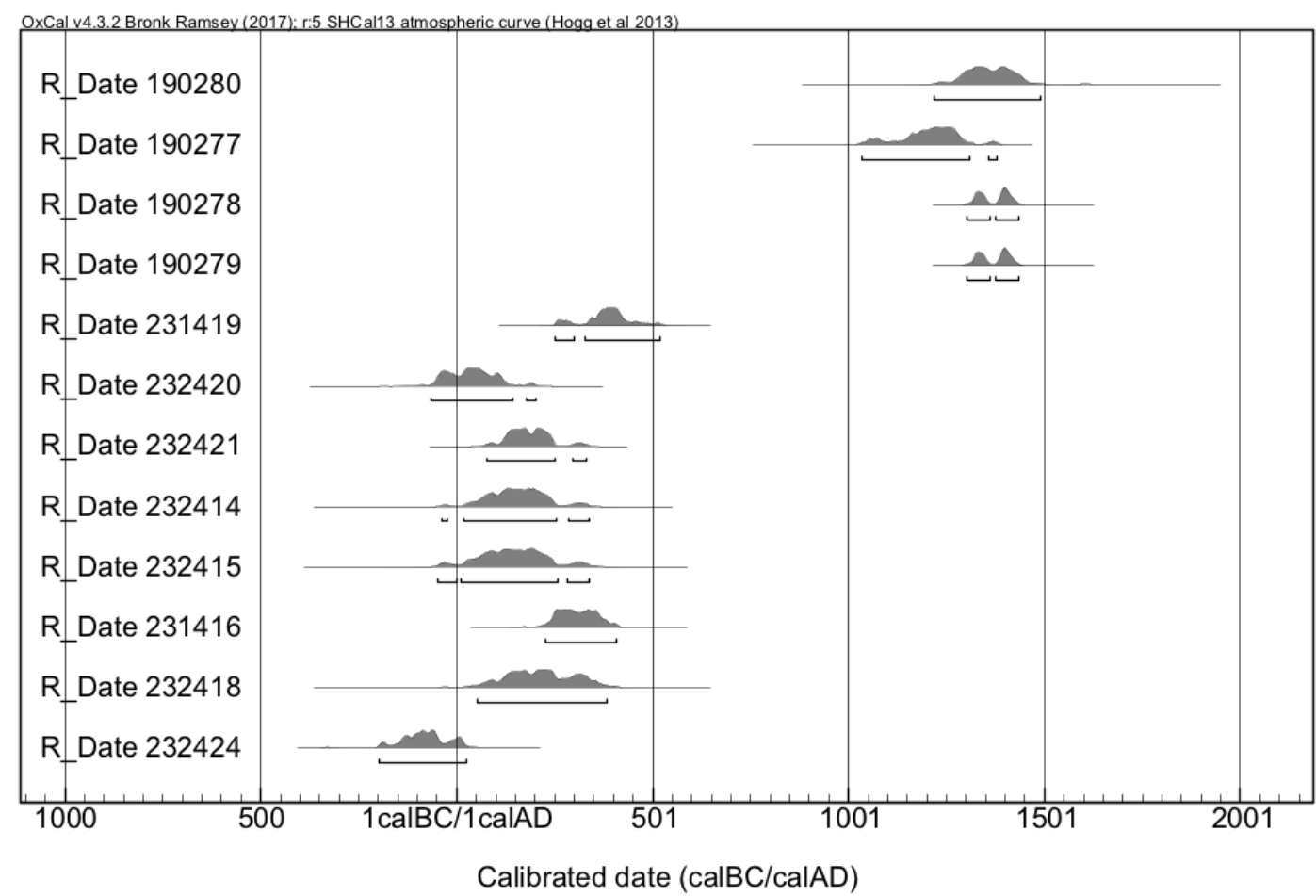

Gráfico 4 Datações calibradas obtidas para o sítio Boa Vista entre 500 a.C e 1500 AD a partir de informações publicadas em Guapindaia (2008). Fonte: OxCal v4.2.4 (Ramsey; Lee, 2013), r:5 SHCal13 atmospheric curve (Hogg et al., 2013)

Em termos estratigráficos, há em relação aos sítios multicomponenciais um problema ainda em debate, como mencionado no Capítulo 1. Ao mesmo tempo em que se propõe um hiato ocupacional entre as ocupações produtoras de cerâmica Pocó e Konduri, materiais desses dois estilos são encontrados nos mesmos níveis estratigráficos (GUAPINDAIA, 2008; GUAPINDAIA; LOPES, 2011; GUAPINDAIA; FONSECA, 2013; PANACHUK, 2016a; CHUMBRE, 2014). Chumbre (2014, p. 158) chegou a propor que a presença desses materiais distintos indicaria "uma coexistência, onde as inter-relações deveriam se dar na prática cotidiana". A ausência de hiato no sítio Cipoal do Araticum pode, por outro lado, estar ligada a perturbações desenvolvidas ao longo de diferentes reocupações dos sítios, como na Amazônia Central (MACHADO, 2005).

As datações radiocarbônicas disponíveis ainda não são muito numerosas e o problema de contaminação das amostras oferece um problema adicional. No caso do sítio unicomponencial Aviso I, por exemplo, das três datas obtidas, duas ofereceram uma antiguidade superior a dois mil anos e foram descartadas. No caso dos sítios 
multicomponenciais pode ser mais difícil diferenciar. A cronologia do sítio Boa Vista, por exemplo, oferece um hiato de cerca de 700 anos entre as datações mais antigas, dos primeiros séculos da era cristã (até séc. VI) e as datas posteriores ao ano 1000 AD (Gráfico 4). Em Juruti, nos sítios Terra Preta 1 e 2, a cronologia é semelhante tendo em vista a margem de erro, formando um hiato de sete ou oito séculos entre o começo da era cristã e as datas posteriores ao ano mil. As datações disponíveis para o sítio Cipoal do Araticum deixam o quadro um pouco mais complicado porque há uma aparente continuidade a partir do Anno Domini até o período colonial (Gráfico 5).

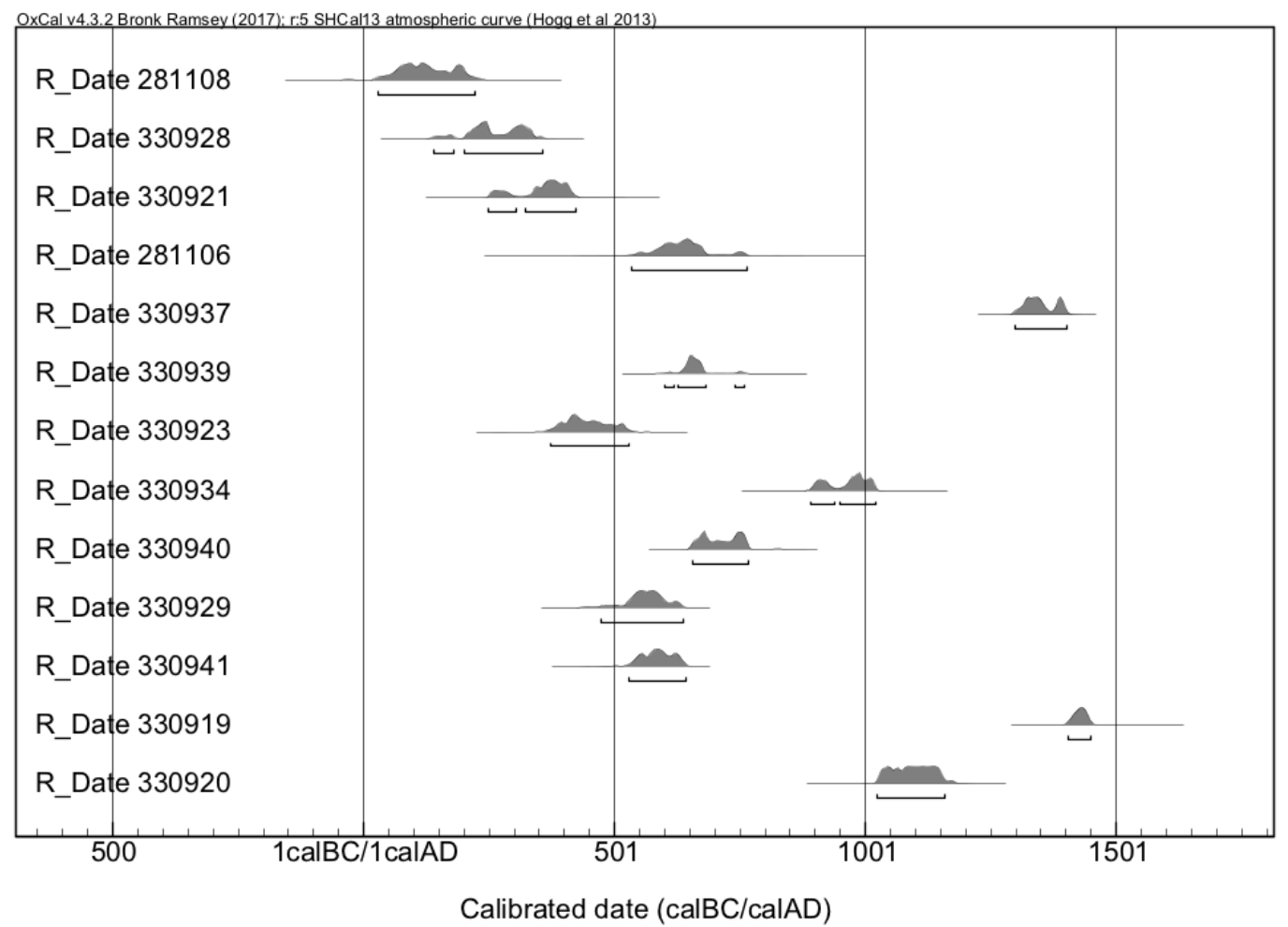

Gráfico 5 Datações obtidas para o sítio Cipoal do Araticum entre 500 a.C e 1500 AD publicadas em Guapindaia e Fonseca (2013) . Fonte: OxCal v4.2.4 (Ramsey; Lee, 2013), r:5 SHCal13 atmospheric curve (Hogg et al., 2013).

Guapindaia e Fonseca (2013) construíram um modelo de ocupação deste sítio baseando-se na variação da extensão da terra preta em profundidade (expansão e retração) e as datações obtidas. Esse modelo se baseia no pressuposto de uma sequência ocupacional dividia entre início $(100-80 \mathrm{~cm})$, consolidação $(70-40 \mathrm{~cm})$ e abandono $(30-$ superfície). Nesse modelo, entretanto, há uma sobreposição entre a cronologia do período de intensificação e o de abandono. Provavelmente, isso ocorreu porque os 
autores correlacionaram diretamente à profundidade do pacote arqueológico e os períodos de ocupação. Parte da conclusão apresentada por Chumbre (2014) de uma coexistência entre produtores de cerâmica Pocó e Konduri está alicerçada neste modelo. Há pelo menos três datações que levam a essa conclusão: uma de 893 e 1023 cal AD e outras duas de respectivamente 601 a 761 e 656 a 767 cal. AD.

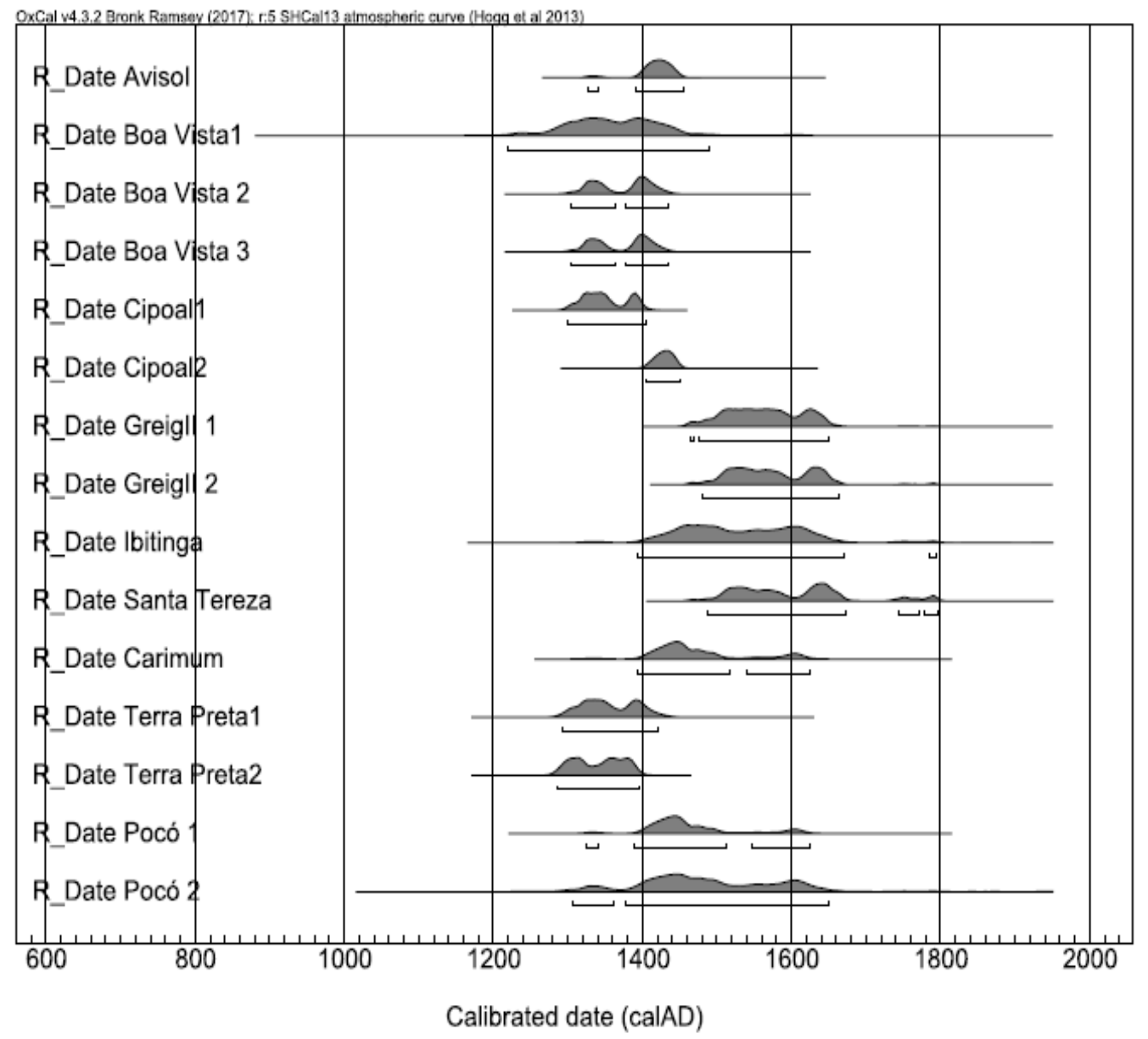

Gráfico 6 Datações radiocarbônicas publicadas e inéditas posteriores ao ano 1000 AD em sítios com cerâmica Konduri. Fonte: Hilbert; Hilbert, 1980; Guapindaia, 2008; Guapindaia; Chumbre, 2012; Guapindaia; Fonseca, 2013; Panachuk, 2016a; Hilbert, sd. Fonte: OxCal v4.2.4 (Ramsey; Lee, 2013), r:5 SHCal13 atmospheric curve (Hogg et al., 2013).

Outra interpretação é possível se a data mais recente entre o primeiro e o segundo milênio obtida para o sítio Cipoal do Araticum for desconsiderada ao menos até novos dados serem publicados. Haveria um hiato semelhante ao identificado em 
outros sítios, com 550 anos entre a ocupação Pocó e Konduri. Ao invés de um momento de "abandono", a ocupação menos densa desse sítio poderia ser entendida como resultado de uma reocupação Konduri, que tendem a ser menos densas na terra firme (GUAPINDAIA, 2008). O hiato cronológico entre ocupações do início da era cristã e outras posteriores ao ano mil também foi identificado no baixo Urubu (STAMPANONI, 2016) e no baixo Tapajós (STENBORG, 2016; GOMES, 2016a), indicando que esse é um fenômeno geograficamente mais amplo.

Há, ao todo, nove datas publicadas na área de dispersão da cerâmica Konduri posteriores ao ano $1000 \mathrm{AD}$, com exceção daquela desconsiderada, obtida no sítio Cipoal do Araticum (Gráfico 6). Outras três não-publicadas foram obtidas para o sítio Greig II pelo Projeto Arqueológico Porto Trombetas (GUAPINDAIA; CHUMBRE, 2012). Uma delas da mesma maneira que no sítio Aviso I remonta a cerca de dois mil anos, o que é incoerente com um sítio unicomponencial raso em terra firme e, por isso, pode ser descartada. As outras duas são bastante recentes sugerindo uma ocupação até o século XVII AD. Peter e Klaus Hilbert pesquisando o sítio Santa Tereza, próximo a cidade de Oriximiná, obtiveram uma datação do mesmo período. Em 1992, Klaus Hilbert também obteve mais duas datas para sítios do baixo Trombetas do mesmo período (Carimum e Ibitinga) e mais uma para o sítio Pocó, no baixo Nhamundá. Reunidas essas datações radiocarbônicas, temos uma cronologia que provavelmente cobre o final do século XIII e alcança a primeira metade do século XVII AD. Com os dados disponíveis ainda não é possível construir hipóteses sobre a dispersão do estilo em uma perspectiva diacrônica.

A produção do estilo cerâmico, como as datações sugerem, alcança o início do período colonial, como acontece com os estilos Santarém e Saracá, no baixo Tapajós e baixo Urubu (STAMPANONI, 2016; GOMES, 2016). O ouvidor-mor Maurício de Heriarte (1874 [1662], p. 39), em um texto datado de 1662, menciona, por exemplo, que os índios do rio Trombetas faziam de um "finíssimo barro (...) muito e boa louça de toda sorte". As datações obtidas para o sítio Santa Tereza, Ibitinga, Greig II e Pocó são contemporâneas à expedição de navegação do rio Amazonas chefiada por Pedro Teixeira entre 1637 e 1639. Cristobal de Acuña (1941 [1639]), que fez parte dessa expedição, relatou a brutalidade da conquista dos Tapajó, na atual cidade de Santarém, por Bento Maciel e a escravização de indígenas. Longe de ser um evento isolado, na 
segunda metade do século XVII, limite conhecido da cronologia do estilo Konduri, houve uma e intensificação da colonização europeia no baixo Amazonas, com a expansão das missões religiosas e expedições de captura de escravos (HARRIS, 2015, 2018). João Felipe Betendorff (1910 [1698], p. 499), por exemplo, visitou o rio Trombetas de "bellas praias de arêa e lindos outeiros", onde existia uma base de atuação jesuíta entre os Conduri denominada Maruapig. Serafim Leite (1943) localiza a Aldeia Maruapig próximo à foz do rio Erepecuru, na margem esquerda do rio Trombetas. Nessa época ele menciona uma incursão realizada por um cabo João Seixas a áreas mais distantes da foz.

Em 1691, Samuel Fritz relata que entre a aldeia Tapajós (atual cidade Santarém) e a Ilha de Tupinambarana (atual município de Parintins) seguindo rio Amazonas não havia nenhum assentamento. Sobre os habitantes do rio Trombetas, o cronista cita que "[o]n the north bank among some hills the Condurises live" (FRITZ p. 1922 [1691], 71 - grifo nosso). A presença europeia na área pode ter levado a ocupação de áreas mais afastadas, entre as montanhas, com um abandono de ilhas como a Paru, no rio Amazonas. Vindos do Xingu, foram trazidos os indígenas Pauxi, falante de língua Tupi, para onde hoje se situa Óbidos. Na Ilha de Tupinambarana, os cronistas registraram as migração dos Tupinambá, fugindo da dominação portuguesa na costa brasílica e em busca do "paraíso terreal” (ACUÑA, 1941 [1639]). A chegada deste grupo, muito mais belicoso que os autóctones, deve ter tido consequências para os produtores do estilo Konduri no começo do período colonial, que possivelmente foram expulsos da área ou se tornaram "vassalos".

O começo do século XVIII é o marco para o despovoamento indígena do baixo curso dos rios Trombetas, Nhamundá e a margem direita do Amazonas. O padre Francisco de São Manços relata que reuniu indígenas "Babhuis" (Uaboy) no rio Trombetas em 1725 e os levou para São João Batista de Nhamundás, atual cidade de Faro (PORRO, 2008). Dois anos mais tarde as expedições dos religiosos chegaram até o alto curso do rio Mapuera. Os indígenas dessa área, como os Parucuató (Parukoto), já mantinham contato com os holandeses, com os quais realizavam trocas (PORRO, 2008, p.392). Ao longo das décadas seguintes, o baixo Trombetas já não mantinha uma população indígena fora dos aldeamentos católicos. Como propõe Harris (2018), o trecho encachoeirado do rio, a partir de Cachoeira Porteira, serviu para um "auto- 
isolamento". Não sabemos até que ponto os indígenas produtores do estilo Konduri migraram para as cabeceiras e afluentes do rio Trombetas e se tinham alguma ligação direta com as nações mencionadas no Mapuera. A história oral dos Wai Wai nessas áreas incluiu o baixo Trombetas e as cidades de Óbidos e Oriximiná (JÁCOME, 2017).

O estudo de dendrocronologia realizado com castanheiras-do-brasil (Bertholletia excelsa) no platô Almeida, na região de Porto Trombetas, estimaram a idade média de uma árvore em 300 anos e outra, mais grossa, de 502 anos. Scoles (2011) argumenta que provavelmente as florestas com alta densidade de castanheiras na região se desenvolveram durante o início da colonização e são um resultado indireto do abandono forçado dos indígenas de suas áreas de habitação entre os séculos XVII e XVIII. Talvez, ao invés de um sítio utilizado para fins rituais (CASTRO, 2018), Greig II, datado do século XVII, e suas idiossincrasias, como ausência de terra preta e localização sobre um platô, reflitam as mudanças trazidas pelas frequentes portuguesas na região.

\subsection{Cadeia operatória e variabilidade técnica}

As cadeias operatórias são “documentos históricos” cuja variabilidade tecnológica permite inferir diferentes processos e relações ao longo do espaço e do tempo. Cada etapa de produção de uma vasilha cerâmica está relacionada a vários conhecimentos reunidos ao longo da vida de um oleiro/a. Esse saber resulta de experimentações individuais e coletivas em relação a performance das matérias e instrumentos e sua transmissão ao longo de gerações (SCHIFFER; SKIBO, 1987, 1997). Por meio de imitação, explicação verbal e demonstração forma-se um engajamento como "pistas" para a percepção reatualizadas na produção de cada vasilha e interesse em suas performances (INGOLD, 2000). Na escala de produção doméstica (household production), como é provável que tenha sido no caso Konduri, as pessoas que transmitem esse conhecimento são, em geral, entre parentes, moradores de uma mesma aldeia ou aldeias com vínculos sociais estabelecidos (ver HERBICH, 1987). A mobilidade dessas pessoas entre diferentes áreas ou regiões e a interação entre pessoas com conhecimentos distintos pode se levar a adoção de práticas de práticas desconhecidas em uma dada comunidade. Isso pode ocorrer tanto em relação a coletivos em que compartilham grande parte de seus modos de fazer (talvez, língua e costumes) quanto entre coletivos que produzem objetos a partir de maneiras marcadamente diferentes. Por princípio, “[a]rtifacts and chaîne opératoires like individuals and socials 
groups, are not clearly bounded and monolithic units, but complex, dynamic, and profoundly mixed constructions" (GOSSELAIN, 2000, p. 208).

A partir das coleções analisadas e resultados publicados selecionamos onze atributos que podem oferecer uma perspectiva regional ao estilo Konduri. Os estilos técnicos dispersos em uma área tão ampla devem, em princípio, exibir variabilidade interna resultante de fatores diversos como disponibilidade de recursos na paisagem, resistência à difusão de alguma inovação, contatos com outras tradições oleiras ou a preferência por determinados materiais causada por divergências sociais, políticas ou ideológicas. A observação dessas divergências, no entanto, depende da resolução e densidade das informações arqueológicas disponíveis. Nossa amostra apresenta vários problemas de vieses que serão, na medida do possível, contraposta as informações obtidas em escavações sistemáticas.

\subsubsection{Inclusões}

A cadeia operatória da produção cerâmica é composta de diferentes etapas de produção. A seleção e coleta de matérias primas, como argila, temperos e combustível, é a primeira etapa para a manufatura de vasilhas cerâmicas. As inclusões não plásticas presentes nos objetos cerâmicos são os elementos mais visíveis arqueologicamente dessa etapa de manufatura, bem como a obtenção de pigmentos e resinas para acabamentos de superfície. A presença de inclusões pode resultar tanto da adição de materiais a argila (temperos) quanto da seleção de argilas que contenham naturalmente inclusões. Esses materiais agem na secagem e queima, diminuído os efeitos da retração da argila e evitando rachaduras (RICE, 1987). Os efeitos desses materiais vão muito além, modificando as características de performance durante o uso em termos de resistência mecânica, térmica, de abrasão e também porosidade, peso, etc. Essas características podem, e geralmente são, consideradas durante a produção.

A cerâmica Konduri apresenta tanto inclusões de origem orgânica e quanto inorgânica. Os elementos orgânicos são espículas silicosas de esponja (cauixi), casca de árvore silicosa carbonizada (caraipé) e carvão. Guapindaia (2008) identificou no sítio Aviso I alguns exemplares com concha. Os materiais inorgânicos são quartzo, óxido de ferro, mica, feldspato, bolotas de argila (clay pellets) e caco moído ou chamote. O caraipé é o único na cerâmica Konduri que sem sombra de dúvidas foi adicionado, uma 
vez que sua transformação ao estado atual necessariamente resulta da ação humana. As espículas de esponja são geralmente consideradas elementos adicionados à cerâmica na arqueologia amazônica. Exemplos etnográficos na Amazônia atestam a prática da adição de esponjas queimadas (LIMA, 1950; BARCELOS NETO, 2005-2006; LINNÉ, 1932; MACHADO, 1947; MÉTRAUX, 1948). Diferente do caraipé, não é necessário pilar o cauixi, que depois de queimado, desmancha facilmente. Em áreas de Cerrado, entretanto, foi identificada cerâmica pré-colonial produzida com argila associada naturalmente a espículas (espongilito) (RODRIGUES et al., 2017.). Não se conhece a formação de espongilitos na bacia amazônica, mas é possível encontrar espículas em lagos jovens e colunas d'água (COSTA et al., 2004b). Na região dos rios Trombetas, Nhamundá e no município de Juruti, esponjas de água doce são encontradas presas a galhos de árvores nas margens de lagos durante o período de vazante ou "verão". Panachuk (2016c, p. 39) menciona que durante uma pesquisa etnográfica no município de Juruti, as ceramistas falavam que "só de pegar na argila é possível perceber o cauixi”. A observação com a lupa binocular da argila confirmou a observação feita pelo tato. Isso levou a pesquisadora a propor a hipótese que durante o período pré-colonial também teria sido usada argila com a presença natural de cauixi (p.40). Morais (2013, p. 126) também relata que o ceramista indígena Everaldo Munduruku, no baixo Tapajós, utiliza argila com cauixi presente na fonte. Em áreas próximas, alguns pesquisadores, entretanto, apresentaram argumentos para a adição intencional do cauixi. Gomes (2002), a partir de análises da zoóloga Cecília Volkmer-Ribeiro, concluiu que o cauixi seria adicionado devido à presença de "feixes" de espículas, que dificilmente se conservam unidas em condições naturais. Stampanoni (2016) considera que a alta concentração na qual o cauixi aparece em cerâmica Saracá (rio Urubu) deve resultar de uma mistura. Ainda não foram pesquisadas sistematicamente fontes de argila na área de dispersão da cerâmica Konduri para verificar qual a disponibilidade e concentração de espículas.

Nos estudos de cerâmica Konduri tem sido destacada a presença de caco moído na cerâmica (GUIMARÃES, 1985; GOMES, 2002; GUAPINDAIA, 2008; CHUMBRE, 2014; JÁCOME, 2017). Esse elemento é um dos mais facilmente relacionáveis a adição intencional, como o caraipé. É caracterizado por sua dureza igual ou superior a da matriz cerâmica, angulosidade, limites bem definidos e, às vezes, coloração variada. As bolotas de argila são arredondadas, alongadas, com limites difusos, e uma dureza menor 
que a da cerâmica. O caco moído é um elemento adicionado intencionalmente enquanto as bolotas de argila são resultado do contexto de deposição das argilas ou a mistura de diferentes argilas. A análise das coleções mostrou elementos com características um pouco distintas das esperadas, como elementos relativamente duros e bem definidos, mas arredondados, mas com baixa concentração na pasta. Em uma fotografia publicada por Costal et al. (2009) com a identificação "caco moído" é possível observar o mesmo arredondamento. A cor destes elementos tende a ser amarelada, sendo sua composição mais ou menos homogênea, com rara presença de cauixi ou quartzo. A dureza e a textura desses elementos assemelham-se ao dos elementos avermelhados como óxidos de ferro. Parte desses antiplásticos podem ser "fragmentos de rocha argilosa", seguindo a caracterização proposta Whitbread (1986). Tais elementos são detritos litificados presentes naturalmente na argila e solos, mas que podem ter sido selecionados e misturados. A dureza, limites bem delimitados e angulosidade são características que podem ser compartilhadas com o caco moído. Se os fragmentos de rocha tiverem sido muito transportados, entretanto, eles podem ser arredondados. Rocha (2017) destacou a presença desses três elementos na cerâmica do médio Tapajós e os problemas para diferenciá-los.

Costa et al. (2004a) e Guapindaia (2008) mencionam quartzo muito anguloso e feldspato não intemperizado ("rocha triturada") como indicador de seu processamento intencional na bacia do rio Trombetas. No sítio Oriximiná 3 também foram identificadas peças com grãos de quartzo angulosos, remetendo a trituração de minerais. O mesmo pode ter acontecido com a coleta e adição de areia, disponíveis nas praias de lagos e rios, como parece sugerir a última autora. Não foi realizada uma observação sistemática da angulosidade dos antiplásticos, mas, a maioria dos elementos minerais observados tende a ser subangulares e subarredondados. Estes aparecem em baixa frequência, geralmente associados a outros elementos. Tais características levam a crer que não foram adicionados intencionalmente.

Nas amostras analisadas o cauixi é o elemento antiplástico predominante, sendo encontrado em mais da metade das peças (53,6\%) (Gráfico 7). Em outros 11,1\% as espículas aparecem combinadas a quartzo, óxido de ferro e inclusões argilosas. Há uma grande diversidade de permutações entre os antiplásticos, apesar de estas não serem muito expressivas numericamente. $\mathrm{Na}$ categoria "outros" foram incluídas 26 
possibilidades de combinações identificadas, com apenas um tipo de elemento ou reunido quatro tipos diferentes em um mesmo fragmento. Todos os elementos antiplásticos ocorrem isolados, mas os minerais, bolota de argila e carvão são pouco frequentes nessa configuração. Esses resultados confirmam a observação apresentada por Guapindaia (2008) de que, apesar da ênfase no cauixi, há uma grande varibiliade dos antiplásticos na cerâmica Konduri. Hilbert (1955a) não realizou uma análise sistemática com uma lupa.

A predominância do cauixi isolado como antiplástico é constante nas amostras de sítios do baixo e médio rio Trombetas, baixo Nhamundá e município de Juruti. Isso, no entanto, pode ser resultado dos vieses da seleção realizada pelos coletores e colecionadores. A alta frequência de cauixi, por exemplo, pode estar vinculado a um determinado conjunto de vasilhas e variar regionalmente de uma maneira mais marcada (Gráfico 7).

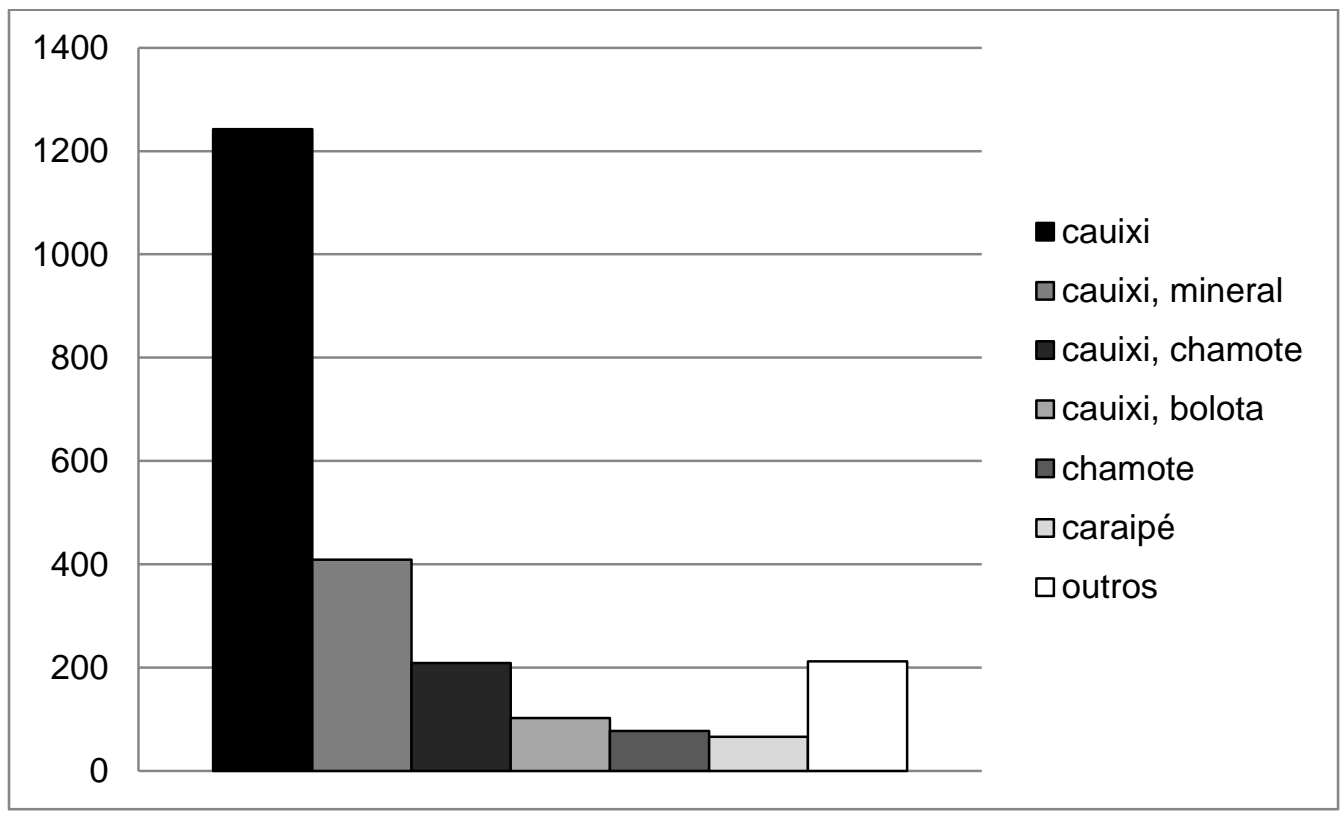

Gráfico 7. Frequência de combinações de antiplástico nas peças Konduri analisadas neste estudo.. 


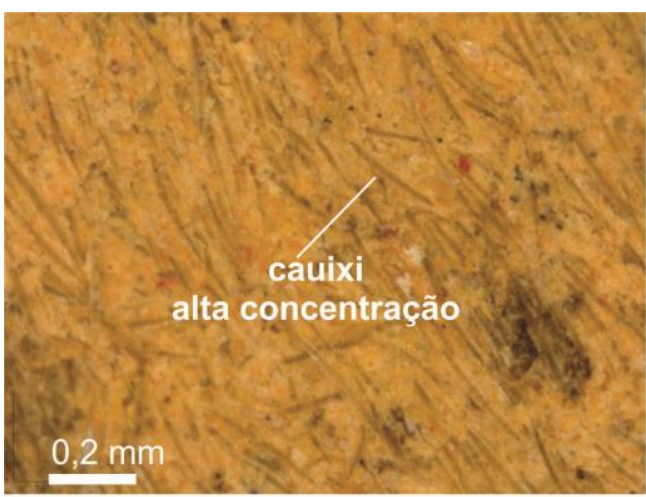

a

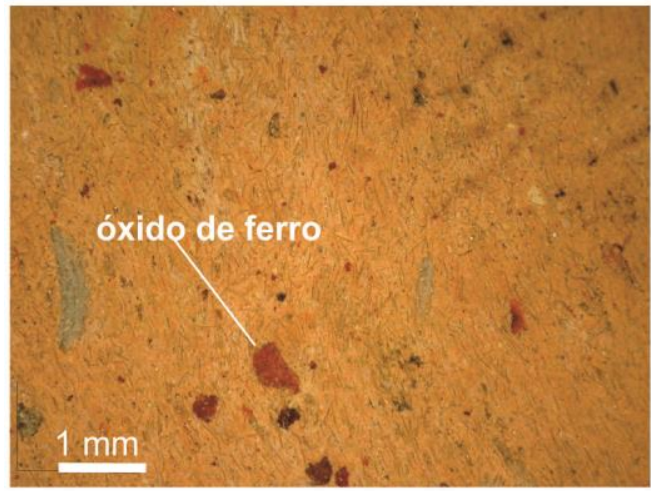

C

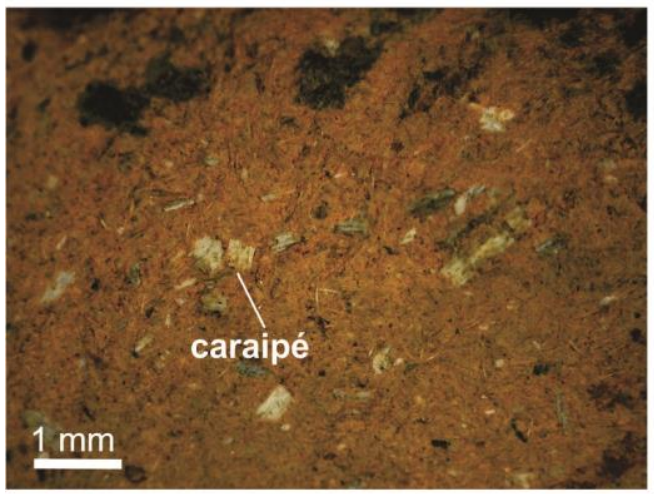

e

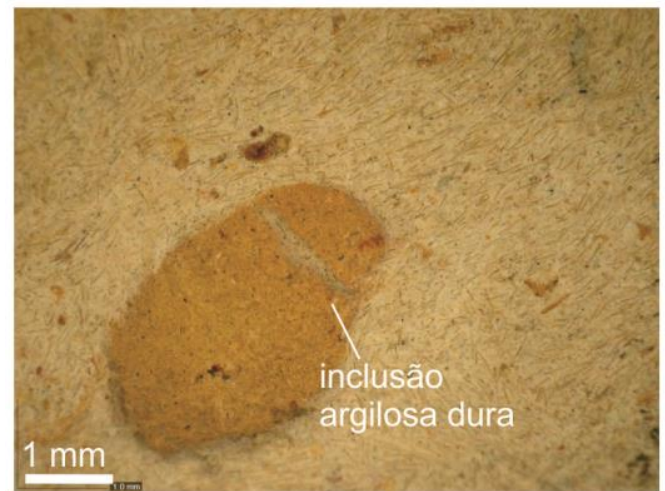

g

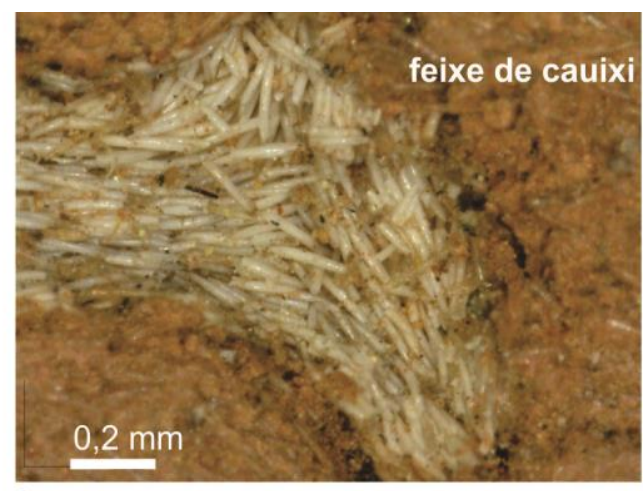

b
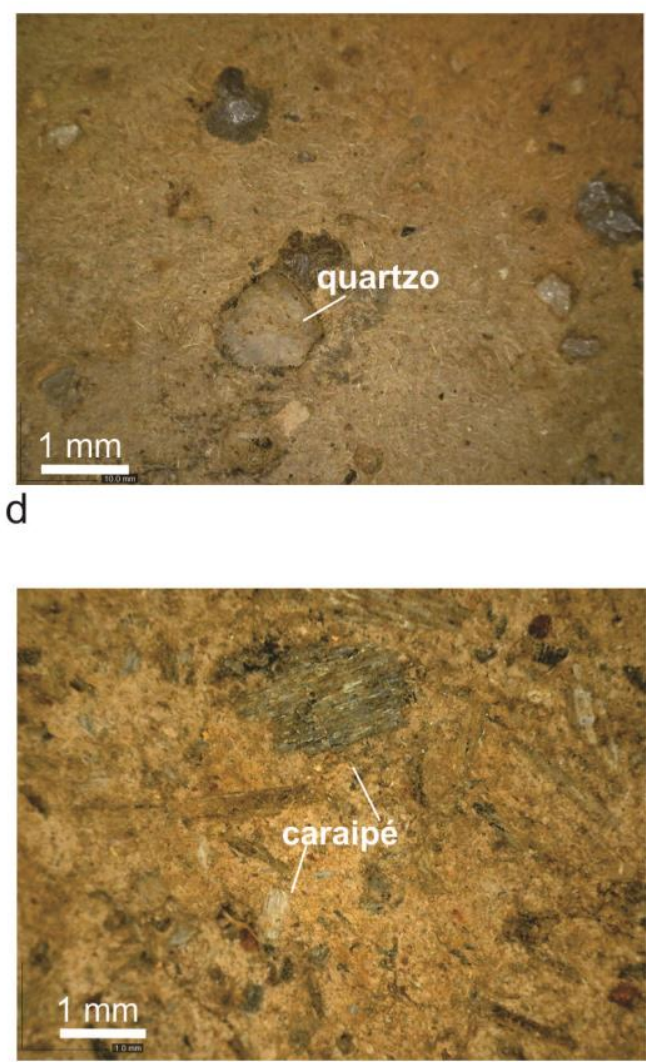

f

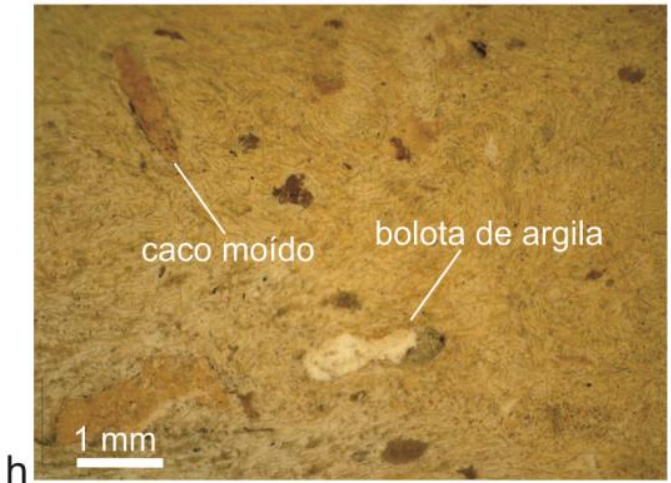

Figura 36 Antiplásticos do sítio Posto Aurora II, (Coleção Aricy Curvelo). A foto F é de uma peça coletada por Peter Hilbert no lago de Faro. 
A comparação desse resultado com o de análises de amostras obtidas em escavações sistemáticas é fundamental. Seria o uso do cauixi isolado um padrão na cerâmica Konduri? Os resultados disponíveis exibem algumas diferenças em relação aos critérios dos atributos observados, dificultando a comparação. O primeiro problema é que não são separados os resultados obtidos para a cerâmica Pocó e Konduri em sítios multicomponenciais. Dessa maneira, as proporções disponíveis para o sítio Boa Vista, Cipoal do Araticum, Terra Preta 1 e 2 combinam dados de peças de ambos os estilos, seja porque estão misturados em níveis superficiais ou porque não foi estabelecida uma diferenciação dos resultados. Além disso, até o momento pouco se conhece sobre os conjuntos identificados aqui como "não locais" e estes também não foram diferenciados das amostras analisadas em sítios Konduri.

Em sítios unicomponenciais Konduri da região de Porto Trombetas (Aviso I, Bela Cruz I e Bela Cruz II) o cauixi isolado está presente em mais de 50\% do material, como nas coleções que estudamos (GUAPINDAIA, 2008). Esse antiplástico isolado é também majoritário nos sítios multicomponenciais. Não figura nessas quantificações, entretanto, os elementos minerais associados ao cauixi. Não sabemos se isso resulta de uma escolha metodológica que considera apenas os "aditivos" ou se está vinculado a sua baixa frequência de minerais na amostra. No sítio Oriximiná 3, em uma localidade próxima a Porto Trombetas, onde outra abordagem foi adotada, o cauixi combinado a minerais representa quase $40 \%$ da amostra, enquanto o cauixi isolado compõe apenas 5\% (SCIENTIA, 2013).

No médio Trombetas, o material coletado nos sítios Colônia eTawanî apresenta alta frequência de antiplástico mineral (COSTA et al., 2004a, 2004b; JÁCOME, 2017). Todos esses sítios foram relacionados ao complexo Konduri, entretanto, quase não foram identificados fragmentos decorados nesses sítios nas escavações realizadas pelo MPEG e as morfologias reconstituídas não apresentam nenhum elemento diagnóstico dessa cerâmica. As amostras estudadas da coleção Barbosa de Faria/Comissão Rondon (Abuí, Santa Maria, Laranjal) e T-1465/66 (lago Jacaré) exibem a mesma predominância de cauixi evidenciada em outras áreas. Mais pesquisas no médio Trombetas são necessárias para compreender se nessa área o estilo Konduri apresenta uma marcante diferença no uso de antiplásticos. Costa et al. (2004a, p. 167) mencionam que forma coletadas amostras de esponjas e cascas de árvore no médio Trombetas 
durante os trabalhos de campo. Isso indica que na área ambas as matérias primas estão disponíveis, apesar de não ser conhecida sua frequência. A diminuição do número de lagos na área pode ter um efeito sobre a disponibilidade de cauixi, que vivem preferencialmente nas áreas com águas mais paradas de lagos. O médio Trombetas está situado na transição entre uma bacia sedimentar (Amazônica) e um embasamento cristalino (Escudo das Guianas), com grande disponibilidade de rochas magmáticas, como granito, riolito e dacito. As cachoeiras que aparecem a partir do médio Trombetas são um marco na paisagem, como a mais extensa delas, denominada Cachoeira Porteira. A diferença no uso de antiplástico mineral também pode se vincular com relações com produtores de um complexo cerâmico do rio Mapuera, onde há maior ênfase no uso de minerais. Outra possibilidade, que no atual estágio do conhecimento não pode ser descartada, é a de que esses sítios não estão diretamente vinculados ao complexo Konduri.

A presença do caraipé na cerâmica Konduri merece uma atenção especial. Sua presença foi mencionada pela primeira vez por Guapindaia (2008). Em maiores ou menores proporções foi identificado em sítios de toda a área de dispersão do estilo Konduri. A frequência desse elemento é bastante restrita na nas coleções estudadas, seja esse elementos isolado ou em combinação com cauixi e minerais. As coleções de museu subrepresentam esses materiais se comparados a sua frequência em sítios da área de Porto Trombetas e baixo Mapuera. As amostras da margem direita do rio Amazonas (Juruti e Parintins) exibem uma proporção ainda menor de caraipé que as encontrada no lago Sapucuá e sítios nas proximidades de Porto Trombetas. Os sítios Lago Batata, Posto Aurora II, Cocal e Sacuri apresentam proporções relativamente altas de caraipé. Isso contrasta com o único exemplar com caraipé no sítio Babaçu e sua completa ausência da amostra de Fortaleza. Essa tendência é confirmada a partir de escavações sistemáticas (SCIENTIA, 2008) e coleções de superfície (DUARTE-FILHO, 2010, p. 91). Em 59 sítios em que foram feitas coletas de superfície entre Juruti e Parintins apenas em dois foi identificado algum fragmento com caraipé associado a cauixi em cerâmica Konduri. 


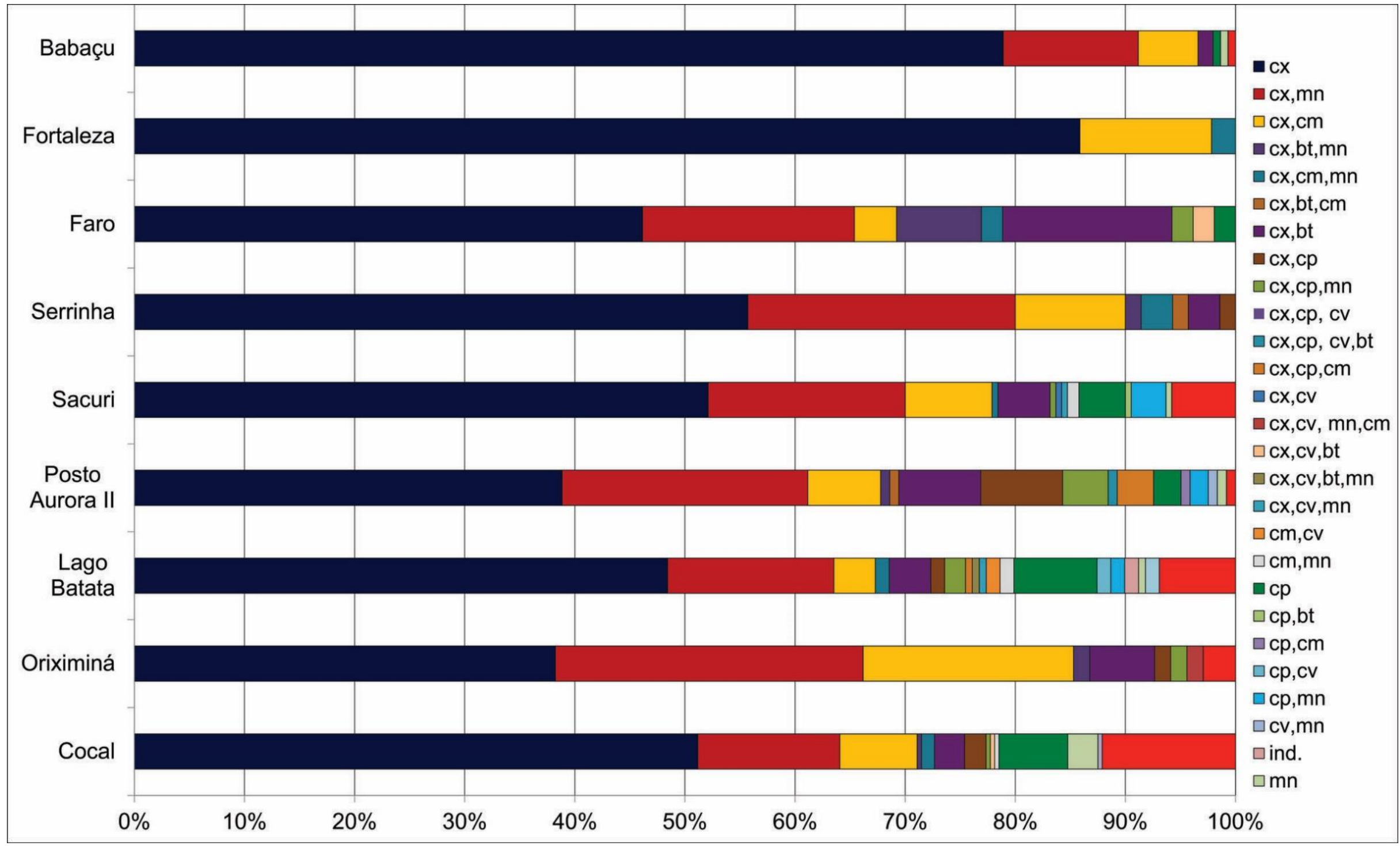

Gráfico 8. Porcentagem de combinações de antiplástico por proveniência. Abreviações: $\mathrm{cx}=$ cauixi; $\mathrm{mn}=$ mineral; $\mathrm{cm}=\mathrm{caco}$ moído/chamote; $\mathrm{bt}=\mathrm{bolota}$ de argila; $\mathrm{cp}=$ caraipé; cv = carvão; ind $=$ indeterminado 
A concentração e o tamanho dos elementos têm efeitos na produção e uso. A proporção de antiplástico está relacionada à taxa de retração da argila (SHEPARD, 1956). Para construir um pote a partir de uma argila mais plástica é preciso adicionar uma proporção maior de antiplásticos para alcançar as condições de trabalho desejadas.

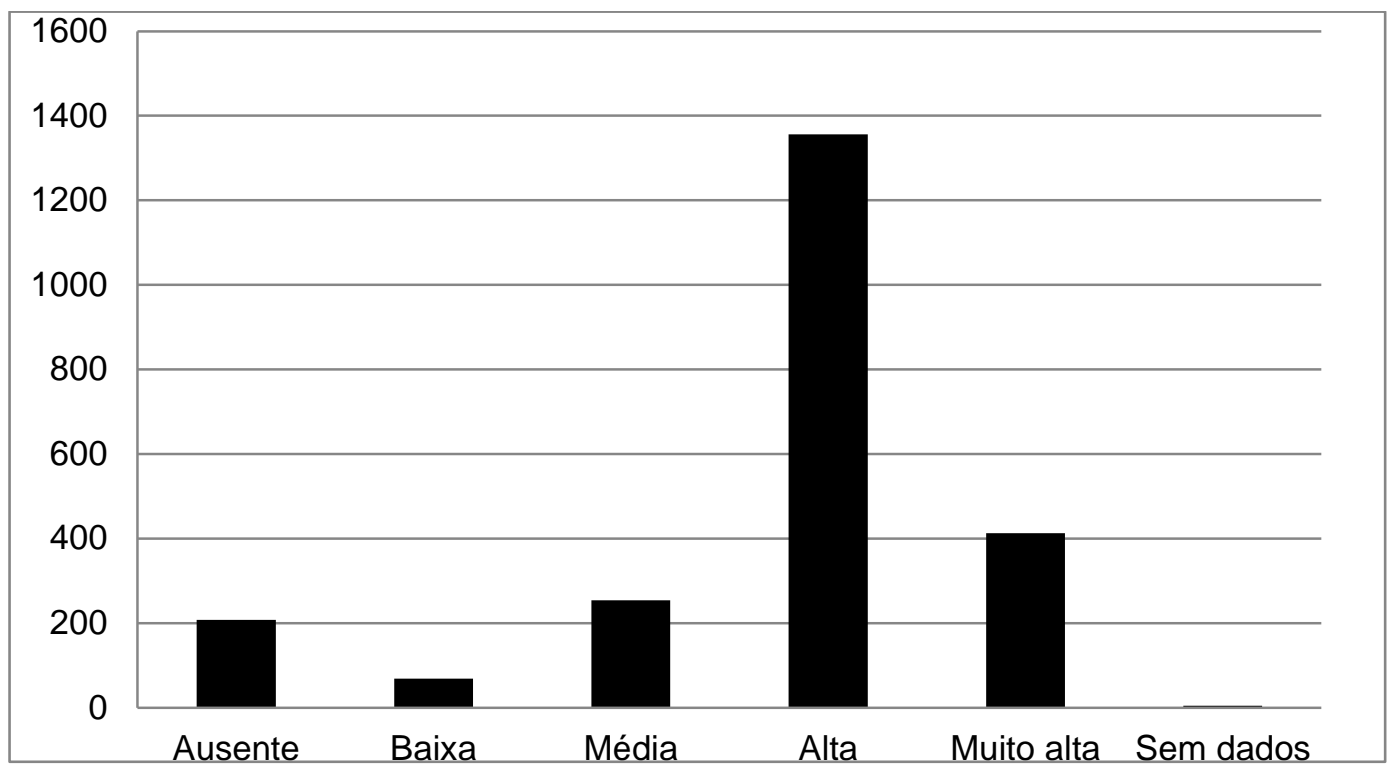

Gráfico 9. Frequência de classe de concentração de cauixi nas peças Konduri analisadas.

O cauixi, na cerâmica Konduri, aparece em concentrações variadas, mas predomina entre alta e muito alta (Gráfico 9). Apesar de Hilbert (1955a) ter enfatizado a densidade das espículas na cerâmica Konduri, em geral, esta não difere da encontrada em outras cerâmicas amazônicas, como a Saracá (STAMPANONI, 2016), Bacabal (ZIMPEL, 2018) ou ainda na cerâmica produzida pelos Wauja e Mehinaku no alto Xingu. Em todo caso, as peças com concentração muito alta, de fato, destacam-se. Nenhum outro elemento aparece em concentração muito alta tal como o cauixi. Além das espículas separadas foram identificados feixes de cauixi, também encontrados em outros estilos pré-coloniais amazônicos (GOMES, 2002; LIMA; NEVES, 2011). Em uma borda do sítio Posto Aurora II, os feixes eram tão grandes que, a olho nu, pareciam ser caraipé. As inclusões minerais aparecem quase sempre em baixas ou médias concentrações (Gráfico 10). O carvão não foi identificado em nenhuma amostra com concentração alta. Os elementos identificados como chamote - que também podem ser 
fragmentos de rochas argilosas - aparecem com frequência em baixa concentração, mas, à diferença dos minerais (quartzo e óxido de ferro), há uma proporção razoável de exemplares com média e alta concentração. Isolado, o caraipé exibe predominantemente proporções médias e altas

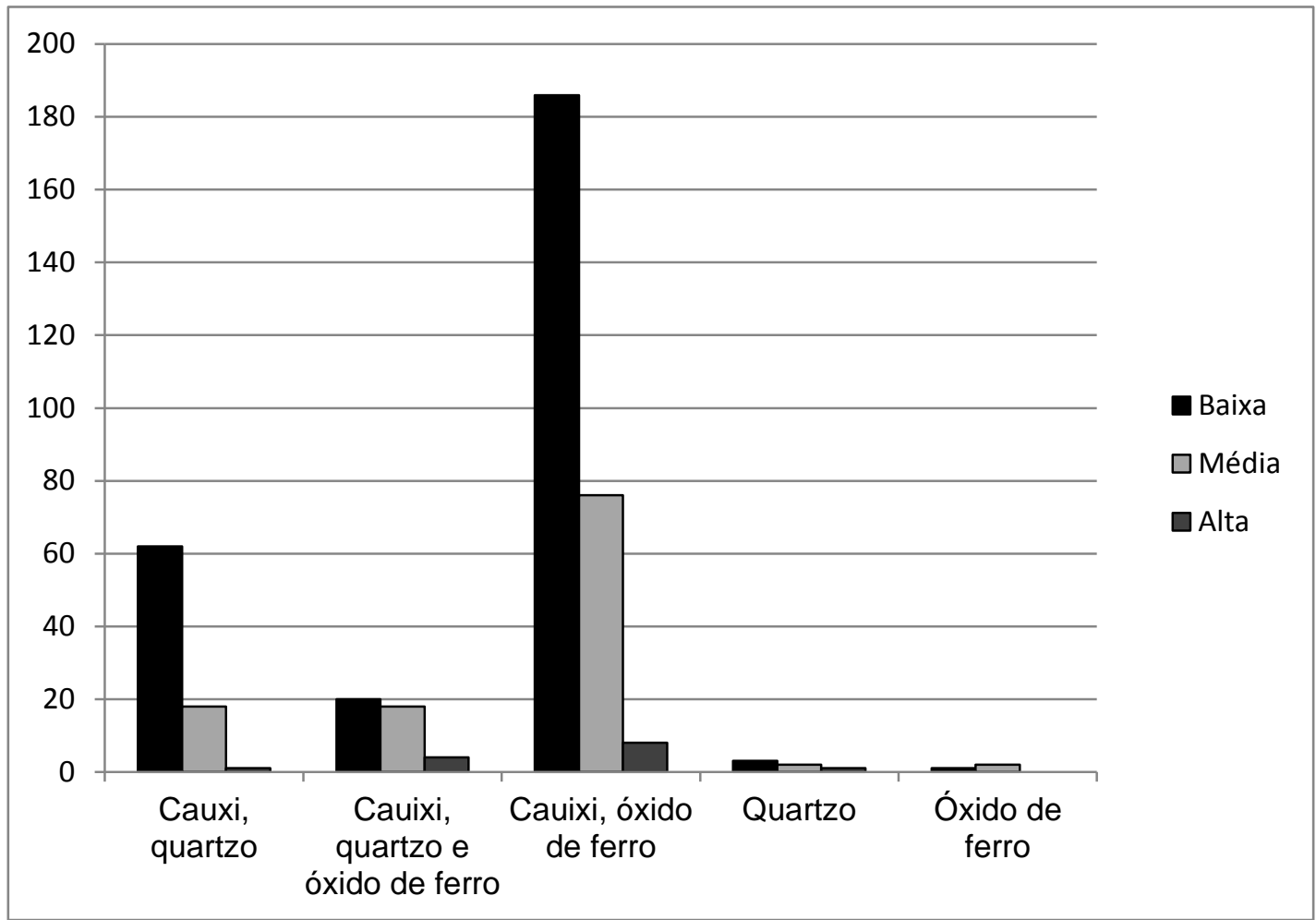

Gráfico 10. Frequência de classe de concentração de antiplásticos minerais isolados ou associados a cauixi.

A textura da pasta encontrada na cerâmica Konduri é fina tanto devido as dimensões micrométricas das espículas quanto as dimensões das outras inclusões, em geral. A maioria dos antiplásticos tem comprimento máximo de até 1,0 mm (70,9\%) (Gráfico 11). O caraipé é um importante marcador desse interesse por grãos de tamanhos reduzidos, uma vez que segue a tendência geral e, com certeza, foi socado e peneirado. Muito menos frequentes $(1,1 \%)$ os grãos com mais de $3,5 \mathrm{~mm}$ de 
comprimento são quase sempre minerais, especialmente óxido de ferro, além de algumas raras bolotas de argila e caraipé ${ }^{53}$.

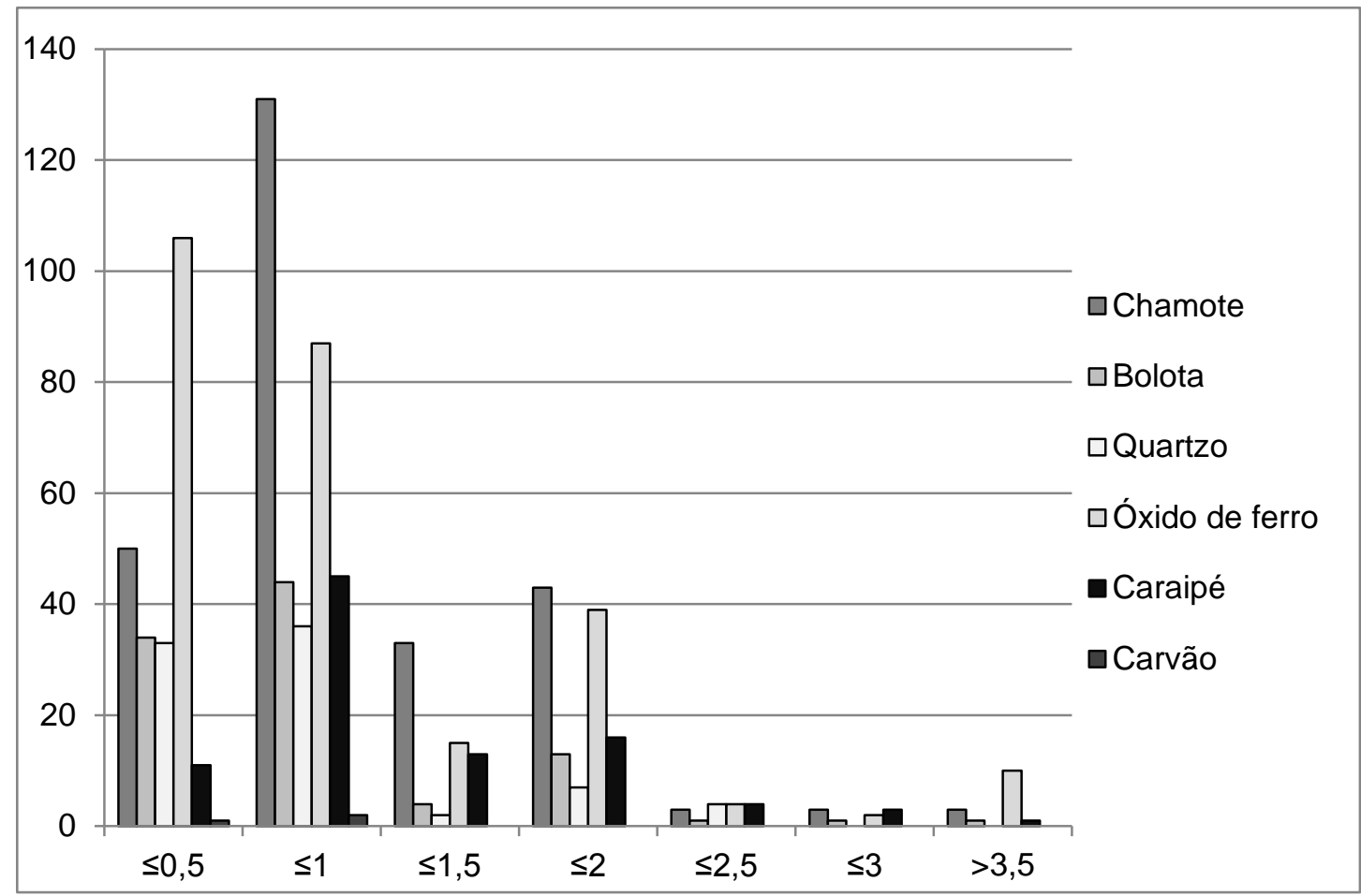

Gráfico 11. Frequência de intervalos de comprimento máximo de elementos antiplásticos a partir de todas as peças Konduri analisadas neste trabalho. .

\subsubsection{Técnicas e métodos de produção}

A etapa da cadeia operatória posterior à preparação da pasta é a construção da vasilha cerâmica. Gosselain (2018) propõe que sejam diferenciados os procedimentos gerais de produção (técnicas) das sequências específicas (métodos), como nos estudos de tecnologia lítica. As técnicas empregadas na confecção das vasilhas Konduri não diferem de outros estilos cerâmicos amazônicos do período pré-colonial tardio ou utilizadas por vários grupos indígenas contemporâneos. As técnicas identificadas são o roletado e o modelado. Esta última é empregada no estilo Konduri na confecção de bases e apliques, sendo o corpo das vasilhas sempre construído pela sobreposição de roletes. Essas técnicas são as mesmas em toda ao longo de toda a sua dispersão tanto a partir de nossas análises quanto os resultados disponíveis na bibliografia (PANACHUK,

${ }^{53}$ Durante a análise da coleção Aricy Curvello não foi possível medir o comprimento máximo das inclusões de 122 fragmentos devido a um erro do sistema do microscópio digital Cooling Tech. Foram considerados nos gráficos apenas os dados disponíveis, sem indicar sua ausência. 
2016a; GUAPINDAIA，2008; GUAPINDAIA; LOPES，2011; CHUMBRE，2014; CASTRO, 2018).

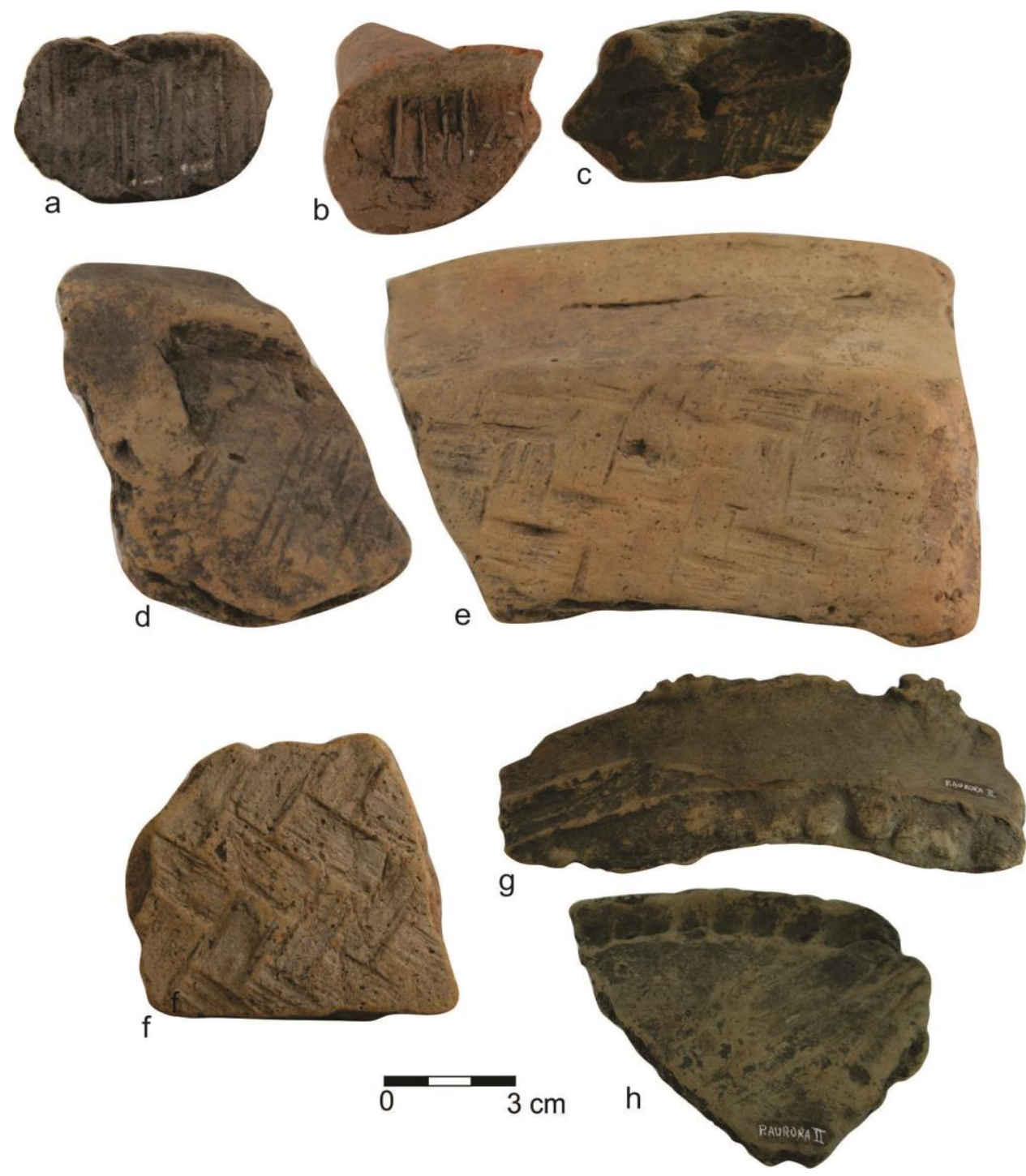

Figura 37. Métodos de construção das vasilhas: uso de ranhuras de ligação (a-d), produção de assadores sobre trançado (e-f), furos para unir borda de paredes $(\mathrm{g}-\mathrm{h})$.

Em termos de comparação regional, os métodos tendem a ser mais localizados espacial e geograficamente, mas tem uma visibilidade arqueológica menor, sendo pouco mencionados (GOSSELAIN, 2018). Os métodos de construção das vasilhas muitas vezes precisam ser observados a partir de petrografia, raio $\mathrm{X}$ ou outro meio de 
observações em escalas microscópicas. Os métodos que pudemos identificar são bastante restritos em relação ao total da amostra e se relacionam a conjuntos específicos, como os assadores e/ou os pés modelados.

O uso de trançados como suporte para a produção e secagem de vasilhas com bases de grande diâmetro, denominadas genericamente como assadores, é um método encontrado na cerâmica Konduri, mas é bastante generalizado em cerâmicas amazônicas, o que o torna pouco diagnóstico - ao contrário do que pensou Hilbert (1955a). As marcas em negativo de traçado não são muito frequentes nas coleções analisadas: apenas $13^{54}(10,2 \%)$ das 127 bordas de assadores analisadas apresentam marcas de cestaria $^{55}$ (Figura 37 e-f). No sítio Oriximiná 3, por exemplo, menos de 3\% do material coletado apresenta impressões de cestaria (SCIENTIA, 2013). Diferentes de outras áreas, como a Amazônia Central, são conhecidas marcas de folhas vegetais no fundo dos assadores (NORDENSKIÖLD, 1924; NIMUENDAJÚ, 2004; MACHADO, 2005-2006).

O motivo para a manutenção dos negativos deve resultar da dificuldade em deslocar essas peças durante a secagem. Barbosa Rodrigues (1876, p. 18) explica que os oleiros de sua época faziam torradores de farinha de até $2,5 \mathrm{~m}$ diâmetro, que "demandam muito cuidado no seccar, porque pelo seu tamanho (...) com muita facilidade se quebram". Por isso também o torrador "é feito sobre um tupé [esteira] ou sobre folhas de bananeiras, cujas fórmas e nervuras sempre ficam impressas. Quase sempre depois de secco ao sol, fazem fogo sobre elle, no mesmo lugar em que foi fabricado". Essa parece ser uma explicação satisfatória para os exemplares précoloniais, que fazem parte da mesma tradição de processamento de mandioca e milho (NORDENSKIOLD, 1924). No caso de outros elementos do vasilhame tanto é possível que as bases tenham sido feitas em suportes planos (MACHADO, 2005, p. 101) como a parte de trás de raladores de maneira ou tábuas (YDE, 1965; VELTHEM, 2017). As impressões também podem ter sido apagadas, uma vez que as vasilhas menores podem ser movimentadas com mais facilidade, como pode ser o caso de algumas vasilhas Wai Wai feitas sobre peneira (YDE, op. cit.; RYE, 1981).

\footnotetext{
${ }^{54}$ Outras três bases sem referência foram contabilizadas na coleção Barbosa de Faria/Comissão Rondon.

${ }^{55}$ As impressões de trançado em sua maioria apresentam tramas relativamente largas e apenas uma marca apresenta tramas finas. As técnicas de traçado são quase sempre o sarjado e em um único caso, trata-se de trançado cruzado (Igor Rodrigues, com. pess., 2019). O sarjado com tramas largas predomina em outras coleções analisadas.
} 

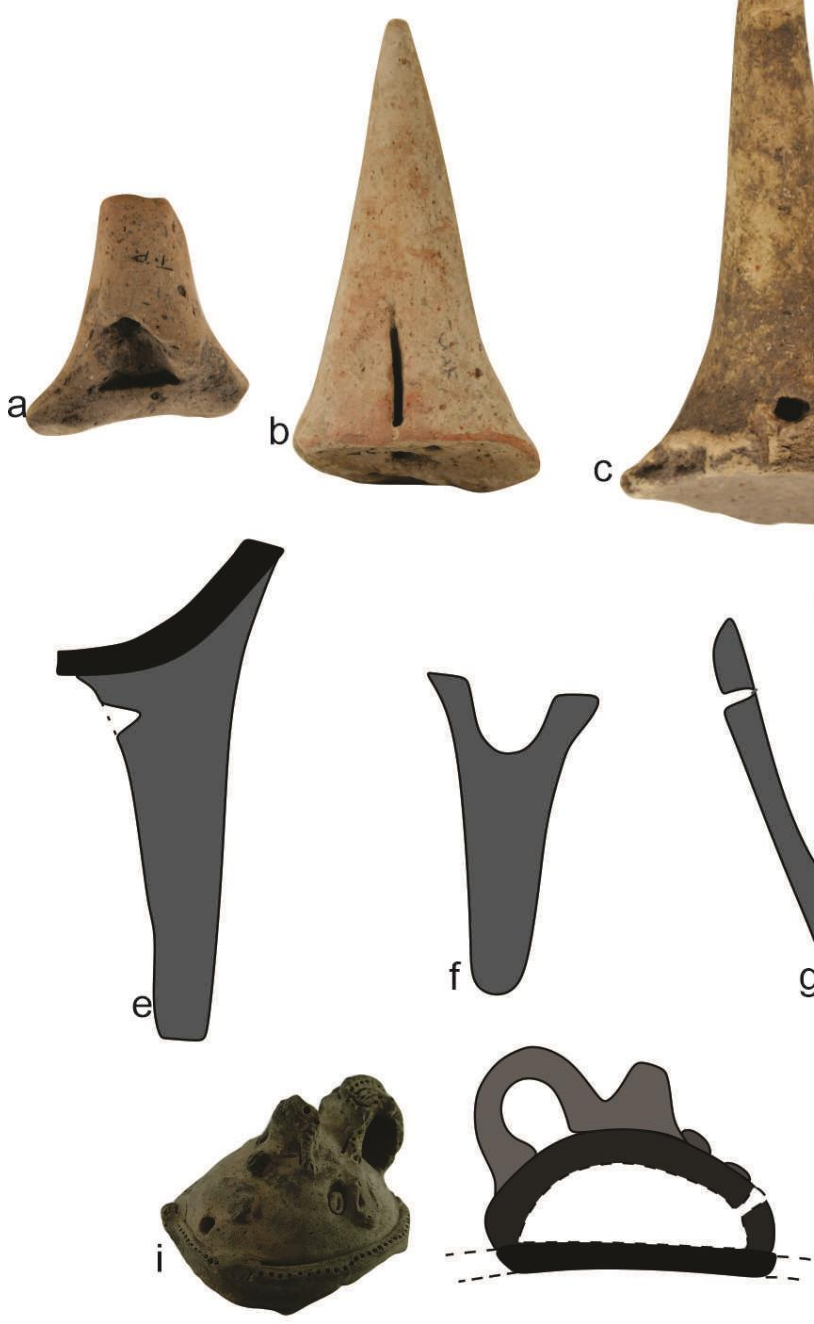

0

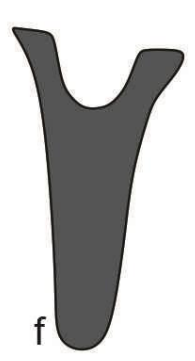

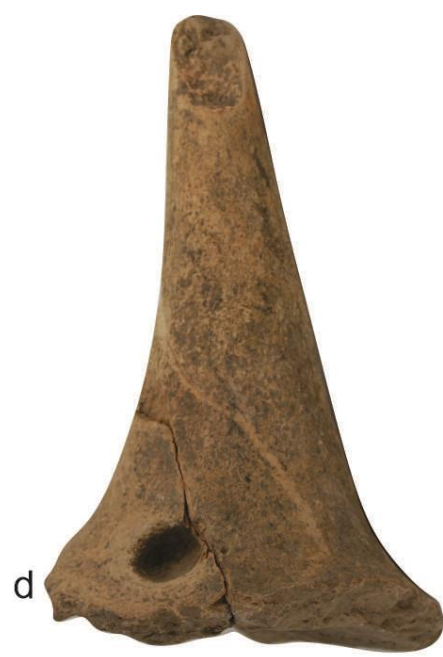

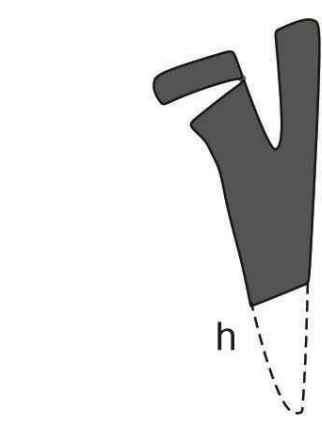

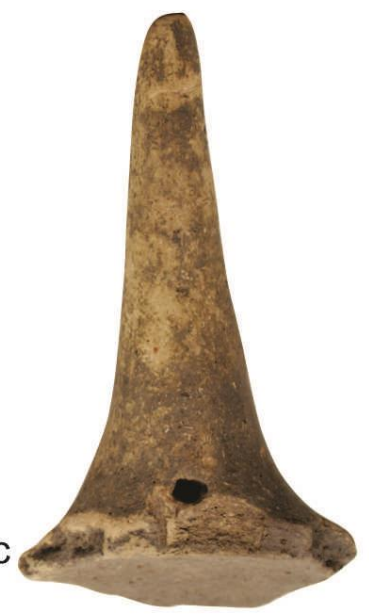
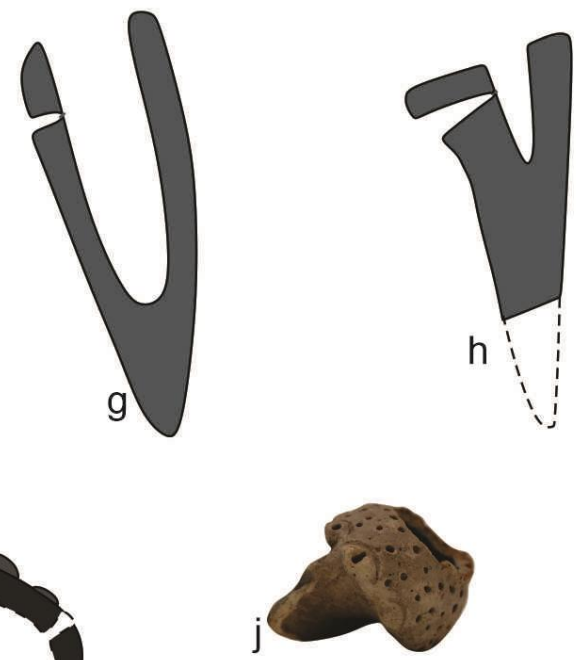

Figura 38. Apliques ocos e com furo de ventilação. a - pé oco; b- pé oco com furo retilíneo; c- pé oco com furo cônico; d- pé maciço com furo com o dedo; e - pé maciço com furo; f - pé com ocagem pouco profunda; g- pé com ocagem profunda. h- pé oco com ocagem rasa e furo; i- apêndice oco com furo; $\mathrm{j}$ apêndice aplicado em borda oco. Proveniência/procedência:a-Terra Preta (Col. Peter Hilbert); b- Ponta da Mafada (Col. Peter Hilbert); c- Sucurijú (Col. Barbosa de Faria); d - Babaçu (Col. Peter Hilbert e Harald Schultz); e- Posto Aurora II (Col. Aricy Curvello); f - sem proveniência (Col. Tapajônica); gAraticum (Col. Aricy Curvello); h- Lago Batata (Col. Aricy Curvello); i- Posto Aurora II; j- sem proveniência (Col. Tapajônica).

Em relação à distribuição espacial, há bases com marcas de trançado nos sítios do baixo Trombetas e Nhamundá, mas em nenhuma amostra do município de Juruti. Em coleções obtidas em prospecção ou escavação sistemática foram encontrados exemplares em praticamente toda a dispersão do estilo Konduri (SCIENTIA, 2003; SCIENTIA, 2013; GUAPINDAIA, 2008). Um pé modelado também apresenta marca 
"positiva", devido a sua junção a uma vasilha feita sobre cestaria. Isso mostra que a adição do aplique ao corpo da vasilha (assador?) foi feita depois de secar (Figura 37 c).

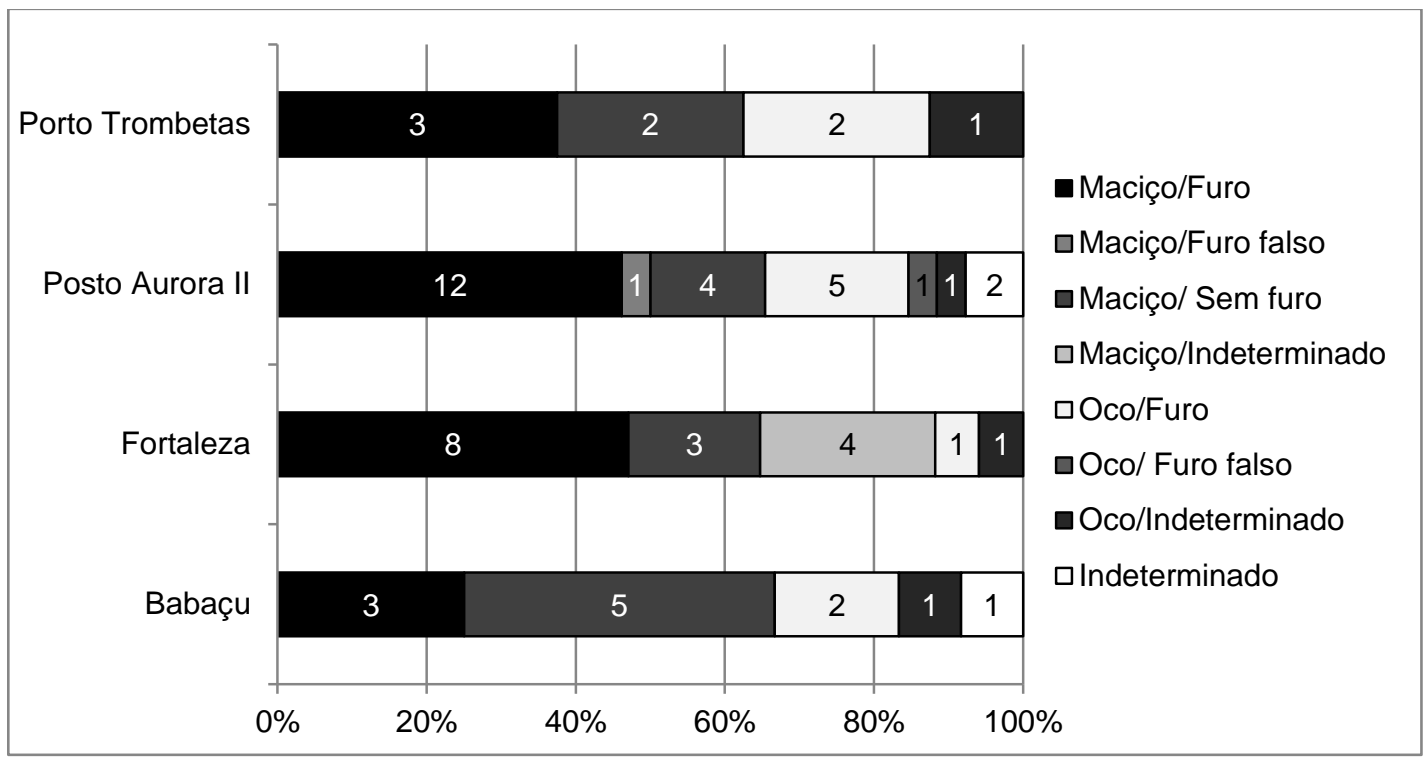

Gráfico 12. Porcentagem e frequência de uso do método de ocagem e/ou furo de ventilação em pés modelados.por proveniência.

Outro método encontrado na cerâmica Konduri é denominado "costura" nas artes plásticas (Figura 37 a-d). Esse é caracterizado pela produção de ranhuras visando conectar com maior segurança partes modeladas separadamente. Hilbert (1955, p. 48) afirmou que este método não foi identificado na cerâmica Konduri, mas era frequente no estilo Santarém. A análise sistemática das coleções mostrou que, mesmo na coleção Peter Hilbert há ranhuras nas áreas de fixação de pés modelados. Quantitativamente o uso do método é muito baixo; em todo o material analisado foram identificadas apenas 10 peças com ranhuras (7 pés modelados e 3 bases/bordas de assadores). As peças Konduri com ranhuras são provenientes de sítios de toda a área de dispersão, sendo mencionado em outras pesquisas sobre esta área (SCIENTIA, 2008; CASTRO, 2018). Ao contrário do que sugeriu Hilbert (1955a), a costura não era desconhecida pelos produtores da cerâmica Konduri, mas por algum motivo, tinha uma baixa frequência de uso. Um método similar à costura foi identificado apenas na amostra do sítio Posto Aurora II. Em uma base com uma série de pontos feitos com dedos na face interna, 
provavelmente para uni-la aos roletes aplicados na sequência. Uma borda com pasta diferente da base exibe pequenas protuberâncias que podem indicar o "positivo" da aplicação de pontos com os dedos. $\mathrm{O}$ uso da costura em baixa frequência pode estar relacionado ao fluxo de informações e mobilidade de pessoas no Baixo Amazonas. Esse método é mais frequente na cerâmica Santarém, tanto na fixação de apêndices quanto pés modelados. No sítio Santa Rita, a cerâmica pintada (Paredão?) apresenta junção de roletes.

Outros dois métodos identificados durante a análise se reStringem ao uso de apliques:ocagem e furo de ventilação, relacionados à manufatura de apliques (apêndices e pés) e usados em combinação ou separadamente (Figura 38). Os dois são empregados como complementares em escultura em argila para evitar a explosão de objetos muito espessos durante a queima (PETERSON; PETERSON, 2003). A porção oca permite que a peça queime homogeneamente, enquanto os furos permitem a circulação do ar preso dentro da modelagem. Em relação aos apêndices a combinação de ocagem e furo ocorre apenas em um conjunto muito específico de figuras maiores aplicadas ao bojo mais a frente denominadas “calotas". Muitos dos apêndices são finos ou achatados, anulado a necessidade da aplicação de ambos os métodos Apesar da expectativa suscitada pela consulta de manuais de escultura em argila, alguns dos maiores apêndices e pés modelados encontrados nas coleções não apresentavam furos (Gráfico 12). Ao mesmo tempo, alguns pés apresentam furos rasos feitos com as pontas dos dedos, muitas vezes em peças maciças. A produção de modelagens ocas, a julgar pelas coleções analisadas, é menos frequente. Além disso, a profundidade da porção oca varia em grande medida. Entre os pés coletados no sítio Araticum, por exemplo, quase todo o comprimento é oco. $\mathrm{Na}$ maioria das modelagens, entretanto, trata-se de uma concavidade relativamente rasa limitada à parte superior com maior diâmetro. Como no caso do método de costura ou uso de trançado como suporte, é interessante notar que mesmo sendo conhecida a ocagem, sua aplicação estava longe de ser uma "regra". A amostra do sítio Posto Aurora II é um bom exemplo dada a quantidade de exemplares de uma única localidade. Entre os 26 exemplares de pés modelados, a maioria é maciça e exibe furo, mas há maciças com sem furo e ocas com furos muito rasos feito com os dedos. Os menores pés modelados são sólidos e sem furos. Em alguma medida, a preparação da pasta ou outros processos técnicos devem ter sido mobilizados para evitar 
a fragmentação dos apliques. Os furos de ventilação e a ocagem são muito frequentes em apliques da cerâmica Santarém.

\subsubsection{Tratamento e conservação de superfície}

Depois da produção da morfologia geral e a adição de apliques, as vasilhas são submetidas a diferentes técnicas de regularização de superfície. Os tratamentos de superfície aplicados à cerâmica Konduri são considerados mais grosseiro do que o de outras cerâmicas, como a Santarém (GOMES, 2002; SCHAAN, 2012). A observação dos materiais arqueológicos pode, contudo, estar sendo direcionada por processos pós deposicionais (Figura 39). Nas coleções analisadas a maioria das peças em que foi possível identificar o tipo de alisamento, havia quase à mesma proporção de alisamento fino e grosso. O polimento, frequente nas vasilhas mais elaboradas do estilo Santarém, de fato, é mais raro. Tendo em vista o total da amostra, as superfícies erodidas predominam nas coleções analisadas (Gráfico 13) . O grau dessa erosão tende a não ser muito elevado, sem um arredondamento intenso dos ângulos, mas oblitera significativamente a observação do tratamento de superfície. Como dito no capítulo anterior, a maioria das peças foi obtida em coleta de superfície em áreas de erosão. Assim, a amostra dos sítios da margem do lago Sapucuá, coletados por Peter Hilbert, são muito mais erodidos que os coletados por Aricy Curvello em sítios de terra firme na região de Porto Trombetas. A alta frequência de superfícies erodidas também é mencionada na análise do material cerâmico coletado em escavações sistemáticas (SCIENTIA, 2013, 2016; JÁCOME, 2017). 


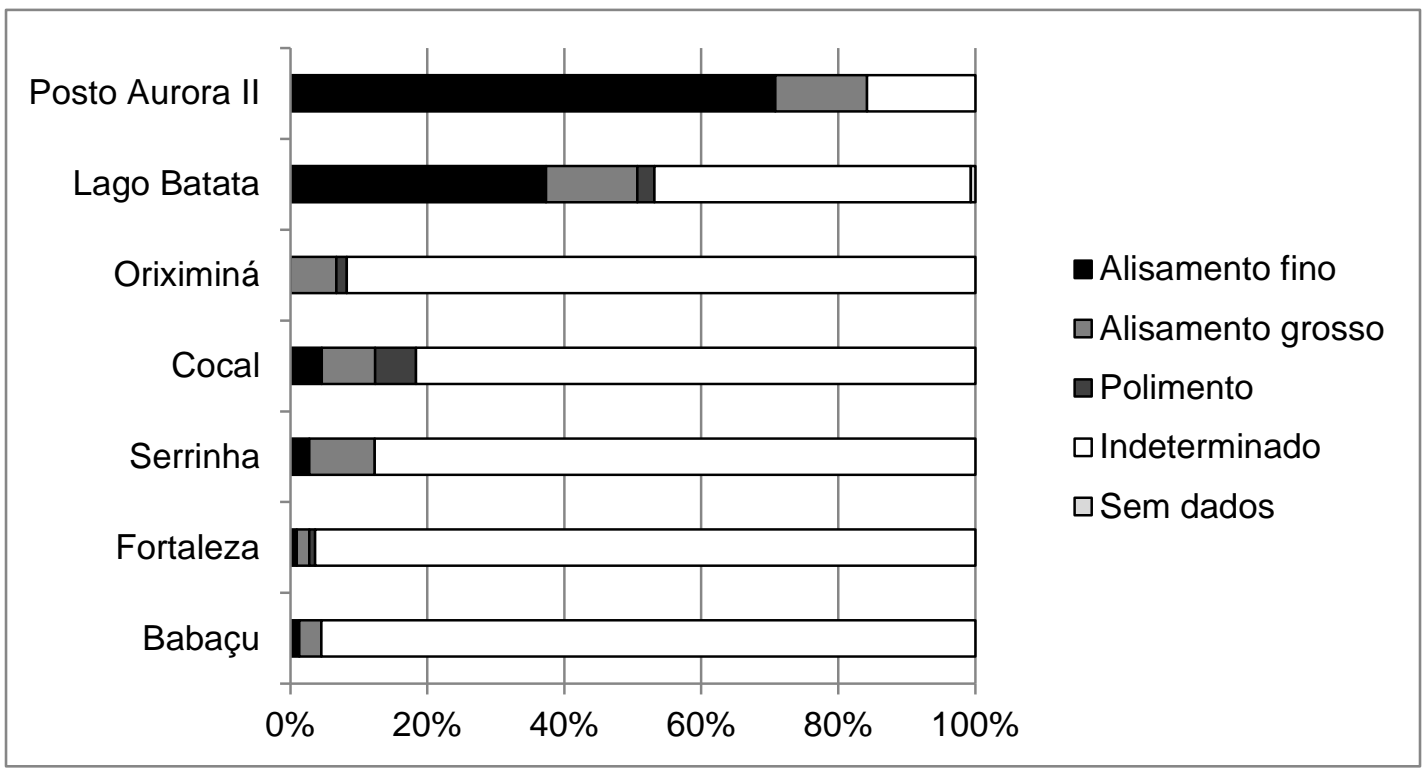

Gráfico 13. Porcentagem de classe tratamento de superfície na face externa por proveniência

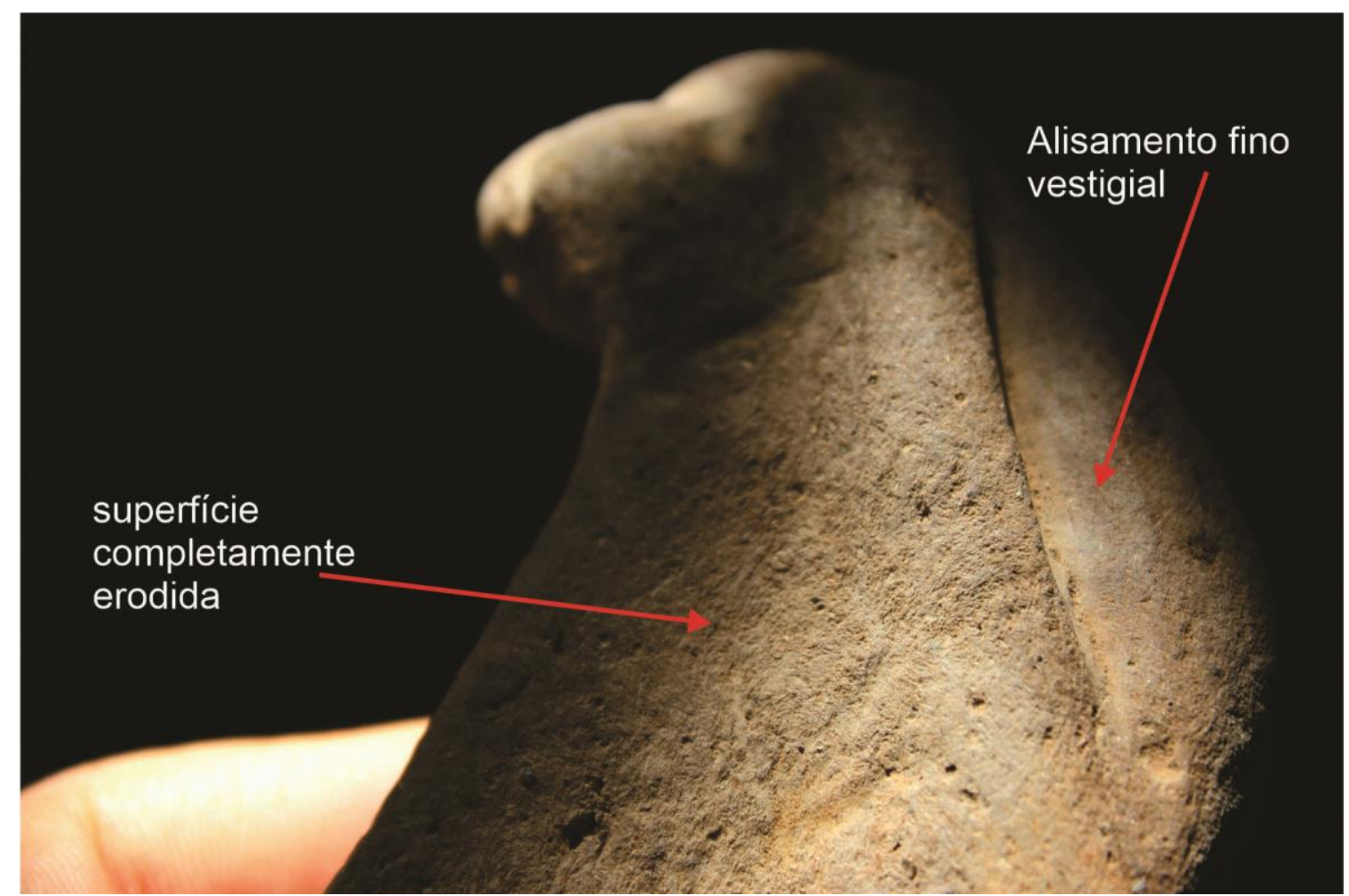

Figura 39. Fragmento bastante erodido com vestígio de alisamento fino abaixo de um ângulo. Procedência: Coleção Tapajônica/ MAE-USP.

Amorim (2008, p. 29) desenvolveu uma hipótese a partir da análise do material coletada no sítio Terra Preta 2 (Juruti). Para a autora o desgaste das peças seria causado 
pela "abundância de cauixi”. Durante as análises tivemos uma impressão semelhante de que o cauixi seria um fator importante nesse processo. Muitos fragmentos mostravam-se friáveis e macios. Hilbert (1955a) já havia notado a baixa dureza da cerâmica Konduri entre 2 e 3 na escala de Mohs. O potencial das espículas de cauixi em aumentar a taxa de abrasão das superfícies ainda não foi avaliado experimentalmente. As pesquisas desenvolvidas em laboratório mostram que temperaturas de queima mais altas aumentam a resistência a abrasão, aumentando sua dureza de modo geral. O tipo de antiplástico, por outro lado, influencia de várias maneiras na taxa de abrasão da cerâmica, como sua dureza, forma, tamanho e quantidade (VAZ et al., 1987; SCHIFFER, 1989). Uma das observações interessantes para o caso do cauixi é de que partículas maiores tendem ser menos vulneráveis ao deslocamento porque exibem uma ligação mais forte com a argila devido a área de contato. Cerâmica temperada com areia grossa, por exemplo, exibiu uma maior resistência à abrasão que outra temperada com areia fina. Os resultados apresentados sobre a proporção de antiplástico não foram muito seguros, mas no caso da areia, o aumento de $20 \%$ para $40 \%$ diminuiu a resistência à abrasão. A composição das espículas de esponja, sua morfologia e dimensão são muito distintas de outros materiais testados, sendo necessários experimentos específicos para verificar o comportamento desse material. Outros fatores como a existência de ângulos ou tipos de tratamento de superfície podem favorecer o desgaste da cerâmica. A cerâmica Konduri analisada apresenta vários ângulos com modelagens aplicadas ou reforço de borda, o que pode ter alavancado a erosão, especialmente quando as peças ficavam expostas em praias. 


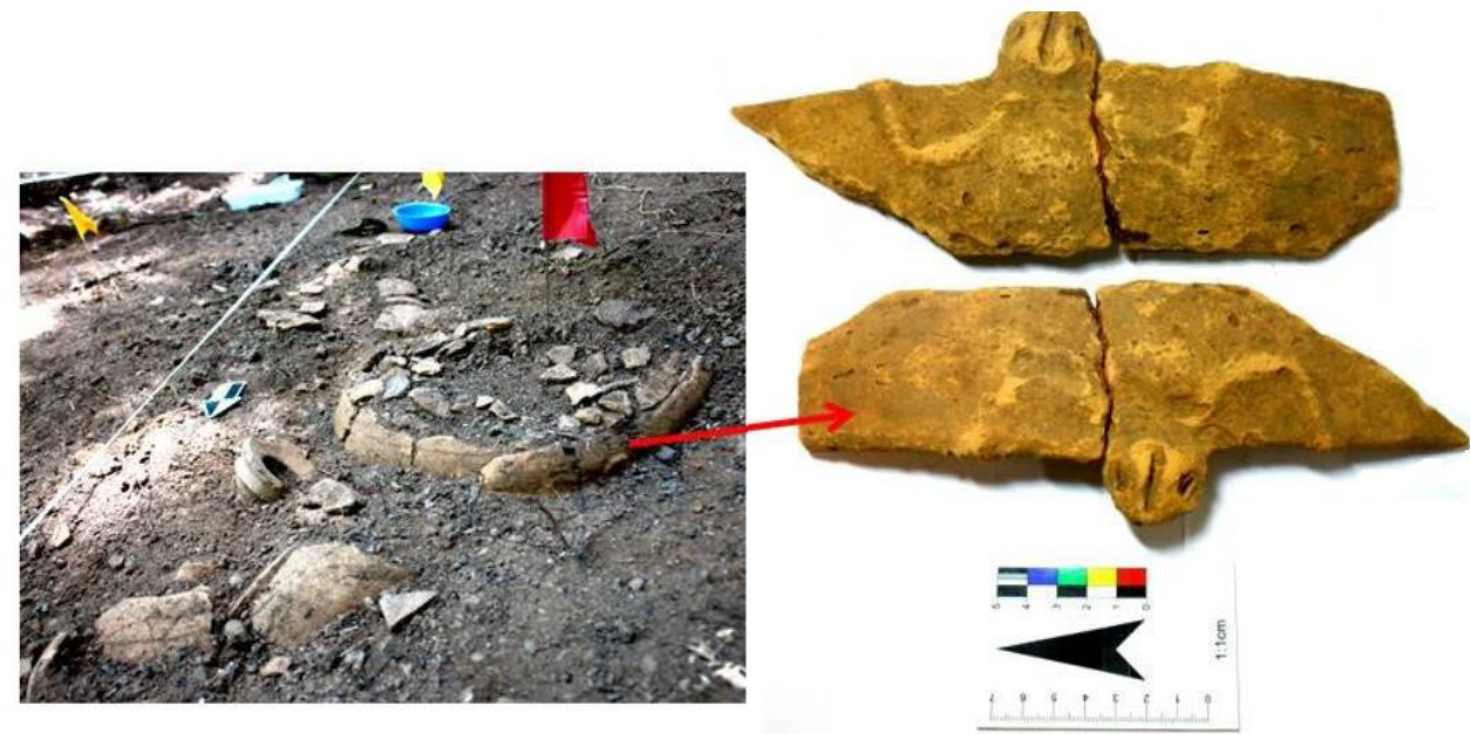

Figura 40. Fragmento de borda encontrado ainda articulado a outros fragmentos no sítio Greig II. Sua superfície mostra-se bastante erodida. Adaptado de Castro, 2018.

A maioria das pesquisas recentes não menciona o estado de conservação dos fragmentos cerâmicos, mas é notável em alguns casos o contraste entre fragmentos bem conservados e outros bastante erodidos. O caso do sítio Greig II parece, nesse sentido, bastante curioso porque muitas peças foram encontradas in situ e a maioria exibe superfícies conservadas com polimento, alisamento fino ou grosso e pintura (ver CASTRO, 2018). Entretanto há alguns fragmentos bastante erodidos.

\subsubsection{Cor da face externa}

A coloração da cerâmica está relacionada a vários fatores, especialmente a presença na argila de óxido de ferro e materiais orgânicos e também tempo, temperatura e atmosfera da queima (RICE, 1987, p. 333). As cores da face externa identificadas são as mesmas mencionadas por Hilbert (1955a). A cor predominante é um amarelo claro, qualificado pelo autor como "sujo". Em menor proporção, há tanto peças alaranjadas como também outras com uma coloração esbranquiçada próxima ao bege, cinza e rosa claro. Outras cores como preta, vermelha e marrom aparecem em uma proporção muito baixa. É notável que a coloração amarelada e esbranquiçada predomine na maioria das amostras em áreas distintas. A coloração alaranjada exibe uma maior variação, estando 
mais representada em coleções de alguns sítios do que em outras. Experimentos com as argilas locais poderão explicar a predominância de determinadas cores.

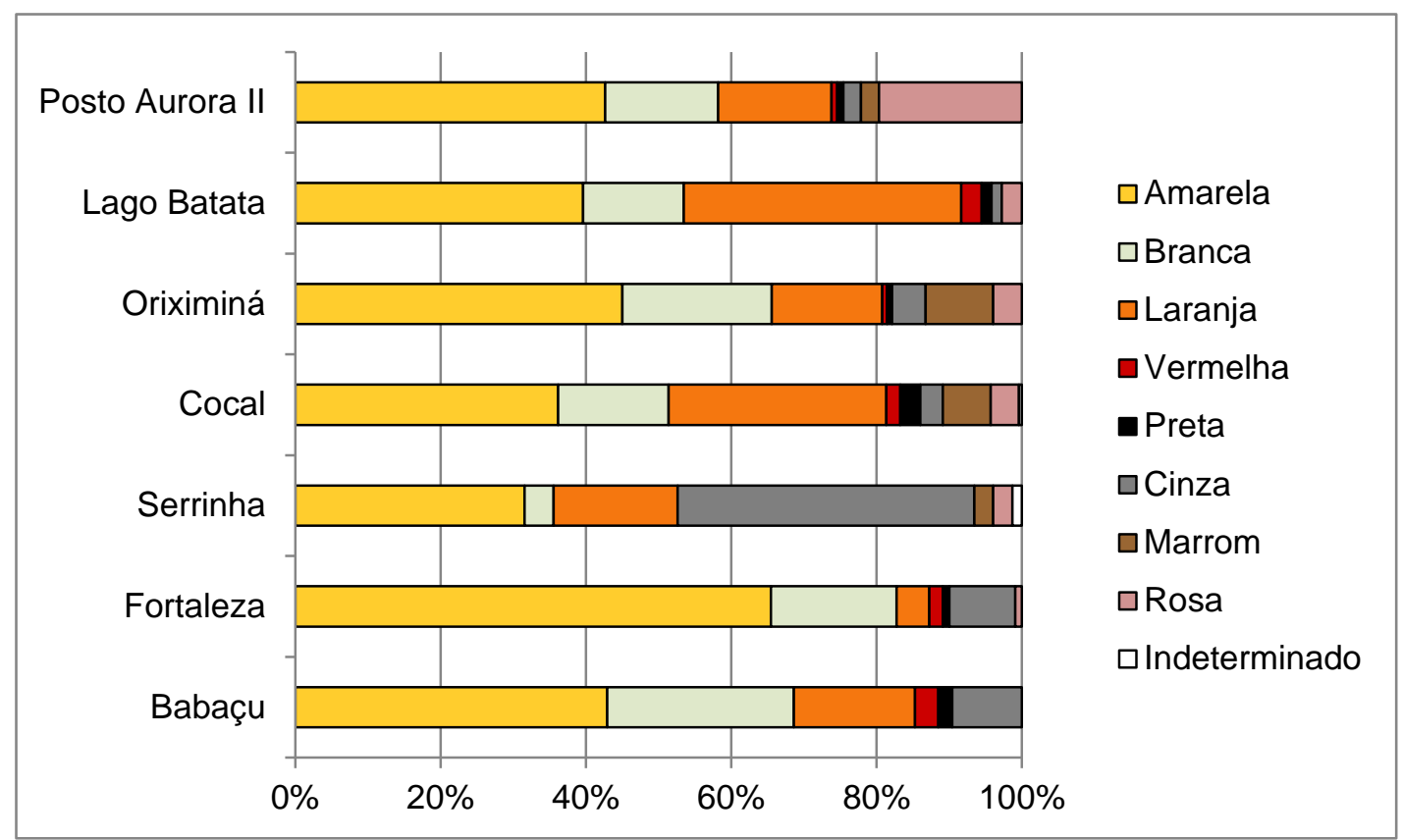

Gráfico 14. Porcentagem de classes de coloração por proveniência.

\subsubsection{Configuração de núcleos}

A configuração dos núcleos sugere um uso de argilas com pouca matéria orgânica e queima em atmosfera oxidante, ou seja, com quantidade excessiva de ar. Isso é coerente com as queimas em fogueiras ao ar livre, que é o método generalizado entre os indígenas contemporâneos nas terras baixas da América do Sul (LIMA, 1987). Não se conhece nenhuma evidência de uso de forno no passado pré-colonial nessa porção do continente americano. 


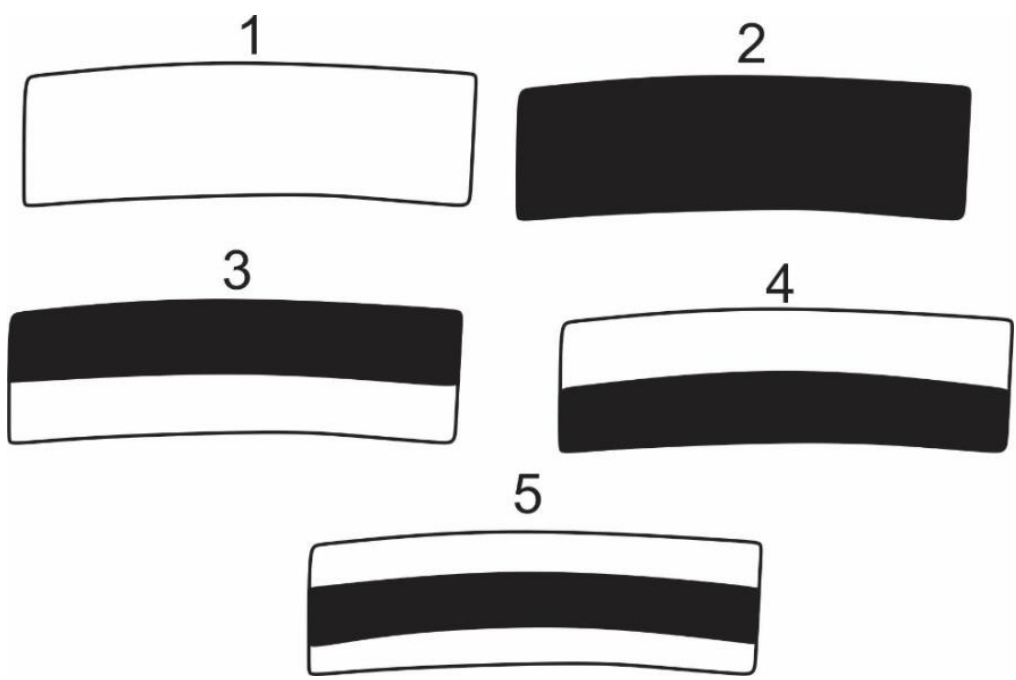

Figura 41. Tipos de configuração do núcleo. A face externa nessa figura é convexa (superior) e a interna é côncava (inferior).

A maioria dos núcleos nas coleções analisadas tem cor clara e uniforme (tipo 1), o que representa 69,6\% da amostra (Figura 41/ Gráfico 15). Em proporção ainda menor aparece o núcleo escuro (Tipo 5/ 16,1\%) ou apenas a face interna escurecida (tipo 3/ 8,4\%). Em relação às amostras de sítios, o núcleo de tipo 1 é encontrado em mais de $60 \%$ das peças analisadas.. As outras configurações mais frequentes, o tipo 5 e 3 respectivamente, podem sugerir uma presença maior de matéria orgânica. A separação do núcleo escuro e as faces mais claras tendem a ser difusas. Outra possibilidade é que, no caso de algumas peças em que foi notada uma separação marcada do núcleo escuro, a peça tenha sido retirada da área de queima para resfriar em outro lugar. A proporção menor de fragmentos totalmente escuros deve estar vinculada ao processo de redução desenvolvido com a manutenção da peça em contato com cinzas e carvão (RYE, 1981, p. 117). Não foram quantificadas as incidências de firecloud, mas estas não são muito frequentes. Em uma das vasilhas inteiras da coleção Frederico Barata, algumas dessas marcas de queima são visíveis nas áreas em que o engobo vermelho erodiu. A friabilidade e a baixa dureza de muitos fragmentos podem estar vinculadas às baixas temperaturas alcançadas durante a queima. 


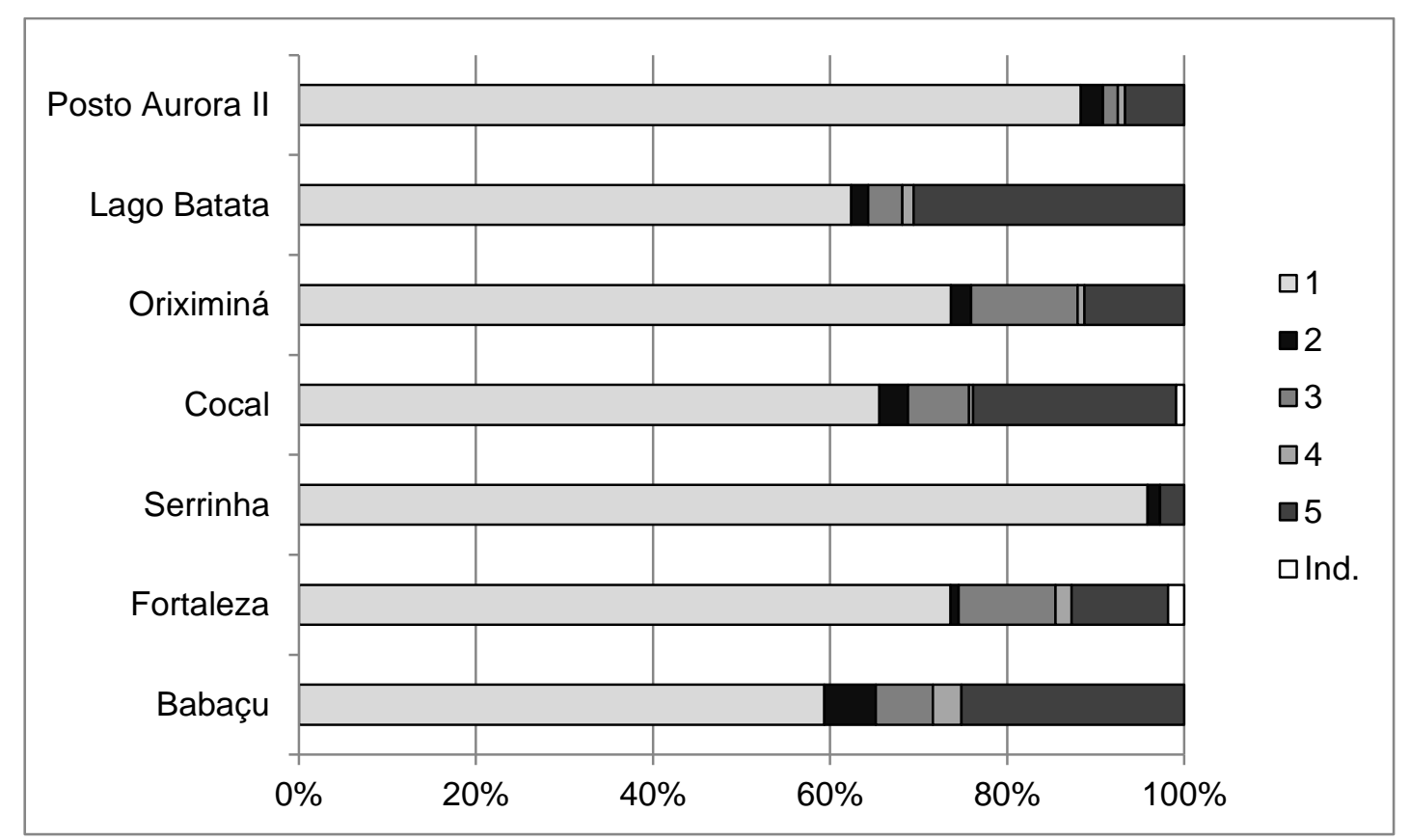

Gráfico 15. Porcentagem configuração de núcleo por proveniência.

Os resultados obtidos no estudo de coleções de museu em relação à configuração dos núcleos não são comparáveis aos disponíveis na bibliografia sobre o estilo Konduri devido a diferenças no modo de classificação ou a inexistência desse atributo nas fichas de análise. Há dois conjuntos descrito a partir das mesmas categorias adotada aqui é o do sítio Oriximiná 3 analisado pela Scientia Consultoria (SCIENTIA, 2013) e o do sítio Tawanî analisado por Jácome (2017). Em Oriximiná 3, o tipo 1 é encontrado na amostra deste sítio em 45,7\%, sendo o tipo 5 o segundo mais frequente, identificado em 30,4\% (SCIENTIA, 2013).. Em relação ao sítio Tawanî predomina a configuração de núcleo "oxidante incompleta", mas esta não é exatamente equivalente a uma coloração escura ("redutora") em toda a secção do fragmento (JÁCOME, 2017). Nas análises dos sítios Terra Preta 1 e 2 foi utilizada a categoria "redução tabatinga" para caracterizar uma das configurações do núcleo que é predominante na maioria das amostras coletadas (SCIENTIA, 2016). Essa categoria, entretanto, não foi definida, mas é provável que seja equivalente a uma coloração totalmente homogênea em toda a secção do fragmento (tipo 1). A segunda categoria mais numerosa nessa análise foi a queima totalmente oxidada que também faz parte do tipo 1. No caso do sítio Cipoal do Araticum, a pesquisadora separa apenas as configurações de núcleo entre indicativos que queima 
completa (cor homogênea) ou incompleta (cores distintas), com a predominância das primeiras (CHUMBRE, 2014).

\subsubsection{Espessura de paredes}

As paredes das vasilhas Konduri são predominantemente finas. A espessura da maioria das peças analisadas varia entre 5 e $10 \mathrm{~mm}$ (77,6\%/1181). Mesmo as bases não costumam ter uma espessura significativamente distinta da parede. Essa tendência a paredes mais finas está presente em todas as amostras mais numerosas por sítio. As maiores espessuras são encontradas em assadores. Mesmo vasilhas com um diâmetro próximo a de $100 \mathrm{~cm}$, como identificadas no sítio Lago Batata não possuem paredes muito mais grossas que a maioria. A amostra do sítio Posto Aurora II apresenta uma sensível diferença na proporção de paredes com até 5,0 $\mathrm{mm}$ em relação a outras amostras, mas isso pode estar relacionado à coleta menos seletiva em coleções diagnósticas. A mesma tendência a paredes finas é encontrada em sítios unicomponenciais Konduri como Oriximiná 3 e Tawanî (SCIENTIA, 2013; JÁCOME, 2017). No primeiro, por exemplo, $86 \%$ da amostra exibe espessura máxima entre 5 e 11 $\mathrm{mm}$.

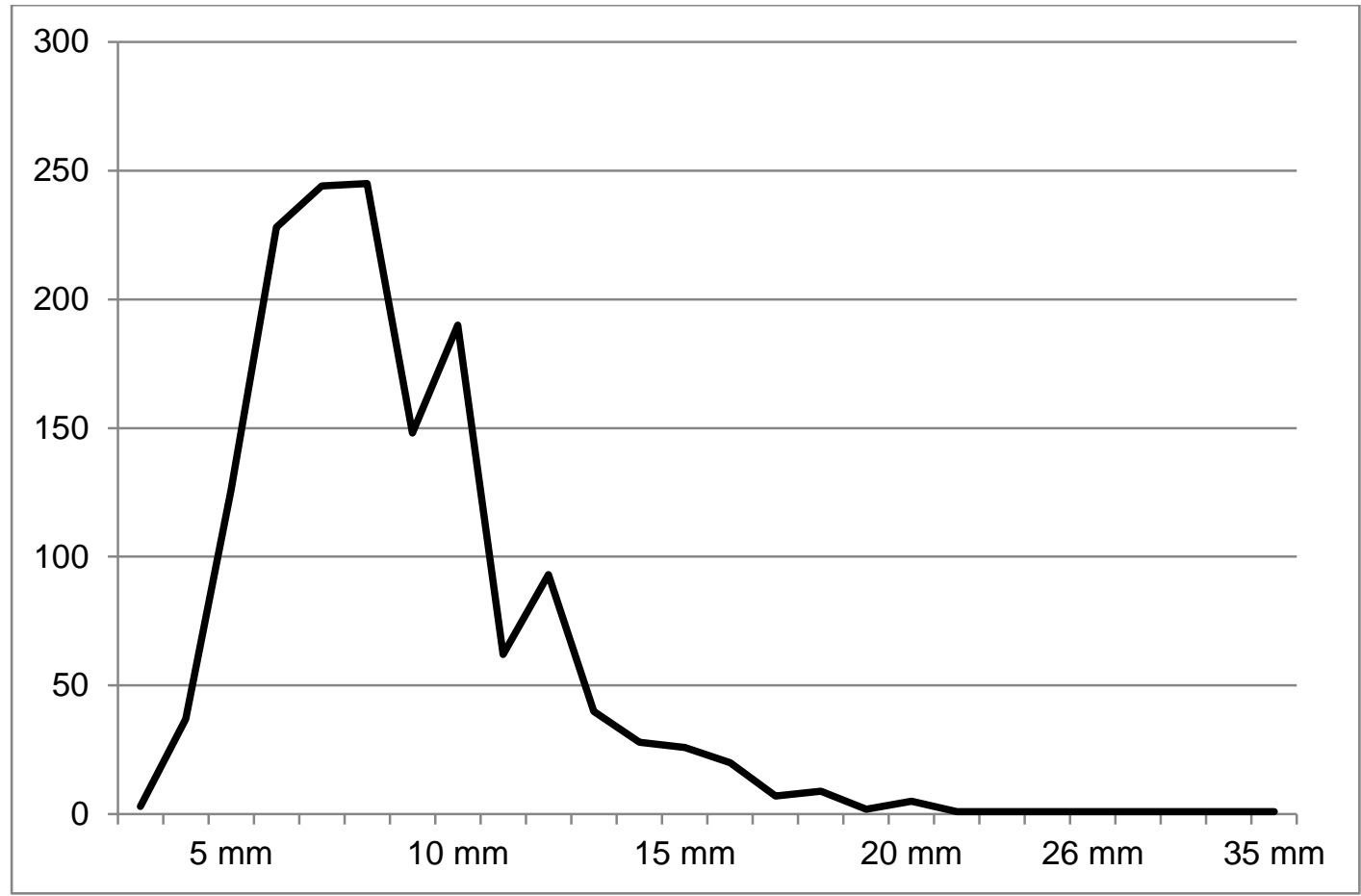

Gráfico 16. Quantidade por espessura nas coleções analisadas 
O uso de cauixi em concentrações elevadas pode estar vinculado à escolha por paredes mais finas. Para construir uma vasilha é necessário que as paredes ainda moles mantenham-se firmes o suficiente para que não haja nenhuma deformação (RICE, 1987). Em recipientes maiores, que também tem paredes finas no caso Konduri, essa pressão é ainda maior durante a manufatura.

\subsubsection{Morfologia}

As morfologias da cerâmica Konduri ainda são pouco conhecidas, sendo raros os exemplares inteiros identificados até o momento. Nas instituições pesquisadas foram identificadas apenas 5 vasilhas inteiras/semi-inteiras sendo que duas já eram conhecidas desde a década de 1950 (HILBERT, 1955a; PALMATARY, 1960) . Há outras duas vasilhas identificadas nas coleções do MPEG que podem ser relacionadas ao estilo Konduri, mas não é possível fazer uma classificação segura dada suas características particulares (Figura 43). Outras três vasilhas Konduri são conhecidas a partir da bibliografia (CASTRO, 2018; LIMA; SILVA, 2005). Hilbert (1955a) apresentou duas hipóteses para a raridade de vasilhas inteiras: (1) grande fragmentação da cerâmica motivada por múltiplas reocupações dos sítios; (2) quebras intencionais praticadas pelos indígenas, como no caso dos Wayana e outros coletivos que habitam as cabeceiras dos rios Trombetas, Cuminá e Paru de Leste (ver VELTHEM, 2003). Nenhuma dessas hipóteses pôde ser verificada ou falseada, mas a nosso ver, o principal motivo dessa ausência, evidenciada em comparação a outros contextos, deve ser a inexistência ou raridade de urnas funerárias ou enterramentos intencionais, que garantem a integridade das vasilhas em muitos contextos arqueológicos amazônicos. 

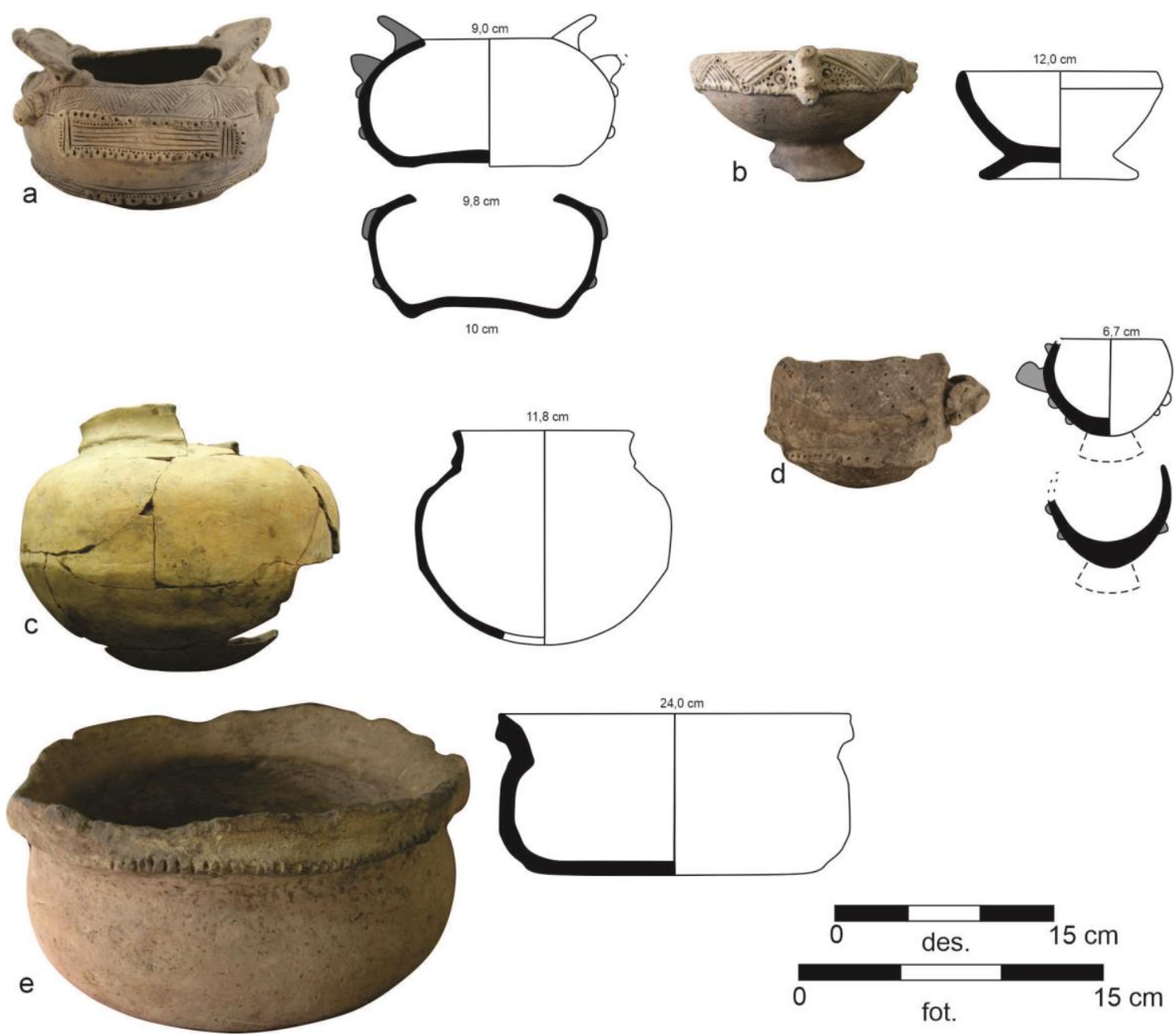

Figura 42. Vasilhas inteiras ou semi-inteira. Proveniência/ procedência: a-b Oriximiná (Col. Frederico Barata); c- Cajual (Col. Peter e Klaus Hilbert); d - Trombetas enseada (Col. T-881); e - Lago Sapucuá (doador desconhecido).

Uma das vasilhas na coleção Frederico Barata (T-405), talvez a peça mais conhecida, é pequena com boca elíptica, borda introvertida, lábio plano, base levemente convexa, com dois apêndices na borda, motivos gráficos incisos no bojo superior, dois de apêndices na mesma área, somados a outros dois na porção mesial (Figura 42). Outra vasilha da mesma coleção (T-413) apresenta boca circular, borda direta com reforço externo, lábio arredondado, base anelar e contorno simples. Há vários apêndices no reforço da borda. Na coleção T- $881^{56}$ identificamo o que parece ser uma miniatura com borda introvertida, lábio biselado, boca elíptica, negativo de base anelar e contorno simples. Essa peça também exibe padrão inciso próximo à borda e um apêndice

${ }^{56}$ Foi tombada com o número 824 mas, de fato, faz parte do mesmo conjunto doado no final do século XIX com a informação escrita "Trombeta enseada". 
figurativo. Identificamos também no acervo do MPEG uma vasilha com proveniência do Lago Sapucuá, que apresenta borda extrovertida com reforço externo, lábio fragmentado, base plana e contorno infletido. Por fim, há uma vasilha semi-inteira coletada por Klaus e Peter Hilbert no sítio Cajual. Essa vasilha tem borda extrovertida com reforço interno, lábio plano, boca circular, base conexa, contorno infletido.
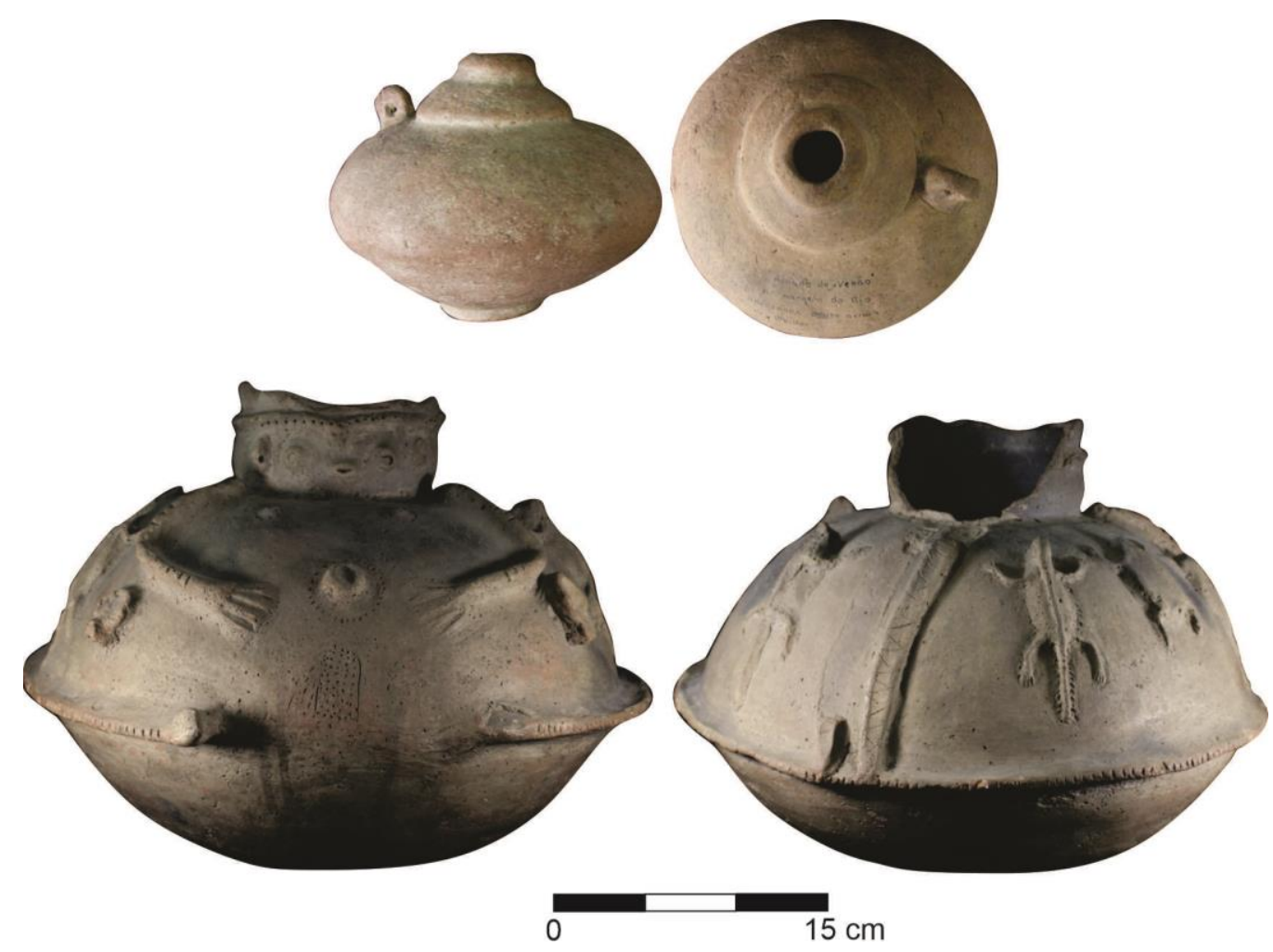

Figura 43. Vasilhas possivelmente relacionadas ao estilo Konduri. Proveniência/procedência: Superior (Superior/ Col. Paul Le Cointe); Inferior(Lago Grande de Curuaí/ Doação Harald Sioli).

A análise das coleções permitiu reconstituir a morfologia de 92 vasilhas. Como são raras as vasilha inteiras e há poucas reconstituições na bibliografia, reconhecemos a limitação das projetções. São necessários novos trabalhos que possam ratificar ou revisar como as vasilhas foram reconstituídas. Optamos por representar todas as bases como sendo planas tendo em vista sua predominância tanto nas coleções analisadas quanto nas amostras sistematicamente coletadas. Nesse sentido nos diferenciamos de pesquisas recentes na região de dispersão do estilo Konduri que representaram sempre 
suas projeções com base convexa (AMORIM, 2008; SCIENTIA, 2013, 2016; GUAPINDAIA, 2008).
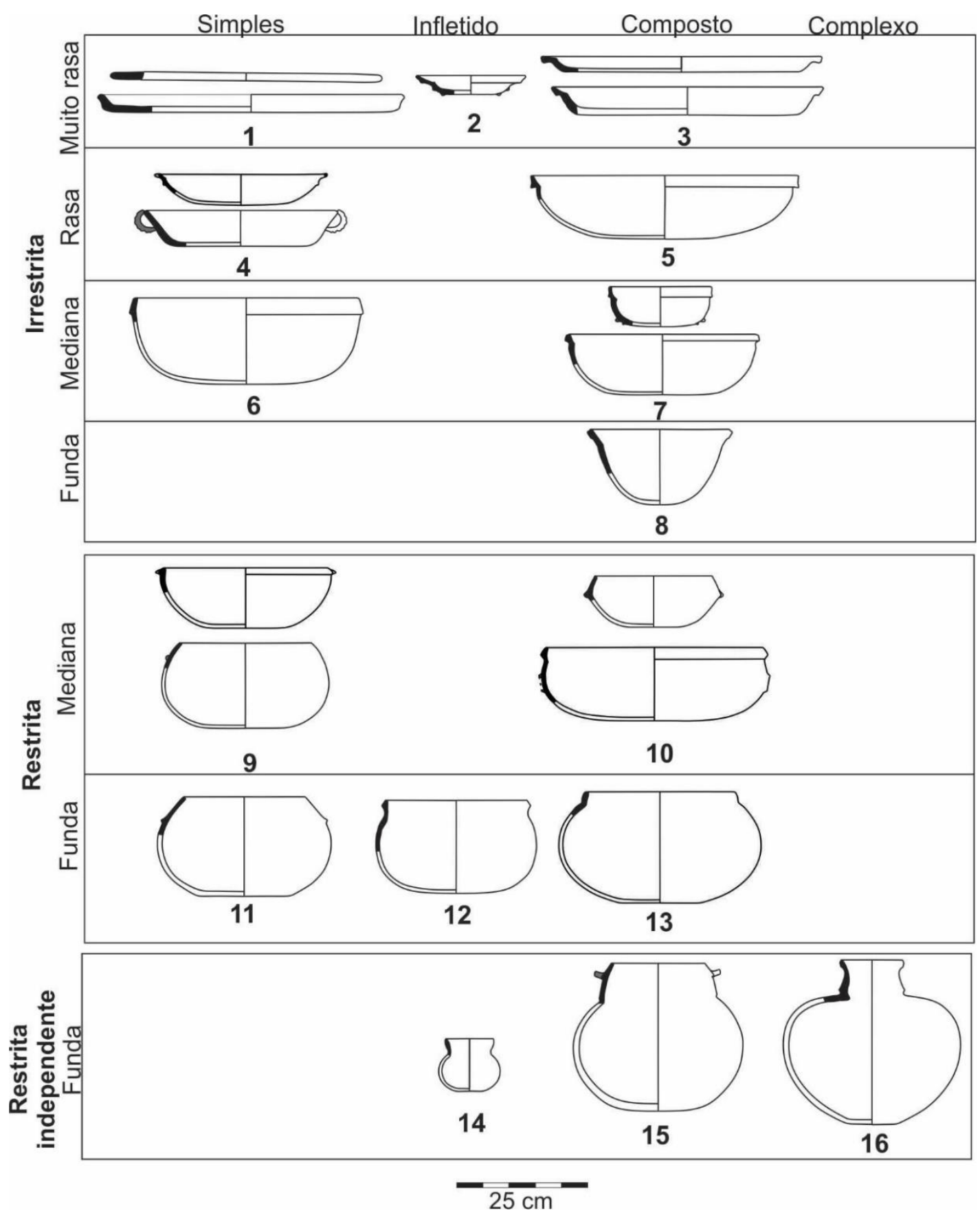

Figura 44. Classificiação de morfologias a partir das reconstituições. 
A partir das morfologias reconstituídas realizados sua classificação a partir de sua abertura (irrestrita, restrita e restrita independente), contorno (simples, infletido, composto e complexo) e razão altura/diâmetro $(\leq 0,15, \leq 0,30,>0,3 / \leq 0,5$ e $<0,5)$ (SHEPARD, 1956). Entre as $47^{57}$ permutações possíveis, formamos 16 classes, sendo predominantes aquelas marcadas por contorno simples. É notável também a presença de vasilhas de contorno composto, marcado por um ângulo próximo a borda em vasilhas de abertura irrestrita e restrita (Figura 44). Apenas um gargalo coletado no sítio lago do Jacaré apresenta mais de dois ângulos, configurando uma vasilha de contorno complexo. A classificação não considerou a morfologia das vasilhas (elipsoide, esferóide, troncocônica, cilíndrica, etc.), mas as vasilhas irrestritas muito rasas apresentam predominantemente morfologia troncocônica. Enquanto as classes 4, 5, 6, 7 são majoritariamente compostas por vasilhas elipsóides e algumas troncônicas. As vasilhas com abertura restritas têm bojos esferóides e elipsóides. A projeção das morfologias restritas independentes é menos confiável dada à presença de apenas uma pequena porção do bojo. Considerando as informações disponíveis, seu corpo tende ao ovóide e elipsoide e gargalos e inflexões troncônicos e hiperbólicos. Outra questão não enfatizada em nossa classificação é a diferença entre vasilhas com abertura pouco restrita, mas que pode ser uma diferença importante para estudos futuros (ver classes 9 e $10)$.

Mais da metade das reconstituições (50/54,34\%) são de peças provenientes de cinco sítios: Babaçu (12 peças), Fortaleza (7 peça), Posto Aurora II (11 peças), Lago Batata (5 peças) e Serrinha (11 peças). Essas amostras mostram uma variabilidade semelhante à encontrada com a análise de materiais obtidos sistematicamente nos sítios Aviso I, Oriximiná 3, Terra Preta 1 e Terra Preta 2 (GUAPINDAIA, 2008; SCIENTIA, 2013, 2016). Nas reconstituições presente na bibliografia predominam as morfologias irrestritas simples e compostas rasas $^{58}$ (classes 4,5,6 e 7) (Gráfico 17). Também estão presentes vasilhas com orifício irrestrito e muito rasas, com um exemplar da classe 1 também exumado no sítio Tawanî. Nas coleções analisadas por nós a classe 1 é muito frequente por causa de viés de coleta voltado para peças diagnósticas e decoradas.

\footnotetext{
57 Não existe vasilha de restrita independente que exiba contorno simples, por isso não são 48 possibilidades de permutação.

${ }^{58}$ Forma 3, 5 e 7 no sítio Aviso I; Forma 2 do sítio Bela Cruz II (GUAPINDAIA, 2008); Tipo 2 em Terra Preta 1 e Terra Preta 2 (SCIENTIA, 2016); diversas formas no sítio Oriximiná 3 (SCIENTIA, 2013).
} 


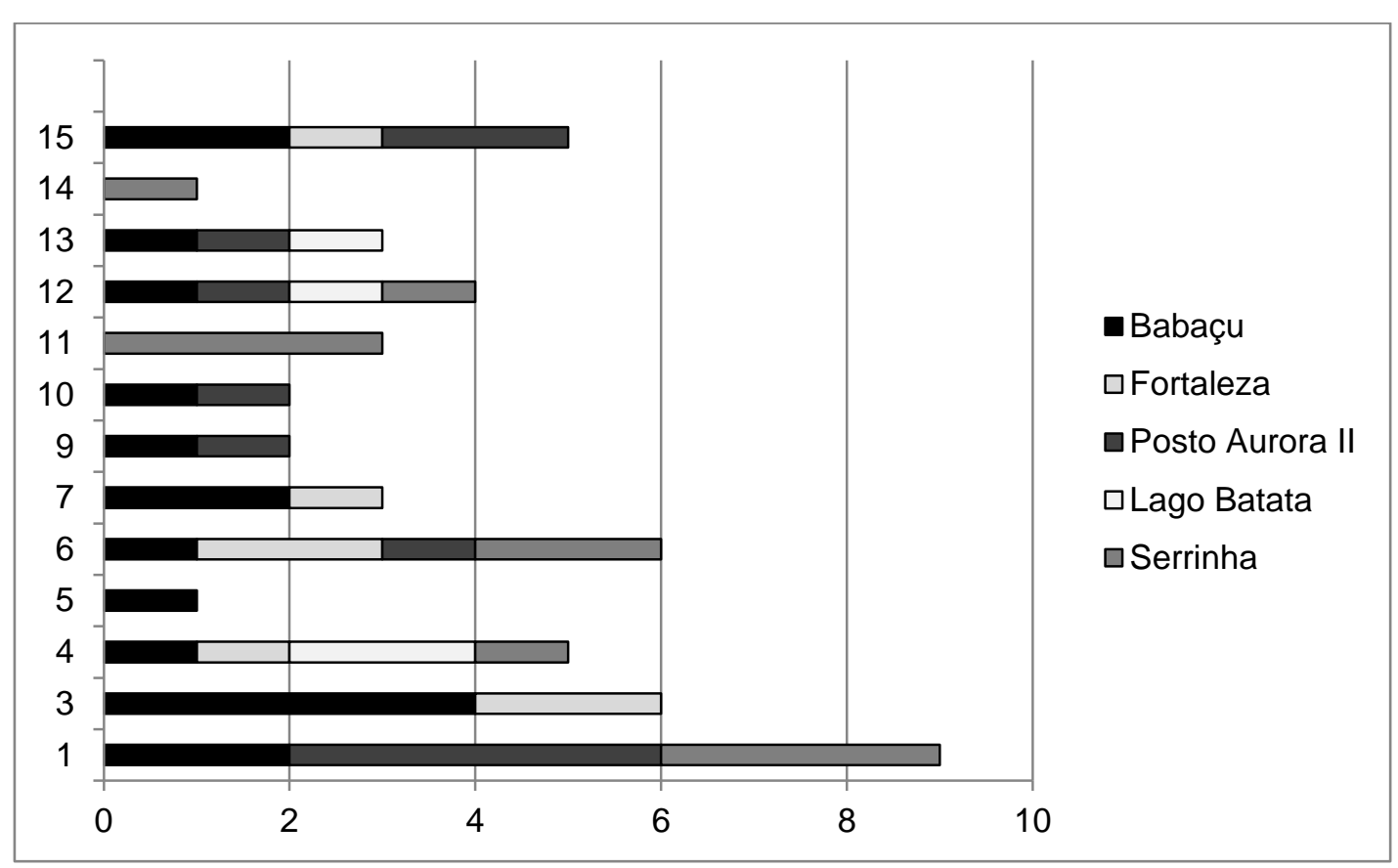

Gráfico 17. Frequência de classes morfológicas por proveniência.

A predominância de vasilhas irrestritas rasas e medianas no estilo Konduri pode estar vinculada ao uso frequente das vasilhas para servir alimentos, dada a maior facilidade de acessar o seu conteúdo (SHEPARD, 1956; RICE, 1987). Muitas dos diâmetros estimados para os tipos 4, 5, 6 e 7 medem entre 20 e $40 \mathrm{~cm}$ de diâmetro possibilitando o serviço coletivo de alimentos (Gráfico 23) Algumas das poucas projeções com grandes apêndices elaborados, é importante frisar, são do tipo 4. Não dispomos de evidências, mas é possível que, especialmente as mais profundas tenham sido usadas para cozinhar. Duas bordas coletadas no sítio Lago Batata tiveram seu diâmetro estimado em mais de $90 \mathrm{~cm}$, o que leva a pensar em grandes recipientes para a preparação de alimentos. A potencial multifuncionalidade de vasilhas irrestritas com contorno simples pode justificar ainda sua relativa abundância em coleções diagnósticas e, principalmente em amostras de larga escala obtidas em sítios extensos, como Terra Preta 1 e 2 (SCIENTIA, 2016). A presença de fuligem foi documentada em poucos exemplares. Um deles proveniente de Ponta da Mafada do tipo 12. Vasilhas dessa mesma classe foram reconstituídas com uma frequência não muito alta nos sítios Aviso 
I, Terra Preta 1 e Terra Preta 2. Frequentes nas coleções analisadas as morfologias de orifício restrito e contorno composto são menos frequentes nos sítios citados anteriormente e também Oriximiná 3. Tais morfologias poderiam ter tido um uso mais limitado nas ocupações pré-coloniais restrito a armazenar e transportar alguns líquidos. É necessário que se estude mais detalhadamente os vestígios de uso, tanto macroscópicos quanto microscópicos, para possamos compreender melhor a funcionalidade dessas vasilhas.

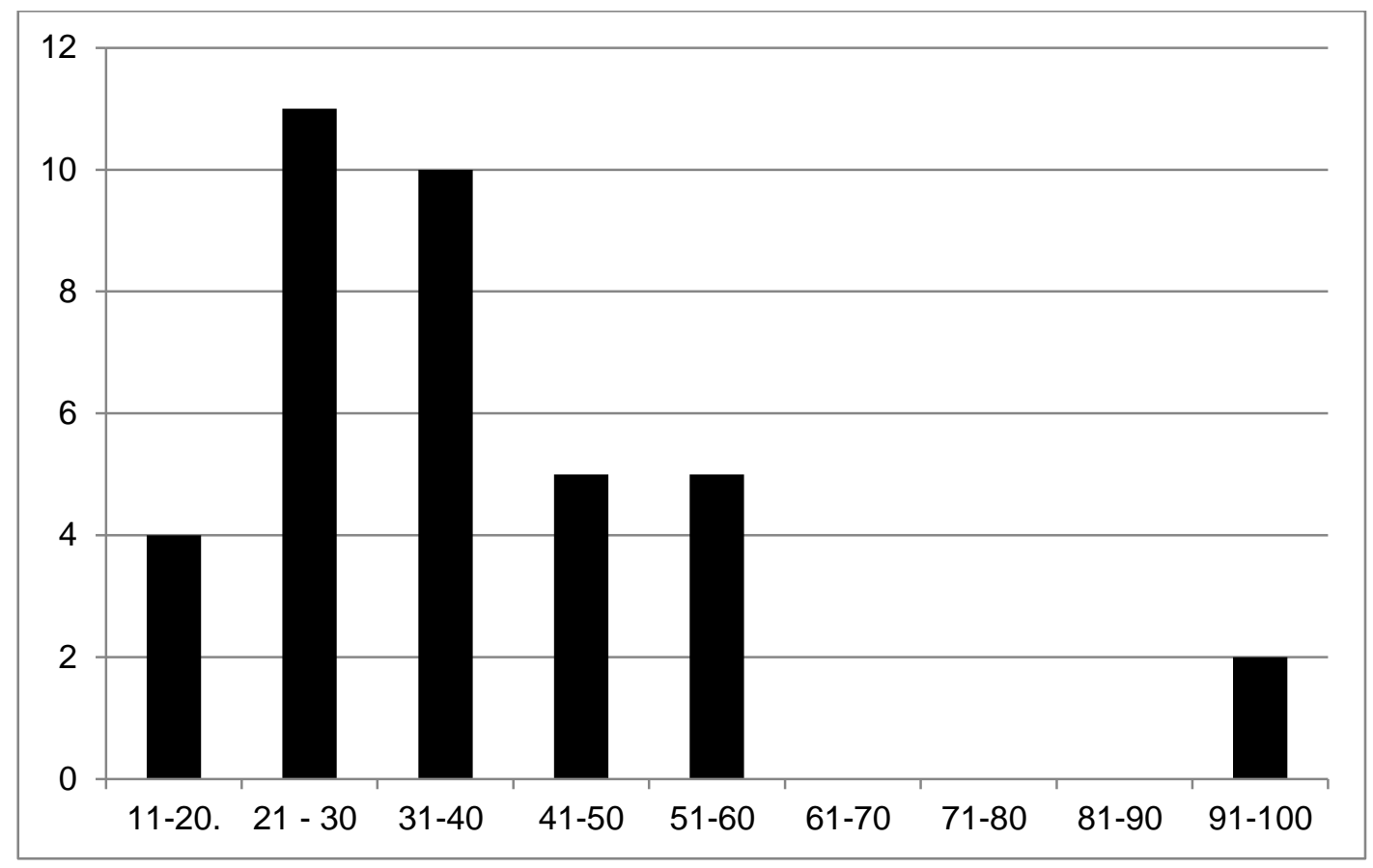

Gráfico 18. Frequência de intervalos de diâmetros nas classes morfológicas 4, 5,6 e 7.

As categorias "prato" e "grelha" foram utilizadas por Hilbert (1955a) para classificar morfologias com abertura irrestrita e muito rasa (morfologias 1, 2 e 3). O termo "grelha" é uma tradução literal de griddle presente em uma das obra citadas nas referências bibliográficas (WILLEY, 1949). Atualmente, a categoria morfo-funcional mais frequente em português é assador. A denominação deriva da analogia etnográfica advinda do uso generalizado de vasilhas morfologicamente semelhantes para a produção de pães achatados de massa de mandioca, o beiju, e também tortilhas de milho em toda a Amazônia (NORDENSKIÖLD, 1922; ROTH, 1924; BARRETO, LIMA, BETANCOURT, 2016). Em arqueologia, a denominação é aplicada a morfologias 
ligeiramente distintas, caracterizadas por serem muito rasas e com diâmetros grandes, de $50 \mathrm{~cm}$ ou mais (DeBOER, 1975). A nosso ver, a denominação assador pode ser aplicada a duas variantes (1 e 3), dado que são conjuntos morfologicamente similar em relação ao diâmetro, altura, além de exibirem um conjunto de padrões gráficos caracteristicamente aplicados a face interna da borda. Os assadores coletados nos sítios Posto Aurora II, Lago Batata, Cocal (1), Babaçu (1) exibem marcas de fuligem na face externa, confirmado a expectativa gerada pelos exemplos etnográficos. Em consonância com esses resultados, Castro (2018) identificou também exemplares com uma nítida camada de fuligem cobrindo a face externa de vasilhas.

Há anos tem se discutido o potencial de correlação das morfologias muito rasas e aberta com o consumo de mandioca (DeBOER, 1975; PERRY, 2002; van den BEL, 2015). Esta é uma questão que só pode ser solucionada contextualmente com a análise de microvestígios. A mesma forma pode ser usada também para a preparação de tortilhas de milha, por exemplo. A leitura da crônica escrita por Maurício de Heriarte, por outro lado, menciona explicitamente a importância do consumo de mandioca na região do rio Trombeta. Afirma o cronista que "[a]s terras d'este rio das Trombetas (...) sam mais fartas de mandioca que a dos Tapajó” (HERIARTE, 1874, p. 38-39). O material lítico também pode conter um indicativo do consumo de mandioca. DuarteTalim (2015) defende que pequenos instrumentos líticos lascados encontrados no sítio Cipoal do Araticum poderiam ser evidências do uso de raladores, geralmente vinculados a ralação da mandioca.

Hilbert (1955, p. 49) relaciona dois dos fragmentos coletados na região do rio Trombetas com elemento aplicado em seu interior a uma "segunda borda" como a dos pratos concêntricos do estilo Santarém (ver um dos exemplares Konduri em Figura 49 a). Observando exemplares do estilo Santarém em diferentes instituições (MAE, MN e MPEG) essa afirmação nos parece precipitada. Os pratos Santarém são bastante padronizados e exibem uma "segunda borda" com secção retangular quase no mesmo nível da borda, sugerindo a restrição de uma área para o uso (Figura 45).. Em uma das peças Konduri mencionadas pelo autor tem-se apenas um filete, enquanto na outra peça um rolete mais grosso com secção triangular Algumas vasilhas exibem também ângulos internos com reforço, inclusive filetes aplicados, como acontece na cerâmica coletada 
em Oriximiná 3 (SCIENTIA, 2013). Em um exemplar do sítio Lago Batata identificamos esse mesmo filete na face interna.
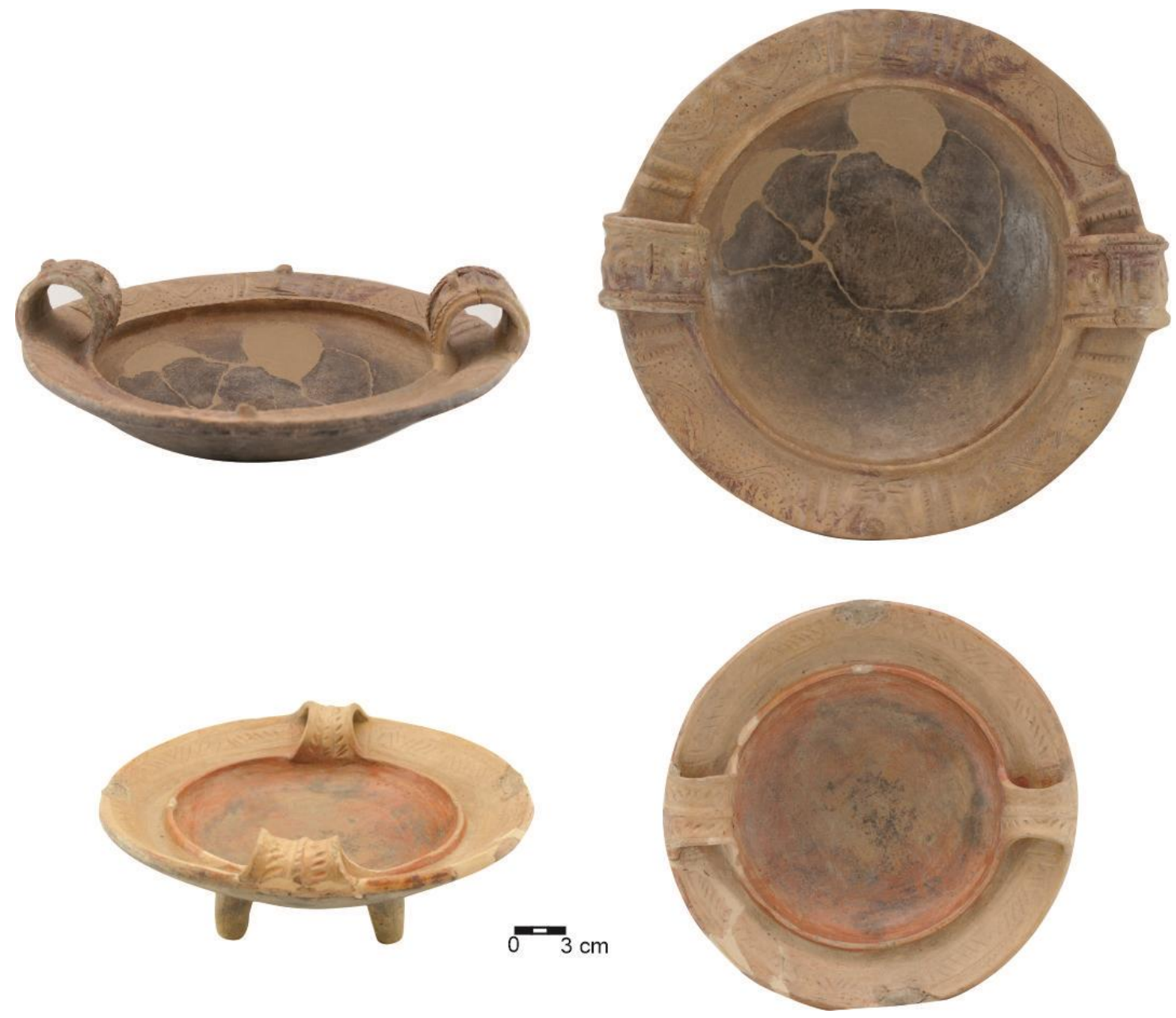

Figura 45. Pratos concêntricos ou vasilhas de dupla borda do estilo Santarém. Não são conhecidos exemplares com "segunda borda" na cerâmica Konduri.

Em termos de atributos morfológicos das vasilhas, há um predomínio de lábios planos, bordas extrovertidas e diretas e bases planas nas coleções que nós analisamos. Lábios apontados, biselados e afilados são muito menos frequentes. Bordas introvertidas são mais raras que os outros dois tipos, apesar de proporcionalmente não ser tão inferior sua quantidade nas amostras ${ }^{59}$. No caso das bases, há um predomínio

${ }^{59}$ Há também 40 bordas $(6,01 \%)$ cuja inclinação não pode ser determinada e uma da qual não se dispõe os dados $(0,15 \%)$. 
absoluto da forma plana. A frequência de base anelar, a segunda mais representada, é dez vezes menor. Também foram identificados alguns exemplares de base em pedestal e, a partir de vasilhas inteiras/semi-inteiras, uma base côncava e outra convexa. Em todas as bases em que foi possível identificar um pé modelado ou seu negativo, esta tinha forma plana, com ângulo de junção marcado.

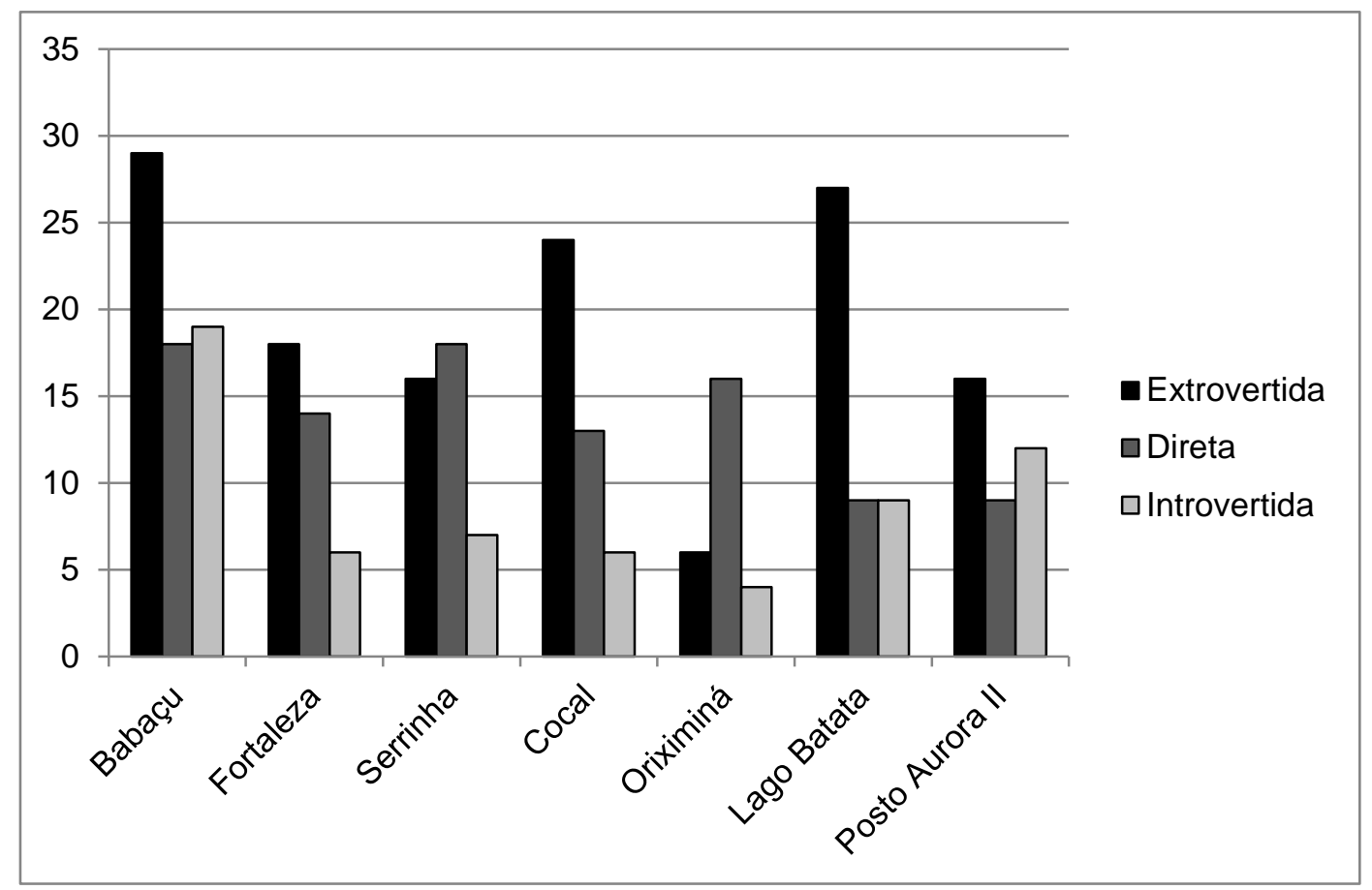

Gráfico 19. Frequência de classes de inclinação de borda por sítio..

Ao observar as proporções de inclinação de borda, forma do lábio e da base a partir de amostras de sítios específicos a tendência geral tende a se manter (Gráfico 19/ Gráfico 20). Há exceções, entretanto, como no caso das amostras dos sítios Serrinha e Oriximiná, nas quais há mais bordas diretas que extrovertidas. A quantidade de bordas disponíveis provenientes de Oriximiná é, entretanto muito menor que a dos outros considerados. É notável também uma frequência mais alta de bordas introvertidas que diretas nos sítios Babaçu e Posto Aurora II. Dada a alta incidência de bases planas, a proporção praticamente não muda entre os sítios. Há bases do tipo anelar nas amostras encontrado em Babaçu, Fortaleza, Cocal, Oriximiná e Lago Batata. Bases em pedestal foram identificadas em Babaçu, Serrinha, Lago Batata e Posto Aurora II. A amostra do 
sítio Cocal, mesmo sendo numerosa, apresenta a predominância de lábios arredondados, diferindo dos outros seis sítios.

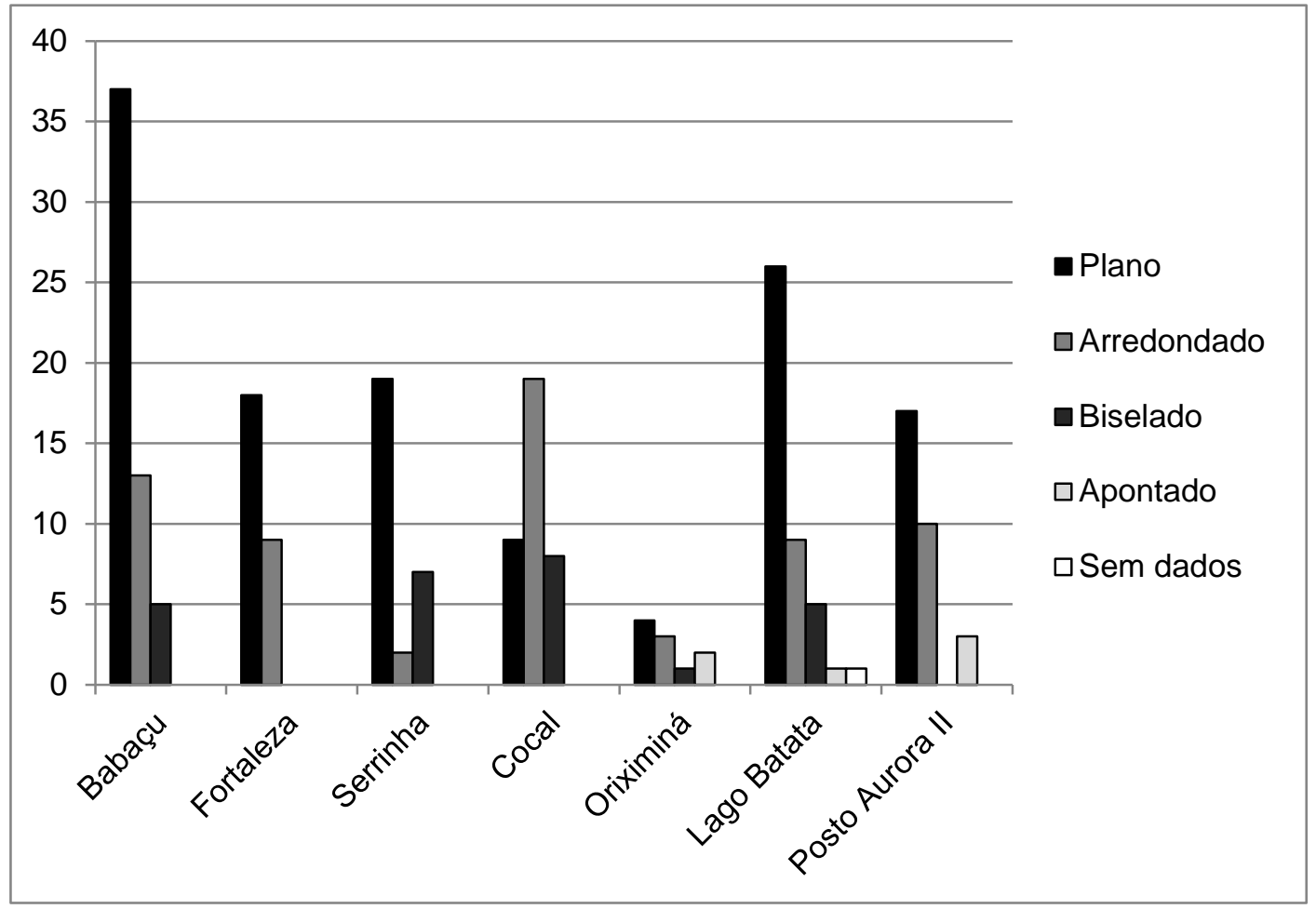

Gráfico 20. Frequência de classes de lábios por sítio.

Hilbert (1955a) destacou a presença de reforço externo nas bordas como um elemento característico do estilo Konduri. Em 42,0\% das bordas analisadas identificamos a presença desse elemento. Em geral, como destacou o autor, o reforço possui uma secção triangular. Em algumas peças notamos que a secção está mais próxima de um retângulo. Esse elemento é aplicado em bordas diretas, extrovertidas e diretas. $\mathrm{O}$ reforço interno foi identificado em apenas um exemplar. 


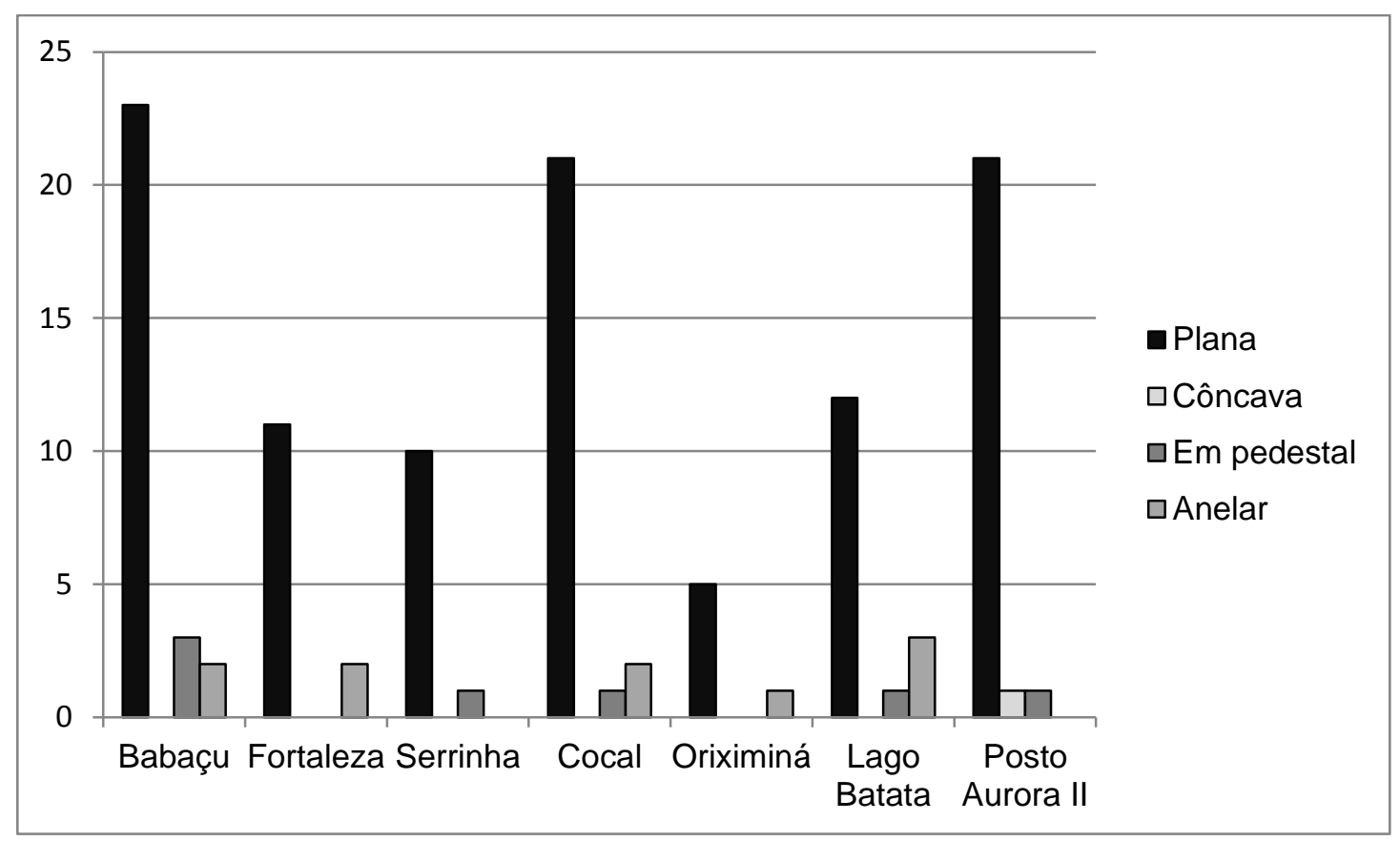

Gráfico 21. Frequência de classes de base por sítio.

Na bibliografia não há muitos dados apresentados sistematicamente em relação à morfologia de bases, bordas e lábios da cerâmica Konduri. Há apenas informações deste tipo, não associadas com as relativas à cerâmica Pocó, para os sítios Oriximiná 3 e Tawanî. No primeiro predominam bordas diretas, seguidas de bordas introvertidas e uma porcentagem muito menor de bordas extrovertidas (SCIENTIA, 2013). Em Oriximiná 3 foram exumadas também bordas vazadas ou ocas, que não foram identificadas nas coleções de museu. No sítio Tawanî, as bordas diretas também são majoritárias, mas são seguidas por bordas extrovertidas e não há nenhuma borda introvertida (JÁCOME, 2017). A frequência de reforço interno em Oriximiná 3 é superior a $10 \%$ da amostra de bordas, também estão presentes reforço interno, interno e externo e angular. No sítio Tawanî, ao contrário, bordas reforçadas interna e externamente são muito raras. Metade dos lábios em Oriximiná 3 são arredondados, sendo menos frequentes lábios planos e apontados e raros biselados. Mais da metade das bases em ambos os sítios é plana. Bases côncavas são as segundas mais numerosas em Oriximiná 3, seguidas de bases anelares. Em Tawanî há mais bases anelares que côncavas. Em Tawanî, os lábios apontados são ligeiramente mais numerosos que os arredondados, sendo os arredondados, afilados e biselados pouco frequentes. 


\section{Pleno relevo}
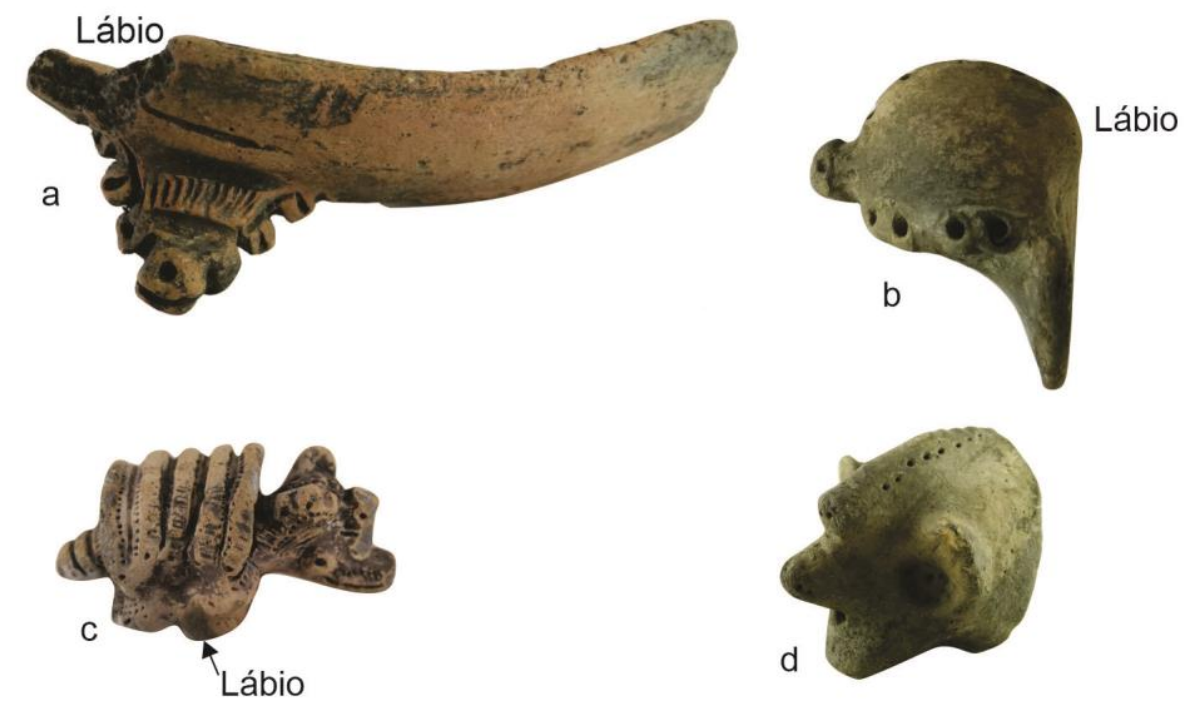

Achatado (placa)

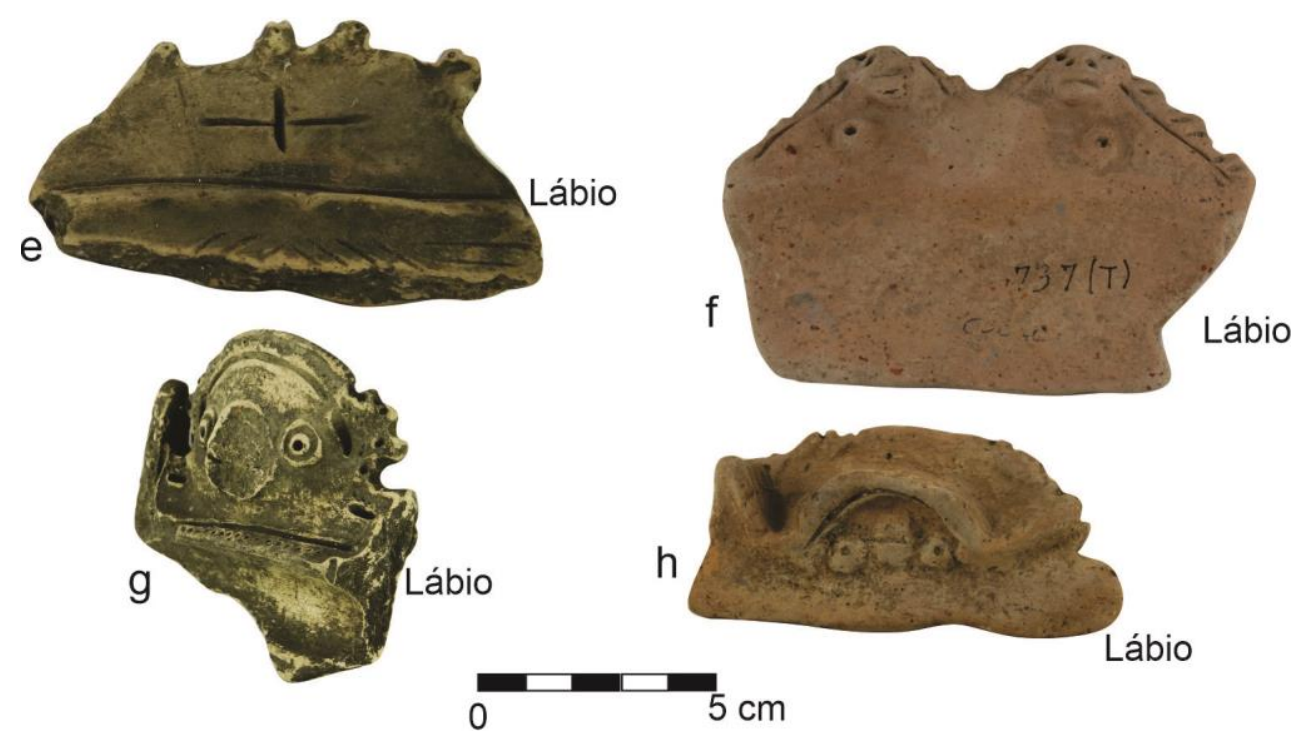

Figura 46. Diferença entre apêndices em pleno relevo (a-d) e apêndices achatados (e-h). As peças a e e são apêndices não figurativos. Proveniência/procedência: a - Posto Aurora II (Col. Aricy Curvello); b Alema (Col. Aricy Curvello); Terra Santa (Col. Peter Hilbert); d - Aimim (Col. Aricy Curvello); e Faro (Col. Aricy Curvello); f- Cocal (Col. Peter Hilbert); g - Posto Aurora II (Col. Aricy Curvello) h Ponta da Mafada (Col. Peter Hilbert).

Os resultados obtidos em relação às bordas e lábios mostram diferenças significativas se comparados com as coleções de museu. Uma hipótese para explicar isso é a de que os coletores tenderam a escolher bordas extrovertidas devido a maior frequência de decoração nessa morfologia. Como consequência, as frequências de lábio 
plano e reforço externo também podem ter sido magnificadas. Por outro lado, não é possível generalizar os dados obtidos na análise da cerâmica dos sítios Oriximiná 3 e Tawanî. A variabilidade desses elementos morfológicos pode se vincular a variabilidade interna do estilo e formas de ocupação e uso da paisagem, como sítios de habitação e acampamento (ver GUAPINDAIA, 2008). A frequência das bases planas, por sua vez, tanto nas coleções de museu quanto nas escavações sistemáticas é bastante elevada.

\subsubsection{Apliques}

Os apliques são modelagens afixadas após a construção da vasilha e, às vezes, após sua secagem. Nas coleções analisadas foram diferenciados três conjuntos de apliques distintos: pés ou suportes, alças e apêndices. Os pés são modelagens inseridas entre o bojo inferior e a base. Seu método de afixação já foi mencionado na seção a respeito de técnicas e métodos. As alças por sua vez são modelagens vasadas, cuja função presumida é a de suspensão do recipiente cerâmico (CHMYZ, 1976). Os apêndices, por sua vez, são modelagens consideradas "adornos" das vasilhas, sendo frequentemente figurativos.

Os apêndices são as modelagens mais frequentes nas coleções estudadas, certamente devido ao interesse dos coletores. As áreas de aplicação de apêndices na cerâmica Konduri são o lábio, face externa da borda, bojo superior e em alças sobre borda. Nas coleções analisadas a maioria é aplicada ao lábio (331/ 35,90\%), mas também há parcela considerável que era aplicada ao bojo superior (215/ 23,31\%). São menos frequentes apêndices aplicados na face externa das bordas $(158 / 17,13 \%)$ e raros os situados no centro de alças sobre bordas $(6 / 1,41 \%)$. Uma parcela significativa das peças não pode ser localizada porque não apresentava elementos suficientes para identificação (199/21,58\%). Um único exemplar, coletado no sítio Lago Batata, parece ter sido aplicado à face externa da base de uma vasilha. Há uma estrutura de aplicação dos apêndices relativamente rígida, uma vez que apêndices com a mesma figuração são aplicados quase sempre às mesmas áreas.. Os apêndices têm dimensões variadas: desde menos de 3,0 cm de comprimento até mais $20,0 \mathrm{~cm}$. A maioria, entretanto, mede entre 5,0 e $10,0 \mathrm{~cm}$.

Entre os apêndices fixados no lábio, há dois modos de composição volumétrica: (1) em pleno relevo e (2) achatado ou em placa (Figura 46). Este último modo reúne 
apliques com espessura igual ou um pouco superior a das paredes. Não configuram, todavia, uma "extensão de borda" porque não há uma continuidade entre o aplique e a borda, como apresentado por Rocha (2017) em um contexto do médio Tapajós. Outro modo, com apenas um exemplar identificado nas coleções é de um aplique no bojo que é mais fino que a parede. Santos (2018) descreveu dois exemplares semelhantes exumados no sítio Greig II.

Os apêndices não figurativos presentes nas coleções são majoritariamente aqueles denominados por Hilbert (1955, p. 60, fig. 21 e 22) denominou "saliências" ou “asas". Estes são aplicados na face externa das bordas e são compostos por incisões, ponteados e entalhes. Em muitos casos, essas modelagens são aplicadas junto a um filete que circunda a borda da vasilha. Outras morfologias desse mesmo conjunto também são encontradas nas coleções analisadas. Na vasilha T-405, por exemplo, há dois pares de três protuberâncias cônicas aplicadas ao bojo superior.

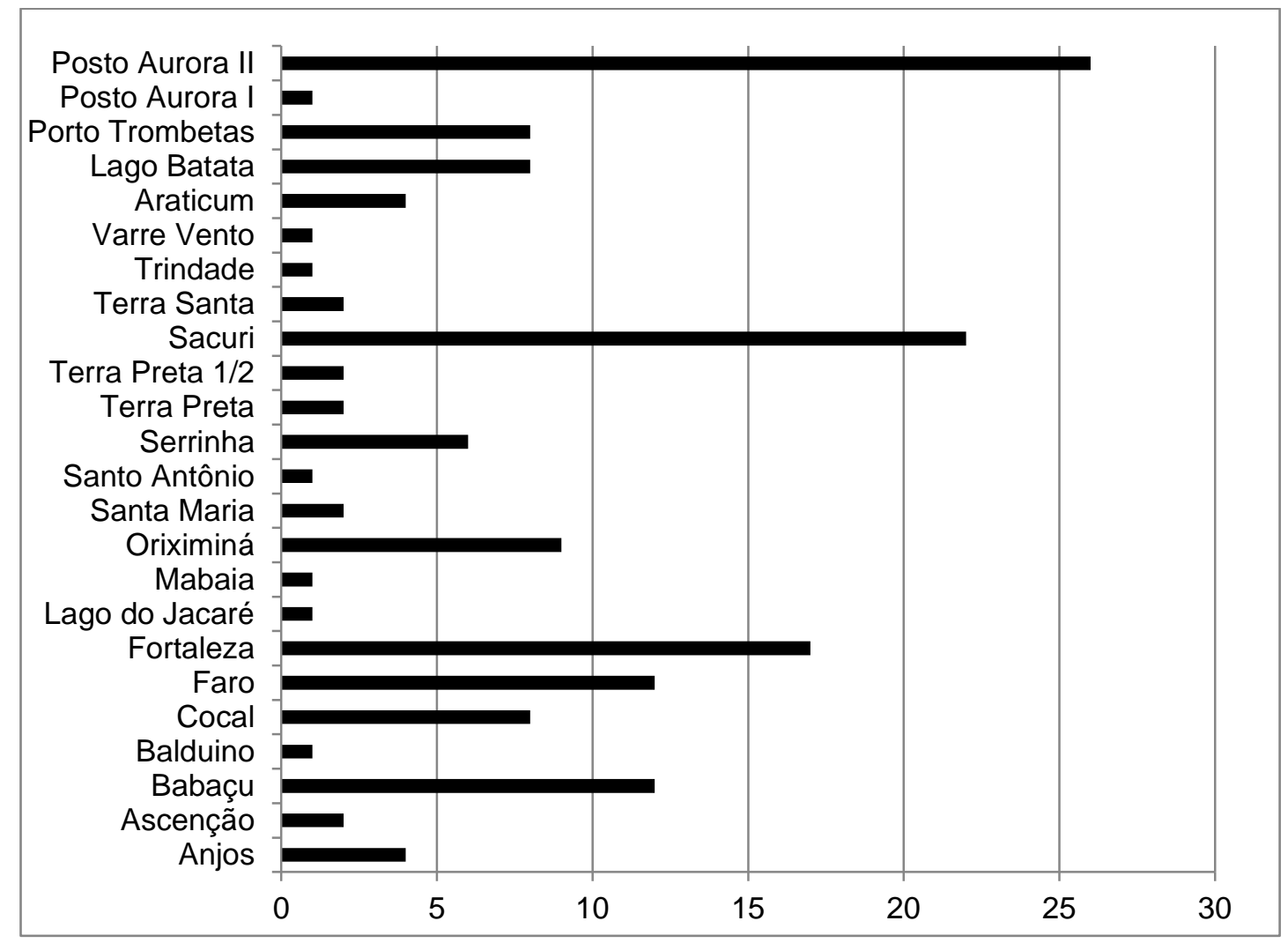

Gráfico 22. Frequência de pés modelados considerando todas as peças analisadas com informação de proveniência. 
A presença de apêndices na cerâmica Konduri está relacionada com sua performance visual, mas essas modelagens podem ter influído para facilitar a preensão das vasilhas (RICE, 1987). A vasilha T-405 apresenta uma composição de apliques que sugerem modos segurá-la a partir do bojo e dos apliques no lábio. Dessa maneira, nossa interpretação acerca dos apêndices é semelhante à de Hilbert (1955a), apesar de não considerarmos que alguns apliques sejam formalmente "asas". Os apêndices podem ter cumprido outras funções para citar novamente o exemplo da vasilha T-405, que possui placas aplicadas aos lábios com pares de furos que estar vinculadas a sua suspensão ou inserção de algum adereço.

Os pés modelados também são bastante frequentes nas amostras analisadas (Gráfico 22). São encontrados ao longo de toda a dispersão do estilo Konduri, desde o sítio Santa Rita, em Parintins, até Tawanî na faz do rio Mapuera. Hilbert (1955a) afirma, com razão, que "[t]amanha é a sua frequência [em sítios Konduri] que insensivelmente somos levados a considerá-los como os artefatos-guias das terras-pretas". A partir das coleções analisada essa dispersão se confirma. Essas modelagens são encontradas desde Sucurijú (área Óbidos) até Santa Maria (área Médio Trombetas) e alcançando Fortaleza (área Juruti). A maioria dos pés identificados exibe uma morfologia cônica, mas há também exemplares troncocônicos e cilíndricos, sendo que muitos são levemente curvos. A secção superior do pé tende a ser elíptica e inferior circular. As suas extremidades ou pontas podem ser afiladas ou planas. 


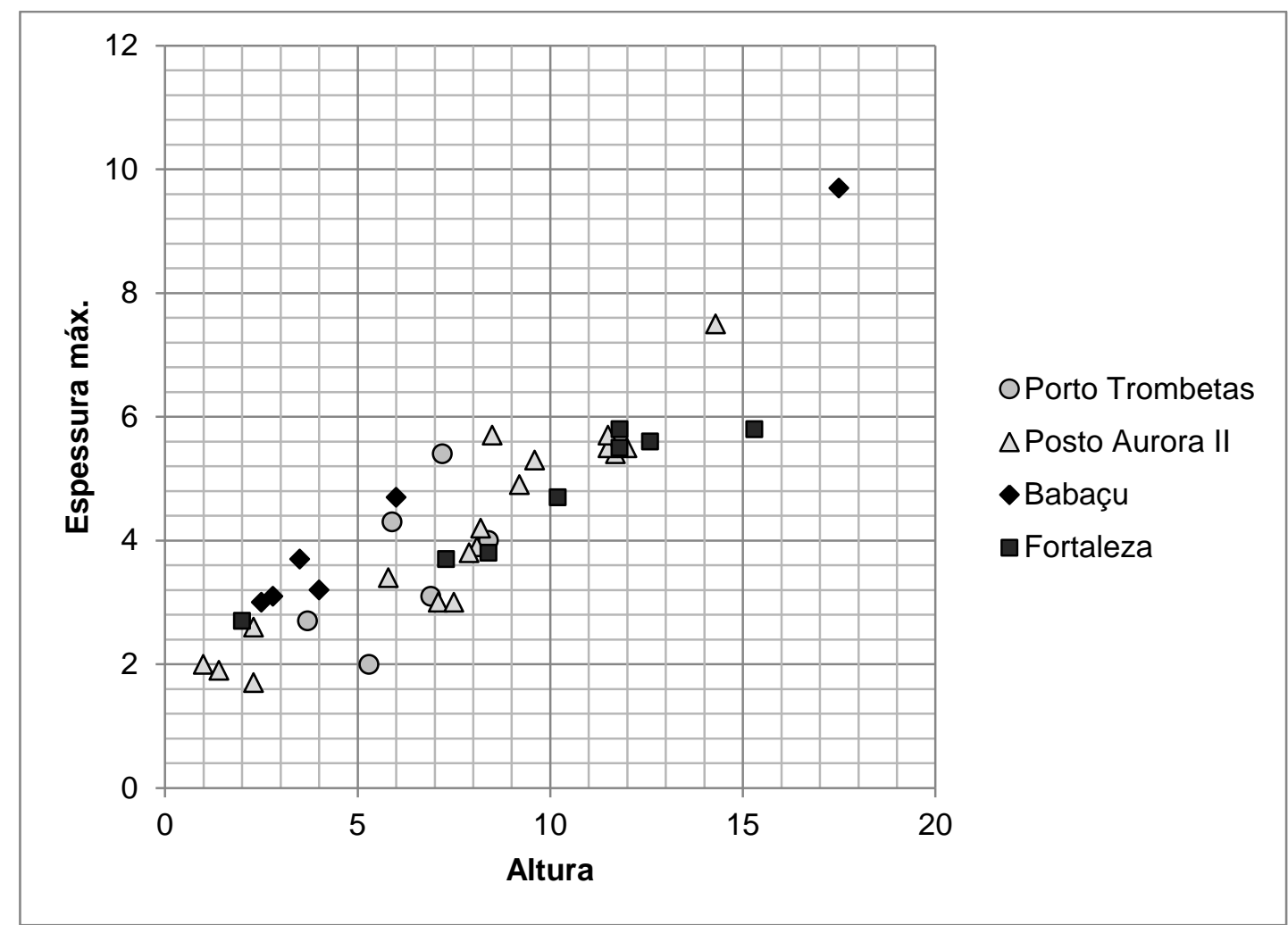

Gráfico 23. Altura e comprimento máximo (junção com a base) de pés modelados quatro amostras.

As dimensões dos pés são muito variadas; alguns exemplares medem 1,0 cm de altura enquanto outras chegam a mais de $17,0 \mathrm{~cm}$ (Gráfico 23). Não parece haver uma descontinuidade que permita criar grupos de tamanho, apesar de diferenças sensíveis nas peças muito pequenas, com até $4,0 \mathrm{~cm}$ de altura. Os pés menores tendem a exibir morfologia mais variada e não apenas cônica, como é o caso dos maiores (Figura 47). A variação de tamanho está relacionada às vasilhas aos quais as modelagens foram aplicadas: vasilhas medianas e fundas (tigelas, alguidares) ou muito rasas (assadores). 


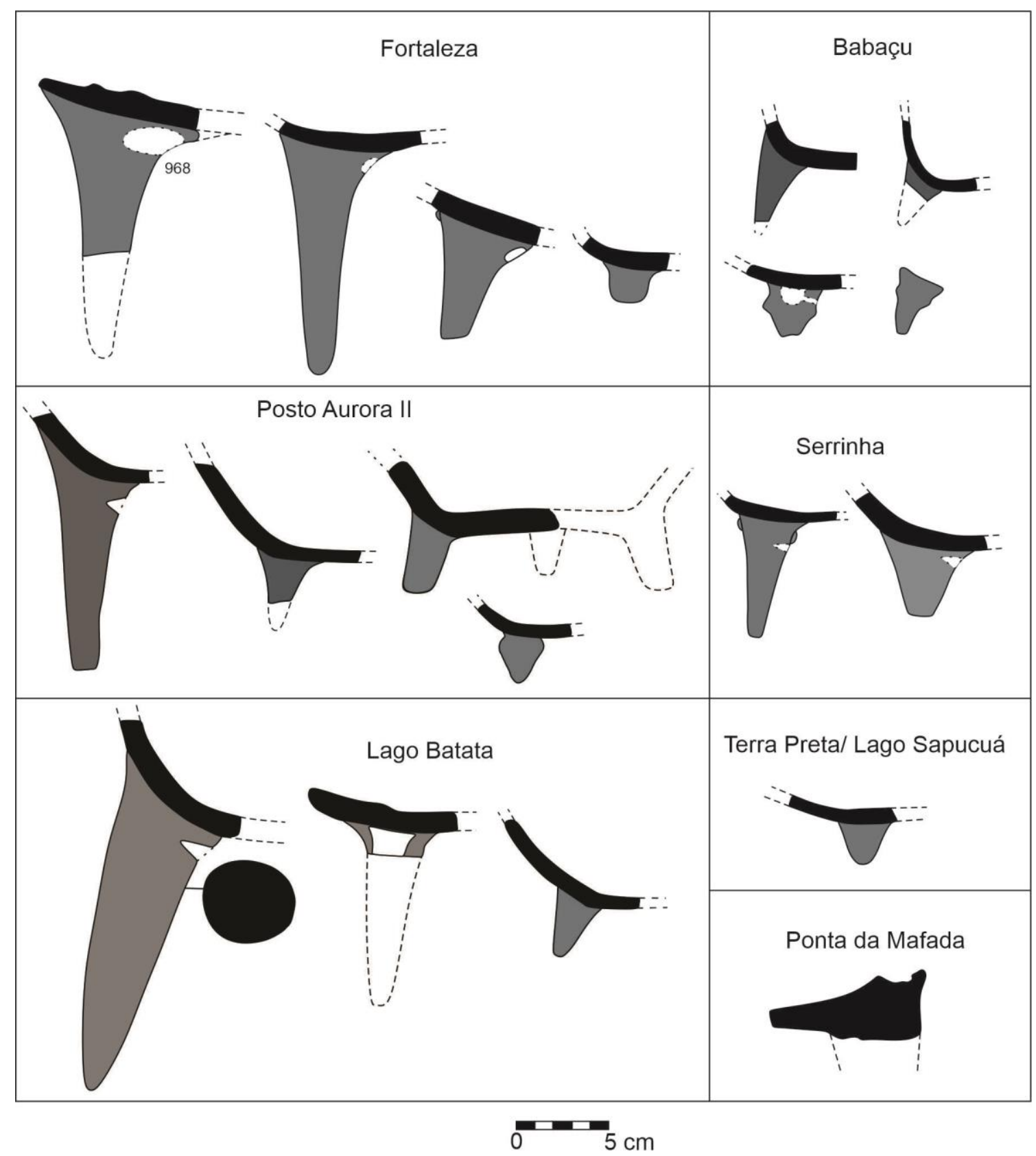

Figura 47. Pés ou suportes com diferentes proveniências e tamanhos. 


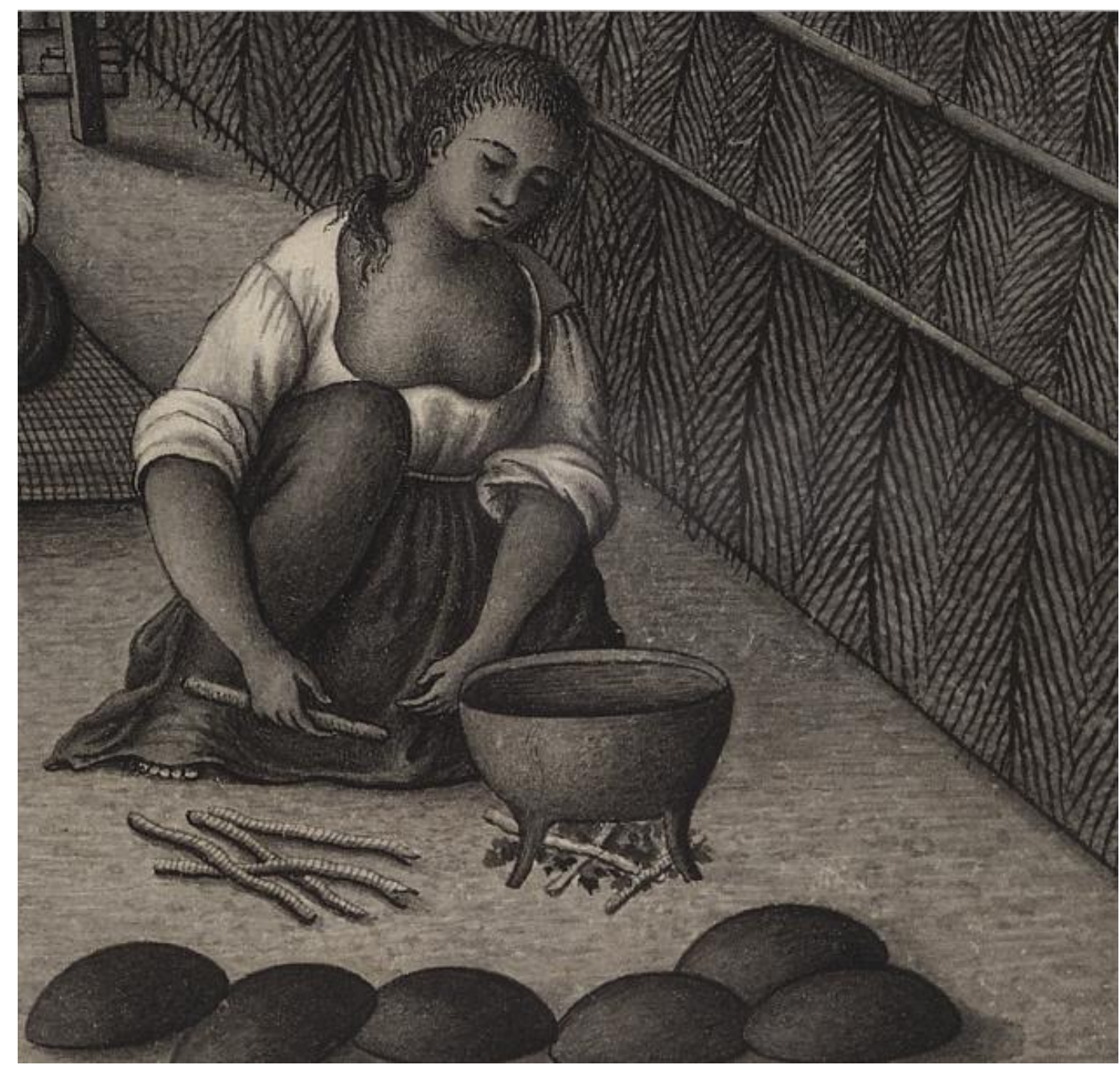

Figura 48. Detalhe da produção de cuias pintadas em Monte Alegre (José Joaquim Freire, 1785). Disponível em http://objdigital.bn.br/acervo_digital/div_manuscritos/mss1255454/mss1255454.htm. Acesso em 21 de junho de 2019.

Os suportes cônicos foram interpretados como pés de vasilhas trípodes por Hilbert (1955a) a partir de relatos de moradores e dos manuscritos de Protásio Frikel. O levantamento por nós realizado nas coleções não logrou nenhuma base com mais de um aplique ou negativo. Vasilhas trípodes inteiras são conhecidas apenas em estilo encontrados nos estilos Santarém e Axinim, encontrados em áreas adjacentes (GOMES, 2002; SIMÕES; LOPES, 1987). A partir das escavações do sítio Greig II, com muitos fragmentos de uma mesma vasilha articulados ou muito próximos foi possível identificar uma base com três pequenos pés troncocônicos (COSTA, 2018, p. 74). Na coleção Walter Marinho, na Casa de Cultura de Oriximiná, há uma base plana com quatro pés cilíndricos, sugerindo a existência desta possibilidade. A morfologia 
cilíndrica e a existência uma concavidade nas extremidades dos pés, entretanto, leva-nos a supor de que se trata de um caso particular, ao invés de uma característica frequente.
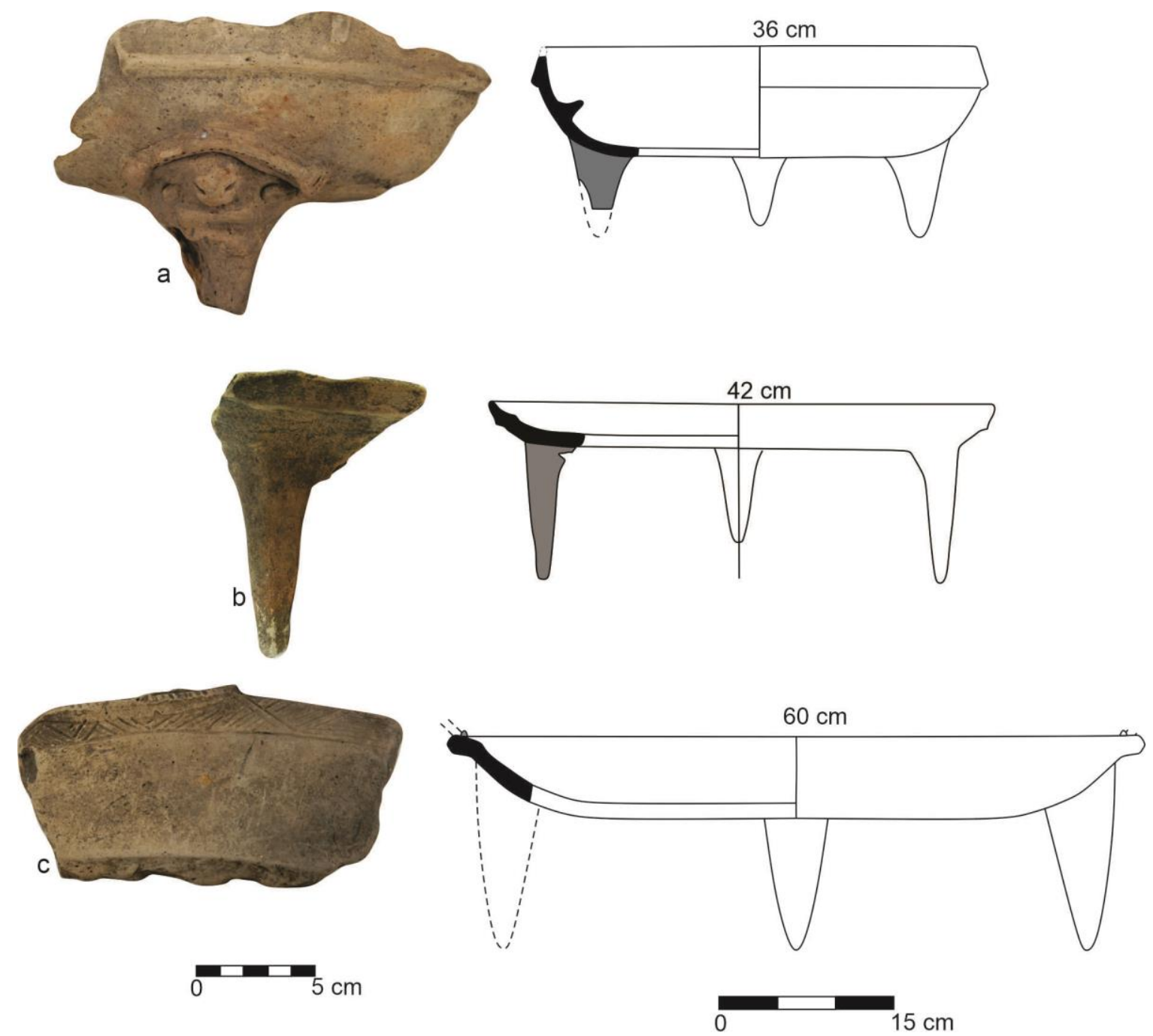

Figura 49. Projeções de vasilhas Konduri com pés trípodes, uma vasilha com abertura restrita e mais profunda e dois assadores. Proveniência: a- Santo Antônio (Coleção Peter Hilbert); b- Posto Aurora II; cBabaçu.

O uso de vasilhas com suportes fixos pode estar vinculado ao menos três funcionalidades distintas. A primeira é manter a vasilha mais estável em um terreno irregular. Bases planas, convexas ou anelares são mais instáveis dependendo do lugar e contexto de uso. A segunda funcionalidade dos pés é manter o conteúdo distante do chão ou mais próximo do usuário. No rio Negro e alto Xingu são usados suportes 
trançados, feitos com talas rígidas e cipó, em forma de ampulheta usados para manter potes ou cabaças acima do nível do chão. Em um das raras menções a vasilhas trípodes em contextos etnográficos das terras baixas da América do Sul, Ehrenreich (1948, p. 48) fala que os Karajá tinham uma "tigelinha de três pés" que era usada "principalmente pelas crianças". Nenhuma informação é oferecida para o uso voltado a uma faixa etária, mas é possível que essa vasilha facilitasse o acesso a seu conteúdo. Outra possibilidade é a utilização de vasilhas com pés modelados em contextos de exposição ao fogo sem a necessidade de implementos adicionais, como trempes. Diferentes grupos indígenas nas Guianas, rio Negro e alto Xingu, utilizam suportes móveis modelados, produzidos exclusivamente para manter panelas e assadores sobre as chamas (ROTH, 1924; FARABEE, 1918; NORDENSKIÖLD, 1924; EVANS; MEGGERS, 1960; RIBEIRO, 1988). Outros grupos indígenas usam como suporte pedras, pedaços de cupinzeiro ou mesmo tijolos industriais (ROTH, 1924; SILVA, 2000; TONEY, 2012).

A presença de fuligem foi identificada em um pés provenientes do sítio Faro, Porto Trombetas de grande fragmento de vasilha com pé coletado em Oriximiná 3 (SCIENTIA, 2013) e algumas bases com suportes no sítio Greig II (CASTRO, 2018) levam a crer que, ao menos parte das vasilhas trípodes eram usadas sobre o fogo em contextos Konduri. As evidências encontradas em escavações controladas deixam claro que não havia uma restrição morfológica; tanto assadores quanto outra morfologia poderia ser usada como panelas. As vasilhas com suportes cônicos muito curtos (talvez menores que 3,0 cm altura) provavelmente não poderiam ser usadas sobre fogo. No Baixo Amazonas, muitos dos chamados "pratos concêntricos" do estilo Santarém exibem um característico padrão de depósito de fuligem na face externa, incluindo exemplares com pés modelados. Na aquarela "Prospecto das casas das índias de Monte Alegre, onde fazem as cuias", que acompanhou a expedição do naturalista Alexandre Rodrigues Ferreira, há uma indígena acendendo fogo abaixo de uma panela com suportes cônicos fixos. Esta panela servia para a aderência de um tipo de fuligem usado como pigmento. É possível que o uso dessa vasilha seja a continuidade de conhecimento nativo da região do rio Trombetas e áreas adjacentes ${ }^{60}$.

${ }^{60} \mathrm{O}$ uso de vasilhas trípodes sobre o fogo, especialmente para cozinhar, é encontrado em diversos contextos ao redor do globo, como o neolítico grego (LIS, 2015), do sudeste asiático (HENG, 2003) ou entre grupos contemporâneos na África Subsaariana (DAVID et al., 1988) vasilhas com três pés são utilizadas sobre o fogo. 


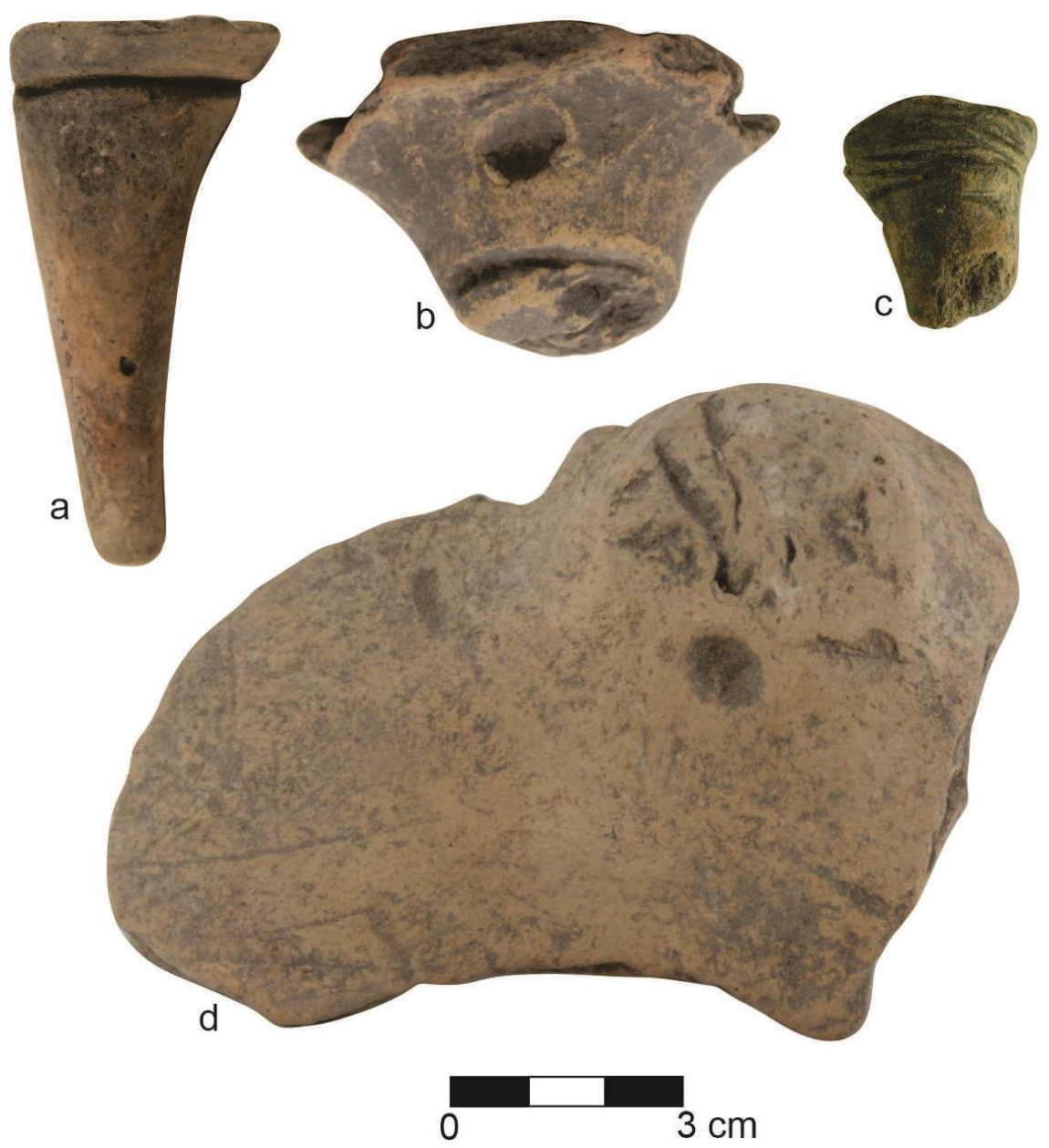

Figura 50. Pés com marcas de corte na porção superior. Proveniência/procedência:a- Fortaleza (Col. Peter Hilbert e Harald Schultz); b- Sacuri (Col. Barbosa de Faria); c- Lago Batata (Col. Aricy Curvello); d- Ponta da Mafada (Col. Peter Hilbert).

A existência de apliques fixos nas vasilhas também pode ter trazido desafios para seus usuários. Os pés podem se fragmentar com certa facilidade, especialmente as pontas, que podem medir menos de $1,0 \mathrm{~cm}$ de espessura. Identificamos três exemplares com visíveis marcas de corte feitas com cordas ou material de gume agudo (lítico?), sugerindo uma tentativa de remoção intencional. Na coleção Walter Marinho (Casa de Cultura de Oriximiná), vários exemplares apresentam essas mesmas marcas de serragem ou corte. Além disso, nas coleções analisadas por nós, dois fragmentos de base apresentam a porção superior de suporte cônico cuja quebra foi quase completamente abrasada, o que também indica um reaproveitamento ou adaptação da vasilha pósqueima (Figura 53-d). 


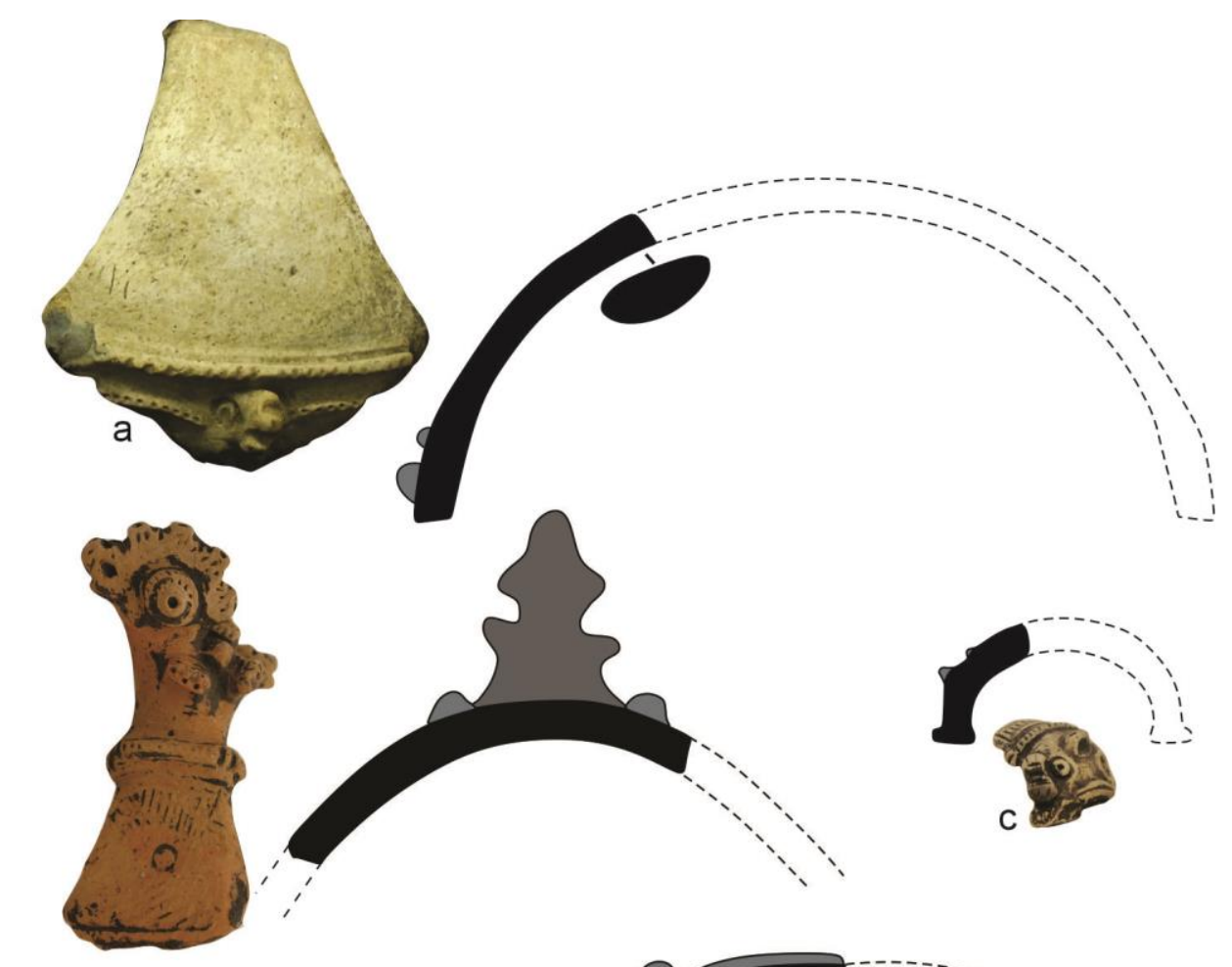

b
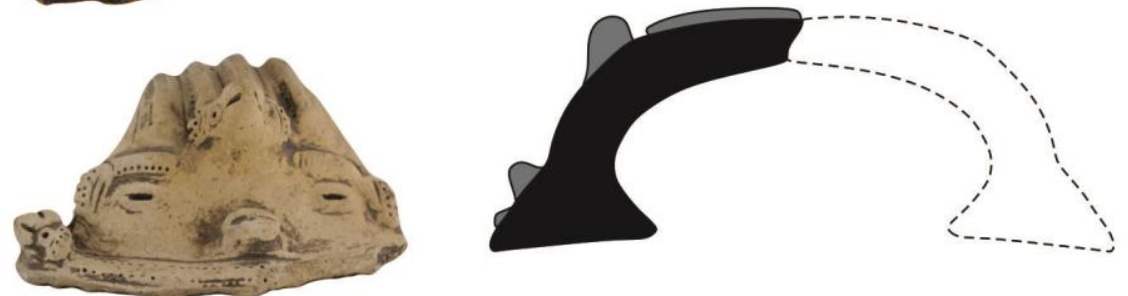

d
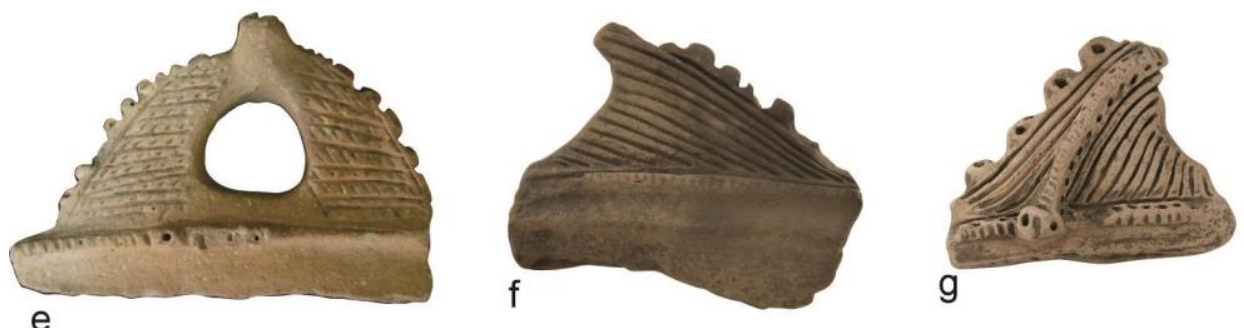

e
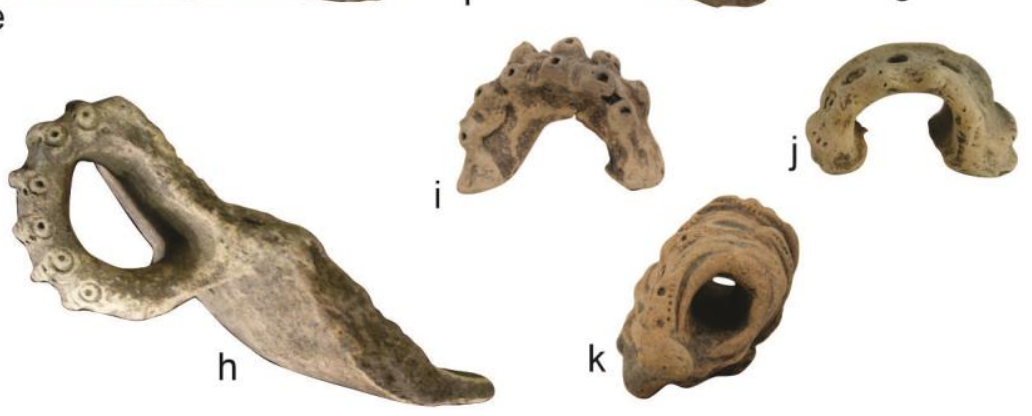

0

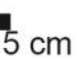

Figura 51. Alças. Proveniência/procedência: a- Pocó (Col. Peter e Klaus Hilbert); b- sem procedência (Col. Tapajônica); c - Cocal (Col. Barbosa de Faria); d - Posto Aurora II (Col. Aricy Curvello e- sem proveniência (Col. Frederico Barata); f- sem proveniência (Col. Tapajônica); g- sem proveniência (Col. Peter Hilbert e Harald Schultz); ); h - Faro (Col. Charles Townsend Jr.); i- rio Trombetas (Col. Luís Paixão/MP); j - Porto Trombetas (Col. Aricy Curvello); k - Faro (Col. Peter Hilbert). 
A terceira categoria de apliques encontrados no estilo Konduri são as alças. Estas modelagens apresentam morfologias diversas; há alças formam um arco sobre a borda (tipo 1/ alça túnel), outras são vazadas em paralelo ao eixo da borda (tipo 2) e vazadas transversalmente ao eixo da borda (tipo 3). O tipo 1 é o mais frequente nas coleções, (69 peças) especialmente na reunida por Peter Hilbert e por este e Harald Schultz. Essas alças são muito semelhantes às encontradas em estilos cerâmicos précoloniais da Amazônia Central (MORAES, 2013). A secção das alças na cerâmica Konduri é retangular ou elíptica na junção com o lábio e sempre elíptica na porção central. Diferente dos exemplares de outros complexos cerâmicos, a espessura dessas modelagens tende a não diferir significativamente das paredes nas quais eram aplicadas e ao longo de seu comprimento. Isso pode indicar que essas alças podem não ter servido a suspensão das vasilhas. Como o comprimento dessas modelagens acompanha o da boca, há desde um exemplar em miniatura até outras que podem ter tido $30 \mathrm{ou} 40 \mathrm{~cm} \mathrm{de}$ diâmetro (Figura 51 a-d). Esse tipo de alça é encontrado em toda a área de dispersão do estilo. Exemplares deste tipo foram coletados nos sítios Boa Vista, Cipoal do Araticum, Greig II, Terra Preta 1 (GUAPINADAIA, 2008; CHUMBRE, 2014; COSTA, 2018; SCIENTIA, 2018).

O tipo de alça 2 soma 9 peças cuja espessura é quase a mesma do lábio em que foram aplicadas $(51 \mathrm{e}-\mathrm{g})$. As alças do tipo 3 nas coleções por nós analisadas contabilizam 10 peças. Estas estão afixadas em diferentes áreas das vasilhas: borda, lábio ou bojo superior. Além dessas, há pequenas alças do tipo 1 utilizadas na composição de 11 apêndices figurativos de um grupo específico (Grupo G). As dimensões dessas peças são muito reduzidas em alguns casos, o que leva pensar que essas modelagens podem não ter servido para segurar as vasilhas.

\subsubsection{Rodelas de tortual de fuso}

As rodelas de tortual de fuso são o único tipo de artefato cerâmico formal, que não é um recipiente, vinculado ao estilo Konduri ${ }^{61}$. As rodelas de tortual de fuso peças modeladas são usadas como parte de um tortual usado para fiar algodão e outros materiais fibrosos (RIBEIRO, 1986). Apenas duas peças desse tipo em cerâmica foram

\footnotetext{
${ }^{61}$ Apesar de Hilbert (1955a) sugerir a existência de estatuetas produzidas neste estilo técnico, é provável que as peças que ele identificou façam parte de conjuntos de produção não local. As descrições transcritas das notas de Protásio Frikel foram erroneamente associadas a estatuetas por Hilbert.
} 
identificadas nas coleções analisadas. A peça representada e descrita por Hilbert (1955, p. 52) não foi identificada durante o período de análises no MPEG. Esse exemplar era quase cilíndrico e uma leve incisão em seu centro. As peças analisadas são diferentes. Uma apresenta um formato de esferóide espesso e assimétrico, sendo sua proveniência indicada Santa Maria, no Médio Trombetas (Figura 52 a). Outro apresenta a soma de dois troncos de cone, com o maior diâmetro na área mesial, coletado em Terra Santa (Figura 52 b). Nos sítios Terra Preta 1 e Aviso I foi coletado um exemplar em argilito vermelho polido com uma morfologia também composta por troncos de cone. Em uma das coleções (T-881) foi identificado uma rodela fragmentada em argilito vermelho semelhante ao coletado no sítio Aviso I.

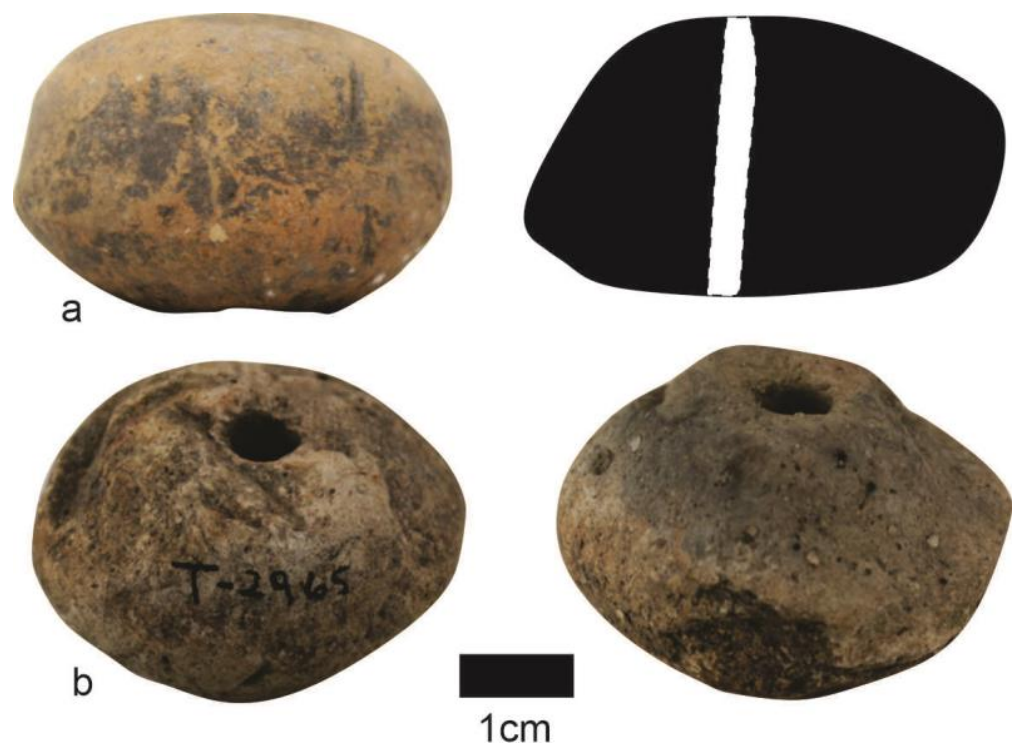

Figura 52. Rodelas de tortual de fuso. Proveniência/procedência: a- Santa Maria (Col. Barbosa de Faria); b - Terra Santa (Col. MD 112).

\subsubsection{Fragmentos reutilizados}

Entre os fragmentos coletados no sítio Mabaia, três paredes (bojo) apresentam canaletas indicando que foram usadas como abrasadores. Outro fragmento, provavelmente coletado em Juruti Velho, exibe várias canaletas em ambas as faces (Figura 53 b). Exemplares parecidos foram coletados nos sítio Tawanî (JÁCOME. 2017).Há também um fragmento com dois furos feitos pós-queima, o que pode resultar 
de uma tentativa de "reformar" uma vasilha (Figura 53 c). A extremidade de um pé modelado apresenta um furo transversal, como se a peça tivesse sido convertida em um pingente, mas não sabemos se isso é uma modificação moderna (Figura 53 d).

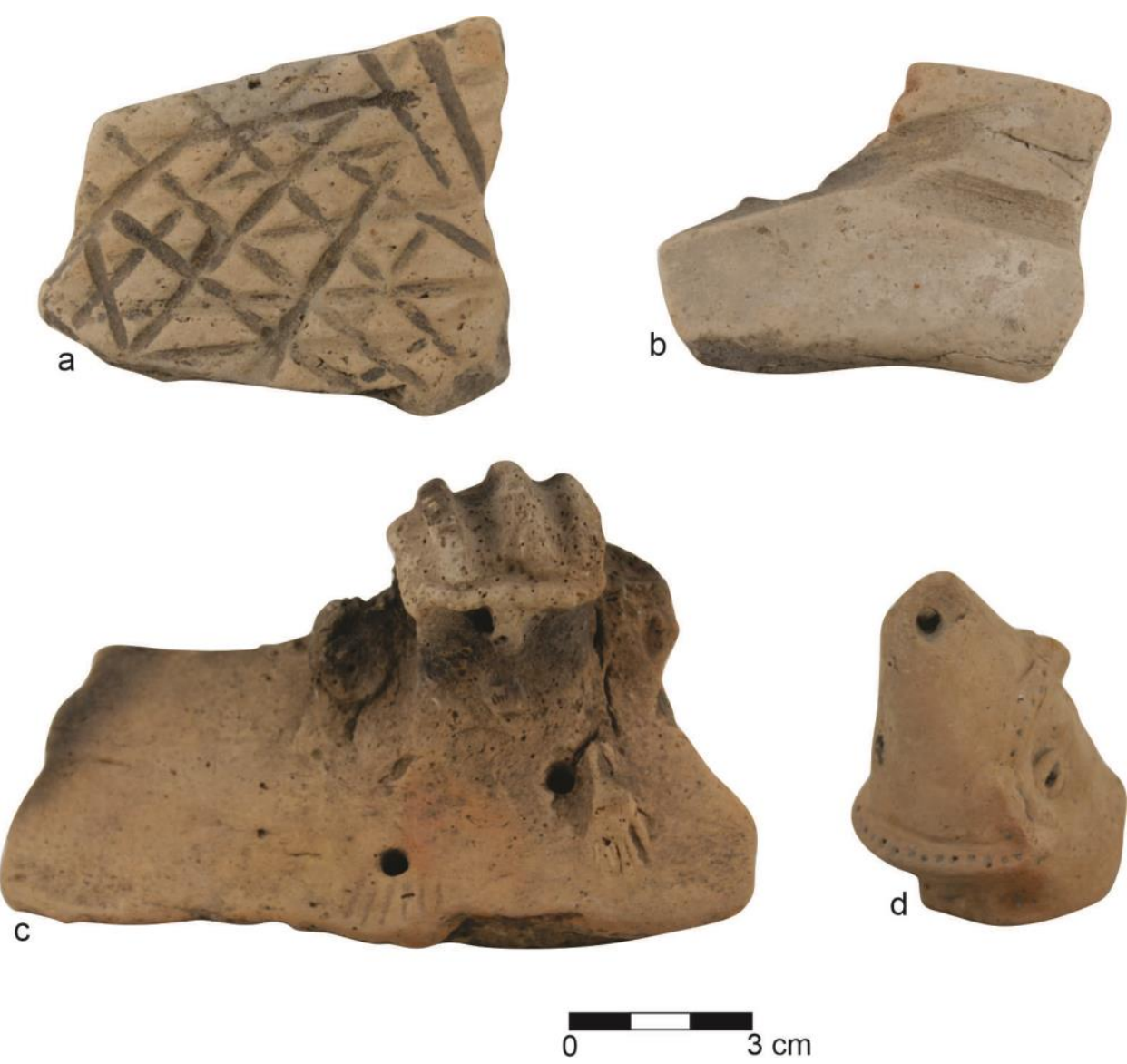

Figura 53. Fragmentos com canaletas (a-b) e furos pós-queima (c-d). Proveniência/procedência: Juruti Velho? (Col. Peter Hilbert e Harald Schultz); b - Mabaia (Col. Peter Hilbert); c - Babaçu (Col. Peter Hilbert e Harald Schultz); d - Serrinha (Col. Peter Hilbert).

\subsubsection{Revestimentos de superfície}

A porosidade de fragmentos de cerâmica Konduri não foi testada na realização deste trabalho. A baixa dureza e o aspecto "esponjoso" de alguns fragmentos causam a impressão de boa parte das peças estudadas eram muito porosas. Um modo de reduzir a porosidade da cerâmica é aplicar revestimentos de superfície, como brunidura ou uso de resinas (RYE, 1981). A brunidura é uma técnica baseada na exposição pós-queima da cerâmica a fuligem produzida a partir de determinadas espécies vegetais ou a aplicação 
de certos tipos de resina quando a vasilha ainda está quente. Foram identificadas 12 peças, com brunidura tanto na face externa quanto interna, especialmente em apliques sobre o lábio (5) e bordas (3) (Figura 54 a-c). A coloração deste revestimento vai do preto ao roxo ou vinho e representa uma camada muito fina sobre a superfície. As maiorias dos fragmentos com brunidura é da coleção Aricy Curvello, especialmente de Posto Aurora II (5), onde parece ter havido uma melhor conservação das superfícies. Outro com um revestimento mais espesso e brilhante foi coletado em Lago Batata ${ }^{62}$. Da mesma coleção, há peças de Faro (1), Posto Aurora I (1). Além dessas, há outras coletas em Terra Santa (1), Serra de Matió (1) e Lago Sapucuá (1), respectivamente das coleções Charles Townsend Jr., Peter Hilbert e Barbosa de Faria/Comissão Rondon. Outras duas não tem nenhuma referência de área de coleta (coleção Charles Townsend Jr. e Tapajônica).

A presença de brunidura na cerâmica Konduri quase não foi mencionada na bibliografia. Guapindaia (2008, p. 136, fig. 31 f) apresenta a fotografia de uma peça homogeneamente preta na face externa que parece o mesmo tipo de brunidura identificada durante nossa pesquisa. Um pequeno fragmento coletado em Cipoal do Araticum poderia ter uma brunidura ao invés de pintura (CHUMBRE, 2014, p. 165). Nos sítios do rio Mapuera foram identificados mais exemplares com brunidura e também engobo vinho. A nosso ver o "engobo vinho" é apenas uma variação da brunidura que pode ser completamente preta ou ter tons de roxo escuro. O que foi identificado como brunidura só foi encontrado no sítio Tawanî, mas o "engobo vinho" também aparece em raros fragmentos que podem ser relacionados ao estilo Konduri (com uso de cauixi), nos sítios Mapium, Takará Velho e Poropu (JÁCOME, 2017). Esse revestimento escurecido parece ser feito com o mesmo material usado para a pintura preta ou roxa identificada em Porto Trombetas e no rio Mapuera.

Em relação à presença de resina, um fragmento coletado em Posto Aurora II apresenta vestígios de uma cobertura vítrea, esbranquiçada e craquelada (Figura $54 \mathrm{~d}$ ). A partir da consulta de parte do acervo coletado no sítio Greig II, foi possível identificar esse mesmo revestimento na face externa de uma borda. Não foi realizada nenhuma análise físico-química para confirmar se esse elemento, de fato, é resina. A possível

\footnotetext{
${ }^{62}$ Ou também pode ter se misturado com a amostra de Posto Aurora II (ver capítulo 3).
} 
conservação especial deste material em uma área tropical poderia ser explicada pela ocupação tardia destes sítios.
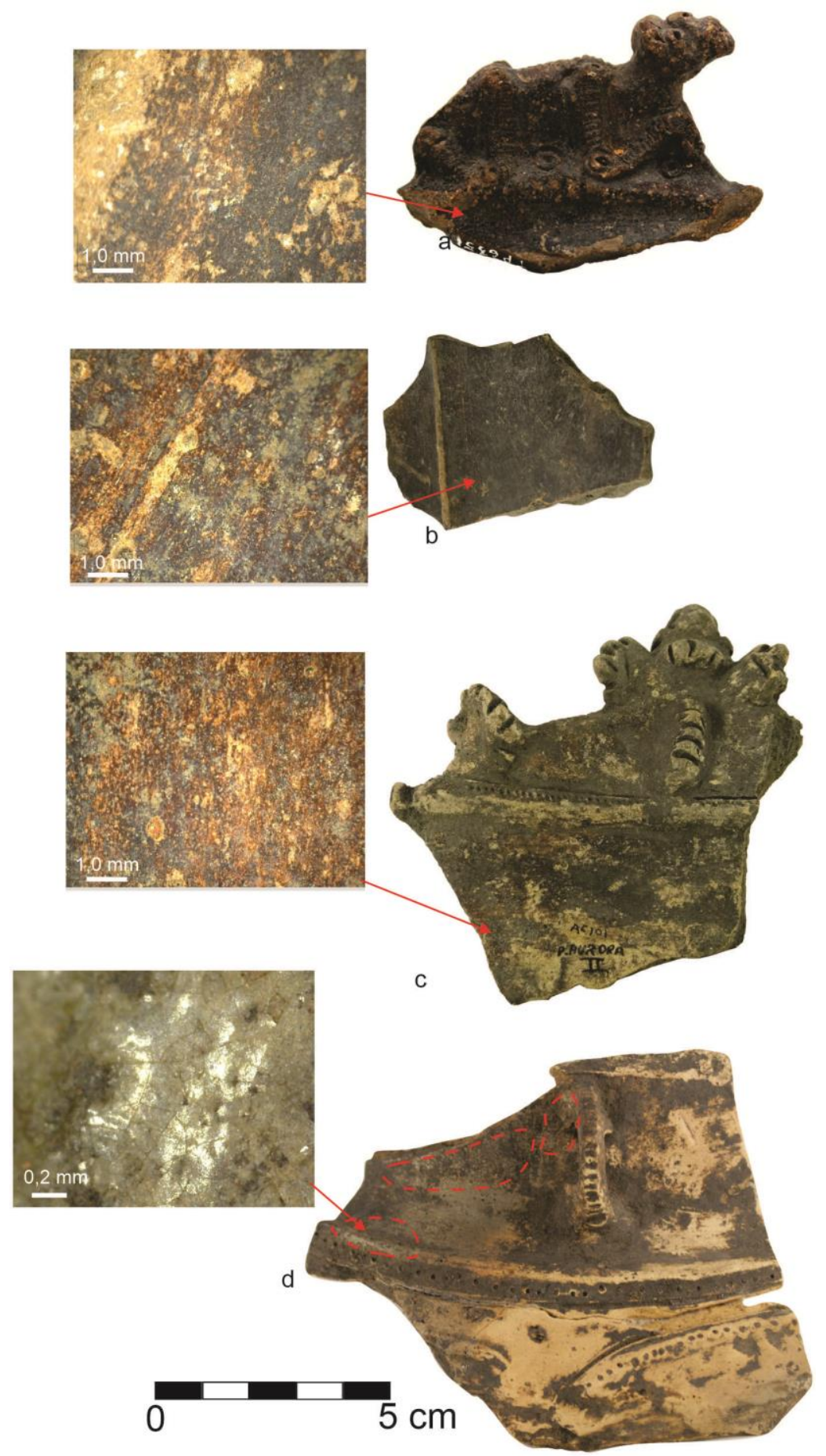

Figura 54. Brunidura (a-c) e possível resina (d). Proveniência/procedência: a - sem proveniência (Col. Tapajônica/ Foto: Alexandre Reocaro); b - Lago Batata (Col. Aricy Curvello/Foto: Caroline Teixeira); c - Posto Aurora II (Col. Aricy Curvello/Foto: Caroline Teixeira); d - Posto Aurora II (Col. Aricy Curvello). 


\subsubsection{Decoração pintada e engobo}

A decoração pictórica é rara na cerâmica Konduri. Somente em 4,15\% do total de peças desse estilo (97 peças) há algum tipo de pintura ou engobo. Em geral, a pintura aparece como complemento à decoração plástica e aos apêndices figurativos. Sua presença, contudo, foi fortemente afetada pela alta incidência da erosão das superfícies e a fragilidade de pigmentos minerais e orgânicos aplicados após a queima. O engobo, especialmente, foi subrepresentado, uma vez que fragmentos de parede tendem a ser menos coletados que as peças com decoração plástica. Isso fica evidente ao se constatar que as amostras de coletadas em sítios com melhor preservação (Posto Aurora II, Lago Batata) e menor seletividade (Cocal), com mais exemplares com pintura e engobo.

O engobo vermelho foi identificado em apenas 19 peças, formando tanto camadas espessas quanto outras muito finas. A maioria dos exemplares com engobo é proveniente de coleções diagnósticas, como no sítio Cocal (11 peças), Posto Aurora II (3 peças) e Lago Batata (3 peças). Outra peça é uma parede sem marcação da coleção Peter Hilbert, mas que provavelmente também foi coletada no sítio Cocal. Na coleção Barbosa de Faria, um fragmento com engobo vermelho foi identificado, mas este não possui informação de proveniência. A vasilha T-413 (Col. Frederico Barata) exibe engobo em toda a face interna e na base e bojo na face externa - excluindo apenas a borda com reforço e padrão inciso, ponteado e modelado. Em sítios do baixo rio Trombetas, o engobo vermelho é frequente nas amostras do sítio Aviso I e Oriximiná 3 e uma baixa frequência em sítios menores - Bela Cruz I, Bela Cruz II (GUAPINDAIA, 2008; SCIENTIA, 2013). Uma das peças coletadas em Oriximiná 3, inclusive parece sugerir um pequeno prato com a face externa totalmente com engobo. Em Tawanî foram identificadas algumas peças com engobo vermelho e algumas com um tom vinho (JÁCOME, 2017). Não é possível relacionar a frequência do engobo vermelho em sítios multicomponenciais porque este é um atributo compartilhado tanto pela cerâmica Konduri quanto pela Pocó. 

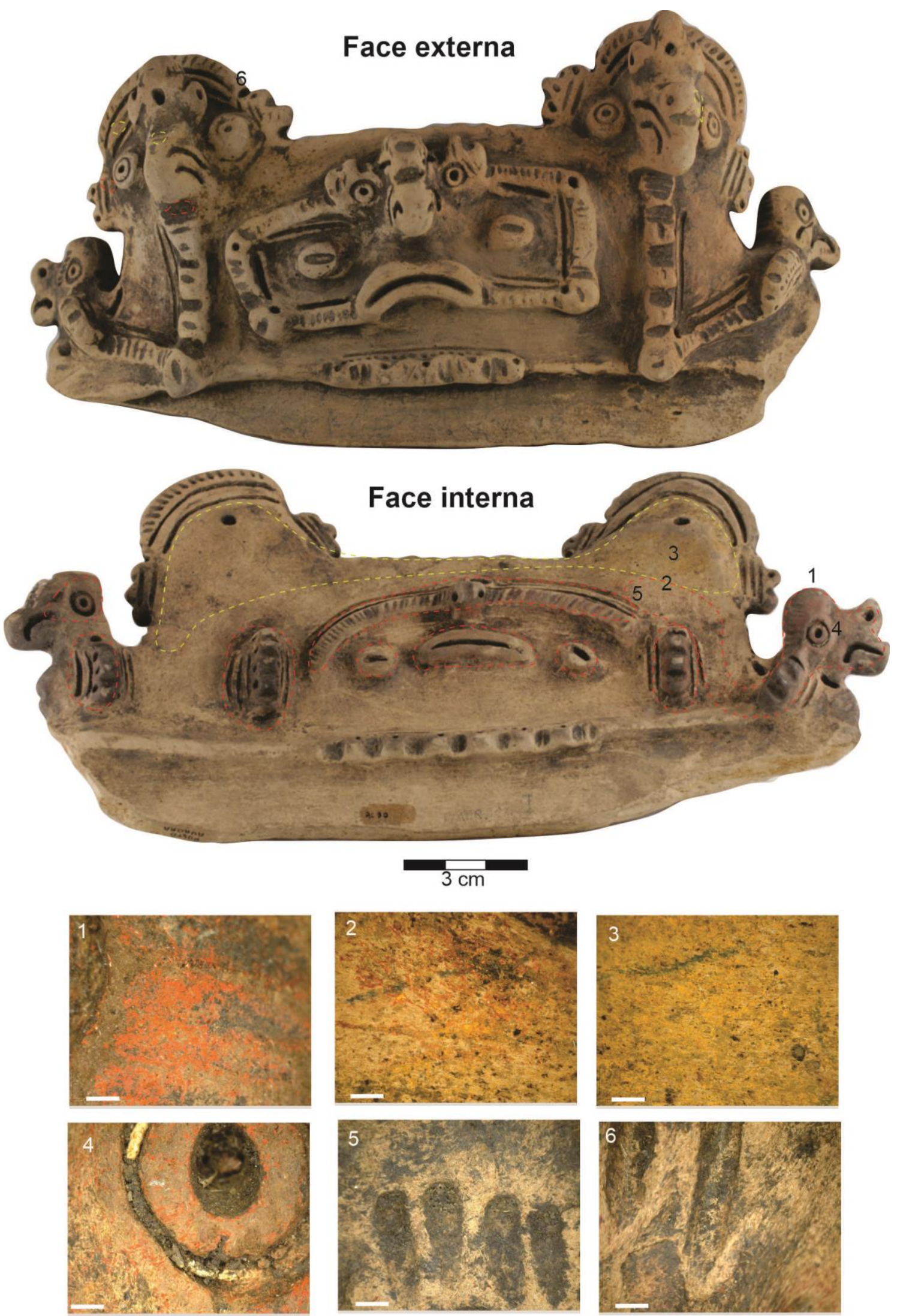

Figura 55. Apêndice achatado com presença de pintura na face interna e externa, além de detalhes da incisão e entalhe aplicados na pasta úmida. Proveniência/procedência: Posto Aurora I (Col. Aricy Curvello). 

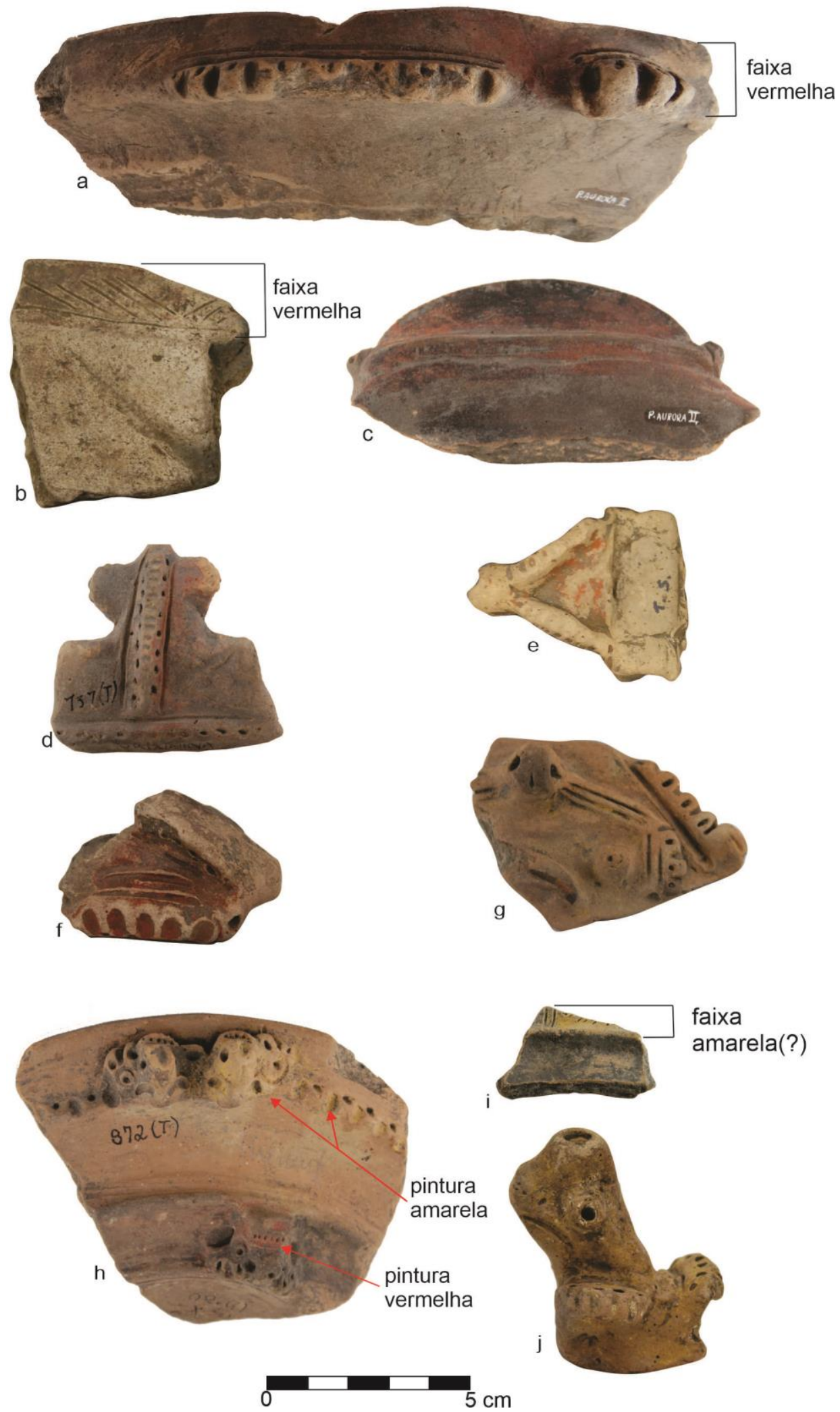

Figura 56. Fragmentos com vestígios de pintura vermelha (a-f), vermelha e amarela (g-h) e amarela (i, j). Proveniência/procedência: a- Posto Aurora II (Col. Aricy Curvello/ Foto: Caroline Teixeira); Babaçu (Col. Peter Hilbert e Harald Schultz); c - Posto Aurora II (Col. Aricy Curvello); d - Oriximiná (Col. Peter Hilbert); g e- Terra Santa (Col. Peter Hilbert/PUCRS); f - sem referência (Col. Tapajônica); g- sem referência (Col. Charles Townsend Jr.); h- Oriximiná (Col. Peter Hilbert); i- Posto Aurora II (Col. Aricy Curvello); j - sem proveniência (Col. Tapajônica). 
A pintura vermelha foi identificada em 67 fragmentos (Figuras 55 e 56). É em geral espessa e, às vezes, friável. Essa pintura é encontrada de maneira vestigial em apêndices (aplicados ao lábio, borda e alça em túnel). Na face interna ou externa de bordas está presente forma uma banda aplicada sobre a decoração plástica. Na face externa de três peças a pintura aparece parcialmente sobreposta por uma camada de fuligem. As proveniências com mais pintura são Terra Santa (7), Sacuri (6), Posto Aurora II (6) e Oriximiná (4). Há também exemplares coletados em Sucurijú (3), Boca dos Anjos (3), Ascensão (1), Faro (1), Jacupá (1), Terra Preta/Juruti (1), Terra Preta 1/2 (2), além das sem informação de proveniência (23) ou com referência genérica "Nhamundá" (1). O sítio Greig II apresenta vários exemplares com pintura com uma faixa na face interna e externa das bordas, incluindo um assador. Além disso, há pintura em toda a base e bojo de outro assador. Há assadores com padrão inciso pintado tanto em Greigi II quanto em Cipoal do Araticum (CHUMBRE, 2014; CASTRO, 2018). Notamos também exemplares com fuligem sobrepondo-se a pintura vermelha no material coletado em Greig II (ver CASTRO, 2018, p. 74 e 76).

A pintura amarela é muito menos frequente que a vermelha, não tendo sido mencionada por Hilbert (1955a) ou em outros estudos. A diferença entre a área de uma aplicação e outra reforça a ideia de que não se trata de uma consequência do intemperismo sobre o pigmento vermelho. Foram identificada em 8 peças, sendo que em apenas 3 não aparece em combinação com pintura vermelha (Figuras 55 e 56 h-j). Suas características físicas são as mesmas que da vermelha. A maioria não apresenta informações de proveniência, havendo uma peça de Posto Aurora I, Oriximiná e Lago Batata. Os exemplares com pintura amarela são apêndices (aplicados ao lábio, face externa da borda e alça em túnel) e provavelmente um fragmento de borda sem lábio. Esta peça exibe parte de um padrão inciso na face interna sobre o qual foi aplicada a pintura - provavelmente uma banda.

A pintura preta também é bastante rara nas coleções por nós analisadas. Apenas em 3 exemplares pinturas com essa cor foi identificada (Figura 57). Duas delas apresentam uma fina camada de engobo vermelho sobre a qual a pintura preta foi aplicada. Um desses exemplares, proveniente do Lago Batata, apresenta linhas pretas na face interna da base e do bojo de uma pequena vasilha trípode. O outro, sem proveniência, é um apêndice aplicado ao lábio, cuja face externa apresenta círculos 
pretos. Por fim, há borda coletada no sítio Porto Trombetas que apresenta linhas craqueladas na face interna. De modo geral, o aspecto da pintura preta difere das vermelha e amarela e se assemelha ao da brunidura.

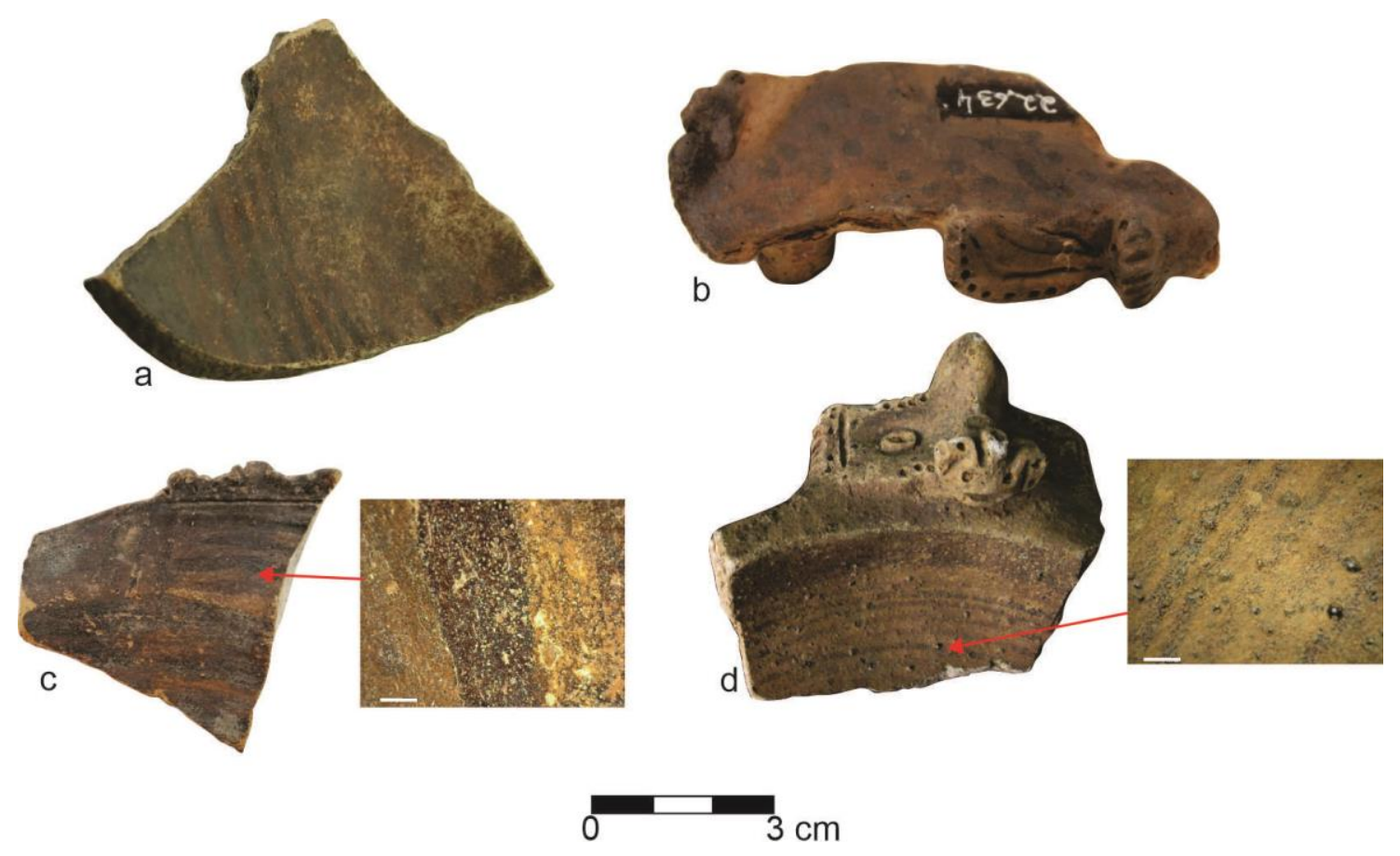

Figura 57. Pintura preta sobre engobo vermelho (a-b) e pintura preta aplicada diretamente sobre o suporte (c-d). Proveniência/procedência: a - Lago Batata (Col. Aricy Curvello); b- rio Trombetas (Col. Barbosa de Faria); c- Porto Trombetas (Col. Aricy Curvello); d - Greig II (Projeto Arqueológico Porto Trombetas).

Na bibliografia a pintura em linhas pretas aparece em baixa frequência nos sítios Aviso I, Oriximiná 3 e Greig II. Neste sítio a pintura apresenta melhor preservação, exibindo uma diversidade de motivos face interna das vasilhas (linhas, bandas, losangos, chevron) e bandas na face externa. Em todos os exemplares a pintura aparece aplicada sobre o suporte (COSTA, 2018). Em Oriximiná 3, há fragmentos com pintura aplicada tanto sobre o suporte quanto engobo vermelho e branco. Nesse mesmo sítio aparece a combinação de bandas vermelhas e pretas em um mesmo exemplar (SCIENTIA, 2013; PANACHUK, 2016a). 


\subsubsection{Decoração plástica}

A decoração plástica abunda nas coleções analisadas, estando presente em $62,89 \%$ das peças Konduri $(\mathrm{n}=1468)$, sendo encontrada em amostras de todas as proveniências. Isso tanto reflete em grande medida processo seletivo do material que compõe as coleções, mas mesmo de modo enviesado, a importância da decoração plástica neste estilo. Foram identificadas apenas quatro técnicas plásticas (modelado, inciso, ponteado e entalhado) que aparecem tanto isoladas quanto em diferentes combinações (Gráfico 24). Como foram coletadas as peças mais elaboradas, é majoritária a combinação das quatro técnicas, caracterizando as "superfícies sobrecarregadas" ou com "um tom de rococó". A combinação de inciso, ponteado e entalhado também é bastante frequente. O uso da incisão para compor padrões gráficos ou figurações reflete uma parcela mais sóbria do estilo que também ocorre.

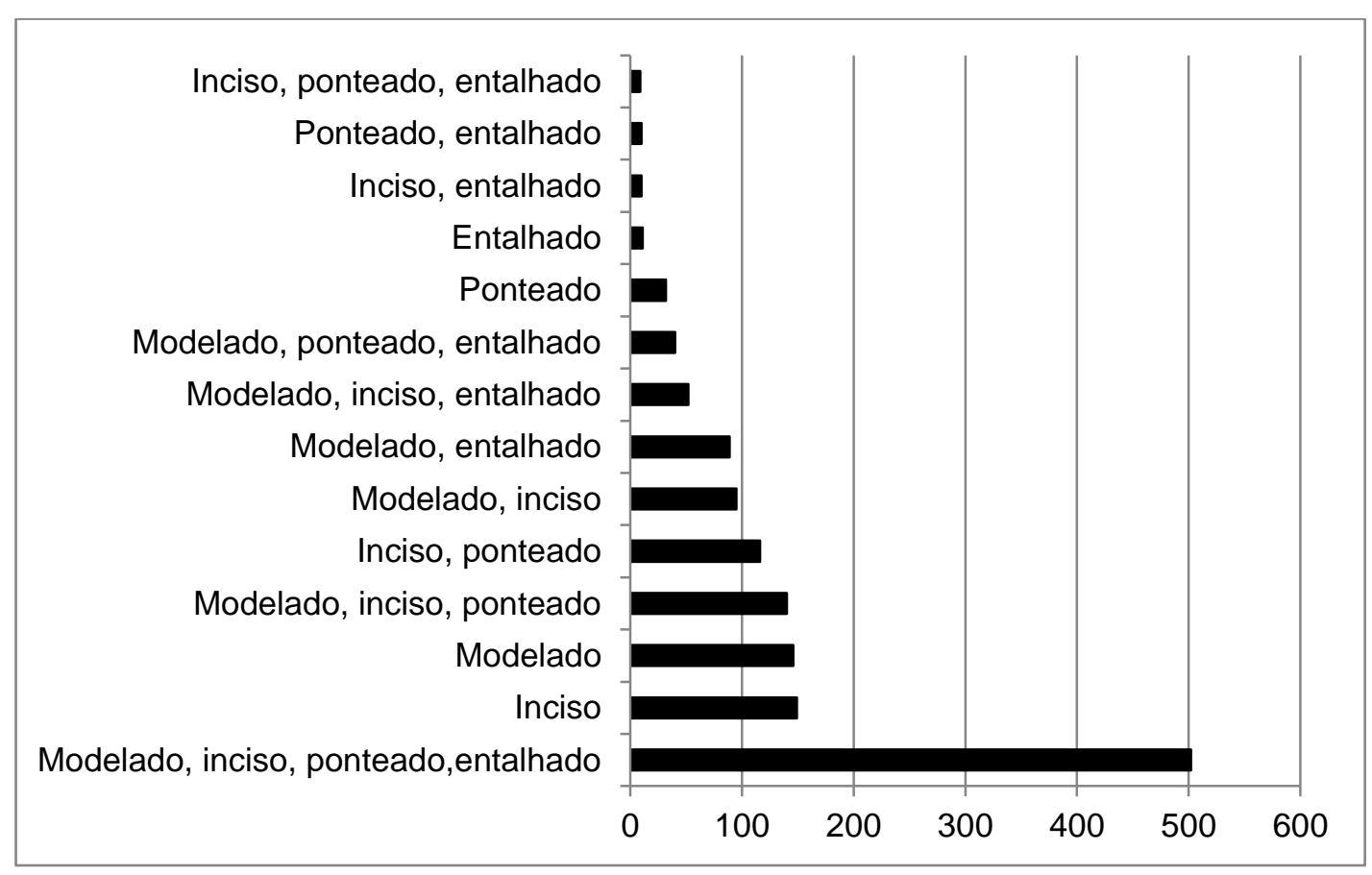

Gráfico 24. Frequência de combinações de técnicas de decoração plástica identificadas nas peças Konduri analisadas.

A decoração modelada é composta, como destacou Hilbert (1955) essencialmente por filetes e botões. Os filetes são encontrados em áreas diversas, 
compondo linhas que circundam o bojo superior ou inferior, padrões gráficos aplicados ao bojo e borda e, principalmente, na construção de elementos figurativos em apêndices. Os botões, ao contrário, raramente aparecem isolados; compõem padrões e apêndices figurativos. Esses elementos figuram principalmente olhos, mas também narizes e, ás vezes, bocas e orelhas. Uma borda coletada no sítio Cocal (Barbosa de Faria) apresenta um padrão composto pela combinação de botões.

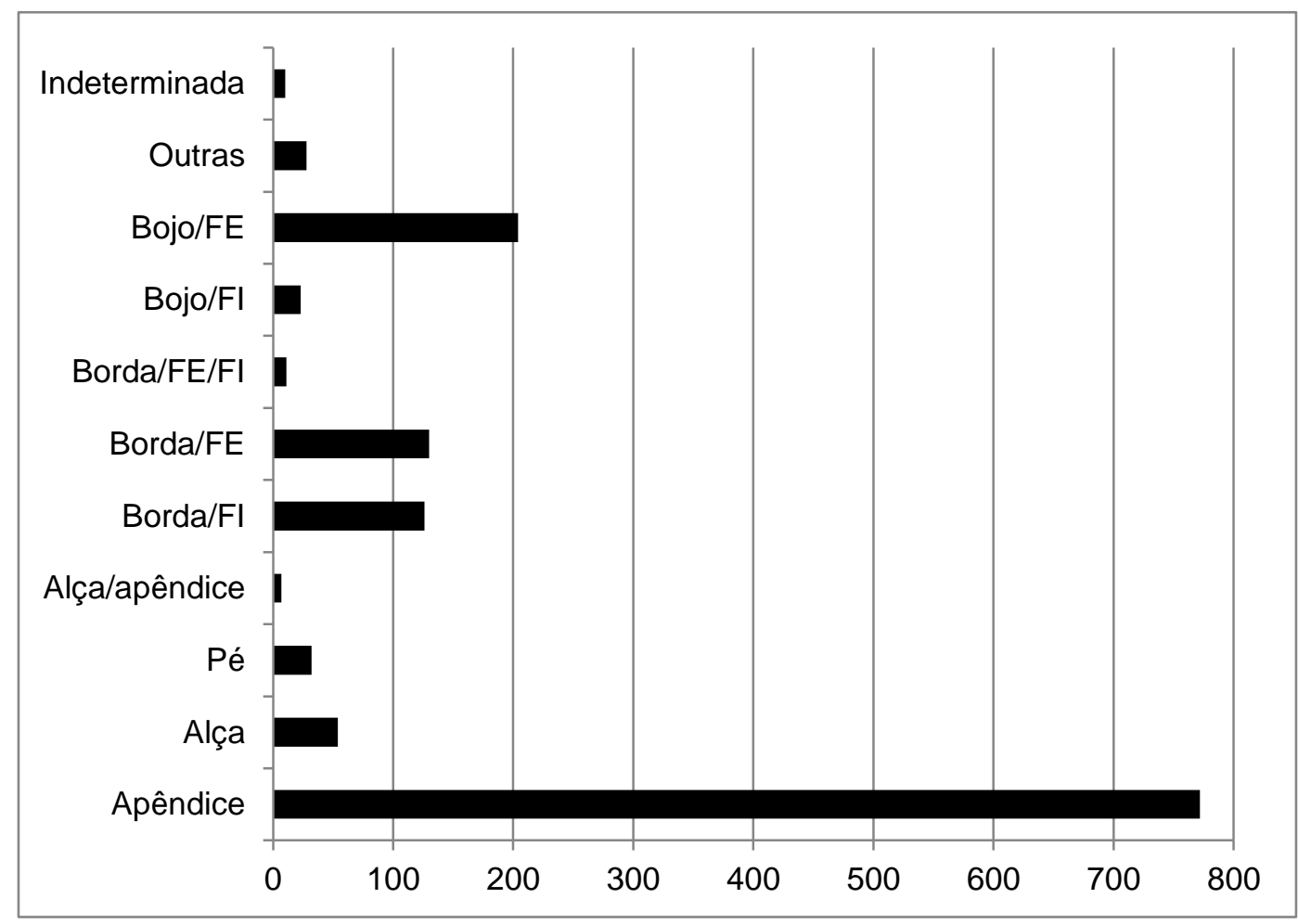

Gráfico 25. Frequência de áreas de aplicação de técnicas de decoração plástica nas amostras de cerâmica Konduri analisadas. $\mathrm{FE}=$ Face Externa; FI = Face Interna .

A decoração modelada é geralmente acompanhada de incisão, ponteado e entalhes. A exceção destas técnicas é geralmente realizada argila plástica (úmida), o que é evidenciado por uma alta frequência de rebarbas nas margens (SHEPARD, 1956; RYE, 1981; RICE, 1987). Alguns fragmentos do sítio Serrinha apresentam incisões mais rasas e "limpas" sugerindo incisões em pasta em ponto de couro. Entre as peças consultadas do sítio Greig II, um fragmento de assador exibe incisões com lascamentos nos bordos indicando a aplicação da técnica em ponto de osso. Em dois fragmentos 
observados em superfície na comunidade de Ajará (sítio Uajará), no lago Sapucuá, observamos bordas do mesmo tipo de vasilha também com lascamentos ao longo das incisões. Não sabemos até que medida as decorações plásticas podem ter sido usadas quando a argila estava menos úmida. É possível que a erosão tenha obliterado parte dos lascamentos, que são mais sutis que as rebarbas. As peças consideradas mais elaboradas do estilo Konduri, com aspecto de "esponja" com mencionado por Hilbert (1955), tiveram as técnicas plásticas aplicadas enquanto a pasta estava muito úmida, o que explica parte desse efeito visual.

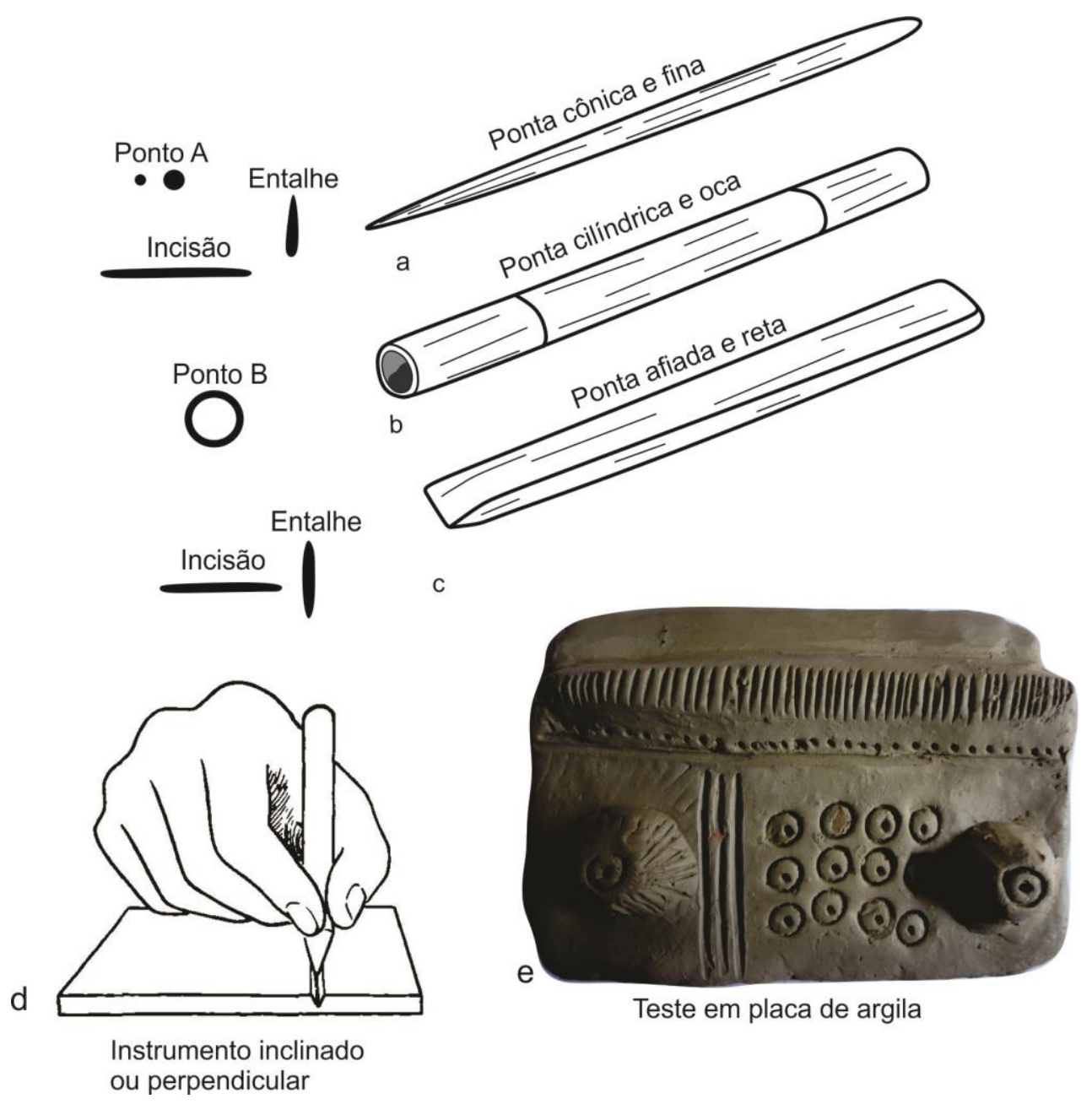

Figura 58. A aplicação das técnicas decorativas plásticas na cerâmica Konduri: possíveis instrumentos e gestos. Desenhos autorais e d extraído de Shepard, 1956. 
a

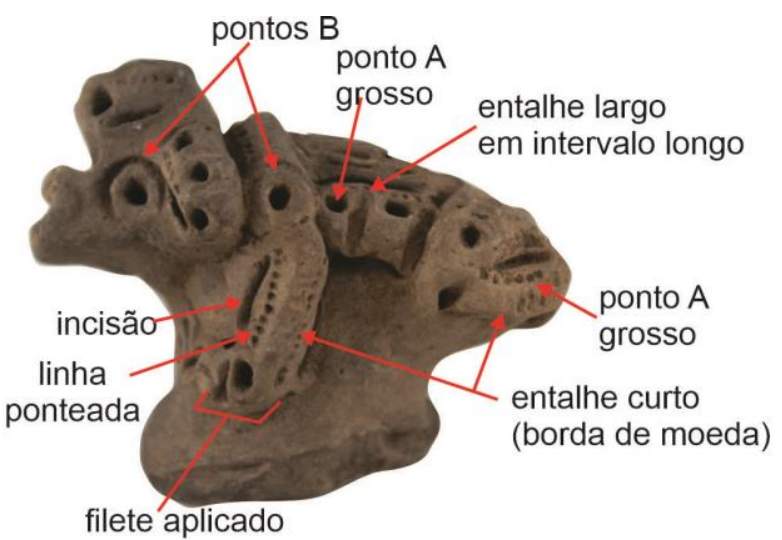

b

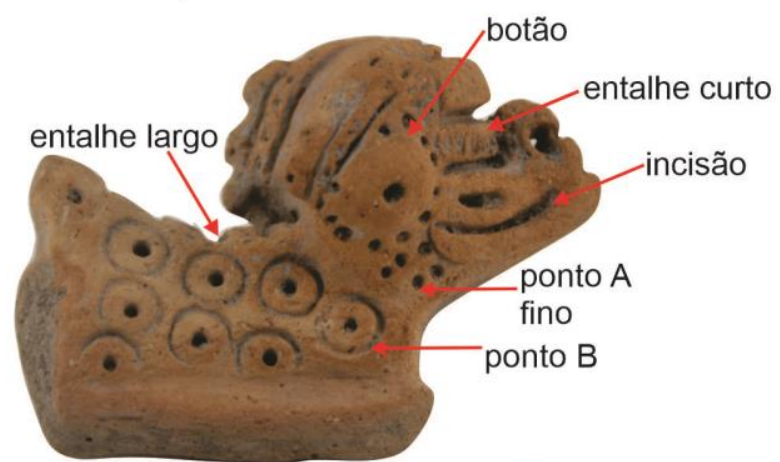

C
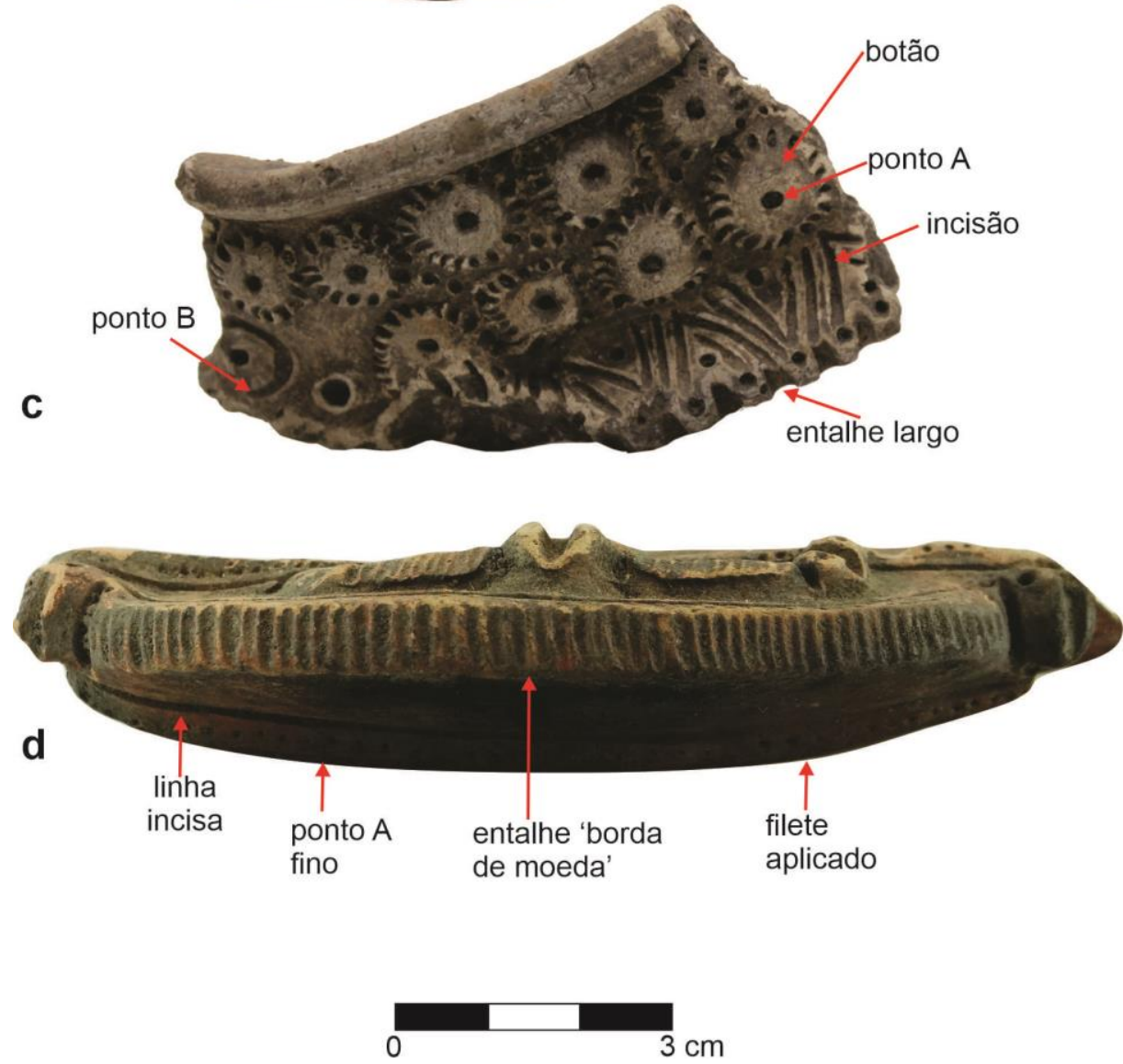

Figura 59. Combinação de técnicas decorativas plásticas na cerâmica Konduri. Proveniência/procedência: a- Faro (Col. Peter Hilbert); b- sem proveniência (Col. Frederico Barata); cJacupá (Col. Barbosa de Faria); d- Posto Aurora II (Col. Aricy Curvello). 
Os apêndices são a parte das vasilhas que mais receberam decoração (Gráfico 25). Nas coleções analisadas isso se relaciona a seleção das amostras. Os campos de decoração na cerâmica Konduri vão além deste tipo de aplique. A face externa das bordas é uma área preferencial para a aplicação de decoração plástica. Os reforços de borda foram muitas vezes convertidos em suporte para a criação de grafismos, acompanhados ou não de apêndices, como no vaso T-413. A face externa das bordas, por sua vez, também pode exibir bandas incisas, especialmente em assadores, mas também em outras morfologias. Um dos elementos mais característicos da decoração plástica é a combinação de filete ponteado com entalhes e em uma de seus lados (ou ambos) uma linha incisa (ou mais) acompanhada de uma ponteada. Essa combinação aparece tanto na composição de apêndices e alças quanto em filetes que circundam o bojo superior ou inferior. Grande parte das ocorrências de decoração no bojo se vincula a esse motivo. Além disso, há também padrões incisos ou compostos por várias técnicas presente nessa área. Nas alças sempre há ao menos uma técnica decorativa aplicada, sendo frequente a combinação de todas as técnicas de decoração plástica. No sentido contrário, apesar de numericamente frequentes, poucos pés modelados exibem decoração. Quando exibem, esta é sempre na parcela superior, próxima à borda.

Os instrumentos utilizados para executar as incisões eram provavelmente estecas com ponta fina - talvez cônica, como muitos furos de ventilação pés de vasilhas trípodes (Figura 58). Os entalhes, por sua vez, podem ter sido feitos com esse mesmo instrumento pontiagudo ou com estecas de com gume reto. O ponteado era realizado predominantemente também com uma esteca de ponta fina, medindo em geral 1,0 a 2,0 mm diâmetro, mas que pode chegar a 10,0 mm. A realização de pontos com esse tipo de instrumento foi denominada "ponteado A" por Guapindaia (1993). Outro instrumento usado para produzir pontos era um tubo oco com $1,0 \mathrm{~cm}$ ou mais de diâmetro. Por oposição, este foi denominado "ponteado B" pela mesma autora. Os entalhes, em última medida são uma variação do ponteado, mas realizado formado uma linha de traços paralelos. 


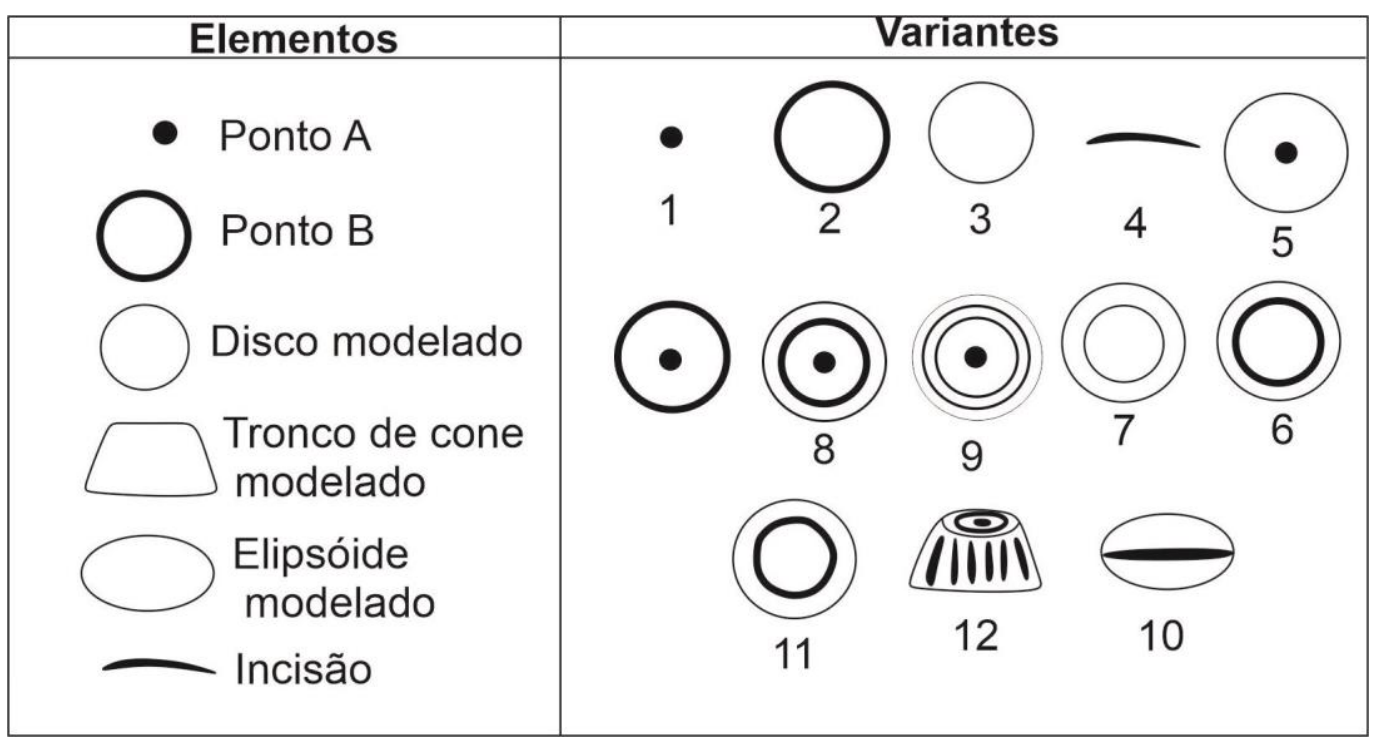

Figura 60. Elementos decorativos usados na composição dos olhos em apêndices e motivos gráficos

O ritmo da decoração plástica é quase sempre linear, como enfatizou Hilbert (1955). A sequência de construção dos motivos é predominantemente baseada na aplicação de um filete modelado (secção retangular ou triangular) seguido de linha (s) incisa (s) e ponteada (s) nas laterais. O filete recebe, em muitos casos, entalhes espaçados ou muito próximos (como em um bordo de moeda). No caso de entalhes espaçados, em cada "aba" é colocado um ponto (ou mais), como destacou Hilbert (1955). Os filetes em alguns casos são alargados formando quase flanges que, com os entalhes, podem tanto lembrar ao "glacê de bolo" (LATHRAP, 1970) quanto a babados de crochê. O efeito de "superfícies sobrecarregadas", além da pasta úmida, deriva da combinação ostensiva de ponteados com diâmetros distintos junto a incisões e entalhes. São raros os exemplares com essa combinação, identificados em sua maioria nas coleções Tapajônica (MAE) e Frederico Barata (MPEG), marcadas por uma maior seletividade. Peter Hilbert também coletou raras peças com os espaços quase totalmente ocupados por decoração plástica. Os pontos feitos com instrumento oco raramente aparece na forma de uma sequência de pontos - algumas vezes preenchidos com ponto A central. Em alguns casos, os pontos feitos com instrumentos ocos demarcam articulações dos corpos antropo e zoomorfos ou seus olhos (Figura 60). 

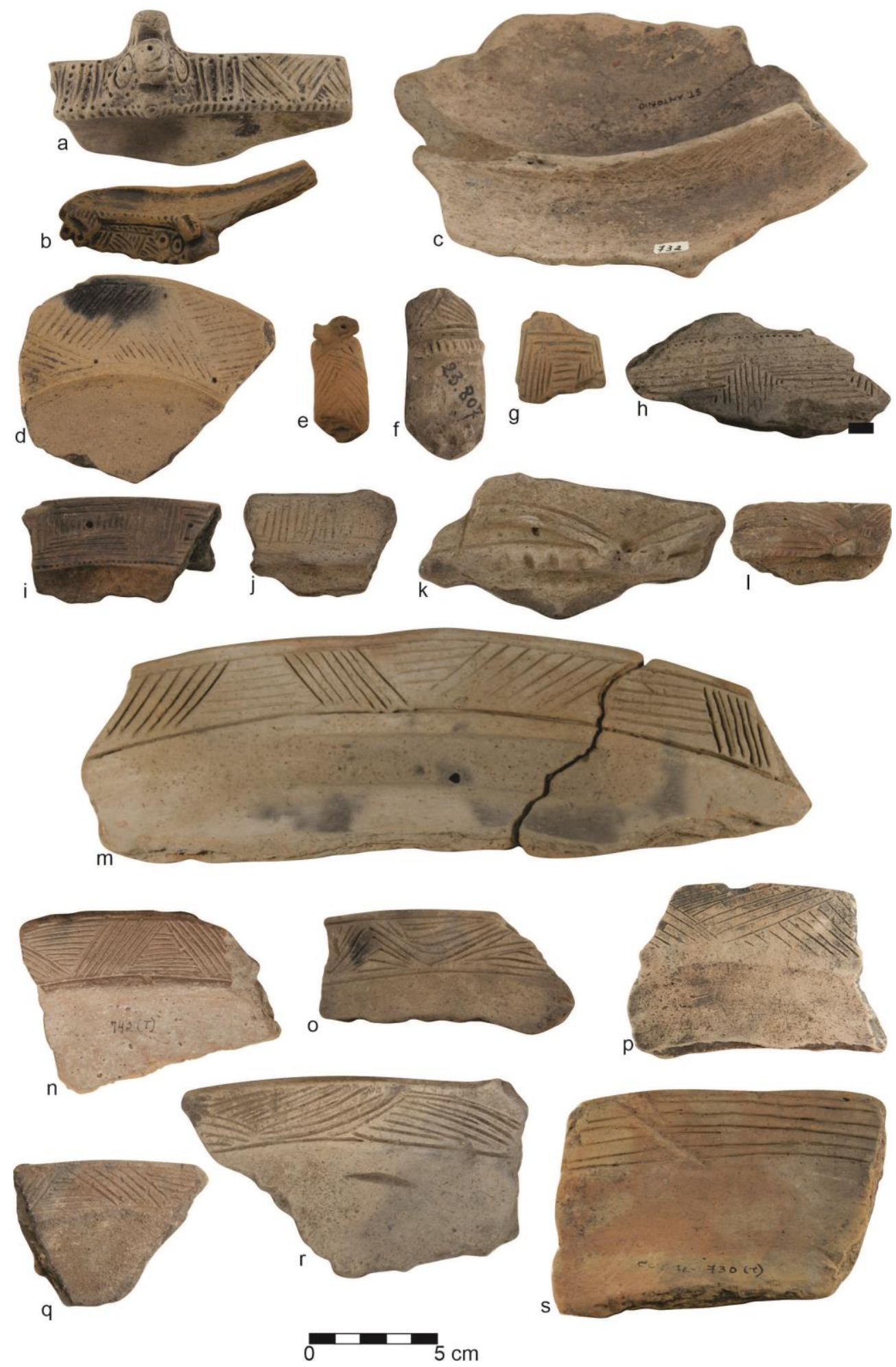

Figura 61. Padrões incisos Proveniência/procedência: a- sem proveniência (Col. Frederico Barata); bsem referência (Col. Comissão Rondon); c- Santo Antônio (Col. Peter Hilbert); d - Oriximiná (Col. Peter Hilbert); e - Serrinha (Col. Peter Hilbert); f- Sacuri (Col. Barbosa de Faria); g - Babaçu (Col. Peter Hilbert e Harald Schultz); h - Serrinha(Col. Peter Hilbert); i - Sacuri (Col. Barbosa de Faria); j Fortaleza (Col. Peter Hilbert e Harald Schultz); k - Babaçu (Col. Peter Hilbert e Harald Schultz); 1 Fortaleza (Col. Peter Hilbert e Harald Schultz); m - Mabaia (Col. Peter Hilbert); n - Oriximiná (Col. Peter Hilbert); o - Serrinha (Col. Peter Hilbert); p - Posto Aurora II (Col. Aricy Curvello); q - Fortaleza (Col. Peter Hilbert e Harald Schultz); r - Babaçu (Col. Peter Hilbert e Harald Schultz); s - Cocal (Col. Peter Hilbert). 
Apesar de muito raros, motivos ondulados são encontrados na cerâmica Konduri (Figura 61 r). No sítio Greig II, Santos (2018) identificou uma borda de assador com um padrão inciso curvilíneo. Na coleção Peter Hilbert/ Harald Schultz, há ao menos 10 fragmentos que exibem um motivo composto por filetes em arco com incisões, entalhes e pontos, que é aplicado a face externa das bordas. Essas peças são provenientes de Babaçu (3), Fortaleza (4) e outras não possuem indicação de proveniência (3). No sítio Oriximiná 3 o mesmo motivo foi identificado em um fragmento de vasilha trípode (SCIENTIA, 2013, p. 141).

A decoração incisa é uma que mais se destaca isoladamente na cerâmica Konduri (Figura 61). O modelado, que também aparece em alta proporção nas coleções analisadas, compõe somente detalhes de pés de vasilha trípode e pequenos apêndices, sem formar nenhum motivo ou padrão. As incisões ao contrário formam bandas aplicadas à face interna da borda de assadores e outras vasilhas rasas; partes das alças em túnel; no bojo superior (como a peça T-405); e, em alguns casos em apêndices ou filetes. O fragmento de vasilha trípode coletado por Peter Hilbert no sítio Santo Antônio apresenta também incisões sem o acompanhamento de outras técnicas. Os padrões gráficos formados quase sempre rementém a triângulos compostos por diferentes modos de simetria, como reflexão vertical e rotação alternada com reflexão transversal (ver SHEPARD, 1956, p. 269). Há também bandas compostas por linhas retas, diagonais e, em um único caso, um hachurado (Babaçu). Um motivo composto por retângulos concêntricos foi identificado em bordas de assadores provenientes dos sítios Fortaleza (2), Babaçu (1) e Serrinha (2) e uma alça túnel proveniente também de Babaçu. Hilbert (1955, p. 43) apresenta o desenho de uma peça coletada em Faro com um motivo semelhante, que não foi encontrada na instituição de guarda. Esse mesmo motivo foi identificado em borda de assador nos sítios Greig II e Cipoal do Araticum (CASTRO, 2018; CHUMBRE 2014). Em Terra Preta 1 está presente em uma alça ponte.

\subsection{Iconografia e técnicas visuais}

As técnicas decorativas no estilo Konduri são mobilizadas principalmente para a composição dessas figuras, seja na forma de apêndice ou motivo em alto relevo. Compreender a relação entre as figura, morfologias de vasilhas e possíveis contextos de uso é fundamental. O chamado "estilo visual" pode ser pensado de maneira integrada a todos os outros elementos da cadeia operatória (REEDY; REEDY, 1994) e a 
performance visual (SCHIFFER; SKIBO, 1997). O estudo da iconografia, em particular, pode oferecer informações importantes sobre aspectos dos modos de vida indígena e, especialmente, cosmologia, no caso de estilos com ênfase na figuração (DAVID et al., 1988; BARRETO; OLIVEIRA, 2016; BARRETO, 2014; GOMES, 2001, 2012, 2016b, 2019; OLIVEIRA, 2016; NOBRE, 2017).

O estilo visual Konduri, para além de sua profusão de incisões de pontos, incisões e modelados é ainda pouco conhecido. Seu principal locus da figuração da cerâmica são nos apêndices, como acontece também as cerâmicas da tradição Arauquinóide e Barrancóide, além da produção atual dos Wauja e a fase Ipavu recente no Alto Xingu (ROOSEVELT, 1997; WALDRON, 2011; ROSTAIN; VEERSTAG, 2004; TONEY, 2016). Em A cerâmica arqueológica da região de Oriximiná, Hilbert (1955, p.55) apenas mencionou a existência de "figuras de aspecto grotesco, com pormenores exagerados e quase no campo caricatural". O autor também listou espécies animais que estariam sendo representadas nessas modelagens. Guimarães (1985) e Prous (1992) apresentaram uma lista maior de espécies, mas, como Hilbert, não justificaram suas interpretações. Castro (2018) apresentou uma interpretação semiótica de apêndices figurativos e padrões gráficos da cerâmica coletada no sítio Greig II. Esse estudo é mais explícito sobre sua metodologia de análise, porém, como os que o precederam, postula uma relação mimética entre as figurações e espécies naturais.

Inicialmente nos propusemos a realizar a tarefa de classificação zoológica, mas isso se mostrou um tanto frustrante. A ideia difundida por Linné $(1928$, p.83) de a cerâmica Santarém seria "un véritable catalogue de toute la faune du bassin amazonien", se tomada em sentido literal pode levar a falsa impressão das figurações naquela cerâmica e também na Konduri são de alguma maneira "naturalistas" ou "realista". As identificações são carregadas de uma incontornável subjetividade do observador, de sua experiência prévia e conhecimento de anatomia animal. O professor Dr. Flávio Rodrigues do Instituto de Ciências Biológicas da Universidade Federal de Minas Gerais observou várias das peças da coleção Aricy Curvello no MHN durante nosso trabalho de monografia e argumentou que os elementos morfológicos figurados não eram seguros para uma inferência a partir de uma perspectiva da anatomia animal (ALVES, 2016). A premissa que as figuras são uma representação da Natureza está baseada em conceitos muito arraigados na ontologia ocidental (DESCOLA, 2013). 
Vera Penteado Coelho, a partir de sua experiência etnográfica com os Wauja, relata como advertência o desencontro entre suas interpretações das figuras e as próprias identificações feitas por seus interlocutores. Sua conclusão é válida para o estudo de iconografia Konduri

(...) more than a model to be copied, the figures in the real world [em nossa ontologia naturalista] constitute a point of reference to be interpreted, abbreviated and, in many cases, presented in a way beyond the recognition of people who, like us used to dealing with a particular set of conventions. (COELHO, 1977, p. 248 - ênfase adicionada).

Diferentes exemplos podem ser arrolados para as terras baixas da América do Sul ou outras regiões do mundo para exemplificar que os modos de construir uma figura e reconhecer os elementos morfológicos que definem sua identidade variam. Mesmo no caso das sociedades ocidentais de ontologia naturalista, um urso de pelúcia não é um protótipo da família Ursidae. Outro elemento a se considerar é de que, do ponto dos produtores e usuários indígenas, podem existir uma série de seres monstruosos, compósitos ou quiméricos, desconhecidos na "Natureza"(VIVEIROS DE CASTRO, 2002). A iconografia Wauja, por exemplo, é repleta de representações desses entes, denominados apaapatai e yerupoho, cujas imagens são obtidas a partir das práticas xamânicas e não com observação das espécies naturais (BARCELOS NETO, 2001, 2005-2006). Como explica Barcelos Neto (2008, p. 79),

Um dado yerupoho [por exemplo] é um correspondente zooantropomorfo de uma dada espécie animal, e seu corpo é uma unidade formal singular e prototípica para aquela espécie. Assim, o jacaré tem pele muito áspera, boca alongada, dentes afiados e os olhos estufados porque o Jacaré também os tem (...).

Em uma perspectiva ética, a maioria das figuras produzidas pelos Wauja teriam associações muito distintas ou seriam consideradas irreconhecíveis, uma vez que não existe nenhum referencial faunístico equivalente. Antes de tentar correlacionar as figuras com as características anatômicas observadas em espécies da fauna é necessário compreender os eixos de coerência visual e observar seus princípios de simplificação e estilização (COELHO, op. cit.; GELL, 1998). Em determinados contextos arqueológicos é possível encontrar elementos bastante específicos da anatomia animal 
de um gênero ou mesmo espécie (PROUS, 1992), mas esta não é uma regra universal. É provável que existam vários elementos figurativos com dezenas de interpretações possíveis.
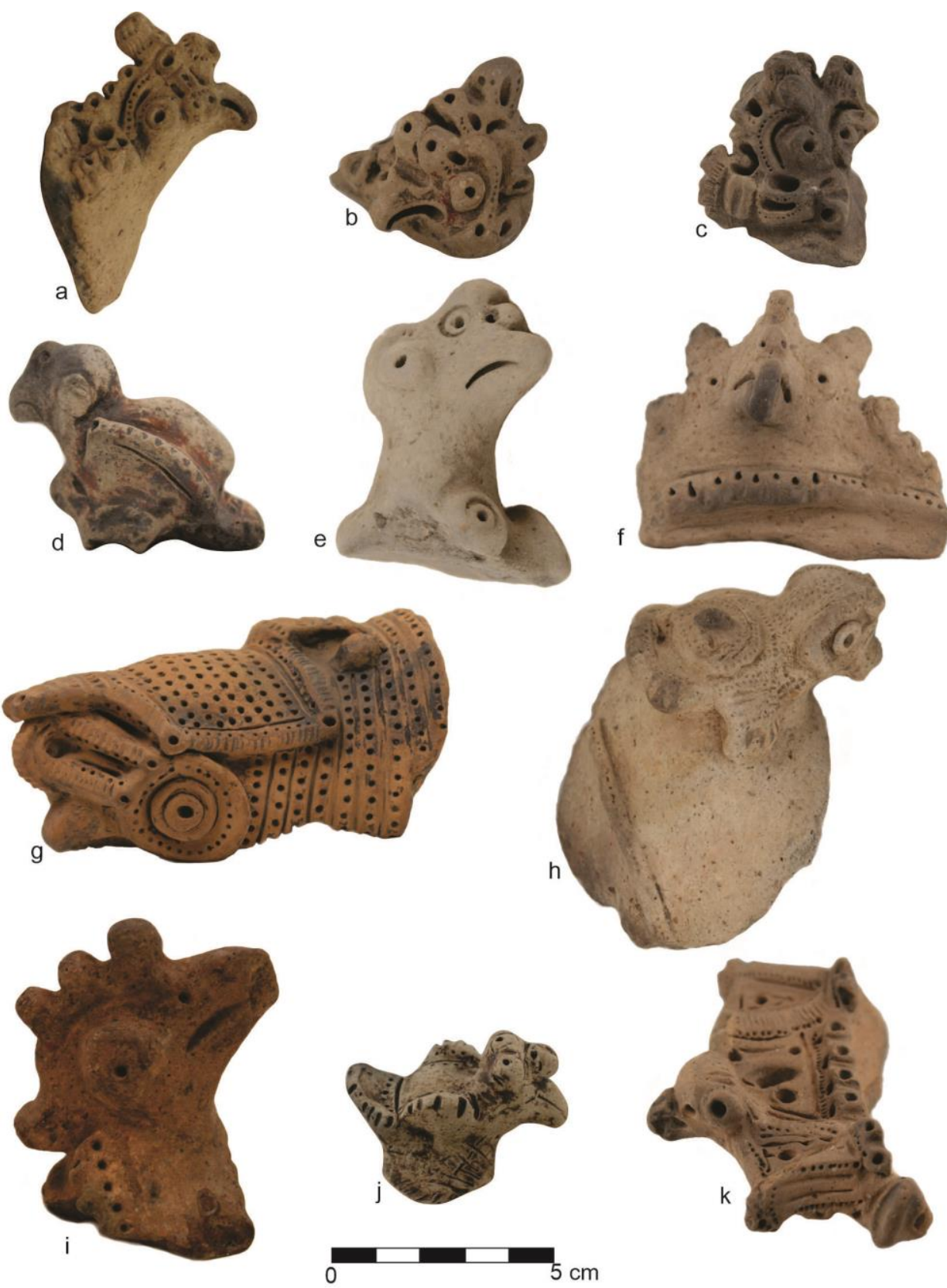

Figura 62. Apêndices aviformes e sua diversidade morfológica. Proveniência/procedência: a - sem proveniência (Col. Tapajônica); b- Terra Santa (Col. Peter Hilbert); c - sem proveniência (Col. Charles Townsend Jr.); d - Santa Maria (Col. Barbosa de Faria); e - Fortaleza (Col. Peter Hilbert e Harald Schultz); f - sem proveniência (Col. Peter Hilbert); g - sem proveniência (Col. Comissão Rondon); h sem proveniência (Col. Peter Hilbert); i - sem proveniência (Col. Tapajônica); j- Terra Preta 1/2/ Juruti (MD-19); k - sem proveniência (Col. Peter Hilbert). 

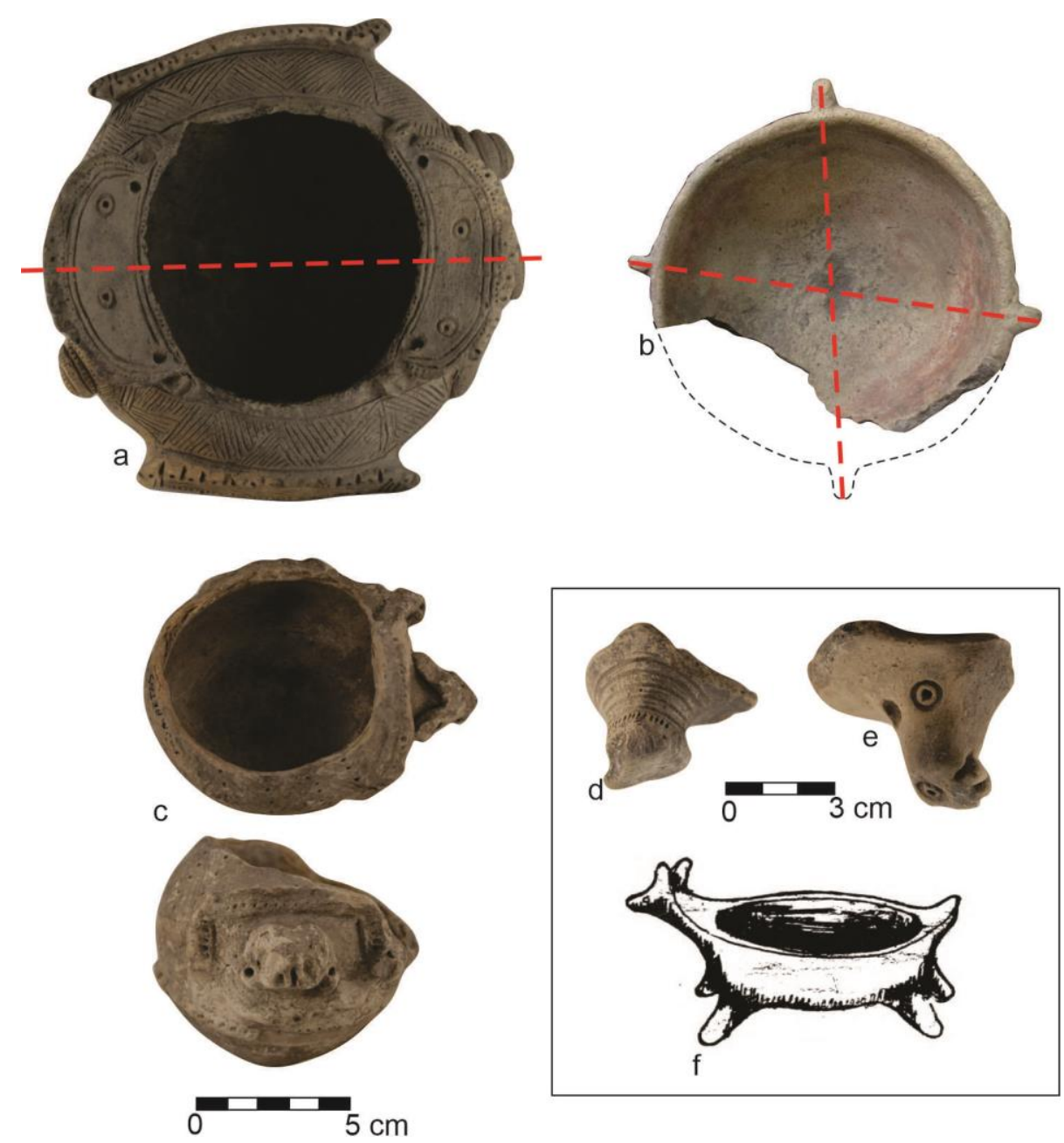

Figura 63. Disposição nos apêndices em vasilhas: refletidos em eixos de simetria (a-b) ,apêndice compondo a partir do corpo da vasilha um zoomorfo (c) e suportes sugerindo possíveis pés de seres zoomorfos (d-e), como ocorre em vasilhas tetrápodes Wauja (f/ extraído de Ribeiro, 1988).

A partir das coleções estudadas e de nossa perspectiva empirista, identificamos no estilo Konduri apenas um conjunto figuras com atribuição zoológica mais segura ${ }^{63}$. Esse conjunto é formado por apêndices aviformes, diagnosticados pela presença de um bico mais ou menos proeminente e outros elementos morfológicos que caracterizam esta classe zoológica (asas e cauda) (Figura 63). Não é possível dizer quais poderiam ser as espécies figuradas. Um estudo detalhado sobre o tema poderia encontrar evidências para a construção de algumas interpretações nesse sentido. Em alguns casos, as aves aparecem com quase todo corpo representado. Em outros, a presença do bico é o único

\footnotetext{
${ }^{63}$ Camila Jácome , Igor Rodrigues e Cooni Wai Wai estão desenvolvendo um trabalho de interpretação da iconografia Konduri a partir da perspectiva de jovens caçadores Wai Wai. Esse trabalho poderá oferecer um contraponto interessante a nossa perspectiva em relação às figurações na cerâmica Koduri.
} 
indicador de que se trata de uma ave. Há elementos morfológicos que sugerem uma figura compósita com bico de ave, mas a sugestão de uma postura ereta humana.

A raridade de vasilhas inteiras ou fragmentos maiores que incluam elementos para além dos próprios apêndices, ainda é um desafio para compreender as relações entre as figuras. Há, até o momento, poucos indícios que as vasilhas formavam anatomias corpos antropomorfos ou zoomorfos, como acontece em algumas vasilhas do estilo Santarém ou na cerâmica produzida no alto Xingu pelos Wauja (Figura 71). É provável que os apêndices fossem organizados em eixos de simetria refletida, como é notável nas vasilhas T-405 e T-413 (Figura 63). Foram identificados, entretanto, quatro pés modelados que sugerem patas zoomorfas. Isso remete a vasilhas tetrápodes baseadas na estrutura anatômica de animais, como as produzidas pelos Juruna (RIBEIRO, 1988).

\subsubsection{Grupos apêndices figurativos}

Durante o estudo tentamos construir agrupamentos relativamente coerentes de personagens com atributo relacionáveis. Com essa perspectiva exploratória, conseguimos formamos seis grupos de modelagens simalares, mas que não são idênticas. A iconografia Konduri parece exibir uma diversidade iconográfica significativa. Apresentamos em sequência uma breve descrição qualitativa de cada grupo, como uma proposta inicial a ser expandida em pesquisas futuras e enfatizamos que estes estão longe de esgotar os conjuntos figurativos do estilo:

\section{Grupo A (zooantropomorfo)}

Apêndices afixados perpendicular ou obliquamente ao lábio, com volume achatado, cuja forma sugere uma postura bípede (Figura 64). Todas as figuras têm a face voltada para o interior da vasilha. A partir das partes de bordas conservadas em alguns apliques é possível afirmar que esses apêndices compuseram vasilhas abertas. Essas figurações podem tanto aparecer isoladas quanto em pares ("gêmeos"). Esse grupo incluiu alguns dos apêndices Konduri mais elaborados em termos de combinação de técnicas decorativas, apesar de não exibirem. Os corpos figurados podem ser compostos apenas por uma cabeça, ou exibir tronco, braços e pernas - estas últimas menos frequentes. A maioria possui braços, sendo menos frequentes as indicações de pernas. Os braços, quando presentes, podem aparecem aparecer: (1) transversais ao eixo 
da figura, com as mãos unidas (palma com palma); (2) erguidos com as mãos próximas ou sobre o queixo; (3) paralelas ao eixo da figura, como se estivessem dependurados. As pernas, por sua vez, podem ser representadas: (1) paralelas e abaixo da cabeça; (2) paralelas na altura da cabeça. As cabeças possuem um formato predominantemente elipsoide e variam enormemente nos elementos que as compõem, como olhos, narizes, bocas e possíveis adornos corporais. podem sugerir diferentes identidades figurativas. Algumas apresentam bicos, indicando que se trata de uma figura zooantropomorfa aviforme. Outras com bocas compostas por semiesferas com incisão podem ser interpretadas com a sugestão de espécies de macacos. Nas peças mais elaboradas com técnicas a partir de incisões, entalhes e ponteados e filetes, que podem sugerir um diadema. No dorso das figuras (na face externa), há frequentemente um filete aplicado ao eixo de simetria bilateral que pode tanto sugerir uma coluna vertebral, como acontece em urnas Maracá e Marajoara (BARRETO, 2009), quanto "tranças" ou adornos de cabelo. A presença desses elementos já havia sido notada por Frikel (citado em Hilbert, 1955), mas esse era um atributo vinculado às estatuetas antropomorfas. Esse elemento lembra o tubo vegetal com um "buquê" de penas na extremidade usado pelos homens Wai Wai, Hixkaryana, Mawayana, Tiriyó, Makuxi e diversos povos Tukano do rio Negro (Figura 65). (FARABEE, 1918; YDE, 1965) No cocuruto da cabeça também é notável a presença de pequenos apêndices em forma de aves, esferas ou duas pontas (“chifres").

Existem ainda apêndices localizados nos lábios das vasilhas que apresentam volumetria semelhante, mas que não sugerem seres com a mesma postura. Há também elementos comuns encontrados neste e no Grupo B, sugerindo caras. Este grupo pode ser pensado apenas a partir de critérios mais amplos e estruturais (apêndices achatados em borda), mas optamos por limitar ao conjunto mais facilmente delimitável. 

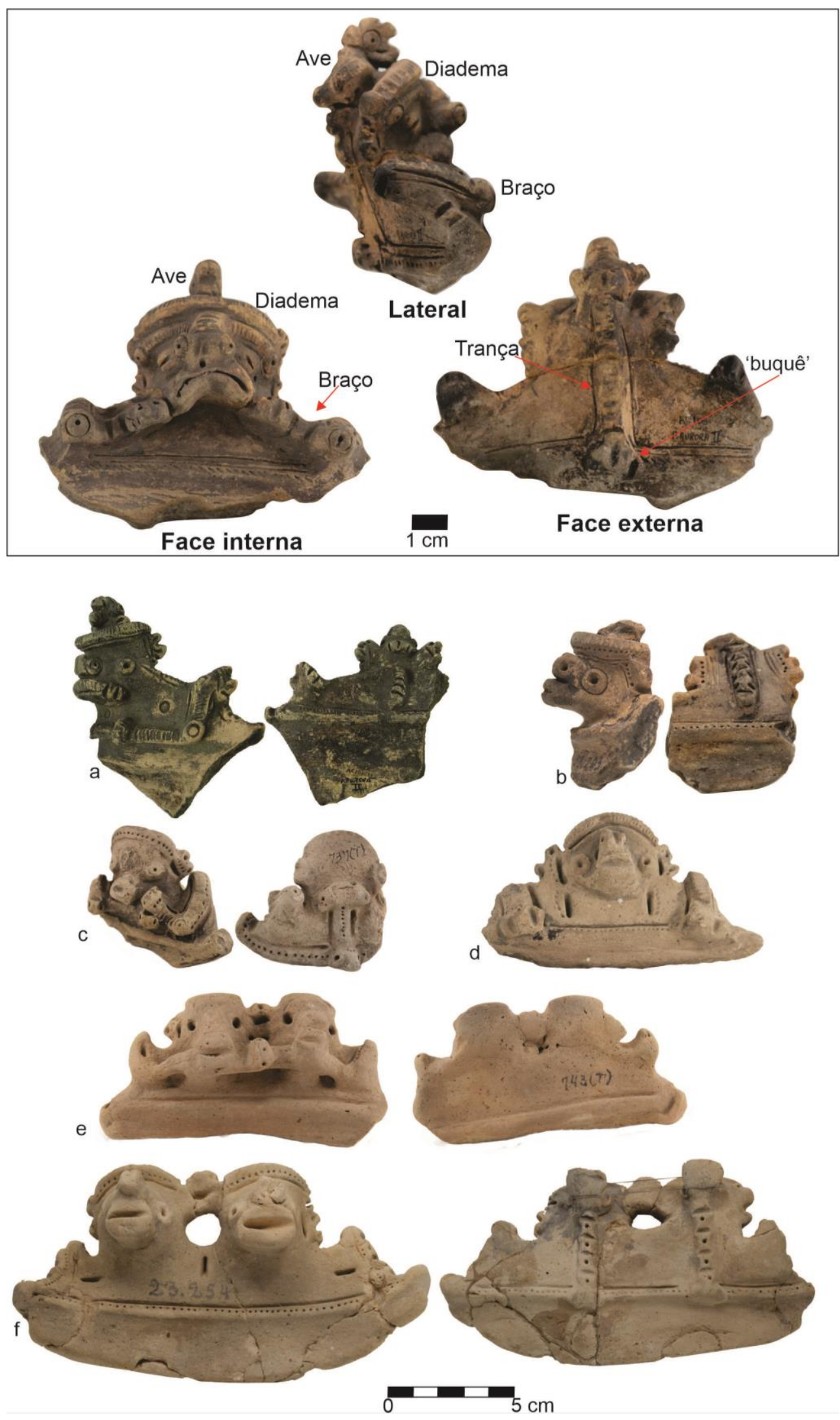

Figura 64. Apêndices do grupo "A" composto por figuras zooantropomorfas aplicadas ao lábio. Proveniência: Superior, Posto Aurora II (Col. Aricy Curvello); a - Posto Aurora II (Col. Aricy Curvello); b- Santa Maria (Col. Barbosa de Faria); c - Aibi (Col. Peter Hilbert); d - Terra Santa (Col. Aricy Curvello); e- Oriximiná (Col. Peter Hilbert); f- Boca dos Anjos (Col. Barbosa de Faria). 


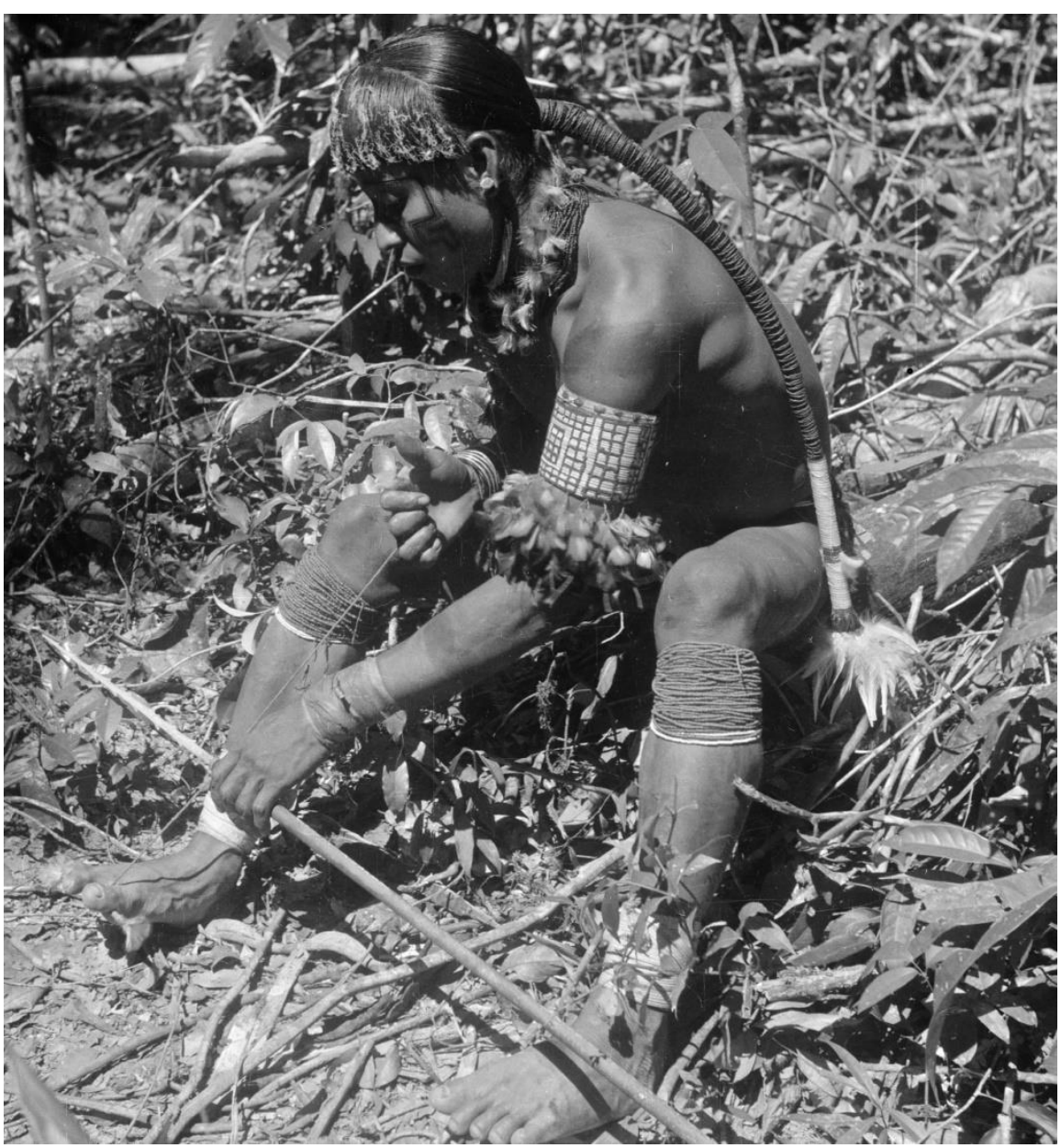

Figura 65. Homem Wai Wai com um grande tubo de cabelo com plumas na extremidade. Esse elemento pode ser análogo ao encontrado em apêndices do Grupo A. Disponível em: https://samlinger.natmus.dk/ES/asset/222327 Acesso em 25 de junho de 2019.

\section{Grupo B ("cara achatada")}

Apêndices afixados obliquamente aos lábios, com volume achatado, que não forma o corpo de ser, mas apresenta o motivo de uma cara antropomorfa (Figura 66 a). Essas caras podem estar tanto voltadas para o interior e exterior das vasilhas, bem como Com exceção dos apliques encontrados na vasilha T-405, as outras quatro peças são muito elaboradas em termos de técnicas decorativas. Chama a atenção o aplique coletado em Posto Aurora I, com três caras na face externa e figuras de aves e mais uma cara na face interna, composto por técnicas plásticas e pintura vermelha e amarela. Outro exemplar, menor, coletado em Posto Aurora II exibe também pintura vermelha.

\section{Grupo C ("jacaré")}


Apêndices afixados obliquamente aos lábios, com volume achatado e morfologia alongada trapezoidal (Figura 66 b-c). Na maioria dos exemplares não é possível o olho da figura, restando a dúvida de que se este é um apêndice figurativo ou não. Aparentemente há uma sugestão de boca composta por filetes que acompanham seus bordos, pequenos elementos pontiagudos que poderiam indicar narinas e, próximo ao lábio da vasilha, indicações de olhos. Há também pequenos apliques aviformes em alguns exemplares. O epíteto "jacaré" não pode ser interpretado de maneira literal, mas tem a função heurística de indicar uma morfologia assemelhada.

\section{Grupo D ("porífero")}

Apêndices afixados perpendicularmente aos lábios, em pleno relevo, maciços ou ocos, sem indicações claras de partes anatômicas (olhos, boca, nariz, etc.) (Figura 66 df). A maioria desses apêndices apresenta morfologia arredondada, ponteado tipo A com grandes diâmetros (cerca de 5,0 mm). Suas características lembram, em alguns casos, uma esponja, mas não parece o caso de um apêndice figurativo.

\section{Grupo E ("cabeça de quelônio")}

Apêndices em forma de cabeças afixados a face externa das bordas, em pleno relevo, maciços e morfologia quase em tronco de pirâmide (Figura 66g-i) A figuração é caracterizada pela presença de filetes entalhados sobre os olhos sugerindo uma membrana, narinas separadas e proeminentes e também boca arqueada para baixo (em U invertido). Na vasilha em miniatura da coleção T-881, é notável que o aplique é acompanhado de braços inseridos acima da cabeça. O mesmo elemento é encontrado em outro exemplar, mas há vasilhas que, certamente, só exibiam a cabeça. 


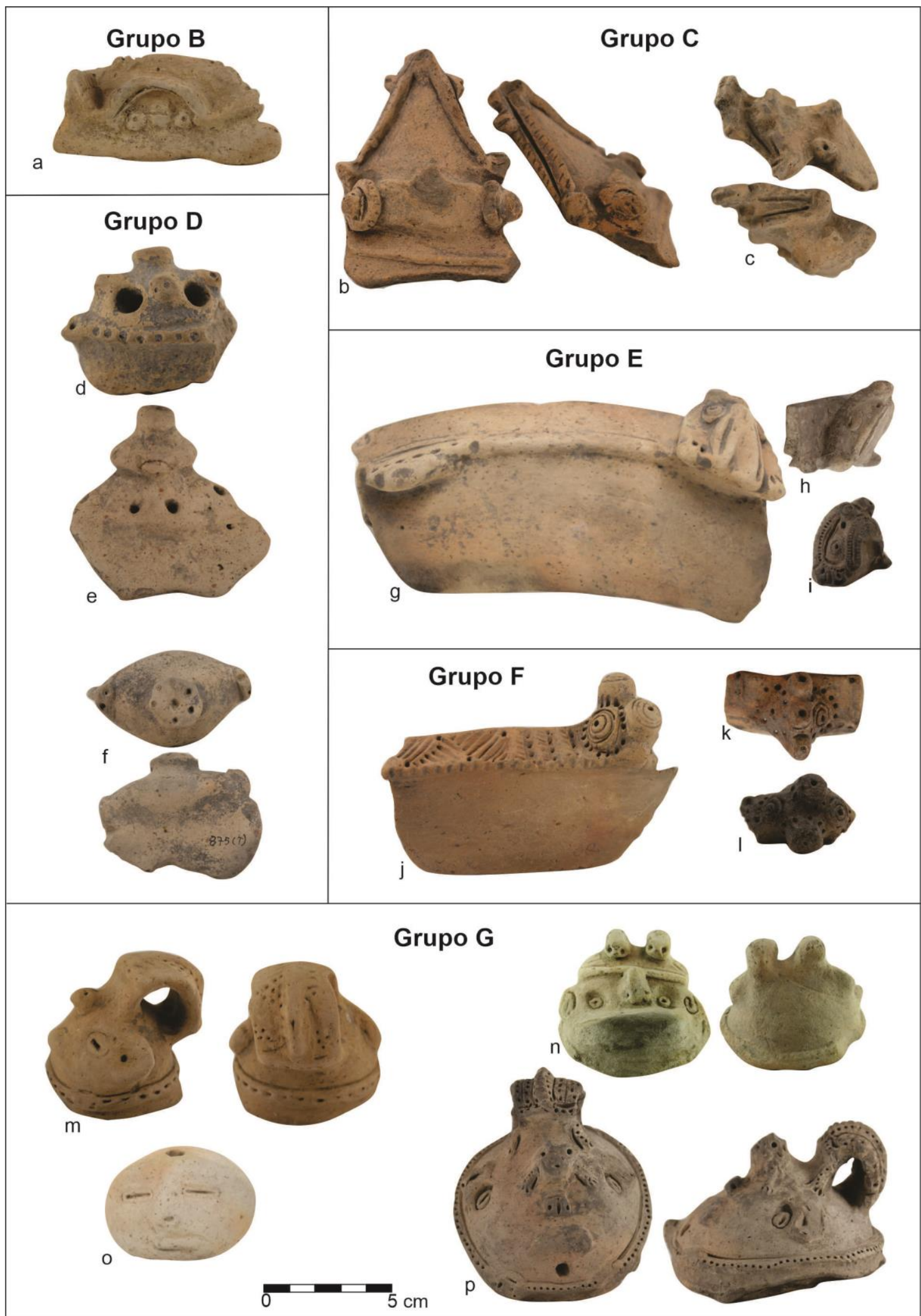

Figura 66. Grupos de apêndices B, C, D, E, F, e G. Proveniência/procedência: a - Ponta da Mafada (Col. Peter Hilbert).b, h, 1 - sem proveniência (Col. Tapajônica); c, d - Babaçu (Col. Peter Hilbert e Harald Schultz); d, f - Santo Antônio (Col. Peter Hilbert); e- Cocal (Col. Peter Hilbert); g- Abuí (Col. Barbosa de Faria); i - sem proveniência (Col. Charles Townsend Jr.); j, n - Oriximiná (Col. Peter Hilbert); m sem proveniência (Col. Frederico Barata); n - Alema (Col. Aricy Curvello); o - Cocal (Col. Barbosa de Faria); p - Posto Aurora II (Col. Aricy Curvello). 


\section{Grupo F ("biquinho")}

Apêndice em forma de cabeça afixado a face externa das bordas, com volumes em pleno relevo e maciços (Figura 66 j-1). Esses apêndices são caracterizados pela presença de duas protuberâncias, uma acima da outra, ladeados por olhos. Como é possível notar na vasilha T-413 e em um fragmento de borda, o apêndice aparece integrado a padrões aplicados e incisos no reforço da borda.

\section{Grupo G ("cara em meia calota")}

Apêndices em forma de meia calota afixados ao bojo, ocos ou maciços, com ou sem furos de ventilação (Figura $66 \mathrm{~m}$-p). Esses são apêndices relativamente maiores em termos volumétricos porque tem mais ou menos o mesmo comprimento e largura além de uma espessura grande. Essas modelagens figuram uma cara (antropromorfa?) com olhos, boca, nariz e orelhas. Muitos apliques deste grupo apresentam um pequeno apêndice zoomorfo quadrúpede no cocuruto, cuja cauda é figurada na forma de alça do tipo 1. Outros elementos importantes são pequenos braços aplicados no bordo do apêndice em direção ao que poderia ser o queixo. Em outros exemplares há apenas a "alça" ou, ao contrário, quase não há indicadores elementos morfológicos da cara, apenas o arco aplicado e braços. Figurações um pouco distintas apresentam a mesma morfologia em meia calota e afixada ao bojo.

\subsubsection{Motivo rosto, sobreposição e dualismo}

Os apêndices não são o único locus da figuração na cerâmica Konduri. Há também motivo figurativo aplicado a paredes e bordas das vasilhas denominado aqui como "rosto". Esse motivo se destaca em relação aos apêndices figurativos porque é praticamente o único que pode ser relacionado à representação da forma humana.

Os motivos formando caras são compostos por filetes aplicados e outras técnicas plásticas. A configuração da cara antropomorfa pode ser apresentada de diversas maneiras, desde o caso da vasilha T-405, onde há apenas a indicação de olhos ou figurações muito mais repletas de detalhes, com indicações de orelhas e bocas e, às vezes, narizes. Há ainda um terceiro modo de compor as figuras a partir de "molduras" ou “delimitadores". Esses elementos realizados em filetes aplicados (com ou sem outras técnicas decorativas) formando linhas retas, arcos, arcos retilíneos ou retângulos. Ao 
centro desses filetes pode haver uma cabeça de um pequeno zoomorfo (aves ou quadrúpede). Soma-se a esse elemento, entalhes nas extremidades sugerindo patas, que fazem emergir um pequeno corpo sobreposto a cara antropomorfa. Este é o motivo “cara dupla” já descrito por Hilbert (1955a). Essa figuração é encontrada ao longo de toda a dispersão da cerâmica Konduri, tanto em sítios do rio Nhamundá, quanto no município de Juruti e na foz do rio Trombetas e nos sítios de terra firme de Porto Trombetas. Exemplares com esse motivo foram coletados nos sítios Greig II, Boa Vista, Aviso I, Tawanî, Terra Preta 1 (Juruti) e Santa Rita (GUAPINDAIA, 2008; CASTRO, 2018; JÁCOME, 2017; SCIENTIA, 2002, 2008).

O motivo rosto ocorre em apêndices (3 peças), alças túnel (11 peças), bojo (6 peças) e área indeterminada (1) nas coleções analisadas É provável que apareça em outras 23 peças, mas dada sua fragmentação não é possível afirmar. Entre estas 11 possuem patas sugeridas por filetes. Na face externa de uma borda na coleção Idelza (comunidade de Conuri/ lago Sapucuá) observamos o mesmo motivo em uma cara sem boca. Um elemento interessante e bastante frequente é a presença do motivo "cara dupla" sempre na base da alça (junção com a borda) e uma ave ou quadrúpede no centro do arco.

Existem também 6 peças com um elemento bastante semelhante ao da "cara dupla", mas sem uma figura sobreposta. No lugar do zoomorfo há um mesmo tipo de botão utilizado para indicar a narina e sexo em apêndices do grupo A. Isso lembra as caras antropomorfas presentes nos vasos de gargalo e outras vasilhas do estilo Santarém (GOMES, 2002, p. 232 248), nas quais a cabeça é circundada por volutas, possíveis monocelhas ou tiaras, e um nariz entre elas. Os motivos cara antropomorfa que apresentam nariz não exibem o zoomorfo sobreposto. É possível que as figurações "substituam" de alguma maneira sobrancelhas e narizes nesse motivo 

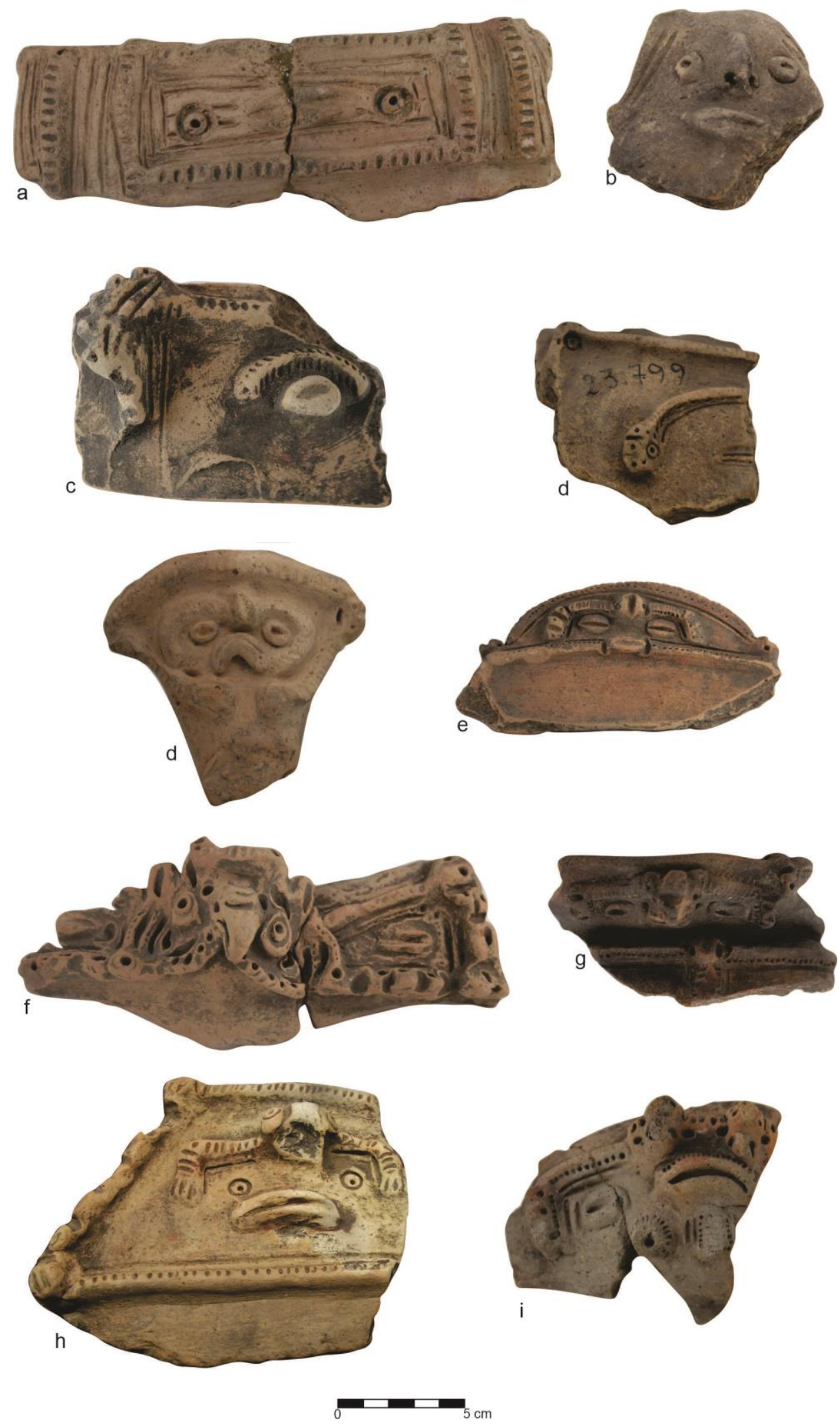

Figura 67. Motivo cara antropomorfa delimitada por retângulo (a, c, d), com nariz (b), com elemento sobre o rosto (botão) semelhante a nariz (d-e), sobreposta por ave (s) ou zoomorfo indeterminado (f-i). Proveniência/procedência: a, f- Terra Santa (Col. Charles Townsend Jr.); b, d - Sacuri (Col. Barbosa de Faria); c- Posto Aurora II (Col. Aricy Curvello); g- sem proveniência (Col. Tapajônica); h - Terra Preta/Juruti (Col. Protásio Frikel/PUCRS); i - Serra do Matió (Col. Peter Hilbert). 


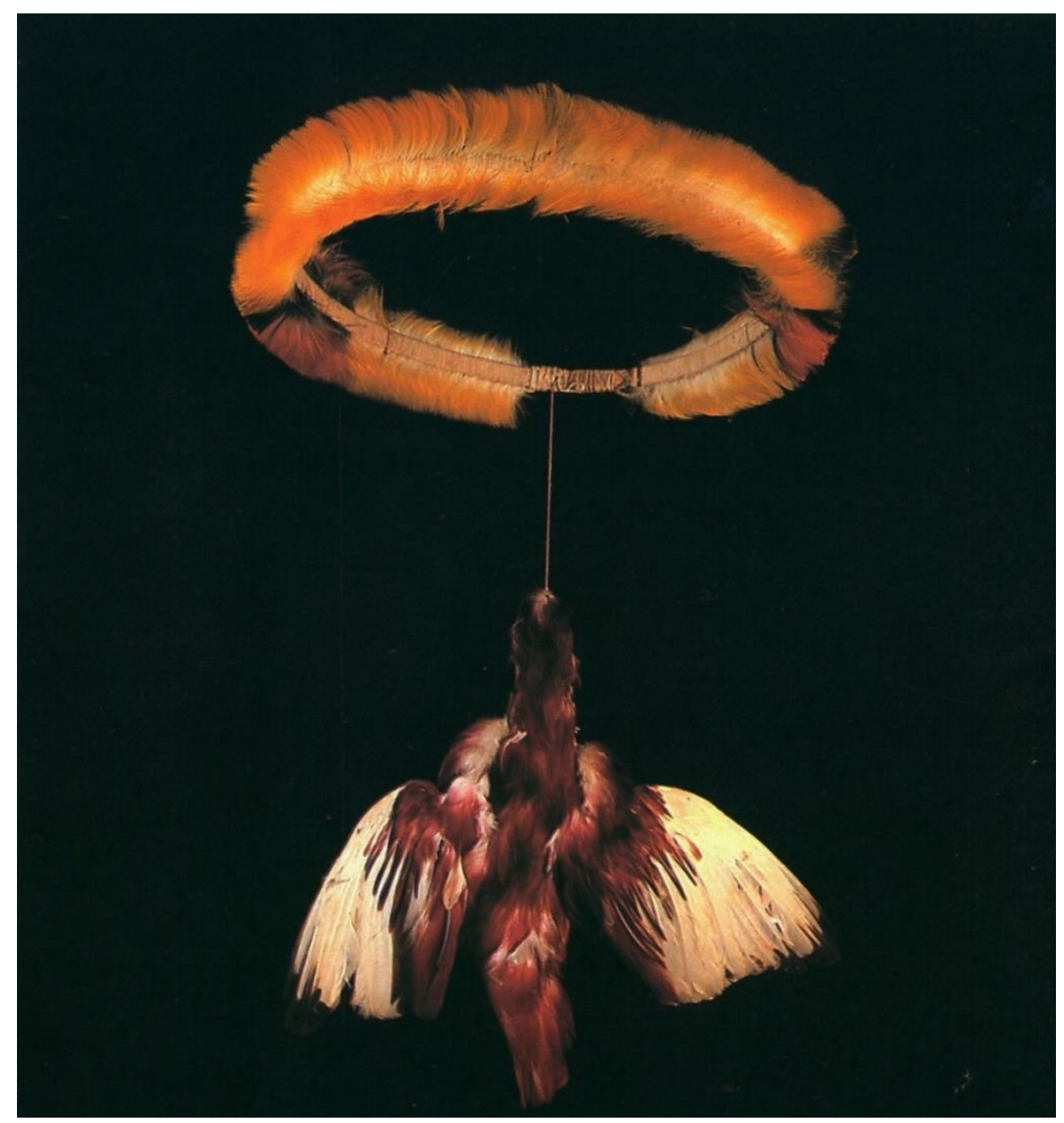

Figura 68. Aro emplumado com pingente de pele de ave atada ao aro produzido pelos Tiriyó do rio Erepecuru. Esse elemento pode ter sido figurado tanto nos apêndices do Grupo A quanto no motivo cara antropomorfa. Fonte: O MUSEU GOELDI (1986).

Hilbert (1955a) acredita que o motivo "cara dupla" com a sobreposição de um ser por outro identificado representa um compartilhamento iconográfico com estatuetas líticas do Baixo Amazonas, provavelmente associadas ao estilo Konduri (PORRO, 2010; FONSECA, 2010). Essas figuras foram interpretadas a partir de analogias etnográficas como indicadoras da "alter egos" “espíritos auxiliares”, ou "duplos” de xamãs. Também a partir de exemplos de vários contextos esses artefatos foram associados ao consumo de alucinógenos, apesar de nenhuma análise de microvestígios ter sido realizada. Ao longo da América do Sul e Central figuras com seres sobrepostos tem sido interpretadas da mesma maneira, reproduzindo uma ideia desenvolvida por Konrad Preuss, no começo do século XX, e desenvolvidas por Otto Zerries e Henry Wassén (PORRO, 2010). Boomert (2001) interpretou figurações Barrancóide do baixo 
Orinoco, com mãos no queixo e uma ave se sobrepondo como indicadores de práticas xamânicas. A própria frequência da representação de aves foi relacionada ao seu papel em voos xamânicos em diversos contextos da América do Sul (REICHELDOLMATOFF, 1988). Gomes $(2012,2019)$ menciona a existência da sobreposição em apêndices da Konduri e também os relaciona a "espíritos auxiliares".

A correlação entre a justaposição entre cara antropomorfa e zoomorfa permanece muito direta dado que, na maioria dos casos, a associação tem sido feita sem uma discussão dos eixos de coerência do estilo e em uma área que vai desde a Nicarágua até o Baixo Amazonas. A extensão geográfica não é um problema em si, uma vez que podem existir princípios cosmológicos amplamente compartilhados, como mostrou Viveiros de Castro em relação ao que denominou de "perspectivismo ameríndio" (2002). A sobreposição de figuras pode ser explicada devido ao uso de ornamentos corporais, como sugerido em relação aos apêndices do grupo A. Existem adornos plumários que incluem o corpo inteiro de uma ave, como o produzido pelos Tiriyó, por exemplo (Figura 68).

Outro elemento relacionado às caras antropomorfas é a técnica visual chamada de "dualismo" por Barata (1950). Esta técnica também foi associada a uma estatueta lítica (FONSECA, 2010). O dualismo compreende "ornamentos escultóricos [apliques] que mudados de posição continuam a representar a mesma figuração, antropomorfa ou zoomorfa" (op.cit., p. 23). Apesar do autor se foca na cerâmica Santarém, apresenta um pé modelado característico do estilo Konduri, provavelmente misturado àquele estilo no processo de formação das coleções (- a). Um grande problema das observações apresentadas por Barata (1950) em relação ao dualismo é que o autor se baseia em apêndices isolados sem considerar sua inserção nas vasilhas ou outros exemplares do mesmo tipo. Fora de da estrutura da vasilhas, muitas modelagens podem ser consideradas "dualistas", mas se pensadas em conjunto ou em relação ao vaso inteiro, essa interpretação pode não se sustentar. A nosso ver não há duas perspectivas para a mesma figura: o botão utilizado para construir a boca (com incisão central) não é igual ao usado para criar o nariz (com três pontos). É intrigante, por outro lado, que a posição em que há claramente uma boca representada é contrária à orientação do pé em uma vasilha. Em dois pé modelados conhecidos, um da coleção Charles Townsend Jr e outra na Walter Marinho também há pé também com a cara invertida. 

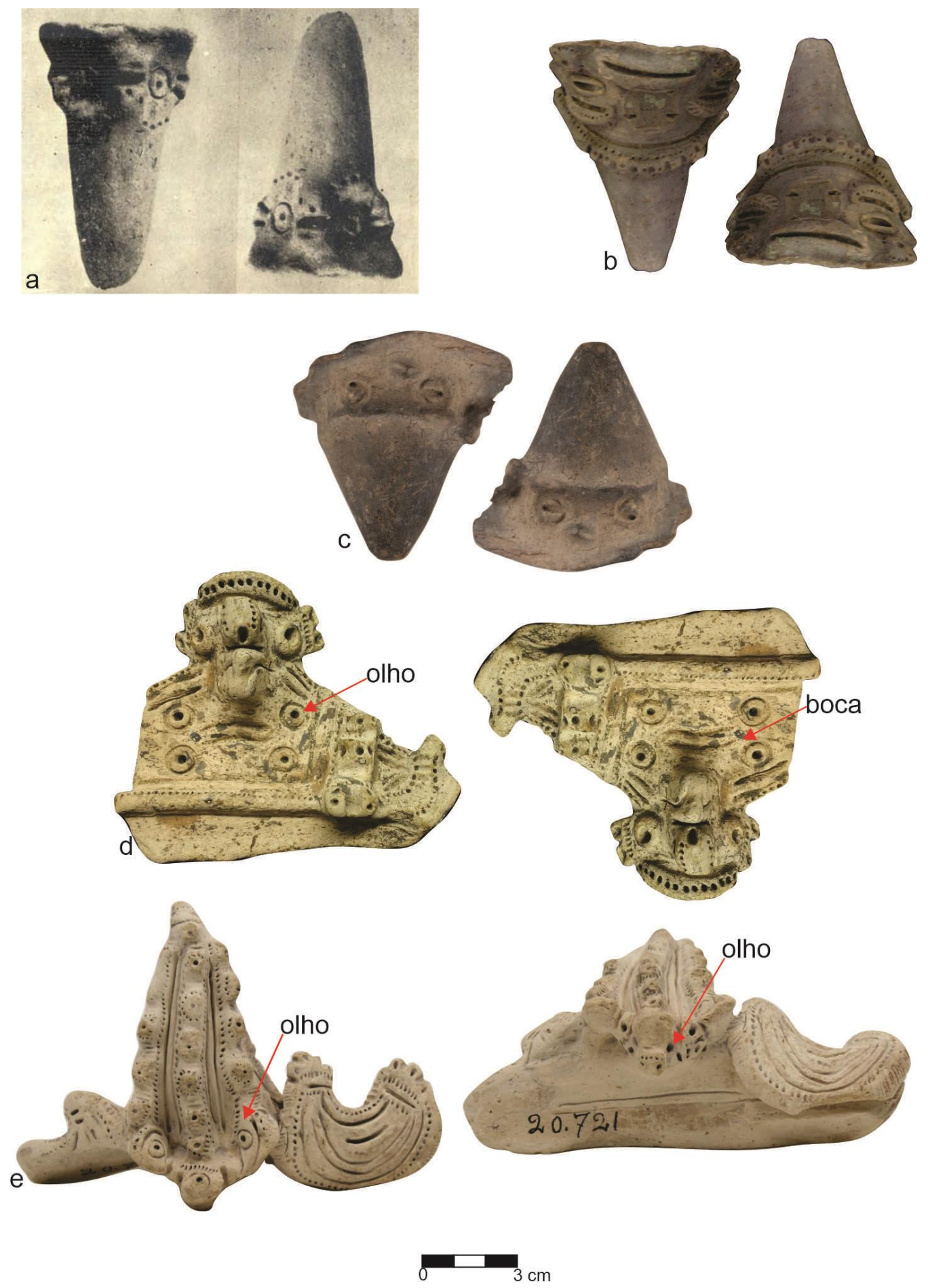

Figura 69. O "dualismo" na iconografia Konduri. Pés com motivo cara antropomorfa em posição invertida a orientação da vasilha (a-c); apêndice do Grupo A com cara sugerida em posição da borda para cima e emborcada (d); apêndice com cara sugerida na lateral e também vista da face interna (e). Proveniência/procedência: a- sem proveniência (Col. Rose e Robert Brown/ extraído de Barata, 1950); b- sem proveniência (Col. Walter Marinho/ foto Igor Rodrigues); c - sem proveniência (Col. Charles Townsend Jr.); d- Pocó (Col. Peter e Klaus Hilbert); e - Óbidos (Col. Comissão Rondon). 
Se o "dualismo" não está presente em suportes modelados do estilo Konduri, isso não quer dizer que essa técnica visual não seja utilizada. Em um apêndice do grupo B coletado no sítio Posto Aurora I, que exibe faces antropomorfas voltadas para dentro e para fora das vasilhas. Outro caso é o de um apêndice do grupo A, coletado no sítio Pocó (coleção Peter e Klaus Hilbert). Seu tronco exibe quatro pontos do tipo B simetricamente dispostos e ao centro um filete em "U" invertido com incisão central. Girando a peça em $180^{\circ}$, é possível ver uma cara antropomorfa com a boca para baixo ou para cima (Figura 69 d). Em qual contexto a vasilha seria vista de cabeça para baixo torna-se uma questão que ainda não podemos resolver. Um aplique coletado na cidade de Óbidos sugere uma pequena cara volta para dentro da vasilha a partir da combinação de pontos do tipo A e outra, paralela ao eixo da borda (Figura 69 e).

A construção do estilo visual Konduri é muito mais complexa que a ênfase em superfícies "sobrecarregadas". As/os oleiras/os no baixo Amazonas mobilizam a decoração plástica para figurar seres quiméricos, especialmente na forma de apêndices, cuja identidade pode se aproximar de seres monstruosos, encontrados nas práticas xamânicas e presentes na mitologia. O caráter genérico das caras aplicadas em diversas partes das vasilhas, talvez, não reflita um antropomorfismo específico aos humanos que não é encontrado em praticamente nenhum apêndice figurativo - mas ao contrário, uma sugestão do compartilhamento de atribuições humanas entre outros seres e coisas (VIVEIROS DE CASTRO, 2002; BARCELOS NETO, 2008). A hipótese de um "esquema de antropomorfia" no estilo Konduri pode oferecer um caminho profícuo em relação a possibilidades de conexão entre as cosmologias indígenas atuais e as do passado. Os elementos classificados como "não figurativos" poderiam ser interpretados, em alguns casos, com indicações de um dessa antropomorfia compartilhada. Os apêndices retangulares aplicados ao vaso T-405, por exemplo, apresentam o mesmo elemento modelado usado na composição das orelhas em caras antropomorfas. Isso também é coerente com a formação de caras, que são apenas sugeridas por alguns pontos e incisões. Dessa maneira, os modos de construção figurativa encontrados na cerâmica Konduri são semelhantes aos de outros estilos pré-coloniais da calha do rio Amazonas. É notável como aparecem faces antropomorfas acompanhadas ou compostas por elementos zoomorfas em motivos pintados e aplicados análogos aos do estilo Konduri, nas cerâmicas Santarém (GOMES, 2012), Marajoara (BARRETO, 2009; NOBRE, 2017) e Polícroma (OLIVEIRA, 2016). 


\subsection{Discussão}

Os resultados de nossas análises sugerem uma marcada padronização tecnológica. A cadeia operatória da cerâmica Konduri é, grosso modo, carcterizada pelo uso de cauixi com antiplástico (provavelmente tempero) em média e alta concentração, formação do bojo e borda das vasilhas com a técnica de roletes sobrepostos e construção de bases e apliques com modelagem, decoração plástica aplicada à pasta úmida com instrumentos sólidos e ocos, pintura e engobo espessos de origem mineral. No caso de alguns apliques está presente método de ocagem e furo de ventilação para a produção de alguns apliques. Apenas os assadores são produzidos sobre trançados sem a obliteração dos negativos. Em termos morfológicos, as vasilhas tendem a exibir paredes finas (5-10 $\mathrm{mm}$ ), bases planas, bordas diretas, extrovertidas ou introvertidadas com reforço externo, contornos simples e compostos. A dimensão reduzida das amostras estudadas e seus vieses impedem uma comparação refinada de frequências dos atributos e morfologias, mas os dados disponíveis na bibliografia parecem corroborar a existência de certo grau de homogeneidade na cadeia operatória da cerâmica Konduri. Existem aspectos da variabilidade dos conjuntos relativos à frequência de morfologias, marcas de uso e densidade de material cerâmico. Não foi possível abordar essa questão dados os vieses amostrais. A variabilidade entre o material cerâmico encontrado em diferentes sítios arqueológicos pode ser identificada e relacionada a funcionalidades distintas dentro de um sistema de assentamento, como já apontou Guapindaia (2008). A ampliação das pesquisas ao longo da dispersão do estilo Konduri poderá esclarecer como essa variabilidade se deu no tempo e no espaço.

A ausência de uma divergência na maior parte da cadeia operatória cerâmica, como as indicadas por Gosselain (2016) no caso da Tradição Policrômica do Niger, pode ser indicador histórico importante (ROUX, 2019). Como manter a semelhança em uma região de cerca de 20 mil $\mathrm{km}^{2}$ ao longo de quatro séculos? Se essa homogeneidade não for um reflexo dos problemas amostrais e/ou o baixo número de pesquisas na região, quais poderiam ser os processos históricos que poderiam explicá-la? Nossa hipótese, ainda bastante especulativa, é de que essa continuidade marcante resulta de uma ocupação relativamente rápida durante o final do século XIII e começo do XIV de um território geograficamente semelhante (ou seja, com recursos e condições de vida similares), após um hiato ocupacional de séculos. Interações contínuas entre comunidades de prática distintas nas duas margens do rio Amazonas, por meio de 
festas, casamentos e outras formas de aliança, podem ter garantido a manutenção de uma cadeia operatória semelhante, mesmo após séculos de um relativo afastamento geográfico. Há ainda muitas áreas pouco conhecidas ou totalmente desconhecidas. As pesquisas futuras poderão mostrar em que medida esse cenário é coerente com realidades particulares.

Em meio à semelhança regional da cadeia operatória da cerâmica Konduri, existe uma diferença em frequências de alguns tipos de antiplásticos notada a partir do levantamento bibliográfico. No Médio Trombetas, a cerâmica apresenta uma maior proporção de minerais ao contrário de outras áreas. O caraipé, por sua vez, é pouquíssimo frequente na cerâmica da margem direita do rio Amazonas, mas aparece em uma porcentagem relativamente alta nas imediações de Porto Trombetas. Exemplos etnográficos dos Wai Wai e Palikur mostram que dependendo da disponibilidade de antiplásticos, as receitas podem ser substituídas por alternativas de mais fácil acesso (GLÓRIA, 2017; ROSTAIN, 2016). Entretanto, apenas esse fator pragmático pode não explicar satisfatoriamente as escolhas técnicas. Muitos dos sítios no baixo Trombetas estão localizados próximos a praias de areia, expostas durante o período de estiagem, o que tornaria a escolha por antiplástico mineral igualmente mais fácil. Arnold (1985) mostrou que, de modo geral, produções oleiras artesanais têm as fontes de temperos muito próximos da área de produção, predominando em distâncias menores que 1,0 km e chegando até $7,0 \mathrm{~km}$. Isso se vincula às próprias áreas de atividades em que as pessoas estão imersas mais do que uma simples relação de gastos de energia para coleta (KELLY et al., 2011). Areia e cauixi estavam disponíveis em abundância durante a vazante em lagos e rios, praticamente a mesma distância no baixo curso do rio Trombetas. No caso dos sítios em terra firme na área de Porto Trombetas os espongiários poderiam ter de ser coletados em áreas mais distantes, mas isso não parece ter tido consequências para a porcentagem do antiplástico na cerâmica. Ainda não sabemos se, de fato, a cerâmica do Médio Trombetas pode ser classificada como Konduri ou se deveria ser agrupada junto ao material encontrado ao longo do curso do rio Mapuera e associado à fase Tarumã (GLÓRIA, 2017; JÁCOME, 2017). A interação entre pessoas detentoras de conhecimentos distintos poderia levar a adoração de antiplástico mineral (ver GOSSELAIN, 2016). 
No caso do caraipé, em princípio, mesmo se não houvesse árvores disponíveis para sua obtenção, o manejo poderia ser uma possibilidade. Por algum motivo isso não aconteceu nem durante a ocupação Pocó e Konduri na margem direita do rio Amazonas, até onde se sabe. Por mais de 1500 anos o caraipé aparece em baixíssima frequência e, ao contrário, na margem esquerda do rio Amazonas onde sua frequência é relativamente alta. Durante o período colonial e pós-emancipação esse cenário parece ter se transformado drasticamente, com o uso de ao menos duas espécies de árvores para a produção de caraipé, na margem direita do rio Amazonas, entre Parintins e Juruti (PANACHUK, 2011, 2016c) (Figura 70). Ao mesmo tempo, o cauixi predominante na cerâmica Konduri passou a fonte de repulsa pelas oleiras no presente.

O uso dos antiplásticos está vinculado a diferentes propriedades percebidas durante a produção cerâmica pelo oleiro ou pela oleira. Essas características físicas podem ser relacionadas a interesses em determinadas performances em relação à produção e uso dos artefatos cerâmicos, tendo consequências também em processos pós-deposicionais, como pode ser o caso em relação à taxa de abrasão em cerâmica com cauixi. Um dos principais meios de compreender os efeitos de antiplásticos na cerâmica é a realização de experimentos controlados. Ainda são quase inexistentes trabalhos sobre antiplásticos biominerais predominantes nas cerâmicas pré-coloniais amazônicas, como o cauixi e caraipé. As pesquisas experimentais realizadas em outras partes do mundo focaram-se em materiais inorgânicos e uma pequena variedade de orgânicos, como conchas, estrume e grama (VAZ et al., 1987; SCHIFFER; SKIBO, 1987; SKIBO et al., 1989). A maioria das informações disponíveis sobre as propriedades físicas de cauixi e caraipé vem de informações etnográficas assistemáticas usadas atualmente por populações tradicionais. Essas informações infelizmente ainda são muito limitadas; apenas mencionam o uso de determinada matéria e mais raramente mencionam a percepção da/o oleira/o em relação aos antiplásticos. Além disso, parte do conhecimento técnico se baseia em princípios implícitos (SCHIFFER; SKIBO, 1987). 


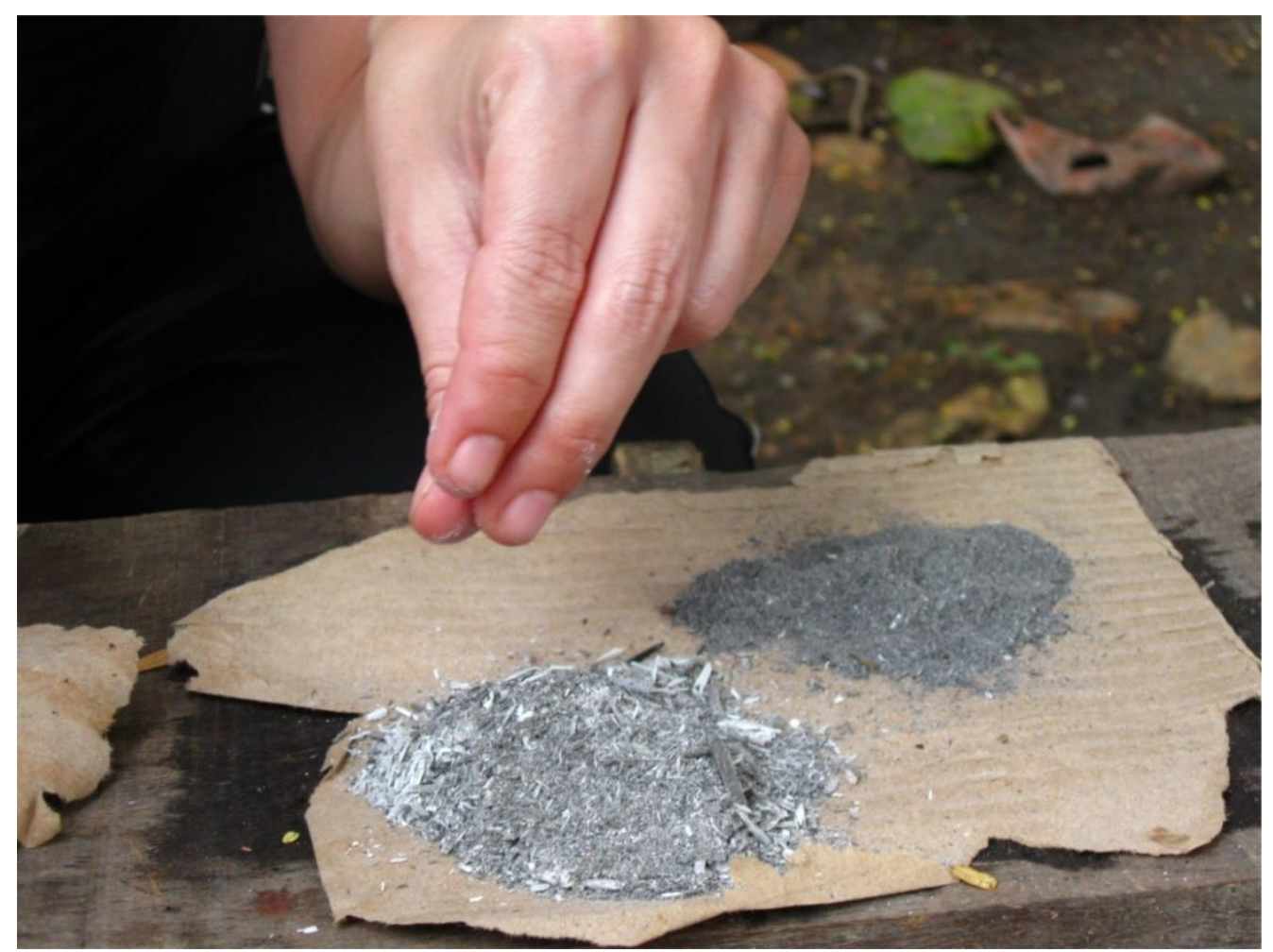

Figura 70. Variedades de caraipé (ou caripé) utilizados atualmente por ceramistas no município de Juruti. Notar primeiro monte a esquerda com elementos maiores e mais grossos e o outro, à direita, com elementos mais finos. Ceramistas na comunidade pesquisada denominam o primeiro como "caripévidro" e o outro apenas como "caripé". Extraído de Panachuk, 2011

O único estudo experimental realizado até o momento testou os efeitos do cauixi na queima e em relação à resistência ao impacto (NATALIO et al., 2015). A partir de roletes experimentais foi possível notar que a presença de cauixi durante a queima reduz significativamente o percentual de retração da argila durante a secagem e a queima. A produção de roletes de argila com cauixi, por sua vez, propicia a orientação das espículas que evitam a propagação de rachaduras. A modelagem, ao contrário, cria uma distribuição aleatória das espículas que não tem efeito em relação à resistência mecânica. As dimensões micrométricas das espículas têm um papel importante nesse fortalecimento, uma vez que inclusões tendem a tornar as vasilhas mais resistentes (RICE, 1987, p 69). Isso também reforça outros experimentos que mostraram que a resistência à rachadura é uma consequência direta de sua resistência seca, sem queimar. Os testes confirmam as hipóteses desenvolvidas e as explicações fornecidas por oleiras/os indígenas e não indígenas. Linné (1932), por exemplo, havia sugerido que o 
cauixi misturado à argila teria um papel análogo a das armações de ferro usadas na alvenaria moderna. Hilbert (1955, p. 35) relata que ceramistas do rio Trombetas mencionaram que o cauixi teria uma melhor performance na secagem e queima que o caraipé, evitando rachaduras e quebras. Entre os Wauja também se afirma que a adição de esponjas queimadas garante a resistência das vasilhas (BARCELOS NETO, 20052006). Ainda não foi realizada nenhuma pesquisa experimental com o caraipé ou este foi contraposto a outros materiais. Natalio et al. (2015) utilizaram para comparar os resultados do cauixi, apenas areia e fibras de vidro. Da mesma maneira não foram testadas a resistência ao choque térmico, a abrasão e outras características de interesse para vasilhas cerâmicas. Barbosa Rodrigues (1876), por exemplo, sugeriu que o uso de cauixi tornava a cerâmica pré-colonial mais leve que a feita no século XIX com caraipé.

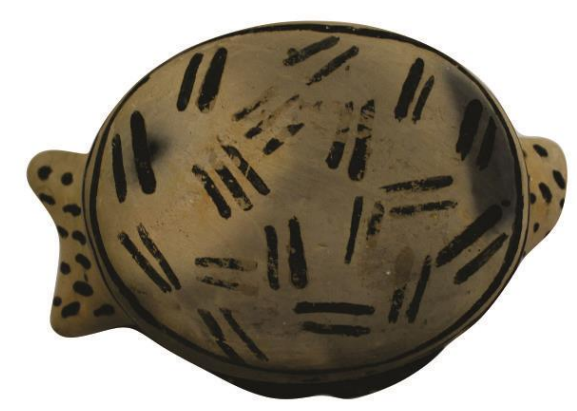

a

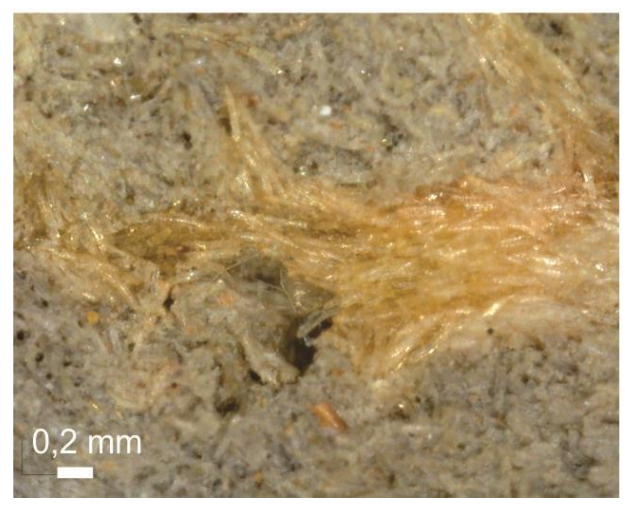

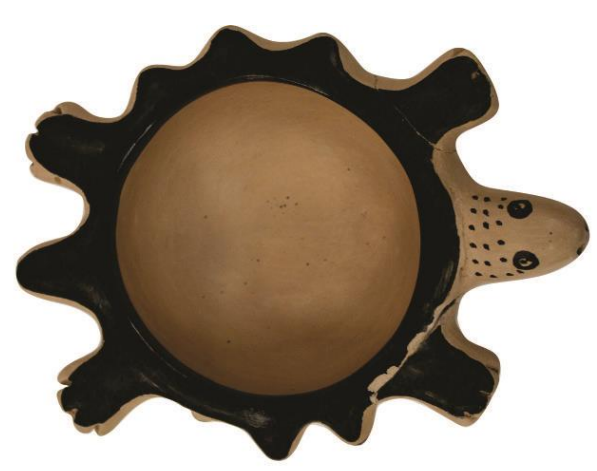

b

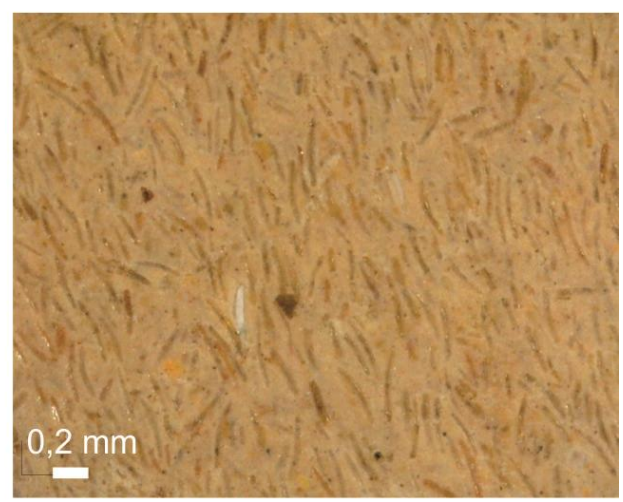

Figura 71. Vasilhas cerâmicas do Alto Xingu com cauixi em alta concentração na pasta: a - produção Kuikuro com feixe de cauixi; b - produção Wauja com espículas relativamente alinhadas. Coleção particular (doação de Iandé Arte Indígena). 
Mesmo sem experimentos é possível tecer algumas hipóteses sobre o uso de cauixi na cerâmica Konduri. Machado (2005-2006, p. 109) pesquisado contextos da Amazônia Central propôs que o aumento da resistência mecânica ${ }^{64}$ proporcionado pelo uso de cauixi estaria vinculado "a uma priorização estética, pelo aumento da resistência nas curvas nas paredes". Essa parece ser uma possibilidade que tem ressonância em vários complexos cerâmicos amazônicos, o caso Konduri não parece ser diferente. Várias dessas cerâmicas com grande frequência de cauixi apresentam morfologias compostas ou complexas com apliques, da mesma maneira que as vasilhas Xinguanas produzidas pelos Wauja e Mehinaku (Figura 71). A alta frequência de apêndices nos lábios associada a paredes relativamente finas, como acontece na cerâmica Konduri, reforça a necessidade de uma "armação" ou "esqueleto" que sustente tal profusão de formas.

Outra característica de performance que também pode estar em questão é a relação entre o tamanho das inclusões e a aplicação de decorações plásticas e tratamento de superfície (SHEPARD, 1956, p. 27). Os antiplásticos mais grossos tendem a dificultar a realização de incisões porque ou alisamento porque saltam ou criam relevos que atrapalhando a criação de linhas retas ou superfícies regulares. Para obter uma granulometria mais próxima ao do cauixi é necessário pulverizar o caraipé ou chamote. O cauixi oferece, nesse sentido, a possibilidade de formar um esqueleto resistente para a inclusão de ângulos ao mesmo tempo em que dá maior facilidade às/aos oleiras/os para aplicar acabamentos.

O cauixi tem efeitos não apenas na argila, mas também na pele das /dos artesã/ãos que o utilizam. Entre os ceramistas ribeirinhos e quilombolas do baixo Amazonas, há uma alta rejeição do cauixi como tempero na cerâmica do baixo Amazonas. Isso foi registrado a primeira vez por Nimuendajú, mas desde pelo menos a segunda metade do século XIX este antiplástico já não era utilizado (BARBOSA RODRIGUES, 1876). Nimuendajú conta em uma carta a Linné que

Sur les bords du lac Curumucury (sur la rive sud de l'Amazone, au dessus d'Óbidos) les potière de l'endroit me déclarèrent qu'elles

64 A autora afirma também que o cauixi aumentaria a resistência ao choque térmico das vasilhas cerâmicas fazendo referência a um trecho de Hilbert (1955a). A leitura da obra nos levou a uma interpretação diferente. As oleiras mencionada por Hilbert atribuíam ao cauixi uma melhor performance durante a queima e não durante o uso (resistência ao choque térmico). 
savaint bien que le [sic] caa-uixy était un ingrediente remarquable pour l'argile. Leurs ancestres l'avaient employé, mais aujourd'hui on en ignore l'usage. Lorsqu'on veut l'utiliser comme la cendre de l'écorce de caraïpé, personne ne peut résister à la terrible démangeaison qu'elle produit sur le corps et si on les malade avec l'argile, les main se couvrent rapidement de blessures. (LINNÉ, 1932, p. 206)

Ceramistas no rio Trombetas relataram a Peter Hilbert que preferem não usá-lo porque "a preparação do barro com cauixy provoca inchações nas mãos e, além disso, causa desarranjos estomacais comer em vasilhames temperados com êsse ingrediente" (p.35). Décadas depois, na comunidade quilombola Boa Vista (também no rio Trombetas) um relato muito semelhante de uma ceramista foi registrado: "Desde o tempo da minha avó eles não gostavam de usar cauixi [...] Coça, fere e eu não me agradei do trabalho com cauixi" (VIDEIRA et al., 2010, p. 65). Em comunidades de Juruti também se mantém uma forte rejeição dessa matéria devido a seus efeitos à pele (PANACHUK, 2016c, p. 40). Esses efeitos não são mencionados apenas no trabalho da argila, mas também conhecidas irritações na pele, no estômago e até cegueira desenvolvidas com o contato ou ingestão de água com espículas (VOLKMERRIBEIRO; BATISTA, 2007).

Apesar da repulsa em relação ao uso do cauixi no baixo Amazonas, as consequências deletérias do uso desse tempero não são mencionadas nas etnografias realizadas no Xingu (LIMA, 1950). Com a adição das esponjas queimadas, todavia, a “argila pura (fria por definição) torna-se 'quente"” (BARCELOS NETO, 2005-2006, p.366), o que pode ser uma referência à coceira. Mesmo com dermatites entre as oleiras Karajá ainda continuava-se a usar o antiplástico, denominado como "cupim d'água" (MACHADO, 1947; LINNÉ, 1932). Como explica Moraes "no Triangulo Mineiro, os oleiros preferem usar espongilito de mistura com argila, apesar da coceira a que sujeitam, devido à boa qualidade do artigo manufaturado." (MORAES, 1944, p. 17). Essa conclusão pode ser estendida a outros contextos: mesmo com as irritações tradições se formaram do uso das esponjas de água doce em cerâmica.

A disseminação do caraipé durante o período colonial na Amazônia, com o consequente abandono do cauixi em diversas áreas, pode resultar de um processo histórico homogeneizante paralelo à expansão dos aldeamentos indígenas, do uso da 
Língua Geral, escravização e a inserção de novos atores e concepções europeias e africanas, conformado novas identidades (ex. GALVÃO, 1954). A análise do material cerâmico datado do século XVIII e XIX na cidade de Santarém, por exemplo, mostrou a continuidade do uso de cauixi, mas com uma marcada predominância do caraipé (MUNIZ; GOMES, 2017). Esse fenômeno teve uma grande dispersão entre indígenas e não indígenas, desde os afluentes meridionais do rio Amazonas até o Orinoco. No médio Orinoco, onde há uma cronologia estabelecida para os estilos cerâmicos desde o período pré-colonial até o século $\mathrm{XX}$, o cauixi foi utilizado até o início do período colonial no estilo Valloide. O uso das espículos, no entanto, foi sendo suprimido até que no século XIX, começou a predominar o chamado estilo Caipito, caracterizado pelo uso de caraipé - um tempero quase sempre precedentes na região durante o período précolonial (SCARAMELLI; SCARAMELLI, 2011).

A diferença em relação à avaliação do cauixi como tempero no caso das oleiras do século XX e XXI no Baixo Amazonas pode resultar de uma nova percepção sobre seus efeitos no corpo ceramista formada ao longo do século XVIII e começo do XIX (ver INGOLD, 2000, 2001). O corpo humano, não se pode esquecer, é um importante instrumento na produção cerâmica, que desenvolve habilidades ao longo das atividades cotidianas (PANACHUK, 2016c). Vários fatores devem ter influído no abandono do cauixi em áreas distintas da Amazônia, mas aspecto sóbrio dos estilos cerâmicos locais durante o período colonial e pós-independência, pode ter esvaziado o sentido da educação do corpo as ardências do cauixi. Talvez, a própria dor corpórea tenha passado a ser percebida de outra maneira com as relações entre as cosmologias cristãs e indígenas. O raciocínio inverso poderia ser aplicado no outro extremo da cronologia regional: a cerâmica tradição Pocó-Açutuba, a aparente continuidade com o complexo Konduri no uso de antiplásticos (CHUMBRE, 2014) pode refletir uma ênfase similar em elementos morfológicos e na percepção e produção do corpo indígena.

\subsection{Conclusão}

A análise sistemática da coleção cerâmica reunida por Peter Hilbert em 1952 e de várias outras confirma, em boa medida, as observações do autor. Se retomarmos a tabela de síntese apresentada no final de A cerâmica arqueológica da região de Oriximiná (Tabelas 1 e 2 do Capítulo 1), algumas de suas considerações a respeito a atributos diagnósticos puderam ser revistas ou ao menos relativizadas. Como já havia 
sido destacado na bibliografia, os elementos antiplásticos presentes na cerâmica Konduri, por exemplo, exibem uma certa variabilidade de tipos, combinações e concentração. As marcas de cestaria, por sua vez, não são uma característica diagnóstica do estilo, mas, ao contrário, são encontradas em vários outros estilos amazônicos. O método da costura, bastante frequente na cerâmica Santarém, está presente no estilo Konduri também apesar de sua baixa frequência. As alças sobre a abertura das vasilhas são também uma característica comum a outros estilos. Os pés modelados são encontrados em outros estilos amazônicos, mas nenhum tem a frequência e a variabilidade observada (ver capítulo 5 para comparação). Em relação à decoração incisa, como indicou Hilbert, os resultados de nossas análises e o levantamento bibliográfico confirmam que a quase totalidade é retilínea. A decoração pintada é rara, porém é mais diversa do que foi identificado pelo autor: há tanto pintura amarela quanto preta, além da vermelha. Além disso, a pintura pode formar padrões específicos e não apenas recobrir apliques. O motivo "cara dupla" é recorrente em toda a área de dispersão do estilo Konduri e um elemento bastante característico. Por fim, é possível afirmar que não existem "vasilhas com bordas duplas" ou "pratos concêntricos" no estilo Konduri, mas a presença de alguns ângulos internos criados a partir da aplicação de filetes que são muito menos pronunciados que os dos pratos Santarém.

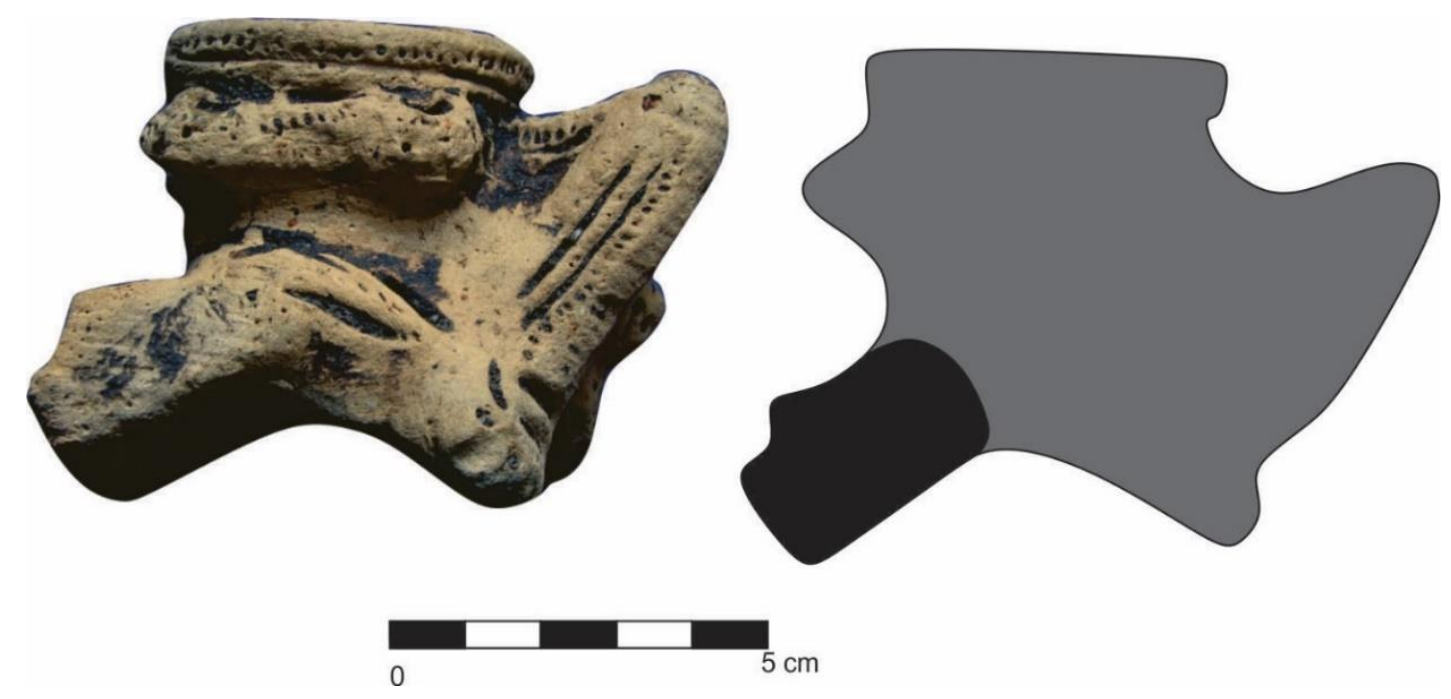

Figura 72. Borda com aplique grosso e maciço aplicado ao lábio. Coleção Idelza/ Lago Sapucuá. 
Um artefato não pode, por princípio, conter toda a variabilidade de um estilo técnico ou visual. Contudo, como mostra Gell (1998), a partir de um exemplar é possível traçar paralelos e compreender uma "unidade macroscópica" compostas de relações tênues e parciais - isto é, um objeto distribuído. Em 2014, ao vistarmos uma das comunidades no lago Sapucuá, encontramos em uma coleção doméstica uma borda fina com um apêndice bastante espesso e maciço no lábio, repleto de incisões, entalhes e modelagens, que nos chamou a atenção. Depois de analisar milhares de fragmentos, essa peça, apesar de ser muito elaborada, não nos parece excepcional ou um outlier. $\mathrm{O}$ estilo Konduri pode ser caracterizado, de maneira sintética, como uma "arquitetura complexa" que sobrecarrega as bordas e bojos finos com grandes apêndices, ângulos e reforços de borda. O vasilhame, mantendo-se sólido e leve com uma "armação" silicosa, adquire simultaneamente resistência mecânica e o que poderíamos chamar de uma plasticidade visual. A peça vista lago Sapucuá evidencia a maestria técnica dos produtores do estilo. Com explica Gell (1992, p. 44 - ênfase no original) " $[\mathrm{t}]$ he power of art objects stems from the technical processes they objectively embody: the technology of enchantment is founded on the enchantment of technology". A distribuição ou reconhecibilidade desse estilo é parte de um "encanto" muito particular da argila, outras matérias e suas propriedades na Amazônia do período pré-colonial tardio. 


\section{Capítulo 5 - Cerâmicas e esferas de interação no Baixo Amazonas}

"Misturam-se as almas nas coisas, misturam-se as coisas nas almas. Misturam-se as vidas, e assim, as pessoas e as coisas misturadas saem cada qual de sua esfera e se misturam: o que é precisamente o contrato e a troca".

(MAUSS, 2003 [1923-1924], p. 212)

As crônicas do século XVI e XVII mostram uma série de referências de redes de interação de longa distância no Baixo e Médio Amazonas, Escudo das Guianas e Orinoco (PORRO, 1996). As etnografias sobre povos indígenas no planalto das Guianas permitem vislumbrar um cenário de continuidade histórica dessas redes de interação, marcadas pela movimentação de pessoas, objetos e informações desde a invasão europeia até o presente (BIORD; ARVELO-JIMENEZ, 1994; GALLOIS, 2005; BARBOSA, 2005). Os autore não deixam de destacar que essas redes devem ter uma origem pré-colonial (DREYFUS, 1992) e que, no início da colonização, estas foram englobando objetos e atores europeus. Resta à arqueologia identificar e relacionar as evidências de interação.

O presente capítulo busca delimitar, caracterizar e discutir os estilos classificados como de "produção não local" encontradas junto ao complexo Konduri. Esses materiais aparecem em baixa frequência nas coleções analisadas, com pasta, tratamento de superfície e decoração característico. Apesar da mistura de materiais de diferentes proveniências nas coleções e as consequências interpretativas desse fato, nas coleções melhor documentadas e organizadas é possível identificar peças que não são coerentes com as características estilísticas Konduri. Propomos, a partir desse material, um modelo ainda bastante hipotético de trocas de objetos, movimentação de pessos e fluxo de conhecimento técnico ao longo do Baixo Amazonas e áreas adjacentes como antecedentes pré-coloniais das redes de interação conhecidas pela etno-história. Esses objetos chamam a atenção para os diferentes processos históricos envolvidos na distribuição e produção de artefatos cerâmicos e que conformam os conjuntos 
identificados no registro arqueológico (GOSSELAIN, 2016, 2017; ANTHONY, 2007;

CALDWELL, 1964; BOOMERT; KROONENBERG， 1977; BOOMERT, 1987; ANTZACK et al., 2017).

\subsection{O problema da "influência Santarém"}

Os conjuntos cerâmicos em baixa frequência não são um interesse recente na arqueologia do Baixo Amazonas. Uma das principais questões levantadas desde as pesquisas de Nimuendajú refere-se à existência de trocas e "influências" entre diferentes áreas evidenciadas pelo material cerâmico. Essas questões tiveram um tratamento específico a partir dos estudos de coleções de museu e seus efeitos podem ser notados nas pesquisas mais recentes. A premissa adotada em muitas dessas pesquisas é que a divergência do "padrão" resultaria, necessariamente, de contatos culturais, desconsiderando a variabilidade interna.
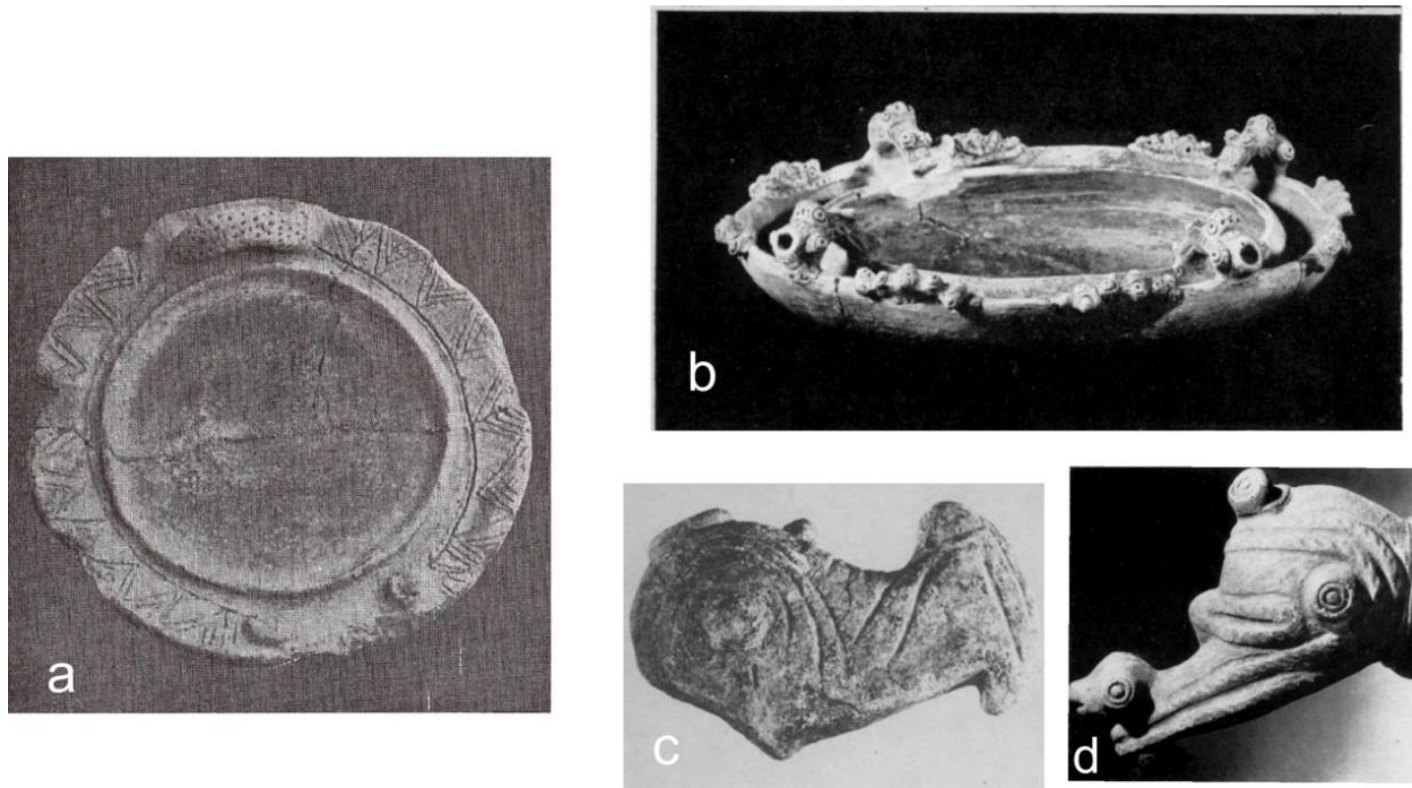

Figura 73. Peças associadas por diferentes autores a uma relação entre os produtores das cerâmicas Konduri e Santarém: a) prato de dupla borda da coleção Frederico Barata mencionado por Hilbert (1955a); b) prato de dupla borda mencionado por Palmatary (1960); c) aplique "cabeça de urubu" encontrado por Nimuendajú no Lago Sapucuá; d) aplique cabeça de urubu da coleção Barbosa de Faria mencionado por Palmatary (1960). Extraído respectivamente de Hilbert (1955a), Palmatary (1960), Nordenskiold (1930) e Palmatary (1960).

Nimuendajú destacou a presença de apêndices em forma de "cabeças de uruburei" do "legítimo estilo dos Tapajós" (HARTMANN, 2000, p. 88; NIMUENDAJÚ, 
2004). O mapa de distribuição dos estilos Tapajó e Konduri no Baixo Amazonas indicou o limite da presença dessas "cabeças de urubu" na Serra de Parintins. O autor sugere em carta que existiria um "mixto [sic] de ambos os estilos (Tapajó e Kondurí)"65, o que seria evidente em "pratos concêntricos". Em outras áreas, ele também marcou a presença de raros fragmentos do estilo Tapajó. Seguindo essa proposta, Palmatary sugeriu a existência de "combinação" e "influência" estilística entre a cerâmica Santarém e Konduri (PALMATARY, 1960, p. 21). A autora também fala de "peças de troca" em estilo Tapajó na coleção de cerâmica do rio Trombetas coletadas pela Comissão Rondon, com os apêndices em forma de cabeça de urubu. Esses elementos foram interpretados como evidências de "associação" ou "integração" tribal. Hilbert (1955a), por sua vez, também teria encontrado "peças de troca" do estilo Santarém na região do rio Trombetas (Figura 73).

Os estudos de coleções de museu na década de 1990 retomaram a categoria "influência". Guapindaia (1993) diferenciou "cerâmica tipicamente Tapajó" e "cerâmica com influência Tapajó”. Gomes (2002, p. 78), por sua vez, criou as categorias "Influência Santarém" e "Influência Konduri" que indicam semelhança "quanto à forma e aos motivos decorativos [Santarém ou Konduri], mas que geralmente diferem na maneira de execução e padrões tecnológicos". Para ambas as autoras esses conjuntos reuniam peças com alguma divergência em termos do padrão esperado tendo em vista a bibliografia disponível e objetos considerados "típicos". Como não havia praticamente nenhuma informação de proveniência na coleção Tapajônica, por exemplo, fragmentos "cauixi em abundância" ou "ponteado em profusão" de morfologias características da cerâmica Santarém foram interpretados como "Influência Konduri”" (GOMES, 2002). Hilbert (1955a, p.35) já havia feito uma oposição semelhante em relação a um prato concêntrico encontrado no sítio Aldeia (Santarém), apesar de não concluir a mesma relação (influência) que as autoras que o sucederam.

A oposição marcada entre a presença ou não de antiplásticos ou técnicas decorativas carrega em si uma premissa "normativa", que desconsidera a variabilidade formal dos estilos Santarém e Konduri. Assim, por exemplo, acabaram sendo vistos como resultado de interação vasos de "cariátides cuja construção e emprego das técnicas decorativas diferem da maior parte dos exemplares analisados" (GOMES, 2002, p. 160

\footnotetext{
${ }^{65}$ Carta de Curt Nimuendajú a Helen Palmatary, 27/10/1939, Arquivo Curt Nimuendajú/ CELÍN/MN.
} 
- Figura 74 ). Em alguma medida também fica subentendido que peças menos elaboradas do estilo Santarém seriam correlacionáveis à cerâmica Konduri. Uma das peças classificadas como "Modo Konduri Incisões Retilíneas” é, por exemplo, um vaso concêntrico cujo "acabamento [é] grosseiro" e apresenta "irregularidade das incisões" (GOMES, 2002, p. 241). Schaan (2012) deixa explícito que considera a decoração Konduri mais "tosca" (coarse) que a da cerâmica Santarém. Guapindaia (1993) considerou uma vasilha Konduri como "influência Tapajó" também devido a um desencontro de informações entre as publicações e o livro tombo da instituição.

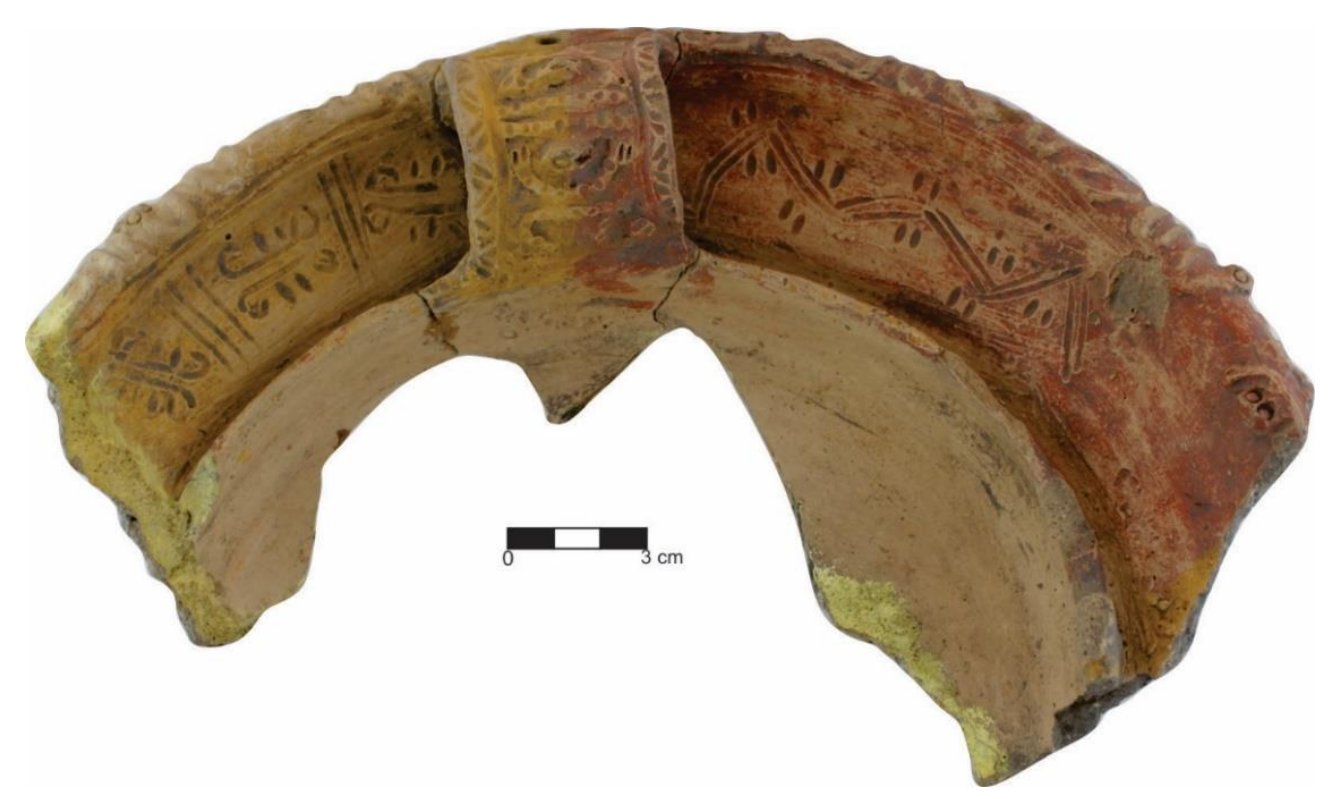

Figura 74. Fragmento de prato concêntrico classificado como parte do "Modo Konduri Incisões Retilíneas" e considerado um marcador de "influências" Santarém sobre a cerâmica Konduri em Gomes (2002). Coleção Tapajônica/MAE-USP.

As pesquisas sistemáticas no Baixo Amazonas ainda são muito recentes e incorporaram o legado dos estudos de coleção do século passado. Em Parauá, a cerca de $100 \mathrm{~km}$ da cidade de Santarém, foi identificado um estilo cerâmico particular tendo sido encontrado um fragmento de prato concêntrico ou de bordas duplas foi encontrado (GOMES, 2008). Gomes relaciona esse objeto às cerâmicas Santarém e Konduri e o interpreta como indício de "contatos e trocas" com os produtores daqueles estilos. Em um estudo da cerâmica Santarém encontrada em sítios do município de Belterra, Schaan 
(2016:33) destaca que "[i]nfluence of Konduri style was noticed at four sites (Barreto, Iruçanga, Murarema and São Martinho), in the form of profuse punctation and fish bone incisions". O pressuposto de que "ponteado em profusão" está, necessariamente, vinculado ao estilo Konduri permaneceu nessas análises, apesar das mudanças teóricas e metodológicas recentes.

A consulta das peças mencionadas como "influências" na coleção Frederico Barata (MPEG) e Tapajônica (MAE) e sua contraposição aos materiais conhecidos em coleções com melhor documentação ou obtidos em escavações sistemáticas levam a crer que muitas peças consideradas "influências" resultam da própria variabilidade interna dos estilos - que é muito complexa - ou resulta da mistura de peças Konduri e sua perda de informação contextual. Os pratos concêntricos, por exemplo, não são encontrados em contextos Konduri ao mesmo tempo que existem vasilhas do estilo Santarém com alta concentração de cauixi. Parte dos indicadores de troca e interações identificadas nas coleções é produto do processo de formação das coleções museológicas.

Se a categoria de "influência" é problemática, as pesquisas no Baixo Amazonas mostram que existem conjuntos minoritários de materiais resultantes de trocas e interações pré-coloniais. Um levantamento de coleções de museu e bibliografia de pesquisas sistemáticas evidenciou que, as cabeças de urubu e outros fragmentos do estilo Santarém são, de fato, encontrados em contextos Konduri (ALVES, 2018). É necessário tornar mais explícitas as premissas em torno da explicação das semelhanças tecnológicas em sua relação com diferentes processos históricos. Esse é um campo marcado por ambiguidades e há uma grande dificuldade em distinguir indicadores de contatos e empréstimos daqueles vinculados a ancestralidade comum.

\subsection{Diferenciando processos históricos}

Culturas arqueológicas foram construídas e contrastadas a partir de listas de traços na arqueologia histórico-cultural, como o próprio estilo Konduri. A partir da distribuição desses mesmos traços foram criados mapas de dispersão, rotas de difusão e migração A presença de "traços" ou "influências estilísticas" em materiais locais seria o indicador da difusão de normas. A existência de um objeto com características destoantes dentro de um conjunto, por sua vez, era o resultado de trocas com outros grupos. As migrações e invasões se tornariam visíveis com a "substituição" de um 
conjunto artefatual por outro ou a "mistura" entre características de diferentes tradições. As mudanças em uma dado contexto eram explicadas por fenômenos externos aos grupos. Esses mecanismos de explicação se repetem na arqueologia americanista e não é diferente na arqueologia amazônica. O interesse de Palmatary e Hilbert por "peças de troca" faz parte desse ambiente teórico. Meggers e Evans (1957) e Evans e Meggers (1960) na descrição de conjuntos cerâmicos amazônicos, quase sempre, enfatizaram a presença de "fragmentos de troca” (ver GLÓRIA, 2017).

A aplicação desses conceitos foi criticada por Binford (1965) e a arqueologia processual, de modo geral. No cerne da crítica está uma ênfase na variabilidade interna dos conjuntos artefatuais. Os estudos histórico-culturais tenderam a tratar de modo genérico os artefatos em termos de semelhanças e diferenças. Assim, materiais com características distintos, interpretados como resultados de influências externas no modelo histórico-cultural, poderiam ser resultados de variações nos modos de subsistência e funcionalidade dentro de um mesmo "sistema". O debate sobre o Musteriense entre Bordes e Binford evidencia o contraste entre premissas e suas consequências na interpretação do registro arqueológico (BINFORD, BINFORD, 1966). Ao fundo há uma divergência entre compreender cultura como o compartilhamento de normas e outro como meio extra-somático de adaptação. Binford também criticou a ideia de "fluxos de elementos culturais", uma vez que uma cultura seria realizada na prática das interações sociais e não em regras partilhadas. A explicações históricas, difusionistas e migracionistas não se enquadraram no modelo nomotético proposto pela Nova Arqueologia (TRIGGER, 2008).

Ao mesmo tempo em que críticas foram tecidas aos modelos explicativos da arqueologia histórico-cultural, distribuição, troca ou comércio de matérias primas e artefatos acabados foi um tema de especial interesse na arqueologia processual, em contraste com as noções difusão e migração. Esse impulso, em parte, foi promovido pela expansão do uso de técnicas físico-químicas (RENFREW,1975; EARLE, ERICSSON, 1977). O conceito de "esfera de interação" foi desenvolvido por Caldwell (1964) para caracterizar interações regionais que incluíam troca de materiais via "instituições" específicas, perpassando os conceitos tradicionais de cultura arqueológica. A noção de peer polity interaction, em continuidade com a noção de esfera de interação, produziu um modelo que conceptualiza a mudança no qual as 
relações internas e externas de um grupo não são contraditórias, mas propiciam a complexificação social (RENFREW, 1986). Essas discussões têm se avolumado a partir da aplicação de métodos de análise de rede a arqueologia (ex. MOL, 2014).

As críticas aos modelos histórico-culturais, desde a Nova Arqueologia até o presente mostraram os limites da concepção de culturas como fechadas em si mesmas, como "bolas de bilhar", cujos contatos resultariam literalmente em "intrusões" em um corpo homogêneo e coeso. A partir da década de 1970, pesquisas etnoarqueológicas e arqueológicas deixaram claro que as interações entre os grupos, formação de identidades e fronteiras sociais são processos complexos que podem ou não resultar na adoção de práticas de outros grupos (HODDER, 1982; JONES, 1997). A materialização das identidades reúne diferentes fatores não existindo uma relação necessária entre estilos e identidades (GOSSELAIN, 2000, 2017).

O uso irrestrito dos conceitos de troca e difusão na primeira metade do século XX gerou grande descrédito dentro da disciplina até o presente. A noção de difusão, por exemplo, ficou muito associada à limitação dos seres humanos em termos de sua capacidade de inovação e, em alguns casos, justificando atitudes racistas em relação a povos originários de áreas colonizadas (TRIGGER, 2008). Não é preciso, entretanto, abandonar o estudo das interações e os conceitos de troca e difusão, da mesma maneira o conceito de migração não pode ser simplesmente abandonado (ANTHONY, 1990, 2007). As categorias analíticas histórico-culturais sinalizam para temas centrais da pesquisa arqueológica, mas ao invés de serem considerados como elementos explicativos, devem ser entendidos como descritivas. Transmissão de conhecimento e relações comerciais são fenômenos ubíquos tanto em fontes históricas quanto etnográficas. O desenvolvimento dos estudos de etnogênese, por exemplo, mostram como as relações entre grupos com tradições culturais distintas é um elemento importante em diversos contextos da história humana, desde a extrema violência do colonialismo moderno às interações entre coletivos humanos em períodos mais recuados (HORNBORG, HILL, 2011).

Abordagens distintas foram construídas para tratar semelhanças e diferenças tecnológicas e sua relação com interações sociais, nas últimas décadas em arqueologia, antropologia e outras ciências. Schiffer e Skibo (1987), por exemplo, construíram um 
modelo comportamental baseado na interação com a matéria-prima capaz de explicar mudanças diacrônicas. Não são discutidos, entretanto, neste e em outros modelos processos de empréstimos, ou a continuidade de tradições na longa duração. Dessa maneira, a base conceitual desse e outros modelos não suplantam os conceitos desenvolvidos dentro da tradição boasiana e dos Kulturkreise. Há, na verdade, um desenvolvimento conceitual paralelo, indicando ênfase sem a invalidação necessária de um pelos outros - inclusive permitindo combiná-los (SKIBO, SCHIFFER, 2008). Alguns dos conceitos desenvolvidos pela arqueologia histórico-cultural, para além das críticas ainda mantém sua capacidade de estruturar analiticamente relações históricas de grande profundidade temporal e também alguns aspectos das relações de contato (LYMAN et al., 1997; BALÉE, 2000; KRISTIANSEN, LARSSON, 2005; ROBERTS, LINDEN, 2011). Entre esses conceitos estão processos elementares, destacados desde o século XVIII pela linguística histórica (GOSSELAIN, 2000; ANTHONY, 2007; O’BRIEN et al., 2001; ROUX, 2019).

Em comparações regionais e macrorregionais, em diferentes escalas temporais, as semelhanças dos conjuntos artefatuais podem resultar de, pelo menos, quatro fenômenos distintos:

1. Convergência (invenção independente/analogia)

2. Ancestralidade comum (continuidade histórica/ homologia)

3. Circulação de conhecimento (difusão/ empréstimo)

4. Circulação de objetos (troca)

É preciso sempre considerar todas essas possibilidades valendo-se das evidências encontradas em cada contexto arqueológico e pressupondo a variabilidade interna nos conjuntos artefatuais. Nenhum dos processos é uma explicação em si, uma vez que é preciso ainda encontrar o porquê ou como estes ocorreram. Além disso, em muitos casos, é possível haver a combinação de vários processos (GOSSELAIN, 1998).

A construção de hipóteses para explicar as camadas sincrônicas e diacrônicas presentes em tradições tecnológicas é um tema majoritariamente implícito nas análises arqueológicas. As convergências não são explicitamente identificadas, mas dada uma distância espacial e/ou temporal é excluída a possibilidade de uma relação histórica - ao contrário das propostas hiperdifusionistas. Rye (1981) usa o termo "padrão tecnológico" 
para descrever o desenvolvimento paralelo de tradições tecnológicas muito parecidas, sem relações históricas. Em diferentes lugares e períodos, tecnologias cerâmicas, agricultura e escrita foram desenvolvidas. Por vezes, essas convergências são relacionadas às interações com o ambiente, como a disponibilidade ou falta de alguma matéria-prima. Se há uma semelhança com maior proximidade espaço-temporal, em relação a atributos como morfologia, padrões gráficos e técnicas decorativas é pressuposta uma relação filética. Ao longo de gerações, conhecimentos são transmitidos, modificados, persistindo alguns elementos ao longo do tempo. As unidades arqueológicas integrativas como "horizonte" e tradição" são indicadores de continuidade histórica, de uma maneira similar a "família" linguística, apesar de esta ter uma aplicação muito menos problemática que sua análoga em arqueologia.

A transmissão do conhecimento técnico pode acontecer baseada no parentesco e núcleos familiares (intergeracional), mas também se dá a partir da interação com outros oleiros/as de uma mesma localidade ou de várias áreas distintas, como acontece nos mercados na África Sub-Saariana (GOSSELAIN, 2016). Gosselain defende que as diferentes etapas das cadeias operatórias, seguindo Arnold $(1981,1985)$ variam e também são influenciadas por empréstimos de acordo com ritmos diferentes, dada a sua maior ou menor visibilidade ${ }^{66}$. Esse princípio também não é plenamente uma novidade, uma vez que outros estudos já pressupunham uma taxa de mudança entre "técnica" e “estilo” (decoração) (SHEPARD, 1956, p. 314-15; ver RYE, 1981, p. 5). Lathrap e Brochado (1982) seguiram um princípio semelhante, dando prioridade para morfologia e padrões gráficos em as relação a técnicas decorativas (incisão, pintura, ponteado). A linguística histórica parte do mesmo princípio, mostrando que existem conjuntos lexicais com variações distintas. Balée (2000), por exemplo, comenta que os termos em relação a plantas domesticadas divergem menos do que o de plantas não domesticadas entre falantes de língua Tupi.

Excluídas as possibilidades de convergência e relação de ancestralidade resta a produção não local e difusão. Há dois elementos normalmente empregados para identificar peças obtidas por trocas (SHEPARD, 1956; RICE, 1987; ORTON; HUGHES, 2013; RENFREW, 1975):

\footnotetext{
66 Em textos mais recentes Gosselain $(2017,2018)$ criticou esses postulados e defende que essa precedência nem sempre pode ocorrer, dependendo dos modos que se dão as interações sociais.
} 
1. Existência de um conjunto minoritário que apresenta características de um estilo conhecido em abundância em outra área;

2. Existência de um conjunto com características muito distintas do padrão predominante, especialmente em relação à decoração e morfologia.

As trocas não podem ser comprovadas apenas a partir dos atributos estilísticos, uma vez que existem diferentes permutações de imitação ou combinação de estilos (pasta, técnica, morfologia, motivo gráfico), algumas não detectáveis a olho nu. Dessa maneira, a produção em outra área só pode ser plenamente confirmada pela presença de documentação histórica, ou com a aplicação de métodos mineralógicos ou físicoquímicos.

Em termos de interpretação do registro arqueológico, difusão e "influência" são conceitos bastante vagos, especialmente em contextos sem informações escritas. Meggers e Evans (1969, p. 20) admite que "there are no simple rules for differentiating between diffusion and independent invention". Uma mesma técnica pode ter se desenvolvido como parte de uma mesma trajetória histórica (homologia), difundindo-se, ou ser apenas uma convergência. Diferente das trocas, o empréstimo de uma técnica não pode ser demonstrada por meio de análises físicas ou mineralógicas. Apesar das críticas à noção de difusão, há um aspecto interessante a ser destacado, ou seja, que a transmissão de conhecimentos entre pessoas, com tradições diferentes ainda é um fenômeno importante a ser mapeado e explicitado (GELBERT, 1999; ROUX, 2015, 2019). Outras denominações e nuances também podem ser utilizadas para compreender a noção de difusão, como, por exemplo, "emulação" ou "etnogênse", se não pressupomos que o conceito se refere apenas um processo mecânico de reprodução de um motivo ou forma.

$\mathrm{Na}$ arqueologia amazônica, os processos históricos de circulação de objetos, empréstimos técnicos e ancestralidade comum são frequentemente acionados para explicar a variabilidade cerâmica, apesar de quase sempre aparecerem de maneira implícita. O modo mecânico como se desenvolveram as classificações cerâmicas na arqueologia amazônica com o PRONAPA e PRONAPABA e as críticas subsequentes, como as de Machado (1991) e Schaan (2007), não permitiram ainda a rediscussão dos processos envolvidos na formação e transmissão de estilos cerâmicos. Isso resultou em uma dificuldade para tratar os processos históricos em escalas temporais e espaciais. As 
fases e tradições não foram criadas apenas para serem rótulos multiplicados ao infinito ou categorias estéreis e monolíticas, mas ferramentas heurísticas capazes de indicar ancestralidade comum de maneira análoga à empregada pela linguística histórica (WILLEY, PHILIPPS, 1958; ROUSE, 1955). É preciso retomar o sentido original desses conceitos que já se mostraram de grande importância na arqueologia amazônica (LATHRAP, 1970; BROCHADO, LATHRAP, 1982; NEVES, 2010), alimentando-os com as discussões sobre a complexidade da construção das identidades culturais e a noção de "agregado" de múltiplos eventos históricos na composição de estilos tecnológicos (GOSSELAIN, 2000; HORNBORG, HILL, 2011). Isso nos permitirá qualificar melhor as semelhanças e diferenças que observamos entre complexos cerâmicos, permitindo-nos construir modelos para explicar os processos históricos que compuseram o mosaico cultural das terras baixas da América do Sul e suas trajetórias específicas (CORRÊA, 2014; SILVA, NOELLI, 2017). Como as pesquisas iniciais mostram, os contextos do Baixo Amazonas são de especial importância para discutir e diferenciar ancestralidade comum, difusão e trocas.

\subsection{Objetos trocados}

A partir da avaliação em relação dos atributos mais frequentes na cerâmica Konduri foi possível identificar três conjuntos com baixa frequência nas amostras analisadas. Esses conjuntos são relativamente padronizados e, em dois casos, apresentam as mesmas características de estilos encontrados em outras áreas. A documentação das coleções mostra que os conjuntos minoritários estavam associados à cerâmica Konduri no momento da coleta. Isso também confirmado pelas pesquisas sistemáticas recentes a partir das quais alguns desses artefatos foram exumados nas mesmas camadas estratigráficas (GUAPINDAIA, 2008; PANACHUK, 2016; SCIENTIA, 2003, 2008; JÁCOME, 2017). Os estilos não locais são compostos por fragmentos da cerâmica Santarém, Paurá e "cerâmica temperada com areia" ou Espinha de Peixe. Um quarto conjunto com a denominação genérica "pasta laranja" foi incluído como possivelmente relacionado à recepção de materiais produzidos em outras áreas talvez, vinculado ao material Santarém. Outros raros exemplares ainda podem ser provenientes de contextos Guarita ou com cerâmica Polícroma, como o rio Urubu (STAMPANONI, 2016). 


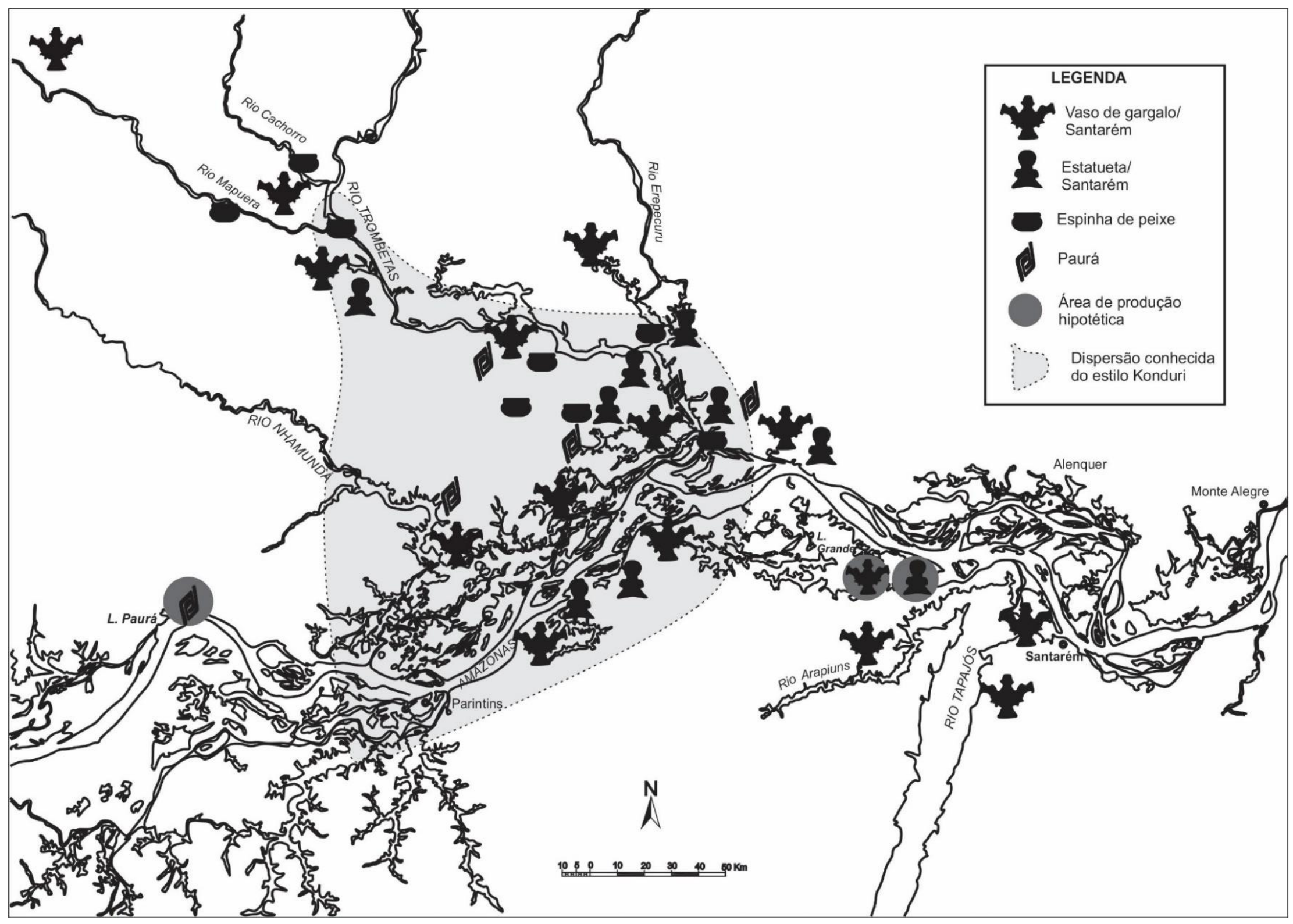




\subsubsection{Estilo Santarém}

Entre os conjuntos identificados como de produção não local na coleções com cerâmica Konduri, o material relacionável ao estilo Santarém é o mais numeroso e o mais disperso geograficamente. Em quase todas as áreas em que se encontrou cerâmica Konduri, há alguma peça deste estilo (Mapa 7).Apesar da bibliografia não enfatizar a presença desses materiais ou sua relação com o estilo Santarém é notável a sua presença constante nas ilustrações das publicações ou relatórios de pesquisa (ex. GUAPINDAIA, 2008; PANACHUK, 2016). No caso da coleção Peter Hilbert, alguns desses exemplares não foram mencionados em A cerâmcia arqueológia da região de Oriximiná, mas puderam ser facilmente identificados durante o estudo da coleção.

O material do estilo Santarém associado a cerâmica Konduri pode ser agrupado entre: (1) vasos de gargalo, (2) estatuetas antropomorfas femininas e (3) morfologias variadas. Como característica comum a maior parte dessas peças é possível destacar: média ou alta concentração de caco moído (às vezes associado a cauixi), face externa de cor alaranjada/amarelada, incisões largas e rasas, além de polimento das superfícies. A morfologia das peças e sua iconografia são bastante diagnósticas, como já havia notado Nimuendajú (2004). Esses atributos diferenciam tais peças da cerâmica Konduri e permitem inferir sua produção em outra área.

\subsubsection{Vasos de gargalo}

Os vasos de gargalo são um dos tipos de vasilha mais características do estilo Santarém. Esses vasos de estrutura tripartida (gargalo, corpo e base anelar) exibem gargalos constritos e pares de apêndices aplicados ao bojo em eixos de simetria perpendiculares (Figura 75) (ALVES, 2016, 2018). Realizamos um intenso levantamento de vasos de gargalo do estilo Santarém em museus brasileiros e na bibliografia, identificando 49 exemplares inteiros e semi-inteiros. A partir disso, foi possível construir referências morfológicas para identificação de partes dos vasos de gargalo a partir de fragmentos, como sugere Gell (1998) com a noção de "estilo em transformação". A padronização iconográfica e morfológica permitiu facilmente relacionar fragmentos a partes específicas dos vasos de gargalo. A consulta à bibliografia reafirmou a ubiquidade desses materiais nas pesquisas mais recentes na área de dispersão deste estilo (BRANDT, 1996; SCIENTIA, 2003, 2013; GUAPINDAIA, 2008; JÁCOME, 2017). 
A maioria dos vasos gargalo inteiros conhecidos é proveniente do sítio Aldeia, localizado no atual centro urbano de Santarém (Figura 76). Essas peças exibem superfícies polidas, algumas vezes com vestígios de brunidura. A coloração da face externa tende a ser amarela e o núcleo escuro (tipo 3 ou 5). A técnica aplicada em sua confecção é predominantemente a modelagem, podendo ter sido utilizada o roletado para construir parte ou a totalidade do bojo ${ }^{67}$. Outras partes são modeladas separadamente e depois afixadas umas nas outras. Os antiplásticos presentes nas pastas desses vasos são, como ocorre predominantemente no estilo Santarém, cauixi, caco moído ou a combinação de ambos. Os vasos são pequenos medindo entre 10,0 e 30,0 $\mathrm{cm}$ de altura e capacidade volumétrica entre 140 a $670 \mathrm{ml}$. O diâmetro dos gargalo mede entre 1,8 e $3,0 \mathrm{~cm}$, sendo a média e a mediana $2,1 \mathrm{~cm}$.
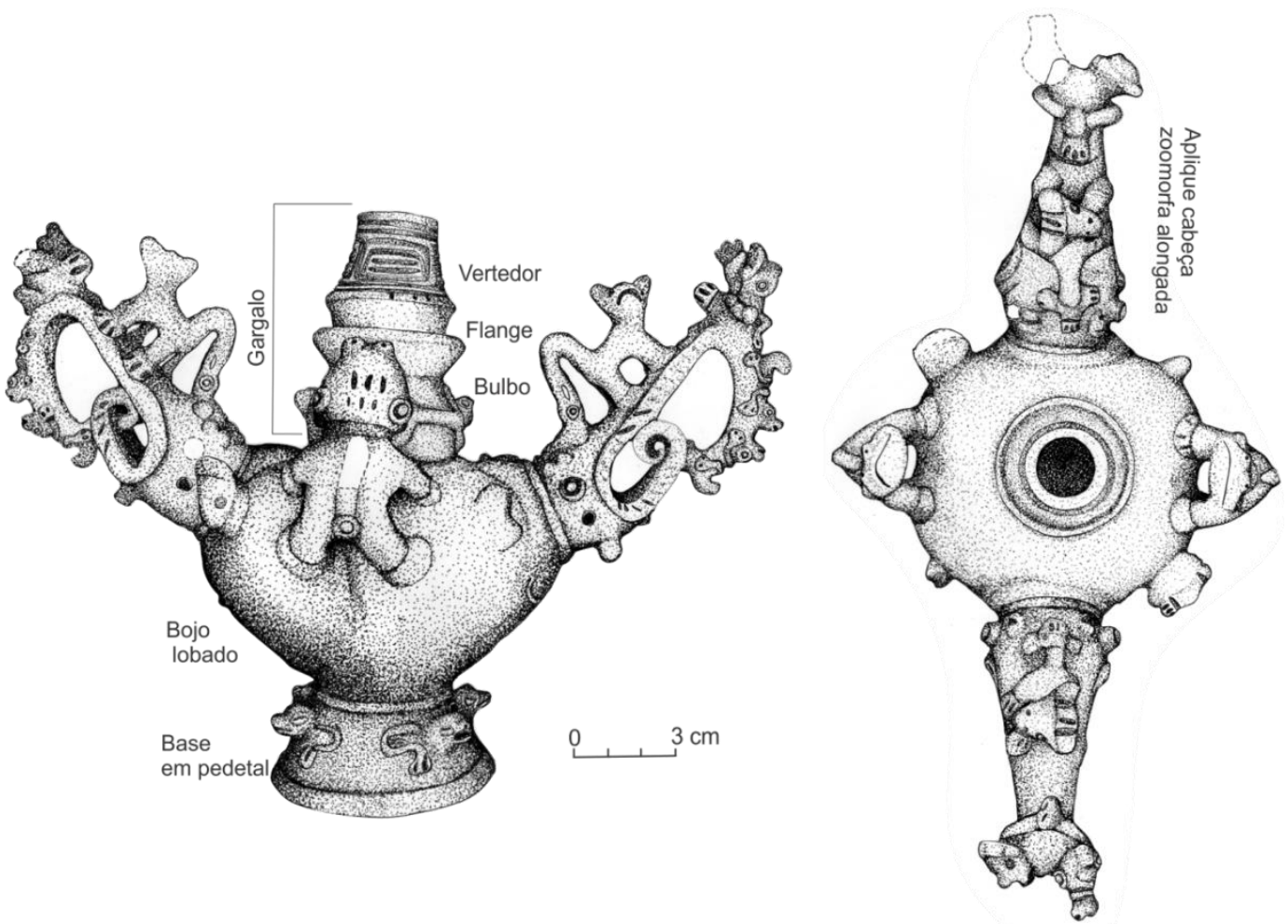

Figura 75. Partes estruturais dos vasos de gargalo. coleção Valentim Bouças, Museu Nacional/Universidade Federal do Rio de Janeiro, Rio de Janeiro. Extraído de Alves, 2018.

\footnotetext{
${ }^{67}$ Em parceria com o professor André Strauss e o Dr. Rodrigo Oliveira estamos realizando tomografias dos vasos de gargalo para a melhor compreensão de suas técnicas de produção.
} 


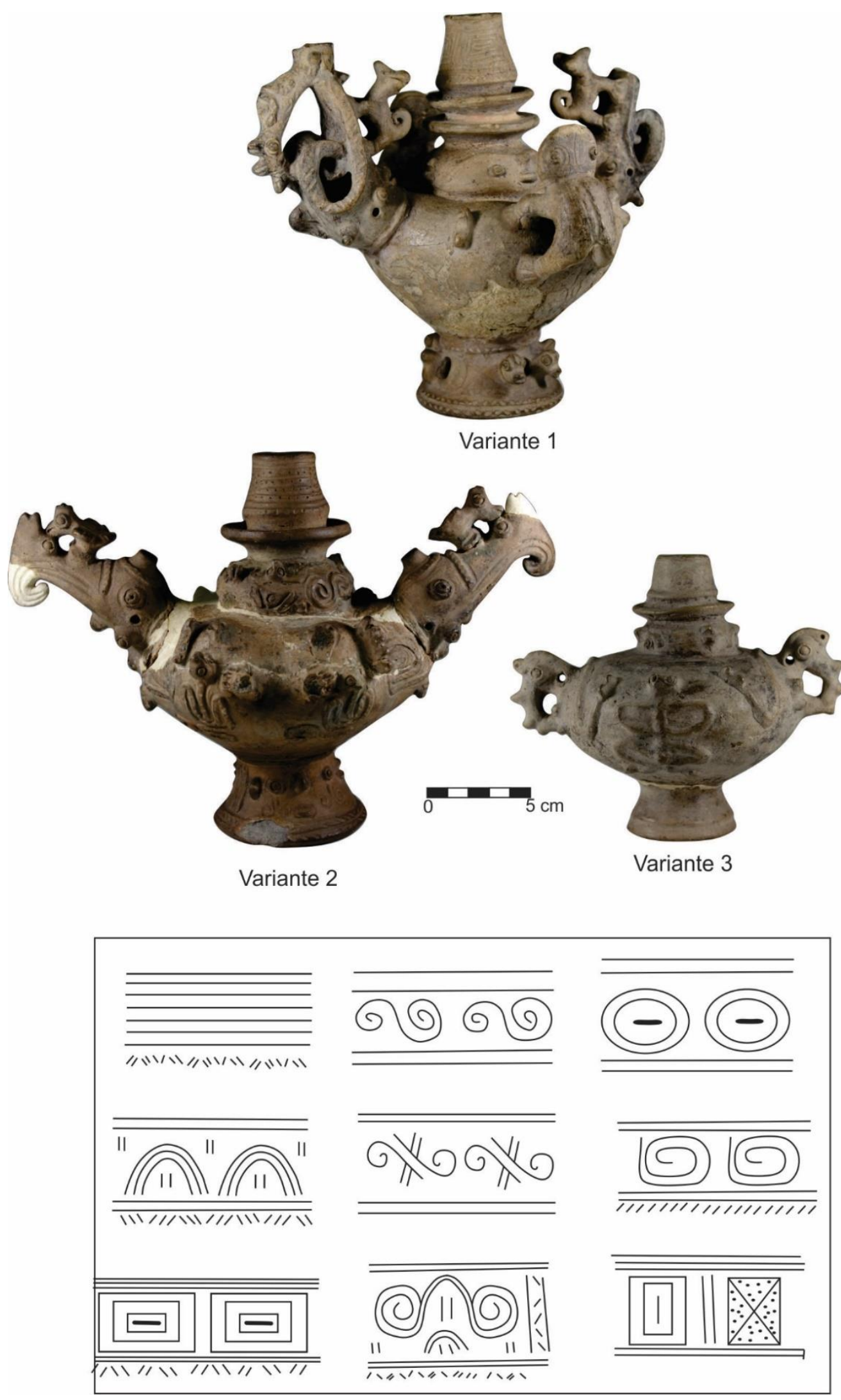

Figura 76. Diversidade morfológica, de apêndices e motivos incisos em vasos de gargalo Santarém. Coleção Frederico Barata (MPEG). Motivos incisos de diferentes coleções (Adaptado de Alves, 2016). 
Em termos iconográficos, os vasos de gargalo Santarém são um "microcosmos" composto por grande diversidade de figuras (Figura 76) . O vertedor exibe um friso inciso delimitado por linhas e composto por um padrão central. Abaixo do flange, quase sempre há um "bulbo" arredondado, no qual é apresentado um padrão de cara antropomorfa, pequenas cobras e lagartos ou ainda filetes aplicados formando sigmóides. O bojo, com seis "gomos" ou globular, apresenta apliques de cabeças zoomorfas alongadas e quadrúpedes, que se destacam no conjunto. Em termos figurativos, os primeiros possuem quatro formas variantes enquanto os quadrúpedes são quase invariáveis. As cabeças zoomorfas apresentam no bojo filetes aplicados que compõem um corpo de ave, com asas, patas e, ás vezes, caudas. Em sua forma mais frequente e também elaborada as cabeças alongadas exibem pequenas modelagens de aves e quadrúpedes (cachorros do mato). As outras variantes, quando apresentam esses elementos, sua frequência na mesma peça é menor. Ao longo do bojo também aparecem pequenos apliques zoomorfos. Os pedestais, por sua vez, exibem caras antropomorfas, apliques zoomorfos, padrões incisos ou mesmo nenhuma decoração. A complexidade iconográfica dos vasos contrasta com suas dimensões reduzidas.

Os vasos de gargalo são singulares em relação a outras morfologias da cerâmica Santarém devido a predominância de corpo lobado e a presença de "bulbo" no gargalo. Por outro lado, são frequentes vasilhas com gargalos e pedestais entre o vasilhame mais elaborado (PALMATARY, 1960; GUAPINDAIA, 1993; GOMES, 2002) e alguns apresentam semelhanças morfológicas com estes - como o bojo globular. Os antiplásticos utilizados e a brunidura também são relativamente frequentes na cerâmica Santarém (GUAPINDAIA, 1993; GOMES, 2002; SCHAAN, 2015, 2016). Em relação aos padrões gráficos e figurações, há também semelhanças com outras vasilhas do mesmo estilo. São frequentes frisos próximos a borda com os mesmos padrões ou padrões muito parecidos, como no caso dos vasos de cariátides, vasos globulares e alguns outros. Figurações de pequenas aves e caras antropomorfas semelhantes também aparecem em outras vasilhas. Em suma, há vários elementos para considerar os vasos de gargalo como perfeitamente "coerente" como o estilo Santarém.

Nas coleções com cerâmica Konduri são encontrados apêndices "cabeça de urubu" e quadrúpedes batraquiformes, gargalos constritos com flanges, paredes com gomos e também pedestais. Esses fragmentos, apesar de não permitirem uma 
remontagem direta são claramente relacionados à morfologia dos vasos de gargalo (Figura 77). Isso é confirmado pela existência de três vasos inteiros ou semi-inteiros com as mesmas características similares identificadas na região do rio Trombetas. Um desses vasos foi coletado no começo do século XX no rio Acapu, afluente do rio Erepecuru ou Cuminá (NIMUENDAJÚ, 2004) (Figura 78 b). Outro desses vasos foi encontrado no alto curso do rio Mapuera, na aldeia indígena Tamiúru (Terra Indígena Trombetas-Mapuera) e foi fotografado durante a realização de campo do Projeto Norte Amazônico (Figura 78 a). O último desses vasos não tem proveniência precisa, mas pertence à coleção Protásio Frikel no Museu do Índio (Lagoa Seca, PB), e pode ter sido encontrado entre os rios Trombetas e Nhamundá, uma vez que a maioria das peças dessa foi coletada nessa região (Figura 78-c).

Os fragmentos e os vasos inteiros indicam uma estrutura tripartida igual a dos vasos encontrados em Santarém, sendo também recorrente o polimento das superfícies, núcleo escuro (tipo 3 ou 5), o uso da combinação de alta e média concentração de chamote, associado ou não ao cauixi (Figura 79) (Gráfico 26). Além disso, é notável a presença de incisões relativamente largas e rasas (em U), como as encontradas na cerâmica Santarém.

Observando os detalhes, todavia, fica claro que há elementos particulares aos vasos encontrados na área de dispersão Konduri (Figuras 77 e 78):

1. Menor diversidade iconográfica que a encontrada nos vasos de gargalo do baixo Tapajós (ex. apenas cabeça de urubu)

2. Os frisos nos gargalos são quase sempre compostos somente de linhas paralelas (Figura 77 a-d; Figura 80 a);

3. Os apêndices em forma de cabeças alongadas representam apenas a variante cabeça de urubu-rei (Figura 77 n-q); 


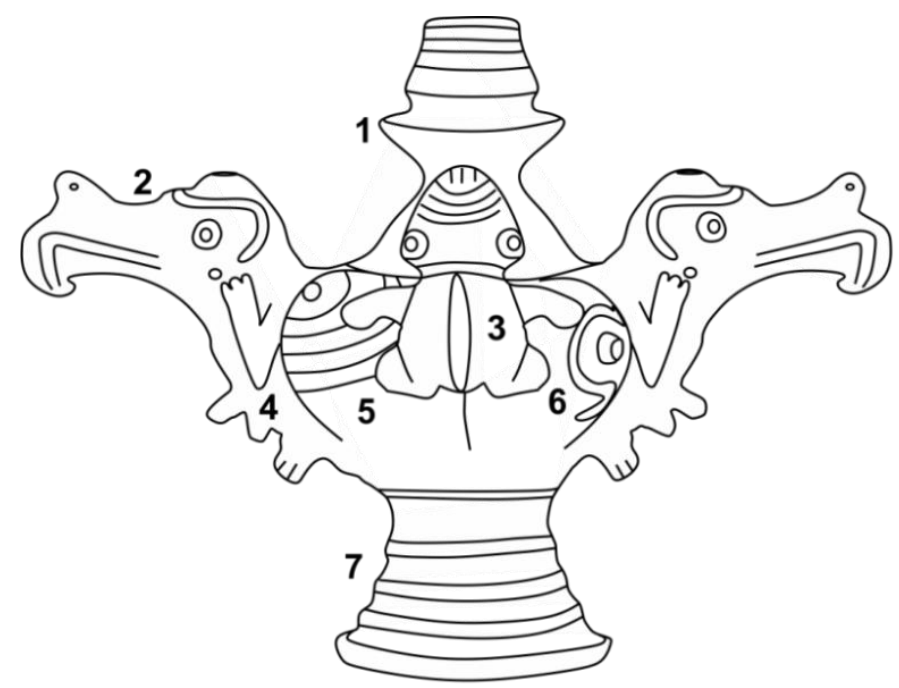

\section{Gargalo}

2 Aplique 'cabeça de urubu'

3 Aplique 'sapo'

4 Parede com corpo aviforme

5 Parede com incisões circulares

6 Parede com 'ômega' aplicado

7 Base com filetes aplicados

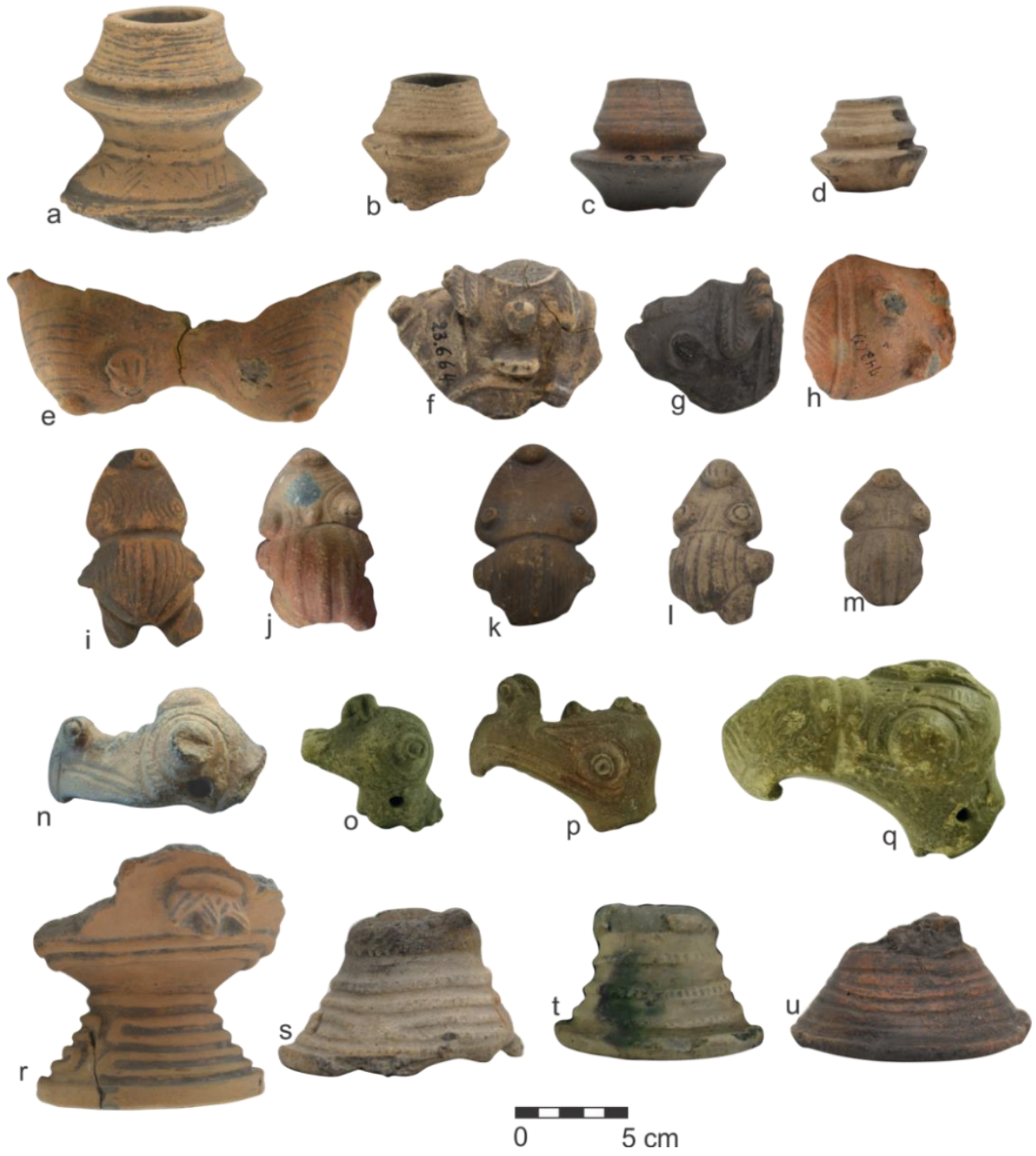

Figura 77. Partes dos vasos de gargalo. Proveniência: sem informação (a, e, r), lago Sapucuá (b,j), Sucurijú (c), Sacuri (d, f, g), Cocal (h, u), Conuri (k), Santa Maria (k-m, s), Porto Trombetas (o), Aimim (p-q), coleções Tapajônica (a,e, r), Peter Hilbert (b,h,i), Aricy Curvello (o-q), Rosilane/Conuri (j, n) e Barbosa de Faria/Comissão Rondon (c, d, f, k-m, s-u). 

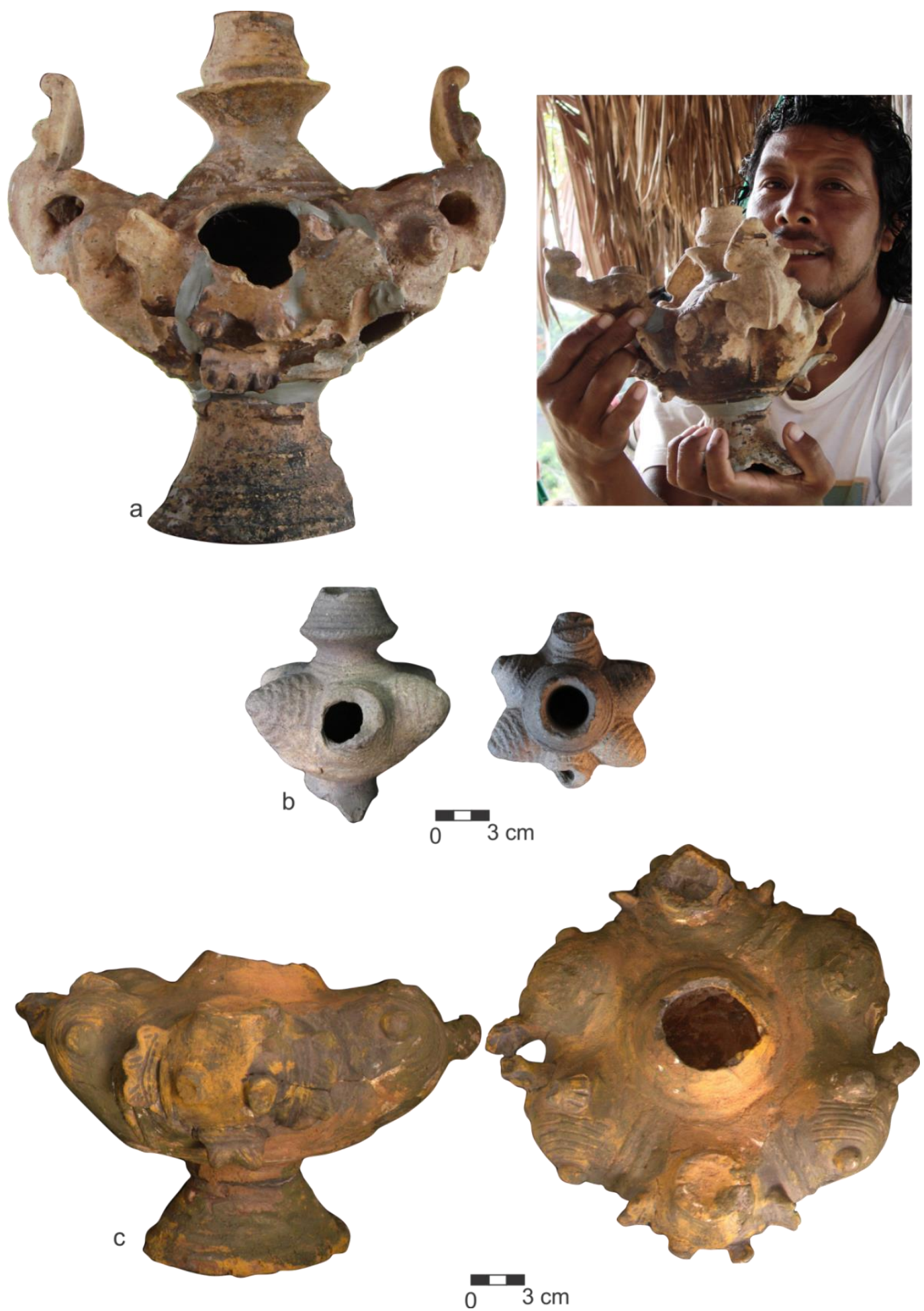

Figura 78. Vasos de gargalo com as mesmas características dos fragmentos identificados nas coleções com cerâmica Konduri: a- peça coletada por indígenas no rio Mapuera (aldeia Tamiúru)/Foto Rogério Tobias. B- vaso de gargalo coletado no rio Acaupu/Coleção Curt Nimuendajú (MPEG); c- vaso sem proveniência da coleção Protásio Frikel (Museu do Índio, Lagoa Seca/PB). Foto: Ana Carolina Cunha. 

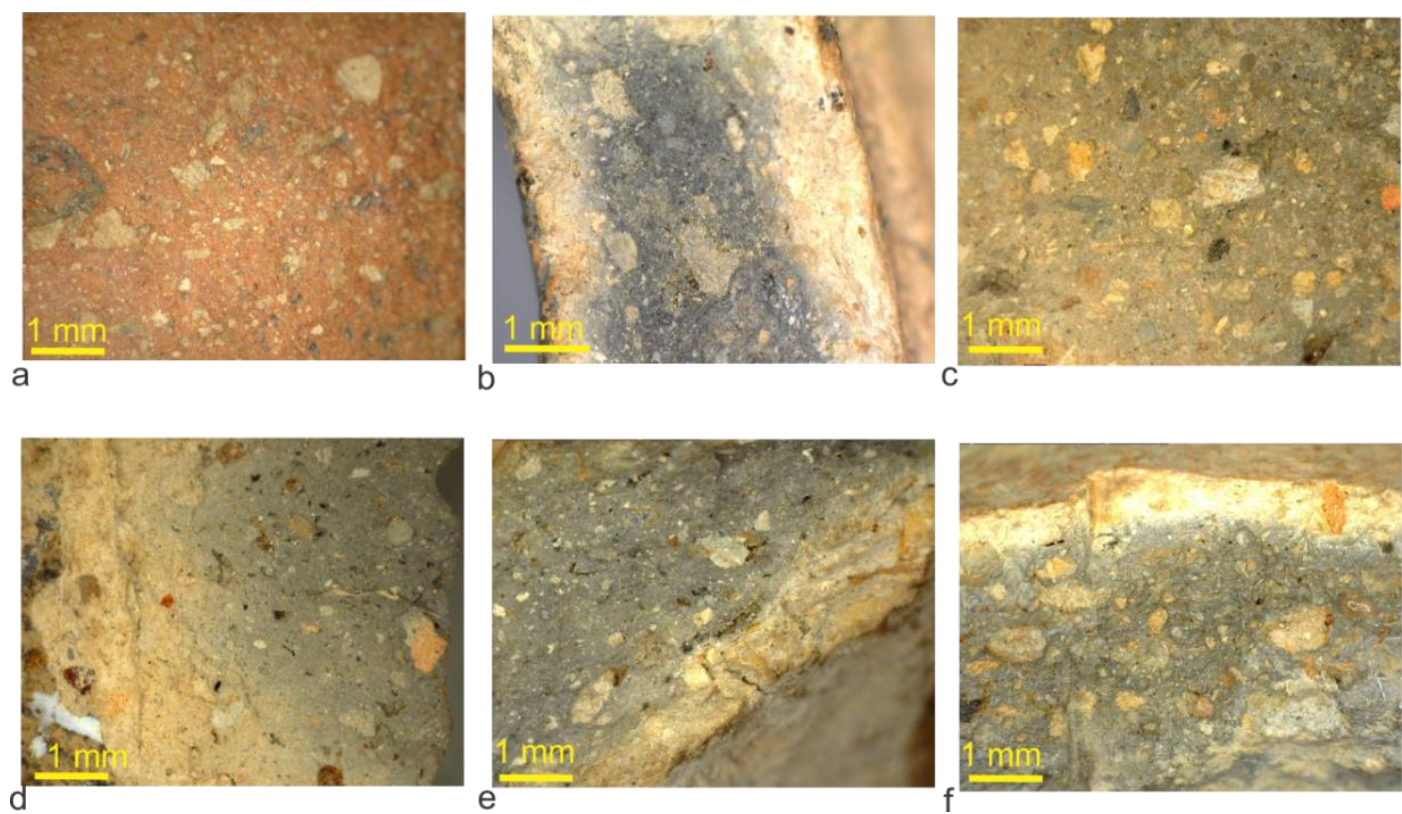

Figura 79. Pasta de vasos de gargalo com alta concentração de caco moído e predominância de núcleos escuros. Fragmentos das coleções Peter Hilbert (a-b), Aricy Curvello (c-e) e Projeto Norte Amazônico (f).

Os vasos de gargalo associados à cerâmica Konduri não são meras simplificações do estilo Santarém. Os padrões gráficos desenvolvidos no bojo são distintos daqueles encontrados na cerâmica Santarém. Há doi s tipos de motivos gráficos aplicados ao bojos: um caracterizado pela aplicação de filetes em forma de ômega (Figura 77 a) e outro composto por círculos incisos concêntricos com uma semiesfera central (Figura 77 b-c). O motivo ômega é encontrado também nos apliques cabeça de urubu-rei tanto nos encontrados na bacia do rio Trombetas e município de Juruti quanto nas peças coletadas no baixo Tapajós. $O$ corpo dos apêndices batraquiformes com ventres ocos com furo central ao invés de ventres côncavos como predominam em vasos gargalo "clássicos”. Em certa ressonância com o estilo Konduri, há uma notável ênfase em ponteados, o que quase não ocorre nos vasos encontrados no baixo Tapajós. É particularmente importante essa técnica decorativa nos pedestais, com diferentes padrões compostos por filetes aplicados (às vezes ponteados) ou incisões (Figura $77 \mathrm{r}-\mathrm{u}$ ). 


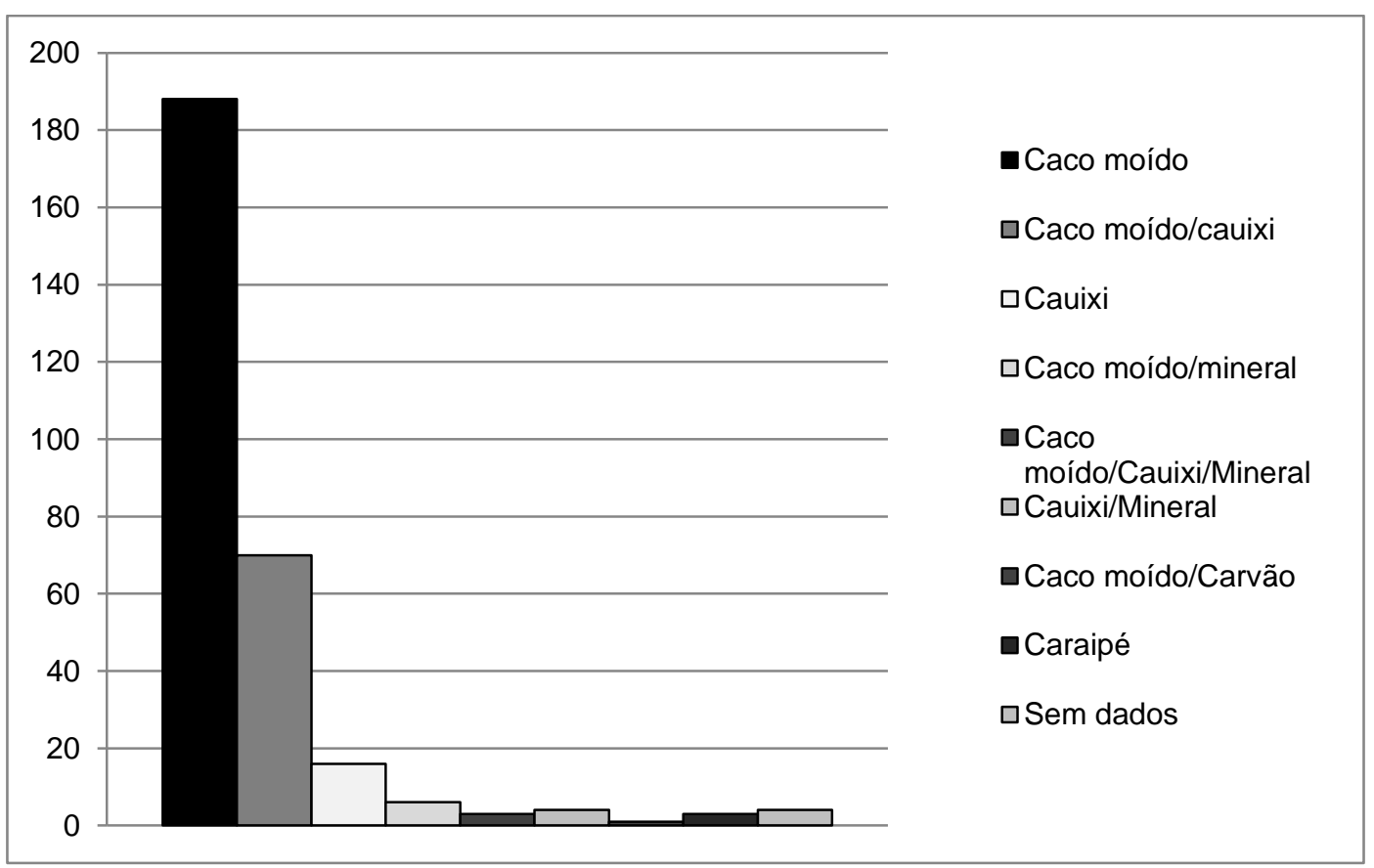

Gráfico 26. Frequência de antiplástico em fragmentos de vasos de gargalo. Coleções Aricy Curvello, Barbosa de Faria/Comissão Rondon, Peter Hilbert (1952), Peter Hilbert e Harald Schultz (1953), 881, 1564 e material doado (MPEG).

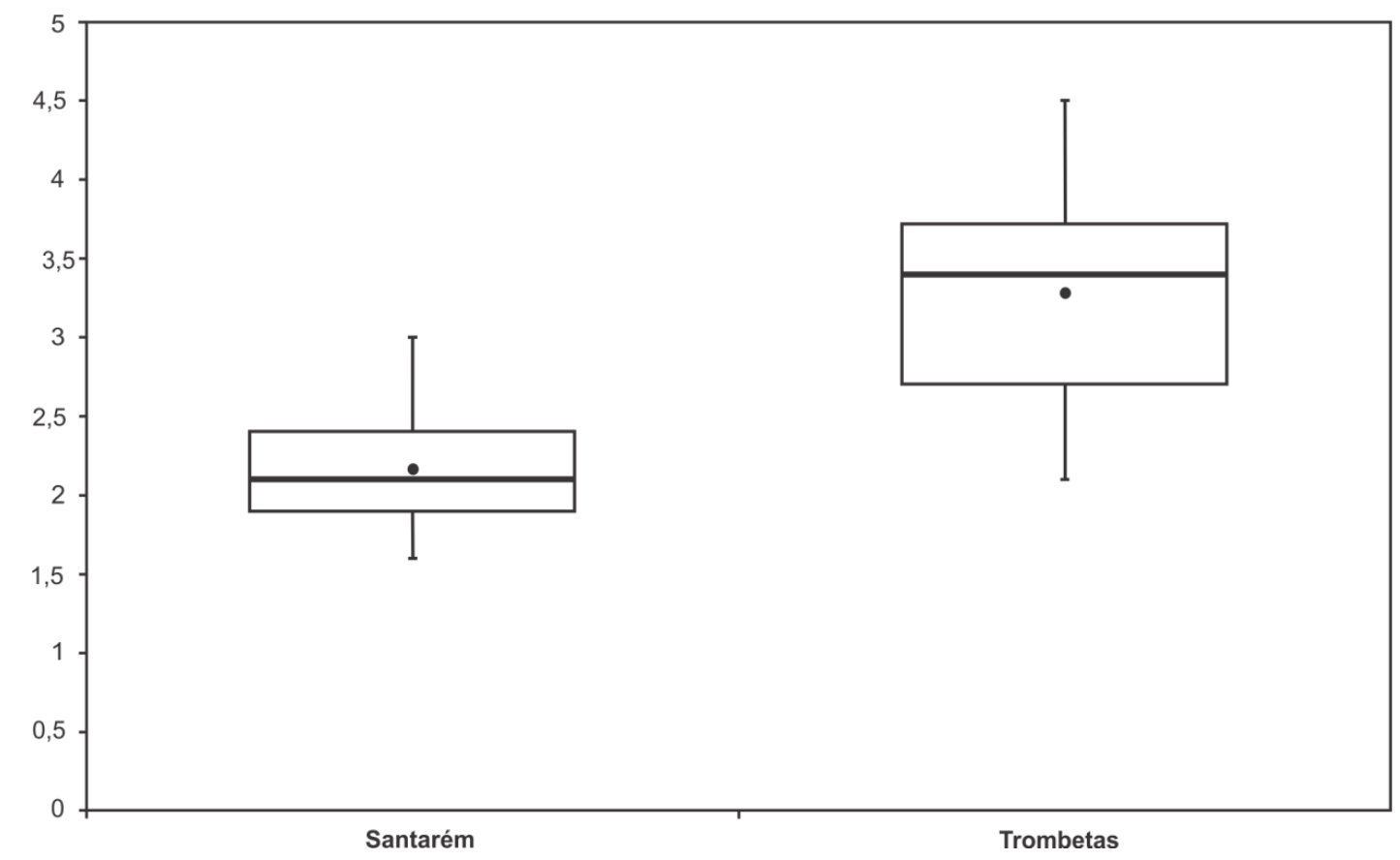

Gráfico 27. Comparação entre diâmetros dos vasos de gargalos inteiros provenientes do sítio Aldeia e adjacências e os gargalos associados a mesma morfologia encontrados em coleções provenientes do rio Trombetas. 


\begin{tabular}{|c|c|c|c|c|c|c|}
\hline Coleção & Proveniência & Apêndice & Borda & Parede & Base & Total \\
\hline \multirow{2}{*}{$\begin{array}{l}\text { Aricy } \\
\text { Curvello }\end{array}$} & Aimim & 3 & 0 & 0 & 0 & 3 \\
\hline & Lago Batata & 0 & 1 & 0 & 1 & 2 \\
\hline \multirow[t]{2}{*}{ MHN } & Urupanã & 2 & 0 & 0 & 0 & 2 \\
\hline & Porto Trombetas & 2 & 0 & 0 & 0 & 2 \\
\hline \multirow{4}{*}{$\begin{array}{l}\text { Barbosa de } \\
\text { Faria }\end{array}$} & Abuí & 17 & 0 & 0 & 2 & 19 \\
\hline & Arapapá & 1 & 0 & 0 & 0 & 1 \\
\hline & Laranjal & 2 & 0 & 0 & 0 & 2 \\
\hline & Cocal & 11 & 0 & 0 & 1 & 12 \\
\hline \multirow{2}{*}{$\begin{array}{l}\text { Comissão } \\
\text { Rondon }\end{array}$} & Santa Maria & 67 & 3 & 8 & 1 & 79 \\
\hline & Sucurijú & 8 & 1 & 0 & 2 & 11 \\
\hline \multirow{6}{*}{ MN } & Jacopá & 4 & 0 & 0 & 0 & 4 \\
\hline & Sacuri & 58 & 6 & 21 & 4 & 89 \\
\hline & Uajará & 2 & 0 & 0 & 1 & 3 \\
\hline & Oriximiná & 3 & 0 & 0 & 0 & 3 \\
\hline & Lago Sapucuá & 2 & 0 & 0 & 0 & 2 \\
\hline & Sem referência & 26 & 2 & 5 & 7 & 40 \\
\hline $\begin{array}{l}\text { Peter Hilbert } \\
\text { Harald } \\
\text { Schultz }\end{array}$ & Babaçu & 0 & 0 & 1 & 0 & 1 \\
\hline MPEG & & & & & & \\
\hline \multirow{5}{*}{ Peter Hilbert } & Cocal & 0 & 1 & 2 & 0 & 3 \\
\hline & Faro & 1 & 0 & 0 & 0 & 1 \\
\hline & Lago Sapucuá & 1 & 1 & 0 & 0 & 2 \\
\hline & Oriximiná & 1 & 0 & 0 & 0 & 1 \\
\hline & Ponta da Mafada & 0 & 1 & 0 & 0 & 1 \\
\hline \multirow[t]{2}{*}{ T-881 } & Oriximiná & 3 & 0 & 0 & 0 & 3 \\
\hline & Trombetas enseada & 1 & 0 & 0 & 0 & 1 \\
\hline $\begin{array}{l}1564 \\
\text { MPEG }\end{array}$ & Oriximiná & 3 & 0 & 0 & 0 & 3 \\
\hline
\end{tabular}




\begin{tabular}{|c|c|c|c|c|c|c|}
\hline $\begin{array}{l}\text { Material } \\
\text { doado } \\
\text { MPEG }\end{array}$ & Terra Preta $1 / 2$ & 2 & 0 & 0 & 0 & 2 \\
\hline \multirow{2}{*}{$\begin{array}{l}\text { Projeto Norte } \\
\text { Amazônico }\end{array}$} & Tawanî & 2 & 0 & 0 & 0 & 2 \\
\hline & Mapium & 1 & 0 & 0 & 0 & 1 \\
\hline \multicolumn{7}{|l|}{ MHN } \\
\hline & TOTAL & 224 & 16 & 29 & 19 & 296 \\
\hline
\end{tabular}

Tabela 10. Fragmentos de vasos de gargalo em coleções estudadas.

Os vasos de gargalo encontrados na região do rio Trombetas e município de Juruti são, em geral, mais robustos que os encontrados inteiros na cidade de Santarém. As paredes tendem a ser mais grossas nos primeiros, o que fica particularmente visível nos pedestais. A diferença de tamanho é evidenciada nos diâmetros do gargalo (Gráfico 27), na altura dos pedestais, tamanho dos "gomos" ou no comprimento dos apêndices batraquiformes. Apesar de não ter sido possível realizar uma estimativa o conjunto, essa diferença se reflete na volumetria. Se os vasos de gargalo de Santarém têm em média $350 \mathrm{ml}$ e a medida máxima é de $670 \mathrm{ml}$, talvez os outros vasos possam ter chegado ao máximo de 1 litro. O vaso coletado no rio Acapu, na contramão dessa tendência, é o menor vaso de gargalo inteiro conhecido, sendo sua capacidade volumétrica de apenas $70 \mathrm{ml}$. Existem também exemplares de apliques ou gargalo com dimensões semelhantes ou menores do que os dos típicos vasos de Santarém. Isso indica mesmo que tenham sido os vasos maiores predominantes - o que precisa ser verificado a partir de amostras coletadas sistematicamente - existiam vasos de tamanhos muito variados, maiores e menores que os encontrados no baixo Tapajós. 


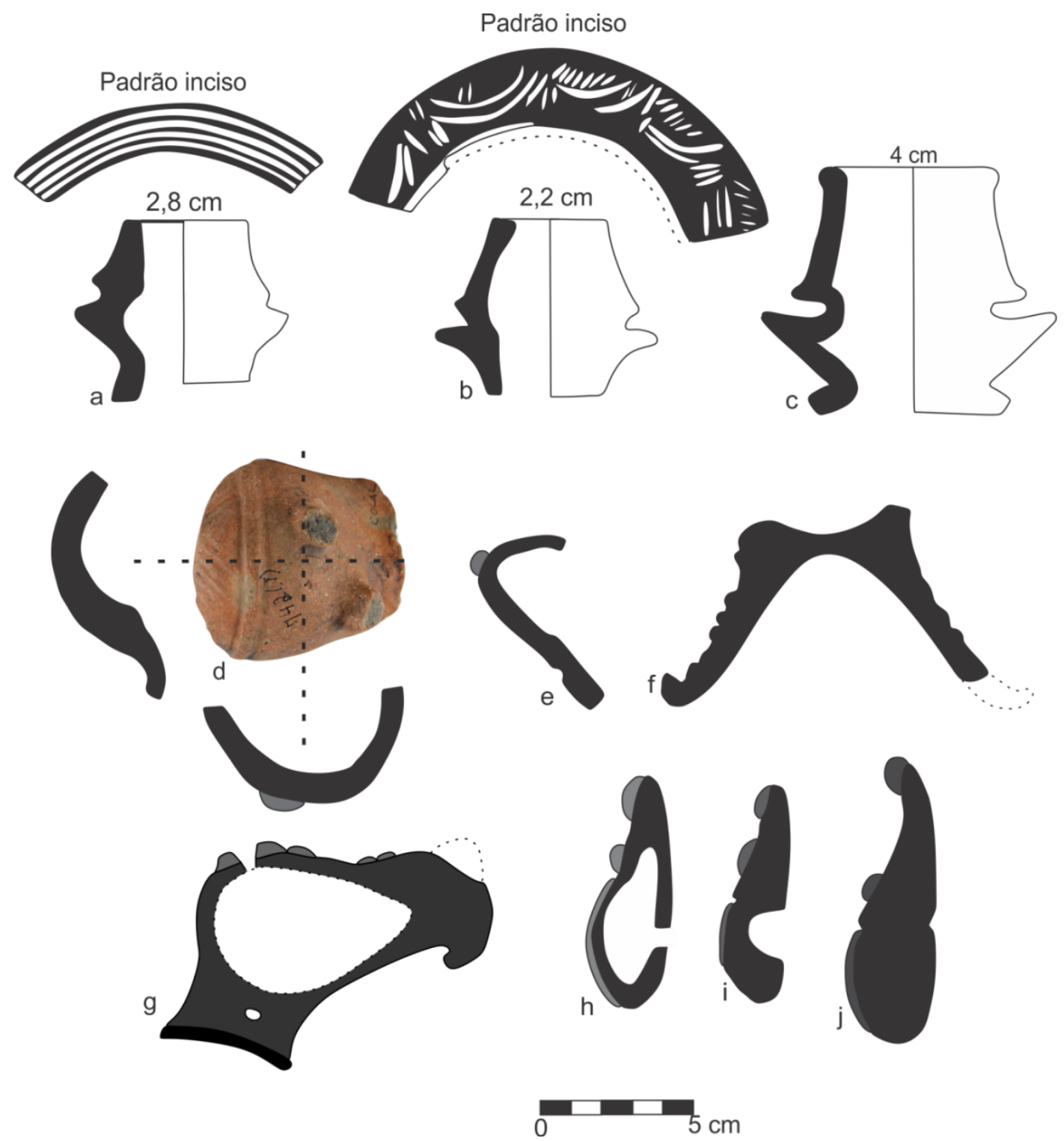

Figura 80. Perfil de diferentes fragmentos que compõem vasos de gargalo: gargalos (a-c), bojo lobado (de), anelar (f), apêndices em forma de cabeça de ave (g) e batraquiformes com variações de modos de construção (h-j). Coleções Peter Hilbert (a, d), Barbosa de Faria/Comissão Rondon (b,-c, e-f, h-j) e Aricy Curvello (g).

A diferença entre os vasos de gargalo encontrados no baixo Tapajós e os encontrados na bacia do rio Trombetas levaria, em princípio, a pensar que se trata de uma imitação ou cópia, que resultou em uma variante relativamente distinta. A padronização dos vasos e a diferença nos modos de execução das incisões, ponteados e mistura de tempero indica, entretanto, que não houve uma combinação com as técnicas aplicadas ao estilo Konduri. A falta de correlação entre os materiais encontrados nas duas áreas deve resultar da falta de conhecimento de outras, onde tais objetos podem ter 
sido produzidos, como o Lago Grande de Curuaí (antes Vila Franca). A coleção reunida por Nimuendajú nessa área apresenta apêndices, gargalos e pedestais com características muito similares às do material encontrado em contextos Konduri (Figura 81). Troufflard (2012:63) também apresenta uma fotografia dessa mesma área com vários fragmentos relacionáveis a vasos de gargalo mais robustos. Ainda não foram realizadas escavações sistemáticas nos sítios do Lago Grande, mas é provável que essas evidências se avolumem. Na extremidade ocidental da margem do lago, Nimuendajú encontrou, inclusive, um sítio com material Konduri e Santarém associado. Mariano (2017) evidenciou que há algumas peças Konduri em meio às do estilo Santarém, no sítio João Braz, em uma ilha próxima ao mesmo lago. A alta concentração de caco moído identificada nos fragmentos dos vasos de gargalo, muitas vezes visíveis a olho nu, é característica de várias peças coletadas no sítio João Braz. Além disso, essa área foi onde mais Nimuendajú coletou cabeças de urubu - mais do que nas imediações de Santarém (ALVES, 2016, p. 112). Tudo leva a crer que o Lago Grande isso ainda seja o principal centro hipotético de produção e distribuição de vasos de gargalo para a região do atual município de Juruti e a bacia do rio Trombetas.

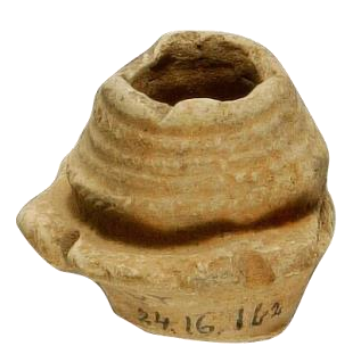

a

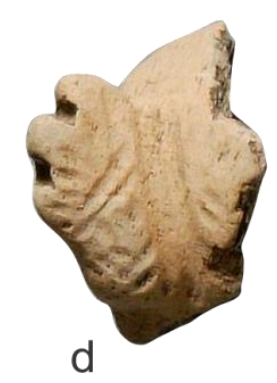

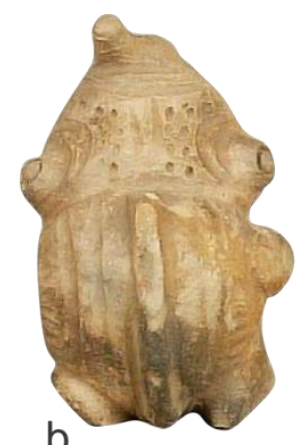

b

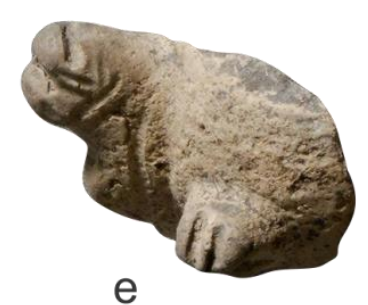

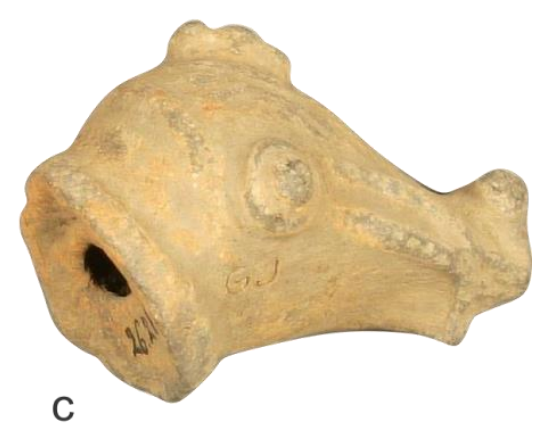

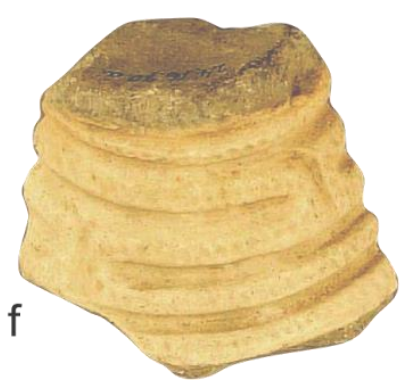

Figura 81. Fragmentos de vasos de gargalo coletados por Nimuendajú no Lago Grande de Curuaí. Esses fragmentos exibem características muito similares à dos encontrados na área de dispersão da cerâmica Konduri. Disponível em: http://collections.smvk.se/carlotta-vkm/web. Acesso em 25 de abril de 2019. 
Observando as fotografias disponíveis em relatórios e na tese de Guapindaia (2008), saltou aos olhos um exemplar de cabeça de urubu proveniente do sítio Aviso I com ponteados e incisões com profundidade e combinação à maneira Konduri. Essa peça pode ser resultado de uma produção local, imitando os vasos de gargalo do estilo Santarém As dezenas de quilômetros de distância deste sítio e a margem do rio Trombetas poderia dificultar a chegada desse tipo objeto frágil, levando a produções locais. Dessa maneira, se a maior parte dos vasos de gargalo ao longo da dispersão do estilo Konduri é de produção não local, é possível que existam alguns exemplares de produção local.

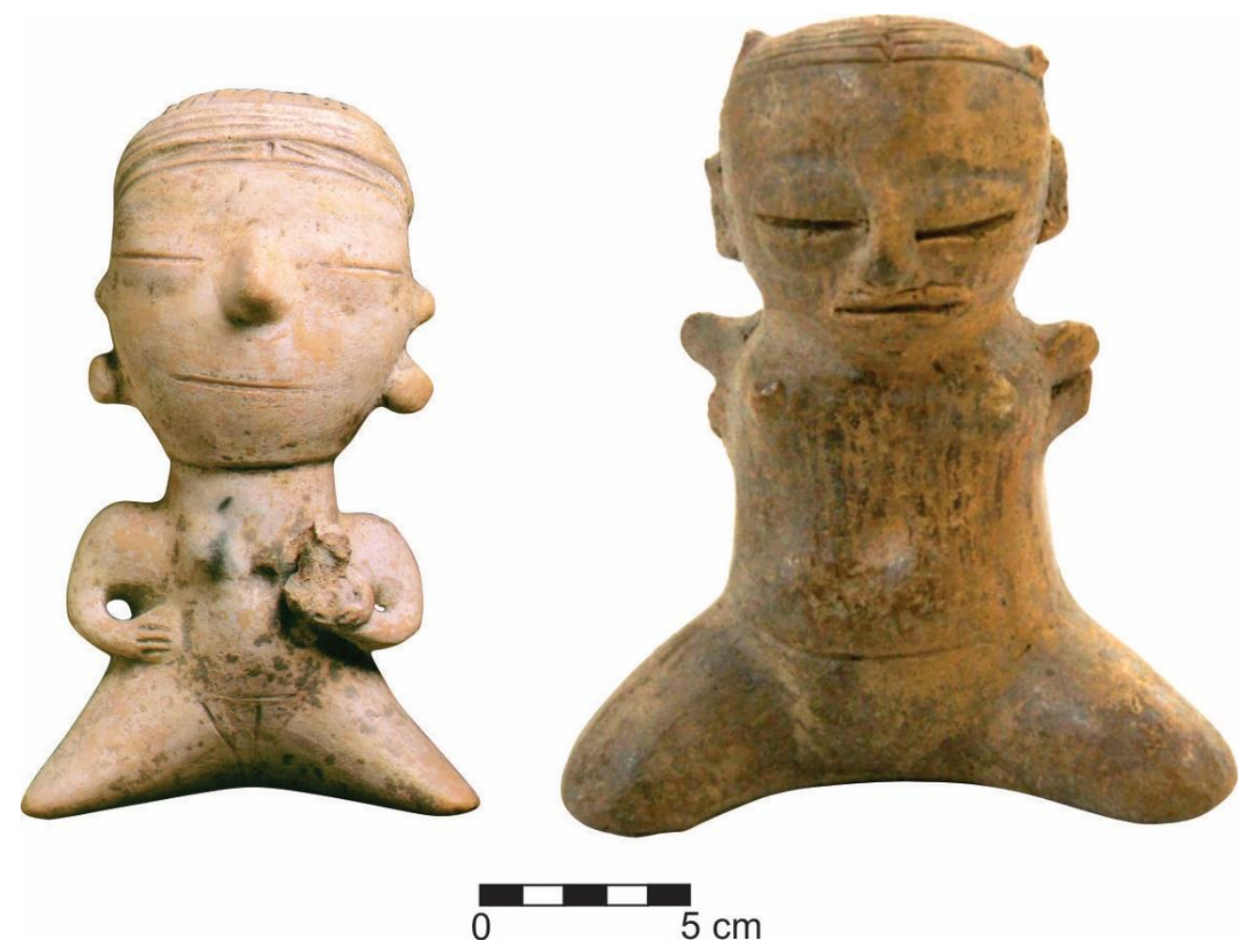

Figura 82. Estatuetas antropomorfas com base semilunar do estilo Santarém. Extraído de Funarte (1981), à esquerda, e Barros et al. (2015), à direita.

\subsubsection{Estatuetas antropomorfas}

As estatuetas antropomorfas femininas, como os vasos de gargalo, são bastante características do estilo cerâmico Santarém (Figura 82). A morfologia mais frequente desses artefatos é a de um corpo feminino sentado com pernas abertas (base semilunar) e, às vezes, indicação de vulva marcada por triângulo inciso e a cabeça quase com o 
tamanho do corpo (BARRETO, 2014b, 2017). Muitas dessas peças apresentam policromia sobre engobo branco ou apenas engobo vermelho. Fragmentos semelhantes foram encontrados associados à cerâmica Konduri. Entre o material coletado no sítio Oriximiná 3 foram coletados pelo menos três fragmentos de estatuetas (SCIENTIA, 2013). No sítio Terra Preta 1 (Juruti), dois fragmentos com engobo branco podem ser fragmentos de estatuetas - e não de "cachimbos" (SCIENTIA, 2008, p. 92). No sítio Juruti Velho foi encontrada uma estatueta quase inteira (SCIENTIA, 2003, p. 130).
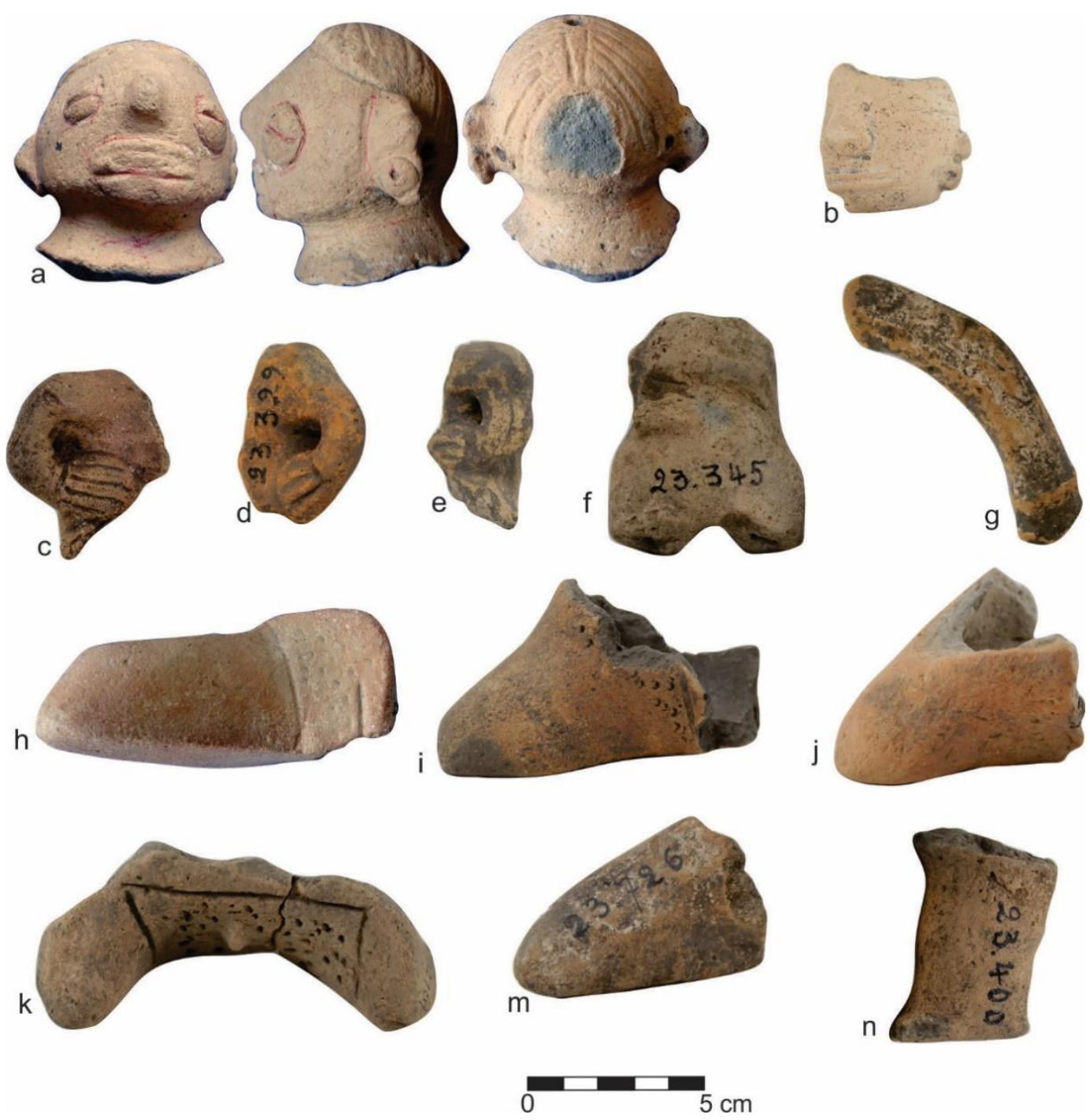

Figura 83. Fragmentos de estatuetas encontradas em contextos Konduri. Coleção Idelza/Conuri (a, h), Oriximiná (b), Terra Preta 1/2 (c), Sacuri (d, m), Santa Maria (e, i), Cuminá (f) lago Juruti Velho (g), Fortaleza (j), Babaçu (k), lago Sapucuá (n). Coleção Peter Hilbert (b), Peter Hilbert e Harald Schultz (g, j, k) Barbosa de Faria/Comissão Rondon (d-f, i, m-n), material doado/MPEG (c) e Idealza/Conuri (a, h). 


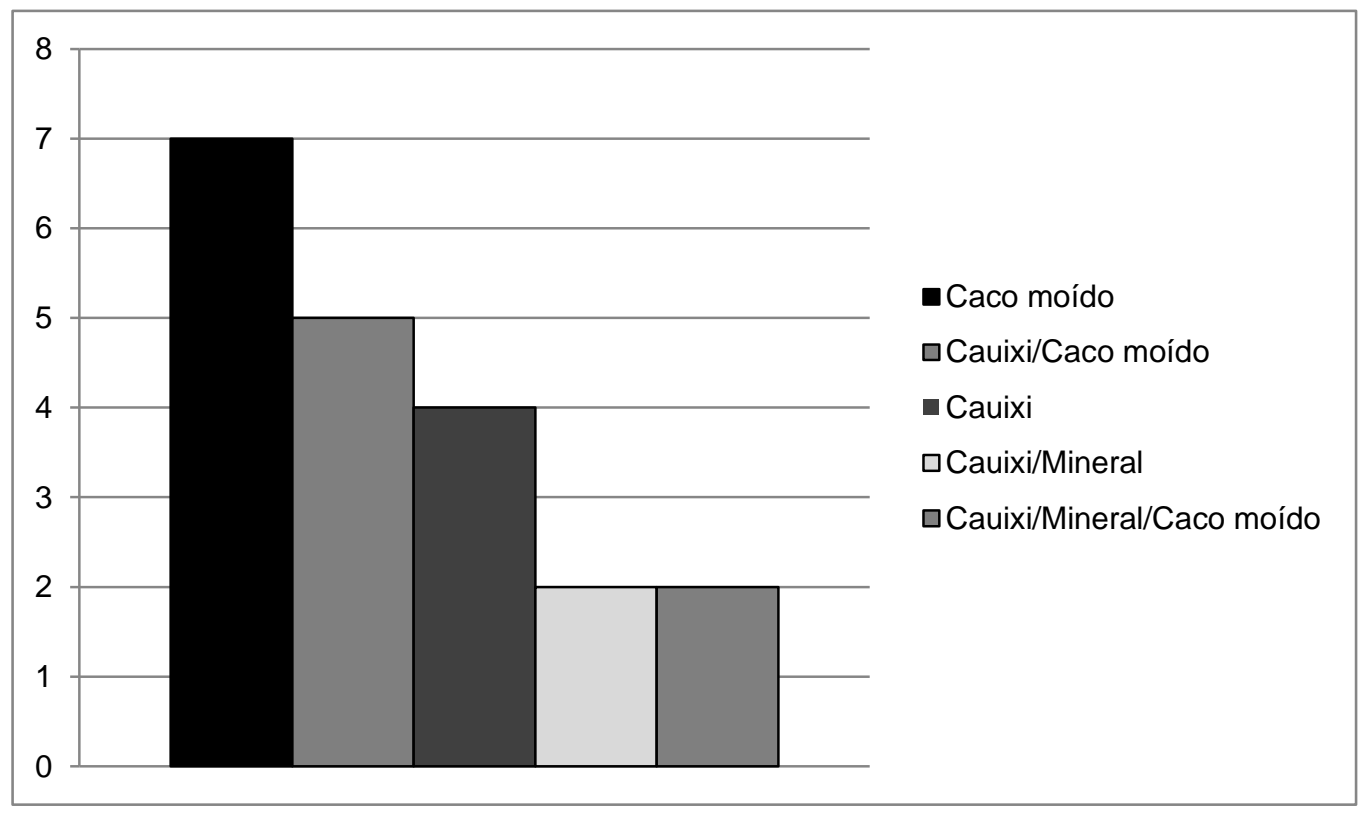

Gráfico 28. Antiplástico em fragmentos de estatuetas antropomorfas nas coleções Barbosa de Faria/Comissão Rondon, Peter Hilbert e Aricy Curvello.

Os fragmentos de estatuetas são muito mais raros nas coleções que os de vasos de gargalo. Nas coleções estudadas foram identificados apenas 20 fragmentos, somados a outros 3 identificados nas coleções "domésticas” do Lago Sapucuá (Figura 83). A amostra é composta por fragmentos de pés, partes de tronco com braço, braço, cabeças e um corpo com braços e pernas. Todos são ocos e alguns apresentam furo de ventilação no pescoço, centro da cabeça e/ou entre as nádegas. A maioria sugere postura sentada (base semilunar), mas há pelo menos três fragmentos de estatuetas em pé. As pernas possuem forma cônica e não são figurados os pés no caso das bases semilunares. Nas estatuetas com as figuras eretas aparecem pequenas sugestões de pés. Em 4 peças é visível uma indicação da região pubiana, com incisões e ponteado. Uma delas possui uma pequena protuberância central e duas exibem incisão central. Um dos fragmentos de cabeça é o mesmo mencionado por Hilbert (1955a, p. 52). Este exibe um olho alongado em "grão de café", muito característico de algumas estatuetas Santarém (Figura 83 b). Outra peça tem olhos em "grão de café" circulares, alargador auricular e indicações do penteado feito no cabelo (Figura 83 a). As mãos aparecem majoritariamente na cintura, com um único caso de mãos sobre a barriga. Também foi identificado um braço alongado semelhante ao encontrado no sítio Bela Cruz I, 
sugerindo outro modo de construção de estatueta ou vaso efígie. Vestígios de engobo vermelho são visíveis em um dos pés e engobo branco em um pé e um braço.

As pastas usadas na produção das estatuetas, em sua maioria, são semelhantes as do estilo Santarém e dos vasos de gargalo em geral. A maioria apresenta caco moído ou este combinado com cauixi e/ou elementos minerais (quartzo e óxido de ferro). A menor parte apresenta cauixi ou cauixi combinado com mineral. Os 3 fragmentos de coleções domésticas não foram observados com lupa binocular, mas, pelo menos dois, possuem caco moído visível a olho nu. A porcentagem do caco moído na pasta é predominantemente alta ou média, com grãos de tamanhos variados, entre 0,5 e 2,5 mm. A coloração da face externa é laranja, branca ou amarela. Os núcleos são predominantemente do tipo 3, mas há também núcleos do tipo 1 e 2. Quando as superfícies não se encontram erodidas, é possível identificar o polimento. Uma peça apresenta vestígios de engobo vermelho e outras duas com engobo branco.
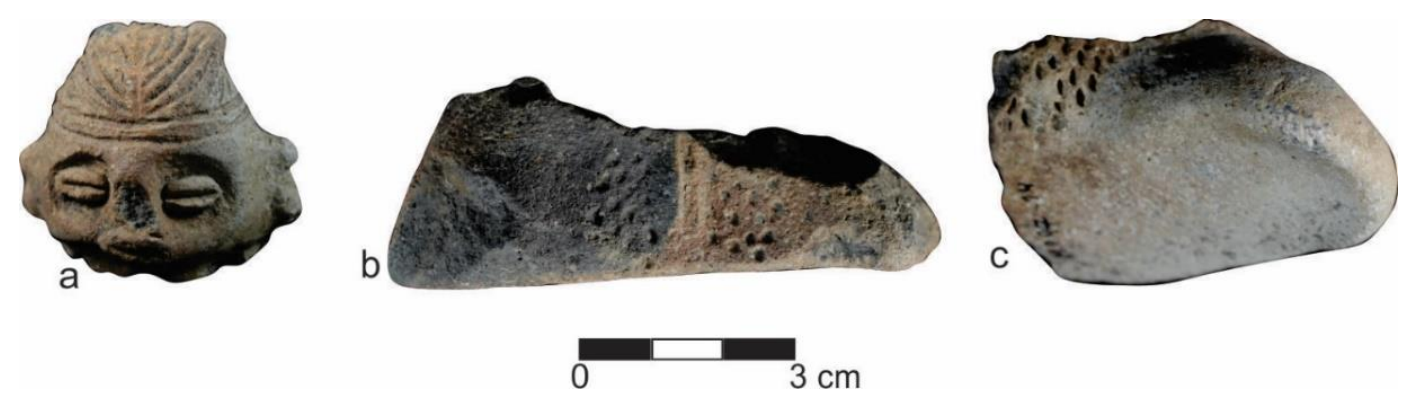

Figura 84. Fragmentos de estatueta provenientes do sítio João Braz Material doado (MPEG).

Com exceção de um único exemplar muito semelhante às estatuetas mais conhecidas da cerâmica Santarém, todas as outras apresentam um aspecto ligeiramente distinto. Como no caso dos vasos de gargalo, isso pode indicar uma área de produção distinta no baixo Tapajós. No sítio João Braz, em uma ilha no rio Amazonas, cerâmica semelhante à coletada por Nimuendajú em sítios da margem do Lago Grande, foram coletados fragmentos de estatueta com uma pasta com grãos de caco moído visíveis a olho nu e uma execução semelhante dos ponteados na região pubiana (Figura 84) (MARIANO, 2017). No sítio Aldeia e áreas adjacentes pode ter se desenvolvido a 
produção de uma fine ware que não era produzida em outras áreas e nem chegava à região onde era feita a cerâmica Konduri.
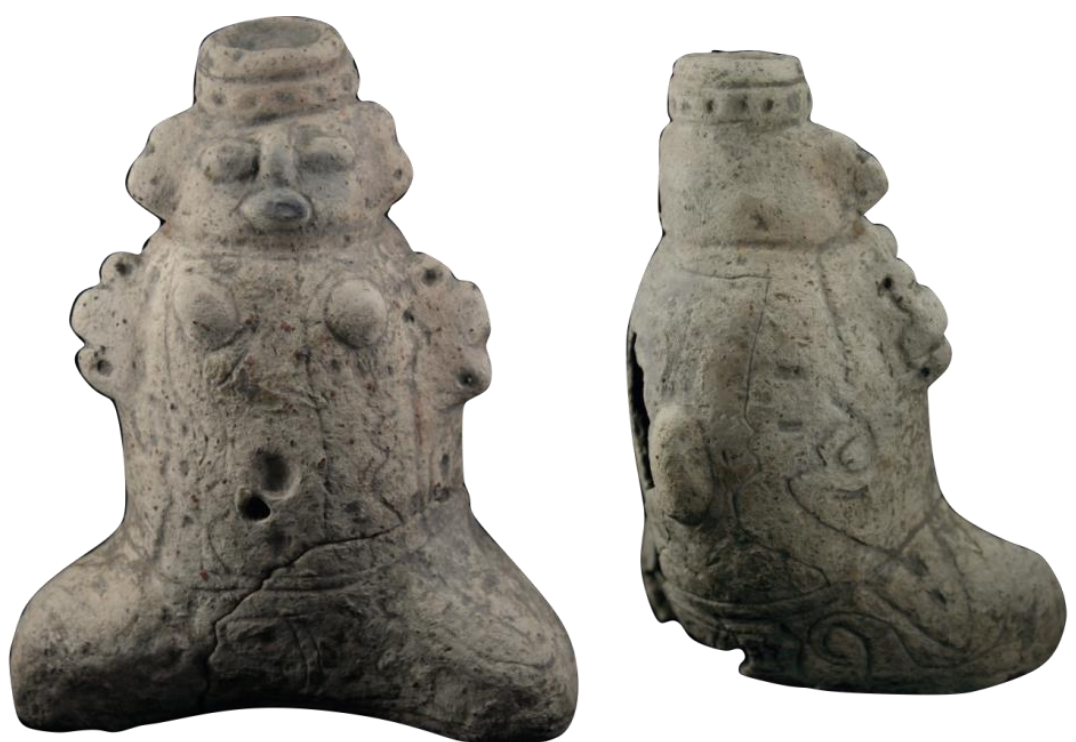

a
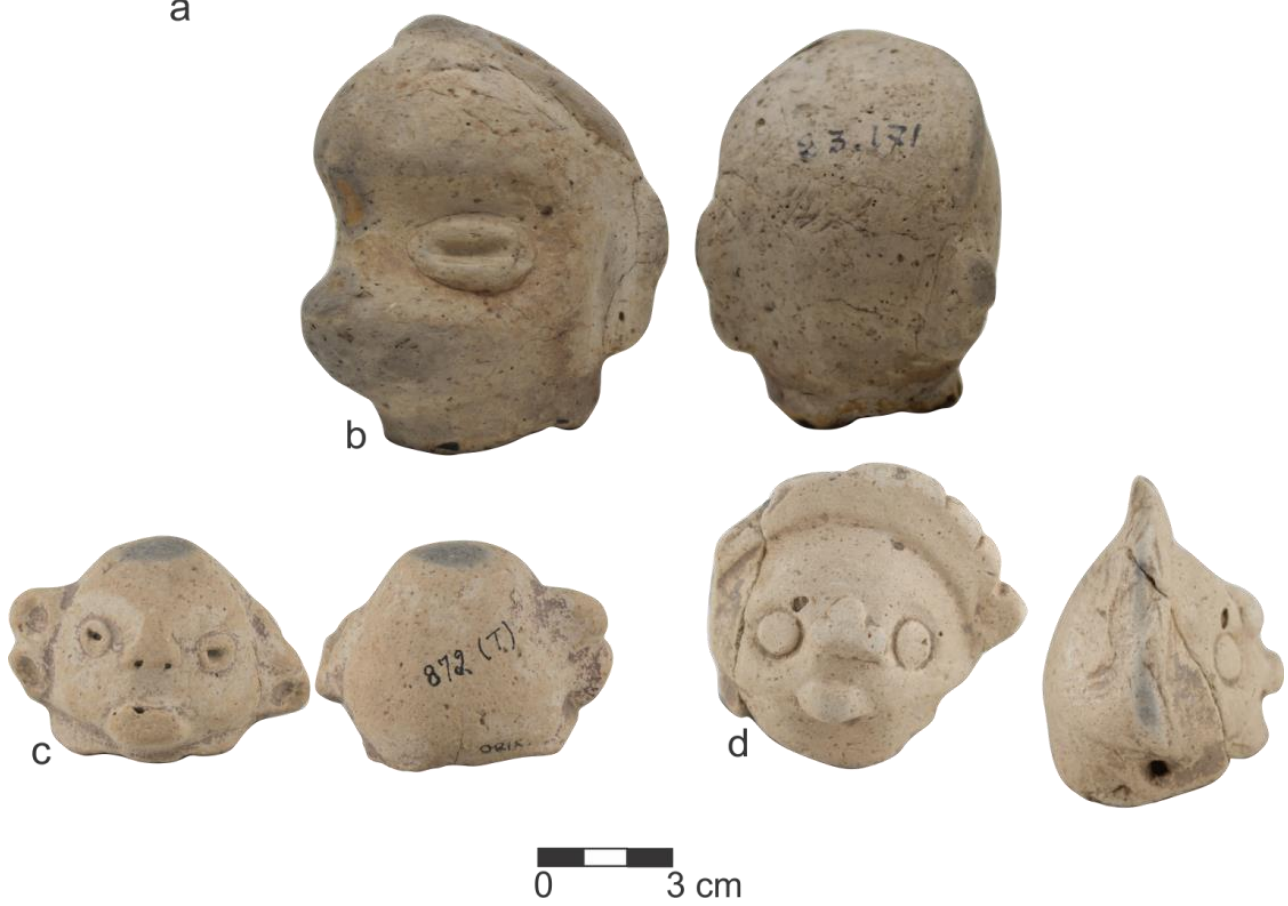

Figura 85. Estatueta e fragmentos de estatueta distintos. Proveniência: Terra Santa (a), Boca dos Anjos (b), Oriximiná (c-d). Coleções Barbosa de Faria/Comissão Rondon (b), Peter Hilbert (b-c) e material doado/MPEG (a). 
Há entre as peças identificadas nas coleções três cabeças e uma peça inteira apenas com cauixi na pasta (sem caco moído), coloração da face externa branca A estatueta inteira exibe base semilunar e braços pequenos semelhantes aos de algumas peças Santarém, sendo a principal diferença a presença de padrões incisos pelo corpo e a alta concentração de cauixi (Figura 85). Uma das cabeças é a mesma identificada por Hilbert como caracteristicamente Konduri, mas discordamos do autor. Esta peça apresenta engobo branco e pintura vermelha, o que a aproxima mais das estatuetas Santarém. Não é possível dizer, entretanto, se este é um caso de produção local.
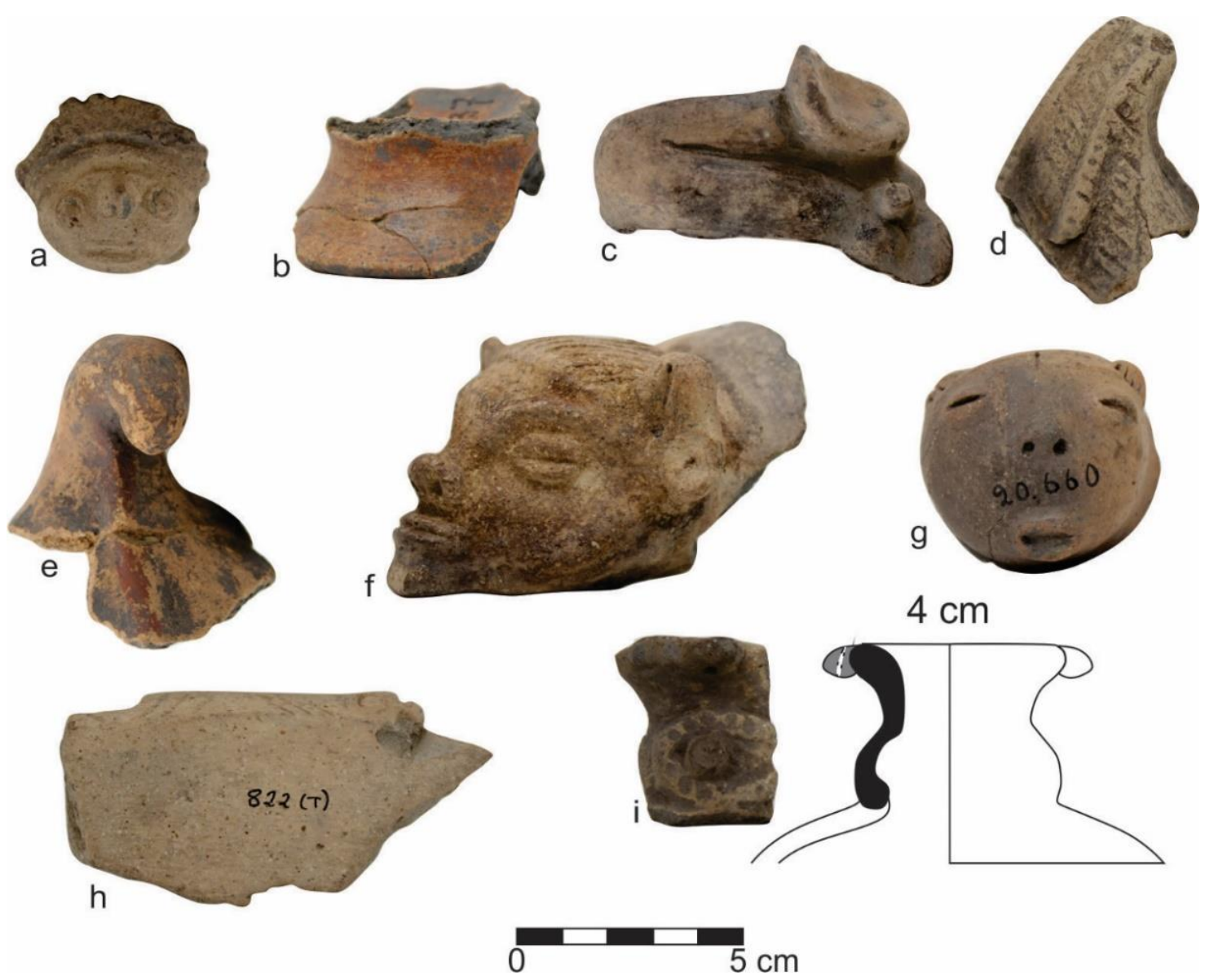

Figura 86. Outros fragmentos com características do estilo Santarém. Proveniência: Fortaleza $(a, h)$, Sacuri (b, d, e, i), Ilha Paru (f) Oriximiná (g). Coleções Peter Hilbert (a, c, h) e Barbosa de Faria/Comissão Rondon (b, d-g, i). 


\subsubsection{Objetos diversos}

Há pelo menos 10 fragmentos com essas características nas coleções, provenientes do sítio Oriximiná, Ilha Paru (Arapapá), Babaçu e outros com proveniência genérica "Trombetas" (Figura 86). Entre essas peças, há um exemplar com face antropomorfa elaborada, com uma espécie de adorno sobre a cabeça. Outros são apêndices em forma de caudas modeladas que encontram análogos em pequenos vasos do estilo Santarém como bojo figurando corpo zoomorfo ou os chamados vasos globulares. Há peças variadas também, como uma borda de vasilha aberta e rasa; aplique em forma de perna de zoo ou antropomorfo com ranhuras de fixação; um apêndice oco em forma de cara zoomorfa também é muito semelhante ao encontrado em vasos globulares Santarém ${ }^{68}$; um grande apêndice de cabeça antropomorfa com penteado delineado.

Outro conjunto de fragmentos foi agrupado com a denominação provisória "pasta laranja" (Figura 87). Possivelmente, também se relaciona ao estilo Santarém, dada a semelhança em termos de antiplástico e coloração. Essas peças, como as precedentes são caracterizadas majoritariamente pela presença de caco moído em média ou alta concentração e grãos relativamente grandes (até $2,5 \mathrm{~mm}$ ). Apenas na coleção reunida por Nimuendajú foram identificados alguns apliques semelhantes identificados no conjunto, mas sua proveniência indicada "Santarém" (Figura 87 a-b, d). Essa proveniência, no entanto, parece ser apenas genérica, englobando peças coletadas em vários sítios ${ }^{69}$. Entre o material coletado em Carariacá (Lago Grande) há apêndices com a mesma figuração de uma das peças reunidas neste grupo (NIMUENDAJÚ, 2004, p.101) (Figura 88 c). Na Coleção Tapajônica (MAE-USP) há vários apêndices como este, sendo que alguns exibem a inscrição "Lago Grande” e “Óbidos”. Não é possível afirmar que se trata também de um conjunto associado ao estilo Santarém, mas dadas as características das pastas, essa é uma relação muito provável. A hipótese de que se trata de apenas uma ware distinta dentro do conjunto Konduri, todavia, ainda não pode ser descartada.

\footnotetext{
68 Além desses 14 exemplares, foi identificado um apêndice antropomorfo aplicado a borda com configuração muito semelhante à encontrada em cariátides e estatuetas. Esta peça, pertencente a coleção Peter Hilbert (1952) não apresenta marcação de proveniência, e pode ter chegado a coleção como resultado de misturas entre sacos.

${ }^{69}$ Essa hipótese se baseia na presença de alguns fragmentos Konduri, o que não ocorre em materiais com proveniência específica como "Santarém Aldeia" ou sítios de áreas adjacentes.
} 

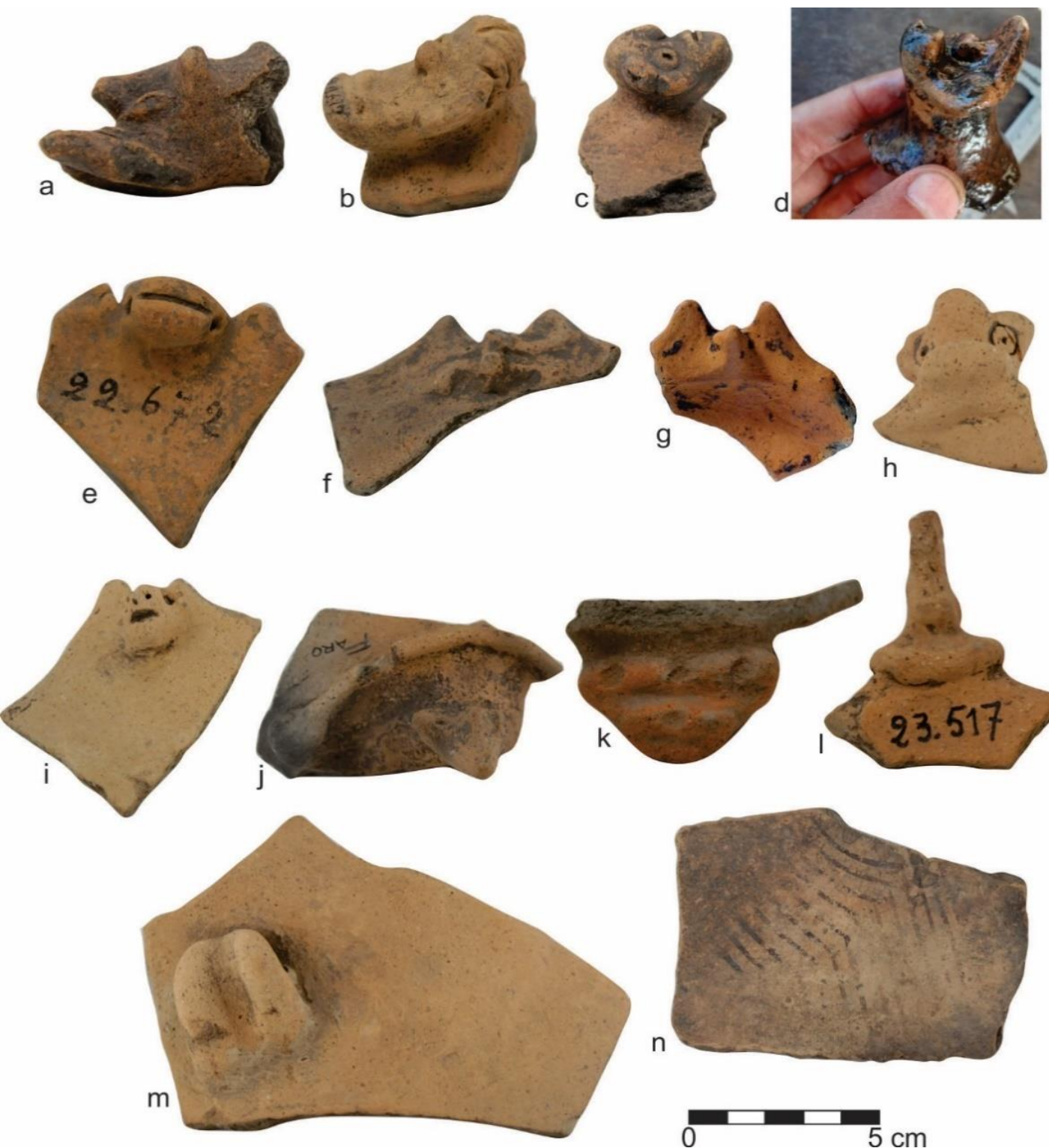

h
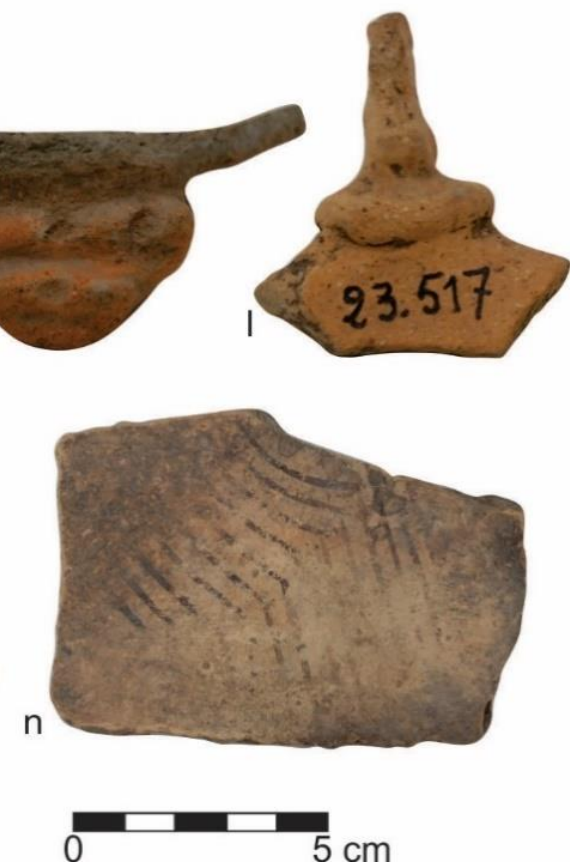

Figura 87. Cerâmicas do grupo "pasta laranja" associado ao estilo Santarém. Proveniência: Santa Maria (a-c), Castanhal (d), Sacuri (f), Cocal (m), Babaçu (n), Oriximiná (h), rio Trombetas (e), Conuri (g), sem referência (i, k), Faro (j), Sucurijú (l). Coleções Barbosa de Faria Comissão Rondon (a-c, e-f, k), Peter Hilbert (j, m), Peter Hilbert e Harald Schultz (i, n), superfície da comunidade de Castanhal (d), coleção Reuni/Conuri.

Entre essas peças destacam-se apêndices em forma de faces antropomorfas protuberantes (Figura 87 a-d). Dois desses apêndices e duas paredes exibem linhas marrons pintadas (Figura 87 c, n), como um exemplar da coleção Tapajônica. Um dos exemplares conhecidos foi fotografado em um quintal na comunidade de Castanhal, no Lago Sapucuá, em 2014 (Figura 87 d). No sítio Oriximiná 3 um exemplar muito parecido foi coletado (SCIENTIA, 2013). Duarte-Filho (2010) também apresenta um 
exemplar coletado em um sítio do município de Juruti. Outras peças também apresentam essas mesmas linhas finas pintadas. Destaca-se nesse conjunto bordas extrovertidas de vasilhas rasas (pratos) com um apliques (extensões de borda) em forma de "morcego" no lábio. Foram encontradas 3 bordas com esse tipo de aplique foi encontrada no sítio Boa Vista (CHUMBRE, sd). Na coleção mantida na Casa de Cultura do município de Oriximiná, um fragmento de borda com este mesmo aplique apresenta finas linhas marrom pintadas.
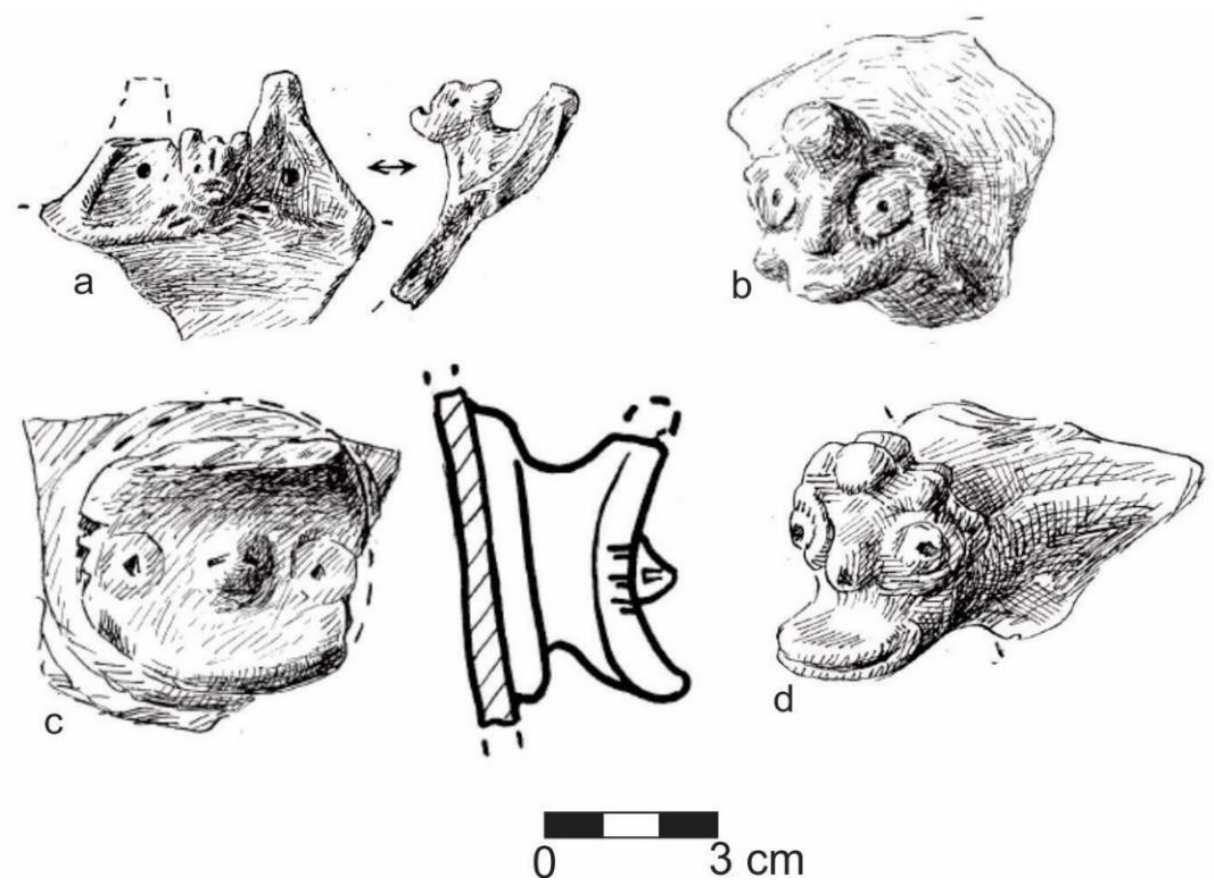

Figura 88. Apêndices em forma de "morcego" (a) e caras antropomorfas na coleção Nimuendajú. (b-d). Proveniência: Santarém (a,b, d) e Carariacá/Lago Grande (c).

\subsubsection{Estilo Paurá}

O estilo cerâmico Paurá foi definido por Nimuendajú (2004) e até o momento não foi revisto. Nordenskiold (1930, p. 55) apresenta brevemente esse estilo na descrição da Prancha XXXVII. A principal característica desta cerâmica é um padrão em intrincado de ondas retilíneas cobrindo quase toda a face externa das vasilhas e, às vezes, a interna. Nimuendajú notou a presença de pequenos apêndices em forma de cabeças zoomorfas com olhos ponteados e aplicação de revestimento marrom. Essa 
cerâmica foi encontrada no lago Paurá e Remanso e, na margem oposta rio Amazonas, em sítios a margem do Pará de Ramos (NIMUENDAJÚ, 2004, p. 157). Em sua coleção se destacam vários exemplares com gargalo e bases anelares. Harald Schultz visitou o lago Paurá pesquisado por Nimuendajú, tendo coletado alguns fragmentos do estilo homônimo e que atualmente compõem a coleção 006 do MAE-USP (Figura 89). Um fragmento com com essa padrão inciso característico aparece em meio ao material do lago de Silves associado a fase Iraci (SIMÕES; MACHADO, 1987, p. 76), que foi revista como parte do conjunto Saracá (LIMA, 2013; STAMPANONI, 2016) . Machado (1991) apresenta uma vasilha inteira com a decoração característica do estilo Paurá coletada na região do rio Urubu (sítio AM-IT-26), mas não a relaciona a nenhum complexo cerâmico. Na exposição do material coletado em Nova Urucurituba no Palacete Provincial de Manaus (sítio AM-UT-01), há alguns fragmentos com os atributos deste estilo.

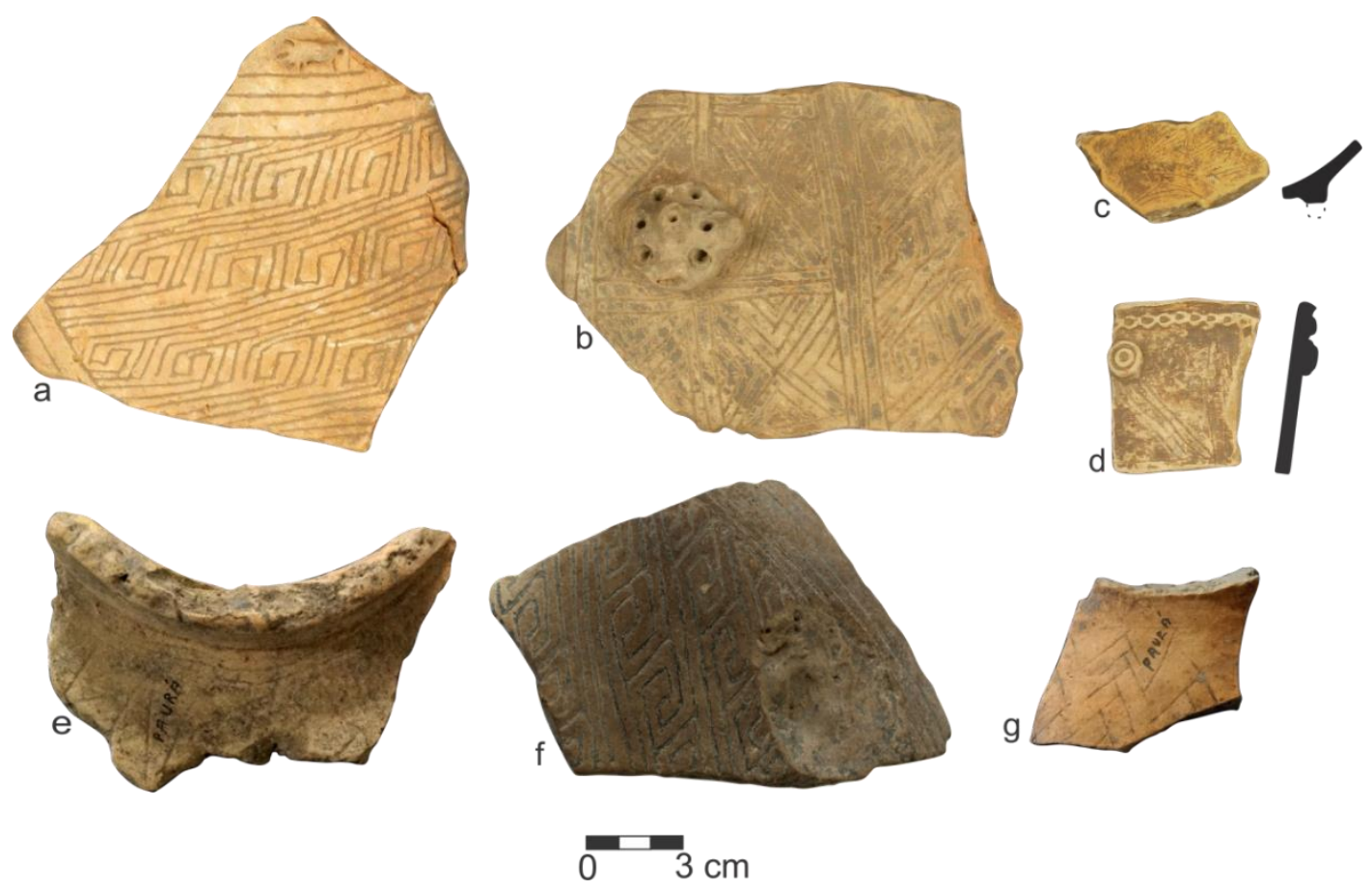

Figura 89. Fragmentos do estilo Paurá. Coleção Nimuendajú (a-d) extraído de www.varldskulturmuseerna.se; coleção 006 (MAE/USP)/ Fotos: DAPE/MAE. 
O material relacionado ao estilo Paurá nas coleções com cerâmica Konduri são muito raros. Hilbert (1955a) já havia destacado a presença de "fragmentos com incisões" que pareciam distintos em relação ao conjunto. Nas coleções estudadas apenas 11 fragmentos do estilo Paurá foram identificados: 6 na coleção Barbosa de Faria e 5 na coleção Peter Hilbert (Figura 90). Uma das peças que aparece representada na publicação deste autor não foi identificada durante a análise.
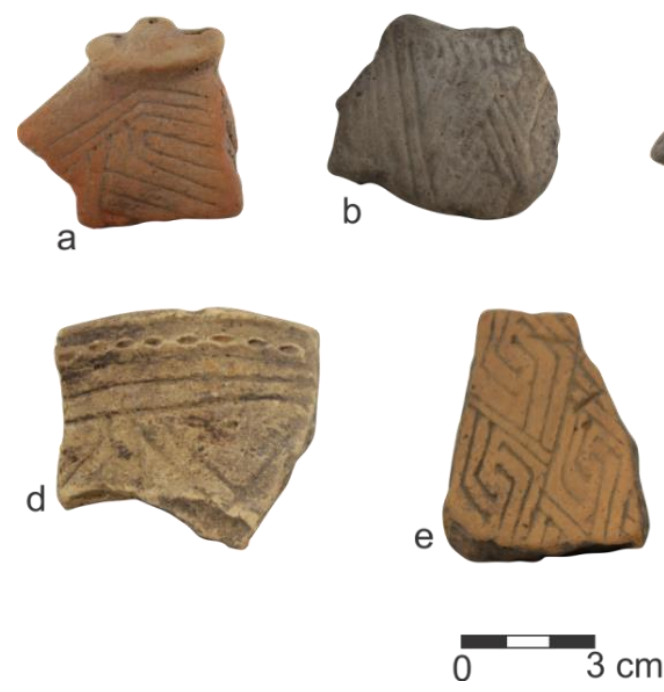
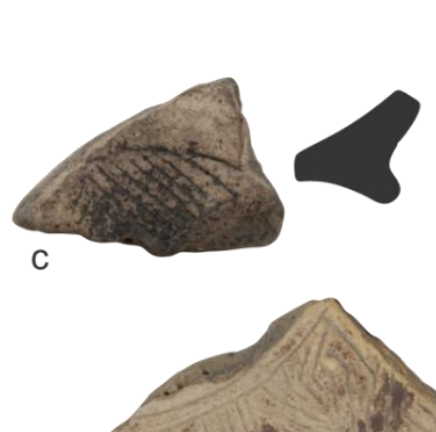

g
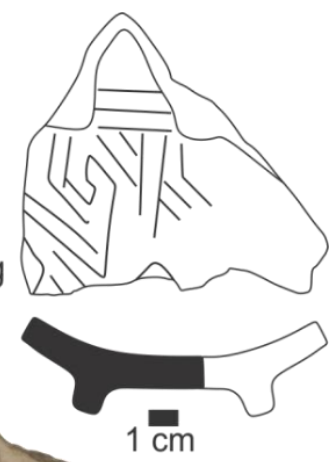

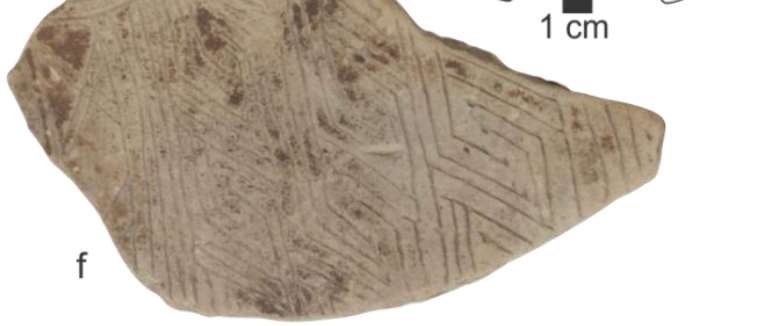

Figura 90. Fragmentos de cerâmica do estilo Paurá nas coleções de cerâmica Konduri. Proveniência: Mabaia (a), Serrinha (b), Varre Vento (c), sem proveniência (d), Sacuru (e), Preguiça (f), Boa Vista (g). Coleções Peter Hilbert (a-c), Barbosa de Faria/Comissão Rondon (d-f) e material de superfície (Chumbre sd).

A pasta dos fragmentos Paurá não é diferente do estilo Konduri. Quase todas as peças apresentam apenas cauixi em alta concentração - apenas um exibe também caco moído. A coloração da face externa é predominantemente amarela e laranja, havendo também branca, cinza e preta. Os núcleos têm a mesma coloração das faces (tipo 1). Não foi feita uma estimativa de dureza, mas estas peças pareciam ser mais duras que as Konduri. Em termos de partes das vasilhas representadas, há duas bordas, uma base e todos os outros fragmentos são paredes. Uma das bordas é de uma vasilha fechada e a outra é provavelmente de uma vasilha aberta com boca irregular. A base é anelar e se parece com a das "cuias com pedestal" (ver MORAES, 2013). 


\begin{tabular}{|c|c|c|}
\hline Coleção & Sítio & Quantiade \\
\hline \multirow{3}{*}{$\begin{array}{l}\text { Peter } \quad \text { Hilbert } \\
(1952)\end{array}$} & Serrinha & 2 \\
\hline & Varre Vento & 2 \\
\hline & Mabaia & 1 \\
\hline \multirow{3}{*}{ Barbosa Faria/ } & Santa Maria & 1 \\
\hline & Jacopá & 1 \\
\hline & Preguiça & 1 \\
\hline Comissão Rondon & Sem referência & 3 \\
\hline TOTAL & & 11 \\
\hline
\end{tabular}

Tabela 11. Proveniência de fragmentos do estilo Paurá em coleções da região dos rios Trombetas e Nhamundá.

Quase todos fragmentos associados ao estilo Paurá apresentam o padrão de incisões onduladas característico. Apenas um fragmento foi identificado pela presença de um pequeno apêndice. As incisões são majoritariamente na face externa - apenas 2 exemplares com incisão na face interna. Uma das bordas exibe ainda um pequeno filete com ponteado e a outra possui um pequeno aplique no lábio. Uma fina camada revestimento amarronzado/avermelhado, como mencionado por Nimuendajú, foi identificada na face externa de três peças.

A baixa quantidade das peças do estilo Paurá, contrasta com sua dispersão (). As peças do coleção Peter Hilbert são todas de sítios do baixo curso do rio Nhamundá (Serrinha, Varre Vento e Mabaia). No caso da coleção Barbosa de Faria/Comissão Rondon, há peças coletadas no médio Trombetas (Santa Maria), foz do Trombetas (Jacupá) e na região entre Oriximiná e Óbidos (Preguiça). As informações sobre essa coleção não são muito seguras, mas um fragmento deste estilo foi encontrada no sítio Boa Vista (CHUMBRE, sd). Apesar da baixa frequência, os objetos desse estilo alcançavam possivelmente toda a dispersão Konduri. 


\subsubsection{Estilo Espinha de Peixe}

Considerando a presença de artefatos dos estilo Santarém e Parauá associados a cerâmica Konduri e também a padronização da cerâmica Espinha de Peixe, propomos a hipótese de que esse material também pode fazer parte de circuito de trocas. No atual estágio do conhecimento não pode ser descartada a possibilidade de que se trata de uma produção local resultante da variabilidade interna. Como afirma Rye, "[i]t is conceivable that potters working in the same place at the same time could produce vessels that an archeologist might assign to separate technological traditions. For example, untempered clay may be used for large water containers and shell-tempered clay for cooking vessels" (1981, p.5). Essas duas possibilidades explicativas não se excluem: uma cerâmica com determinadas potencialidades físicas, como capacidade de transmissão de calor ou resistência ao choque térmico pode ter sido preferidas durante a realização de trocas devido a suas características de performance. Apenas com análises arqueométricas de proveniência será possível verificar qual pode ser o cenário mais adequado sobre a relação entre as cerâmicas Espinha de Peixe e Konduri.

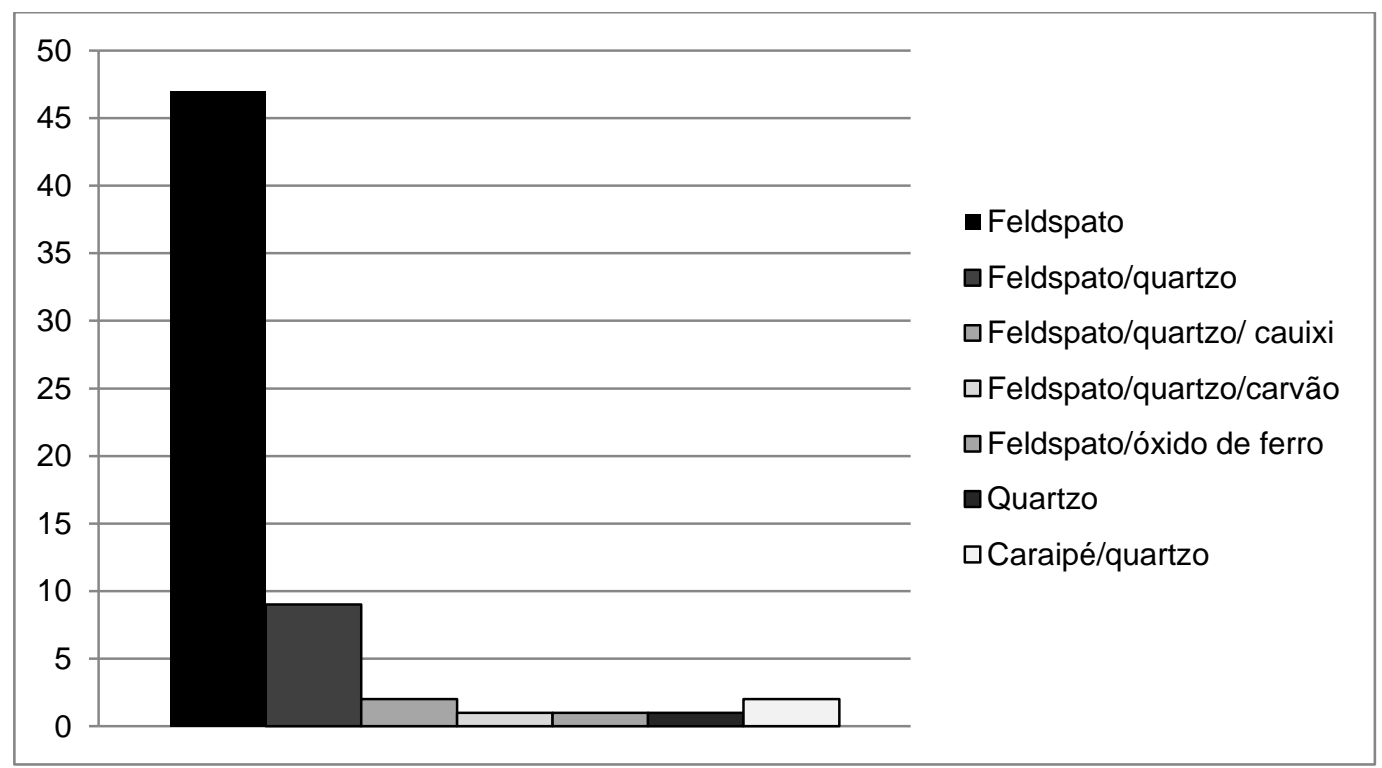

Gráfico 29. Frequência por tipo de antiplástico em cerâmica Espinha de Peixe nas coleções Aricy Curvello, Barbosa de Faria/Comissão Rondon e Peter Hilbert. 

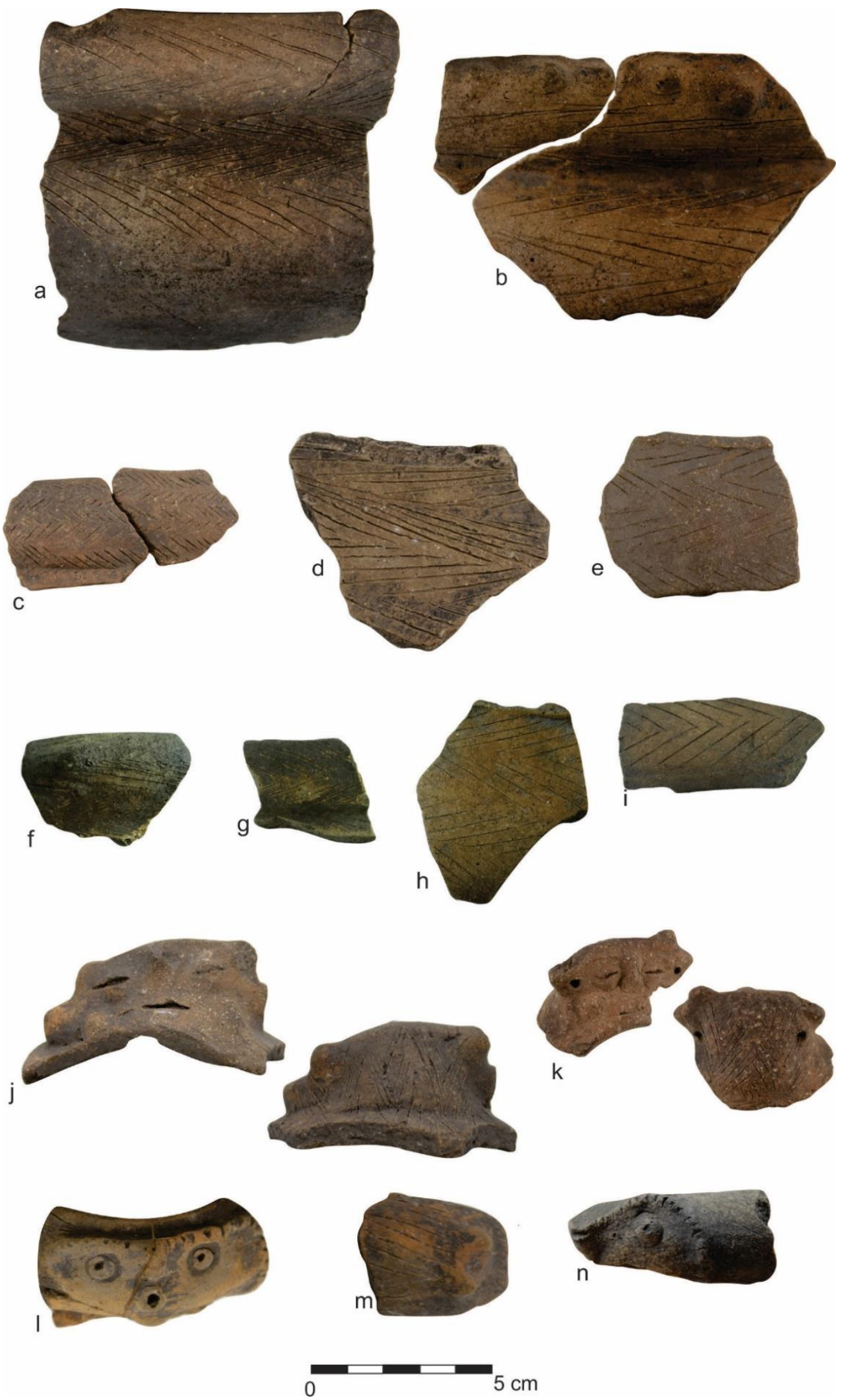

Figura 91. Fragmentos de cerâmica Espinha de Peixe: Erepecuru (a-b), Cocal (b-c, k, m), Oriximiná (e), Lago Batata (f-i), Sucurijú (j, 1), Sacuri (n). Coleções Barbosa de Faria/Comissão Rondon (j, 1, m, n), Peter Hilbert (a-e, k) e Aricy Curvello (f-i). 

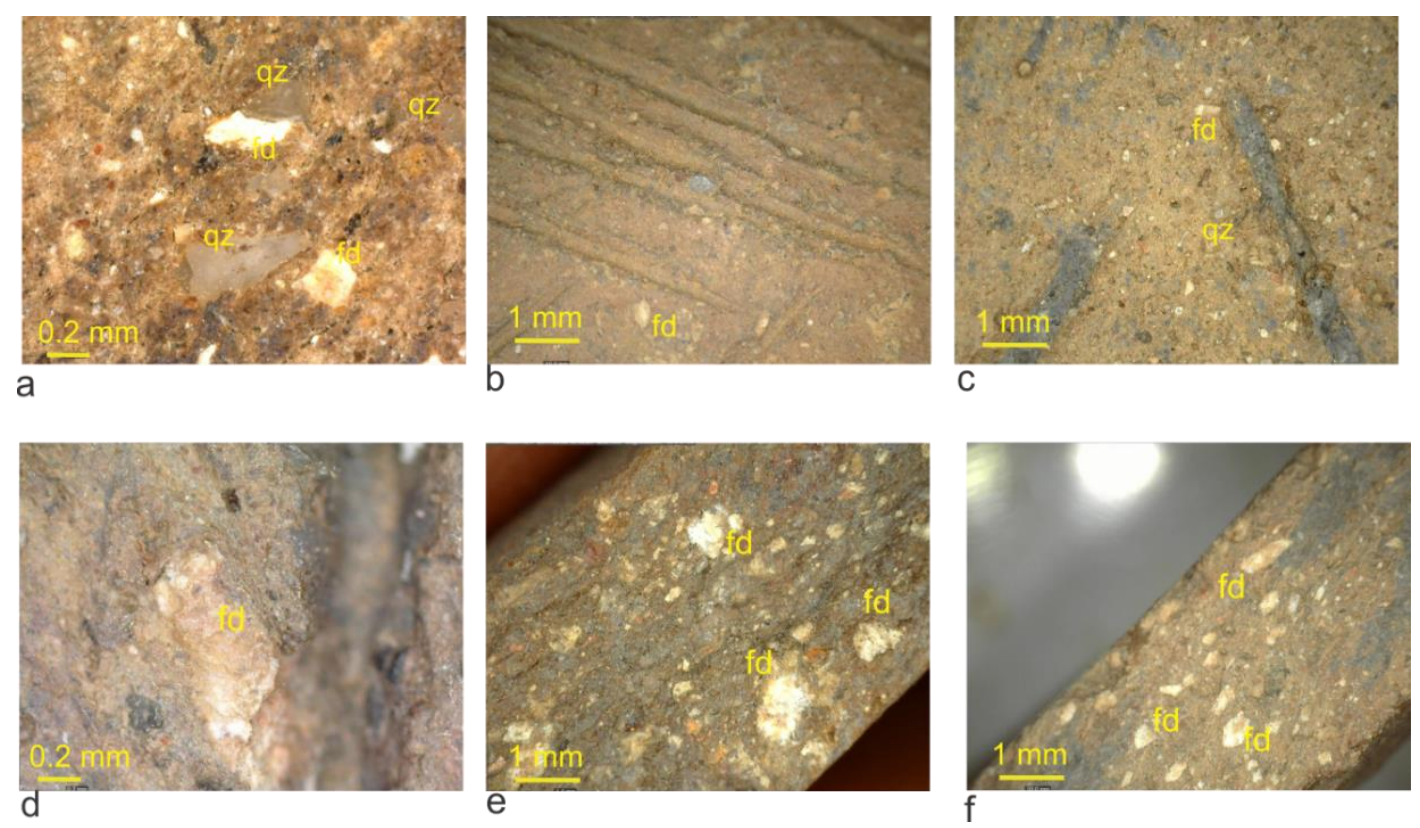

Figura 92. Elementos antiplásticos e concentração na cerâmica Espinha de Peixe: Erepecuru (a, d), Cocal (b, e) e Lago Batata (c, f). Coleções Peter Hilbert (a,b, d, e ) e Aricy Curvello (c, f). A indicação "fd" marca feldspato e "qz", quartzo.

A decoração tanto na amostra estudada quanto no material descrito nas publicações também é bastante regular. O padrão inciso presente nessa cerâmica é composto por linhas retas muito finas (cerca de 1,0 mm) formando faixas em "V deitado" ou "espinha de peixe", que se alternam, como setas em uma direção e outra (Figura 91 a-i). A área de decoração é entre a borda até bojo superior, sendo o campo decorativo delimitado por uma linha, em alguns casos. Apesar de uma aparente regularidade nas incisões, muitas são assimétricas, com variação no comprimento das linhas e de sua inclinação. Menos frequentes são modelagens de "botões" filetes aplicadas às bordas (Figura 91 b, e). Duas peças da coleção Barbosa de Faria apresentam um padrão de cara antropomorfa composta por olhos aplicados com pontos e filetes - um deles entalhado. Na mesma coleção há um apêndice antropomorfo com olhos em grão de café e cabelo com padrão “espinha de peixe”. Na coleção Peter Hilbert, há uma pequena borda $(5,0 \mathrm{~cm}$ de diâmetro $)$ com um apêndice muito semelhante, mas um pouco menor. Em uma das coleções na Cultura de Oriximiná, Camila Jácome fotografou um pé modelado Espinha de Peixe também com um padrão cara antropomorfa. Essas poucas modelagens mostram uma possível conexão com o estilo Konduri, especialmente gargalos com padrão antropomorfo. 


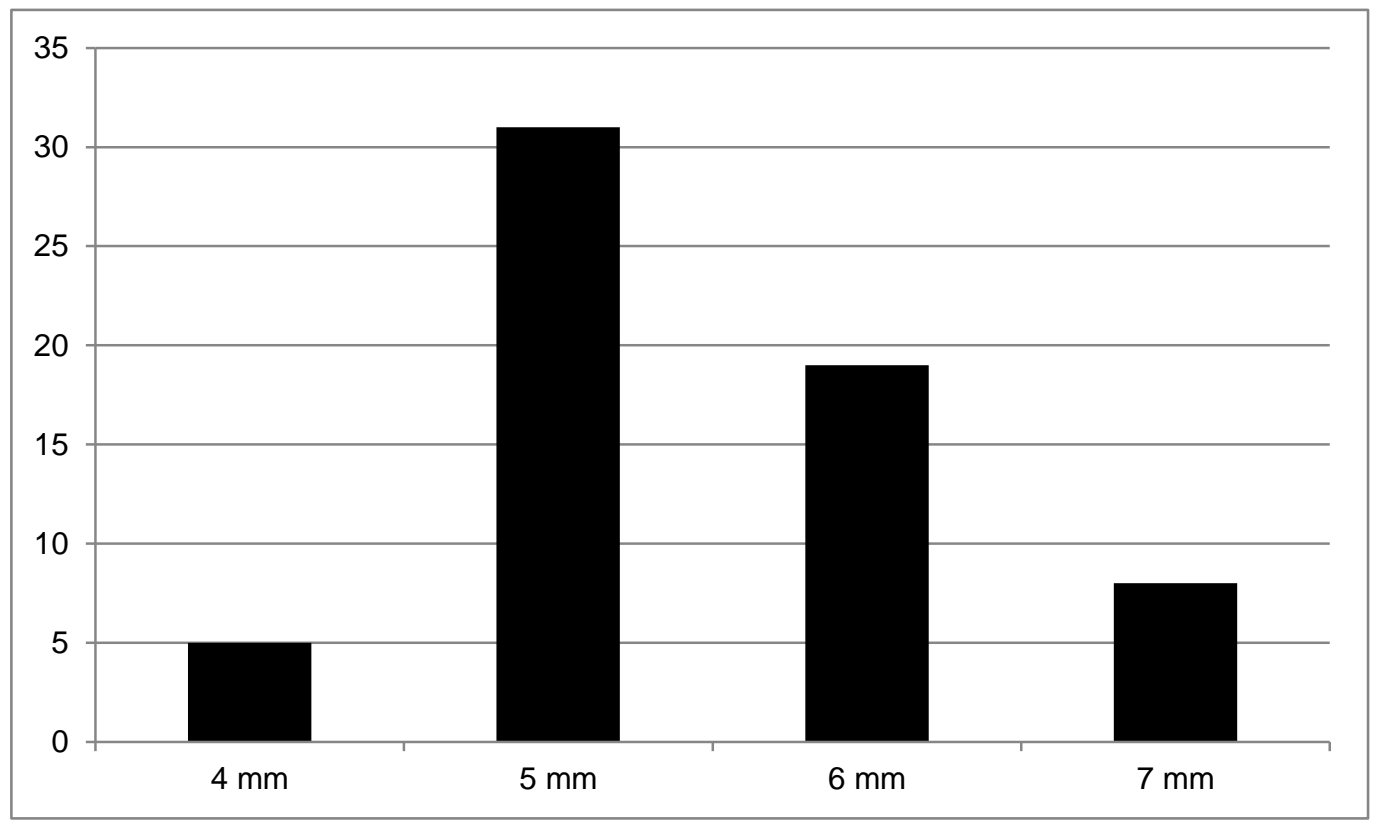

Gráfico 30. Frequência de classes de espessura em cerâmica Espinha de Peixe. Coleções Aricy Curvello, Barbosa de Faria/Comissão Rondon e Peter Hilbert.

Nas coleções estudadas são raras as marcas de uso, o que deve resultar dos processos pós-deposicionais atuando em peças na superfície. Duas peças Espinha de Peixe, entretanto, exibem vestígios de fuligem na face externa. Nos sítios do rio Mapuera e no sítio Oriximiná 3 são mencionadas também peças com vestígios de fuligem. Considerando a espessura das paredes e a predominância de antiplástico mineral - características que aumentam a performance térmica em termos de velocidade de aquecimento - é provável que as vasilhas Espinha de Peixe tivessem um uso frequente sobre o fogo.

A dispersão da cerâmica Espinha de Peixe está restrita ao baixo e médio curso do rio Trombetas (Tabela 11), chegando à foz dos rios Erepecuru e Mapuera. Na coleção Barbosa de Faria, há dois fragmentos cuja proveniência é indicada como "Sucurijú", sugerindo a presença dessa cerâmica nas imediações de Óbidos. A falta de pesquisa nessa área e a história de formação complexa da coleção deixam dúvidas se tais peças resultariam de misturas durante o transporte ou armazenamento. Nenhum exemplar de cerâmica Espinha de Peixe foi encontrado no município de Juruti, mesmo com a intensidade de pesquisas, o que indica que essa cerâmica não está sempre associada à cerâmica Konduri. 


\begin{tabular}{|c|c|c|}
\hline Coleção & Sítio & Quantidade \\
\hline Aricy Curvello & Lago Batata & 32 \\
\hline \multirow{5}{*}{$\begin{array}{l}\text { Peter } \\
(1952)\end{array}$} & Cocal & 16 \\
\hline & Oriximiná & 2 \\
\hline & Boca dos Anjos & 1 \\
\hline & Erepecuru & 2 \\
\hline & Ponta da Mafada & 1 \\
\hline \multirow{3}{*}{$\begin{array}{l}\text { Barbosa } \\
\text { Faria/Comissão } \\
\text { Rondon }\end{array}$} & Sacuri & 4 \\
\hline & Sucurijú & 4 \\
\hline & Cocal & 1 \\
\hline \multicolumn{2}{|l|}{ TOTAL } & 63 \\
\hline
\end{tabular}

Tabela 12. Quantidade de fragmentos do estilo Espinha de Peixe por proveniência.

A proporção de cerâmica Espinha de Peixe no sítio Aviso I ainda é uma questão em aberto. Guapindaia denomina o antiplástico presente na cerâmica Espinha de Peixe como "rocha triturada", seguindo a indicação de Costa et al. (2004b) sobre a adição intencional de feldspato e quartzo na cerâmica do médio rio Trombetas. O antiplástico "rocha triturada" foi identificado em 10,6\% $(n=589)$ da amostra do sítio Aviso I. A quantidade de fragmentos com incisão e este antiplástico é bem menor, somando apenas 104 peças. Na discussão apresentada por Guapindaia, não fica claro se a autora acredita que todo o material com "rocha triturada" compõe o conjunto específico da cerâmica Espinha de Peixe, ou se há alguma diferença qualitativa entre as peças com incisões e as sem incisões. Se o material Espinha de Peixe representar 10,6\% do total da amostra, esta quantidade contradiz a expectativa de uma pequena proporção de objetos obtidos por trocas (RENFREW, 1975) - com exceção de objetos em uma "cadeia de prestígio". O número mínimo de vasilhas representadas nesta amostra e o tamanho dos fragmentos coletados também seriam dados importantes para contrapor com o material caracteristicamente Konduri. Considerando apenas o material com incisões e a pasta característica a proporção de cerâmica Espinha de Peixe é bastante baixa (cerca de $1,9 \%$ ), mas, como se sabe, o bojo inferior e a base não costumam receber incisões. 


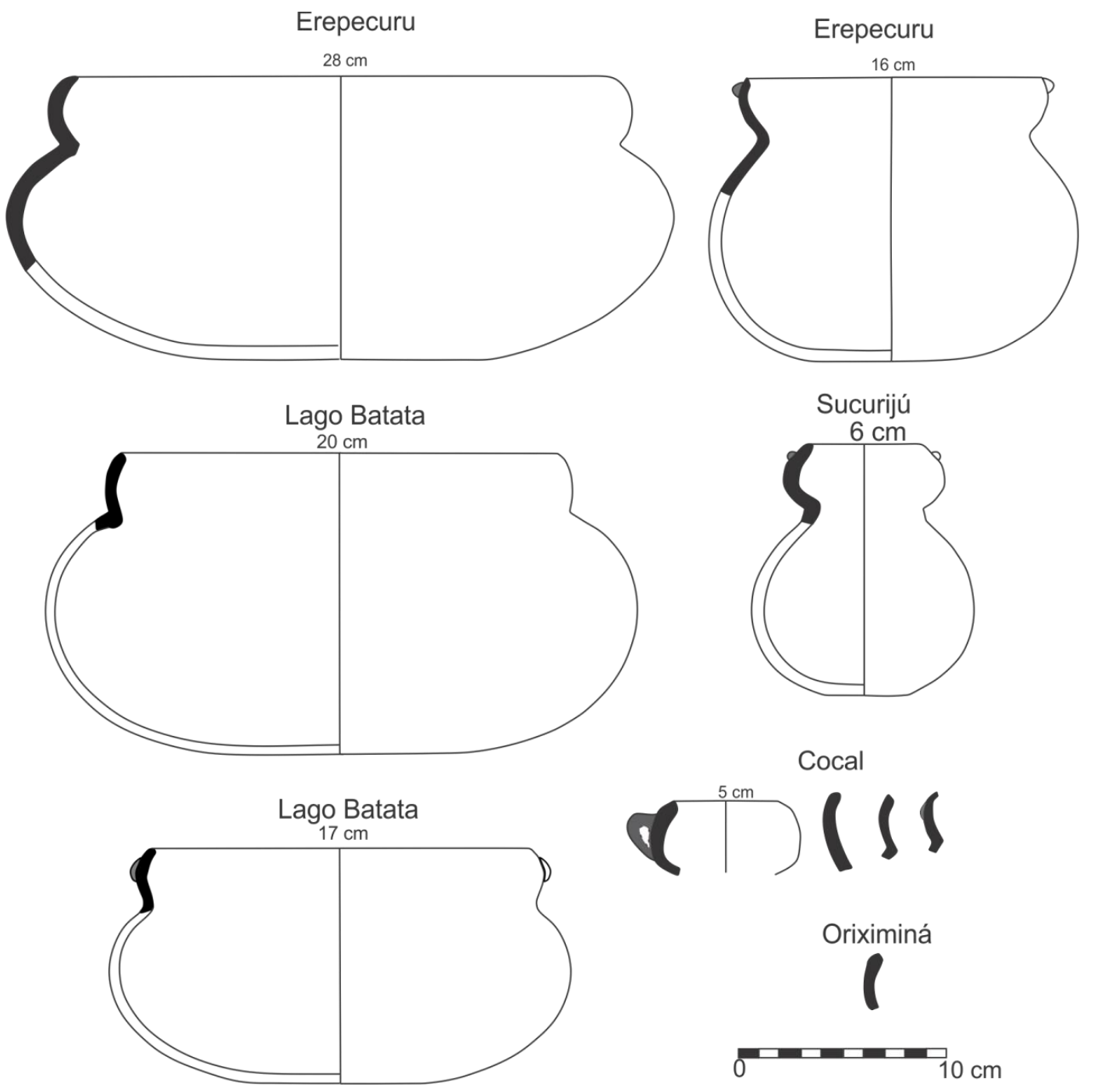

Figura 93. Reconstituições e perfis de borda de vasilhas Espinha de Peixe.

Se a cerâmica Espinha de Peixe não era produzida localmente, de onde estaria vindo? O desconhecimento de sítios com esse estilo pode resultar de vieses amostrais e analíticos para contextos do rio Trombetas e seus afluentes. Protásio Frikel, por exemplo, encontrou essa cerâmica no médio Erepecuru (HILBERT, 1955a, p. 31), mas nada se sabe sobre esses sítios. As informações disponíveis sobre o material do sítio Colônia no médio curso do rio Trombetas indicam uma cerâmica com as mesmas características do conjunto Espinha de Peixe: com feldspato e quartzo como antiplástico, com incisões finas e espessura em torno de 5,0 mm (COSTA et al., 2004b). Como a descrição do material é muito sumária e não há fotografias ou desenhos das peças não é possível saber os autores se referem ao conjunto em questão. Se este for o 
caso, seria possível considerar Espinha de Peixe como um complexo cerâmico tal qual Konduri ou Santarém, como sugere Jácome (2017). Outra possibilidade, que ainda não pode ser descartada, é a de que não tenha existido uma ocupação caracterizada pela cerâmica Espinha de Peixe, mas que esta seja destinada apenas para trocas, como no caso da cerâmica Panzaleo no Equador (BRAY, 1995).

Pesquisas em áreas próximas da bacia do rio Trombetas têm reportado a presença de cerâmica com motivo inciso "espinha de peixe" em Monte Alegre (BARRETO et al., 2016), ao longo do rio Tapajós (SCHAAN, 2016; ROCHA, 2012, 2017) e um de seus afluentes (GASPAR, 2014). Não se trata de um motivo complexo, podendo esta semelhança resultar apenas de convergência. Ainda não foi feita uma comparação sistemática, mas com exceção de alguns fragmentos do sítio Itapacurá I (município de Itaituba) há poucas semelhanças com o material do rio Trombetas na formação do padrão gráfico que encadeia esse motivo, e também na execução das incisões.

\subsection{Semelhanças morfológicas: empréstimo ou ancestralidade?}

As trocas de artefatos são apenas uma faceta das interações visíveis a partir dos conjuntos cerâmicos no Baixo Amazonas datados do período pré-colonial tardio. Esses objetos apontam relações entre os produtores do estilo Konduri com nas adjacências orientais e ocidentais. Além disso, peças do estilo Konduri são encontradas na porção setentrional de seu limite de dispersão. Outras relações fazem parte do desenvolvimento e formação do estilo, mas não são facilmente delimitáveis, podendo indicar processos históricos muito distintos. As semelhanças entre atributos ou etapas da cadeia operatória de complexos cerâmicos podem ser indicadores de ancestralidade comum, difusão de conhecimento ou convergência técnico-funcional. Excluindo esta última razão pragmática, como diferenciar dois processos distintos que podem se sobrepor?

$\mathrm{Na}$ arqueologia da Amazônia, os horizontes estilísticos, depois reclassificados como tradições foram construídos quase exclusivamente por meio das técnicas decorativas, o que se refletiu em suas denominações. Meggers e Evans (1961) destacaram que as técnicas decorativas (inciso, ponteado, raspagem) isoladas não seriam indicadores seguros de "persistências de tradições locais". Décadas depois, Meggers (1990) definiu as tradições cerâmicas a partir de "um conjunto de técnicas diagnósticas 
de decoração". Machado (1991) fez uma crítica a essa perspectiva, expondo a fragilidade das classificações apenas a partir de um tipo de atributo na arqueologia da região. Até o presente, entretanto, continuamos a enfatizar enormemente a relação entre técnicas decorativas, apesar de alguns desenvolvimentos em relação à morfologia e padrões gráficos no caso Tradição Polícroma (BELLETTI, 2015; OLIVEIRA, 2016).

Desde a formulação inicial, a cerâmica Konduri foi incluída no Horizonte Inciso Ponteado, sugerindo uma relação histórica com os complexos cerâmicos Santarém, Mazagão, Arauquín, Maburana tardio e também Itacoatiara - este último revisto nos recentemente anos (LIMA, 2013). A definição desse horizonte se baseou na combinação de três técnicas decorativas: incisão, ponteado e modelado. O traço "mais universal" dessa tradição seria a presença de frisos compostos por incisões e ponteados na face interna de bordas de tigela e no gargalo de potes (MEGGERS, EVANS, 1961). Outras características apontadas por Meggers e Evans são o uso de linhas paralelas e espaçadas e apêndices modelados. Sua redefinição como "tradição" não modificou a caracterização inicial, apenas destacando que alguns complexos poderiam ter pintura (BROCHADO et al., 1968; CHMYZ, 1976). Lathrap (1970) caracterizou essa tradição - por ele denominada "tradição de incisão fina" - pelo uso de cauixi como antiplástico, incisões retilíneas com traço em "V" e o uso de modelagens (apêndices zoomorfos e antropomorfos e padrões geométricos). $\mathrm{O}$ autor também destacou, entre os padrões gráficos, frisos incisos formando triângulos isósceles contíguos e o efeito de "glacê de bolo" na combinação de filetes e semiesferas modelados. A dispersão da Tradição também tem uma grande amplitude para esses autores, incluindo o norte da América do Sul e chegando até abaixo da calha do Amazonas. Não foi proposta uma revisão da caracterização dessa tradição para a bacia amazônica até o momento, apesar das dificuldades em classificar alguns complexos, como o Paredão, vinculado a Tradição Borda Incisa por alguns autores (HILBERT, 1968; LIMA; NEVES, 2011) e também a Incisa Ponteada por outras (LATHRAP, 1970; MORAES, 2006). No caso de materiais também incluídos na Tradição Incisa Ponteada na bacia do Orinoco e nas Guianas, uma caracterização mais recente foi proposta, sendo os principais atributos: lábios incisos, filetes ponteados, apêndices modelados, linhas incisas formando triângulos, bordas lobadas, paredes corrugadas, faces antropomorfas com grandes sobrancelhas incisas em gargalos e estatuetas antropomorfas (ROSTAIN, VERSTEEG, 2004, p. 239; ver também ZUCCHI et al., 1984; ANTZACK et al., 2017). As caracterizações feitas 
diferem em alguns atributos e também nos complexos cerâmicos agrupados, mas tem os mesmos elementos centrais, sendo raros os elementos morfológicos incluídos.

A cerâmica Konduri, em relação às áreas adjacentes, exibe semelhanças em termos de técnicas decorativas com os complexos Santarém, Saracá, Paredão, Axinim, Paurá, Parauá e Sawré Muybu (SCHAAN, 2015, 2016; GOMES, 2002, 2016; MARTINS, 2012a, 2012b; MORAES, 2013; ROCHA, 2017; NIMUENDAJÚ, 2004; MARTINS, 2012a, 2012b). Com exceção do estilo Paurá, do qual não se dispõe de datações, todos são do período pré-colonial tardio, com datas em torno dos anos 600 e 1650 AD. As cerâmicas Paredão, Parauá e Axinim tem idade de produção estimada em torno do século VII da era cristã. O uso frequente do ponteado na cerâmica Konduri é encontrado também em alguns desses conjuntos, mas de modo distintos. No complexo Saracá, por exemplo, há um uso intenso de ponteados e também filetes aplicados e entalhados. A execução dos pontos é muito distinta tanto em termos de forma, tamanho e área de aplicação - borda e bojo superior na face externa. Em algumas peças também aparecem pontos feitos com instrumentos ocos, semelhantes aos muito frequentes no estilo Konduri. Não estão presentes nesse estilo, entretanto, os apêndices zoomorfos. A cerâmica Santarém exibe um grande investimento em apêndices e filetes aplicados semelhante aos Konduri, mas o ponteado está restrito a raros padrões aplicados a bordas e em apliques cabeças de urubu. Os padrões incisos curvilíneos predominam na cerâmica Santarém, mas também há alguns retilíneos formando triângulos. Uma notável semelhança iconográfica entre vários estilos cerâmicos da Tradição Incisa Ponteada é a presença de padrões aplicados em forma de caras antropomorfas - especialmente em vasos com gargalo. Isso também ocorre na cerâmica "Sapupé" ou Sawré Muybu, que apresenta, nos espécimes mais elaborados, filetes e semiesferas ponteados compondo apliques muito semelhantes aos Konduri. Jácome (2017) relaciona os apêndices em pares ("gêmeos") do estilo Konduri aos encontrados no complexo Hertenrits no Suriname (ver ROSTAIN; VERSTEEG, 2004). Apesar de ser classificada como parte da Tradição Borda Incisa por alguns autores (LIMA; NEVES, 2011), a cerâmica Paredão, encontrada no Médio Amazonas, apresenta uma notável semelhança decorativa com a Konduri: apêndices antropomorfos, padrões em incisão fina (às vezes formando triângulos), uso de linhas ponteadas, semiesferas aplicadas com ponto central - além do padrão de face antropomorfa em gargalos (LATHRAP, 1970; MORAES, 2013). 
As semelhanças de técnicas decorativas entre os complexos da Tradição Incisa Ponteada ainda permanecem impressionistas e levam a um problema explicitado por Moraes e Nogueira (2016) sobre a cerâmica Axinim: em nível de observação geral podem ser identificadas semelhanças entre muito conjuntos distintos. O problema de diferenciar ancestralidade comum, permitindo a classificação dentro de uma tradição, e empréstimos também perdura. Moraes (2013), em sua tipologia, sugere brevemente o compartilhamento de algumas morfologias entre as cerâmicas Paredão, Axinim e Konduri. As pesquisas sistemáticas ainda são muito recentes: há poucas vasilhas inteiras encontradas fora das imediações da cidade de Santarém e também não se dispõe da frequência dos padrões gráficos. Os vasos chamados pelo autor como "cuias com pedestal" parecem ser muito genéricos e, apesar das sugestões de Moraes, nenhum vaso naviforme é conhecido na cerâmica Konduri. Ainda não foi realizado um esforço comparativo de morfologias e padrões gráficos.

Apesar das semelhanças com as cerâmicas da Tradição Incisa e Ponteada das Guianas e Orinoco, não identificados esses elementos morfológicos na bibliografia. Isso não significa que não existam relações com produtores de outros estilos cerâmicos. Mais pesquisa é necessária para que comparações cada vez mais detalhadas e confiáveis possam ser construídas. Há três elementos morfológicos que se são salientes no estilo Konduri e também são encontrados em outros complexos do Baixo e Médio Amazonas (Mapa 8/Tabela 13) : assadores com banda incisa, pés ou suportes modelados e alças sobre a abertura da vasilha. Essa combinação de morfologia e motivo gráfico e também tipos de apliques específicos indica alguma relação entre esses conjuntos encontrados ao longo da calha do rio Amazonas ou em áreas próximas. Como no caso das trocas, os elementos semelhantes são encontrados a leste e a oeste da dispersão do estilo Konduri.

Os assadores dos complexos Paredão, Saracá, Santarém, Sawre Muybu têm formas idênticas as classes 1 e 3 do estilo Konduri e também apresentam bandas incisas na face interna das bordas (Figura 94 a-d) (HILBERT, 1968; MACHADO, 2005; MORAES, 2006, 2013; SIMÕES, MACHADO, 1987; MACHADO, 1991; NIMUENDAJÚ, 2004; ROCHA, 2017; MARTINS, 2012a, 2012b). Os padrões gráficos conformam certa identidade visual a esses objetos entre a desembocadura do rio Tapajós até a Amazônia Central. Os exemplares do complexo cerâmico Paredão são os mais semelhantes aos Konduri; podem apresentar padrões em incisões finas em 
hachurado ou formando triângulos e retângulos; também exibem marcas de cestaria na base e certa variação morfológica - algumas mais rasas e outras mais profundas com borda direta ou extrovertida (HILBERT, 1968; MACHADO, 2005; MORAES, 2006, 2013). As semelhanças de alguns assadores são tão notáveis que Panachuk sugeriu que devido aos traços largos poderia haver uma associação direta com a "Tradição Borda Incisa", mais provavelmente com a cerâmica Paredão (PANACHUK, 2016 org., p. 76; SCIENTIA, 2008). Provavelmente, se uma borda extrovertida de assador encontrada em contexto Konduri fosse misturada a um conjunto cerâmico Paredão, dificilmente a diferença seria notada- antiplástico, morfologia e padrão gráfico são muito semelhantes.

Os pés modelados, por sua vez, são encontrados na calha do rio Amazonas apenas nos complexos Konduri, Santarém, Saracá, Axinim, Parauá e Sawré Muybu, sugerindo uma área de concentração que também pode estar vinculadas a processos históricos (Figura 94 i-o). Fora dos contextos Konduri, os pés parecem ser muito menos frequentes. Novas pesquisas poderão ampliar as outras conhecidas para outras áreas, confirmando ou não essa impressão - especialmente no baixo Madeira e na localidade de Parauá (Santarém). No caso do estilo Santarém, os pés estão associados à morfologia dos "pratos concêntricos". A forma dos pés na cerâmica Santarém é cônica, alongada e oca, como a maioria dos casos na cerâmica Konduri. A localização dos furos, entretanto, é lateral e/ou a partir do extremo inferior. Outra semelhança marcante é a presença na porção superior de um padrão de face antropomorfa nos trípodes Santarém. Na cerâmica Axinim são conhecidos pés curtos, cônicos, maciços e sem decoração, sendo estes geralmente encontrados em grandes urnas funerárias (MORAES, 2013). Foram identificados também pés cilíndricos e curtos no sítio Vila Gomes, baixo Madeira. No complexo Saracá, apenas uma vasilha com base trípode é apresentada por Machado (1991). Os pés dessa vasilha são curtos, cilíndricos e maciços. No sítio Lago do Jacaré, localidade de Parauá, Gomes encontrou associado a um estilo local, 6 pés curtos com morfologias variadas (cônicos, troncocônicos e cilíndricos), sendo apenas um oco e outros maciços. 


\begin{tabular}{|c|l|l|l|}
$\begin{array}{c}\text { Complexo } \\
\text { cerâmico }\end{array}$ & \multicolumn{1}{|c|}{$\begin{array}{c}\text { Antiplástico e decoração } \\
\text { predominante }\end{array}$} & \multicolumn{1}{|c|}{$\begin{array}{c}\text { Período de } \\
\text { produção }\end{array}$} & \multicolumn{1}{c|}{$\begin{array}{c}\text { Atributo } \\
\text { compartilhados }\end{array}$} \\
\hline Santarém & $\begin{array}{l}\text { Antiplástico: cauixi e caco moído } \\
\text { Decoração: modelada, incisa, } \\
\text { ponteada e monocromia (vermelho) e } \\
\text { policromia. }\end{array}$ & $\begin{array}{l}\text { XIII-XVII } \\
\text { AD }\end{array}$ & 2. Pé modelado \\
\hline Parauá & $\begin{array}{l}\text { Antiplástico cauixi Decoração: } \\
\text { modelada e incisa. }\end{array}$ & VII-XVII AD & 2. Pé modelado \\
\hline $\begin{array}{c}\text { Sawré } \\
\text { Muybu }\end{array}$ & $\begin{array}{l}\text { Aniplástico: quartzo e cauixi } \\
\text { Decoração: modelada, ponteada e } \\
\text { pintura (vermelha). }\end{array}$ & IX/X-XII AD & 2. Pé modelado \\
\hline Saracá & $\begin{array}{l}\text { Decoração:modelada, entalhada, } \\
\text { incisa, acanalada, ponteada e pintura } \\
\text { (vermelha).. }\end{array}$ & $\begin{array}{l}\text { AIII-XVII } \\
\text { AD }\end{array}$ & 1. Assador \\
\hline Axinim & $\begin{array}{l}\text { Antiplástico cauixi, Decoração } \\
\text { modelada, incisa e pintada (vermelho } \\
\text { e preto). }\end{array}$ & VII-XII AD & 1.Assador \\
\hline Decoração modelada e incisa. & VII-XIII AD & 2. Pé modelado \\
\hline
\end{tabular}

Tabela 13. Complexos cerâmicos do Baixo e Médio Amazonas com elementos morfológicos compartilhados com o estilo Konduri. Fontes: Gomes, 2016; Gomes, 2008; Rocha, 2017; Moraes, 2013; Moraes, 2006, Stampanoni, 2016. 


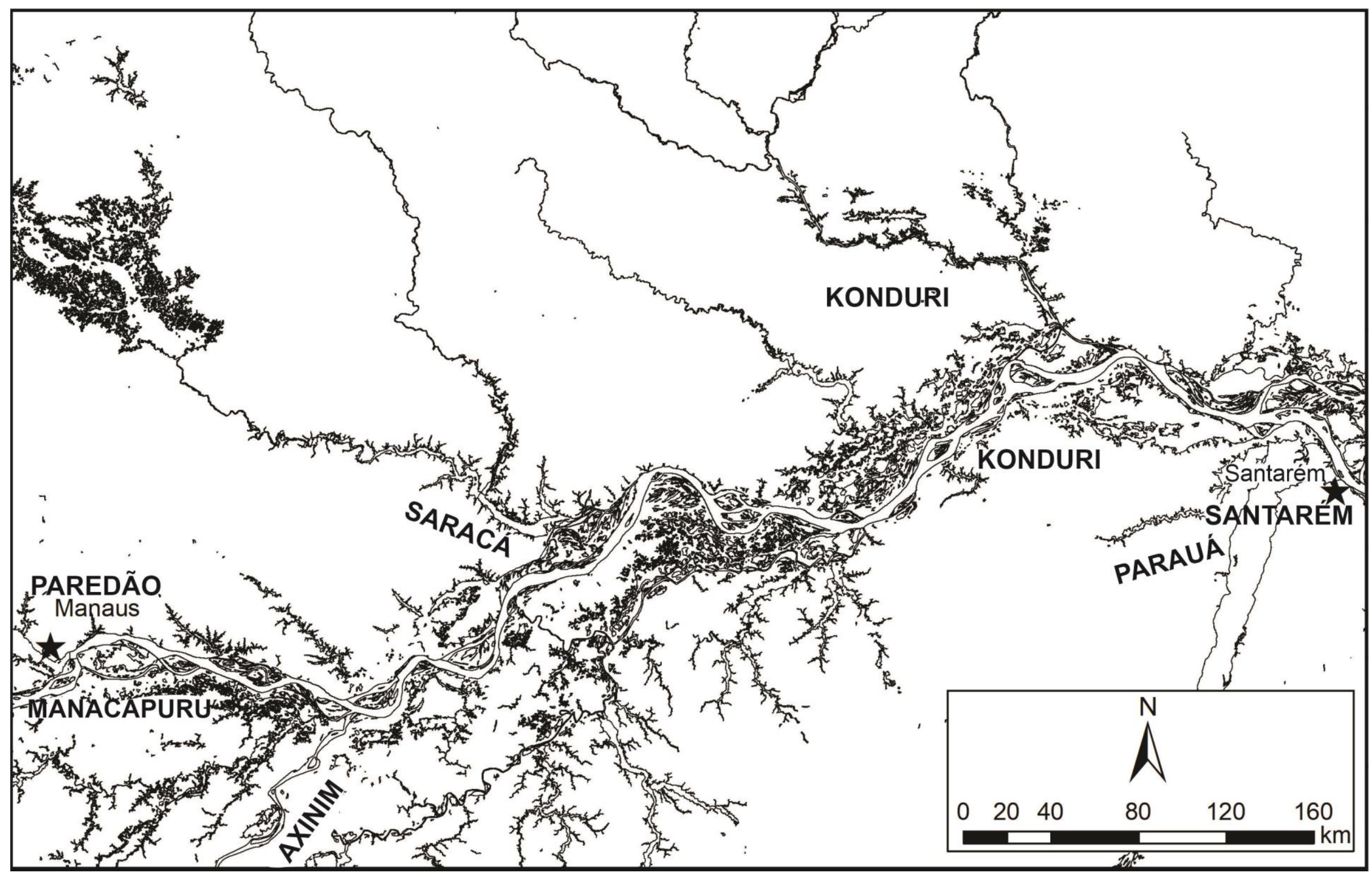

Mapa 8. Localização esquemática de complexos cerâmicos do Baixo e Médio Amazonas (Santarém-Manaus) com elementos morfológicos compartilhados com o estilo Konduri. Elaboração: Hnrique Koslowski e Marcony Alves. 

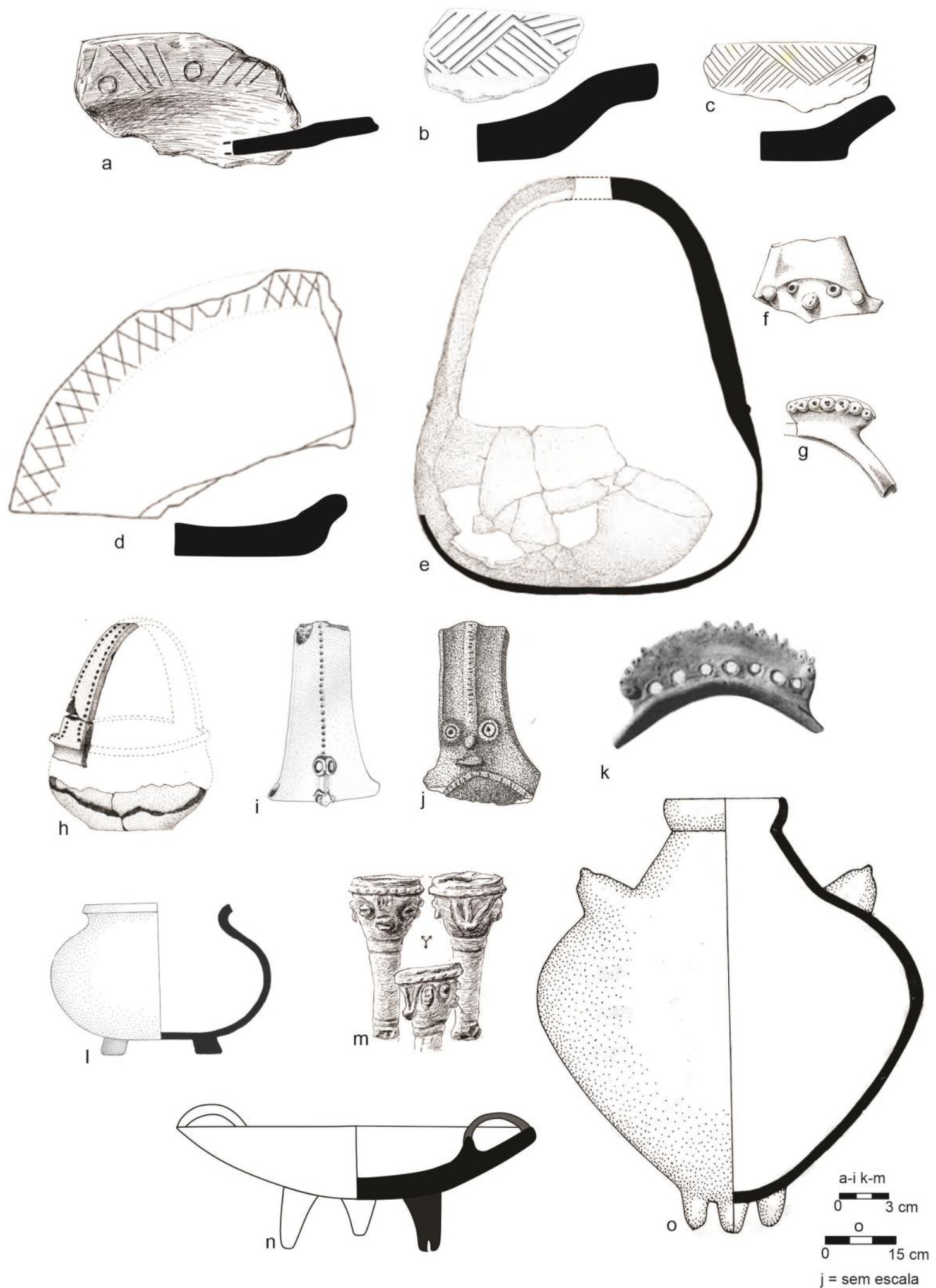

Figura 94. Elementos vinculados ao estilo Konduri por meio de ancestralidade comum e/ou difusão . Assadores: a- Santarém (Nimuendajú, 2004); b- Saracá (Machado, 1991); c-Paredão (Hilbert, 1968/ Moraes, 2013); d - Sawré Muybu (Rocha, 2017). Alças sobre orifício: e -Paredão (Moraes, 2006); f/g Paredão (Hilbert, 1968); h- Saracá (Stampanoni, 2016); i - Saracá (Machado, 1991); j’- Axinim (Bars Hering et al., 2014); k - Manacapuru (Hilbert, 1968). Pés modelados: 1- Saracá (Machado, 1991); m Santarém (Nimuendajú, 2004); n - Santarém (Coleção Tapajônica/MAE-USP/Desenho Marcony Alves); o - Axinim (Simões; Lopes, 1987). 
Mais ou menos a mesma área em que se encontram os assadores com bandas incisas e pés modelados há também vasilhas com alças aplicadas a abertura (Figura 90 e-k). Os complexos cerâmicos em que há evidências dessa morfologia são, além do estilo Konduri, Manacapuru, Paredão, Axinim e Paurá. As alças do estilo Konduri apresentam uma composição visual característica com filetes aplicados com incisões e ponteados, padrões incisos e apliques na base e centro dos arcos. Os apliques análogos encontrados nos outros estilos não apresentam a mesma elaboração, mas há uma ênfase similar em modelagens nas bases dos arcos. A morfologia de vasilha com alça sobre a borda, conhecida como "cesto com alça”, é considerada uma das mais características da cerâmica Paredão (HILBERT, 1968; MACHADO, 2005, LIMA, 2008; MORAES, 2006, 2013). Nesse estilo, o arco modelado é sempre muito mais espesso que as paredes à diferença dos exemplares Konduri. As vasilhas conhecidas ou reconstituídas têm contorno simples, com orifício aberto ou levemente fechado. Em termos de decoração, predominam modelagens aplicadas na junção entre a alça e a borda, como semiesferas e o motivo rosto. Alças sobre borda associadas a contextos Manacapuru foram coletadas por Hilbert (1968) e exibem apêndices elaborados ao centro do arco. A ausência desses apliques em áreas pesquisadas mais recentes pode sugerir que esses objetos são raros, podendo ter sido obtidos por trocas com produtores da cerâmica Paredão (ver NEVES et al., 2019). As alças Axinim exibem filetes aplicados ao longo do centro do arco e sugestões de motivo rosto (MORAES, 2013; BARS HERING et al., 2014). Em contextos do rio Urubu, alças muito semelhantes às Axinim foram encontradas com uma linha ponteada, ao invés de filete aplicado, e duas semiesferas aplicadas à base da modelagem, sugerindo também uma face humana (SIMÕES, MACHADO, 1987, p. 80; MACHADO, 1991; STAMPANONI, 2016). Na coleção reunida por Nimuendajú (2004) no sítio Terra Preta (Paraná de Ramos) aparecem alças com um botão aplicado ao centro com diversos padrões incisos em triângulo associados a fragmentos do estilo Paurá.

As semelhanças entre os assadores, pés modelados e alças sobre borda entre complexos cerâmicos do Médio e Baixo Amazonas podem indicar tanto ancestralidade comum quanto difusão. Para além de elementos morfológicos, há uma notável semelhança entre os estilos cerâmicos em termos de antiplástico e técnicas decorativas (Tabela 13), apesar haver provavelmente diferenças signfivativas em termos de morfologia das vasilhas de modo geral. Gosselain (2000) argumenta que elementos mais visíveis e maleáveis, do ponto de vista técnico, são também mais facilmente difundidos. No sentido contrário, os métodos de formação incial (primary forming) das vasilhas seriam de reprodução mais difícil na 
transmissão de conhecimentos entre adultos de comunidades de prática distintas, uma vez que tem uma baixa visilidade em relação ao produto final e estão vinculados a hábitos motores internalizados nas etapas inciais de aprendizagem. O compartilhamento das morfologias de assadores pode ser um indicador de ancestralidade, por meio de hábito motores e práticas alimentare comuns a uma mesma matriz cultural (BROCHADO, LATHRAP, 1982). A dispersão pan-amazônica dessas vasilhas muito rasas quase impossível determinar isso no atual estágio do conhecimento. É precio verificar se existem métodos distintos para a formação das memas morfologias e se sua distribuição espacial exibe elementos que podem ser indicadores de processos históricos. As bandas incisas nas bordas são um elemento facilmente copiável, se as pessoas de diferentes áreas entram em contato. A forma dos apliques e seus motivos gráficos também podem ser reproduzidos, mesmo que os processos técnicos sejam ligeiramente distintos. Caso as semelhanças resultem de interações entre membros de comunidades de prática distintas, este processo poderia ter se desenvolvido por em áreas de "confluência", como a foz dos rios Urubu e Madeira ou um pouco mais a leste, entre o Paraná de Ramos e rio Nhamundá. Se este for um caso de continuidade, a cronologia regional nos leva a pensar que os produtores dos complexos Paredão e Axinim, de ocupação mais antiga no Médio Amazonas, possam ter originados as variações em outros estilos posteriores ao ano mil AD nos rios Urubu, Trombetas, Nhamundá e Tapajós. Esses cernários, que não são mutuamente exclusivos, são coerentse com a hipótese proposta por Moraes (2013). O autor defende que, entre a área de dispersão do estilo Konduri e as imediações do rio Madeira, seria tanto um indicador de relações filéticas e quanto de difusão. Em sua dissertação, Moraes chegou a sugerir que poderia ter havido uma migração dos produtores da cerâmica Paredão da Amazônia Central para o Baixo Amazonas, dando origem aos estilos Santarém e Konduri (MORAES, 2006, p. 183). Mais recentemente, Belletti et al. (2016) identificaram preliminarmente no sítio Uricurituba Velha, no baixo curso do rio Madeira, fragmentos cerâmicos relacionáveis tanto a cerâmica Axinim, quanto Saracá e Guarita. Os autores sugerem que esses materiais podem indicar troca bem como a existência de "sistemas multiétnicos e multilinguísticos”. Esse problema poderá ser mais bem debatido com a ampliação de pesquisas voltadas para a compreensão de áreas "limítrofes" com o Baixo Madeira e o desenvolvimento de comparação sistemáticas de cadeias operatórias e morfologias cerâmicas. 


\subsection{Discussão}

O mapa criado por Nimuendajú foi o primeiro a ressaltar uma área de dispersão de materiais da cerâmica Santarém fora de sua área de produção, que ia desde a Serra de Parintins, a oeste, e Boca do Coati, a leste, sendo seu limite meridional o rio Iriri, afluente do Xingu (Figura 95). O fenômeno destacado no mapa de Nimuendajú e que se avoluma com o crescimento das pesquisas é equivalente ao que Caldwell (1964) descreveu como uma "esfera de interação": uma área extensa, perpassando diversos estilos cerâmicos, com determinados artefatos trocados e o desenvolvimento de instituições sociais semelhantes (ver BINFORD, 1965; ANTCZAK; ANTCZAK, 1999; ANTCZAK et al., 2017). Os produtores do complexo Konduri faziam parte de uma esfera de interação que abrangia, considerando as informações disponíveis, no eixo norte-sul, desde o baixo ou médio curso do rio Tapajós até alto curso do rio Mapuera. Os limites a oeste poderiam ser o baixo curso dos rios Madeira e Urubu ou até a confluência dos rios Negro e Solimões. A extremidade oriental dessa zona ainda é pouco conhecida, mas sabemos que ultrapassa o atual núcleo de urbano de Óbidos. Barreto et al. (2016) mostraram que os contextos pré-coloniais tardios de Monte Alegre devem estar relacionados a áreas setentrionais, com cerâmica Koriabo, e também ao baixo Tapajós e Trombetas. Os objetos trocados e as semelhanças entre alguns elementos morfológicos e gráficos no Baixo Amazonas sugerem um quadro complexo, marcado por redes de interações multicentradas no sentido leste-oeste e norte-sul, incluindo trocas e fluxo de informação. Trata-se de uma esfera de interação no Baixo Amazonas, mas que se estende muito além dessa região. Esse cenário parece análogo ao evidenciado na arqueologia do Caribe para o período pré-colonial tardio (MOL, 2014). No caso da Amazônia, a ampliação das redes de interação deve ser parte, causa ou consequência do adensamento populacional e diversificação das ocupações iniciado por volta do ano 1000 AD (MORAES, NEVES, 2012).

Lathrap (1973, p. 176) postula que "[i]t is far more probable that a unique item in an archaeological sample represents an established trade pattern than that it records a unique and idiosyncratic event". A justificativa para tal premissa é que quase a totalidade (“90\%”) dos materiais trocados na Amazônia pré-colonial não se preservaram, dada a preponderância de matérias orgânicas e as condições ambientais da região. Essa é uma realidade nas redes indígenas de troca de todo o norte da América Sul atual e também o foi nas do início do período colonial. A crônica de Maurício de Heriarte (1874), por exemplo, confirma essa "subamostragem" no registro arqueológico. No rio Madeira,as vasilhas cerâmicas eram trocadas junto com cordas, milho e tabaco. Os indígenas do rio Trombetas, por sua vez, 
produziam uma bebida fermentada feita com arroz vermelho que era comerciada com outras províncias. Os contextos ao longo da dispersão do estilo Konduri mostram que é possível encontrar bem mais que um único item. Dessa maneira, as amostras cerâmicas devem ser indicadores de relações mais densas e sedimentadas sobre as quais os materiais cerâmicos representam apenas a "ponta do iceberg".
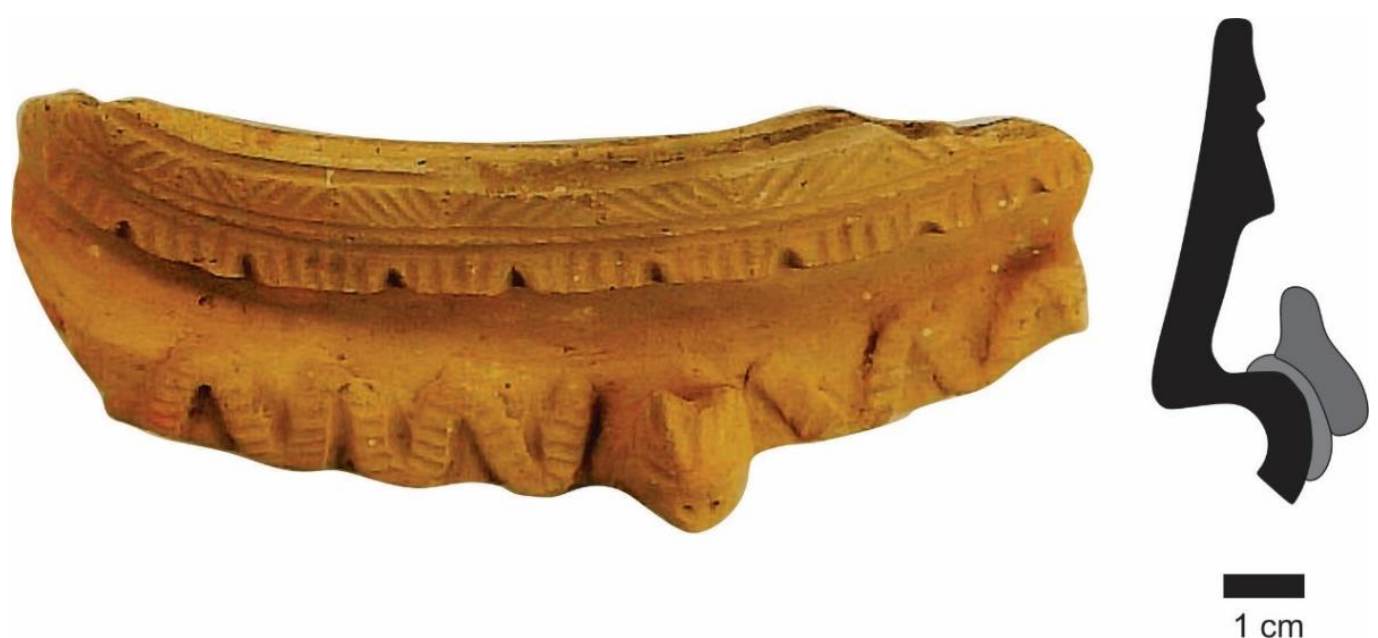

Figura 95. Borda do estilo Santarém encontrada por Nimuendajú no baixo curso do rio Iriri, afluente do Xingu. Fotografia disponível em www.varldskulturmuseerna.se. Desenho adaptado de Nimuendajú, 2004, p. 227.

A presença de cerâmicas em estilo não locais e os relatos etno-históricos ressoam as redes de interação ainda existentes nas Guianas e que já alcançaram a os rios Branco, Negro e Amazonas (PORRO, 1996; DREYFUS, 1992). Nas redes conhecidas etnograficamente as vasilhas cerâmicas produzidas apenas por alguns povos são consideradas de "melhor qualidade" devido à matéria prima e/ou a habilidade das artesãs. No início do século XVIII, ao longo do Orinoco, as cerâmicas Otomaco eram muito solicitadas por sua pintura e a produção de vasilhas espessas, de coloração escura e base plana, usadas para servir óleo de tartaruga (MOREY, MOREY, 1975). Os Akawaio da Guiana produziam sua própria cerâmica,mas também obtinham potes pequenos e frágeis para consumir pimenta com os Arekuna e vasilhas de parede espessa para uso de produção de bebida fermentada com os Patamona (BUTT COLSON, 1973). O interesse por determinadas características de performance na esfera de interação do Baixo Amazonas também pode estar em jogo nos 
contextos pré-coloniais. A iconografia dos vasos de gargalo, com suas modelagens elaboradas e o polimento característico, pode ser relacionada ao interesse que gerou na bacia do rio Trombetas e outras áreas de dispersão do estilo Konduri. $\mathrm{O}$ aspecto brilhoso da superfície poderia ser até potencializado pela diferença de sua pasta com caco moído. Os padrões gráficos das cerâmicas Paurá podem ter atraído os produtores de cerâmica Konduri de uma maneira semelhante. As vasilhas Espinha de Peixe, por sua vez, sugerem também a seleção de matérias e características voltados para a transmissão de calor.

A crônica de Maurício de Heriarte (1874, p. 39) menciona que a cerâmica produzida pelos Tapajós e "índios do Trombetas" é "muito[a] e boa louça" de "um finíssimo barro" que tanto agradava aos portugueses quanto era trocada com "outras provinciais". No rio Madeira, por sua vez, o mesmo cronista que os indígenas faziam "igaçavas" grandes e pequenas feitas de um "barro mui cheiroso". É interessante que, em ambas as áreas, o autor salienta a importância das características da argila usada na produção cerâmica, sem mencionar as modelagens e figurações. Essa é a observação de um funcionário da coroa portuguesa, provavelmente sem nenhum conhecimento da arte oleira, mas como em muitos relatos coloniais, as perspectivas indígenas são agregadas ao texto sem fazer referência, o que é sugerido pelo uso de uma palavra em Língua Geral. As observações feitas mais de dois séculos depois por Im Thurn em relação à qualidade de certas cerâmicas na perspectiva dos índios guianenses reforça essa interpretação. Na então Guiana Britânica, as mulheres Kariña eram consideradas as melhores ceramistas devido à habilidade das oleiras e a argila que utilizavam. Algumas fontes eram inclusive bastante conhecidas. "The clay from certain places on the Cuyuni river", o naturalista explica, "is said by the Indians to be the best [fontes de argila] in the colony; and more goods are always asked in exchange for a vessel made of this clay" (Im THURN, 1883, p. 275). A argila do rio Poomeron, por sua vez era conhecida por ser de "very bad quality", sendo os vasos produzidos com ela muito frágeis. O paralelismo entre os relatos com ênfase nas argilas sugere uma perspectiva indígena da fundamental importância das características de performance das cerâmicas trocadas. Os conjuntos caracteristicamente distintos identificados podem ser vistos com outros "barros" tanto em termos de fontes quanto em relação aos antiplásticos utilizados. Essas características, de modo geral, são qualidades sensíveis, identificadas pela inspeção visual, sonora ou pelo toque e paladar. A valorização de produtos vindos de outros grupos, seu caráter "estrangeiro", além disso, deve ser considerado central, como no tema da "abertura ao outro" tão debatido na etnologia das terras baixas da América do Sul. 
Artefatos como os identificados nas coleções da área de dispersão Konduri, em maior ou menor grau, visivelmente distintos deste estilo e carregam consigo elementos iconográficos singulares, cujos significados podem também ter sido transmitidos entre as margens do rio Amazonas e seus afluentes. Renfrew (1986) desenvolveu o conceito de "arrastamento simbólico" (symbolic entraintment) para destacar o surgimento de ondas simultâneas de compartilhamento ideológico entre unidades sócio-políticas independentes. Como exemplo, ele apresenta a emergência de uma espécie de "espírito internacional" com criação de templos e uso de objetos cerâmicos comuns de carga simbólica. A iconografia dos vasos de gargalo, especialmente a figura de sapos e urubus-rei, tem uma ampla ressonância nas cosmologias das terras baixas da América do Sul, geralmente associadas a mitos da obtenção do fogo pelos humanos, relações de afinidade assimétricas (genro/sogro) e a predação dos mortos (BOOMERT, 2001; MINDLIN, 2002). A figura dos batráquios cerâmicos é, inclusive, muito semelhante à encontrada nos muiraquitãs, o que pode indicar mais uma conexão cosmológica (WÁSSEN, 1934). A morfologia dos vasos de gargalo sugere sua utilização para o consumo de líquidos em pequenas quantidades (GOMES, 2010; ALVES, 2018). As estatuetas femininas Santarém, por sua vez, têm sido interpretadas como instrumentos musicais e parte de performances rituais e festivas (BARRETO, 2017; BARROS et al., 2015). A presença desses dois tipos de artefatos reforça a afirmação de Heriarte (op. cit., p.38) de que os índios do rio Trombetas "tem os proprios idolos, ceremonias, e governo que tem os Tapajós". Os rituais no rio Trombetas, no século XVII, eram muito vigorosos e, segundo o cronista, "os Portugueses lhe deram este nome [ao rio] pelas muitas trombetas de que seus moradores uzam com que fazem suas festas e borracheiras, a que sam mui inclinados" . As estatuetas femininas e também as figurações nos vasos de gargalo podem muito bem ser os "ídolos" usados nas "cerimônias" compartilhadas entre o baixo Tapajós e $\operatorname{Trombetas}^{70}$. Como ressalta Perrone-Moisés (2015, p.82) festas são "locus aparentemente privilegiado de incorporação de "estrangeirismos", como de festas do dia do índio ou cristãs, que ocorrem atualmente. Butt Colson (1985) mostrou como uma reinterpretação indígena dos ensinamentos anglicanos configurou o "culto Hallelujah" que, por sua vez, nas relações de trocas e casamentos disseminou-se entre aldeias e grupos étnicos, entre 1884 e as primeiras décadas do século XX. No fundo dessa valoração diferenciada de artefatos, permonaces e

\footnotetext{
${ }^{70}$ A correlação direta com a crônica de Heriarte é, no entanto, ainda uma tentativa; não é possível inferir qual o grau de semelhança mencionado. Sobre região do rio Madeira, o mesmo cronista afirma que os índios "[s]â idolatras: tem caza de idolos, com as próprias cerimonias dos Tapajós: tem feiticeiros, que lhes annunciain seus agouros, e superstições." (p.43). Esse trecho pode ser tanto uma indicação de que os rituais eram semelhantes em relação aos detalhes das perfomances quanto a constatação da generalidade de práticas xamânicas entre as "nações" do baixo/médio Amazonas.
} 
trocas, há também a importância do contato, o encontro entre pessoas e suas relaçõe de parceria (BARBOSA, 2005).

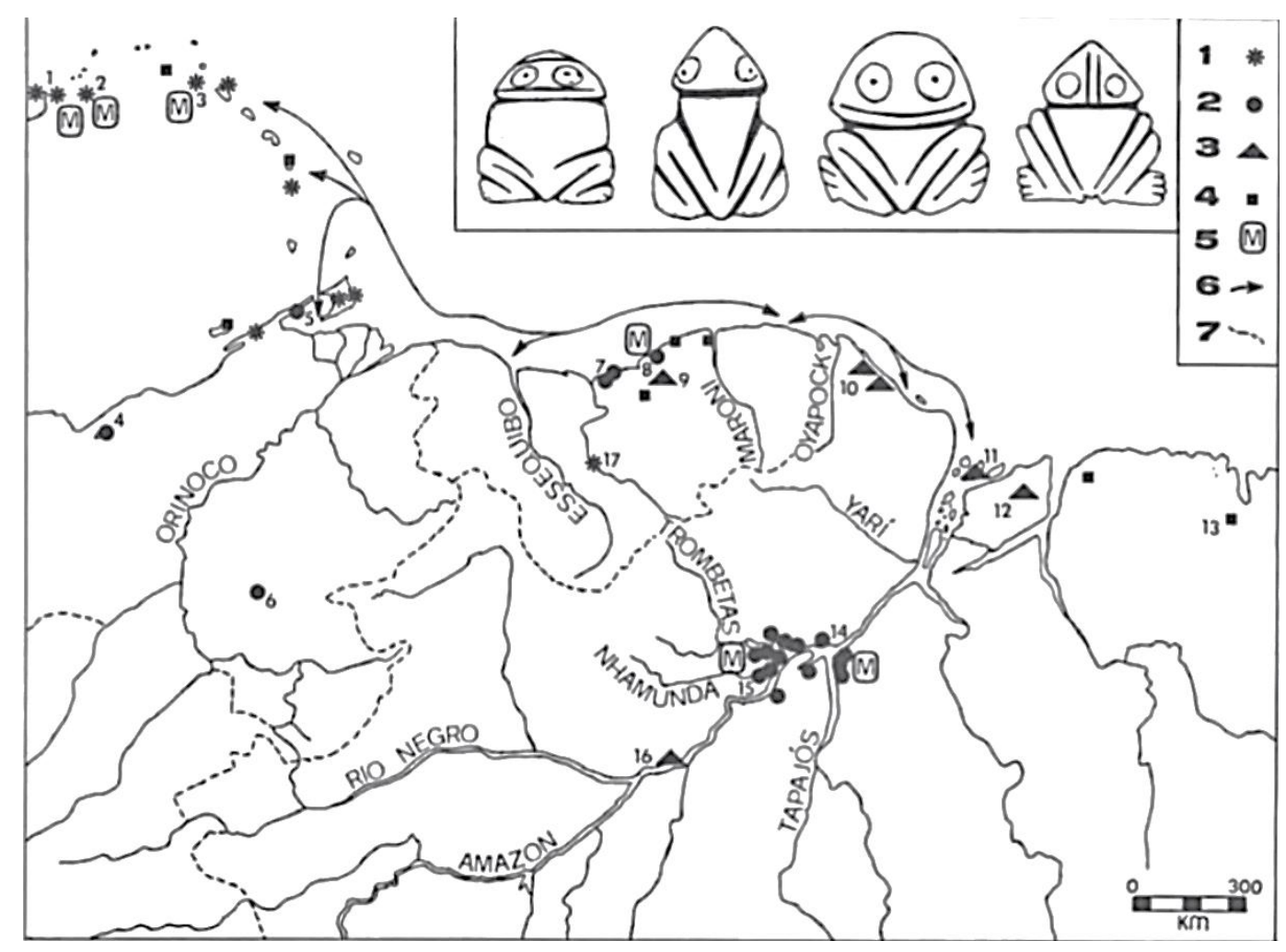

Mapa 9. Mapa de dispersão de muiraquitãs e outros amuletos de pedra verde no norte da América do Sul e Antilhas. Esse mapa não cobre achados mais recentes, como na bacia do rio Xingu. Extraído de Boomert, 1987.

Vistos em relação ao nordeste da América do Sul, o cenário sugerido pelas evidências materiais e etno-históricas é extremamente coerente com as interações indígenas nos séculos iniciais da colonização. A escala subcontinental parece necessária dados os modos de interação documentados desde a invasão europeia. Barbosa (2005, p. 62) enfatiza que formavam-se, no período colonial, cadeias de intermediários de trocas sendo as redes de relações "tão extensas que nenhum dos grupos envolvidos (...) tinham total conhecimento de sua amplitude e diversidade de relações e parcerias envolvidas" (Figura 97). Simone Dreyfus (1992) propôs que teria existido uma "espaço político de comunicação social e ideológica" nos séculos XVII e XVIII que ia desde as Antilhas e alcançava o rio Amazonas. Esse espaço político sobrepõe-se ao da dispersão dos muiraquitãs, encontrados desde o Baixo Amazonas 
até as Antilhas ${ }^{71}$. Esses amuletos são encontrados, em contextos mais ou menos contemporâneos, com uma morfologia muito semelhante desde o rio Xingu e Cajari até o litoral do Suriname (BOOMERT, 1987; AMARAL, 2017) (Mapa 9). Há evidências de produção de muiraquitãs no sítio Porto (Santarém) (MORAES et al., 2014) e a maioria dos exemplares conhecidos com informação de proveniência são da área de dispersão do estilo Tapajó (BARATA, 1954; PALMATARY, 1960).

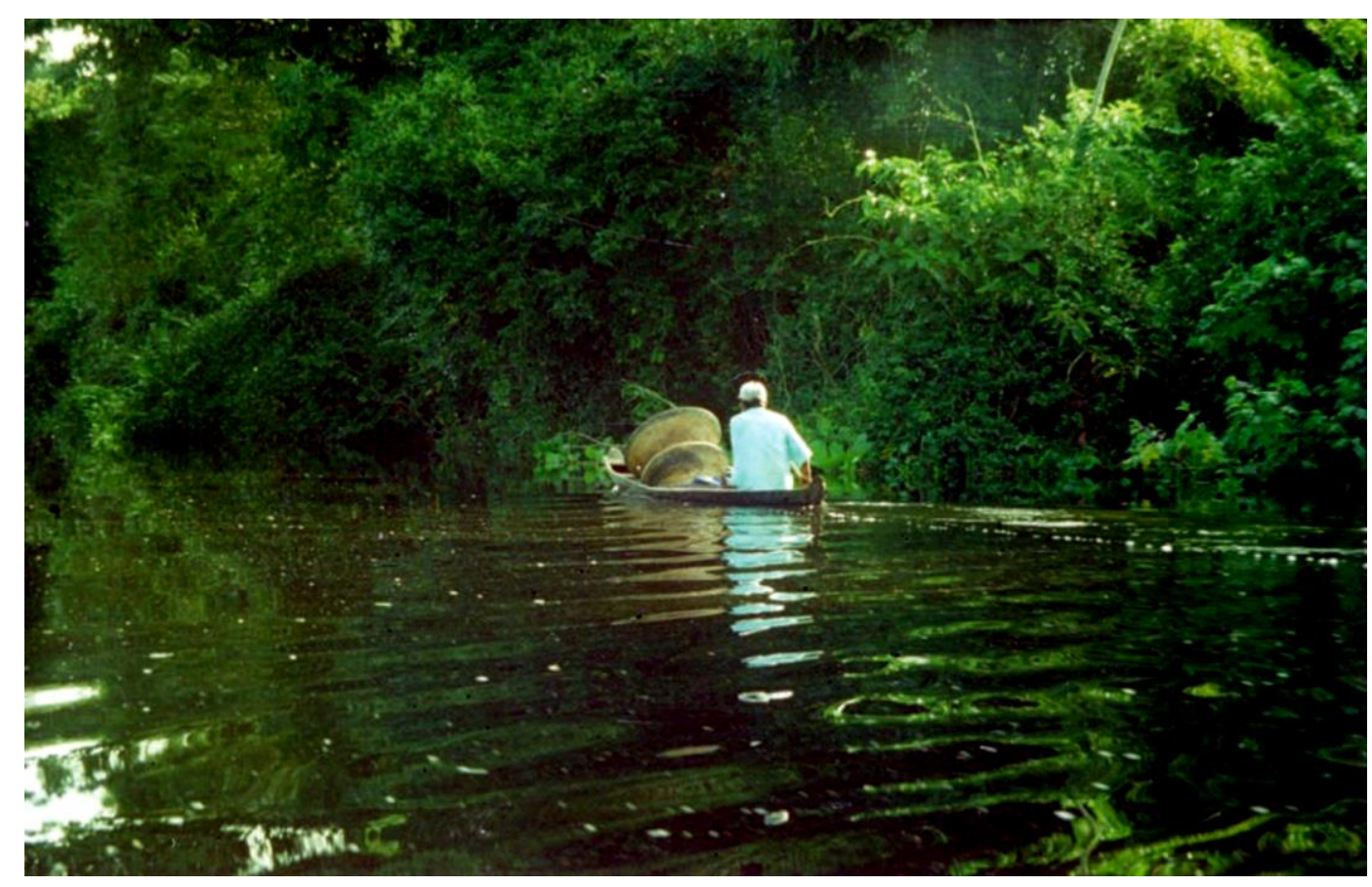

Figura 96. Indígena Palikur transportando uma grande vasilha para armazenamento de bebida fermentada em uma canoa. Vasilhas durante o período pré-colonial podem ter sido transportadas da mesma maneira; as menores, como os vasos de gargalo de mais fácil transporte. Extraído Vidal, 2015.

Em diferentes fontes escritas coloniais os muiraquitãs são mencionados como objetos de grande importância para os povos indígenas das Guianas e Baixo Amazonas. As trocas para obter esses objetos são conhecidas historicamente. Gomberville, por exemplo, conta que, no Orinoco, os Kariña interromperam seus conflitos bélicos com os Aricari para continuar a troca de pedras verdes - a "maior paixão" dos primeiros (GOMBERVILLE, 1682 apud BOOMERT, 1987, p 32). Heriarte (1874) afirma que os muiraquitãs eram "o melhor

${ }^{71}$ Com diferenças cronológicas entre os contextos mais antigos, da tradição Saladóide, e mais recentes da Tradição Araquinóide/Incisa Ponteada. 
contracto" dos Tapajó. Como no caso da cerâmica , os muiraquitãs eram de interesse dos ingleses vindos das colônias nas Antilhas, que os usavam para tratar doenças do baço (RALEIGH, 1751). Na bacia do rio Orinoco, meio século antes, Raleigh menciona que um cacique contou-lhe que as pedras verdes eram obtidas no rio Amazonas, na província dos "Topago" (Tapajó?).

A escala de dispersão dos muiraquitãs, seja de obtenção por trocas ou imitações, é muito ampla, atravessando diversas culturas arqueológicas. As cerâmicas identificadas em contexto Konduri, ao contrário, são encontradas em áreas mais limitadas porque, provavelmente, fazem parte de circuitos locais e regionais. Isso pode resultar da própria dificuldade de transportar artefatos cerâmicos, de tamanhos variados e mais frágeis que artefatos líticos, por longas distâncias em canoas ou a pé (Figura 96). Por outro lado, Natalia Lozado (com. pess., 2019), consultando o material coletado no sítio Aguerito (médio Orinoco), encontrou uma cabeça de urubu com as mesmas características dos apêndices Santarém, o que pode indicar que os vasos de gargalo podem ter viajado por milhares de quilômetros. Isso pode indicar que os materiais cerâmicos, apesar das dificuldades e sua fragilidade, poderiam viajar por milhares de quilômetros.

A palavra "contracto" no texto de Heriarte, talvez ofereça uma pista adicional aos mecanismos mobilizados para a circulação de objetos entre os grupos indígenas do Baixo Amazonas. Nos rios Madeira e Solimões, o mesmo autor usa termos diferentes para descrever as relações de troca ("commercio" e "venda") daqueles utilizados para a região dos rios Trombetas e Tapajós. Mais do que transações econômicas, nesta última região, o termo "contracto" sugere um compromisso entre pares. As crônicas coloniais e etnografias da região das Guianas explicitam uma instituição formal de trocas de bens, baseada no princípio da reciprocidade, tanto a partir de expedições coletivas quanto visitas individuais de parceiros comerciais. A relação de parceria de trocas é pan-guianense. Como ressalta Dreyfus (1992), sua denominação nativa, pawana, foi registrada no dicionário da língua Kalinago pelo padre Breton em 1660. Vários grupos indígenas da região ainda usam o mesmo termo ou similares Akawaio, Aparai, Kamarakoto, Tiriyó, Wajãpi, Waiwai, Wayana (BARBOSA, 2005). Roth (1924) menciona que os quilombolas na Guiana, que viviam em contato frequente com os povos indígenas, estabeleciam a mesma relação, denominada matti - corruptela de mate em inglês. As crônicas coloniais enfatizam expedições de trocas coletivas lideradas por um chefe a outras aldeias, do mesmo modo como acontece no chamado moitará realizado pelos 
indígenas do Alto Xingu (MOREY; MOREY, 1975; DREYFUS, 1992; ver GALVÃO, 1953). Essa expedições podem resultar na movimentação de longas distâncias, por meses ou até anos. Richard Schomburk (1922) relata que encontrou indígenas do rio Cunucunuma, afluente do alto Orinoco até a foz do rio Branco, alcançando o forte São Joaquim, tendo se deslocado por mais de $1.500 \mathrm{~km}$ em por terra e água. Nessas longas jornadas as trocas poderiam ser realizadas sem vínculos como o de parceria. Os momentos de reuniões de pessoas de várias aldeias em rituais podem também ser uma oportunidade para realizar transações, como também ocorre no Xingu (GALVÃO, 1953).

Outros artefatos líticos, além dos muiraquitãs, podem ter feito parte dos circuitos de trocas no Baixo Amazonas do período pré-colonial tardio. Uma estatueta quadrúpede encontrada no fundo do rio Acari, afluente do rio Mapuera, por exemplo, exibe exemplares muito semelhantes provenientes do médio Xingu (ALVES; PROUS, 2016). As lâminas de machado características da área, conhecidas como "tipo Sacuri”, também podem ter sido obtidas em áreas com abundância de rochas magmáticas (Ulisses Pinheiro, com. pess.; ALVES; PROUS, no prelo). Se os famosos "ídolos de pedra" em esteatita estiverem associado a ocupações Konduri, também é possível que esses objetos circulassem por áreas distintas, chegando ao baixo Tapajós, como no caso de uma peça encontrada no lago Joá (FONSECA, 2010).

Renfrew (1975) ressalta que a circulação de objetos atrela-se, em vários contextos, ao fluxo de informações. As redes de troca guianeses, coloniais e etnográficas, podem ser incluídas no modo "down-the-line trade", caracterizado por reciprocidade, trânsito de pessoas e circulação de bens em sucessivas transações. Esse tipo de intercâmbio descentralizado potencializa o contato entre diferentes grupos, de maneira mais próxima (Figura 97). Im Thurn (1883) notou que as informações circulavam entre os grupos indígenas do interior da Guiana "with a rapidity almost as great, if not as certain, as could be achieved by the best system of postal communication" (Im THURN, 1883, p. 271). No mesmo sentido sugerido pelas generalizações de Renfrew, o naturalista correlaciona a velocidade da transmissão de informações nas Guianas a especialização de diferentes grupos na produção de bens, com raladores de mandioca, canoas, cerâmica, etc. Mesmo inimigos eram aceitos em uma aldeia para a realização de trocas. Junto com os negociantes vinham as "últimas notícias" de todas as partes. 


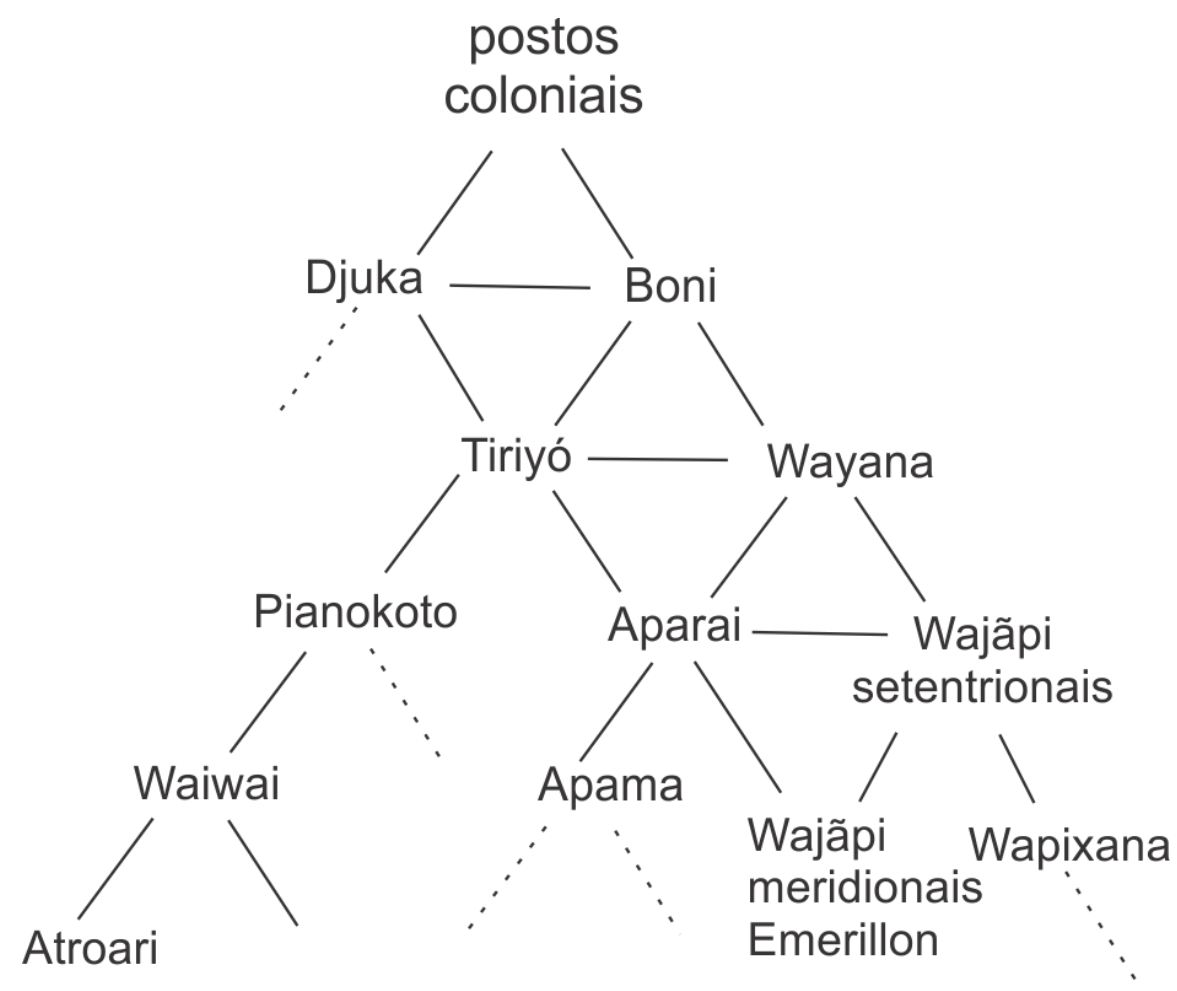

Figura 97. Rede de circulação de bens industrializados no começo do século XX nas Guianas. Adaptado de Barbosa, 2005.

Considerando as evidências de trocas de materiais de diferentes proveniências na área de dispersão da cerâmica Konduri, é provável que as informações e pessoas circulassem de uma maneira parecida ao cenário etnográfico das Guianas. Os possíveis indicadores de difusão - pés modelados, alças sobre borda, padrões de friso de assador - podem ter sido adotados entre o baixo Madeira e Tapajós como resultado das próprias relações comerciais ou da circulação de pessoas. Entre o Amapá e o norte do Pará, os Kaxuyana, Wayana, Aparai, Waiwai, Wajãpi e outros povos compartilham uma série de elementos tecnológicos e decorativos devido às intensas interações (FRIKEL, 1958; GRUPIONI, 2009). Esse fluxo de informações e conhecimentos é facilitado ainda pela predominância de uma mesma família linguística (Karib). Por esse motivo, Frikel (1958) denominou esse fenômeno como "karibismo", marcado pela formação de um padrão regional, marcado por variações locais na língua, cultura material, estrutura social, rituais e cosmologia. 
Parte das relações estabelecidas nas redes de troca pode estar vinculado ao compartilhamento de uma mesma tradição cultural, mas falantes de línguas Arawak e TupiGuarani também movimentaram as interações a longas distâncias. O caso dos Wajãpi, falantes de um língua Tupi-Guarani, é interessante porque é possível mapear historicamente sua inserção na região. Esse grupo chegou ao atual estado do Amapá no século XVIII e partes desse povo experienciou relações distintas com os habitantes da região. Os Wajãpi setentrionais, que ocuparam a região do Oiapoque, devido a sua localização nas redes de troca mantiveram contato direto com os Wayana e Aparai. Isso resultou na adoção de "uma série de traços caribe em sua cultura material, vida cerimonial e organização social” (BARBOSA, 2005, p.67). O mesmo não aconteceu com os Wajãpi meridionais, que se mantiveram mais distantes dos principais centros de distribuição de materiais obtidos em postos coloniais. A circulação de bens, certamente, é apenas um elemento das relações sociais entre grupos trocadores. A difusão de determinadas práticas e saberes pode se manifestar em casamentos em que o cônjuge se desloca para uma nova aldeia ou em guerras nas quais o vencedores tomavam as mulheres e crianças para si (FARAGE, 1985; BUTT COLSON, 1985).

A difusão de conhecimentos vinculados à produção cerâmica não se desenvolve da mesma maneira que a propagação de informações puramente verbais (GOSSELAIN, 1998, 2000). Para que um padrão gráfico ou um elemento morfológico seja imitado tem que haver um interesse, como mostra Hodder (1982). A noção de "arrastamento simbólico", especialmente no caso dos "cestos com alça", parece ainda mais adequada nesse contextos em que pode ter ocorrido, ao invés de trocas, um desenvolvimento simultâneo de vasilhas levemente distintas, com usos em rituais comuns (MOL, 2013). A “abertura ao outro" um tema central na antropologia lévi-straussiana pode ser um motor em um modo de construção de identidade e alteridade a partir do compartilhamento.

\subsection{Conclusão}

Este capítulo discutiu objetos associados à cerâmica Konduri, mas provavelmente de produção não local ou com características muito similares da de outros estilos. A circulação de cerâmica Konduri, contudo, quase um "ponto cego" em nossa discussão, uma vez que não foram analisadas amostras provenientes de áreas onde se encontra outros estilos. Outras pesquias mostra que ao menos no rio Mapuera, no Lago Grande de Curuaí e entre os municípios de Óbidos e Curuá deve ter chegado cerâmica do estilo Konduri (JÁCOME, 2017; MARIANO, 2016). Sua área de dispersão, por tanto, não era apenas "receptora" de objetos 
cerâmicos, mas não sabemos em que grau pode ter sido distribuidora para outras áreas até o momento. A partir da análise das coleções e o levantamento bibliográfico parece claro que os produtores de cerâmica Konduri estavam imersos em uma esfera de interação ou um rede de escala regional entre o baixo rio Tapajós até os rios Urubu e Madeira. As relações com os produtores do estilo Santarém devem ter sido mais intensas, marcadas por rituais, festas e visitas informais.

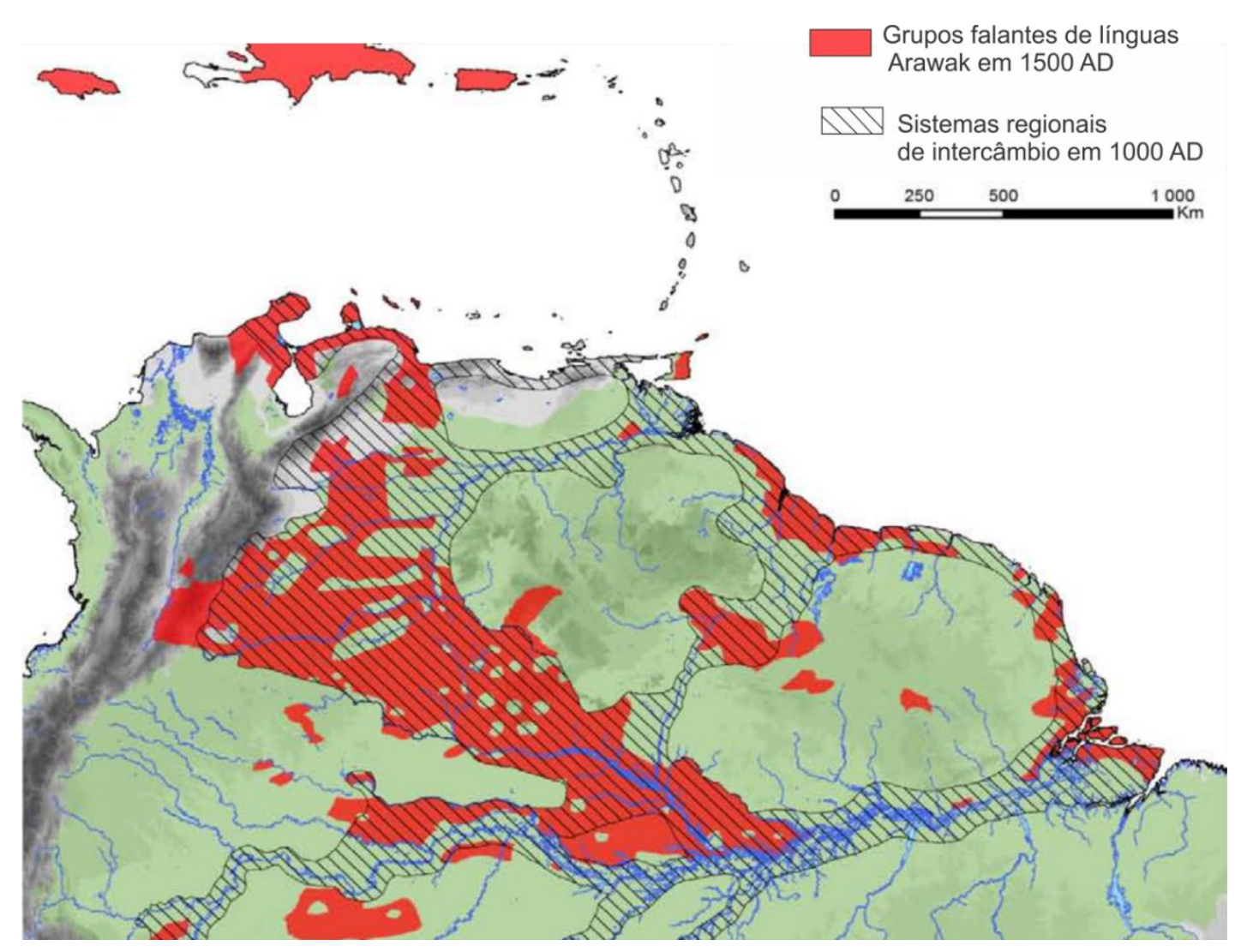

Mapa 10. Modelo postulado de sistemas regionais de intercâmbio Arawak no norte da América do Sul por volta do ano 1000 AD. Notar a área de dispersão da cerâmica Konduri marcada parcialmente como parte desses sistemas seguindo o curso do rio Amazoans, mas excluindo a terra firme. Adaptado de Eriksen, 2011.

O potencial centrípeto da área ocupada pelos Tapajó, localizada entre grandes rios pode ser um fator importante na configuração de políticas pré-coloniais. Conde de Pagan (1656, p. 37) chamou o estreitamento entre Óbidos e o Lago Grande de "bósforo", que potencialmente permitiria um controle privilegiado do comércio às nações europeias ao longo do rio-mar. Poderia esse raciocínio ter alguma validade no entendimento das dinâmicas 
indígenas? Os sítios Aldeia e Porto representavam, como comentou Heriarte (1874, p. 37), “a maior aldeia e povoaçam que por este districto conhecemos athé agora.”. Sua capacidade de reunir pessoas em rituais não pode ser minimizado, bem como seu potencial bélico. Guerras e festas são elementos centrais para a manutenção dos modos de vida indígenas e da extensão de suas relações nas Guianas e em toda a Amazônia indígena (PERRONE-MOISÉS, 2015). A dispersão de fragmentos Santarém em áreas com outros estilos é uma forte evidência de que a foz do Tapajós pode ter sido central para a consolidação dos modos de vida indígena do século XIII ao XVI. As relações dos produtores da cerâmica Konduri não se limitava aos Tapajó; outras relações parecem ter ocorrido mais a oeste. O Lago Grande, apesar de continuar quase desconhecido arqueologicamente, pode ser uma área importante para as dinâmicas políticas e rituais dos Tapajó e outros grupos do período pré-colonial tardio.

Não é clara a relação cronológica e espacial com os produtores da cerâmicas Paredão e Konduri, mas certamente há elementos compartilhados, como já indicado por Moraes (2006, 2013). A questão ainda permanece: difusão e/ou ancestralidade comum? Considerando os contextos de trocas, é possível explicar as semelhanças por imitações de padrões e elementos morfológicos resultem de interações. Os dados do município de Monte Alegre, por sua vez, sugerem que outras redes de escala regional, marcadas pela presença de cerâmica Koriabo, estavam sendo mobilizadas mais a leste, ao eixo Tapajós-Trombetas (BARRETO et al., 2016).

Apesar das diferenças marcantes da paisagem insular e das redes de rios amazônicos, o modelo hipotético de análise de rede para o Caribe por Mol (2013) parece adequado para a calha do Amazonas também; clusters em diferentes escalas se combinam e mostram interações distintas entre sítios, áreas e regiões. Estamos ainda longe de compreender a dimensão e intensidade dessas relações de maneira menos abstratas. Os desafios ainda são grandes e pouco se conhece sobre muitas áreas provavelmente centrais para o desenvolvimento de redes multi-escalares. Concordamos com Rocha (2017) que os materiais do Baixo Amazonas e áreas adjacentes nos levam a pressupor relações contínuas e extensas ao contrário de isolamento.

O cenário etno-histórico e das pesquisas etnográficas mostram relações entre falantes de diferentes línguas ao longo das Guianas. Lathrap (1970) propôs que as cerâmicas da Tradição Incisa Ponteada, como o estilo Konduri, seriam produto da expansão dos falantes de 
língua Karib, desde o Orinoco até os tributários do rio Amazonas. Essa associação permanece hipotética, mas se em parte for correta, pode ser um informação fundamental para compreender a formação das redes de mobilidade e interação. Hornborg (2005) e Eriksen (2011) defendem a constituição das sociedades pré-coloniais tardias na Amazônia e áreas adjacentes seriam marcadas pela formação de "sistemas regionais de trocas" promovido por falantes de línguas Arawak, como no caso do Alto Xingu. A recorrência da associação do "regionalismo" com os falantes Arawak é uma forte evidência de sua relação com o desenvolvimento de extensas redes de circulação de pessoas e coisas (HECKENBERGER, 2001; SANTOS GRANERO, 2002). O modelo de Eriksen (2011) deixa um vazio, entretanto, o curso do rio Tromebtas e parte do Escudo das Guianas em relação aos sistemas regionais do ano $1000 \mathrm{AD}$ (). Os dados levantados nossa pesquisa e em outras mostra que essa área era parte ativa dos circuitos de circulação de coisas, pessoas e informações no período précolonial. Ao invés de uma "ilha Karib", essa área deve ter sido uma intensificadora, integrada a calha do Amazonas e a costa predominantemente Arawak. Como já havia sugerido Hilbert (1955a, p. 74), a relação entre Orinoco e Amazonas, parece se vincular "mais [a]o caminho para o interior, ao longo dos tributários do Amazonas, do que que da costa do Atlântico”. O vaso de gargalo no alto rio Mapuera mostra que longe dos grandes rios navegáveis e em meio as cachoeiras também existem caminhos por terra. O rio Mapuera e provavelmente outros afluentes devem ter sido "caminhos intermediários" para outras áreas do escudo guianense e Orinoco. 


\section{Conclusão}

"Reais como a natureza, narrados como o discurso, coletivos como a sociedade, existenciais como o Ser, tais são os quase-objetos que os modernos fizeram proliferar, e é assim que nos convém segui-los, tornandonos simplesmente aquilo que jamais deixamos de ser, ou seja, nãomodernos".

Bruno Latour, 1994

Esta dissertação teve o intuito de pensar a cerâmica Konduri além dos moldes tradicionais de descrição de sítios, atributos formais e iconografia, visando oferecer a estes trabalhos meios para repensar o legado do colecionismo e as análises de coleções de museu. A expressão "objeto distribuído" permitiu reunir, ainda que de maneira tênue, problemas de formação das coleções, descrições e hipóteses sobre o estilo cerâmico Konduri e outras cerâmicas relacionadas. Este foi um estudo bibliográfico, arquivístico, de análise de material e com alguns elementos de síntese. Ao invés de uma narrativa linear sobre a construção de uma unidade analítica foi possível mapear sua proliferação e multitemporalidade. Os motivos para a escolha desse formato residem tanto nas limitações em relação à documentação de campo quanto à abundância de informações praticamente inexploradas sobre as histórias recentes das coleções. Uma das premissas norteadoras deste trabalho foi de que retornando as antigas coleções seria possível quebrar ciclos viciosos que acompanham a produção científica. A padronização do uso do "cariapé" ao invés de "caraipé" ou "caripé", na arqueologia da Amazônia (CARNEIRO, 2009) é, a nosso ver, elusiva de um processo mais disseminado na produção de conhecimento. Precisamos estar atentos a isso porque a história indígena do Baixo Amazonas mistura-se ao das próprias coleções e os conceitos utilizados para abordálos. É preciso seguir as redes (e as armadilhas) de hipóteses e pressupostos que com a poeira de tempo e da repetição ganham vida própria. O estudo dessas coleções e arquivos não se encerra com esta pesquisa: outros métodos e abordagens devem ser aplicados. Os limites das informações compiladas e das limitações de nossas próprias habilidades de síntese mostram que há muitos estudos necessários para que possamos compreender melhor a história indígena da região. Esperamos que o trabalho desenvolvido nas páginas precedentes possa contribuir 
para uma compreensão mais ampla sobre o passado pré-colonial do Baixo Amazonas e permita que novos estudos avancem ainda mais.

O fio condutor para análise superfícies dos artefatos e documentos permite-nos concluir retomando uma estratégia retórica bastante característica das últimas obras de Alfred Gell a partir de três eixos: o primeiro e, talvez mais evidente, é a "distribuição dos objetos" entre coleções, instituições e coletores; outra "distribuição dos objetos", a indígena e précolonial, notada em relação à cerâmica Konduri é composta por objetos possivelmente obtidos por trocas, formando esferas de interação regionais e, talvez, pan-regionais; finalmente, os “objetos distribuídos" que conforma "eixos de coerência” históricos característicos dos modos de produção do vasilhame Konduri.

\section{Museus e história da arqueologia no Brasil}

Ao fim de uma avaliação de tantas coleções em museus e suas histórias emaranhadas resta uma questão: as coleções são uma página do passado da disciplina, citada em parágrafos introdutórios ou fonte de belas imagens ilustrativas? Essas não parecem boas soluçõe: muito dinheiro público é gasto na manutenção dessas coleções no país e algumas delas apresentam materiais únicos, além de que, como sabemos, as más condições das instituições podem levar ao seu desaparecimento, muito mais intensamente que as intempéries a que estão expostas nos sítios arqueológicos. A destruição de boa parte do acervo um dos maiores museus de história natural do mundo, o Museu Nacional da UFRJ, deixou isso tragicamente claro para todos nós. Precisamos conservar, estudar e divulgar os acervos formados pelas gerações precedentes e troná-los potencializadores para o futuro da arqueologia.

A reanálise de coleções de museu e a pesquisa em arquivo são meios importantes para a compreensão da própria prática científica, sua epistemologia e ontologia. A arqueologia não pode relegar seu próprio passado a História das Ciências e a Museologia. Certamente essas disciplinas desenvolveram teorias e métodos importantes, com contribuições originais, e precisamos estar atentos a eles. Entretanto, a perspectiva arqueológica ainda é fundamental; a relações estabelecidas com os artefatos permite outro modo de interpretar aquele "núcleo duro" da disciplina e agências para além dos humanos (ver LATOUR, 1999). Não estamos com isso advogando por uma perspectiva puramente "internalista". A formação das coleções atravessa diversas relações de poder e concepções profundamente arraigadas em nosso entendimento, como "arte" e "civilização". Da mesma maneira que emaranha concepções 
distintas de "beleza" entre as coleções domésticas de ribeirinhos ou grandes coleções reunidas por uma elite intelectual ou financeira regional ou nacional. A redução dos postulados e interpretações apenas a interesses da política de elites políticas e ideológicas, por outro lado, elimina o que mobiliza a disciplina e seus praticantes: os artefatos, os materiais, os vestígios (BARRETO, 2012).

Encarar os problemas dos acervos de instituiçõos para construir interpretações sobre o passado pré-colonial permanece um desafio. As coleções formadas por particulares ou por pesquisadores entre o final do século XIX e início do XX, exige repensar escalas de análises e, principalmente, uma longa cadeia de reunião e manutenção dos objetos (PAREZO, 1987). O caso da coleção erroneamente atribuída a Curt Nimuendajú, no MPEG, mostra como informações se perdem e outras são incorporadas. Ao mesmo tempo a coleção Tapajônica exemplifica como as coleções de museu podem perder quase por completo as informações contextuais, que por vezes tiveram. Se isso pode parecer desanimador para o estudo do passado pré-colonial, a possibilidade de resolver antigos "quebra-cabeças", como o dos vasos de gargalo, leva-nos a pensar que muitas outras coleções tem potencial para contribuir significativamente para construir interpretações arqueológicas. Reunir os elementos para identificar os vasos de gargalo na bacia do rio Trombetas seria possível sem acessar as coleções de museu, mas a grande seletividade dos materiais tornou mais evidente à padronização e a associação de determinadas figurações, pastas e padrões gráficos.

Estudar arquivos e coleções a partir de uma perspectiva arqueológica é uma forma efetiva de combater lugares-comuns que se formam e cristalizam ao longo dos anos sobre a teoria e prática da disciplina das gerações anteriores. Mariza Corrêa comenta sobre a antropologia social algo que pode ser estendido à arqueologia:

assim como os antropólogos inventaram 'tradições tribais' para povos entre os quais elas não faziam sentido costumam criar e re-criar as suas próprias: como diz Kuper, para toda uma geração, 'a Antropologia Social nasceu em 1914 nas Ilhas Trobriand' (CORRÊA, 1995; referências suprimidas)

A frase de Kuper poderia ser convertida a arqueologia brasileira como "a arqueologia científica nasceu com o PRONAPA e a Missão Francesa”. Apesar do início da segunda metade do século XX ter tido um papel crucial na sistematização da disciplina no país (PROUS, 1992; BARRETO, 1999-2000), existiram outros modos de fazer arqueologia. 
Mesmo que essas pesquisas tenham sido pontuais, sua contribuição para a formação de modelos e hipóteses foi e continua sendo fundamental. Como no caso da arqueologia dos contextos Guarani, nos autores do final do século XIX e início do XX “está já claramente seqüenciada a linha de pensamento que desembocou no ponto de onde partiu o PRONAPA". O papel singular de Peter Hilbert na arqueologia amazônica, especialmente em suas pesquisas iniciais, é ainda um tema a ser estudado com cuidado, da mesma forma que se começa a pensar no Protásio Frikel arqueólogo (MARTINS, 2013).

Ângelo Corrêa (2014, p. 86) comentou, em relação à Arqueologia Tupi, algo que poderia ser generalizado para outros contextos da arqueologia brasileira: "os problemas que buscamos resolver ainda subjazem ao século XIX”. Apesar de concordar com a sua conclusão, essa continuidade mostra que construímos conhecimento a partir do que já é conhecido e não vivemos tantas "revoluções científicas" quanto, às vezes, podem parecer. O caso da noção de "influência" na arqueologia do Baixo Amazonas é um exemplo eloquente da continuidade das coleções de museu para as coleções sistemáticas. Como no caso da padronização ortográfica do "cariapé" (CARNEIRO, 2009), a noção de "influência" ainda está presente em alguns textos recentes. A cerâmica Santarém exibe o uso de ponteado, apesar de ser em uma proporção menor e em áreas mais limitadas do que no estilo Konduri. Não devemos pressupor que essa seja uma técnica exclusivamente Konduri, como se fosse possível traçar uma seta em relação a processos históricos quase desconhecidos - esse é um postulado bastante normativo. Da mesma maneira, não é conhecido nenhum prato concêntrico na região dos rios Trombetas e Nhamundá; esta é uma morfologia característica do material Santarém. Nimuendajú escreveu uma carta a Palmatary, que publicou uma monografia expondo esta hipótese, que se disseminou com os estudos de coleções de museu da década de 1990. Como comenta Noelli (2003, p.310), “(...) velhos problemas de pesquisa permanecem no meio das perspectivas mais contemporâneas, mesmo entre teorias que lhes são antagônicas e que podem 'desconstruir' o seu discurso científico”.

A ideia de que existe uma sobreposição de "revoluções" com a substituição total das concepções anteriores parece muito distante das práticas arqueológicas e científicas de um modo geral. Fazem parte de uma estratégia classificatória moderna baseada no conceito de "progresso". Como explicita Latour, "[é] sua coesão sistemática, bem como a substituição de seus elementos por outros que se tornarão igualmente coerentes no período seguinte, que nos dão a impressão de um tempo que passa, de um fluxo contínuo indo do futuro ao passado, de 
um andaime" (LATOUR, 1994, p. 71). Soma-se a isso, certamente, os altos e baixo de uma arqueologia feita na periferia do Ocidente moderno, o que torna difícil manter uma continuidade nas pesquisas.

Apesar de alguns autores, como Heckenberger (2005), retomarem o legado de Max Schmidt e Erland Nordenskiöld ainda temos pensado pouco sobre seus métodos, premissas e legado na arquelologia amazônica. Esses autores do começo do século passado estão longe do cânone da história da arqueologia e da antropologia social. Há também que redescobrir as pesquisas etnográficas e arqueológicas feitas no passado e cujas hipóteses, de alguma maneira, permanecem vivas (ou deveriam estar) na arqueologia atual, como as belas e elaboradas descrições legadas por Peter Hilbert; as justaposições entre interpretações indígenas e não indígenas deixadas por Protásio Frikel; as vigorosas hipóteses e panoramas de Curt Nimuendajú; ou ainda o olhar iconográfico de Frederico Barata. Tomando em conta as críticas necessárias em relação ao essencialismos e excessos especulativos, a escola dos Kulturkreise e a tradição germânica de modo geral, ainda podem ser importantes para o desenvolvimento analítico em arqueologia. Nesse sentido, os estudos de etnoarqueologia cerâmica da África Subsaariana, como os de Gosselain (1998, 2000, 2008, 2016, 2017) representam um caminho que apenas começa a ser aberto pelas pesquisas das terras baixas da América do Sul (GASPAR, 2019). Além disso, esses mesmos autores de influência germânica oferecem uma oportunidade singular para pensar a interdisciplinaridade dentro da tradição americanista (NOELLI, 1999; JÁCOME, 2011). A etnologia das terras baixas da América do Sul, com influência estruturalista e pós-estruturalista francesa, deixou de lado muitas das questões históricas da tradição germânica, baseada em análises em diferentes escalas informações linguísticas, de cultura material e mitologia. Esse é um fenômeno global na antropologia vinculado a transferência da disciplina para universidades e o predomínio de vertentes intelectualistas (STUTERVANT, 1969). A recente retomada dos estudos das materialidades ameríndias não resultou na incorporação das premissas materialistas e diacrônicas, mantendo uma perspectiva quase sempre baseada no discurso e na sincronia. É necessário repensar as noções de "difusão" e "história conjectural", evitando sua conversão precipitada em um “fóssil” de um passado distante da disciplina (ver TAYLOR, 1984).

\section{Redes de interação e mobilidade pré-coloniais}

A distribuição de objetos ao longo de redes de interação e mobilidade pré-coloniais é um tema profícuo apesar de ainda pouco discutido na arqueologia amazônica. Formam outra 
camada da distribuição dos objetos, agora, em um período mais recuado. A análise das coleções mostrou que os contextos Konduri estão inseridos em redes complexas, nas quais os materiais cerâmicos tiveram um papel importante. A presença dos vasos de gargalo e estatuetas antropomorfas na região do rio Trombetas e outras áreas é uma evidência segura da intensidade das relações entre esta área e o baixo Tapajós. A pesquisa também evidenciou que a circulação de objetos provavelmente incluía outras áreas, ainda menos conhecidas. As interações no período pré-colonial tardio no Baixo Amazonas são um tema latente que, a partir do estudo empreendido, podem ser avaliadas a partir de uma série de elementos delimitados. Alguns dos conjuntos identificados terão de ser reavaliados, tanto porque há poucos dados contextuais para muitos objetos quanto por não terem sido aplicadas métodos físico-químicas ou estruturas teóricas mais formalizadas.

O princípio apresentado por Lathrap (1973) para pensar as interações para arqueologia em áreas tropicais precisa ser levado a sério. A persistência do uso da noção vaga e errônea de “intrusão" ainda diminui o potencial interpretativos do registro arqueológico. Neves (19992000) já havia postulado a necessidade de verificarmos no registro arqueológico os correlatos arqueológicos dos sistemas multiétnicos. Alguns avanços já foram feitos em termos teóricos e metodológicos, ainda estamos longe de termos dados análogos aos da arqueologia do Caribe (ver BARRETO et al., 2016; NEVES et al., 2019).

Em parte, o contraste no estudo de interações locais, regionais e pan-regionais na arqueologia do Caribe e da Amazônia está relacionada a uma questão geográfica: parece ser muito mais fácil controlar proveniências no caso de ilhas relativamente pequenas e com diferentes disponibilidades de matérias-primas. Mas, como sempre, a geografia não é um determinante em si. Há um fator teórico-metodológico explicito, uma vez que na Amazônia o investimento em pesquisas documentais e de arqueológica histórica. No Caribe, ao contrário, tem havido um interesse explícito em pensar a continuidade histórica das ocupações indígenas a partir de um investimento na leitura crítica das crônicas coloniais e sua relação com os contextos pesquisados. Muitas vezes as fontes etno-históricas não estão vinculadas diretamente as Antilhas, mas são de áreas das Guianas e bacia Amazônia. As pesquisas sobre as interações entre ilhas conseguiram esboçar cenários espacial e cronologicamente elaborados dos modos indígenas de interação pré-colonial. As fontes publicadas e não publicadas podem oferecer evidências importantes, da mesma maneira que a expansão das pesquisas em contextos coloniais e de pós-emancipação. Essa possibilidade da aplicação de 
abordagem histórica direta foi enfaticamente defendida por Tarble (1985), que deixa claro não ser possível comprovar correlações entre o passado pré-colonial e o presente etnográfico sem pesquisas de arqueologia histórica e documental. As pesquisas conectadas as metafísicas e históricas indígenas e os materiais arqueológicos são uma possibilidade importante na Amazônia, que tem sido desenvolvida há algumas décadas, e pode ser ampliada e trazer ganhos significativos em diferentes escalas analíticas se somada a pesquisa documental e arqueologia histórica. O legado das pesquisas americanistas interdisciplinares é fundamental para pensar as interações para além de rótulos estanques (NOELLI, 1999).

Se o contexto insular parece "facilitar" as interpretações, ainda é preciso considerar os grandes rios da bacia Amazônica como caminhos, uma proposta encontrada em vários autores, a exemplo de Lathrap (1970). Ao mesmo tempo é preciso desfazer uma série de pressupostos não testados sobre a mobilidade na terra firme, longe da margem dos grandes rios. Os exemplos das Guianas mostram que a mobilidade por terra era e ainda é frequente entre os povos indígenas.

Ferramentas teóricas têm sido desenvolvidas para pensar interações em diferentes escalas, como as propostas de Mol (2014) para arqueologia do Caribe, ou Knappet (2011) em uma abordagem mais ampla. O conceito de "esfera de interação" ainda pode ser útil permitido a delimitação analítica de áreas, ao mesmo tempo, que a perspectiva de "redes" permite vislumbrar uma série de conexões que não precisam ser conformadas em uma unidade. As análises de redes sociais tem grande potencial empírico de estudo de contextos arqueológicos na Amazônia, o que ainda não foi testado. O desenvolvimento de hipóteses sobre a formação de redes de circulação de objetos, por sua vez, deve vir acompanhado da aplicação sistemática de análises físico-químicas que permitam inferir proveniência, como demonstrado na Amazônia Central (NEVES et al., 2019).

Há quase duas décadas Gomes (2002) propôs a necessidade de se considerar o modelo de peer polity interaction desenvolvido por Renfrew (1986). Com exceção da retomada mais recente desse modelo feita por Schaan (2016) para o contexto de Santarém, poucas foram às iniciativas rediscuti-lo a partir do contexto amazônico. Seu potencial continua muito grande para explicar a convergência de adensamento populacional, monumentalidade, artefatos elaborados, evidências de trocas e conflitos em diferentes áreas da Amazônia (MORAES; NEVES, 2012; HECKENBERGER, 2005; CLEMENT et al., 2015). A proposições de 
Roosevelt (1992) poderão ser melhor compreendidas, contextualizadas e matizadas a partir de um princípio simples, mas fundamental para a linguística histórica e outras disciplinas com interesses diacrônicos: quanto maior a interação, maior a taxa de mudança. Se esse princípio for válido para a calha do Amazonas, é possível que as interações de larga escala não sejam apenas uma características das sociedades amazônicas do período pré-colonial tardio, mas um dos catalisadores das mudanças datadas do ano 1000 AD. O tema da complexificação e das chefias da Amazônia pré-colonial tardia pode ser pensada para além de fatores ecológicos e climáticos.

\section{Konduri, objeto distribuído}

A relação na cerâmica Konduri entre o uso do cauixi como antiplástico e características como paredes finas, vasilhas grandes, apliques espessos e um alto investimento em figuração faz pensá-la como "fato social total” ou "sistema tecnológico" (MAUSS, 2003; LEMONNIER, 1992). As escolhas técnicas se concatenam, como argumentam Schiffer e Skibo (1997), e fazem emergir "um ar de familiaridade" - ao menos da perspectiva do analista (SACKETT, 1982). Essas características por sua vez se integram as técnicas do corpo, as práticas alimentares, a estrutura social, a cosmologia, etc. Gell (1998), ao propor a noção de "objeto distribuído", pensava apenas na articulação de atributos de decoração ou morfologia. A “distribuição", entretanto, está muito além do visual. Nenhum indivíduo, cultura, sociedade ou coletivo é uma totalidade completamente integrada, nem é guiada por normas estritas e rígidas, ou ainda pressões ambientais absolutas. Em primeiro lugar, as descontinuidades estilísticas, culturais ou sociais são construções analíticas a partir do contínuo empírico (WAGNER, 1981; DUNNELL, 2002). Em segundo lugar, as práticas culturais não são dadas pelo contexto, mas são formadas a partir da transmissão e a percepção dos sujeitos (ou nas escalas de comunidades ou constelações de prática), que as re-elaboram no contato com o ambiente, as matérias, os humanos e outros seres vivos (INGOLD, 2000). Os estilos, como o Konduri, são "a cumulative process of discovery”, para retomar Gell (1998, p. 237).

O modo como se desenvolveram as classificações cerâmicas na arqueologia amazônica na segunda metade do século passado e as críticas subsequentes, como as de Machado (1991) e Schaan (2007), não permitiram ainda a rediscussão dos processos envolvidos na formação e transmissão de estilos cerâmicos em escalas temporais e espaciais amplas. A aplicação das noções de escolhas e sistemas tecnológicos, apesar de sua imensa 
contribuição, não agregou uma perspectiva comparativa e diacrônica presente em uma de suas principais referências (SCHIFFER; SKIBO, 1987). Isso resultou em uma dificuldade para tratar estilos cerâmicos como "agregados" de processos históricos em distintas escalas temporais e espaciais, um tema de especial interesse nas pesquisas regionais. Assim, tem-se multiplicado as indicações de semelhanças entre conjuntos cerâmicos na região, mas os seus mecanismos ainda permanecem pouco debatidos. Moraes $(2013$, 2016), por exemplo, sugeriu semelhanças entre a fase Axinim no baixo Madeira e outros seis complexos cerâmicos, dispersas por centenas de quilômetros de distância, mas sem indicar quais seriam as possibilidades para explicá-las.

As unidades arqueológicas construídas na arqueologia histórico cultural não foram abandonadas na arqueologia amazônica, do mesmo modo que em várias partes do planeta. As fases e tradições não foram criadas apenas para serem rótulos multiplicados ao infinito ou categorias estéreis e monolíticas, mas, ao contrário, para serem ferramentas heurísticas capazes de indicar ancestralidade comum (WILLEY, PHILIPPS, 1958; ROUSE, 1955, 1986). Seu emprego gerou problemas, excessos e equívocos, mas é preciso retomar o sentido original desses conceitos, alimentando-os a complexidade da construção das identidades culturais e o aspecto de "agregado" de múltiplos eventos históricos dos estilos tecnológicos (GOSSELAIN, 2000; HORNBORG, HILL, 2011). Isso nos permitirá qualificar melhor as semelhanças e diferenças que observamos entre complexos cerâmicos, permitindo-nos construir modelos mais robustos para explicar processos históricos que compuseram o complexo mosaico cultural das terras baixas da América do Sul (CORRÊA, 2014; SILVA, NOELLI, 2017).

A reanálise da coleção reunida por Peter Hilbert em 1952 e de outras, formadas desde o século XIX, deixam claro que continua sendo necessário um maior investimento em pesquisas sistemáticas em sua área de dispersão. As pesquisas recentes, apesar avanços significativos, ainda não conseguiram solucionar as muitas das questões datadas de mais de meio século. Outras tantas sugerem com a expansão dos referenciais teóricos e dos métodos de análise desenvolvidos. 


\section{Referências bibliográficas}

A GRAFIA DOS NOMES TRIBAIS BRASILEIROS. Revista de Antropologia,v. 3, n. 2, .p. 125-132, 1955.

ACUÑA, C. Novo descobrimento do grande rio das Amazonas. In: MELO LEITÃO, C. Descobrimentos do rio das Amazonas. São Paulo: Cia Ed. Nacional, 1941, p. 125-294.

ADAMS, W. Y; ADAMS, E. W. Archaeological Typology and Practical Reality: A Dialectical Approach to Artifact Classification and Sorting, Cambridge University Press, Cambridge, 1991.

ALVES, M. L. Entre Konduri e Santarém: o vaso de gargalo no Baixo Amazonas. 2016. 188 f. Trabalho de Conclusão de Curso (Graduação em Antropologia). Faculdade de Filosofia e Ciências Humanas, Universidade Federal de Minas Gerais, 2016.

Para além de Santarém: os vasos de gargalo na bacia do rio Trombetas. Boletim do Museu Paraense Emílio Goeldi. Ciências Humanas, v. 13, p. 11-36, 2018.

ALVES, M.L.; PROUS, A. Lâminas de machado na bacia do rio Trombetas. Arquivos do Museu de História Natural e Jardim Botânico da UFMG. No prelo.

AMARAL, A.M.. A Ecologia de Assentamentos, Interações Sociais Ameríndias e o Contexto Geográfico dos Muiraquitãs no Baixo Amazonas. Cadernos do LEPAARQ, v. 15, p. 121$141,2018$.

ANTHONY, D. Migration in Archeology: The Baby and the Bathwater. American Anthropologist, v. 92, n. 4, p. 895-914, 1990.

The Horse, the Wheel, and Language: How Bronze-Age Riders from the Eurasian Steppes Shaped the Modern World. Princeton University Press, 2007. 
ANTCZAK, A.; ANTCZAK, M. M. La esfera de interacción Valencioide. In BLANCO, M.A. WAGner, E. (Eds.). El Arte Prehispanico de Venezuela. Caracas: Galerı'a de Arte Nacional, 1999, p. 136-154.

ANTZACK, A.; URBANI, B.; ANTZACK, M.M. Re-thinking the Migration of CaribanSpeakers from the Middle Orinoco River to North-Central Venezuela (AD 800). Journal of World Prehistory, v. 30, n. 2, p 131-17,2017.

ARAÚJO COSTA, F; SENNA, C.; PEREIRA, E. Levantamento arqueológico na área da UHE Cachoeira Porteira - $1^{\circ}$ Relatório. Belém: CNPq/MPEG/Área de Ciências Humanas/Arqueologia, 1985, 120 p.

ARNOLD. D.N. A Model for the Identification of Non-local Ceramic Distribution: a View from the Present. In: HOWARD, H; MORRIS, E. (Ed.) Production and Distribution: a ceramic view point. BAR International Series, v. 120, p. 31-44, 1981.

Ceramic Theory and Cultural Process. Cambridge, Melburne: Cambridge University Press, 1985.

ARVELO-JIMENEZ, N.; BIORD, H. The impact of conquest on contemporary indigenous peoples of the Guiana Shield: The System of Orinoco Regional Interdependence.In. ROOSEVELT, A. C. Amazonian Indians: from prehistory to present. Tucson, London: The University Press of Arizona, 1994, p. 55-78.

AZEVEDO, M. D. P. Coleções que escrevem a história.168 f. 2018. Dissertação (Mestrado em Museologia). Universidade de São Paulo, Museu de Arqueologia e Etnologia, Programa de Pós-Graduação Interunidades em Museologia, 2018.

BALDUS, H. Relatório da Seção de Etnologia, 1948. Revista do Museu Paulista, v.2. 483487, 1949.

Relatório da Seção de Etnologia, 1950. Revista do Museu Paulista, v.4, p.527-533, 1951.

Relatório da Seção de Etnologia, 1953. Revista do Museu Paulista, v.8, p 282-286 1954. 
BALÉE, W. Antiquity of Traditional Ethnobiological Knowledge in Amazonia: The TupíGuaraní Family and Time. Ethnohistory, n.47, v.2, 2000, p. 399-422.

BARATA, F. A arte oleira dos Tapajó I: considerações sobre a cerâmica e dois tipos de vasos característicos. Publicações do Instituto de Antropologia e Etnologia do Pará, n. 2, 1950.

A arte oleira dos Tapajó III: alguns elementos para a tipologia de Santarém. Publicações do Instituto de Antropologia e Etnologia do Pará, v. 6, 1953.

, F. Os muiraquitãs e as 'contas’ dos Tapajó. Revista do Museu Paulista, 8. p. 229259. 1954.

BARBOSA DE FARIA, J. A cerâmica da tribo Uaboí dos rios Trombetas e Jamundá: Contribuição para o estudo da arqueologia pré-histórica do Baixo Amazonas. Ministério da Agricultura, CNPI. Publicação n.89. Rio de Janeiro: Imprensa Nacional, 1946

BARBOSA RODRIGUES, J. Exploração do rio Trombeas. Rio de Janeiro: Typographia Nacional, 1875a.

Exploração do rio Yamundá. Rio de Janeiro: Typographia Nacional, 1875 b.

BARBOSA RODRIGUES, João. Idolo Amazonico. Jornal do Commercio, Rio de Janeiro, 19 ago., p. 3, 1875 c.

O muyrakytã e os ídolos simbólicos: Estudo da origem asiática da civilização do Amazonas nos tempos pré-históricos. v. 2.Rio de Janeiro: Biblioteca Nacional, 1899.

Antiguidades do Amazonas. Arte cerâmica. Ensaios de Sciencia por diversos amadores n.2, p. 3-23 1876.

BARBOSA, C.A.P. As Iconografias Das Urnas Funerárias Antropomorfas Maracá (Amapá): a coleção Gruta das Caretas. 2011.188f. Dissertação (Mestrado em Antropologia e Arqueologia), Universidade Federal do Piauí, Teresina, 2011. 
BARBOSA, G. Das trocas de bens. In: GALLOIS, D.(Org.). Rede de relações nas Guianas. São Paulo: Associação Editorial Humanitas/FAPESP, 2005. p. 59-112

BARCELOS NETO, A. O universo visual dos xamãs wauja (Alto Xingu). Journal de la societé des Americaniste, v. 87, p. 137-160, 2001.

A cerâmica wauja: etnoclassificação, matérias-primas e processos técnicos. Revista do Museu de Arqueologia e Etnologia, São Paulo, n. 15-16, p. 357-370, 2005-2006.

Apapaatai: rituais de máscaras no Alto Xingu. São Paulo: Edusp, 2008.

BARRETO, C. Arqueologia Brasileira: uma perspectiva histórica e comparada. Revista USP, v. 7, p. 201-212, 1999-2000.

Brazilian Archaeology from a Brazilian Perspective. Antiquity, v. 72, n. 277, p. 573582,1998

Cerâmica e complexidade social na Amazônia antiga: uma perspectiva a partir de Marajó. In: PEREIRA, E.; GUAPIDAIA, V. L. (Org.). Arqueologia amazônica 1. Belém: Museu Paraense Emílio Goeldi, SECULT, IPHAN, 2010. v. 1, p. 235-237

Corpo e identidade na Amazônia antiga: um estudo comparativo de estatuetas cerâmicas. Relatório final de projeto de pesquisa de pós-doutorado. São Paulo: MAEUSP/FAPESP, $101 \mathrm{p}$.

Em nome da descolonização da arqueologia brasileira. Resenha do livro "Território Primitivo". Revista de Arqueologia, v. 24, p. 124-131, 2012.

Figurine traditions from the Amazon. In: INSOLL, T. (Org.). Oxford Handbook of prehistoric Figurines. Oxford: Oxford University Press, 2017, p. 418-440

Meios místicos de reprodução social: arte e estilo na cerâmica funerária da Amazônia Antiga. 317f.Tese (Doutorado em Arqueologia). Museu de Arqueologia e Etnologia da Universidade de São Paulo, São Paulo, 2009. 
Modos de figurar o corpo na Amazônia précolonial. In: ROSTAIN, S.(Org.). Antes de Orellana. Actas del 3er Encuentro Internacional de Arqueología Amazónica. 1ed.Quito: Instituto Francés de Estudios Andinos, v, 1, 2014a. p. 123-132.

BARRETO, C.; BETANCOURT, C. J; LIMA, H.P. (Org.) . Cerâmicas Arqueológicas da Amazônia: rumo a uma nova síntese. 1. ed. Belém: IPHAN /Museu Paraense Emílio Goeldi, 2016

BARRETO, C.; NASCIMENTO, H.; PEREIRA, E. Lugares persitentes e identidades distribuídas no Baixo Amazonas: complexos cerâmicos pré-coloniais de Monte Alegre, Pará. Revista de Arqueologia, v. 29, p. 55-85, 2016.

BARRETO, C.; OLIVEIRA, E. Para além de potes e panelas: cerâmica e ritual na Amazônia Antiga. Habitus, v. 14, n.1, p. 51-72, 2016.

BARRETO, M. V. História da pesquisa arqueológica no Museu Paraense Emílio Goeldi. Boletim do Museu Paraense Emílio Goeldi, Antropologia, n. 8, p. 203-294, 1992.

BARROS, L. et al. Música ameríndia no Brasil pré-colonial: uma aproximação com oscasos dos Tupinambá e Tapajó. Opus, v. 21, n. 3, p. 149-182, 2015.

BECKER, M.C.; MELLO, D.P.. Ensaios de tipologia lítica brasileira. Revista do Museu Paulista, v. 14, p. 439-454, 1963.

BELETTI, J.S. Arqueologia do Lago Tefé e a expansão polícroma. 459f. Dissertação (Mestrado em Arqueologia), Museu de Arqueologia e Etnologia da Universidade de São Paulo, 2015.

Tradição Polícroma na Amazônia.BARRETO, C.; BETANCOURT, C. J; LIMA, H.P. (Org.).Cerâmicas Arqueológicas da Amazônia: rumo a uma nova síntese. 1. ed. Belém: IPHAN /Museu Paraense Emílio Goeldi, 2016. p. 348-364.

BELLETTI, J. S. et al. . De tudo um pouco: O material cerâmico encontrado em dois sítios multicomponenciais do baixo Madeira. Cadernos do LEPAARQ (UFPEL) , v. 13, p. 38-67, 2016 
BETTENDORF, J. F. Chronica da Missão dos Padres da Companhia de Jesus no Estado do Maranhão (1625-1698). Revista do Instituto Histórico e Geográfico Brasileiro, n. 72, v. 1, p.1-679.

BEZERRA DE MENESES, U. Arqueologia Amazônica (Santarém). Museu de Arqueologia e Etnologia, São Paulo, 1972.

BEZERRA, M. 'As moedas dos índios': um estudo de caso sobre os significados do patrimônio arqueológico para os moradores da Vila de Joanes, ilha de Marajó, Brasil. Boletim do Museu Paraense Emílio Goeldi. Ciências Humanas, v.6, n.1, p.57-70, 2011

Com os Cacos no Bolso: um ensaio sobre o colecionamento de artefatos arqueológicos na Amazônia Brasileira. Revista do Patrimônio Histórico e Artístico Nacional, v. 38, p. 85-101, 2018.

Os sentidos contemporâneos das coisas do passado: reflexões a partir da Amazônia. Revista de Arqueologia Pública, v. 7, p. 107, 2013

BEZERRA, M.; NAJJAR, R. P. M. ."Semióforos da Riqueza": Um Ensaio Sobre o Tráfico de Objetos Arqueológicos. Habitus, v. 7, p. 289-307, 2009.

BINFORD, L. Archaeological Systematics and the Study of Culture Process. American Antiquity, v. 31, n. 2,p. 203-210, 1965.

BINFORD, L.; BINFORD, S. A Preliminary Analysis of Functional Variability in the Mousterian of Leuallois Facies. American Anthropologist.v. 68, p. 238-295, 1966.

BOAS, F. Primitive art. New York: Dover Publications, 1955.

BOOMERT, A., KROONENBERS G. B. Manufacture and trade of stones artifacts in Prehistoric Surinam. In: VAN BEEK, B. L.; BRANDT, R; WAATERINGE (Eds). Ex Horreo IPP 1951-1976. Cingula, v., p. 4. 9-46

BOOMERT, Arie. 2001. Raptorial birds as icons of shamanism in the prehistoric Caribbean and Amazonia. Annals of XIX International Congress for Caribbean Archaeology, p. 121-157. 
BOOMERT, Arie. Gifts of the Amazons: green stone pendants and beads and items of cerimonial exchange in Amazonia and the Caribbean. Antropologica, v. 67, p. 33-54, 1987.

BRANDT MEIO AMBIENTE. Relatório de vistoria técnica Morro do Papagaio. $18 \mathrm{f}+$ Anexos. Mineração Rio do Norte/ Porto Trombetas. Belo Horizonte, 1996.

BROCHADO, J.P et al. A arqueologia brasileira em 1968. Um relatório preliminar sobre o Programa Nacional de Pesquisas Arqueológicas. CNPq/INPA/MPEG. Publicações Avulsas, n. 12 ,

BROCHADO, J.P.; LATHRAP, D. Chronologies in the New World: Amazonia. 108 f. Editado por José Oliver. Mimeo.

BRODIE N.; LUKE, C. Conclusion: The Social and Cultural Contexts of Collecting In: BROODIE, N.; M. KERSEL, M. M.; LUKE, TUBB, K.W.Archaeology, Cultural Heritage, and the Antiquities Trade. University Press of Florida, p. 303-320, 2005.

BRY, T.L. The Panzaleo Puzzle: Non-Local Pottery in Northern Highland Ecuador. Journal of Field Archaeology, v. 22, n. 2. p. 137-156, 1995.

BUTT COLSON, A. Inter-tribal trade in the Guianas Highlands. Antropológica, v. 34, p. 570 .

Routes of Knowldge: an aspect of regional integration in the circum-Roraima area of the Guianas Highlands. Antropologica, v.63-64, 1985, p. 103-149.

CABRAL, M.P. Juntando Cacos: uma reflexão sobre a classificação da fase Koriabo no Amapá. Amazônica, v.3, n.1, p.88-106, 2011.

CABRAL, M.P. No tempo das pedras moles: arqueologia e simetria na floresta. 2014. 303f. Tese (Doutorado em Antropologia), Universidade Federal do Pará, Belém, 2014.

CALDWELL, J. Interaction Spheres in Prehistory. In: CALDWELL, J.; HALL, R., Hopewellian Studies Papers No. 12. Illinois State Museum, Springfield, pp. 134-143, 1964. 
CARNEIRO, Robert. 'Cariapé': um caso de padronização de erro em Arqueologia. Revista de Arqueologia, v.22, n.1, p. 9 - 13, 2009.

CASTRO, L.P.S.D. Pratos e panelas Konduri: um banquete xamânico na Amazônia Précolonial. 102f. Dissertação (Mestrado em Ciências da Religião). Universidade Estadual do Pará, Belém, 2018.

CHILDE, G. The Danube in Prehistory. Oxford, Oxford University Press, 1929

CHILTON, E. One Size Fits All: Typology and Alternatives for Ceramic Research". In. (Ed). Material Meaning: Critical approaches to the interpretation of material culture. Foundations of Archaeological Inquiry. Salt Lake City: University of Utah Press, p.44-60, 1999.

.The Cultural Origins of Technical Choice: Unraveling Algonquian and Iroquoian Ceramic Traditions in the Northeast. In: STARK, M. The Archaeology of Social Boundaries. Londres e Washington: Smithsonian Institution Press, p. 132-160, 1998.

CHMYZ, I. (org.) Terminologia arqueológica brasileira para a cerâmica. Cadernos de Arqueologia, v. 1, 1976.

CLEMENT, C. R., DENEVAN, W.M.; HECKENBERGER; M. J. JUNQUEIRA, A.B., NEVES, E.G; Teixeira, W.G.; WOODS, W.I. The domestication of Amazonia before European conquest. Proceedings of the Royal Society: Biological Sciences, 282 (1812): 20150813.

CLIFFORD, J. On Collecting Art and Culture. In: The predicament of culture: twentieth-century ethnography, literature, and art. Cambridge: Harvard University Press, 1988, p. 215-282.

COELHO, V.P. Some Aspects of the pottery of the Waurá Indians. Zeitschrift Für Ethnologie, 2(108), 235-254, 1982.

COLWELL-CHANTHAPHONH, C.Myth of the Anasazi: Archaeological Language, Collaborative Communities, and the Contested Past. Public Archaeology v. 8, n. 2-3, p.191207, 2009. 
CONDE DE PAGAN. Relation historique et geographique de la grande riviere des Amazones. Paris: Cardin Bersogne, 1656.

CONKEY, M. Experimenting with style in archaeology: some historical and theoretical issues. In: CONKEY, M.; HASTORFF, C. (Ed.). The uses of style in archaeology. New York, Melbourne: Cambridge University Press, p. 5-17, 1990.

CORRÊA, A.A. Pindorama de Mboîa e îakaré: Continuidade e mudança na trajetória das populações Tupi. 2014. 466f + Anexos.Tese (Doutorado em Arqueologia). Museu de Arqueologia e Etnologia da Universidade de São Paulo, São Paulo, 2014.

CORRÊA, C.G. Estatuetas de cerâmica na cultura Santarém: classificação e catálogo das coleções do Museu Goeldi. CNPq; INPA; MEPEG. Pubulicações Alvulsas, n. 4, 1965. 108 p.

CORRÊA, Mariza. Traficantes do excêntrico: os antropólogos no Brasil dos anos 30 aos anos 60. Revista Brasileira de Ciências Sociais, vol. 3, n. 6, 79-98, 1988

COSTA, M. L et al. The ceramic artifacts in archaeological black earth (Terra Preta) from lower Amazon region, Brazil: Mineralogy. Acta Amazonica, v. 34, n. 2, p. 165-178, 2004a.

COSTA, M.L.et al . The ceramic artifacts in archaeological black earth (terra preta) from Lower Amazon Region, Brazil: chemistry and geochemical evolution. Acta Amazonica,v. 34, n. 3, p. 375-386, 2004b.

CRULS, G. A Amazônia que eu vi. Óbidos-Tumucumaque. Rio de Janeiro, 1930 .Arqueologia amazônica. Revista do Patrimônio Histórico e Artístico Nacional, v.6, p. 169-220, 1942.

CRUXENT, J.M.; ROUSE, I. An archaeological chronology of Venezuela. Washington: Social Sciences Monographs, 6, v.1, 1958/1959.

CRUZ, L.. Nuevo descubrimiento del rio de Marañón llamado de las Amazonas. Madrid: Biblioteca de la Irradiación, 1901. 
DAVID, Nicholas; STERNER, Judy; GAVUA, Kodzo. Why Pots are Decorated. Current Anthropology. v. 29, n. 3, 1988, p.365-389

DeBLASIS, P.; MORALES, W. F. O Potencial dos acervos antigos: recuperando a coleção 030 do Museu Paulista. Revista do Museu de Arqueologia e Etnologia, São Paulo, v. 7, p. 145-178, 1997.

DeBOER, W.R.. The Archaeological Evidence for Manioc Cultivation: A Cautionary Note. American Antiquity, v. 40, n. 4, p. 419-433, 1975.

DeBOER, W.; SUNDSTORM, L. Introduction. In: SANDSTORM, L; DeBOER, W. Enduring Motives: The Archaeology of Tradition and Religion in Native America. Tuscaloosa: The University of Alabama Press, 2012, p. 1-12.

DeBOER, W. \& LATHRAP, D. The Making and Breaking of Shipibo-Conibo Ceramics. In: KRAMER, C. (Ed..), Ethnoarchaeology: Implications of Ethnography for Archaeology. New York: Columbia University Press, 1979, p. 102-138.

DEGOY, L. Technical traditions and cultural identity: an ethnoarchaeological study of Andhara Pradesh Potters. In:STARK, M.; BOWSER, B.; HORNE, L. (Eds.). Cultural transmission and material culture: breaking down boundaries. Tucson: The University of Arizona Press, 2008. p. 199-222.

DERBY, O. O rio Trombetas. Boletim do Museu Paraense de Historia Natural e Ethnographia, v. 2, n.1-4, p. 366-382, 1898.

DESCOLA, Philippe. 2012. Beyond nature and culture. Chicago: University of Chicago Press.

DESCOLA, P; INGOLD, T. Être au monde: quelle expérience commune ? Débat présenté par Michel Lussault. Lyon: PUL, 2014

DIAS, A. S; SILVA, F. 2001. Sistema tecnológico e estilo: as implicações desta inter-relação no estudo das indústrias líticas do sul do Brasil. Revista do Museu de Arqueologia e Etnologia, 11: 95-108. 
DIAS, A. S. Um projeto para a arqueologia brasileira: breve histórico da implementação do Programa Nacional de Pesquisas Arqueológicas (PRONAPA). Revista do CEPA, Santa Cruz do Sul, v. 19, n.22, p.25-39, 1995.

DIAS, A. S. Novas perguntas para um velho problema: escolhas tecnológicas como índices para o estudo de fronteiras e identidades sociais no registro arqueológico. Boletim do Museu Paraense Emílio Goeldi, Ciências Humanas, v. 2, n.1, p. 59-76, 2007.

DIAS, A. S. Repensando a Tradição Umbu Através de um Estudo de Caso. Dissertação de. Mestrado. Porto Alegre, PUCRS. 250 pp

DIAS, A.; HOELTZ, S. Indústrias Líticas em Contexto: O Problema Humaitá na Arqueologia Sul Brasileira. Revista de Arqueologia, v. 2 3, n. 2, p. 40 - 67, 2010.

DIETLER, M. The Archaeology of Colonization and theColonization of Archaeology: Theoretical Challenges from an Ancient Mediterranean Colonial Encounter. In. STEIN, G. The Archaeology of Colonial Encounters. Santa Fe: School of American Research Press, 2005, p. 33-68.

DIETLERT, M.; HERBICH, I.. Habitus, Technique, Style: An Integrated Approach to the Social Understanding of Material Culture and Boundaries In: STARK, M. The Archaeology of Social Boundaries. Londres, Washington: Smithsonian Institution Press, p. 232-263, 1998.

DOW QUÍMICA. Herança: a expressão visual do brasileiro antes da influência do europeu. São Paulo: Empresa Down, 1984.

DRENNAN, R.D. Statistics for Archaeologists: A Commonsense Approach. Dordrecht Heidelberg, London, New York: Springer, 2009.

DREYFUS, S. Les Réseaux politiques indigènes en Guyane occidentale et leurs transformations aux XVIIe et XVIIIe siècles. L'Homme, 1992, tome 32 n¹22-124

DRUC, I. C.; CHAVEZ, L. Pastas cerámicas en lupa digital: Componentes, Textura y Tecnología. Deep University Press, 2014. 
DUARTE FILHO, A. Do rio Nhamundá ao Amazonas e Tapajós: uma rota transversal précolonial na região do Baixo Amazonas. 2010. 94f. Monografia (Especialização em Arqueologia). Universidade Federal do Pará,Instituto de Filosofia e Ciências Humanas, 2010

DUARTE-TALIM, D. As indústrias líticas das ocupações ceramistas da Amazônia: Estudo do sítio PA-OR- 127: Cipoal do Araticum, região de Porto Trombetas, estado do Pará. 268 f. 2012. Dissertação (Mestrado em Antropologia). Universidade Federal de Minas Gerais, Belo Horizonte, 2012.

DUARTE-TALIM, D. Uma Cadeia Operatória Dentro de um Sistema Técnico: Os (Possíveis) Dentes de Ralador da Amazônia. Teoria e Sociedade, v. 23, n.1, p. 13-40, 2015.

DUNNELL, R. Methodological Issues in Americanist Artifact Classification. Advances in Archaeological Method and Theory, v. 9, p. 149-207, 1986.

DUNNELL, R. Systematics in Prehistory. Caldwell: Blackburn Press, 2002

EARLE, T.K.; ERICSON, J.E. Exchange in Archaeological Perspective. In. EARLE, T.K.; ERICSON, J.E. Exhange Systems in Prehistory. New York:Academic Press, 1977, p.

EHRENREICH, P. Contribuições para a etnologia do Brasil. Revista do Museu Paulista, v. 2, p. 7-135, 1948.

ERIKSEN, L. Nature and Culture in Prehistoric Amazonia Using G.I.S. to reconstruct ancient ethnogenetic processes from archaeology, linguistics, geography, and ethnohistory. 376f. 2011. Human Ecology Division, Lund University, 2011.

EVANS, C. e MEGGERS, B. Archeological Investigations in British Guiana. Bulletin of the Bureau of American Ethnology, v.177, 1960

EVENHUIS, N.; PONT, A.C.; WHITMORE, D. Nomenclatural Studies Toward a World List of Diptera Genus-Group Names. Part IV: Charles Henry Tyler Townsend. Zootaxa 397, n. 1, p.1-362. 
FALCI et al. Recontextualizing Bodily Ornaments from North-Central Venezuela (AD 9001500): the Alfredo Jahn collection at the Ethnologisches Museum Berlin, Baessler-Archiv, Band, v. 64, p. 87-112.

FARAGE, N. De Guerreiros, Escravos e Súditos: O Tráfico de Escravos Caribe-holandês no Século XVIII. Anuário Antropológico, v. 84, p.174-187, 1985

As muralhas dos sertões: Os povos indígenas no rio Branco e a colonização. Rio de Janeiro: Paz e Terra, 1991.

FARIA, L.C. Domínios e fronteiras do saber: a identidade da arqueologia. Dédalo, São Paulo, pub. avulsa, 1, p. 26-39, 1989.

FAUSTO, C. A máscara do animista: quimeras e bonecas russas na América indígena. In. LAGROU, E.; SEVERI, C. Quimeras em diálogo: grafismo e figuração nas artes indígenas. Rio de Janeiro: 7 Letras, 2013, p. 305-332.

FERREIRA, A. R. Memória sobre as cuyas. Revista nacional de educação. nº 6, 1933, p. 5863.

FERREIRA, L. M. ; NOELli, F. . A Persistência da Teoria da Degeneração e do Colonialismo nos Fundamentos da Arqueologia Brasileira. História, Ciências, SaúdeManguinhos, v. 14, p. 1239-1264, 2007.

FERREIRA, L. M.; NOELLI, F. João Barbosa Rodrigues: Precursor da Etnoclassificação na Arqueologia Amazônica. Amazônica: Revista de Antropologia, v. 1, p. 68-95, 2009

FERREIRA, L.M. Território Primitivo: A Institucionalização da Arqueologia no Brasil (1870-1917). 2007. 343f.(Doutorado em História), Instituto de Filosofia e Ciências Humanas, Universidade Estadual de Campinas, Campinas, 2007.

Vestígios de Civilização: A Arqueologia no Brasil Imperial (1838-1877). 2002. 181f. (Mestrado em História), Instituto de Filosofia e Ciências Humanas, Universidade Estadual de Campinas, Campinas, 2002. 
FIGUEIREDO, A.M. Parque da cidade, museu da nação: nacionalismo, modernismo e instituições científicas na Amazônia, 1930-1945. In: Priscila Faulhaber; Peter Mann de Toledo. (Org.). Conhecimento e fronteira: história da ciência na Amazônia. Belém: Museu Paraense Emílio Goeldi, 2001, p. 181-204.

FLEMING e FLORENZANO, 2010 Trajetória e perspectivas do Museu de Arqueologia e Etnologia da USP (1964-2011). Estudos Avançados, v. 25, n.73, p.217-228, 2011.

FONSECA, J. A. A. Padrões de distribuição espacial e modelos preditivos: os sítios arqueológicos no baixo curso dos rios Nhamundá e Trombetas.Boletim do Museu Paraense Emílio Goeldi. Ciências Humanas, Belém, v. 13, n. 2, p. 353-376.

FONSECA, J. A. A. As Estatuetas Líticas do Baixo Amazonas. In: PEREIRA, E.; GUAPIDAIA, V. L. (Org.). Arqueologia amazônica 1. Belém: Museu Paraense Emílio Goeldi, SECULT, IPHAN, 2010. v. 1, p. 235-237

FONSECA, J. A. A. . Levantamento regional na arqueologia amazônica: o uso de sistema de informação geográfica e sensoriamento remoto. Boletim do Museu Paraense Emílio Goeldi. Ciências Humanas, v. 8, p. 675-690, 2013.

FOWELS, S.; MILLS, B.On History in Southwest Archaeology. In.MILLS, B.J.; FOWELS, S. (Ed.).The Oxford Handbook of Southwest Archaeology. New York: Oxford University Press, 2017, p. 3-76.

FRANÇOZO, M. O Museu Paulista e a história da antropologia no Brasil entre 1946 e 1956. Revista de Antropologia, São Paulo, v. 48, n. 2, p. 585-612, 2005.

FREITAS, R. P. et al. EDXRF and multivariate statistical analysis of fragments from Marajoara ceramics. X-Ray Spectrometry , v. 39, n. 5, p. 307-310, 2009

FRIKEL, P. Classificação lingüistico-etnologia das tribos indígenas do Pará setentrional e zonas adjacentes. Revista de Antropologia, v. 6, n. 2, p. 113-189, 1958.

.Os Kaxuyana: notas etno-históricas. (Publicações Avulsas, 14).Belém: Museu Paraense Emílio Goeldi, 1970. 
FUNARI, P.P. A. Arqueologia Brasileira: Visão Geral e Reavaliação. Revista da História da Arte e Arqueologia, Campinas, n.1, p.24-41, 1994.

FUNARTE. Instito Nacional de Artes Plásticas.Museu Paraense Emílio Goeldi. Rio de Janeiro, 1981, 208p. (Col. Museus Brasileiros, 4).

FURHOLT, M. Pottery, cultures, people? The European Baden material re-examined. Antiquity, 82, p. 617-628, 2007.

GALVÃO, E. Cultura e sistema de parentesco das tribos do Alto Xingu. Boletim do Museu Nacional, Nova Série, Antropologia, v. 14, p.1-33, 1953.

GARCIA, L. Arqueologia na região dos interflúvios Xingu-Tocantins: A ocupação Tupi no Cateté. 2012. Dissertação (Mestrado em Arqueologia), Museu de Arqueologia de Etnologia, Universidade de São Paulo, 2012.

Paisagens do médio-baixo Xingu: Arqueologia, Temporalidade e Historicidade. 2017.499f. Tese (Doutorado em Arqueologia), Museu de Arqueologia e Etnologia, Universidade de São Paulo, 2017.

GASPAR, M. A cerâmica arqueológica na Terra Indígena Kaiabi (MT/PA). 2014. 263f. Dissertação (Mestrado em Arqueologia), Museu de Arqueologia e Etnologia, Universidade de São Paulo, 2014.

Arqueologia e História dos povos de língua Karib: um estudo da tecnologia cerâmica. 297f. Tese (Doutorado), Museu de Arqueologia e Etnologia, Universidade de São Paulo, 2019.

GELBERT, A. Technological and stylistic borrowings between ceramic traditions: A case study from northeastern Senegal. In. OWEN, L. R.; PORR, M. (Eds.). Ethno-Analogy and the Reconstruction of Prehistoric Artefact Use and Production, Tübingen, Mo Vince Verlag (Urgeschichtliche Materialhefte 14), 1999, p. 207-224.

GELL, Alfred. Art and agency: an anthropological theory. Oxford: Clarendon Press, 1998. 
GELL, Alfred. The technology of enchantment and the enchantment of technology. In COOTE, J.; SHELTON, A. Anthropology, art and aesthetics. Oxford: Clarendon Press, 1992. pp. 40-63.

GELL, Alfred. Vogel's Net: Traps as Artworks and Artworks as Traps. Journal of Material Culture, v.1, 1996. pp.15-38.

GILL, D. W. J. ; CHIPPINDALE, C. Material and Intellectual Consequences of Esteem for Cycladic Figures. American Journal of Archaeology, v. 97, n. 4, p. 601-659, 1993.

GLÓRIA, E.L. A Inconstância da Forma: o sítio Poropu no contexto das Guianas. Trabalho de Conclusão de Curso (Graduação em Antropologia), Faculdade de Filosofia e Ciências Humanas, Universidade Federal de Mianas Gerais, Belo Horizonte, 2017.

GOELDI, Emílio. O estado actual dos conhecimentos sobre os índios do Brasil, especialmente sobre os índios da foz do Amazonas no passado e no presente (Conferência Pública realizada no Museu Paraense em 7 de dezembro de 1896). Boletim do Museu Paraense de Historia Natural e Ethnographia, v. 2, n. 4, p. 397-417, 1898.

GOLEDI, E. Urnas funerárias de povos indígenas extintos e curiosos ídolos de barro e pedra da região amazônica. Boletim do Museu Paraense Emílio Goeldi. Ciências Humanas,v. 4, n. 1, p. 95-133, 2009.

GOETZE, C.E.; B.J.MILLS. Assessment of the Research Potential of Museum Collections: The Babbitt Collection at the Museum of Northern Arizona. Kiva, v. 57, n. 1 p. 77-91, 1991.

GOMES, D. M. C. . Bibliografia sobre a Cultura Santarém: História e Perspectivas. Revista do Museu de Arqueologia e Etnologia, v. 7, p. 155-166, 1997.

. . Santarém Symbolism and Power in the tropical forest. In: MacEWAN; BARRETO, C.; NEVES, E.. (Org.). Unknown Amazon. London: British Museum Press, 2001, p. 134155.

.. Cerâmica Arqueológica da Amazônia: vasilhas da Coleção Tapajônica MAEUSP. São Paulo: Edusp, 2002. 
.. Cotidiano e Poder na Amazônia Pré-Colonial. 1a.. ed. São Paulo: Edusp, 2008.

.Politics and Ritual in Large Villages in Santarém, Lower Amazon, Brazil. Cambridge Archaeological Journal, v.27, n.2, 275-293, 2016.

O Lugar Dos Grafismos E Das Representações Na Arte Pré-Colonial Amazônica. Mana, v. 22, p. 671-703, 2016.

GOMES, D. M. C.; BRAGA, G. B. A Curadoria da Coleção Tapajônica do MAE-USP. Revista do Museu de Arqueologia e Etnologia, v. 8, p. 325-328, 1998.

GONZALEZ-RUIBAL, A.G.An Archaeology of the Contemporary Era. Routledge, 2019

GOSDEN, C.; MARSHALL,Y. The Cultural Biography of Objects. World Archaeology, v.31, n. 2, p.169-178,1999.

GOSSELAIN, O.P. Technology and Style: Potters and Pottery Among Bafia of Cameroon. Man, New Series, v. 27, n. 3, pp. 559-586, 1992.

Social and Technical Identity in a Clay Crystal Ball. In. STARK, M. The archaeology of social boundaries. Smithsonian Institution, 1998, p.78-106.

Materializing identities: An African perspective. Journal of Archaeological Method and Theory, v.7, n.3, p. 187-217, 2000.

. Mother Bella was not a Bella: Inherited and transformed traditions in southwest Niger. In:STARK, M.; BOWSER, B.; HORNE, L. (Eds.). Cultural transmission and material culture: breaking down boundaries. Tucson: The University of Arizona Press, 2008, p. 150-177.

. The world is like a beanstalk: Historicizing potting practice and social relations in the Niger River area. In: RODDICK, A.; STHAL, A. (eds.) Knowledge in motion: Constellations of learning across time and place. Tucson: University of Arizona Press, 2016, p. 36-66. 
.. A tradition in nine maps: Unlayering Niger River polychrome water jars. In. GORI, M; IVANOVA, M (eds) Balkan Dialogues. Negotiating Identity Between Prehistory and the Present, London: Routledge, 2017, p. 85-110.

Pottery chaînes opératoires as Historical Documents.Oxford Research Encyclopedia of African History, 2018, p. 1-41.

GROOTE-BIDLINGMAIER, C. Developing a Data Driven Approach for the Analysis of Functional Settlement Pattern Considering Environmental Space. 282f. 2016. Tese (Doutorado em Geografia), Fakultät für Angewandte Informatik Institut für Geographie, Universität Augsburg, 2016.

GRUPIONI, D.F. Arte Visual dos Povos Tiriyó e Kaxuyana: padrões de uma estética ameríndia. São Paulo: Iepé, 2009.

GRUPIONI, L.D.B. Coleções e expedições vigiadas: os etnólogos no Conselho de Expedições Artísticas e Científicas no Brasil. São Paulo: HUCITEC/ANPOCS, 1998.

GUAPINDAIA, V. L. Fontes históricas e arqueológicas sobre os Tapajó de Santarém: A coleção "Frederico Barata" do Museu paraense Emílio Goeldi. 1993. 294f. Dissertação (Mestrado em História). Universidade Federal de Pernambuco, Recife, 1993

Além da margem do rio: as ocupações Konduri e Pocó na região de Porto Trombetas, PA. 203f. 2008. Tese (Doutorado em Arqueologia). Universidade de São Paulo, São Paulo, 2008.

GUAPINDAIA, V. L.; LOPES, D. Estudos Arqueológicos na Região de Porto Trombetas, PA. Revista de Arqueologia, v. 24, p. 50-73, 2011.

GUAPINDAIA, V.L.; FONSECA, J.A. Metodologia de delimitação no sítio arqueológico Cipoal do Araticum na região do rio Trombetas, Pará, Brasil. Boletim do Museu Paraense Emílio Goeldi. Ciências Humanas, v. 8, n. 3, p. 657-673, 2013.

GUAPINDAiA, V.; CHUMBRE, G. Relatório de Atividades de Campo Sítio PA-OR125:Greig II. $19^{\circ}$ Relatório. Projeto Arqueológico Porto Trombetas. Museu Paraense Emílio Goeldi, 2012, 35p. 
GUIMARÃES, C. Uma coleção de vestígios da cultura Konduri. Arquivos do Museu de História Natural, v. 10, p. 249-286, 1985.

HAMILAKIS, Y. Archaeological Ethnography: A Multitemporal Meeting Ground for Archaeology and Anthropology. Annual Review of Anthropology, v. 40, p.399-414, 2011.

HAMILAKIS, Y. Stories from Exile: Fragments from the Cultural Biography of the Parthenon (or 'Elgin') Marbles. World Archaeology,v. 31, n. 2, p. 303-320, 1999.

HARRIS, M. Sistemas regionais, relações interétnicas e movimentos territoriais: os Tapajó e além na história ameríndia. Revista de Antropologia. 58, 1, p. 33-68, 2015.

The making of regional systems: the Tapajós/Madeira and Trombetas/Nhamundá regions in the lower Brazilian Amazon, seventeenth and eighteenth centuries. Ethnohistory. 65, 4, p. 621-645, 2018.

HARTMAnN, T. (Org.) Cartas do Sertão de Curt Nimuendajú para Carlos Estevão de Oliveira. Lisboa: Assírio \& Alvim/Museu Nacional de Etnologia, 2000.

HARTT, C.F. Contribuição para a Ethnologia do Valle do Amazonas. Archivos do Museu Nacional, n.6, p.1-174, 1885.

HECKENBERGER, M. Deep history, cultural identities, and ethnogenis in the southern Amazon. In: HORNBORG, A.; HILL, J. D. (Eds.). Ethnicity in ancient Amazonia. Reconstructing past identities from archaeology, linguistics, and ethnohistory.Boulder: University of Colorado Press, 2011. p. 57-74.

HECKENBERGER, M. Estrutura, história e transformação: a cultura xinguana na longue durée, 1000-2000 d.C. In. FRANCHETTO, B.; HECKENBERGER, M. (Org.). Os povos do Alto Xingu: história e cultura. Rio de Janeiro: UFRJ, 2001. p. 21-62.

HECKENBERGER, M. The ecology of power: culture, place, and personhood in the southern Amazon, A.D. 1000-2000. New York: Routledge, 2005.

HERBICH, I. Learning patterns, potter interaction and ceramic style among the Luo of Kenya. African Archaeological Review, v.5, p. 193-204, 1987. 
HEGMON, M. Technology, Style, and Social Practices: Archaeological Approaches. In. STARK, M. The Archaeology of Social Boundaries. Washington: Smithsonian Institution Press, 1998. pp. 264-279.

HENG, Leong. Tripod pottery in mainland Southeast Asia. In. MIKSIC, John. Earthenware in Southeast Asia: proceedings of the Singapore Symposium on Premodern Southeast Asian Earthenwares. Singapore University Press with the assistance of the Southeast Asian Ceramic Society, p. 173-186, 1998

HERIARTE, M. Descriçam do Estado do Maranham, Para, Corupa, Rio das Amazonas. Viena, Carlos Gerold, 1874.

HICKS, D. Four-Field Anthrpology: Charter Myths and Time Warps from St. Louis to Oxford. Current Anthropology, v. 54, n.6, p.753-763, 2013.

HILBERT, K. Uma biografia de Peter Paul Hilbert: a história de quem partiu para ver a Amazônia. Boletim do Museu Paraense Emílio Goeldi. Ciências Humanas, Belém, v. 4, n. 1, p. 134-154, 2009.

.Catálogo Sítios Amazônia Hilbert. Manuscrito. Sd.

HILBERT, P. P. Contribuição à arqueologia da ilha de Marajó. Os tesos marajoaras de alto Camutins e a situação da ilha do Pacoval, rio Arari. Belém: Instituto de Antropologia e Etnologia do Pará, 1952. (Publicação n. 5)

A cerâmica arqueológica da região de Oriximiná. Belém: Instituto de Antropologia e Etnologia do Pará, 1955. (Publicação n. 9).

.. Tripods in Lower Amazon. In: Anais do XXXI Congresso Internacional de Americanistas. São Paulo, 1955b, p. 825-828.

Achados arqueológicos num sambaqui do Baixo Amazonas. Belém: Instituto de Antropologia e Etnologia do Pará, 1959. (Publicação n. 10)

Archaologische untersuchungen in mittleren Amazonas. Berlim: Marburger Studien zur Volkerkunde, 1968. 
. Pottery from the Cuminá River, Brazil, and its affiliation with the Koriabo Phase of Guyana. Journal of Archaeology and Anthropology. v.5, n.1-2, p.75-82, 1982.

Archäologie in Amazonien. In: NIEMEYER, H. G. (Org.). Archäologie in Amerika. Salzburg: Andreas \& Andreas, 1986. p. 3123-3142. (Die großen Abenteuer der Archäologie, n. 8).

HILBERT, Peter Paul; HILBERT, Klaus. Resultados preliminares da pesquisa arqueológica nos Rio Nhamundá e Trombetas, Baixo Amazonas. Boletim do Museu Paraense Emílio Goeldi, Antropologia, n. 75, p. 1-11, 1980.

HODDER, I. Symbols in Action: ethnoarchaelogical studies of material culture. Cambridge: Cambridge Univesity Press, 1982.

HOFMAN, C.; HOOGLAND, M. Unravellling the multi-scale networks of mobility and exchange in the pre-colonial circum-Caribbean.In. HOFMAN, C.L; DUIJENBODE, A.Communities in Contact. Essays in archaeology, ethnohistory and ethnography of the Amerindian circum-Caribbean. Slide Stone Press, 2011, p.15-44.

HOFMAN, C.L. et al. (2014), Stage of encounters: migration, mobility and interaction in the pre-colonial and early colonial Caribbean. World Archaeology 46(4): 590-609.

HOFMAN, C.L. et al. Island rhythms. The web of social relationships and interaction networks in the pre-Columbian Lesser Antilles. Latin American Antiquity, v. 18, n 3, p.243268, 2007.

HOGG, A.G. et al. Shcal13 Southern Hemisphere Calibration, 0-50,000 Years Cal BP. Radiocarbon, v. 55, n. 4, p. 1889-1903, 2013.

HOLTORF, C. Notes on the life history of a pot sherd. Journal of Material Culture, v.7, n.1, 2002, p. 49-71.

HORNBORG, A. Ethnogenesis, regional interaction, and ecology in prehistoric Amazonia: towards a systemic perspective. Current Anthropology, v.46, n.4, p. 589-620, 2005. 
HORNBORG, A.; HLL, J. D.Introduction. In: (Eds.). Ethnicity in ancient

Amazonia. Reconstructing past identities from archaeology, linguistics, and ethnohistory. Boulder, University Press of Colorado, , 2011, p. 1-30.

HOWARD, G.D. Prehistoric Ceramic Styles of Lowland South America, Their Distribution and History. Yale University Publications in Anthropology, New Haven, n. 37, 1947.

HARRIS, M. The Making of Regional Systems: The Tapajós/Madeira and Trombetas/Nhamundá Regions in the Lower Brazilian Amazon, Seventeenth and Eighteenth Centuries. Ethnohistory, v. 65, n.4, p. 621-645, p.2018

HUSTER, A.C. Assessing Systematic Bias in Museum Collections: A Case Study of Spindle Whorls. Advances in Archaeological Practice, v.1, n.2, p.78-90, 2013.

Im THURN, E. F. Among the Indians of Guiana: being sketches chiefly anthropologic from the interior of British Guiana. London: Keegan Paul, Trench and Co., 1983.

INGOLD, T (Ed.). 1989 debate The concept of society is theoretically obsolete. In.

(Ed.) Key Debates in Anthropology, p.45-80, 1994

INGOLD, T. The Perception of the Enviroment. Essays in Livelihood, Dwelling and Skill. London/New York: Routledge. 2000.

JÁCOME, C. P. Pelo rio Mapuera: Reflexões sobre arqueologia e etnologia indígena na Amazônia e Guiana.2011. 155f. Dissertação (Mestrado em Antropologia), Faculdade de Filosofia e Ciências Humanas.Universidade Federal de Minas Gerais, 2011.

Dos Waiwai aos Pooco - Fragmentos de história e arqueologia das gentes dos rios Mapuera (Mawtohrî ), Cachorro (Katxuru) e Trombetas (Kahu). 2017. 524f. Tese (Doutorado em Arqueologia), Museu de Arqueologia e Etnologia, Universidade de São Paulo, São Paulo, 2017.

JENKINS, I. Archaeologists and aesthetes : in the sculpture galleries of the British Museum 1800-1939. London: British Museum Press, 1992. 
JONES, S. The Archaeology o f ethnicity: constructing identities in the past and present. Londres, Routledge, 1997.

JOYCE, R. A.; GILLESPIE, S. D. Making thingas out that move.In. Things in

Motion. Objects Itineraries in Anthropological Practice. New Mexico: School for Advanced Research Press, 2015, p. 3-20.

KELLY, S. WATKINS, C.; ABBOTT, D. Revisiting the Exploitable Threshold Model: 14th century resource procurement and landscape dynamics on Perry Mesa, Arizona. Journal of Field Archaeology. v. 36, n. 4, p. 322-336

KERN, D.; KÄMPF, N. Antigos assentamentos indígenas na formação de solos com terra preta arqueológica na região de Oriximiná, Pará. Revista Brasileira de Ciências do Solo, 13, p. 219-225, 1989.

KINTIGH, An Outline for a Chronology of Zuni Ruins, Revisited: Sixty-five Years of Repeated Analysis and Collection. In. CANTWELL, A.M.;GRIFFIN, J.; ROTHSCHILD, N. (Ed.) The research potencial of Anthropological Museum Colletions. Annals New York Academy of Sciences, n. 367, 1981, p. 467-487.

KNAPPETT, C. An Archaeology of Interaction: Network Perspectives on Material Culture and Society, Oxford,: Oxford Univ. Press, 2011.

KOPYTOFF, I. The cultural biography of things: commoditization as process. In: APPADURAI, A. The Social Life of Things: Commodities in Cultural Perspective. Cambridge: Cambridge University Press, p. 64-91, 1986.

KRISTIAnSEN, K.; LARSSON, T. B. The Rise of Bronze Age Society: Travels, Transmissions and Transformations. Cambridge, Cambridge University Press, 2005.

KROEBER, A. Style and Civilization. Cornell University Press: Ithaca,1957.

LATHRAP, D. (Ed.) An Archaeological Classification of Culture Contact Situations. Seminars in Archaeology 1955. Society for American Archaeology Memoirs, n.11, p.1-30.

LATHRAP, D. The upper Amazon. Praeger, New York, 1970. 
.The Antiquity and Importance of Long-Distance Trade Relationships in the Moist Tropics of Pre-Columbian South America, World Archaeology,1973.

.. Recent Shipibo-Conibo ceramics and their implications for archaeological interpretation. In WASHBURN, D. (Ed.) Strutural and cognition in art. (New directions in archaeology), p.25-39, 1983

LATOUR, B. Jamais Fomos Modernos: ensaio de antropologia simétrica. Tradução Carlos Irineu da Costa. Rio de Janeiro: Editora 34, 1994.

Pandora's Hope: essays on the reality of science studies. Cambridge: Harvard University Press, 1999.

LEIGHTON, M; SØRENSEN, M.L.S.Breathing life into the archives: reflections upon decontextualization and the curatorial history of V.G. Childe And The Material From Tószeg. European Journal of Archaeology, v. 7, n.1, p. 41-60, 2004.

LEITE, Serafim. História da Companhia de Jesus no Brasil, v. III. São Paulo: Companhia Editora Nacional, 1943.

LEMONNIER, P.The study of material culture today: toward an anthropology of technical systems. Journal of Anthropological Archaeology, v.5, p. 147-86, 1986.

LEMONIER, P. Elements for an Antropology of Technology. Arbor, Michingan: Anthropological papers. Museum of Anthropology, University of Michigan, 1992.

Introduction. In. (Ed). Technological Choices: transformation in material culture since the Neolithic. London/New York: Routledge, 1993, p. 1-35.

LIMA, H. Projeto Baixo Amazonas. Serviços Técnicos de mapeamento arqueológico e Educação Patrimonial em áreas pré-selecionadas do município de Parintins, Estado do Amazonas. Manaus, IPHAN $1^{\text {a }}$ SR, Relatório não Publicado, 2007.

LIMA, H. P. História das Caretas: a Tradição Borda Incisa na Amazônia Central. 2008. 424f. Tese (Doutorado em Arqueologia) - Museu de Arqueologia e Etnologia, Universidade de São Paulo, São Paulo, 2008. 
LIMA, H. P. . Varibilidade Arqueológica e o estudo de fronteiras culturais na região do baixo rio Urubu. In: (Org.). Fronteiras do Passado: aportes interdisciplinares sobre a arqueologia do baixo rio Urubu, Amazonas, Brasil. 1ed.Manaus: EDUA, 2013, v. 1, p. 35-62.

LIMA, H.P. Análises Cerâmicas Na Arqueologia Amazônica: Contribuições da Amazônia Central a Uma Longa Trajetória de Discussões. Revista de Arqueologia, v. 28, p. 3-29, 2015. 2015.

LIMA, H.P.; NEVES, E.G. Cerâmicas da Tradição Borda Incisa/Barrancóide na Amazônia Central. Revista do Museu de Arqueologia e Etnologia, v.21, 205-230., 2011.

LIMA,; SILVA, C. Levantamento Arqueológico do Médio Amazonas. Manaus, IPHAN $1^{\text {a }}$ SR, Relatório não Publicado, 2005.

LIMA, H. P.; MORAES, B. M. ; PARENTE, M.T. .’Tráfico” De Material Arqueológico, Turismo E Comunidades Ribeirinhas: Experiências De Uma Arqueologia Participativa Em Parintins, AMAZONAS. Revista de Arqueologia Pública , v. 8, p. 61-77, 2013.

LIMA, T.A. A cerâmica indígena do Brasil. In: RIBEIRO, D. (org.).Suma Etnológica Brasileira. Rio de Janeiro: Vozes/Finep, v. II: 173-229, 1987.

LIMA, P. Os índios Waurá. Observações gerais. Boletim do Museu Nacional, Antropologia, n.9, p. 1-44, 1950.

LINDEN, M. V; ROBERTS, B.W. A Tale of Two Countries: Contrasting Archaeological Culture History in British and French Archaeology. In: ROBERTS, B.W.; LIDEN, M.V. Investigating Archaeological Cultures: Material Culture, Variability, and Transmission.Springer, p. 23-40, 2011.

LINHARES, A.M.A Marajoara "civilizado" e identidade nacional brasileira (século XIX). Revista Estudos Amazônicos, v. 13, n.1, p. 134-173, 2015.

LINHARES, A.M.A. Um Grego Agora Nu: Índios Marajoara e Identidade Nacional Brasileira. 2011. 286f. Tese (Doutorado em História), Instituto de Filosofia e Ciências Humanas, Universidade Federal do Pará, Belém, 2015. 
LINNÉ, S. Les recherches archéologiques de Nimuendajú au Brésil. Journal de La Société des Américaniste de Paris, n.20, p. 71-91,1928.

Contribution à l'Etude de la céramique Sudaméricaine. Revista del Institute de Etnologia, Tucuman, v.7, p.199-239, 1932.

LIS, B. From cooking pots to cuisine. Limitations and perspectives of a ceramic-based approach. In. SPATARO, Michela; VILLING, Alexandra. Ceramics, Cuisine and Culture: The Archaeology and Science of Kitchen Pottery in the Ancient Mediterranean World. Oxbow, p. 104-114, 2015.

LISLE DU DRENEUC, P. de. Les idoles de pêche du Brésil. In: Congreso Internacional de Americanistas, IX. Huelva: 1892.

Madrid: Tipografía de los Hijos de M. G. Hernández, 1894. p. 107.

LOPES, M.M. O Brasil descobre a pesquisa cientifica: os museus e as ciencias naturais no seculo XIX. 1. ed. Sao Paulo: HIUCITEC, 1997.

LYMAN, R.L.; O'BRIEN, M.J.; DUNELL, R.C. The Rise and Fall of Culture History. New York: Plenum Press, 1997.

MAC CURDY, George Grant. A study of Chiriquian antiquities. Memoirs of the Connecticut Academy of Arts and Sciences, v. 3, 1911, p. 1-249.

MACEACHERN, S. Scale, Style, and Cultural Variation: technological Traditions in the Northern Mandara Mountains. In: STARK, M. The Archaeology of Social Boundaries. London/Washington: Smithsonian Institution Press, 1998, p.107-131.

MACHADO, M.F. Idolo Amazonico. Revista da Sociedade de Geographia do Rio de Janeiro, v. 7, n. 4, p. 281-286, 1891.

MACHADO, A. L. C. As tradições ceramistas da bacia amazônica: uma análise crítica baseada nas evidências arqueológicas do médio rio Urubu (AM). 1991. 158f + Anexos. Dissertação (Mestrado em História) - Faculdade de Ciências Humanas, Universidade Federal de Pernambuco, Recife, 1991. 
MACHADO, J. S. A Formação de montículos artificiais na Amazônia Central: um estudo de caso do sítio Hatahara. 2005.684f. Dissertação (Mestrado em Arqueologia) - Museu de Arqueologia e Etnologia, Universidade de São Paulo, São Paulo, 2005.

O Potencial interpretativo das análises tecnológicas: um exemplo amazônico. Revista do Museu de Arqueologia e Etnologia, São Paulo, v. 15-16, p. 87-111, 2005-2006.

MACHADO, M. Entre Terra Preta Antropogênica e Cacos de Cerâmicas: A Existência de Sítios Arqueológicos no Município De Parintins - AM. 2018. 38f. Trabalho de Conclusão de Curso (Graduação em História), Centro de Estudos Superiores de Parintins, Universidade Estadual do Amazonas, Parintins, 2018.

MARIANO, M. Dos Vestígios Arqueológicos às Paisagens Culturais: Uma possibilidade analítica da Paisagem a partir da cultura material. 88f. 2017. Trabalho de Conclusão de Curso (Graduação em Geografia e Cartografia), Universidade Federal do Pará, Belém, 2017.

MARTINS, C.M.P. Arqueologia Do Baixo Tapajós: Ocupação Humana Na Periferia Do Domínio Tapajônico. 2012. 233f. Dissertação (Mestrado em Antropologia). Universidade Federal do Pará, 2012a.

MARTINS, C.M.P. Sobre Contatos e Fronteiras: um Enfoque Arqueológico. Amazônica: Revista de Antropologia, v. 4, n.1, p. 150-184, 2012 b.

MARTINS, R. Cuias, cachimbos, muiraquitãs: a arqueologia amazônica e as artes do período colonial ao modernismo. Bol. Mus. Para. Emílio Goeldi. Cienc. Hum., v. 12, n. 2, p. 403426, 2017.

MARTINS, V. Para Além Do Tumucumaque: Protásio Frikel, Arqueologia História Intelectual na Amazônia. 2013.182f. Dissertação (Mestrado em História), Instituto de Filosofia e Ciências Humanas, Universadade Federal do Pará, Belém, 2013.

MAUSS, Marcel. Ensaio sobre a dádiva. In: MAUSS, M. Sociologia e antropologia. Tradução Paulo Neves. São Paulo: Cosac Naify, 2003, p.185-314. 
MEGGERS, B.J. The archaeology of Amazon Basin. STEWARD, J. (Ed.) Handbook of South American Indians, v. 3, Tropical Forest, Bureau of American Ethnology, Bulletin, v. 143, 1948, p. 149-166.

MEGGERS, B. J.; EVANS, C. An experimental formulation of horizon styles in the tropical forest area of South America.In: LOTHROP, S. (Ed.). Essays in Pre-Columbian Art and Archaeology. Cambridge: Harvard University Press, 1961. p.372- 388.

MEGGERS, B. J.; EVANS, C. Archaeological investigations at the mouth of the Amazon. Smithsonian Institution, Bulletin, Washington, D.C., n. 167, 1957.

MEGGERS, B. J.; EVANS, C. Como interpretar a linguagem cerâmica: manual para arqueólogos. Washington: Smithsonian Institution, 1970.

MEGGERS, B.; EVANS, C. Speculations on Early Pottery Diffusion Routes Between South and Middle America. Biotropica, v. 1. n.1, p. 20-27, 1969.

MEGGERS, B. J. Reconstrução do comportamento locacional pré-histórico na Amazônia. Boletim do Museu Paraense Emílio Goeldi, Série Antropologia, v. 6, n.1, p. 181-203, 1990.

MELO, J. Objetos em Trânsito: a musealização de artefatos arqueológicos no Museu Paraense Emílio Goeldi (1866-1907). 2017. 198f. Dissertação (Mestrado em História), Instituto de Filosofia e Ciências Humanas, Universidade Federal do Pará, Belém, 2017.

MENCHÉN, G. Nimuendajú: Bruder der Indianer. Leipzig: VEB Brockhaus, 1979.

MÉTRAUX, A. Les anciennes civilization de l'Amazonie.(État Actuel du Problème de leur Origene). Diogène, n.28, p. 109-124, 1959.

MINDLIN, B. O fogo e as chamas dos mitos. Estudos Avançados, v. 16, n. 44, p. 149-169, 2002 .

MOL, A., Studying Pre-Columbian Interaction Networks: Mobility and Exchange. In: KEEGAN, W.F., HOFMAN, C; RODRIGUEZ RAMOS, R. (Eds.) The Oxford Handbook of Caribbean Archaeology. New York: Oxford University Press, 2013, p. 329-346. 
MOL, A. The Connected Caribbean: A socio-material network approach to patterns of homogeneity and diversity in the pre-Colonial period. Sidestone Press, Leiden, 2014.

MORAES, C. P. Amazônia Ano 1000: territorialidade e conflito no tempo das chefias regionais. 2013. 347f. Tese (Doutorado em Arqueologia) - Museu de Arqueologia e Etnologia, Universidade de São Paulo, São Paulo, 2013.

MORAES, C. P. Arqueologia na Amazônia Central vista de uma perspectiva da região do Lago do Limão. 2006. 243f. Dissertação (Mestrado em Arqueologia) - Museu de Arqueologia e Etnologia, Universidade de São Paulo, São Paulo, 2006.

MORAES, C. P.; LIMA, A. M. A.; SANTOS, R. A. Os artesãos das Amazonas: a diversidade da indústria lítica dos Tapajó e o Muiraquitã. In: ROSTAIN, S. (Ed.). Antes de Orellana. Actas del 3er Encuentro Internacional de Arqueología Amazónica.Quito: IFEA; FLASCO; MCCTH; SENESCYT, 2014. p. 133-140

MORAES, C. P.; NEVES, E. G. O ano 1000. Adensamento populacional, interação e conflito na Amazônia Central. Amazônica: Revista de Antropologia, Belém, v. 4, n. 1, p. 122-148, 2012.

MORAES, C.; NOGUEIRA, A.P.R. Uma maneira alternativa de interpretar: os antiplásticos e a decoração nas cerâmicas amazônicas.BARRETO, C.; BETANCOURT, C. J; LIMA, H.P. (Org.) . Cerâmicas Arqueológicas da Amazônia: rumo a uma nova síntese. 1. ed. Belém: IPHAN /Museu Paraense Emílio Goeldi, 2016, p. 334-347.

MOREY, R.; MOREY, N. (1975). Relaciones comerciales en el pasado en los Llanos de Colombia y Venezuela. Montalbán, 4, 533-564

NATALIO, F. et al.. Siliceous spicules enhance fracture-resistance and stiffness of precolonial Amazonian ceramics. Scientific Reports , v. 5, 2015, Article number: 13303.

NETTO, L. Investigações sobre a Archeologia Brazileira. Archivos do Museu Nacional do Rio de Janeiro, Rio de Janeiro, v. 6, p. 257-260, 1985.

NEVES, E, GUAPINDAIA, V., LIMA, H, COSTA, B.; GOMES, J. A tradição Pocó-Açutuba e os primeiros sinais visíveis de modificações de paisagens na calha do Amazonas. In: 
ROSTAIN, S.(Org.). Antes de Orellana. Actas del 3er Encuentro Internacional de Arqueología Amazónica. Quito: Artes Gráficas Señal, p.137-158, 2014.

NEVES, E. Existe algo que se possa chamar de 'arqueologia brasileira'?. Estudos Avançados , v. 83, p. 7-17, 2015.

NEVES, E. G. Ecology, Ceramic Chronology and Distribution, Long-Term History and Political Change in the Amazonian Floodplain. In: SILVERMANN, H.; ISBELL, W. (Org.). Handbook of South American Archaeology. New York: Springer, p. 359-379, 2008.

NEVES, E. G. O Velho e o Novo na Arqueologia Amazônica. Revista USP, Brasil, v. 44, p. 87-113, 1999-2000.

NEVES, E.Archaeological cultures and past identities in the pre-colonial Central Amazon. In: HORNBORG, A.; HILL, J. (Ed.) Ethnicity in Ancient Amazonia. Boulder: University Press of Colorado, p. 31-56, 2011.

NEVES, E.G. Arqueologia da Amazônia Central e as classificações na Arqueologia Amazônica. In: PEREIRA, E.; GUAPINDAIA, V.L. Arqueologia Amazônica. v.2 Belém: MPEG/ IPHAN/SECULT, 2010, p. 561-579.

NEVES, E.G. et al. Ancient Exchange Networks in the Central Amazon. In: GLASCOCK, M.; NEFF, M.; VAUGHN, K. (Org.). Ceramics of the Indigenous Cultures of South America. Albuquerque: University of New Mexico Press, 2019, p. 231-239.

NEVES, G. O material lítico polido do interior de Minas Gerais e São Paulo: entre a matéria e a cultura.2008. 151f. Dissertação (Mestrado em Arqueologia), Museu de Arqueologia e Etnologia, Universidade de São Paulo, São Paulo, 2008.

NIMUENDAJÚ, C. Excursões pela Amazônia. Revista de Antropologia, 2001, v. 44, n. 1. 2001 [1932].

NIMUENDAJÚ, C. In pursuit of a past Amazon: archaeological researches in the Brazilian Guyana and in the Amazon region. In. STENBORG, E.(Ed.). Ethnological Studies, v.45, 2004. 
NIMUENDAJÚ, C. Os Tapajó. Boletim do Museu Paraense Emílio Goeldi, v. 10, p. 93$106,1949$.

NOELLI, F. S. A Arqueologia Guarani: construção e desconstrução da identidade indígena, por S. N. Oliveira Schiavetto. São Paulo: Revista do Museu de Arqueologia e Etnologia, 13, p. $309-310,2003$

NOELLI, F. S. . Repensando os rótulos e a história dos Jê no sul do Brasil a partir de uma interpretação interdisciplinar. Revista do Museu de Arqueologia e Etnologia. Suplemento, São Paulo, p. 285-301, 1999.

NORDENSKIÖLD, E. Ars Americana: L'Archaeoloie du Basin de L'Amazonie. Paris, Les Éditions G. Van Oest, 1930.

NORDENSKIÖLD, E.The ethnography of South America seen from Mojos in Bolivia. Comparative Ethnological Studies, v 3. G6teborg, 1924.

O MUSEU Nacional. São Paulo: Banco Safra, 1986.

O MUSEU Paraense Emílio Goeldi. São Paulo: Banco Safra, 1986.

O'BRIEN, M.; DARWENT, J.; LYMAN, R.L.. Cladistics Is Useful for Reconstructing Archaeological Phylogenies: Palaeoindian Points from the Southeastern United States. Journal of Archaeological Science, v. 28, p.1115-1136, 2001.

OLIVEIRA, C.E. A Cerâmica de Santarém. Revista do Serviço de Patrimônio Histórico e Artístico Nacional, n. 3, p.7-34, 1939.

OLIVEIRA, E. Potes que Encantam: Estilo e Agência na Cerâmica Polícroma da Amazônia Central. 2016. 378f. Dissertação (Mestrado em Arqueologia) - Museu de Arqueologia e Etnologia, Universidade de São Paulo, São Paulo, 2016.

OLIVER, J.The Archaeology of Agriculture in Ancient Amazonia.In: SILVERMANN, H.; ISBELL, W. (Org.). Handbook of South American Archaeology. New York: Springer, p. 185-216, 2008. 
ORTON, C.; HUGHES, M. Pottery in Archaeology. New York: Cambridge University Press, $2^{a}$ Ed., 2013 ( CambridgeManuals in Archaeology).

PALMATARY, H. Tapajó pottery. Etnologiska Studier, v.8, p.1939

PALMATARY, H. The ceramic art of the Tapajós Indians and its relation to pottery designs in cultures to the north.1936.100f. Dissertação (Master of Arts in Antrhropology). Faculty of the Graduate School of the Un1vers1ty of Pennsylvania, Filadélfia, 1936.

PALMATARY, H.C. The Archaeology of the lower Tapajos valley: Brazil. Transactions of the American Philosophical Society. New Series, 50, 1960.

PANACHUCK, L. Arqueologia preventiva e socialmente responsável! A musealização compartilhada e meu mundo expandido, Baixo Amazonas, Juruti, Pará. 2011. 266f. Dissertação (Mestrado em Arqueologia). Universidade de São Paulo, São Paulo, 2011.

Habilidade na variabilidade gráfica: comportamento motor das oleiras Borda Incisa (Parintins/AM). Arquivos do Museu de Historia Natural e Jardim Botânico da UFMG , v. 23, p. 135-177, 2014.

Cerâmicas Pocó e Konduri no Baixo Amazonas.BARRETO, C.; BETANCOURT, C. J; LIMA, H.P. (Org.) Cerâmicas Arqueológicas da Amazônia: rumo a uma nova síntese. 1. ed. Belém: IPHAN /Museu Paraense Emílio Goeldi, 2016a v. 1, p. 279-287.

A Ciência do barro e os sentidos: Percepções Sobre Experimentos Cerâmicos Arqueológicos Em Juruti, Pará, Baixo Amazonas. Teoria e Sociedade v. 24, n. 2, p. 31-54, 2016 b.

PANACHUK, L. (Org.). Memórias da Terra: análises cerâmicas e geoquímicas nos sítios Terra Preta 1 e Terra Preta 2: estudos de arqueologia na área de intervenção da mineração Juruti-Para. São Paulo: [s. n.], 2016.

PAREZO, N. The Formation of Ethnographic Collections: The Smithsonian Institution in the American Southwest. Advances in Archaeological Method and Theory v.10, p. 1-47, p. 1987. 
PEARCE, S. Museums, objects, and collections: a cultural study. Washington : Smithsonian Institution Press, 1993.

PEARCE, S. On collecting: an investigation into collecting in the European Tradition. Routledge, 1995

PENNA, D. S. F. Apontamentos sobre os Ceramios do Pará. Archivos do Museu Nacional do Rio de Janeiro, Rio de Janeiro, v. 2, p. 46-68, 1877

PENNY, H.G. Objects of Culture: Ethnology and ethnographic museums in Imperial Germany. Chapel Hill/London: The University of North Carolina Press, 2002.

PEREIRA, E. Arte rupestre na Amazônia - Pará. São Paulo:UNESP, Belém: Museu Emílio Goeldi, 2003.

PEREIRA, E. et al. Arqueologia subaquática na Amazônia -documentação e análise das gravuras rupestres do sítio Mussurá, rio Trombetas, Pará, Brasil. Revista de História da Arte e Arqueologia, v. 11, p. 110-126, 2008.

PERRONE-MOISÉS, B. Festa e Guerra. 2015.110f. Tese (Livre Docência), Faculade de Filosofia, Letras e Ciências Humanas, Universidade de São Paulo, São Paulo, 2015.

PETERSEN, S.; PETERSEN, J. The Craft and Art of Clay: A Complete Potter's Handbook. London: Laurence King Publisher, 2003.

PFAFFENBERGER, B. Social Anthropology of Technology.Annual Review of Anthropology, v, 21, p. 491-516, 1992.

PHILLIPS, P.; WILLEY, G. Method and Theory in American Archeology: An Operational Basis for Culture-Historical Integration. American Anthropologist, v. 55, n. 5, p.615-633, 1953.

PINTO, Renan (Org.) O Diário do Padre Samuel Fritz. Manaus: EDUA, 2006

POMIAN, K. Collectors and Curiosities: Paris and Venice, 1500-1800. Polity Press, 1990. 
PORRO, A. O povo das águas: ensaios de etno-história amazônica. Petrópolis: Vozes. São Paulo: Edusp, 1996.

Notas sobre o antigo povoamento indigena do alto Trombetas e Mapuera. Boletim do

Museu Paraense Emílio Goeldi. Ciências Humanas , v. 3 (3), p. 387-397, 2008.

Arte e simbolismo xamânico na Amazônia. Boletim do Museu Paraense Emílio

Goeldi. Ciências Humanas , v. 5, 1, p. 129-144, 2010.

PRICE, S. Primitive Art in Civilized Places. Chicago: University of Chicago Press, 1986.

PROUS, André. Arqueologia Brasileira. Brasília: Editora Unb, 1992.

A Pintura na Cerâmica Tupiguarani. In. PROUS, A.; LIMA, T. Os ceramistas Tupiguarani: elementos decoarativos, vol. II. Belo Horizonte: IPHAN, 2010, p. 105-194.

PROUS, A.; LIMA, A. P. . De Cobras e Lagartos: as tangas marajoaras. Revista do Museu de Arqueologia e Etnologia , v. 21, p. 231-263, 2012.

QUINN, E. Excavating “Tapajó" ceramics at Santarém: their age and archaeological context. 2004. Tese (Doutorado em Antropologia) - University of Illinois, Chicago, 2004.

RAMSEY, C. B.; LEE, S. Recent and planned developments of the program OxCal. Radiocarbon, v. 55, n. 2-3, p. 720-730, 2013.

REBAY-SALISBURY, K.Thoughts in Circles: Kulturkreislehre as a Hidden Paradigm in Past and Present Archaeological Interpretations. In: ROBERTS, B.W.; LIDEN, M.V. Investigating Archaeological Cultures: Material Culture, Variability, and Transmission.Springer, 2011, p.41-60.

REICHEL-DORMATOFF, G. Orfebrería y chamanismo: un estudio iconográfico del Museo del Oro Editorial Colina, 1988.

REEDY, C.; REEDY, T. Relating Visual and Technological Styles in Tibetan Sculpture Analysis. World Archaeology, v.25, n. 3,p. 304-320, 1994. 
RELEIGH, W. The Discovery of Guiana. In. The works of sir Walter Religh, vol. 2. London: R. Dodsley Ed., 1751, p. 151-237.

RENFREW, C. Trade as action at a distance: questions of integration and communication. SLABOFF, J.; LAMBERG-KARLOVSKY, C. Ancient civilization and trade, University of New Mexico Press, 1975, p. 3-59.

C. Introduction: peer polity interaction and socio-political change. In. RENFREW, C.; CHERRY, J. (Ed.) Peer polity interaction and socio-political change.Cambridge: Cambridge University Press, 1986, p.1-18.

RIBEIRO, B.L.A Tradição Vieira vista de outra perspectiva: uma análise tecnológica ontologicamente orientada (e interpretada). Revista de Arqueologia, v. 29, n.1, p. 114-135, 2016.

RICE, P. Pottery Analysis: a sourcebook. London/Chicago: University of Chicago Press, 1987.

ROBERTS, B.W.; LINDEN, M. V. Investigating Archaeological Cultures: Material Culture, Variability, and Transmission. In: ROBERTS, B.W.; LIDEN, M.V. Investigating Archaeological Cultures: Material Culture, Variability, and Transmission.Springer, p. 1-22, 2011.

ROCHA, B.C. et al. Na Margem e à Margem: Arqueologia Amazônica em Territórios Tradicionalmente Ocupados. Amazônica: Revista de Antropologia, v.6, n.2, p. 358-384, 2014.

ROCHA, B.C. Ipi Ocemumuge: A Regional Archaeology of the Upper Tapajós River. 2017. 427f + Anexos. Tese (Doutorado em Arqueologia). Institute of Archaeology University College London, London, 2017.

ROCHA, B.C. What can ceramic decoration tell us about the pre- and post- colonial past on the Upper Tapajós River?. Dissertação (Mestrado em Arqueologia), Institute of Archaeology University College London, London, 2012. 
RODET, M. J; GUAPINDAIA, V.; MATOS, A. Análise tecnológica e cadeia operatória: uma nova proposta para a indústria lítica lascada das culturas ceramistas da Amazônia. in. Edithe Pereira; Vera Guapindaia. (Org.). Arqueologia Amazônica. Belém: MPEG; IPHAN; SECULT, v.2, 2010, p. 681-712.

RODET, M.J ; DUARTE-TALIM, D.L.; GUAPINDAIA, V.; MATOS, A. Cadeia operatória, lâminas de machado polidas e imaginário amazônico no sítio arqueológico Boa Vista, Pará. Teoria e Sociedade, Especial, p. 307-331, 2014.

RODRIGUES, A. Sobre A Contribuição Lingüística Da Comissão Rondon. Anais da 56 Reunião Anual da SBPC. Cuiabá, MT, julho/2004. Disponível em: http://www.sbpcnet.org.br/livro/56ra/banco_conf_simp/textos/aryonrodrigues-conf.htm. Acesso em 30 de junho de 2019.

RODRIGUES, I.; VOLKMER-RIBEIRO, C.; MACHADO, V.. Cauixi em cerâmica arqueológica da região de Lagoa Santa, Minas Gerais: inclusão de esponjas processadas ou exploração de depósitos sedimentares com espículas?. Bol. Mus. Para. Emílio Goeldi. Ciênc. hum., Belém, v. 12, n. 1, p. 85-100, Jan. 2017

RODRIGUES, Igor Morais Mariano. Fora das grandes aldeias: a ocupação do recôndito sítio arqueológico Vereda III. 2011. 318 f. Dissertação (Mestrado em Antropologia) Universidade Federal de Minas Gerais, Belo Horizonte, 2011.

RONDON, C.M.S. Índios do Brasil: do norte do rio Amazonas. Rio de Janeiro: Conselho Nacional de Proteção dos Índios/Ministério da Agricultura, v.3, 1953.

ROODBANK, C.The spirit is willing. Antiquity, v.66, p 542-546

ROOSEVELT, A. C. Arqueologia amazônica. In: CARNEIRO DA CUNHA, M. (Org.). História dos índios no Brasil. São Paulo: Companhia das Letras; Secretaria Municipal de Cultura; FAPESP, 1992, p.

The Development of Prehistoric Complex Societies: Amazonia, a Tropical Forest. In: BACUS, E. A.; LUCERO, L. (Eds.). Complex Politics in the Ancient Tropical World. Archaeological Papers of the American Anthropological Association, n. 9, p. 13-34, 1999 
.The Rise and Fall of the Amazon Chiefdoms. L'homme, v. 33, n. 126-128, p. 255284, 1993.

ROOSEVELT, A. et al. C.Eighth Millennium Pottery from a Prehistoric Shell Midden in the Brazilian Amazon. Science, v. 254, n. 5038, p. 1621-1624, 1991.

ROOSEVELT, A. C.et al. Paleoindian Cave Dwellers in the Amazon. The peopling of the Americas. Science, v. 271, p. 373-384, 1996.

ROSA, C. Contribuição para história da arqueologia na Amazônia: um estudo histórico e arqueológico das coleções Townsend e Frederico Barata do Museu Paraense Emílio Goeldi (1950-1960). 2004.79f. Trabalho de Conclusão de Curso (Graduação em História). Instituto de Filosofia e Ciências Humanas. Universidade Federal do Pará, Belém, 2004.

Ilusão e Paraíso: História e Arqueologia na Amazônia (1948-1965). 2008.112f. Dissertação (Mestrado em História). Instituto de Filosofia e Ciências Humanas, Universidade Federal do Pará, Belém, 2008.

ROSTAIN, S. "C'est curieux chez les Amazoniens ce besoin de faire des vases": Alfareras Palikur De Guyana. In: BARRETO, C.; BETANCOURT, C. J; LIMA, H.P. (Org.) • Cerâmicas Arqueológicas da Amazônia: rumo a uma nova síntese. 1. ed. Belém: IPHAN /Museu Paraense Emílio Goeldi, 2016, p.97-114.

La collection Cullère. In Stupéfiante Amazonie. Nantes: Grand Patrimoine de Loire-Atlantique, p.53-60.

ROSTAIN, S.; VERSTEEG, A.H. The Arauquinoid Tradition in the Guianas. In. DELPUECH, A.; HOFMAN, C. Late Ceramic Age Societies in the Eastern Caribbean. Oxford: Archaeopress/BAR S1273, 2004, p.233-250. (Paris Monographas in American Archaeology).

ROTH, W.An Introductory Study of the Arts, Crafts, and Customs of the Guiana Indians.Johnson Reprint Corporation, 1924

ROUSE, I. Migrations in Prehistory: Inferring Population Movement from Cultural Remains. Yale University Press, 1986. 
ROUSE, I.; CRUXENT, J.M. Arqueología Venezolana. Tradução de Érika Wagner.Caracas: Instituto Venezolano de Investiagiones Científicas, 1963.

ROUX, V. Standardization of ceramic assemblages: transmission mechanisms and diffusion of morpho-functional traits across social boundaries. Journal of Anthropological Archaeology, v.40, p. 1-9, 2015.

Ceramics and Society: A technological Approach to Archaeological Assemblages. Springer, 2019.

RYE, Owen. Pottery Technology: principles and reconstruction. Washington, D.C.: Taraxacum, 1981

SACKETT, J. Approaches to style in lithic archaeology. Journal of Anthropological Archaeology, v.1, p. 59-112.

. The Meaning of Style in Archaeology: A General Model. American Antiquity.v, 42, n.3, p.369-380, 1977.

Style and ethnicity in archaeology: the case of isochrestism. In: CONKEY, M.; HASTORFF, C. (Ed.). The uses of style in archaeology. New York, Melbourne: Cambridge University Press, 1990, p. 32-43.

SANTOS, L.P.S. Pratos e Panelas Konduri: um banquete xamânico na Amazônia précolonial. 2018.102f. Dissertação (Mestrado em Ciências da Religião), Centro de Ciências Sociais e Educação, Universidade Estadual do Pará, Belém, 2018.

SANTOS-GRANERO, F. The Arawakan Matrix: Ethos, Language, and History in Native South America. In: HILL, J.D.; SANTOS-GRANERO, F. Comparative Arawakan Histories: Rethinking Language Family and Culture Area in Amazonia. Urbana/Chicago: University of Illinois Press, 2002, p. 25-50.

SCATAMACCHIA, M. C. M. Arqueologia. Mostra do descobrimento. 1. ed. São Paulo: Fundação Bienal de São Paulo/Associação Brasil 500 anos, v. 1, 2000. 
SCATAMACCHIA, M.C.; DEMARTINI, C. M.; BUSTAMANTE, A. O aproveitamento científico de coleções arqueológicas: a coleção Tapajônica do MAE-USP. Revista do Museu de Arqueologia e Etnologia v. 6, p. 317-333, 1996.

SCARAMELLI, K.; SCARAMELLI, F. Generic Pots and Generic Indians: The Archaeology of Ethnogenesis in the Middle Orinoco. In: HORNBORG, A.; HILL, J. (Ed.) Ethnicity in Ancient Amazonia. Boulder: University Press of Colorado, p. 99-128, 2011.

SCHAAN, D. P. Múltiplas vozes, memórias e histórias: por uma gestão compartilhada do patrimônio arqueológico na Amazônia. Revista do Patrimônio Histórico e Artístico Nacional, n.33, p. 108-135, 2007b.

SCHAAN, D. P. Uma janela para a história pré-colonial da Amazônia: olhando além - e apesar - das fases e tradições. Boletim do Museu Paraense Emilio Goeldi. Ciências Humanas, v. 3, p. 27-39, 2007.

SCHAAN, D.P. A indústria cerâmica dos Tapajó. In.SCHAAN, D.; ALVES, D. (Org.). Um Porto, muitas Histórias. Arqueologia no Porto de Santarém. 1. ed. Belém: Supercores, p.35$62,2015$.

SCHAAN, D. P. Discussing centre-periphery relations within the Tapajó domain, lower Amazon. In: STENBORG, P. (Org.). Beyond Waters: Archaeology and Environmental History of the Amazonian Inland. Gothenburg: University of Gothenburg, 2016, 6, p. 23-36, 2016.

SCHAAN, D.P. Ponds, Lakes, and Feasts: The Cultural Geography of Anthropogenic Soils. In._____acred Geographiesof ancient Amazonia: Historical ecology of social complexity. 1. ed. Walnut Creek, CA: Left Coast Press, 2012, p.105-139

SCHIFFER, M. B.; SKIBO, J. The Explanation of Artifact Variability. American Antiquity, v.62, n.1, p.27-50, 1997.

SCHIFFER, M. B.; SKIBO, J. Theory and experiment in the study of technological change.Current Anthropology, v. 28,p. 595-622, 1987. 
SCHMIDT, M.J. et al. Dark earths and the human built landscape in Amazonia: a widespread pattern of anthrosol formation. Journal of Archaeological Science , v. 42, p. 152-165, 2014.

SCHOMBURGK, R. Richard Schomburgk's Travels in British Guiana, 1840-1844. Traduzido por Walter Roth. Georgetown: Daily Chronicle Office, 1922.

SCHWARCZ, Lilia. O Espetáculo das Raças: cientistas, instituições e questão racial no Brasil 1870 - 1930. São Paulo: Companhia das Letras, 1993.

SCIENTIA CONSUlTORIA CIENTÍFICA. Arqueologia Preventiva Na Área De Intervenção Da Linha De Transmissão 500 Kv Oriximiná (Pa) - Itacoatiara (AM) Cariri (AM). Etapa De Resgate. Relatório Parcial. Análise De Laboratório, 2013, 207p.

SCIENTIA CONSULTORIA CIENTÍFICA. LT em 230 kV Oriximiná - Mineração Rio do Norte - PA: Arqueologia: Diagnóstico, Avaliação De Impactos E Programa Recomendado, 2012, 44p.

SCIENTIA CONSULTORIA CIENTÍFICA. Arqueologia preventiva na área de intervenção do Projeto Juruti, PA. Relatório Final.São Paulo, 2008.298p.

SCIENTIA CONSULTORIA CIENTÍFICA. Levantamento Arqueológico na área de Intervenção do Projeto de Mineração, Juruti, PA. Relatório Final.São Paulo, 2003. 230p.

SCOLES, R. Do rio Madeira ao rio Trombetas: novas evidências ecológicas e históricas da origem antrópica dos castanhais amazônicos. Cadernos NAEA, v. 14, n. 2, p. 265-282, 2011.

SERRANO, A. Ceramica Santarem. Revista Geografica Americana, v. 9, n.5, p. 197-203, 1939.

SHENNAN, S. Introduction: archaeological approaches to cultural identity.In. Archaeological Approaches to Cultural Identity. London/New York: Routledge, 1989, p.130.

SHEPARD, A. Ceramics for the archaeologist. Washington D.C.,Carnegie Institution of Washington, 1956. 
SIEGEL, P. An Interview with Irving Rouse. Current Anthropology, v.37, n.4, 671-698, 1996.

SILVA, Fabíola. As Tecnologias e seus Significados. Um Estudo da Cerâmica dos Asuriní do Xingu e da Cestaria dos Kayapó-Xikrin sob uma Perspectiva Etnoarqueológica. Tese (Doutorado em Antropologia). Universidade de São Paulo, São Paulo, 2000.

SILVA, F.A. Mito e Arqueologia: a interpretação dos Asurini do Xingu sobre os vestígios arqueológicos encontrados no Parque Indígena Kuatinemu - Pará. Horizontes Antropológicos, v. 8, n.18, p. 175-187, 2002.

SILVA, F.A. O significado da variabilidade artefatual: a cerâmica dos Asurini do Xingu e a plumária dos Kayapó-Xikrin do Cateté. Bol. Mus. Para. Emílio Goeldi. Ciências Humanas, Belém, v. 2, n. 1, p. 91-103, 2007.

SILVA, F.A Tipos cerâmicos ou modos de vida? Etnoarqueologia e as Tradições Arqueológicas Cerâmicas na Amazônica In: BARRETO, C.; LIMA, H.P.; BETANCOURT, C.J. Cerâmicas arqueológicas da Amazônia: rumo a uma nova síntese. Belém: IPHAN/Ministério da Cultura,2016 p.40-49.

SILVA, F.A; NOELLI, F. S. Arqueologia e linguística: Construindo as trajetórias históricoculturais dos povos Tupí. Crítica e Sociedade: revista de cultura política , v. 7, p. 55-87, 2017.

SILVA, M. Memórias e histórias no sudoeste amazônico: o Museu Regional de Arqueologia de Rondônia. 2015. 442f. Dissertação (Mestrado em Arqueologia). Universidade de São Paulo, 2015.

SILVA. A Instituição Dos Territórios da Ordem Franciscana No Brasil: Uma Análise Sobre Seus Elementos. Espaço e Cultura, UERJ, n.32. p.13-29, 2012.

SIMÕES, M.; LOPES, D..Pesquisas arqueológicas no baixo/médio rio Madeira. Revista de Arqueologia, v.4, n. 1, p. 117-134, 1987.

SIMÕES, M.; MACHADO, A.L.Pesquisas arqueológicas no lago Silves (AM). Revista de Arqueologia, v.4, n. 1, p. 49-82, 1987. 
SIMÕES, M.As pesquisas arqueológicas no Museu Paraense Emilio Goeldi (1870-1981). Acta Amazonica, v.1, n.1, p.149-165, 1981.

SKIBO, J.; SCHIFFER, M.B. Understanding artifact variability and change: A behavioral framework. In SCHIFFER, M.B.Anthropological Perspectives on Technology. Albuquerque: University of New Mexico Press, Albuquerque, p. 139-149, 2001.

SKIBO, J.; SCHIFFER, M.B.People and Things: A Behavioral Approach to Material Culture. Springer, 2008.

SLATER, C. Entangled Edens: Visions of the Amazon. Berkley: University of California Press, 2002.

SMITH, M; WHARTON, J.; OLSON, J. Aztec Feasts, Rituals, and Markets: Political Uses of Ceramic Vessels in a Commercial Economy. In. BRAY, Tamara (Ed.) The Archaeology and Politics of Food and Feasting in Early States and Empires Kluwer Academic Publishers, p. $235-270,2002$.

CHUMBRE, G. A Tecnologia dos grupos pré- históricos do Sítio Cipoal do Araticum (PA). 2014. 215f. Dissertação de Mestrado em Arqueologia. Universidade Federal de Pernambuco, Recife, 2014.

STAMPANONI, F. A maloca Saracá: uma fronteira cultural no médio Amazonas précolonial, vista da perspectiva de uma casa. 2016. 343f. Tese (Doutorado em Arqueologia) Museu de Arqueologia e Etnologia, Universidade de São Paulo, São Paulo, 2016.

STARK, M. (ed.) The Archaeology of Social Boundaries. Washington/London: Smithsonian Institution Press. 1998.

STENBORG, P. Towards a Regional History of Pre-Columbian Settlements in the Santarém and Belterra Regions, Pará, Brazil. In: STENBORG, P. (Org.). Beyond Waters: Archaeology and Environmental History of the Amazonian Inland. Gothenburg: University of Gothenburg, 2016, p. 9-22, . 
STOCKING, G.W.Essays on Museums and Material Culture. In. (Ed.) Object and

Other: Essays on Museums and Material Culture. The University of Wisconsin Press, 1985, p. 3-14.

STRATHERN, M. O gênero da dádiva. Problemas com as mulheres e problemas com a sociedade na Melanésia. Campinas, Editora da Unicamp, 2006.

STRONG, Wm. The archeology of Costa Rica and Nicaragua.,Handbook of South American Indians, v. 4, Tropical Forest, Bureau of American Ethnology, Bulletin, v. 143, 1948, p. 121142

STURTEVAnT, W.C. Does Anthropology Need Museums? Proceedings of the Biological Society of Washington, v. 82, p. 619-649, 1969.

TARBLE, K. Un nuevo modelo de expansión Caribe para la época prehispánica. Antropológica, v. 63-64, p.45-81, 1985.

TAYLOR, A. C. L'américanisme tropical: une frontière fossile de l'ethnologie? In: RUPPEISENREICH, B. (org.), Histoires de l'anthropologie: XVI-XIX siècles. Paris: Klinksieck, 1984, p.213-233.

TRIGGER, B.G.A History of Archaeological Thought. 2a Edição. New York: Cambridge University Press, 2008.

TONEY, Joshua Robert The product of labor: pottery technology in the Upper Xingu, Southern Amazon, Brazil, A.D. 700-1770. 327 f. Tese (Doutorado em Antropologia) Universidade da Flórida, 2012.

TROUFFLARD, J. O que nos dizem as coleções da relação entre moradores e vestígios arqueológicos na região de Santarém, Pará? In: SCHAAN, D. (Org.). Arqueologia, patrimônio e multiculturalismo na beira da estrada: pesquisando ao longo das rodovias Transamazônica e Santarém-Cuiabá, Pará.Belém: GK Noronha, p. 59-74.

Van den BEL, M. Uma nota sobre a introdução de raladores de metal e sobre a produção e consumo da mandioca e do milho na zona costeira das Guianas durante o século XVII. Amazônica: Revista de Antropologia, v.7, n.1, p. 100-131, 2015 
van der LEEUW, S. Giving the Potter a Choice. In: LEMONNIER, P. (ed.). Technological Choices. Transformation in Material Cultures since the Neolithic. London:Routledge. 1993

VETHEM, L. O livro da argila: Ëliwë Pampila : Orino Papeh. Iepé, São Paulo, 2017.

VIDAL, J.J.A. Cerâmica dos Suruí de Rondônia e dos Asurini do Xingu: visões diferenciadas de povos indígenas da Amazônia.2015. 254f. Tese (Doutorado em Artes) Insituto de Artes, Universiade Estadual Paulista "Júlio Mesquita Filho", São Paulo, 2015.

VIDEIRA, L.F.G ; REIS, L.G.C. ; SILVA, R.C.; AIRES, A.S.. A Cultura do Barro: arte e ciência nas margens do rio Trombetas. Belém: Núcleo Editorial de Livros-MPEG, 2010

VIVEIROS DE CASTRO, Eduardo. 2002. Perspectivismo e multinaturalismo na América Indígena. In. A inconstância da alma selvagem. São Paulo: Cosac-Naify,p. 345-399.

VOSS, B. Curation as research. A case study in orphaned and underreported archaeological collections. Archaeological Dialogues, v.19 n.2, p 145 - 169, 2012.

VOLKMER-RIBEIRO, C.; BATISTA,T. Levantamento de cauixi (Porifera, Demospongiae), provável agente etiológico de doença ocular em humanos, Araguatins, rio Araguaia, Estado do Tocantins, Brasil. Revista Brasileira de Zoologia, 24, p. 133-143, 2007.

WALDRON, L. Geographic Distributions of Zoomorphic Motifs in Saladoid Ceramics. Caribbean Connections Journal, n. 1, v.2

WAGNER, R. The invention of the culture. $2^{\mathrm{a}}$ Ed. Chicago: University of Chicago Press, 1981.

WÁSSEN, Henry. The Frog-Motive among the South American Indians, Ornamental Studies. Anthropos, n. 29, p. 319-370, 1934.

WELPER, E. A aventura etnográfi ca de Curt Nimuendajú. Tellus, n. 24, p. 99-120, 2013.

WELPER, E. Curt Unckel Nimuendajú: Um Capítulo Alemão na Tradição Etnográfica Brasileira. 2002. 245f. Dissertação (Mestrado em Antropologia) - Museu Nacional, Universidade Federal do Rio de Janeiro, 2002. 
WHITEHEAD, N. The lord of the tiger spirit. A history of the Caribs in Colonial Venezuela and Guyana. 1498 - 1820. Dortrecht - Holanda; Providence - USA. Foris Publications, 1988.

WILLEY, G.; PHILLIPS, P. Method and theory in American archaeology. University of Chicago Press, Chicago, 1958.

WILLEY, G.R. Ceramics. In. STEWARD, J. (Ed.) Handbook of South American Indians. Bureau American Ethnology, Bulletin, v. 143, n.5, 1949, p.139-204.

WILLIAMS, D. Ancient Guyana. Georgetown: Departament of Culture, 1985.

WILLIAMNS, E.A. Art and Artifact at the Trocadero: Ars Americana and the primitivist revolution. In. STOCKING, G.W. (Ed.) Object and Other: Essays on Museums and Material Culture. The University of Wisconsin Press, 1985

WOLF, E. Culture: panacea or problem. American Antiquity, Washington, v. 49, n. 2, p. 393-400, 1984.

YDE, J. Material culture of the Waiwái. Copenhagen: Nationalmuseets Skrifter, Etnografisk Rœkke, X, 1965.

ZIMPEL, C.A. A fase Bacabal e seus correlatos arqueológicos no sudoeste da Amazônia. 2018. 256f. Tese (Doutorado em Arqueologia) Museu de Arqueologia e Etnologia, Universidade de São Paulo, São Paulo, 2018.

ZUCCHI, A. Evidencias arqueológicas sobre grupos de posible lengua Caribe. Antropológica, v. 63-64, p.23-44, 1985

ZUCCHI, A; TARBLE, K; VAZ, J.E.The Ceramic Sequence and New TL and C-14 Dates for the Aguierito Site of the Middle Orinoco, Venezuela. Journal of Field Archaeology, n.11, p. 155-180, 1984. 
Anexos 
Ficha de análise 
Museu

Número (instituição)

Número (estudo)

Proveniência

Marcação

Etiqueta

1 - Igual marcação

2- Diferente da marcação

\section{Coleção}

1- Aplique

2- Borda

3- Parede

4- Base

5- Fragmento de estatueta

6- Vasilha inteira/semi-inteira

7- Fuso

\section{Técnica}

1- Roletado

2- Modelado

\section{Antiplástico}

1. Cauixi

2. Caraipé

3. Quartzo
4. Carvão

5. Bolota de argila

6. Óxido de ferro

7. Caco moído

8. Feldspato

Porcentagem de antiplástico

1. Baixa

2. Média

3. Alta

4. Altíssima (apenas cauixi)

\section{Espessura da parede}

\section{Diâmetro da boca}

\section{Contorno da vasilha}

1- Simples

2- Infletido

3- Complexo

4- Composto

\section{Cor da face externa}

1. Amarela (10 YR 8/4, 8/6, 2.5YR $8 / 4,8 / 6$ )

2. Branca (5YR $8 / 1,8 / 2,8 / 3$ )

3. Laranja (5YR $7 / 6,5 / 6)$

4. Vermelha (2.5 YR 4/4, 4/6, 4/8).

5. Preta (2.5 YR 8/1)

6. Cinza (7.5 YR 6/1 5/1 4/1)

7. Marrom (7.5 YR 4/3 4/4 3/4)

8. Rosada (2.5 YR 8/2, 8/3, 7/4)

\section{Indicativos de queima}

1. Claro

2. Escuro 
3. Face interna escura

4. Face externa escura

5. Núcleo escuro

Tratamento de superfície

1- Fino

2- Grosso

3- Polimento

Modificações de superfície

1- Aplicado

2- Inciso

3- Ponteado

4- Entalhado

5- Pintura amarela

6- Pintura vermelha

7- Pintura marrom (linhas)

8- Pintura preta (linhas)

9- Engobo vermelho

10- Engobo amarelo

11- Engobo branco

12- Enegrecimento/Brunidura

13- Exciso

14- Acanalado
1- Plana

2-Côncava

3- Em pedestal

4- Anelar

5- Trípode

6 - Convexa

Forma do lábio

1- Plano

2- Arredondado

3- Biselado

4- Apontado

5- Afilado

\section{Forma da borda}

1- Extrovertida

2- Direta

3- Introvertida

Reforço de borda

Área de modificação de superfície

1- Face interna - borda

2- Face externa - borda

3- Aplique

4- Face externa - bojo

5- Face interna - bojo

6- Face externa - base

7- Lábio

8- Estatueta

\section{Forma da base}

1- Presente

2- Ausente

Tipo de aplique

1- Apêndice

2- Alça

3- Pé modelado

9 - não se aplica

Ranhuras 
1- Presentes

2- Ausentes

9 - Não se aplica

\section{Localização do aplique}

1- Borda

2- Bojo superior

3- Bojo inferior

4- Mesial

5- Base

6- Lábio

\section{Forma do aplique}

1- Relevo pleno (arredondado)

2- Achatado (placa)

\section{Solidez}

1. Maciço

2. Oco

3. Face Côncava

Forma dos olhos

1. Ponto

2. Círculo inciso

3. Círculo inciso com ponto central

4. Circular aplicado com círculo inciso e ponto central

5. Elipsoidal aplicado com linha incisa - "grão de café"

6. Subretangular aplicado com linha incisa no centro

7. Aplicado com círculos concêntricos e ponto central

8. Linha incisa

9. Círculo aplicado

10. Troncocônico com ponto central
11. Circular esfera aplicada sobre esfera

12. Circular aplicado com círculo inciso $\mathrm{F}$

13. Circular aplicado com ponto central

\section{Pés ou suportes}

Diâmetro máximo

Diâmetro mínimo

Altura

Solidez

1. Oco

2. Maciço

Furo

1- Presente

2- Ausente

3- "Furo falso"

Tipo de ponta

Intervenções

recentes 
Levantamento de coordenadas geográficas de sítios Konduri 


\begin{tabular}{|c|c|c|c|c|}
\hline PA-OR-50 & São Lourenço & 607256 & 9803622 & Fonseca, 2018 \\
\hline PA-OR-51 & Gonçalves & 614100 & 9801605 & Fonseca, 2018 \\
\hline PA-OR-52 & Ascenção & 611367 & 9802838 & Fonseca, 2018 \\
\hline PA-OR-53 & Uajará & 603283 & 9803407 & Fonseca, 2018 \\
\hline PA-OR-54 & Cacal & 599154 & 9804363 & Fonseca, 2018 \\
\hline PA-OR-55 & Pimenta & 590932 & 9801097 & Fonseca, 2018 \\
\hline PA-OR-56 & Boca dos Anjos & 585700 & 9802416 & Fonseca, 2018 \\
\hline PA-OR-57 & Ponta dos Souzas & 589174 & 9798856 & Fonseca, 2018 \\
\hline PA-OR-58 & Ponta da Mafada & 583088 & 9797977 & Fonseca, 2018 \\
\hline PA-OR-59 & São Braz & 582209 & 9797253 & Fonseca, 2018 \\
\hline PA-OR-60 & Santo Antonio & 581210 & 9797830 & Fonseca, 2018 \\
\hline PA-OR-61 & Terra Preta Saracá & 581278 & 9798666 & Fonseca, 2018 \\
\hline PA-OR-63 & Boa Vista & 567066 & 9838676 & Fonseca, 2018 \\
\hline PA-OR-64 & Ponta do Celeste & 567910 & 9813034 & Fonseca, 2018 \\
\hline PA-OR-65 & Ponta do BEC & 568514 & 9813172 & Fonseca, 2018 \\
\hline PA-OR-66 & Hakibono & 574806 & 9831074 & Fonseca, 2018 \\
\hline
\end{tabular}




\begin{tabular}{|c|c|c|c|c|}
\hline PA-OR-67 & Inajatuba & 580011 & 9829135 & Fonseca, 2018 \\
\hline PA-OR-68 & Ilha Carana & 572547 & 9837590 & Fonseca, 2018 \\
\hline PA-OR-69 & Buriti & 581934 & 9828764 & Fonseca, 2018 \\
\hline PA-OR-70 & Igarape do Moura & 563368 & 9841236 & Fonseca, 2018 \\
\hline PA-OR-75 & Saracá I & 564153 & 9812672 & Fonseca, 2018 \\
\hline PA-OR-76 & Saracá II & 563308 & 9812733 & Fonseca, 2018 \\
\hline PA-OR-77 & Araticúm & 559817 & 9802769 & Fonseca, 2018 \\
\hline PA-OR-78 & Área de Lazer & 574383 & 9831660 & Fonseca, 2018 \\
\hline PA-OR-79 & & 568117 & 9834978 & Fonseca, 2018 \\
\hline PA-OR-80 & Castanhal & 570255 & 9811534 & Fonseca, 2018 \\
\hline PA-OR-81 & Cemitério & 573711 & 9832099 & Fonseca, 2018 \\
\hline PA-OR-82 & Laranjal & 574616 & 9832574 & Fonseca, 2018 \\
\hline PA-OR-83 & & 573745 & 9832961 & Fonseca, 2018 \\
\hline PA-OR-84 & Ponta do Caranã & 572970 & 9837392 & Fonseca, 2018 \\
\hline PA-OR-85 & Farinha & 574944 & 9832065 & Fonseca, 2018 \\
\hline PA-OR-86 & Cobra & 575409 & 9830841 & Fonseca, 2018 \\
\hline
\end{tabular}




\begin{tabular}{|c|c|c|c|c|}
\hline PA-OR-87 & Acabaxi & 574857 & 9830091 & Fonseca, 2018 \\
\hline PA-OR-88 & & 576857 & 9830177 & Fonseca, 2018 \\
\hline PA-OR-89 & & 577581 & 9829988 & Fonseca, 2018 \\
\hline PA-OR-90 & $\begin{array}{l}\text { Raimundo Cabeça } \\
\text { Quente }\end{array}$ & 577840 & 9829919 & Fonseca, 2018 \\
\hline PA-OR-91 & & 579003 & 9829557 & Fonseca, 2018 \\
\hline PA-OR-92 & Igarape do Camargo & 575926 & 9830703 & Fonseca, 2018 \\
\hline PA-OR-93 & & 566411 & 9839072 & Fonseca, 2018 \\
\hline PA-OR-94 & & 572039 & 9833332 & Fonseca, 2018 \\
\hline PA-OR-95 & & 581141 & 9828997 & Fonseca, 2018 \\
\hline PA-OR-96 & Casa de Risk & 584106 & 9829738 & Fonseca, 2018 \\
\hline PA-OR-97 & Vaca Gorda & 586157 & 9829402 & Fonseca, 2018 \\
\hline PA-OR-98 & & 586648 & 9829453 & Fonseca, 2018 \\
\hline PA-OR-99 & Gafanhoto & 562911 & 9841193 & Fonseca, 2018 \\
\hline PA-OR-100 & & 562946 & 9841718 & Fonseca, 2018 \\
\hline PA-OR-101 & & 562739 & 9841830 & Fonseca, 2018 \\
\hline
\end{tabular}




\begin{tabular}{|c|c|c|c|c|}
\hline PA-OR-104 & & 573840 & 9830367 & Fonseca, 2018 \\
\hline PA-OR-105 & Tubulação & 571910 & 9835306 & Fonseca, 2018 \\
\hline PA-OR-106 & & 574711 & 9818128 & Fonseca, 2018 \\
\hline PA-OR-107 & & 576641 & 9817783 & Fonseca, 2018 \\
\hline PA-OR-108 & & 567678 & 9818378 & Fonseca, 2018 \\
\hline PA-OR-109 & & 565057 & 9835564 & Fonseca, 2018 \\
\hline $\begin{array}{l}\text { PA- } \\
\text { OR-111 }\end{array}$ & & 564066 & 9833246 & Fonseca, 2018 \\
\hline PA-OR-110 & & 564549 & 9834685 & Fonseca, 2018 \\
\hline PA-OR-112 & & 571539 & 9826325 & Fonseca, 2018 \\
\hline PA-OR-113 & & 570737 & 9825868 & Fonseca, 2018 \\
\hline PA-OR-114 & & 567591 & 9838555 & Fonseca, 2018 \\
\hline PA-OR-115 & & 558386 & 9787625 & Fonseca, 2018 \\
\hline PA-OR-116 & & 558567 & 9785721 & Fonseca, 2018 \\
\hline PA-OR-123 & Aramã & 565254 & 9819238 & Fonseca, 2018 \\
\hline PA-OR-127 & Papagaio & 507046 & 9737639 & Fonseca, 2018 \\
\hline
\end{tabular}




\begin{tabular}{|c|c|c|c|}
\hline Maria Rama & 563368 & 9841012 & Fonseca, 2018 \\
\hline Pantanal & 574668 & 9831091 & Fonseca, 2018 \\
\hline JOCA & 574349 & 9832901 & Fonseca, 2018 \\
\hline São Sebastião & 569755 & 9810130 & Fonseca, 2018 \\
\hline Perpétuo Socorro & 563411 & 9841675 & Fonseca, 2018 \\
\hline COTRA Almeidas & 565571 & 9810584 & Fonseca, 2018 \\
\hline COTRA A viso III & 563310 & 9810672 & Fonseca, 2018 \\
\hline COTRA Aviso II & 563882 & 9810420 & Fonseca, 2018 \\
\hline COTRA Aviso I & 563371 & 9810182 & Fonseca, 2018 \\
\hline $\begin{array}{l}\text { PA-OR-127: Cipoal do } \\
\text { Araticum }\end{array}$ & 555326 & 9803939 & Fonseca, 2018 \\
\hline Bela Cruz II & 552054 & 9804510 & Fonseca, 2018 \\
\hline Bela Cruz I & 553272 & 9804073 & Fonseca, 2018 \\
\hline Greig I & 553795 & 9797334 & Fonseca, 2018 \\
\hline Greig II & 561854 & 9796578 & Fonseca, 2018 \\
\hline Santidade & 476514.32 & 9904392.63 & Jácome 2017 \\
\hline
\end{tabular}




\begin{tabular}{|c|c|c|c|c|}
\hline & Tawanî de baixo & 493595.48 & 9876316 & Jácome 2017 \\
\hline & Tawanî de cima & 493536.15 & 9876136.12 & Jácome 2017 \\
\hline PA-OR-43 & América & 627240 & 9802289 & K. Hilbert \\
\hline PA-OR-44 & Santa Tereza & 628499 & 9801589 & K. Hilbert \\
\hline PA-OR-45 & Terra Preta Cuminá & 607665 & 9833767 & K. Hilbert \\
\hline PA-OR-71 & Santa Helena & 495635 & 9877481 & K. Hilbert \\
\hline PA-OR-72 & & 494341 & 9879175 & K. Hilbert \\
\hline PA-OR-73 & Colônia & 497607 & 9876893 & K. Hilbert \\
\hline PA-OR-102 & Caco Velho & 563118 & 9841883 & K. Hilbert \\
\hline PA-OR-103 & Maria do Carmo & 563574 & 9841657 & K. Hilbert \\
\hline PA-OR-119 & Paraiso & 629289 & 9800443 & K. Hilbert \\
\hline PA-OR-120 & Parauacu & 622619 & 9811204 & K. Hilbert \\
\hline PA-OR-121 & Tapixaua & 615267 & 9815608 & $\begin{array}{l}\text { K. } \\
\text { Hilbert }\end{array}$ \\
\hline PA-OR-122 & Ibitinga & 612823 & 9817581 & $\begin{array}{l}\text { K. } \\
\text { Hilbert }\end{array}$ \\
\hline PA-OR-123 & Jarazal & 610213 & 9820305 & K. Hilbert \\
\hline
\end{tabular}




\begin{tabular}{|c|c|c|c|c|}
\hline PA-OR-124 & Samauma & 608918 & 9822192 & K. Hilbert \\
\hline PA-OR-125 & Carimum & 601159 & 9828715 & K. Hilbert \\
\hline PA-OR-126 & Serrinha & 607819 & 9833572 & K. Hilbert \\
\hline PA-OR-127 & Piraruaca & 575271 & 9781844 & K. Hilbert \\
\hline AM-NH-01 & Varre Vento & 523550 & 9769107 & K. Hilbert \\
\hline AM-NH-02 & Serrinha & 524206 & 9765945 & K. Hilbert \\
\hline AM-NH-03 & Serra do Matió & 529226 & 9772013 & K. Hilbert \\
\hline AM-NH-04 & Tataguará & 526540 & 9768580 & K. Hilbert \\
\hline AM-NH-37 & Serra do Espelho & 505011 & 9778990 & K. Hilbert \\
\hline AM-NH-38 & Igaçaba & 561557 & 9779940 & K. Hilbert \\
\hline AM-NH-39 & Nova Olinda & 495305 & 9776901 & K. Hilbert \\
\hline AM-PT-01 & Santa Rita & 562061 & 9725775 & K. Hilbert \\
\hline PA-MP-01 & & 488943 & 9874267 & K. Hilbert \\
\hline PA-MP-17 & & 485028 & 9876130 & K. Hilbert \\
\hline PA-MP-18 & & 491984 & 9878527 & K. Hilbert \\
\hline PA-MP-19 & & 493447 & 9876119 & K. Hilbert \\
\hline
\end{tabular}




\begin{tabular}{|c|c|c|c|c|}
\hline PA-MP-20 & & 491718 & 9879831 & K. Hilbert \\
\hline PA-NH-01 & Poco & 522608 & 9779423 & K. Hilbert \\
\hline PA-NH-02 & Cajual & 554726 & 9766703 & K. Hilbert \\
\hline PA-NH-03 & Terra Santa & 556428 & 9766779 & K. Hilbert \\
\hline PA-NH-04 & Faro & 528579 & 9759784 & K. Hilbert \\
\hline PA-NH-07 & Itauaquera & 514275 & 9781740 & K. Hilbert \\
\hline PA-NH-08 & Mabaia & 531629 & 9779939 & K. Hilbert \\
\hline PA-NH-09 & Juliana & 558501 & 9764667 & K. Hilbert \\
\hline PA-NH-10 & Serrinha & 527318 & 9760611 & K. Hilbert \\
\hline PA-NH-11 & São José & 505290 & 9787583 & K. Hilbert \\
\hline PA-NH-12 & Uixa & 524690 & 9782769 & K. Hilbert \\
\hline PA-TR-01 & & 494791 & 9879985 & K. Hilbert \\
\hline PA-TR-02 & Área 11 & 493169 & 9888392 & K. Hilbert \\
\hline \multirow[t]{2}{*}{ PA-TR-03 } & & 493967 & 9889587 & K. Hilbert \\
\hline & São Benedito & 527988 & 9759730 & $\begin{array}{l}\text { Lima, Silva, } \\
2005\end{array}$ \\
\hline
\end{tabular}




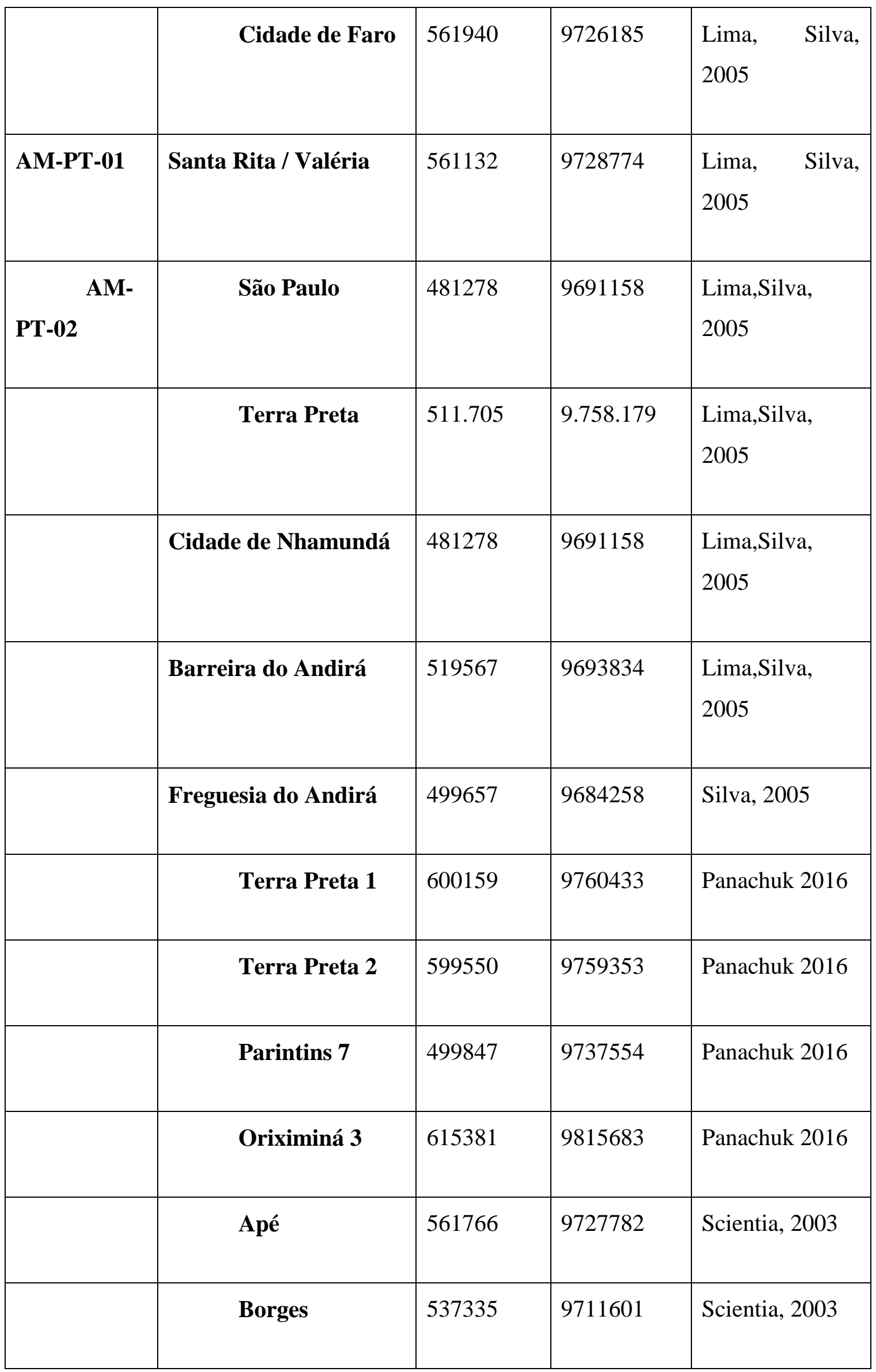




\begin{tabular}{|c|c|c|c|}
\hline Coró Coroí & 593976 & 9742797 & Scientia, 2003 \\
\hline Da Ordem & 571720 & 9714536 & Scientia, 2003 \\
\hline Saudade & 570788 & 9713636 & Scientia, 2003 \\
\hline Serra do Babaçu & 594107 & 9747092 & Scientia, 2003 \\
\hline Serra do Capiranga & 59579 & 9745752 & Scientia, 2003 \\
\hline Viana & 525676 & 9707406 & Scientia, 2003 \\
\hline Américo & 586305 & 9749087 & Scientia, 2003 \\
\hline Assis 1 & 57608 & 9723386 & Scientia, 2003 \\
\hline Babaçuzal & 590433 & 9739022 & Scientia, 2003 \\
\hline Cabeceira da Prata & 587427 & 9731449 & Scientia, 2003 \\
\hline Cabeceira do Folhal & 587582 & 9730338 & Scientia, 2003 \\
\hline Capitão 2 & $\begin{array}{r}572 \\
434\end{array}$ & $\begin{array}{r}9733 \\
674\end{array}$ & $\begin{array}{l}\text { Scientia, } \\
2003\end{array}$ \\
\hline Juruti Velho & 577338 & 9735026 & Scientia, 2003 \\
\hline Mangal & 589744 & 9737252 & Scientia, 2003 \\
\hline Mangueirinha & 576285 & 9739772 & Scientia, 2003 \\
\hline
\end{tabular}




\begin{tabular}{|l|l|l|l|l|}
\hline Maurino & 567483 & 9735418 & Scientia, 2003 \\
\hline & Parintinzinho I & 567240 & 9734969 & Scientia, 2003 \\
\hline & Parintinzinho II & 567686 & 9734941 & Scientia, 2003 \\
\hline & Piquiá & 572491 & 9715999 & Scientia, 2003 \\
\hline & Ponta do Assis & 576217 & 9724758 & Scientia, 2003 \\
\hline & Santa Luzia & 583441 & 9746138 & Scientia, 2003 \\
\hline & São Sebastião & 561909 & 9731831 & Scientia, 2003 \\
\hline & Uruá & 575695 & 9736186 & Scientia, 2003 \\
\hline & & 581609 & 9743840 & Scientia, 2003 \\
\hline & & & & \\
\hline & & & & \\
\hline
\end{tabular}


Mapa com sítio sarqueológicos com cerâmica Konduri 


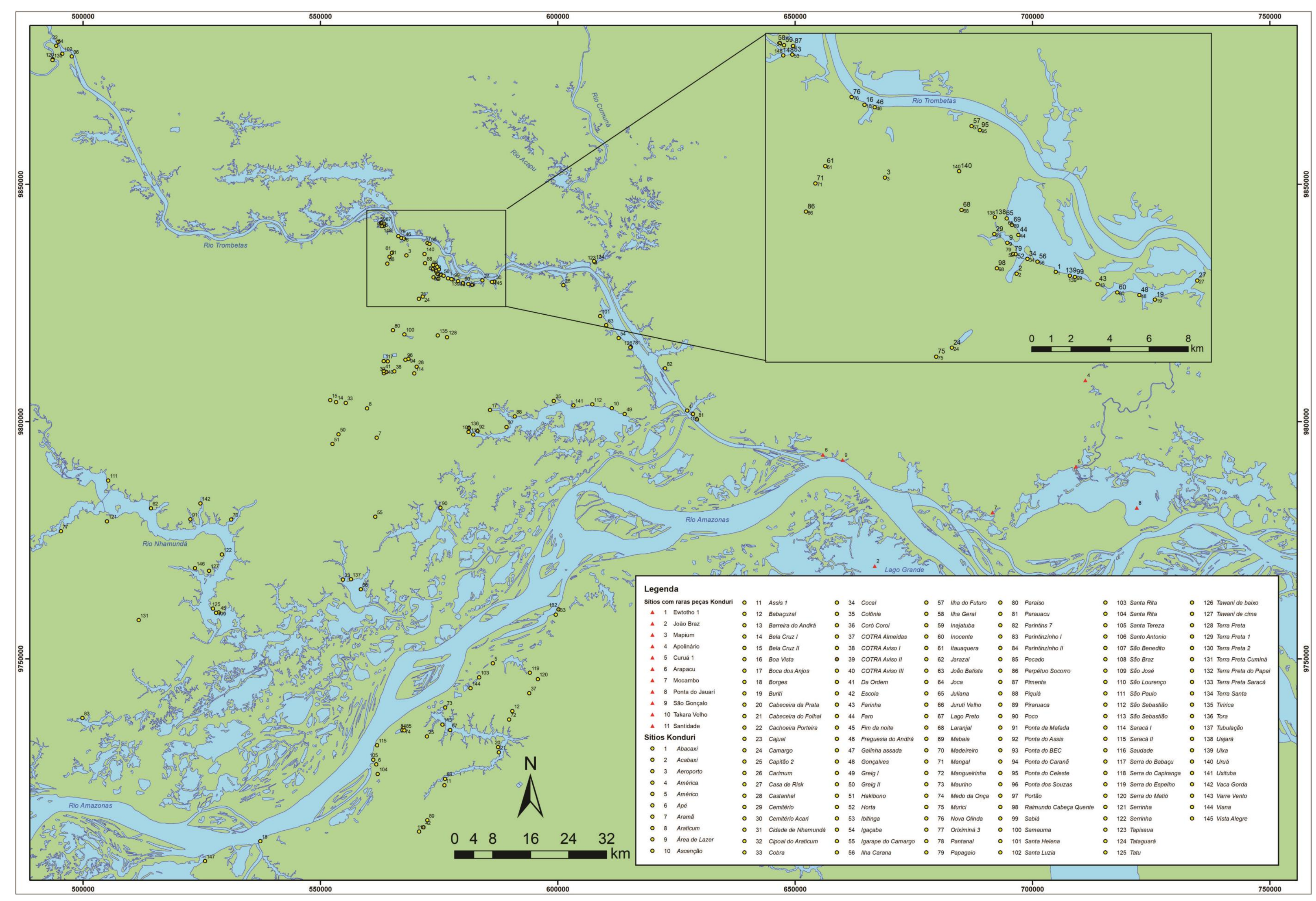


Projeções de morfologia de vasilhas do estilo Konduri 
Coleção Aricy Curvello/ MHN

Lago Batata

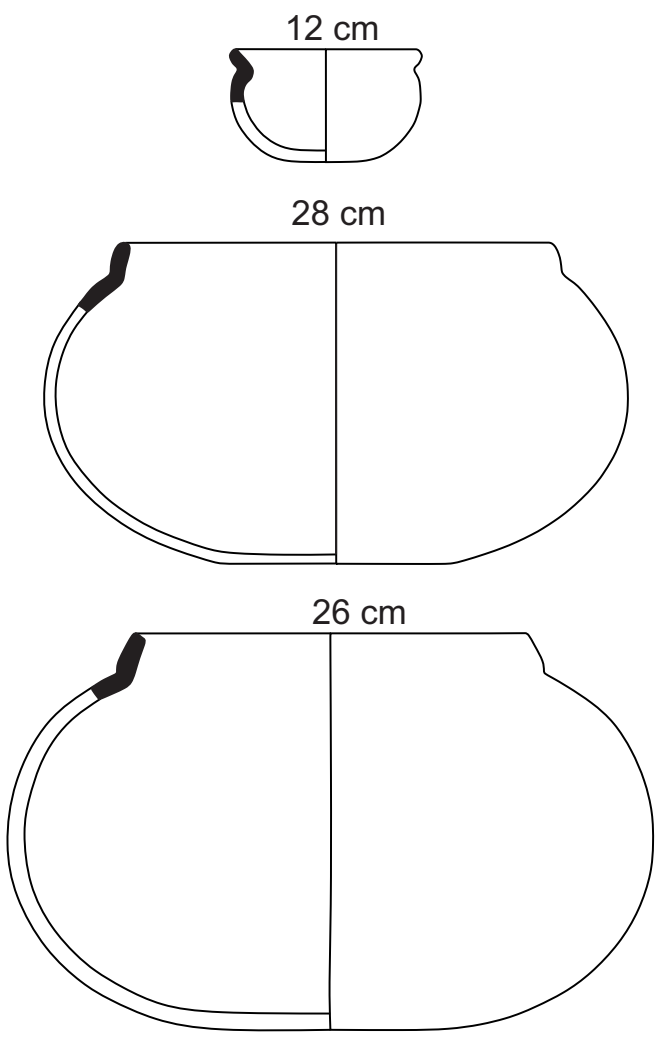

$95 \mathrm{~cm}$
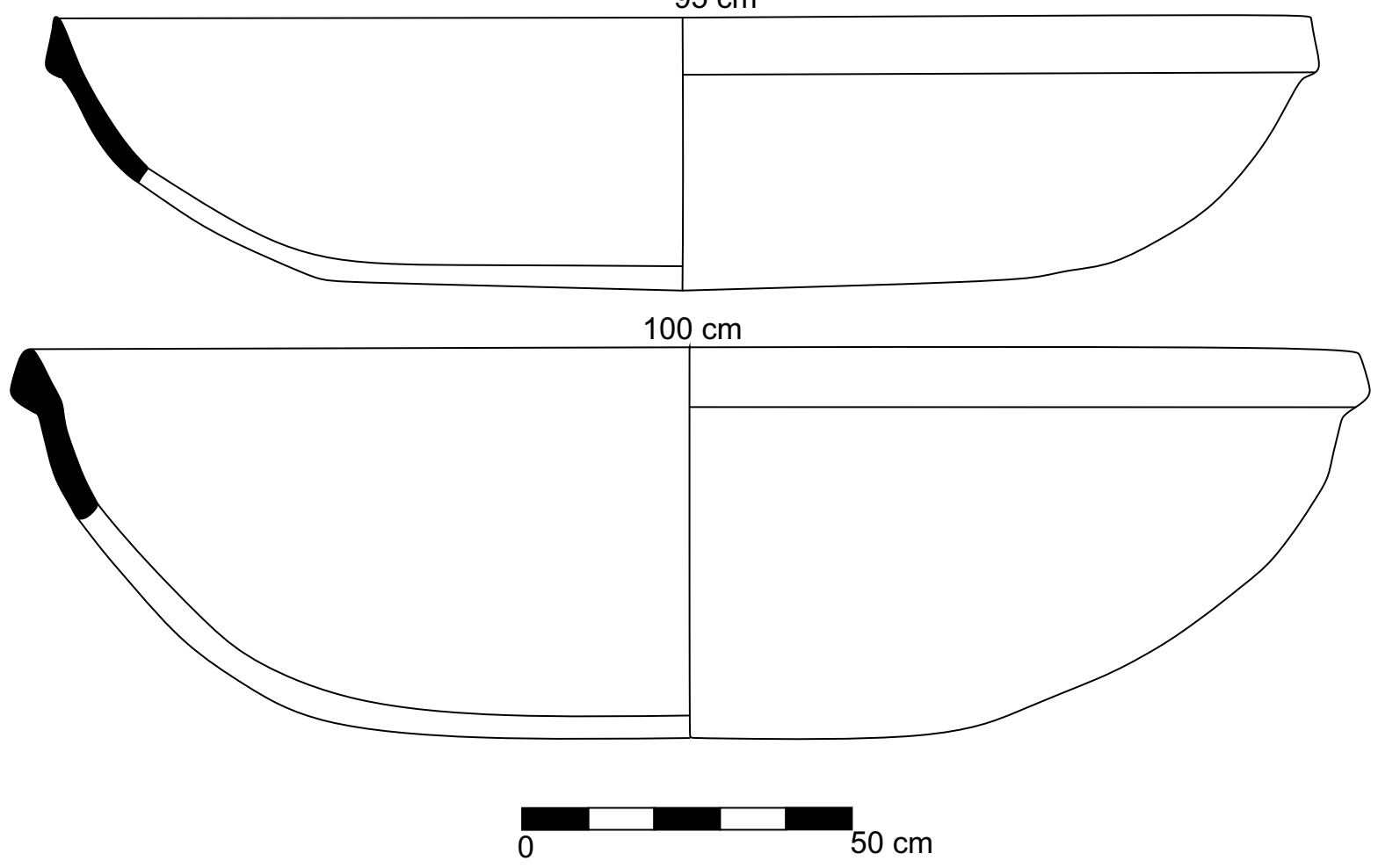
Coleção Aricy Curvello/ MHN Posto Aurora II

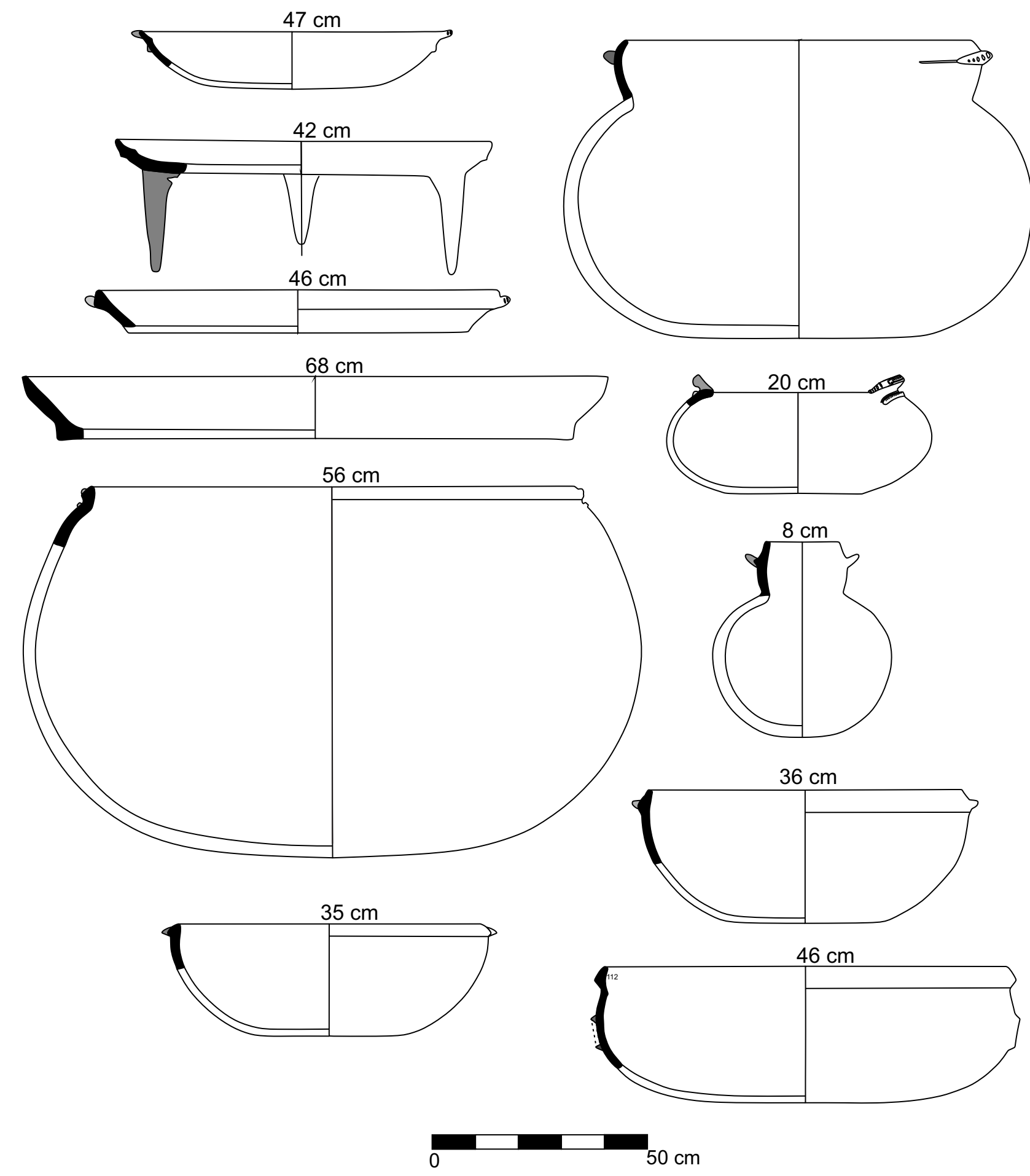


Coleção T-1464/1465/ MPEG

Lago do Jacaré

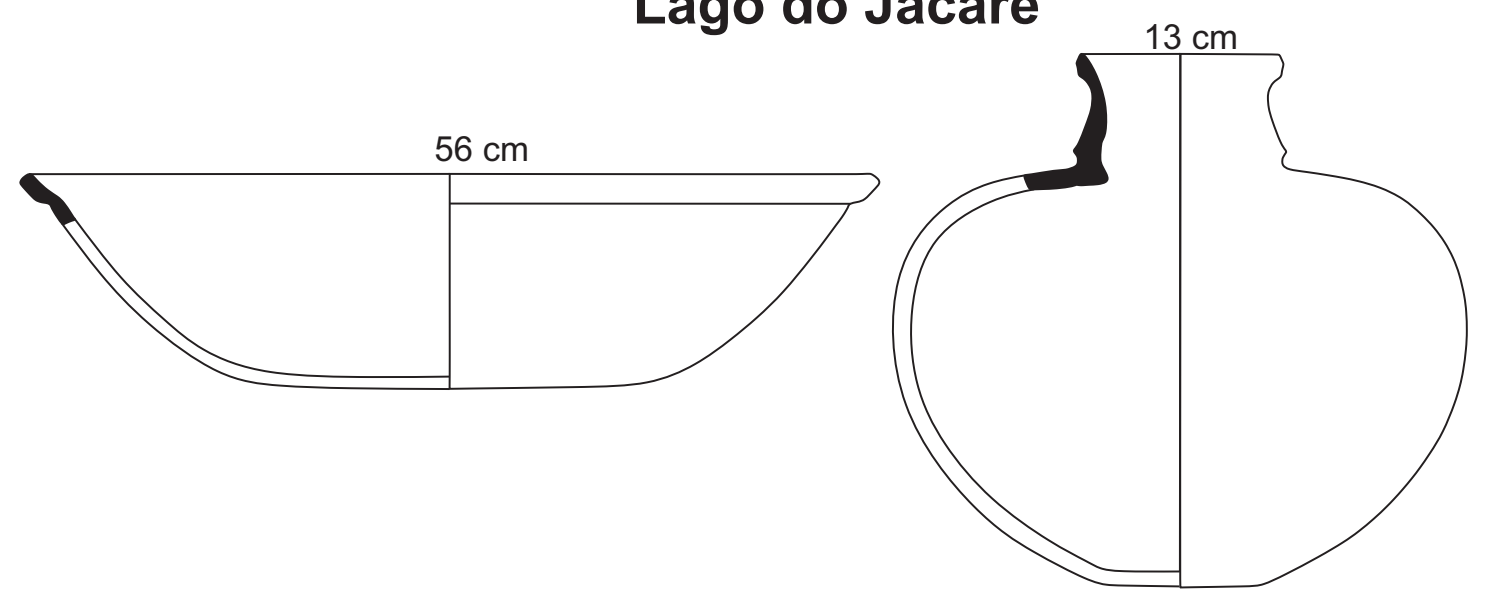

Coleção T-1564/MPEG

Oriximiná
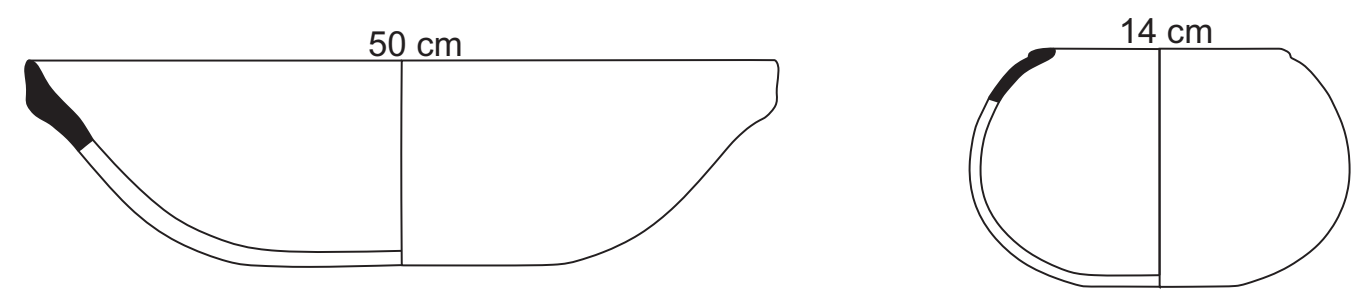

Coleção Charles Townsend Jr./MPEG

Faro

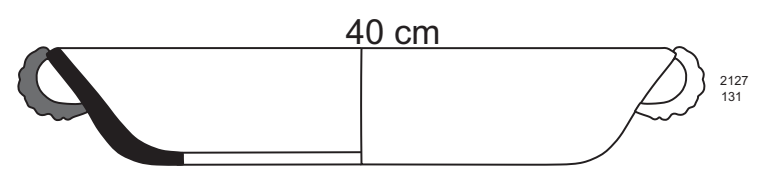

Terra Santa
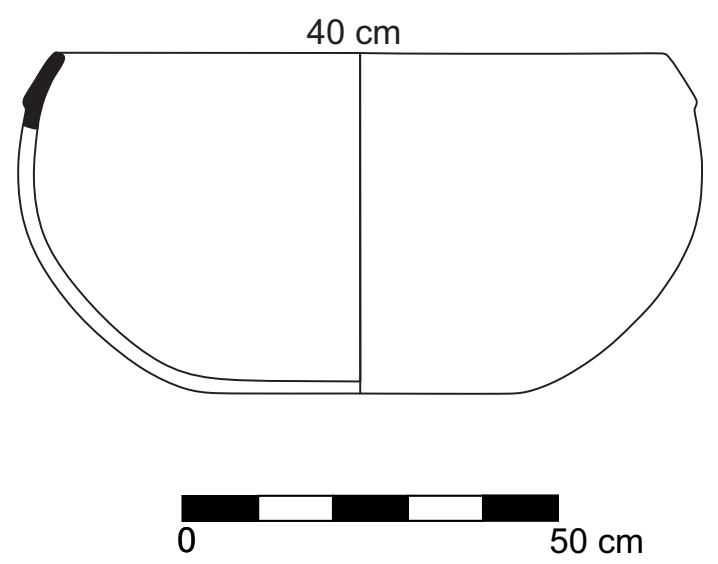


\section{Coleção Peter Hilbert/MPEG}

\section{Mabaia}
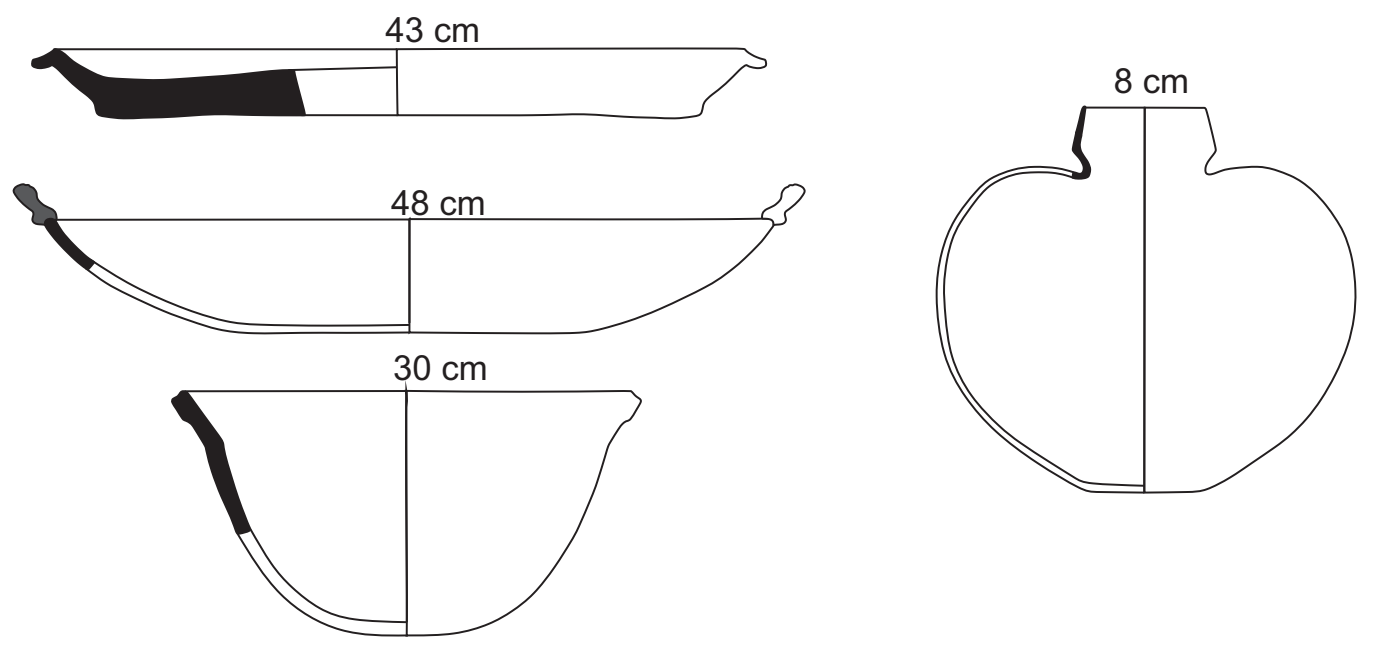

Serrinha
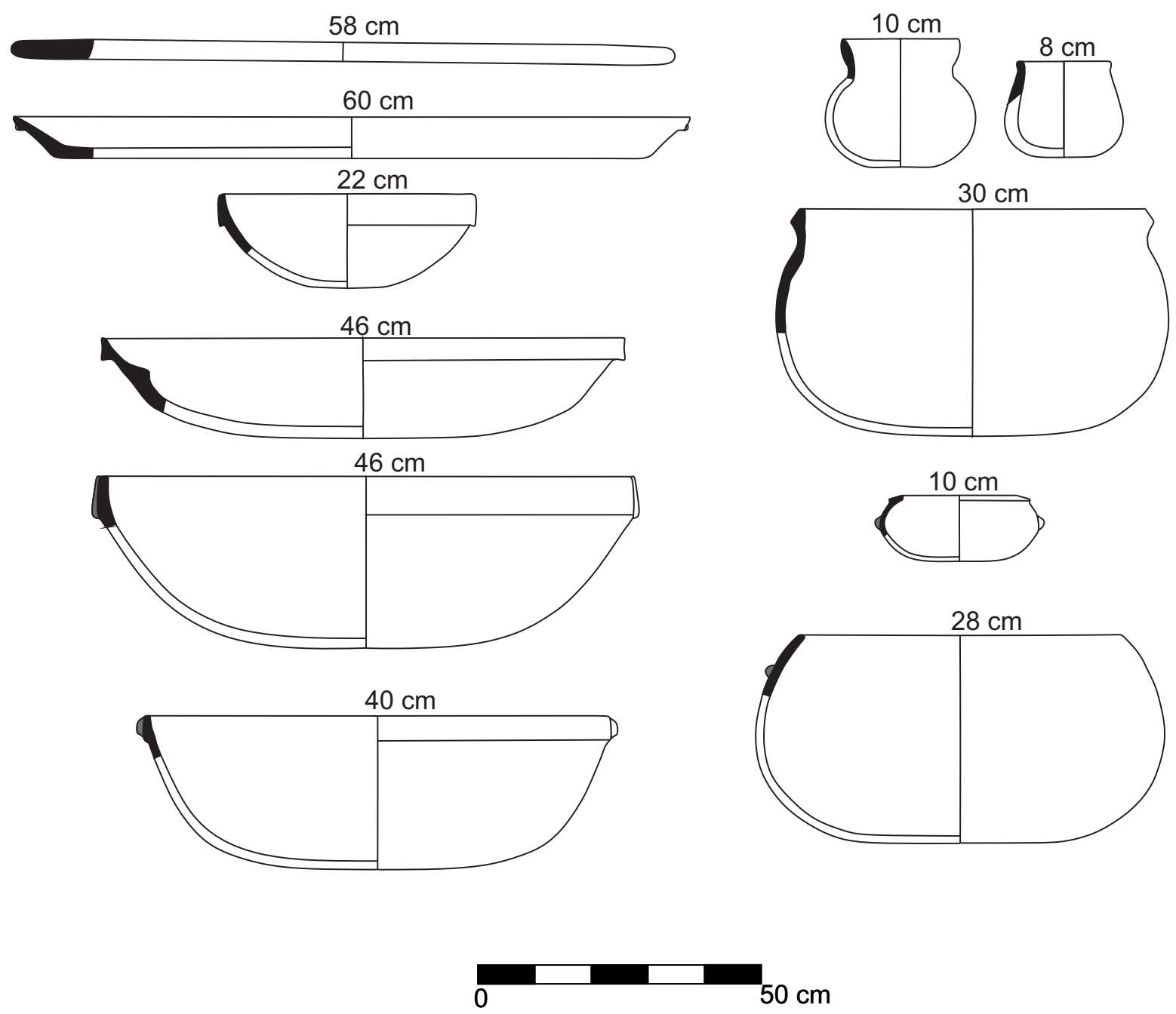


\section{Coleção Peter Hilbert/ MPEG}

\section{Oriximiná}
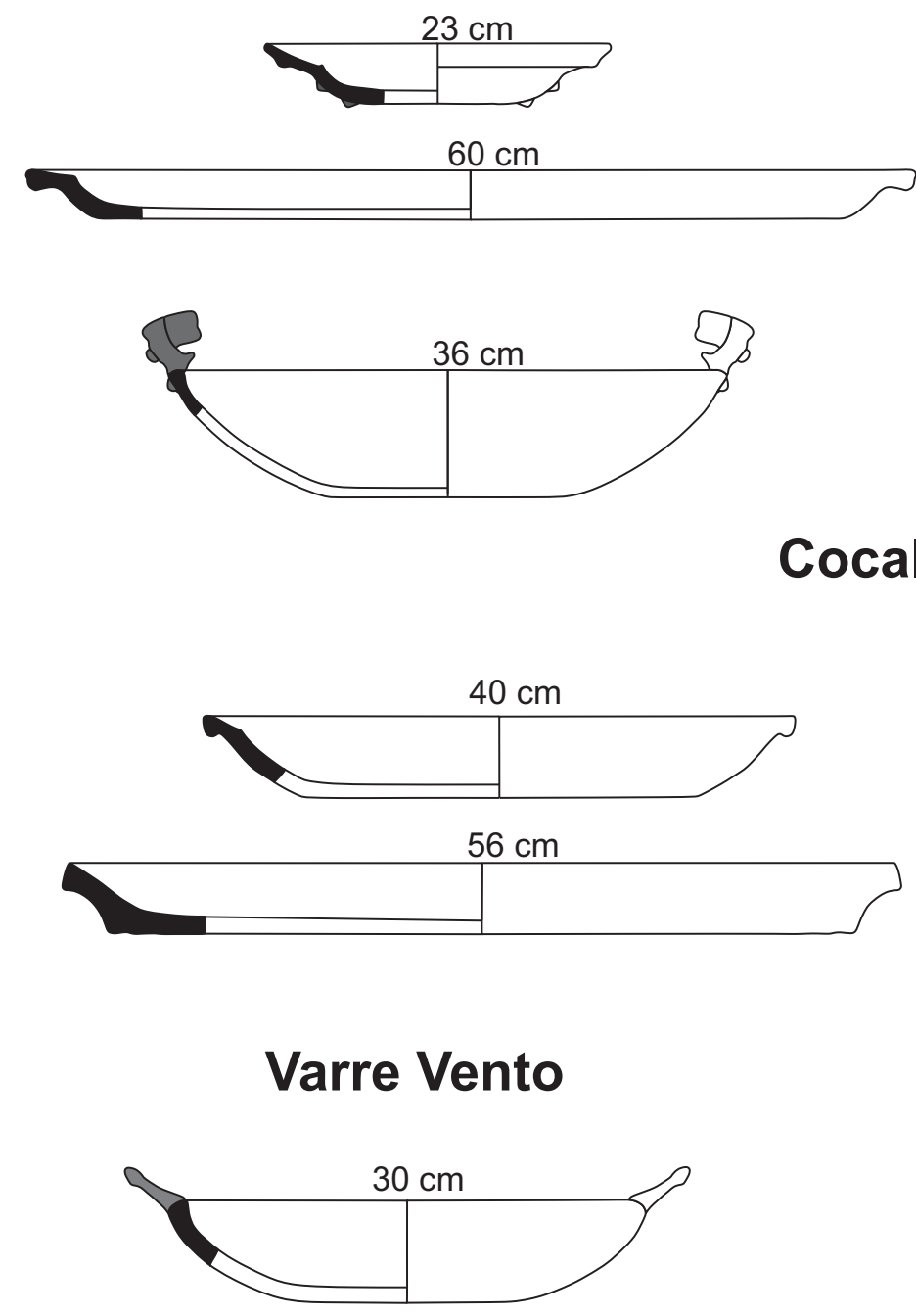

Aibi

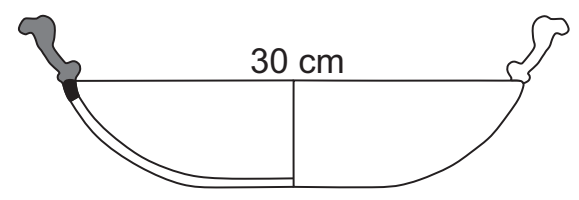

Faro
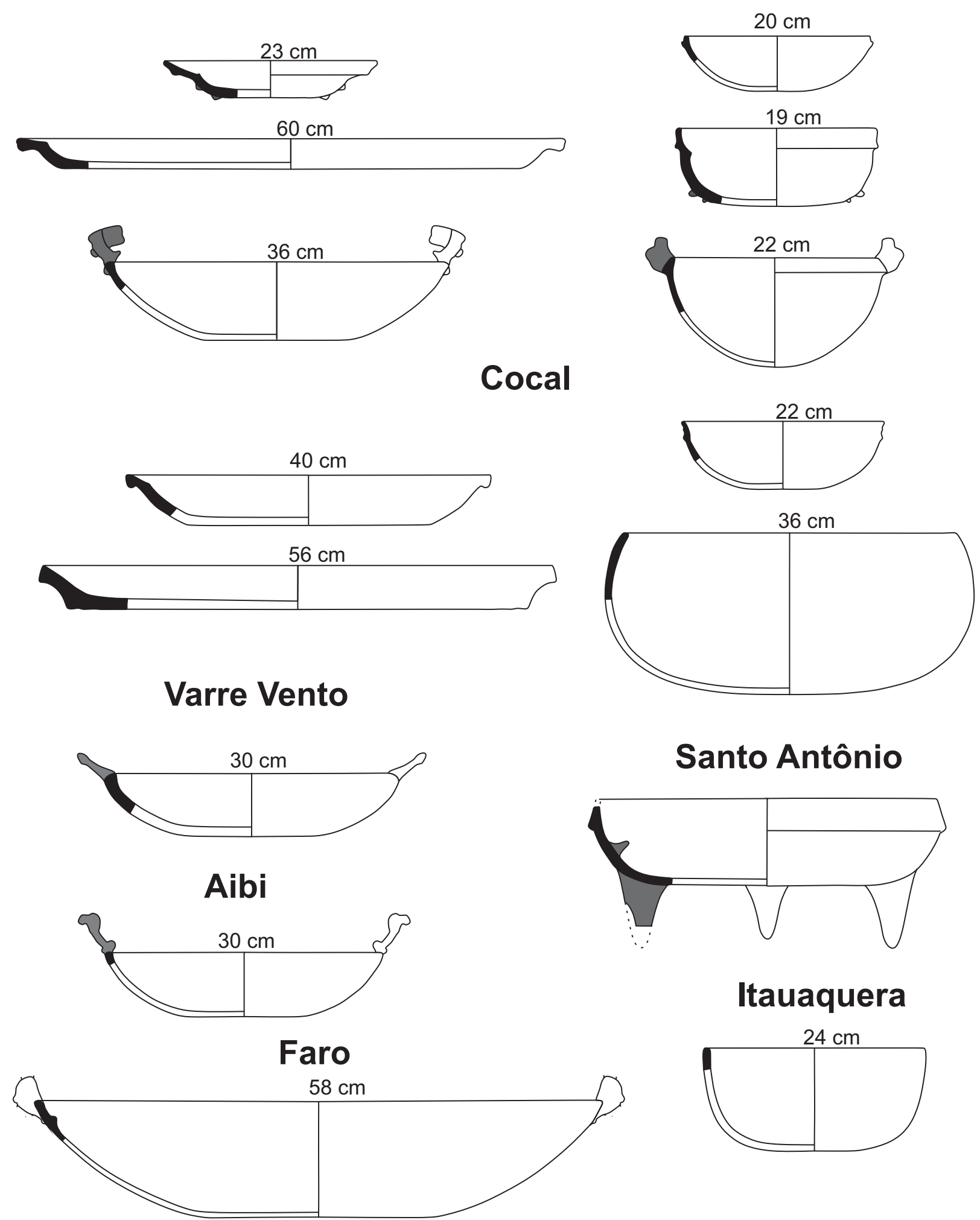

Santo Antônio

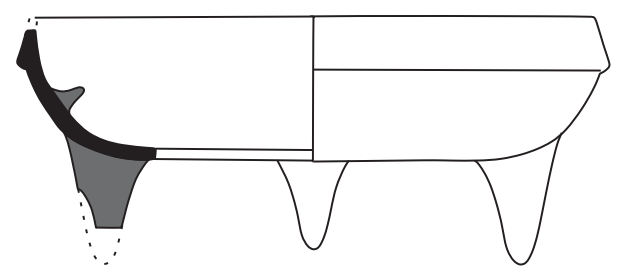

Itauaquera

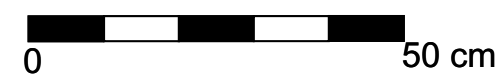


Coleção Peter Hilbert e Harald Schultz/ Babaçu MPEG

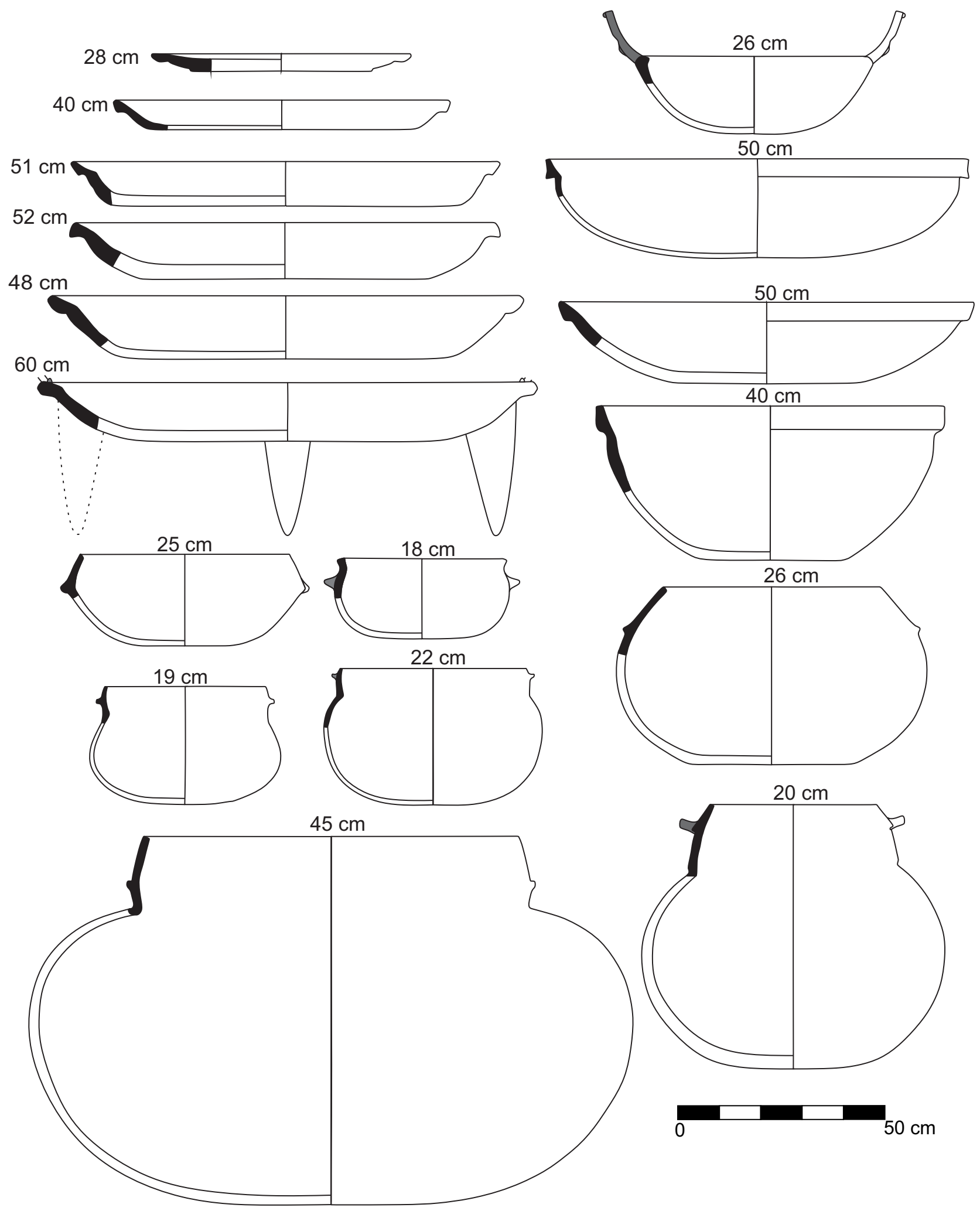


Coleção Peter Hilbert e Harald Schultz/ MPEG

Fortaleza

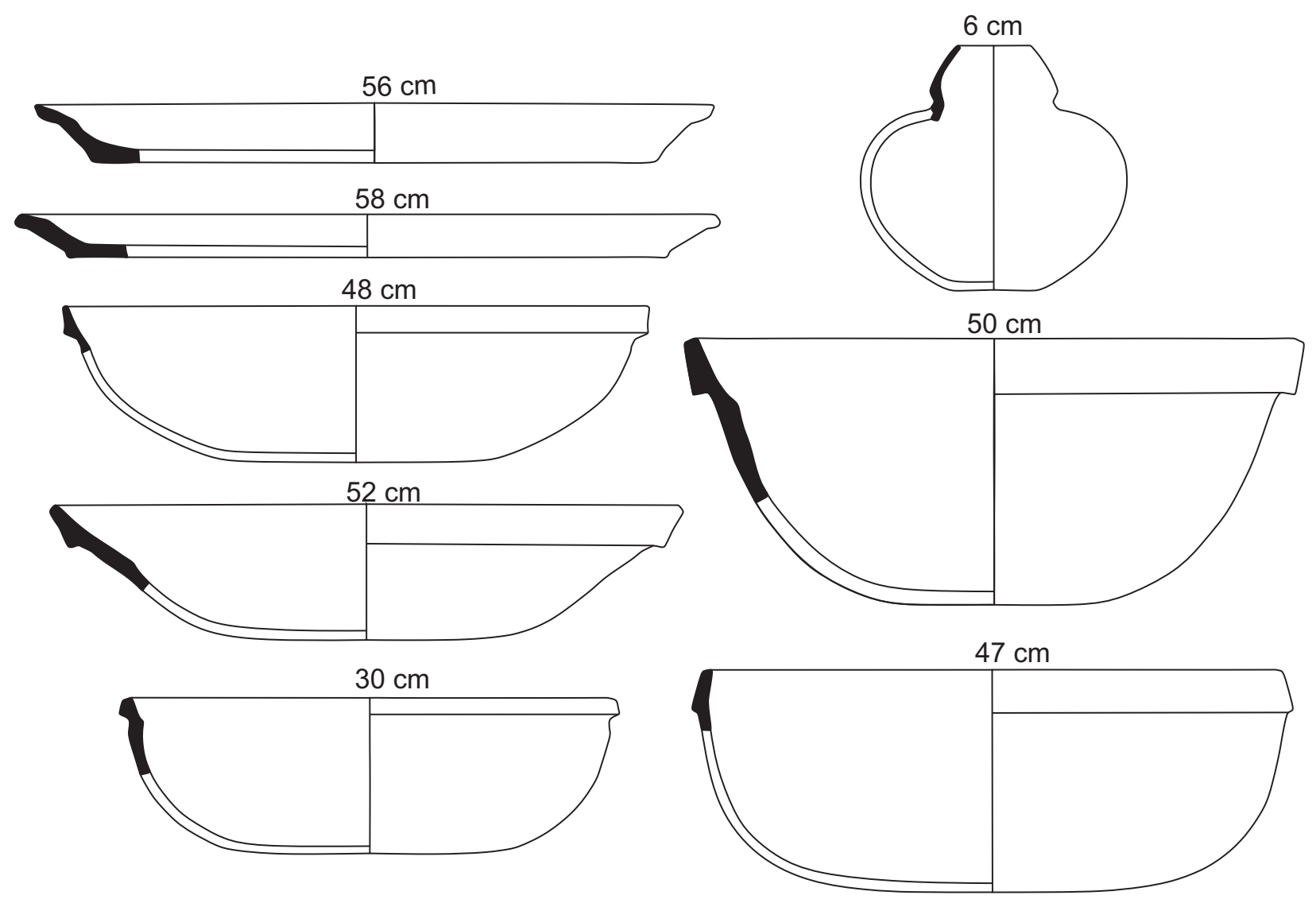

Oriente(?)

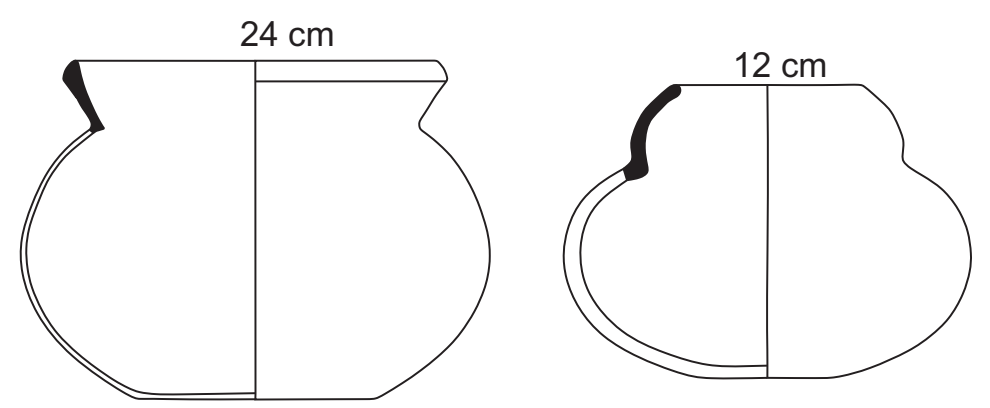

$58 \mathrm{~cm}$

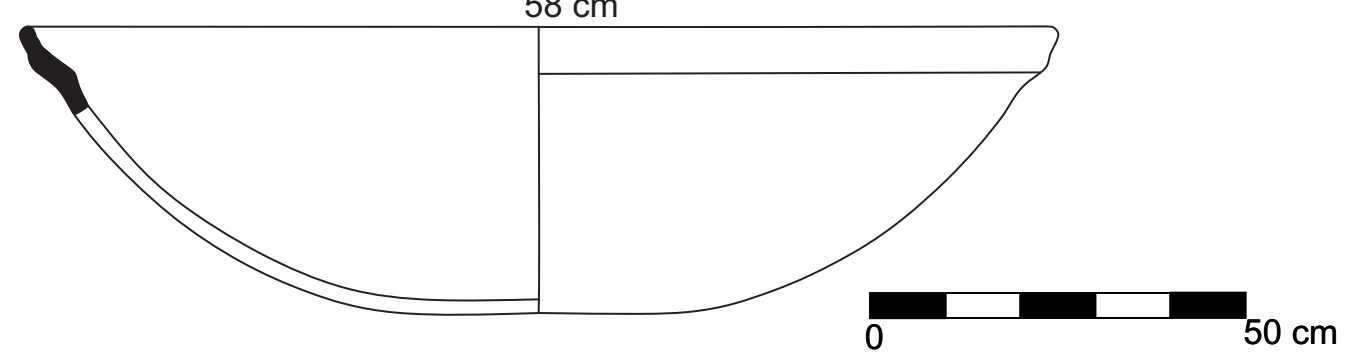


Coleção Peter Hilbert e Harald Schultz/ MPEG Juruti Velho (?)
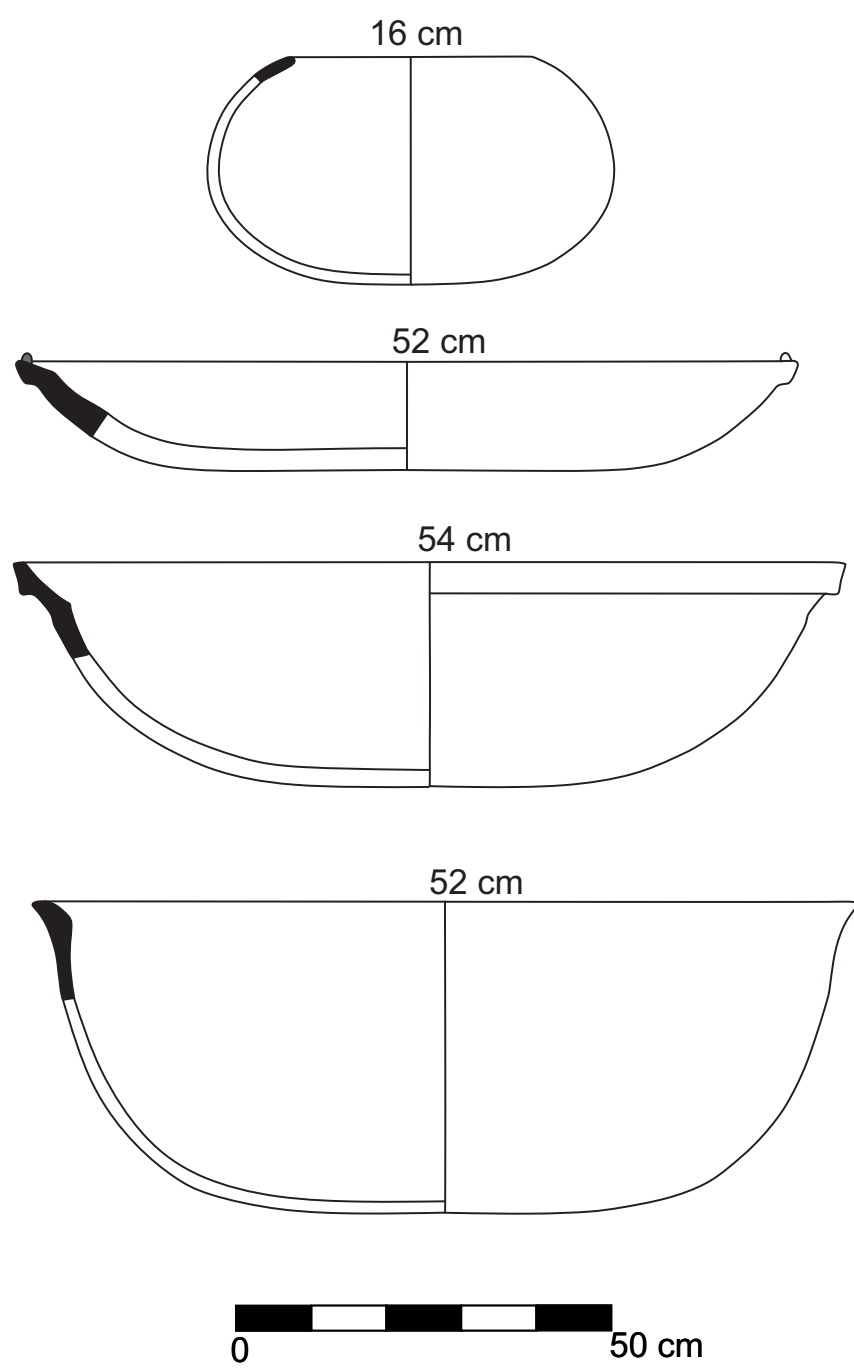
Coleção Barbosa de Faria/ MN

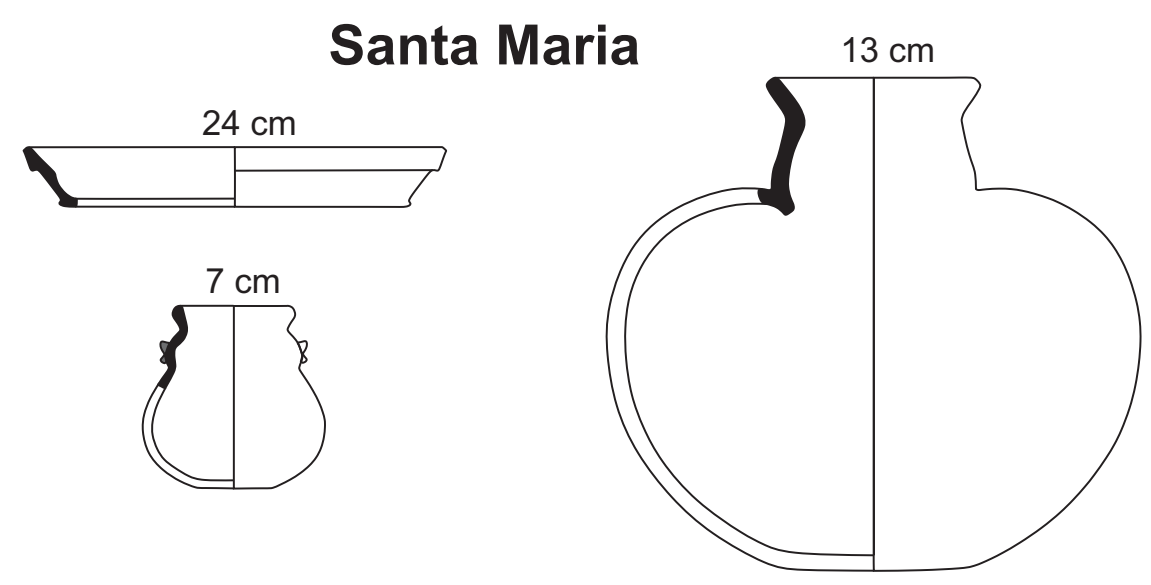

Abuí

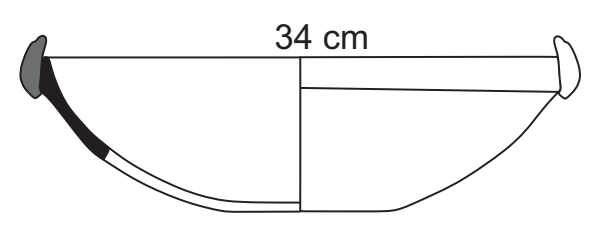

Lago Sapucuá
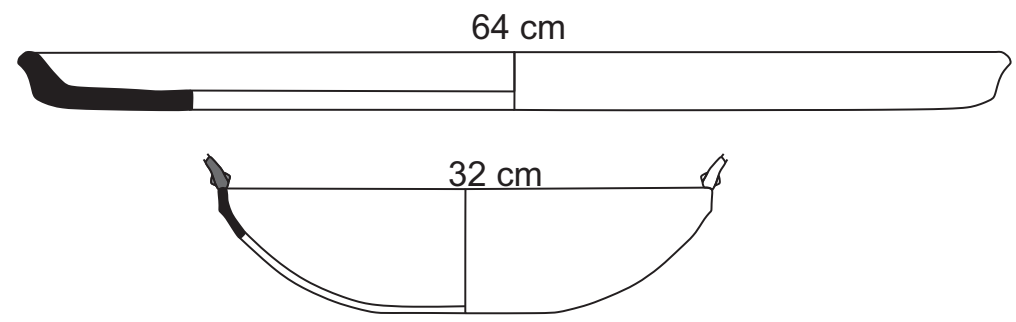

Coleção Comissão Rondon/ MN

Sem proveniência
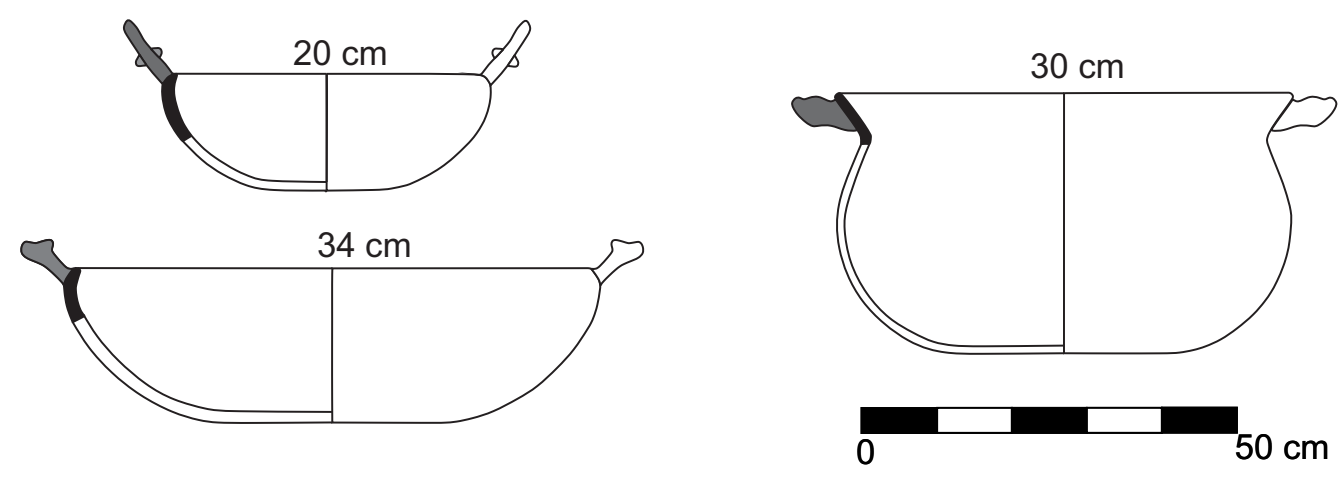